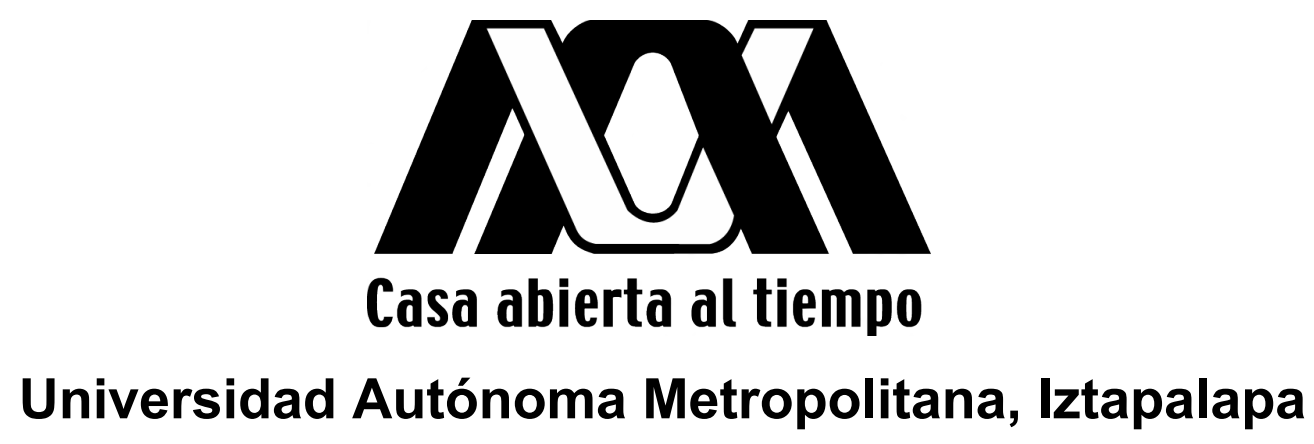

Caracterización de la ruta de señalización activada por el factor de crecimiento y diferenciación 11 (GDF11) y su impacto en la tumorigénesis en hepatocarcinoma humano

TESIS

Para obtener el grado de Maestra en Biología Experimental

Presenta

Biol. Exp. Monserrat Gerardo Ramírez

Comité Tutoral

Dra. María Concepción Gutiérrez Ruiz

Dr. José Carlos Fernández Checa

Dra. Marina Macías Silva 
El programa de Maestría en Biología Experimental de la Universidad Autónoma Metropolitana pertenece al Programa Nacional de Posgrados de Calidad (PNPC) del CONACYT, registro 001481, en el Nivel Consolidado, y cuenta con el apoyo del mismo Consejo, Clave DAFCYT-2003IMPTNNN0020. Número de registro de la beca otorgada por el CONACYT: 633680

Este trabajo estuvo apoyado por los proyectos de CONACYT: CB-252942 y Fronteras de la Ciencia- 1320 siendo responsable de ambos el Dr. Luis Enrique Gómez Quiroz. 
Los miembros del jurado designados por la Comisión Académica del Posgrado en Biología Experimental de la División de Ciencias Biológicas y de la Salud de la Universidad Autónoma Metropolitana- Iztapalapa, abajo firmantes aprobaron la tesis titulada "Caracterización de la ruta de señalización activada por el factor de crecimiento y diferenciación 11 (GDF11) y su impacto en la tumorigénesis en hepatocarcinoma humano" que presenta Monserrat Gerardo Ramírez con fecha de examen el 05 de diciembre del 2019

\section{MIEMBROS DEL JURADO}

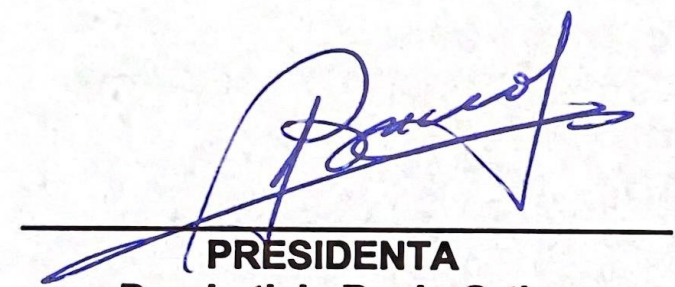

Dra. Leticia Bucio Ortiz

Departamento de Ciencias de la Salud Universidad Autónoma Metropolitana Ciudad de México

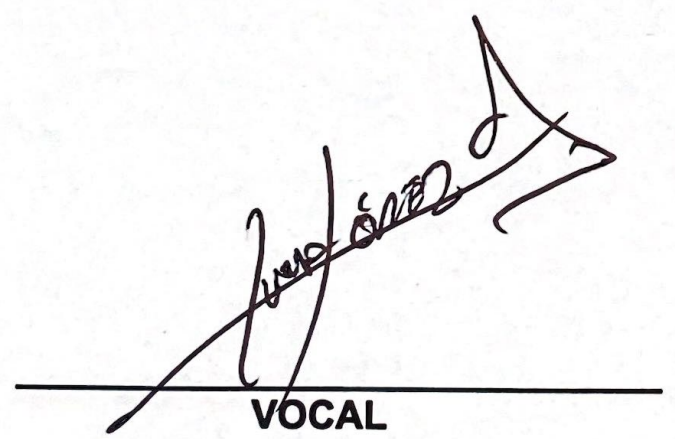

Dr. Armando Luna López Instituto Nacional de Geriatría Ciudad de México

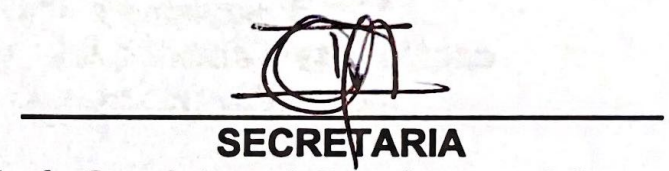

María Guadalupe I. Domínguez Gómez Instituto Nacional de Cancerología Ciudad de México

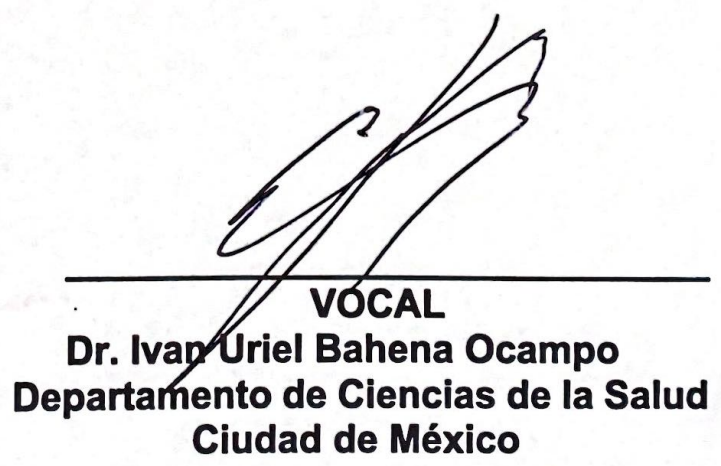




\section{Comité Tutoral}

Directora. Dra. María Concepción Gutiérrez Ruiz

Departamento de Ciencias de la Salud, Universidad Autónoma Metropolitana

Teléfono.5559667520 Correo.mcgr@xanum.uam.mx

Co- director. Dr. José Carlos Fernández Checa

Instituto de Investigaciones Biomédicas de Barcelona, CSIC; Unidad de Hígado,

Hospital Clinic, IDIBAPS y CIBERehd, Barcelona, España.

Doctor Honoris Causa por la Universidad Autónoma Metropolitana

Teléfono. +93-2275709 Correo. checa229@yahoo.com

Asesora. Dra. Marina Macías Silva

Instituto de Fisiología Celular, Universidad Nacional Autónoma de México

Teléfono.5556225729 Correo.mmacias@ifc.unam.mx 


\section{Agradecimientos}

A la Universidad Autónoma Metropolitana, porque fue mi casa de estudios durante este largo tiempo, porque al tener profesores e investigadores de alto nivel me permitieron crecer más.

Al Conacyt, por haberme otorgado la beca que me permitió concluir mis estudios.

A la doctora María Concepción Gutiérrez Ruiz, por ser mi directora de tesis, por su guía y paciencia.

Al doctor José Carlos Fernández Checa, quien también formo parte como codirector de tesis, agradezco también por la oportunidad de haberme dejado trabajar en su laboratorio durante mi estancia en Barcelona.

A la doctora Marina Macías Silva, por ser mi asesora de tesis.

A los miembros del jurado conformado por la doctora Leticia Bucio Ortiz, la doctora María Guadalupe Domínguez Gómez, el doctor Ivan Uriel Bahena Ocampo y al doctor Armando Luna López por los comentarios realizados a la tesis

A la doctora Carmen García Ruiz, del IIBB, por su apoyo durante mi estancia en su laboratorio.

Al doctor Javier Jiménez Salazar y al doctor Roberto Lazzarini, por su apoyo y colaboración durante la realización del proyecto, así como al M en BE Arturo Simoni Nieves, M. en C. Lyssia Castellanos y a la Dra. Elizabeth Tejero por su apoyo en los estudios de RNA-seq.

Al doctor Jens Marquardt, de la Universidad Johannes Gutenberg, Alemania, por su apoyo en la realización de los análisis de RNA- seq.

Al doctor Benjamín Pérez Aguilar, quien formo parte del proyecto durante el desarrollo de este.

Al doctor Luis Enrique Gómez Quiroz, por ser el responsable y líder del proyecto de GDF11, además de ser el encargado de financiarlo, agradezco que me haya dado la oportunidad y la confianza para llevar a cabo esta investigación. 


\section{Agradecimientos}

Al laboratorio de Fisiología Celular (S-351), lugar donde me desarrollé como científica, lugar que me vio crecer y caer algunas veces también, ese espacio que consideré, desde el primer día mi hogar.

A las doctoras que pertenecen al laboratorio, a la Dra. Lety, Dra. Vero y Dra. Roxana por su apoyo.

A la Dra. Conchita, gracias por su apoyo aún cuando me encontraba lejos.

A mis compañeros del laboratorio, por ayudarme, por enseñarme, por hacerme reír y por brindarme su apoyo cuando lo necesitaba (incluso si se trataba de quedarse a trabajar toda la noche) por aquellos experimentos que eran para ayer.

A Benja, quien fue mi maestro, gracias por enseñarme, por tu ayuda, por tu paciencia y por estar ahí cuando me atoraba en los experimentos.

Al Dr. Luis Enrique Gómez Quiroz, no tengo palabras para agradecer todo su apoyo (académico y personal), por ser mi amigo y confidente, por esas platicas mañaneras con una taza de café recién hecho en "la cocina" del lab. acompañado de galletas (algunas veces robadas de mi cajón) y también por las tardes de palomitas de maíz, la herramienta perfecta contra el cansancio de una tarde de trabajo pesado.

Gracias por seguir al pendiente de mi cuando deje el laboratorio y claro por alentarme y apoyarme sabiendo que sería la oportunidad más importante de mi vida y finalmente pero no menos importante...

Gracias también por ser un gran ejemplo por seguir, por ayudarme, por enseñarme y también por soportarme. Agradezco las risas, pero también agradezco los regaños, ya que me forjaron permitiéndome crecer día a día. Gracias, porque usted fue quien vio una chispa en mi para lograr ser un miembro más de su codiciado grupo de trabajo. $Y$ finalmente gracias por enseñarme que "la ciencia es un estilo de vida, no una profesión". 


\section{Dedicatoria}

A mi padre, Federico Gerardo, quien a pesar de la distancia siempre estuvo conmigo, porque me apoyo en todo momento sin cuestionar el futuro por el que estaba trabajando, por alentarme a seguir mis sueños, aun cuando para lograrlos requería de alejarme más de él.

A mi hermano, Edgar Gerardo, quien me apoyo en las decisiones que tomaba, que aun sin vernos diario siempre supe que tú estabas para brindarme una mano y ayudarme a pelear más fuerte para lograr mis objetivos, por celebrar mis batallas ganadas durante esta larga travesía estudiantil, gracias por no dejarme morir sola.

A mi familia, quienes pese a todo se acostumbraron a dejar de verme por el trabajo en el laboratorio, por el apoyo y por el cariño que me brindan día a día, gracias por hacer suyos mis logros y festejarlos como una fiesta nacional.

Una dedicatoria especial a mi madre, Marcela Ramírez, quien tristemente perdió la batalla contra el cáncer, al cual hoy enfrento yo con las mejores herramientas (Ciencia) y con las fuerzas multiplicadas para lograr su control. 


\section{Resumen}

El factor de crecimiento y diferenciación 11 (GDF11) ha sido caracterizado como uno de los principales reguladores de los procesos de diferenciación en células con características troncales a pesar de algunas controversias sobre estudios relacionados con la edad. El GDF11 ha sido pobremente estudiado en patologías como el cáncer, particularmente por las características troncales que presentan las células, principalmente en el carcinoma hepatocelular ( $\mathrm{HCC}$ ), uno de los cánceres más agresivos a nivel mundial. En este trabajo nos propusimos investigar los efectos del GDF11 en las células de cáncer de hígado.

EI GDF11 induce la activación de la ruta de las Smad (Smad2/3) sin activar a las Smad asociadas a la familia de las BMP (Smad1/5) en la línea celular Huh7, pero observamos en la línea celular Hep3B la activación de las proteínas Smad de ambas familias.

El tratamiento con el GDF11 no afecta la viabilidad de las células, pero reduce de manera significativa la proliferación, la formación de esferoides y la formación de colonias en las líneas de HCC.

Se observó también la desregulación de CDK6, Ciclina D1 y Ciclina A y la sobreregulación de p27 después del tratamiento con GDF11. Interesantemente, el tratamiento induce disfunción mitocondrial mediante la disminución de la fosforilación oxidativa (OCR) y la disminución en la capacidad glucolítica (ECAR).

Estos efectos fueron potencialmente inducidos por la expresión de E- Cadherina y Ocludina así como la represión de Snail y N- Cadherina de manera dependiente. 
Además, el tratamiento con el GDF11 por 72 h provoco en las células la disminución en la formación de colonias y de esferoides, estos efectos fueron observados una vez que el tratamiento fue removido dejando las células sin este estímulo hasta por 10 días, indicando que el efecto del GDF11 no es transitorio.

Finalmente, en el ensayo de invasión observamos la disminución de manera significativa en la migración de las células tratadas con GDF11 asociado a la disminución en la proliferación mediante la tinción con Ki67.

Finalmente, nosotros proponemos la activación de ERK1/2 como unos de los principales blancos de la señalización de GDF11 en la disminución en la proliferación. Los datos mostraron que el GDF11 exógeno muestra propiedades supresoras de tumores en las células de HCC. 


\section{Abstract}

Growth differentiation factor 11 (GDF11) has been characterized as a key regulator of differentiation in cells that retain stemness features, despite some controversies in agerelated studies. GDF11 has been poorly investigated in cancer, particularly in those with stemness capacity, such as hepatocellular carcinoma (HCC), one of the most aggressive cancers worldwide. Here, we focused on investigating the effects of GDF11 in liver cancer cells.

GDF11 induced Smad signaling activation (Smad2/3), without activated the BMP associated Smad signaling (Smad 1/5) in Huh7 cell line, but we observe in Hep3B cell line both Smad signaling activated.

GDF11 treatment did not affect the viability but significantly reduced proliferation, colony and spheroid formation in HCC cell lines.

Consistently, down-regulation of CDK6, cyclin D1, cyclin A, and concomitant upregulation of p27 was observed after $24 \mathrm{~h}$ of treatment. Interestingly, GDF11 treatment induce mitochondrial dysfunction by oxidative phosphorylation decrease (OCR) and glycolytic capacity decrease (ECAR).

These effects were potentially induced by the expression of E-cadherin and occludin, as well as Snail and $\mathrm{N}$-cadherin repression, in a time-dependent manner. Furthermore, GDF11 treatment for $72 \mathrm{~h}$ induced that cells were incapable of sustaining colony and sphere capacity in the absent of GDF11, up to 10 days, indicating that the effect of GDF11 on self-renewal capacity is not transient. 
In vivo invasion studies revealed a significant decrease in cell migration of hepatocellular carcinoma cells treated with GDF11 associated to a decreased proliferation judged by Ki67 staining.

Finally, we propose ERK1/2 activation like a principal target for GDF11 signaling in the decrease in the proliferation. Data show that exogenous GDF11 displays tumor suppressor properties in HCC cells. 


\section{Índice}

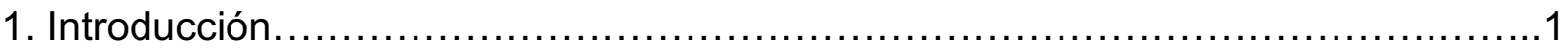

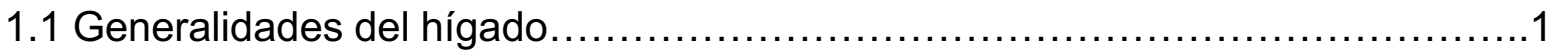

1.2 Principales agentes tóxicos y estadios de daño hepático...........................1

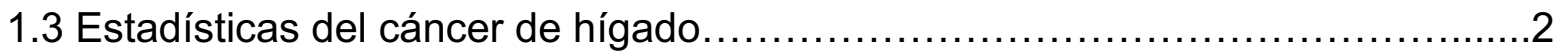

1.4 Características del cáncer hepático...............................................

1.5 El papel de la ruta de las MAPK en el cáncer de hígado..........................

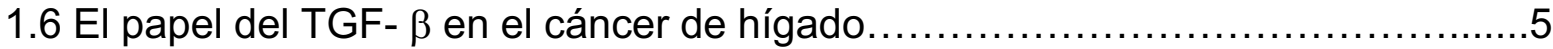

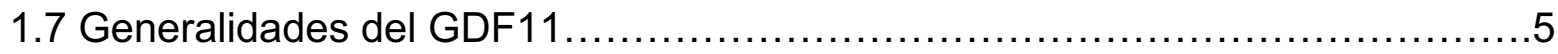

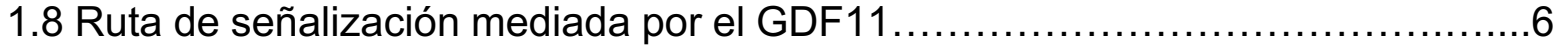

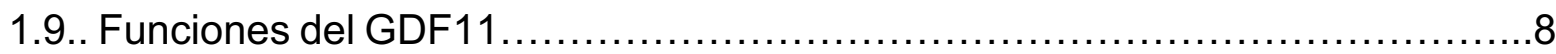

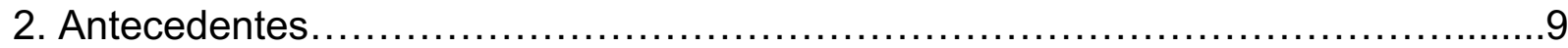

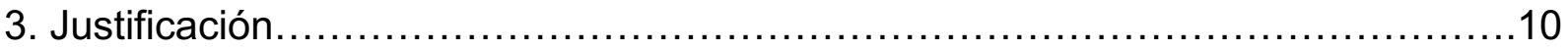

4. Pregunta de investigación.........................................................

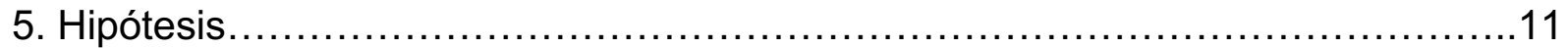

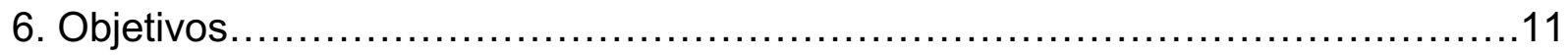

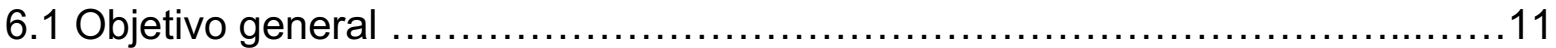

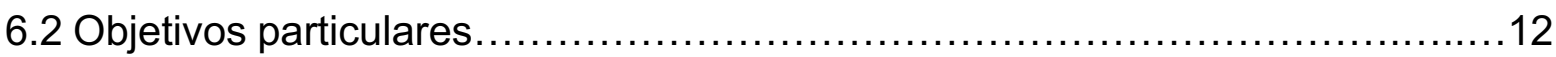

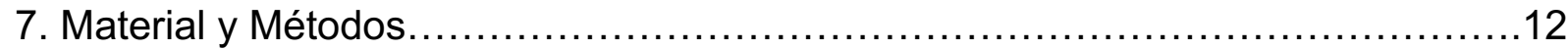

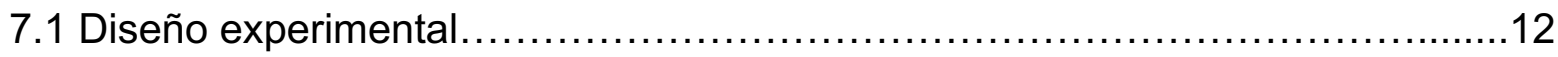

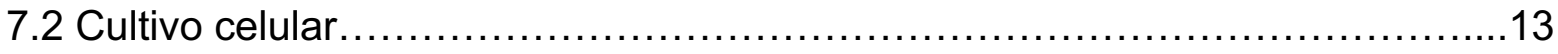

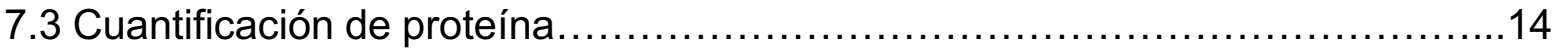




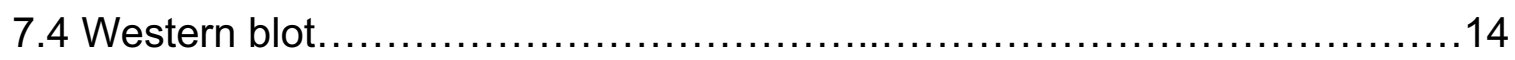

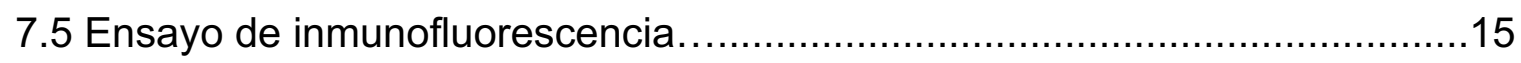

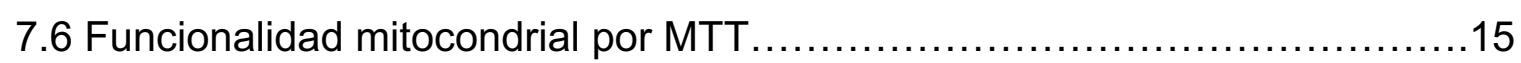

7.7 Determinación en tiempo real del metabolismo mediante

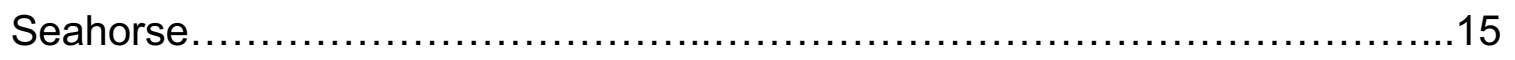

7.8 Estudio de invasión usando el modelo de membrana corioalantoidea

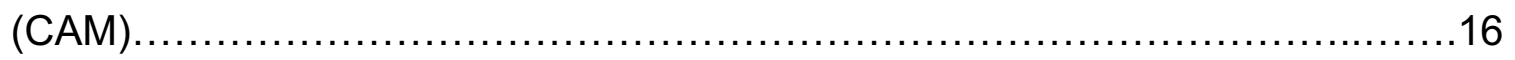

7.9 Reacción en cadena de la polimerasa acoplada a retrotranscripción

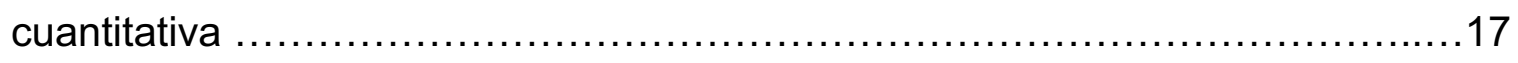

7.10 Ensayo de inmunoprecipitación..........................................17

7.11 Ensayo de proliferación celular.......................................... 18

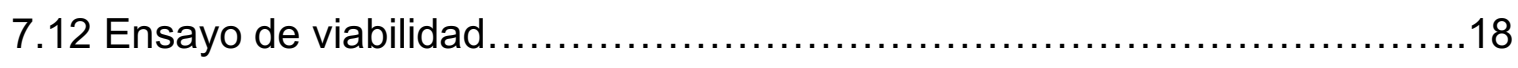

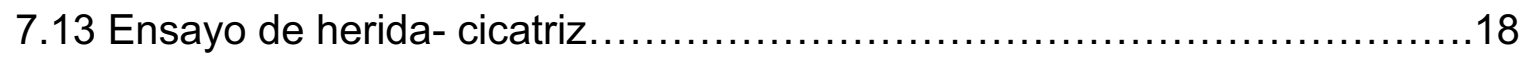

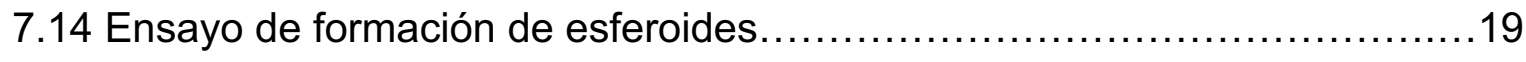

7.15 Ensayo de clonogenicidad.............................................. 19

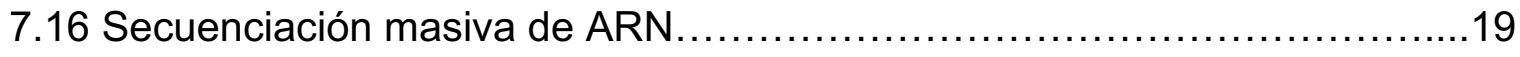

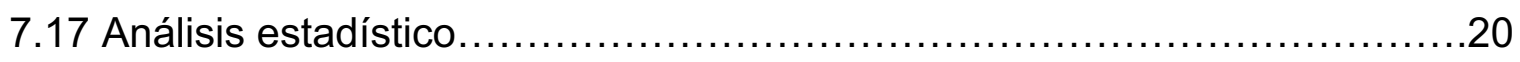

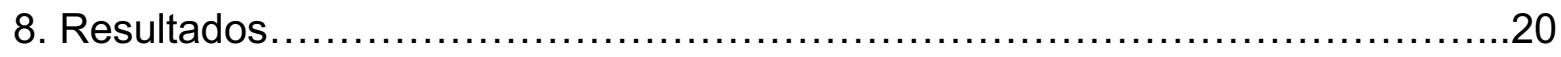

8.1 El GDF11 no afecta la viabilidad de las células de cáncer de

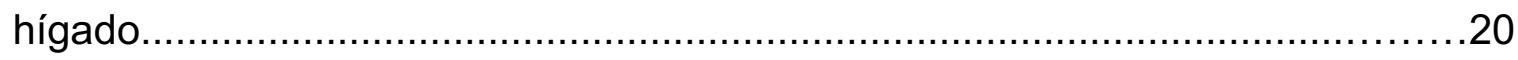

8.2 La línea celular Huh7 presenta los receptores requeridos por el

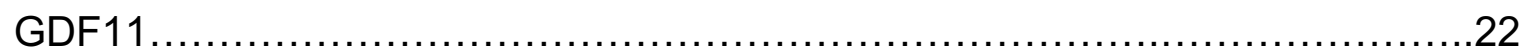


8.3 Las líneas de HCC responden al tratamiento del GDF11 mediante la activación

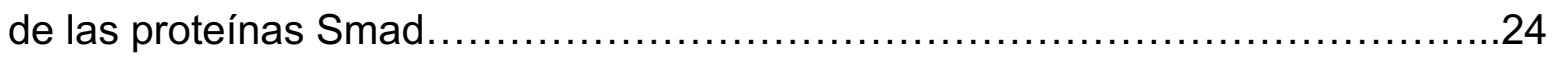

8.4 El GDF11 induce efectos antiproliferativos en las líneas celulares de

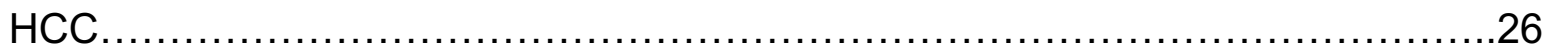

8.5 El GDF11 afecta la funcionalidad mitocondrial de las células de HCC 31

8.6 El GDF11 induce cambios transcriptómicos en la línea celular Huh7. 36 8.7 El GDF11 disminuye la capacidad de formación de esferoides de las células de HCC 39

8.8 El GDF11 disminuye la expresión de algunos genes relacionados con

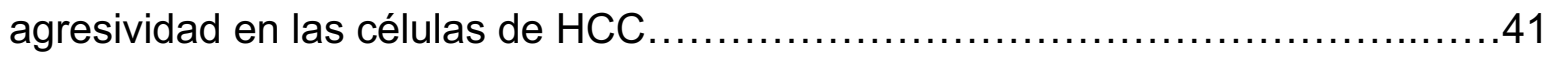

8.9 El GDF11 induce transición mesénquima epitelial............................42 8.10 El GDF11 reprime la capacidad de auto renovación de las células de

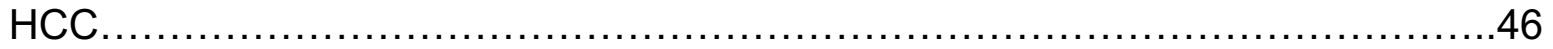

8.11 El GDF11 disminuye la migración de las células de HCC.....................50

8.12 El GDF11 disminuye la formación de esferoides en otras líneas de

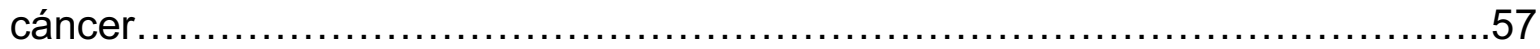

8.13 El GDF11 activa la señalización de ERK1/2 ................................60

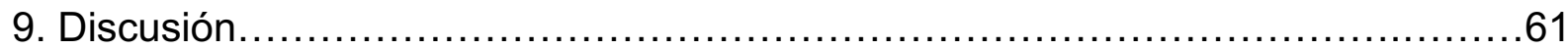

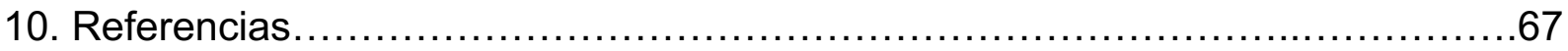

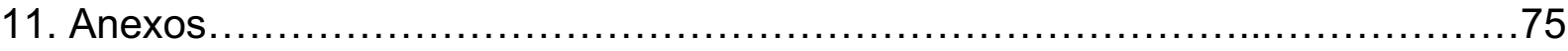




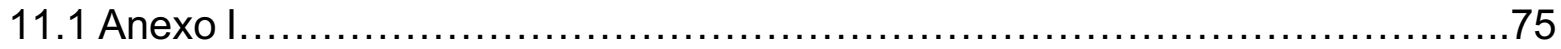

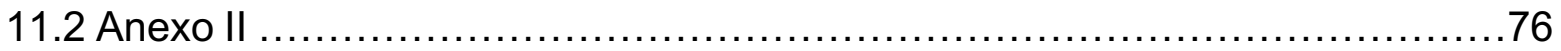




\section{Introducción}

\subsection{Generalidades del hígado}

El hígado es uno de los órganos internos más grande de nuestro cuerpo, tiene un peso promedio de $1.5 \mathrm{~kg}$ en el adulto, en él fluye aproximadamente litro y medio de sangre cada minuto, de ahí su color característico. El hígado realiza más de 500 funciones entre las que están la transformación de los alimentos en energía, la síntesis de factores de coagulación, la eliminación de sustancias tóxicas, produce la bilis que se secreta en el intestino para ayudar a absorber nutrientes que no son hidrosolubles, almacena algunas vitaminas y al glucógeno (un reservorio importante de energía). Aun cuando está especializado para llevar a cabo dichos procesos, es muy susceptible a la agresión que suele comprometer su funcionamiento adecuado.

\subsection{Principales agentes tóxicos y estadios de daño hepático}

Entre los principales agentes que lo afectan se encuentran algunas sustancias toxicas como lo son: el alcohol, fármacos, drogas, exceso de grasas y las infecciones por virus como la hepatitis B y hepatitis C.

Cuando la agresión se vuelve crónica, el órgano puede sufrir una esteatosis, si las agresiones continúan, puede progresar a un proceso de inflamación denominada esteatohepatitis, siguiendo al proceso de fibrosis, cirrosis y culminar finalmente en un hepatocarcinoma celular (HCC, por sus siglas en inglés) (Gutiérrez Ruiz et al., 2014).

El cambio en el estilo de vida de muchas personas está tendiendo a incrementar la prevalencia en las enfermedades hepáticas, como la asociada al consumo de alcohol, la esteatohepatitis no alcohólica y el cáncer hepático. 


\subsection{Estadísticas del cáncer de hígado}

El hepatocarcinoma celular (HCC, por sus siglas en inglés) es uno de los tumores con mayor prevalencia y uno de los más agresivos en todo el mundo, se posiciona como una de las principales causas de muerte por cáncer a nivel mundial (Ferlay et al., 2015; Kaposi-Novak et al., 2006; Liu et al., 2017).

En 2018, el Instituto Nacional del Cáncer en Estados Unidos hizo público en su Reporte Anual de la Nación (Cronin et al., 2018) la incidencia y mortalidad de diversos tipos de cáncer. Sorprendentemente, los datos mostraron que la gran mayoría de los tipos de cáncer han disminuido tanto en la incidencia como en la mortalidad en hombres y mujeres, encontrando que de los 18 tipos de cáncer más comunes en hombres 11 han disminuido y de los 20 tipos más comunes en mujeres 14 han disminuido, lamentablemente, no todos los tipos de canceres siguen la misma tendencia a disminuir, ya que el cáncer de páncreas, encéfalo, algunos relacionados con el sistema nervioso y el cáncer de hígado lejos de disminuir van en aumento.

El Instituto Nacional de Estadística y Geografía INEGI en México (www.inegi.org.mx) reportó en 2015 las cifras de las principales causas de muerte en hombres y mujeres, de las cuales 35,718 muertes registradas fueron causadas por enfermedades relacionadas con el hígado, de las cuales 6,333 muertes fueron por causa de tumores malignos, por lo que, lo posiciona como el tercer tipo de cáncer con mayor índice de mortalidad registrada en dicho año.

Este índice de mortalidad relacionada con enfermedades hepáticas aumenta con la edad, ya que se posiciona como el segundo lugar en hombres con edades entre 30 a 44 años, manteniendo el mismo lugar entre las edades de 45 y 59 años. En hombres 
de 60 años y más, las muertes relacionadas con las enfermedades hepáticas se posicionan como la quinta causa.

Estas cifras se mantienen en mujeres, ya que en edades entre 45 y 59 años esta causa de muerte se posiciona en el tercer lugar y en mujeres mayores a los 60 años las muertes por este padecimiento se posicionan en el sexto lugar (www.inegi.org.mx $)$.

Este incremento en la incidencia y la mortalidad es debido principalmente a la detección en etapas avanzadas de la enfermedad, y son estas etapas donde las terapias no suelen funcionar de manera óptima, por esta razón, en la actualidad uno de los principales objetivos para la ciencia es la búsqueda de nuevas terapias, que sean específicas y eficaces o bien mejoras para la detección temprana del HCC.

\subsection{Características del cáncer hepático}

El HCC se caracteriza por la proliferación descontrolada de los hepatocitos y la acumulación de mutaciones lo que conlleva a desórdenes en diversas rutas de señalización encargadas de modular procesos que confieren a las células cancerosas sobrevivencia, alteración en el metabolismo energético, resistencia a fármacos y capacidad para migrar (Hanahan et al., 2011).

\subsection{El papel de la ruta de las MAPK en el cáncer de hígado}

Una de las rutas que se encuentra afectada en HCC y que se ha reportado que juega un papel esencial es la de la familia de las MAPK (mitogen- activated protein kinase) (Mandal et al., 2016). Esta familia está conformada por aproximadamente 518 miembros y se encuentra ampliamente conservada en los seres vivos (Lu et al., 2006). 
La familia de las MAPK se encuentra orquestando procesos esenciales para las células ya que está implicada en el crecimiento y la diferenciación celular, procesos de mitosis, motilidad celular, metabolismo energético, proliferación, apoptosis, sobrevivencia, procesos de embriogénesis y en la regulación de la expresión de genes (Chen et al., 2001).

Esta ruta actúa mediante una cascada de señalización que implica la activación de intermediarios comenzando por la activación de MAPK3, esta cinasa es la encargada de fosforilar y activar al siguiente intermediario MAPK2 y esta finalmente culmina con la activación de MAPK, quien es la responsable de unirse al núcleo permitiendo la expresión de genes relacionados con los procesos anteriormente mencionados (Chang et al., 2001; Leppa et al., 1999).

Esta familia está conformada por diversos miembros, entre ellos se encuentra ERK (extracellular signal- regulated kinases), JNK y P38 (Lu et al., 2006).

ERK a su vez es una de las principales rutas de señalización debido a que también juega un papel importante en procesos como proliferación celular, diferenciación, progresión del ciclo celular, migración, motilidad, invasión, metástasis e interacción con la matriz celular (Cargnello et al., 2011; Mandal et al., 2016; Mandal et al., 2014; Roberts et al., 2007).

Principalmente la activación de esta ruta se ha relacionado con procesos de agresión como en el caso de la ingesta alta de colesterol (Gomez-Quiroz et al., 2016).

La activación de esta ruta también se lleva a cabo mediante un estímulo derivado de factores de crecimiento como el factor de crecimiento epidermal (EGF), el factor de crecimiento derivado de plaquetas (PDGF), receptores acoplados a proteínas G, 
factores mitogénicos, citocinas y proteínas G. Una vez que llega el estímulo se activará RAS, la cual se va a encargar de la activación de RAF, que a su vez activará a MEK que finalmente activa a ERK (Geest et al., 2009; Mandal et al., 2016; Mandal et al., 2014).

Se ha observado que alteraciones en esta ruta de señalización se encuentra estrechamente ligada con el 30\% de neoplasias (Gollob et al., 2006; Mandal et al., 2016). Hay reportes que indican que el oncogen RAS presenta varias mutaciones, por lo que se está trabajando en el diseño de inhibidores como posible terapia para diversos tipos de cáncer (Gollob et al., 2006).

\subsection{El papel del TGF- $\beta$ en el cáncer de hígado}

Otra de las vías que juega un papel importante en la progresión del cáncer es la de la superfamilia del factor de crecimiento transformante beta (TGF- $\beta$ ) la cual podría considerarse como un posible blanco terapéutico. Sin embargo, dado el papel dual que juega es difícil ya que en etapas tempranas de la enfermedad sus efectos suelen ser citotóxicos, mientras que en etapas avanzadas los principales efectos que suele ejercer sobre el tumor son el crecimiento, procesos de invasión y metástasis, la evasión del sistema inmune entre otros (Moon et al., 2017; Zhang, J. et al., 2016; Zhang et al., 2017).

\subsection{Generalidades del GDF11}

Uno de los miembros de la superfamilia del TGF- $\beta$ es el factor de crecimiento y 
diferenciación 11 (GDF11), quien también se encuentra en la familia de las proteínas morfogenéticas de hueso (BMP), donde es conocido como BMP11 el cual se ha asociado con efectos diferenciales en los distintos linajes celulares, mientras que en unos puede inducir citotoxicidad, en otros, puede iniciar señales de sobrevivencia (Sinha et al., 2014; Zhang et al., 2015; Zhang, Y. H. et al., 2016).

\subsection{Ruta de señalización mediada por el GDF11}

Esta proteína induce su señalización mediante un complejo tetramérico de receptores con actividad de serina treonina cinasa, este complejo de receptores está conformado por dos receptores tipo I a los que pertenecen los receptores ALK y dos receptores tipo II, entre los que se encuentran ACTRII.

Si bien, el GDF11 se encuentra entre dos familias, ambas inducen activación de proteínas Smad de manera distinta y esto se debe al tipo de receptor que se esté activando por el GDF11.

Cuando la activación es mediada por la ruta canónica del TGF- $\beta$, el GDF11 se une a Ios receptores tipo I como ALK4, ALK5 o ALK7 y a receptores tipo II como ACTRIIA o ACTRIIB (Walker et al., 2017; Williams et al., 2013).

Cuando la ruta de señalización es mediada por la familia de las BMP la activación de los receptores es distinta, ya que para esta la ruta va mediada por los receptores ALK1, ALK2, ALK3 y ALK6 (Ning et al., 2019; Zhang, Y. H. et al., 2016).

Una vez que el GDF11 se une a los receptores tipo I, estos se encargan de activar a las proteínas Smad, las cuales también son conocidas como R-Smad, nuevamente, 
según el tipo de receptores que se activen serán las encargadas de activar la ruta de las proteínas Smad, en el caso del TGF- $\beta$, la ruta activada de manera canónica esta mediada por Smad2/3 (Williams et al., 2013), para el caso de las BMP, la ruta canónica de las Smad es vía Smad 1/5 (Zhang, Y. H. et al., 2016) (Fig. 1).

Una vez activadas las proteínas R-Smad una Smad en común (Smad 4), también conocida como Co-Smad, se les une formando así un complejo que se transloca al núcleo para la expresión de diversos genes que se encargan de regular procesos relacionados con el desarrollo, diferenciación, migración y proliferación celular (Finkenzeller et al., 2015; Gaunt et al., 2013; Massague, 2012; Williams et al., 2013).

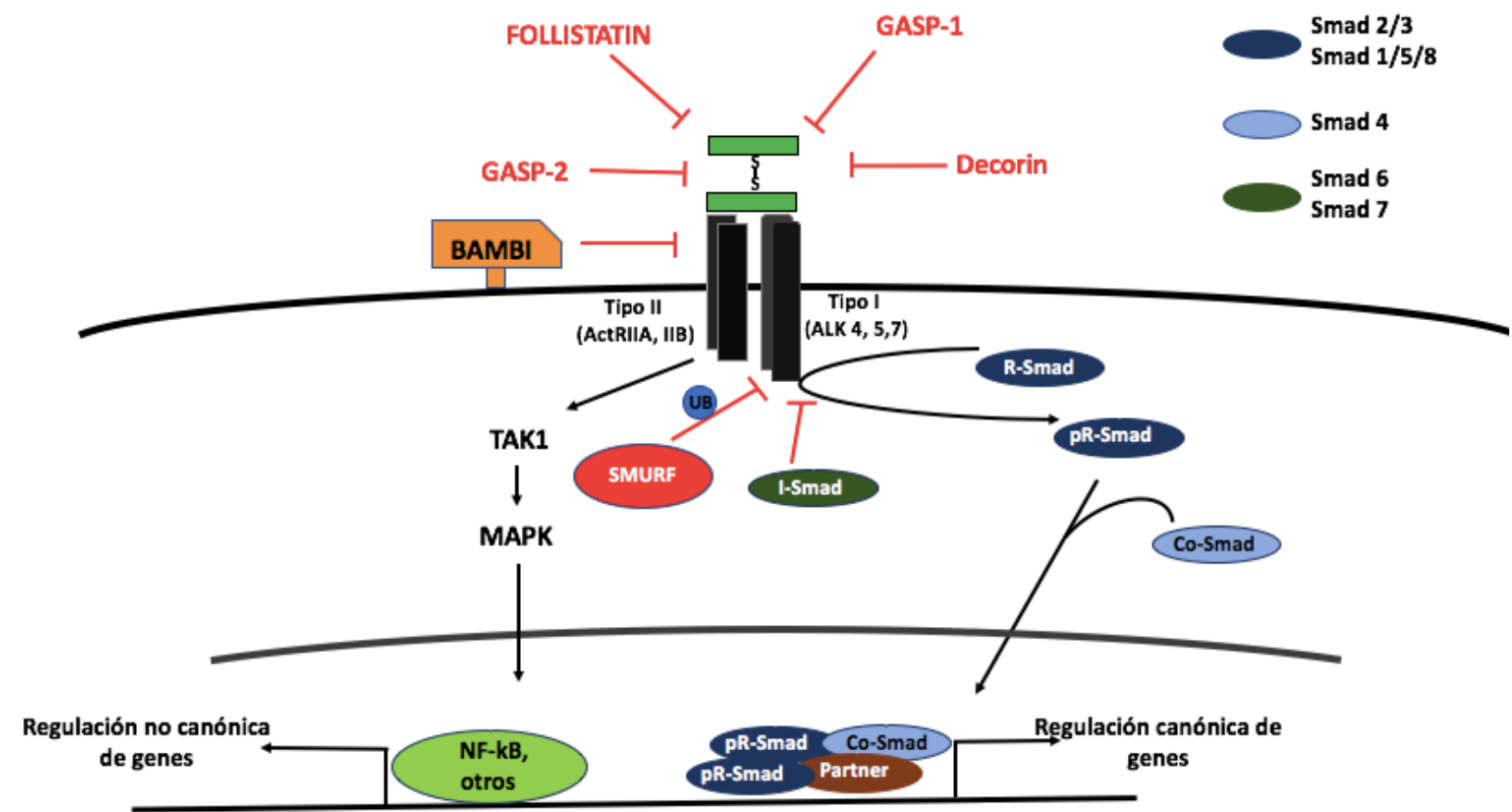

Fig. 1 Ruta de señalización mediada por el GDF11.

Si bien, esta familia se caracteriza por la amplia diversidad de receptores y ligandos, los mencionados para GDF11 tienen respuestas fisiológicas distintas comparadas con 
las respuestas producidas por la unión de otros ligandos con sus receptores correspondientes, sin embargo de las principales respuestas emitidas por GDF11 son las relacionadas con la inhibición de la neurogénesis controlando la expresión de p27, un regulador negativo del ciclo celular que interactúa con las cinasas dependientes de ciclinas, además de regular la expresión de otros genes relacionados con dicho proceso e inhibiendo la proliferación celular, también, suprime la expresión de genes implicados en la migración celular incluyendo FASCIN, LIM y LASP1, ejerce efectos sobre la activación de Hoxd11, un factor de transcripción que juega un papel importante en la morfogénesis de organismos multicelulares (Gaunt et al., 2013; Williams et al., 2013).

\subsection{Funciones del GDF11}

Entre las funciones fisiológicas del GDF11 se encuentran procesos de desarrollo, embriogénesis, diferenciación y organogénesis, regeneración del músculo esquelético, el músculo cardiaco y el sistema neural a partir de células progenitoras; y esto se lleva a cabo mediante el incremento de la proliferación y la diferenciación de las células troncales, las cuales dan origen a más células que, después de su maduración serán las encargadas de sustituir a las células dañadas cuya función se encuentra comprometida devolviendo así a los músculos sus funciones fisiológicas adecuadas (Esquela et al., 2003; McPherron et al., 1999; Nakashima et al., 1999; Sinha et al., 2014). Estos descubrimientos se determinaron mediante el uso del GDF11 recombinante en ratones viejos, donde determinaron que el uso de este factor de 
crecimiento provocó el aumento de la frecuencia de células satélites, lo cual se vio reflejado en el incremento en el mejoramiento muscular (Sinha et al., 2014).

Otro de los efectos que se han demostrado que induce esta molécula son sobre los procesos de invasión y metástasis (Finkenzeller et al., 2015; Ge et al., 2005; Gokoffski et al., 2011; Williams et al., 2013).

\section{Antecedentes}

En 2007, el grupo del Dr. Mori reportó por primera vez la relación existente entre el GDF11 y el cáncer colorectal, donde encontraron un incremento del ARNm del factor de crecimiento en muestras de pacientes con mal pronóstico. Interesantemente, este aumento se hizo más notorio en muestras de pacientes considerados con pobre pronóstico debido a la baja sobrevivencia después de la intervención quirúrgica, por esta razón se relacionó al factor como un posible marcador de agresividad (Yokoe et al., 2007).

En 2017, el grupo del Dr. Bajikar (Bajikar et al., 2017), reportó el efecto antitumorigénico de GDF11 en cáncer de mama humano triple negativo y reportaron que la presencia de dicho factor confería a las células la pérdida de la capacidad migratoria, considerada como una característica de agresividad, debido al aumento de E-cadherina, proteína que se encarga de mantener a las células epiteliales ancladas al sustrato, además, de una disminución en la proliferación celular. Efectos similares se reportaron en ratones a los cuales se le implantaron células MDA- MB- 231, dicho modelo demostró que esta línea celular presenta un aumento en la susceptibilidad a la apoptosis. Al estudiar el mecanismo por el cual se producían estos efectos 
encontraron que se debió principalmente al impedimento de la maduración de GDF11 ya que la convertasa Pcsk5, la cual es la encargada de llevar a cabo este proceso no funcionaba adecuadamente, debido a la presencia de mutaciones principalmente en sus sitios activos. Esto provocó que la célula presentara una acumulación del GDF11 inmaduro en su interior (Bajikar et al., 2017; Essalmani et al., 2008) .

Los resultados anteriores se vieron reforzados por los encontrados en el grupo del Dr. Behr, quien determinó la relación del GDF11 con el cáncer de mama, reportando que las células después del tratamiento con el factor de crecimiento perdieron la capacidad de migrar. Además, encontraron en pacientes con cáncer de mama, con un índice de recaída menor, que los niveles de expresión de GDF11 eran altos (Wallner et al., 2018).

\section{Justificación}

El HCC es una de las principales causas de muerte por cáncer a nivel mundial, mientras que, en México, las defunciones por enfermedades del hígado se posicionan en el tercer lugar, razón por la cual se ha convertido en un serio problema de salud pública. Una de las dificultades para tratar esta patología es debido a su detección tardía ya que esta suele presentarse como un padecimiento asintomático en sus etapas iniciales permitiendo el avance rápido, por lo que cuando se diagnostica, en la mayoría de los casos, las terapias comunes ya no suelen ser efectivas, siendo la principal opción el trasplante del órgano. Sin embargo, esta opción suele ser poco alentadora debido al bajo índice de donación de órganos y al riesgo que presenta. 
Por esta razón, es importante buscar nuevas terapias que sean efectivas, con menor riesgo y menos invasivas para los pacientes.

El GDF11 puede ser una buena opción terapéutica debido a los efectos antitumorales observados in vitro por lo que es importante conocer el mecanismo de acción por el cual actúa dicho factor para inducir tales efectos.

\section{Pregunta de investigación}

¿Cuál es el mecanismo desplegado por el GDF11 en la inducción de sus efectos antitumorigénicos en células de cáncer hepático humano?

\section{Hipótesis}

Por su fenotipo troncal, las células Huh7 y Hep3B responderán al GDF11 induciendo un efecto antitumorigénico medido por la regulación del metabolismo y la transición mesénquima epitelial.

\section{Objetivos}

\subsection{Objetivo general}

Caracterizar el mecanismo por el cual el GDF11 induce efectos antitumorales en células Huh7 y Hep3B derivadas de carcinomas hepatocelular humano. 


\subsection{Objetivos particulares}

- Caracterizar los efectos antitumorigénicos ejercidos por el GDF11 en células Huh7 y Hep3B derivadas de carcinomas hepatocelular humano.

- Determinar la transducción de señales en respuesta al GDF11 en células Huh7 y Hep3B.

- Caracterizar los efectos del GDF11 en la transición mesénquima epitelial.

- Evaluar las propiedades de invasión del GDF11en un modelo de membrana corioalantoidea de embriones de pollo.

- Determinar los efectos transcriptómicos globales que ejerce el GDF11 en células Huh7 por medio de RNA-seq y su relación con el fenotipo celular.

\section{Material y Métodos}

\subsection{Diseño experimental}

Se usó el factor de crecimiento y diferenciación 11 (GDF11) recombinante humano (Peprotech) a una concentración de $50 \mathrm{ng} / \mathrm{ml}$ siguiendo los protocolos (Fig. 2). 

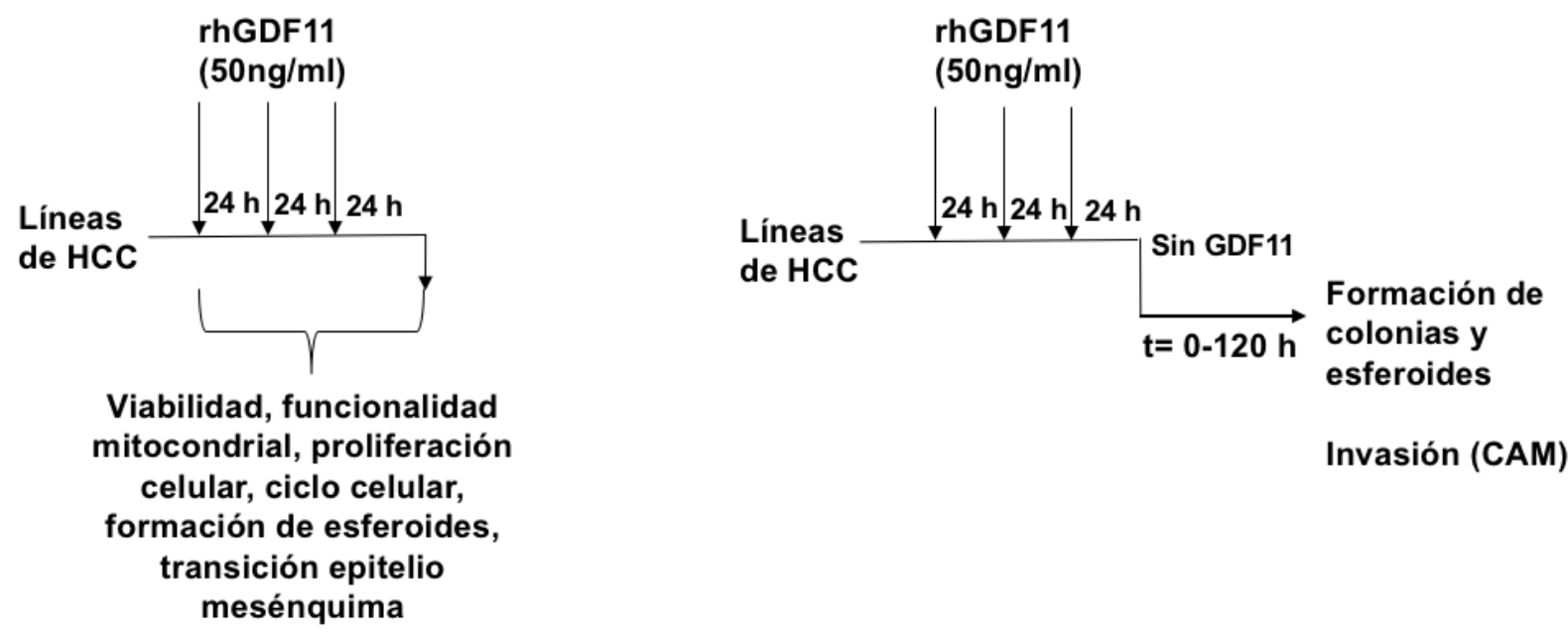

Fig. 2 Diseño experimental del proyecto desarrollado

\subsection{Cultivo celular}

Se usaron las líneas celulares Huh7, Hep3B, HepG2, SNU182 y Hepa1-6 las cuales son derivadas de carcinomas hepatocelulares, MDA-MB-231 derivadas de un carcinoma de mama y CAPAN1 derivada de un cáncer de páncreas. Todas las líneas celulares fueron obtenidas de la ATCC (Manassas, VA, USA). Se cultivaron usando medio Williams (Sigma- Aldrich, USA), con suero fetal bovino (SFB) (Hyclone, USA) al $10 \%$ y antibiótico y antimicótico (Thermo Fisher, USA) al 1\%, las células se mantuvieron al $5 \%$ de $\mathrm{CO}_{2}, 90 \%$ de humedad y $37{ }^{\circ} \mathrm{C}$. Se sembraron en botellas para cultivo de plástico (Costar Inc, USA). Todos los experimentos se realizaron en un

intervalo de pasaje 20-35. Se usó el factor de crecimiento y diferenciación 11 recombinante humano GDF11, (Peprotech Inc, USA) a una concentración de $50 \mathrm{ng} / \mathrm{ml}$ por diferentes intervalos de tiempo. 


\subsection{Cuantificación de proteína}

Se realizó la extracción de proteína usando un buffer de lisis con inhibidores de proteasas (PhosSTOP, Rocher, Complete, Rocher). Se realizó la cuantificación de la proteína mediante el estuche comercial de ácido bicinconínico (BCA, Pierce, Thermo Fisher Scientific) siguiendo el protocolo del fabricante.

\subsection{Western blot}

El western blot se realizó siguiendo el protocolo previamente reportado (EnriquezCortina et al., 2013). Se usó membrana de PVDF (Bio-Rad, USA) con los anticuerpos descritos en la tabla 1. Las membranas fueron expuestas usando Super Signal West Pico Quimioluminiscente (Pierce Biotechnology, USA). Las membranas fueron reveladas usando un Gel Logic 2500 (Kodak, Rochester, NY, USA)

\begin{tabular}{|l|l|l|l|}
\hline Anticuerpo & Dilución & Secundario & Número de catálogo \\
\hline Smad3 & $1: 1000$ & Rabbit & Abcam. Ab40854 \\
\hline pSmad3 & $1: 1000$ & Rabbit & Abcam. Ab52903 \\
\hline Smad2 & $1: 1000$ & Rabbit & Cell Signaling 5339 S \\
\hline pSmad2 & $1: 1000$ & Rabbit & Cell Signaling 3108 S \\
\hline Smad1 & $1: 1000$ & Rabbit & Cell Signaling 6944 S \\
\hline Smad5 & $1: 1000$ & Rabbit & Cell Signaling 12534 S \\
\hline pSmad1/5 & $1: 1000$ & Rabbit & Cell Signaling 9516 S \\
\hline ACVRIIA & $1: 1000$ & Rabbit & Abcam. Ab96793 \\
\hline Cyclin D1 & $1: 200$ & Rabbit & Santa Cruz. Biotechnology sc-753 \\
\hline Cyclin A & $1: 200$ & Rabbit & Santa Cruz. Biotechnology sc-751 \\
\hline Cdk6 & $1: 200$ & Rabbit & Santa Cruz. Biotechnology sc-7181 \\
\hline p27 & $1: 200$ & Rabbit & Santa Cruz. Biotechnology sc-776 \\
\hline Occludin & $1: 200$ & Mouse & Santa Cruz. Biotechnology sc-81812 \\
\hline Snail & $1: 200$ & Rabbit & Santa Cruz. Biotechnology sc-28199 \\
\hline E- Cadherin & $1: 200$ & Mouse & Santa Cruz. Biotechnology sc-21791 \\
\hline N-Cadherin & $1: 200$ & Mouse & Santa Cruz. Biotechnology sc-59987 \\
\hline ERK 1/2 & $1: 1000$ & Rabbit & Cell Signaling 4695 S \\
\hline pERK 1/2 & $1: 1000$ & Rabbit & Cell Signaling 4376 S \\
\hline Actin & $1: 10000$ & Rabbit & Millipore-Sigma A3854
\end{tabular}

Tabla. 1 Lista de anticuerpos 


\subsection{Ensayo de inmunofluorescencia}

Se realizó siguiendo el protocolo descrito (Marquardt et al., 2012). Las células fueron tratadas por diferentes intervalos de tiempo con GDF11 $(50 \mathrm{ng} / \mathrm{ml})$, posteriormente fueron fijadas con paraformaldehido al $4 \%$ en PBS (phosphate buffered saline). Las muestras fueron permeabilizadas con $0.01 \%$ con triton- $X 100$ por 30 min. $y$ bloqueadas con BSA al $3 \%$ por 30 min e incubados con los anticuerpos anti-occludin (Santa Cruz Biotechnology 81812, dilución 1:100), anti-snail (Santa Cruz Biotechnology 28199, dilución 1:100), anti-E-cadherin (Santa Cruz Biotechnology 21791, dilución 1:100) and anti-N-cadherin (Santa Cruz Biotechnology 59987, dilución 1:100). El núcleo fue teñido con DAPI. Las imágenes fueron obtenidas con un microscopio confocal (Carl Zeiss LSM- 780 NLO, Oberkochen, Alemania).

\subsection{Funcionalidad mitocondrial por MTT}

La funcionalidad mitocondrial fue medida usando bromuro de 3-(4,5-dimetiltiazol-2-il)2,5-dimetiltetrazolio mediante un ensayo de funcionalidad mitocondrial comercial (Vybrant MTT cell proliferation assay kit, Thermo Fisher Scientific) siguiendo el protocolo del fabricante.

\subsection{Determinación en tiempo real del metabolismo mediante Seahorse}

La taza del consumo de oxígeno en tiempo real de manera in vivo (OCR) y la taza de acidificación extracelular (ECAR) fue monitoreada mediante el uso del equipo Seahorse XFe24 (Seahorse Bioscience) siguiendo el protocolo estándar. La línea celular Huh7 fue tratada con GDF11 a la concentración reportada anteriormente por 
$48 \mathrm{~h}$ con medio sin SFB. Después de las $48 \mathrm{~h}$ del tratamiento, se obtuvieron 40,000 células fueron sembradas nuevamente en las placas específicas del equipo usando medio con SFB, una vez adheridas las células, se realizó el último tratamiento con GDF11 para completar las 72 h de tratamiento. Para realizar la medición en tiempo real tanto de ECAR como de OCR, las células fueron incubadas con medio de ensayo (XF Base Media) el cual fue suplementado con $2 \mathrm{mM}$ de L-glutamina seguido de una inyección de $10 \mathrm{mM}$ de glucosa, $2 \mathrm{mM}$ de oligomicina y $50 \mathrm{mM}$ de 2-deoxy-glucosa (2DG) (Glycolysis Stress test). El ECAR y el OCR fueron normalizados con el total de proteína.

\subsection{Estudio de invasión usando el modelo de membrana corioalantoidea (CAM)}

Se realizó el experimento siguiendo el protocolo reportado previamente (Quigley et al., 1998; Ribatti, 2017; Sinning et al., 2012). Se usaron huevos fértiles (Granja ALPES SA, Puebla, México), los cuales fueron separados en dos grupos de forma aleatoria. Los huevos fueron incubados a $37.8^{\circ} \mathrm{C}$ y $60 \%$ de humedad, se realizó una ventana sobre el cascaron de $1 \mathrm{~cm}^{2}$. La membrana vitelina fue diseccionada, un millón de células, tratadas y no tratadas con GDF11 por $72 \mathrm{~h}$, fueron trazadas con el colorante comercial vibrant CFDA SE cell tracer kit (Thermo Fisher Scientific) e introducidas en la CAM, entre dos vasos sanguíneos usando $30 \mu \mathrm{l}$ de matrigel (Sigma- Aldrich) como sustrato. La ventana fue cubierta con cinta adhesiva esteril y los huevos fueron incubados por 2 y 4 días. La CAM fue removida e inmediatamente fue fijada con paraformaldehido (4\%) en PBS. Las secciones en parafina fueron usadas para realizar 
las tinciones de inmunofluorescencia. El núcleo fue teñido con DAPI.

Las imágenes fueron obtenidas con un microscopio confocal (Carl Zeiss LSM- 780 NLO, Oberkochen, Alemania).

\subsection{Reacción en cadena de la polimerasa acoplada a retrotranscripción} cuantitativa

$1 \mu \mathrm{g}$ de ARN se transcribió de forma reversa usando $20 \mu \mathrm{l}$ de reacción SuperScript (Invitrogen Corp.) siguiendo el protocolo descrito por el fabricante. Los primers fueron diseñados usando Primer3 v.0.4.0 (http://frodo.wi.mit.edu/primer3/) como se reportó en (Czauderna et al., 2018). El análisis de qRT-PCR fue realizado con un CFX96 Touch (Bio-Rad) termo ciclador de reacción de placas de 96 pozos. $10 \mu$ de reacción fueron mezcladas con $5 \mu \mathrm{l}$ 2X SYBR Green PCR Master Mix (Bio-Rad), 200nM de cada primer y $1 \mu \mathrm{l}$ de cDNA. La reacción fue incubada por $10 \mathrm{~min}$ a $95^{\circ} \mathrm{C}$ seguido de 40 ciclos de 30 s a $95^{\circ} \mathrm{C}$ y 60 s a la temperatura específica del primer. El nivel de expresión de la proteína ribosomal S18 (rs18) se usó como referencia. Los niveles de expresión relativos de los genes fueron calculados usando la formula $2^{(-\Delta \Delta \mathrm{Ct})}$.

\subsection{Ensayo de inmunoprecipitación}

Se realizó siguiendo el protocolo reportado (Clavijo-Cornejo et al., 2013). Se usó la línea celular Huh7 y el GDF11 (50 ng/ml) por diferentes periodos de tiempo. Se usó el anticuerpo pSer/Thr (Abcam 17464), ACVIIA (Abcam 96793) para detectar el receptor en su forma activa. 


\subsection{Ensayo de proliferación celular}

Se realizó siguiendo el protocolo reportado (Perez-Aguilar et al., 2015). Se sembraron las líneas celulares en placas de 96 pozos estériles. Se usó el GDF11 (50 ng/ml) y se incubo por diferentes tiempos en presencia o no de SFB. La proliferación celular se midió mediante el reactivo cck-8 (Dojindo Lab, Kumamoto, Japón) siguiendo las recomendaciones del fabricante.

\subsection{Ensayo de viabilidad}

Se realizó siguiendo el protocolo reportado por (Nakagawa, 1996). Se sembraron las líneas celulares en placas de 96 pozos estériles. Se usó el GDF11 (50 ng/ml) a diferentes tiempos en presencia o no de SFB. La viabilidad celular se midió por medio de la absorbancia obtenida del cristal violeta una vez extraído con SDS.

\subsection{Ensayo de herida- cicatriz}

Se realizó el ensayo siguiendo lo reportado por (Jimenez-Salazar et al., 2014). Se sembraron las líneas células a una confluencia de $90 \%$ aproximadamente en platos de cultivo de $3 \mathrm{~cm}$. Se realizaron dos heridas usando una punta de pipetas de 1-200 $\mu \mathrm{L}$ estéril. Se realizaron lavados de forma delicada con PBS con la finalidad de remover las células no adheridas después de la realización de la herida. Las heridas realizadas fueron monitoreadas cada $24 \mathrm{~h}$. Se usó el GDF11 (50 ng/ml) por $72 \mathrm{~h}$ en presencia o no de SFB. Finalmente, una vez terminado el experimento se tomaron fotografías. 


\subsection{Ensayo de formación de esferoides}

Este ensayo se realizó siguiendo el protocolo reportado por (Perez-Aguilar et al., 2015). Se sembraron las líneas celulares en placas de baja adherencia. Se usó el GDF11 (50 ng/ml) por cinco días. Una vez terminado el tratamiento se contaron los esferoides y se tomaron fotos.

\subsection{Ensayo de clonogenicidad}

Se sembraron las líneas celulares en platos de cultivo de $6 \mathrm{~cm}$. Se usó el GDF11 (50 $\mathrm{ng} / \mathrm{ml}$ ) por $72 \mathrm{~h}$ en presencia o no de SFB. Transcurrido el tiempo, las células fueron despegadas usando tripsina y se sembraron 1000 células en placas de 6 pozos usando medio Williams con suero, pero sin la presencia del factor de crecimiento por 10 días. Al finalizar el experimento las colonias fueron teñidas con cristal violeta y se realizó el conteo de estas.

\subsection{Secuenciación masiva de ARN}

La extracción del ARN se realizó utilizando el reactivo Trizol (Thermo Fisher Scientific) siguiendo las instrucciones del fabricante.

La cantidad de ARN y la pureza se estimó utilizando un espectrofotómetro Nanodrop ND-2000c (NanoDrop Technologies, Wilmington, DE) y la integridad fue evaluada por Agilent 2100 Bioanalyzer (Agilent, Palo Alto, CA). La secuenciación del ARN se realizó utilizando la plataforma de Illumina HiSeq4000, los resultados fueron guardados en la base de datos de Bioproject. 
Las lecturas sin procesar se filtraron mediante la eliminación de secuencias adaptadoras, contaminación y calidad de lectura. Las lecturas se mapearon usando la secuencia de referencia del genoma humano (GRCh37.82) usando HISAT2 (hisat22.0.2-beta) seguido de un resumen de lectura con featureCounts (subread-1.5.0-p1). Los parámetros para el análisis de expresión diferencial fueron la tasa de descubrimiento falso (FDR) igual a 0.5 , valor $p<0.001$ y cambio de registro de pliegue de -1.5 a 1.5. Todos los análisis de datos se realizaron utilizando el lenguaje de programación $\mathrm{R}$ y paquetes relacionados. La matriz de salida de featureCounts se ingresó en el paquete Bioconductor DESeq2 para análisis de expresión diferencial.

\subsection{Análisis estadístico}

Cada experimento se llevó a cabo por triplicado en al menos tres experimentos independientes. El análisis estadístico de los resultados obtenidos se realizó mediante el análisis de varianza (ANOVA) seguido por la prueba no paramétrica Tukey para el análisis de viabilidad, funcionalidad mitocondrial mediante MTT, número de esferoides y número de colonias. La prueba t-student fue realizada para el análisis del número de esferoides.

\section{Resultados}

\subsection{EI GDF11 no afecta la viabilidad de las células de cáncer de hígado}

Debido a que el GDF11 es un miembro de la familia del TGF- $\beta$ y a dicha familia se le han atribuido efectos citotóxicos sobre las células transformadas, esto principalmente 
en etapas avanzadas del cáncer, se evaluó el impacto del GDF11 sobre la viabilidad celular, las células Huh7 y Hep3B fueron tratadas con GDF11 (50 ng/ml) por diferentes intervalos de tiempo.

Como se observa en los resultados, ambas líneas celulares no se vieron afectadas después del tratamiento, sin encontrar cambios significativos incluso $72 \mathrm{~h}$ en presencia del tratamiento (Fig. 3A y 3B)

A)

\section{Línea celular Huh7}

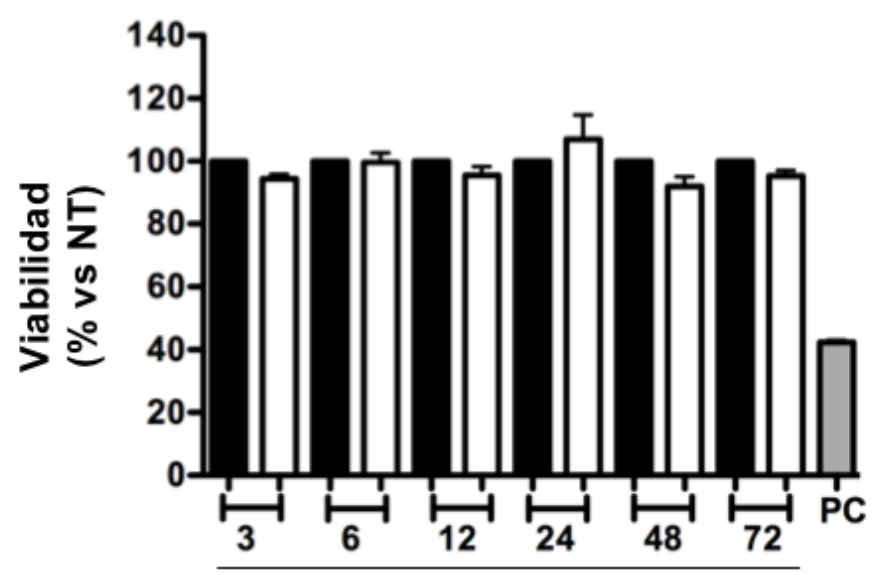

(h) GDF11 
B)

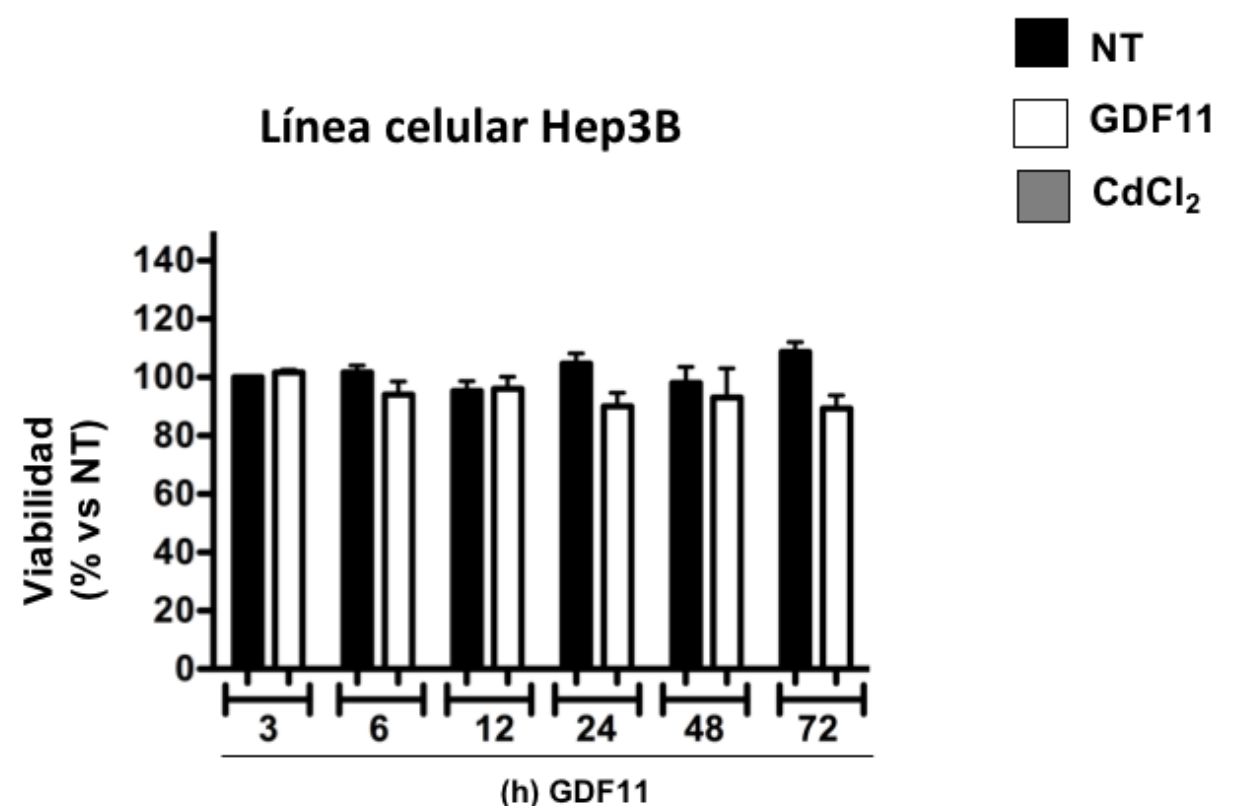

Fig. 3A y 3B El GDF11 no afecta la viabilidad de las células de cáncer de hígado. Ensayo de viabilidad celular determinado mediante cristal violeta. Se usó $\mathrm{CdCl}_{2}$ (5 $\mu \mathrm{M}$ por 6h) como control positivo (PC). Cada columna representa el promedio \pm SEM de al menos cuatro experimentos independientes por triplicado.

\subsection{La línea celular Huh7 presenta los receptores requeridos por el GDF11}

Como se pudo observar, el GDF11 no está afectando la viabilidad celular, por lo que se determinó evaluar cuales eran los receptores implicados en la señalización mediada por el factor de crecimiento. Mediante Western blot se observaron dos de los principales receptores reportados para el GDF11, ALK5, como uno de los receptores tipo I y ACTRIIA como uno de los receptores tipo II.

El resultado muestra que la línea celular Huh7 cuenta con ambos receptores del GDF11 (Fig. 4A) 
A)

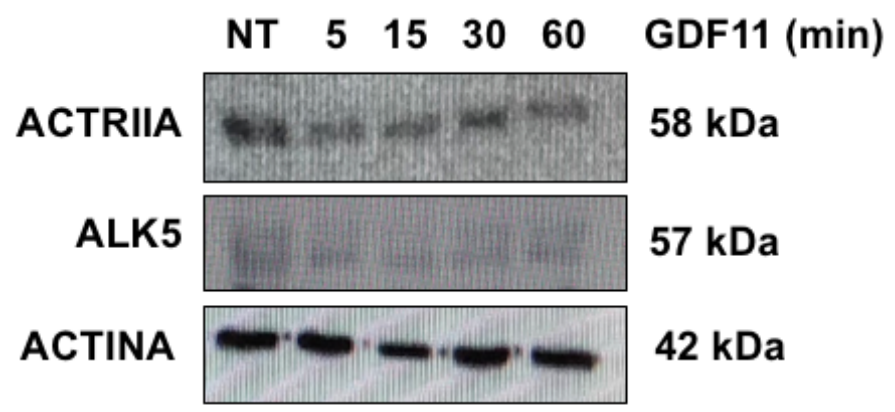

Fig. 4A La línea celular Huh7 presenta los receptores requeridos por el GDF11. Ensayo de Western blot muestra la presencia de los principales receptores usados por el GDF11. Se usó actina como control de carga.

Con la finalidad de estudiar el comportamiento de los receptores en la línea celular Huh7, se realizó un ensayo de inmunoprecipitación, el resultado muestra que el tratamiento con el GDF11 permite la activación del receptor (Fig. 4B).

B)

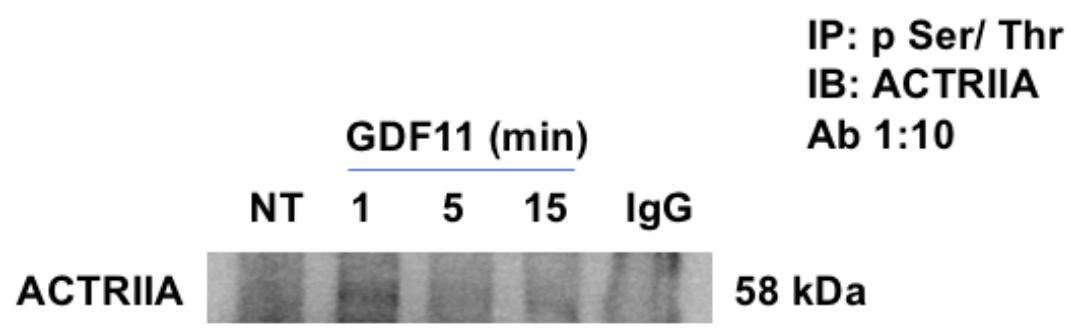

Fig. 4B La línea celular Huh7 presenta los receptores requeridos por el GDF11. Ensayo de Inmunoprecipitación, muestra activación del receptor ACTRIIA. Imagen representativa de al menos tres experimentos independientes. 


\subsection{Las líneas de HCC responden al tratamiento del GDF11 mediante la activación de las proteínas Smad}

Debido a que el GDF11 es un miembro de la superfamilia del TGF- $\beta$ y de la familia de las BMP, a continuación, se evaluó cuál de las vías canónicas de ambas familias se encontraban implicadas en los procesos observados por el GDF11 mediante su activación.

Se realizó un ensayo de Western blot para determinar las proteínas Smad activadas en la línea celular Huh7. Los resultados muestran la activación de las proteínas Smad2 y Smad3 a partir de los 5 minutos del tratamiento, esta ruta es activada de manera canónica por el TGF- $\beta$. Sin embargo, las proteínas río abajo de la familia de las BMP (Smad1 y Smad5) no participan en la señalización del GDF11 en la línea celular Huh7 ya que estas no muestran cambios después de la administración del factor de crecimiento, encontrando, además, la activación de ambas proteínas en el grupo control (Fig. 5A). En la línea celular Hep3B la activación de las proteínas Smad2 y Smad3 es a partir de los 15 minutos después de la administración del GDF11, sin embargo, también se observa la activación de las proteínas Smad1 y Smad5 a los

mismos tiempos que las proteínas canónicas de la familia del TGF- $\beta$, este resultado sugiere que la línea celular Hep3B induce efectos utilizando las dos rutas canónicas del GDF11 sin mostrar alguna preferencia por la señalización de ambas familias (Fig. $5 B)$. 
A)

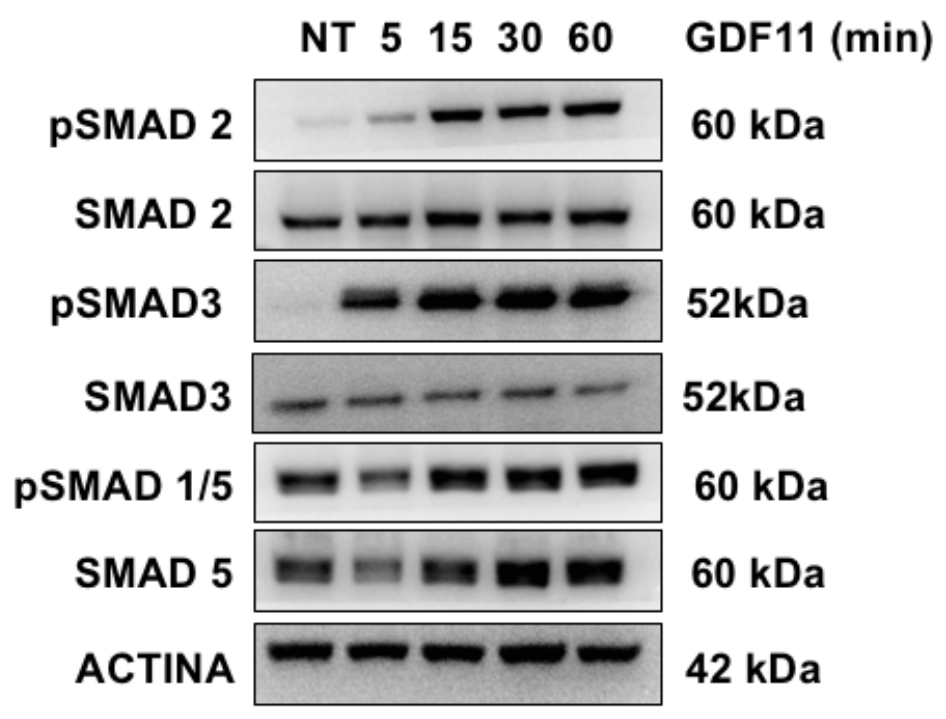

Fig. 5 Las líneas de HCC responden al tratamiento del GDF11 mediante la activación de las proteínas Smad. A) Ensayo de Western blot muestra la activación de las proteínas Smad2/3 sin encontrar cambios en la activación de las proteínas Smad1/5 en la línea celular Huh7. Imágenes representativas de al menos tres experimentos independientes.

B)

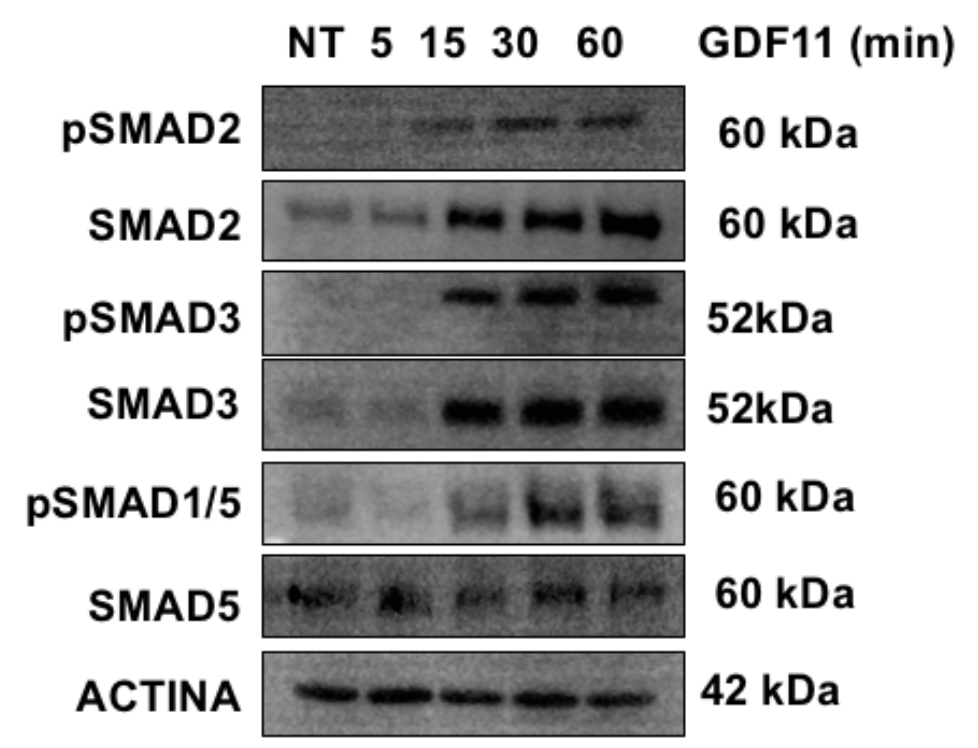

Fig. 5 Las líneas de HCC responden al tratamiento del GDF11 mediante la activación de las proteínas Smad. B) Ensayo de Western blot muestra la activación de las proteínas Smad2/3 además de la activación de las proteínas Smad1/5 en la línea celular Hep3B. Imágenes representativas de al menos tres experimentos independientes. 


\subsection{EI GDF11 induce efectos antiproliferativos en las líneas celulares de HCC}

Posteriormente se evaluó el efecto del GDF11 sobre la proliferación, si bien, resultados anteriores mostraron que no había efectos sobre la viabilidad se evaluó sí el tratamiento afectaba la proliferación de las líneas provenientes de un cáncer de hígado humano.

Los resultados muestran que el GDF11 disminuye la proliferación en ambas líneas celulares, encontrando que en las células Huh7 disminuye la proliferación de manera significativa hasta las $72 \mathrm{~h}$ de tratamiento, estos experimentos se realizaron en presencia o no de SFB, el cual fue utilizado como un agente mitogénico, permitiendo así la progresión acelerada de la proliferación celular (Fig. 6A y 6B).

A)

-/SFB

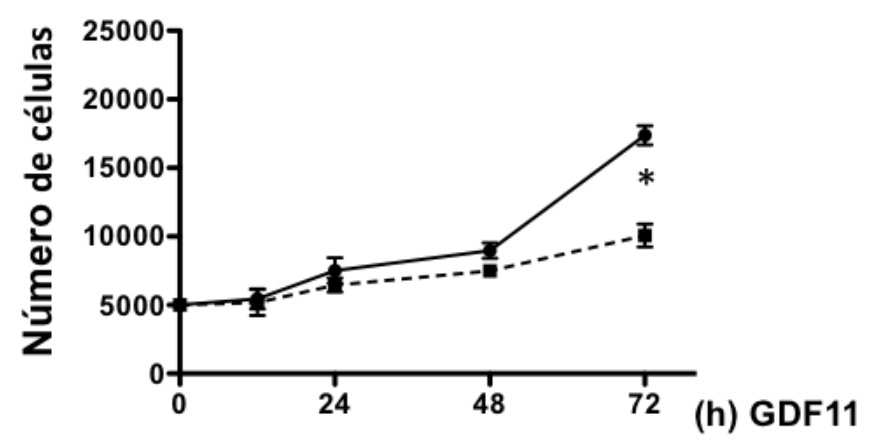


B)
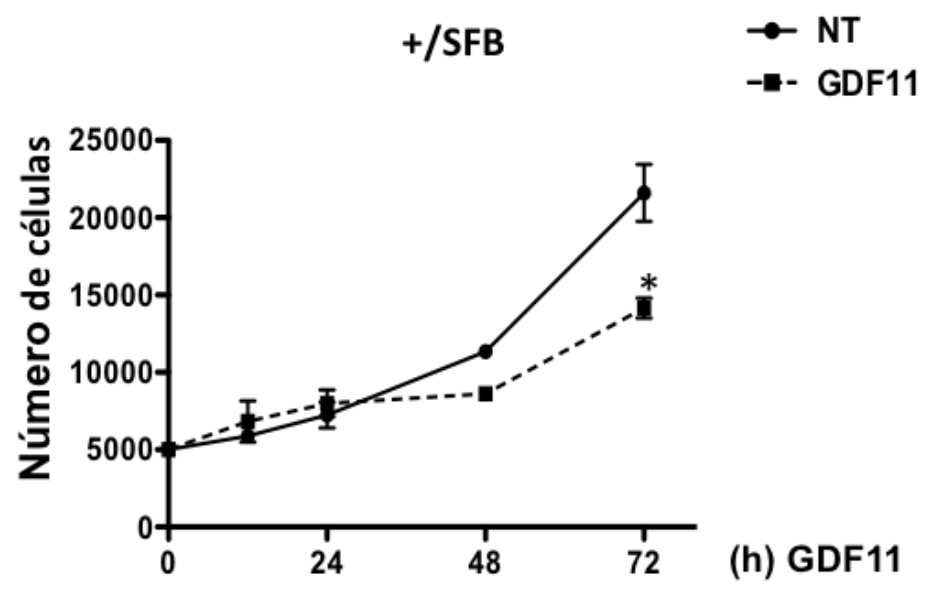

Fig. 6 EI GDF11 induce efectos antiproliferativos en las líneas celulares de HCC. A) Ensayo de proliferación celular muestra que el GDF11 induce la disminución de la proliferación sin la presencia de SFB. B) Ensayo de proliferación en presencia de SFB en la línea celular Huh7. Cada punto representa el promedio \pm SEM de al menos cuatro experimentos independientes por triplicado. ${ }^{*} p<0.05$ vs NT

Efectos similares fueron observados en las células Hep3B, donde la disminución en la proliferación se vio reflejada después de $72 \mathrm{~h}$ con el tratamiento, nuevamente, estos resultados se realizaron en presencia o no de SFB (Fig. 6C y 6D). Si bien, en ambos grupos (-/SFB, +/SFB) se observó disminución en la proliferación, los resultados fueron significativos cuando el experimento se realizó en presencia de SFB. 
C)

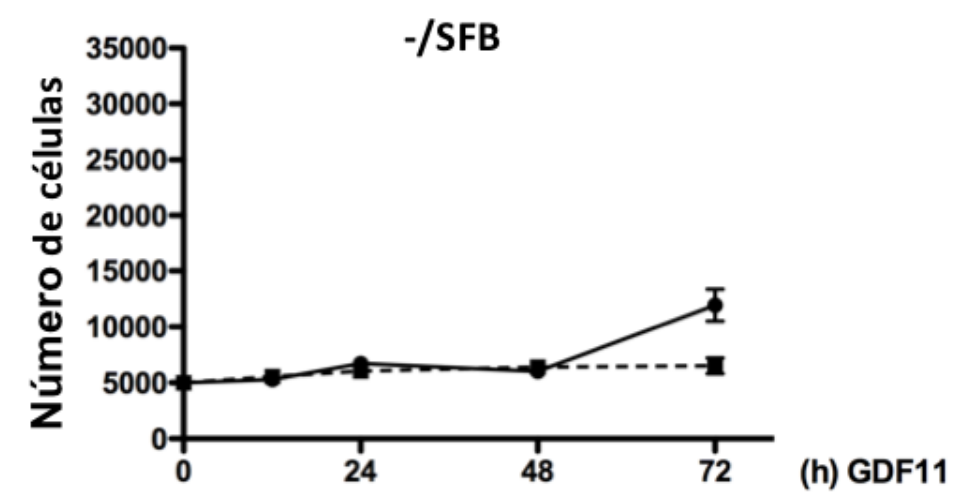

D)

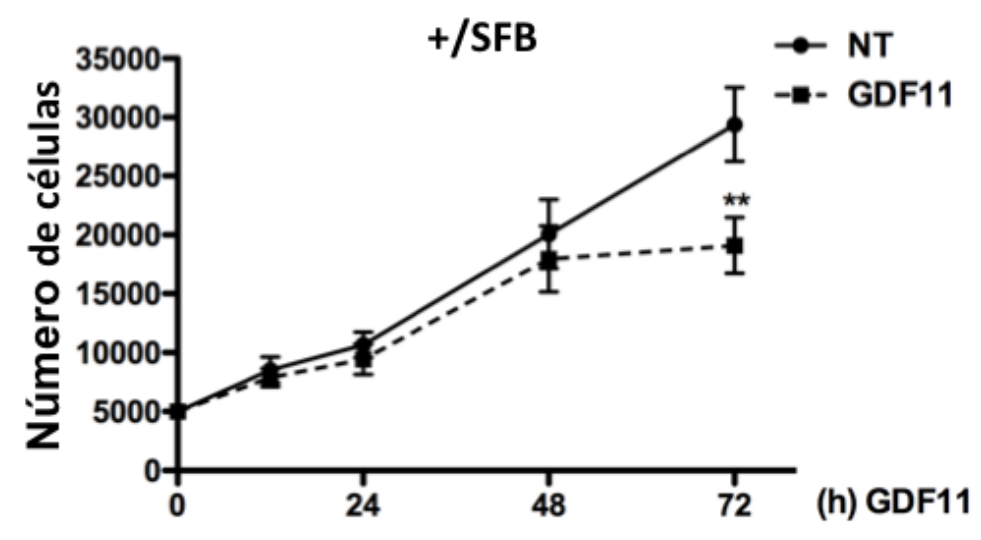

Fig. 6 El GDF11 induce efectos antiproliferativos en las líneas celulares de HCC. C) Ensayo de proliferación celular muestra que el GDF11 induce la disminución de la proliferación sin la presencia de SFB. D) Ensayo de proliferación en presencia de SFB en la línea celular Huh7. Cada punto representa el promedio $\pm S E M$ de al menos cuatro experimentos independientes por triplicado. ${ }^{* *} p<0.05$ vs NT

A continuación, se realizó además un ensayo de herida cicatriz con la finalidad de observar de manera indirecta los efectos sobre la proliferación celular, ya que dicho ensayo nos sugiere además afectos sobre la migración. Como se puede observar en las imágenes, ambas líneas celulares que estuvieron en presencia del GDF11 disminuyeron de manera notoria el cierre de la herida realizada comparada con las 
células control, las cuales, como se puede observar, después de $72 \mathrm{~h}$ la herida realizada estaba cerrada en su gran mayoría, observando efectos similares a la herida realizada en el tiempo cero (Fig. 6E y 6F).

E)
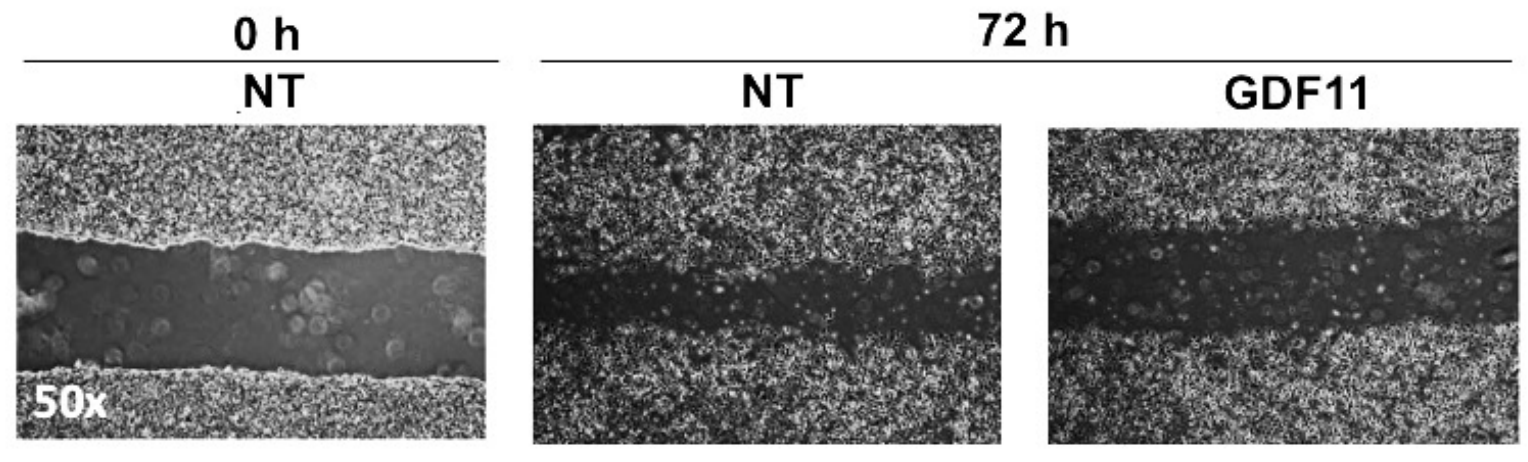

Fig. 6 EI GDF11 induce efectos antiproliferativos en las líneas celulares de HCC. E) Ensayo de herida cicatriz muestras que el tratamiento con el GDF11 retrasa el cierre de la herida en la línea celular Huh7. Imágenes representativas de al menos tres experimentos independientes.

F)

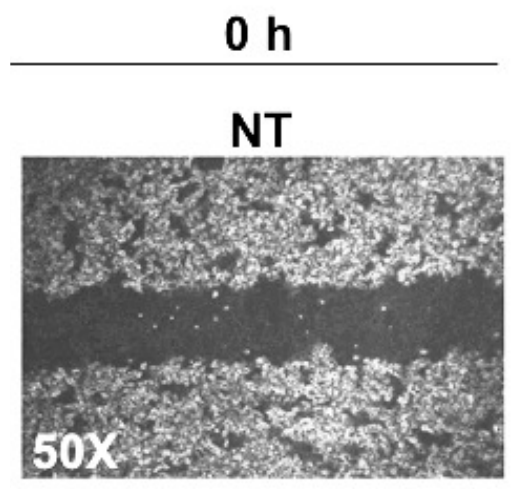

$72 \mathrm{~h}$

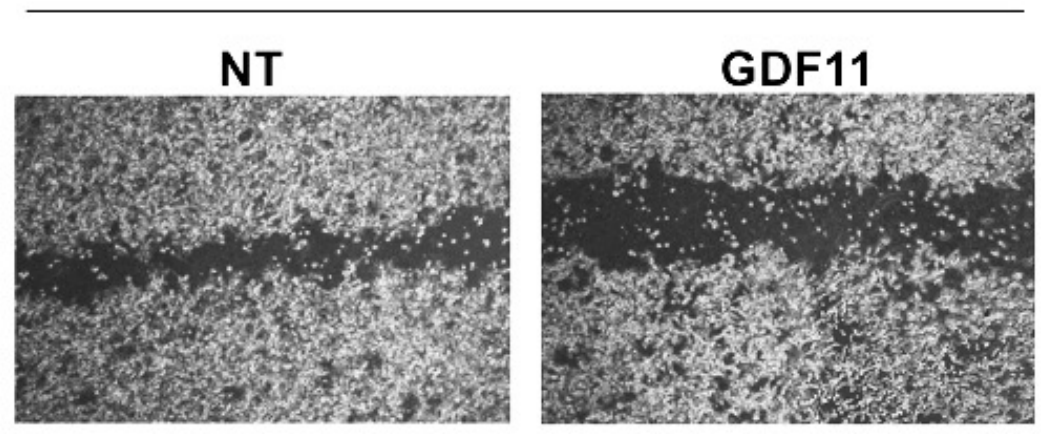

Fig. 6 El GDF11 induce efectos antiproliferativos en las líneas celulares de HCC. F) Ensayo de herida cicatriz muestras que el tratamiento con el GDF11 retrasa el cierre de la herida en la línea celular Hep3B. Imágenes representativas de al menos tres experimentos independientes. 
Para corroborar el efecto de la disminución en la proliferación celular y el cierre del ensayo de herida cicatriz, se decidió observar mediante un ensayo de Western blot algunas proteínas implicadas en la regulación del ciclo celular. Como se puede observar, algunas de las principales proteínas que se encargan de regular de manera positiva, permitiendo la progresión del ciclo celular, como ciclina A, ciclina D1 y la cinasa dependiente de ciclina (cdk6) se encuentran disminuidas después del tratamiento con el GDF11 en el transcurso del tiempo, observándose un mayor efecto después de $72 \mathrm{~h}$ con el tratamiento, mientras que la proteína p27, uno de los reguladores negativos del ciclo celular se encuentra aumentado con el tiempo.

Este resultado nos sugiere porque la proliferación se encontró disminuida (Fig. 6G y $6 \mathrm{H})$.

G)

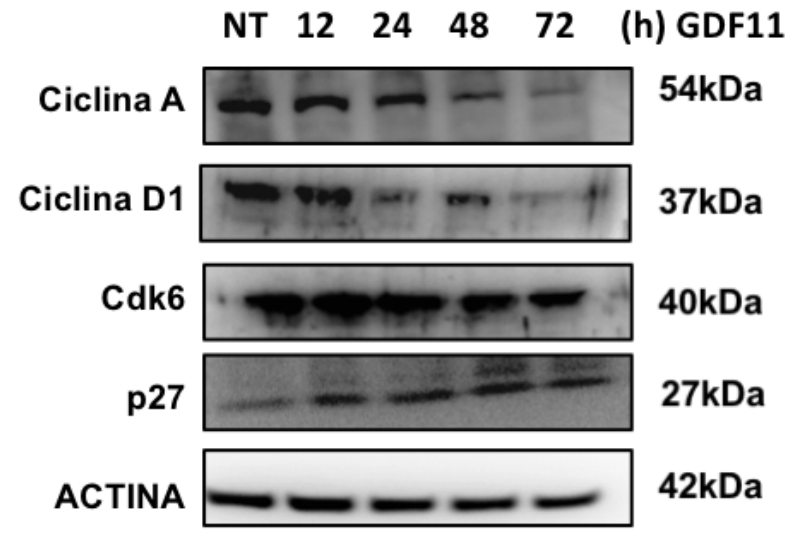


H)
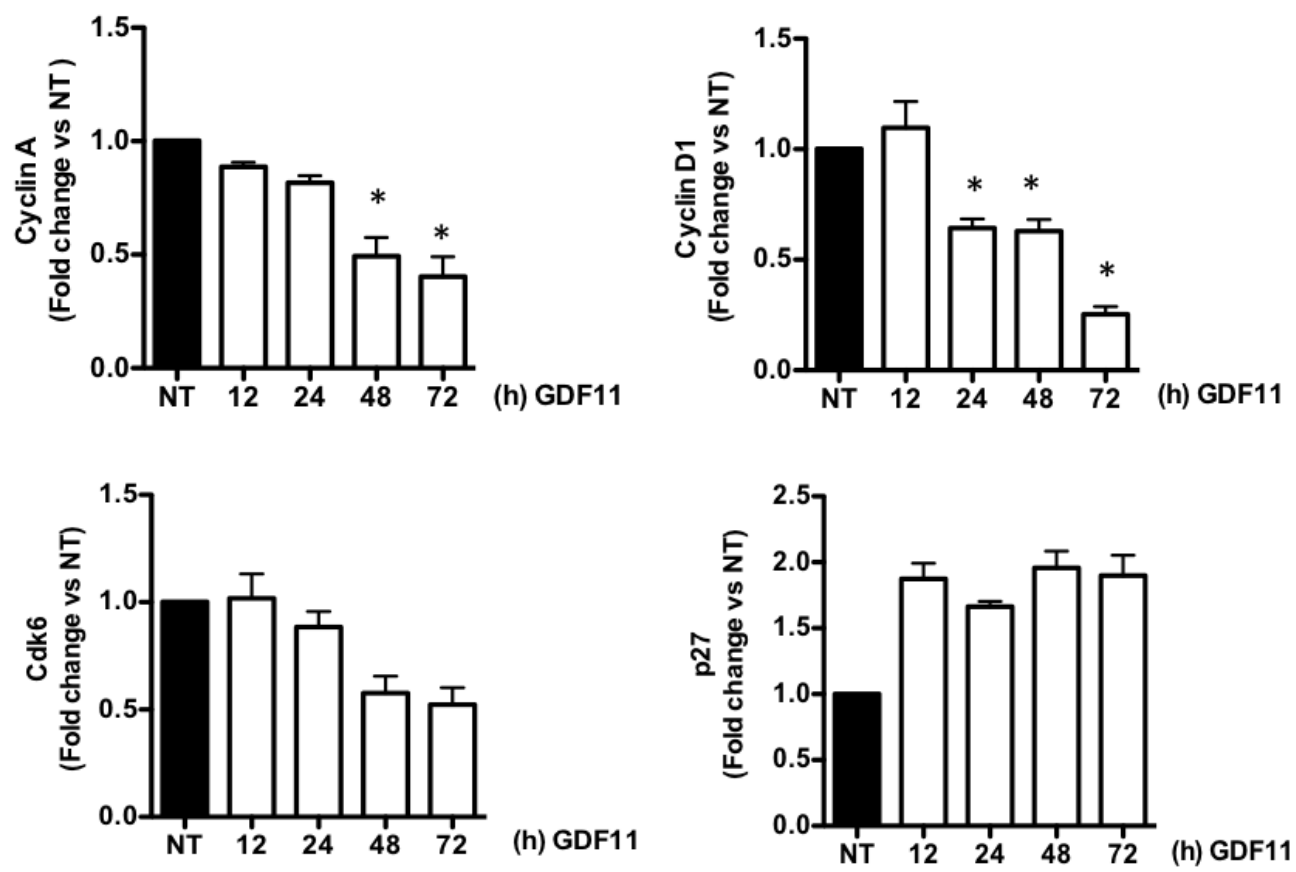

Fig. 6 El GDF11 induce efectos antiproliferativos en las líneas celulares de HCC. G) Ensayo de Western blot muestra la disminución de las principales proteínas regulatorias del ciclo celular y la sobreactivación de $p 27$, regulador negativo del ciclo celular, en la línea celular Huh7. H) Densitometría de las imágenes del ensayo de Western blot. Imagen representativa de al menos tres experimentos independientes.

\subsection{EI GDF11 afecta la funcionalidad mitocondrial de las células de HCC}

Si bien, el GDF11 no estaba afectando la viabilidad celular, pero si estaba afectando la proliferación, se decidió evaluar la funcionalidad mitocondrial por MTT de las células derivadas de HCC.

Como se puede observar, el tratamiento con el GDF11 provoco la disminución de la funcionalidad mitocondrial de la línea celular Huh7, observándose la diferencia de manera significativa a partir de las $24 \mathrm{~h}$ en presencia del tratamiento y observándose 
el punto con mayor efecto después de las $72 \mathrm{~h}$ en presencia del tratamiento en comparación con las células que no recibieron el tratamiento (Fig. 7A).

A)

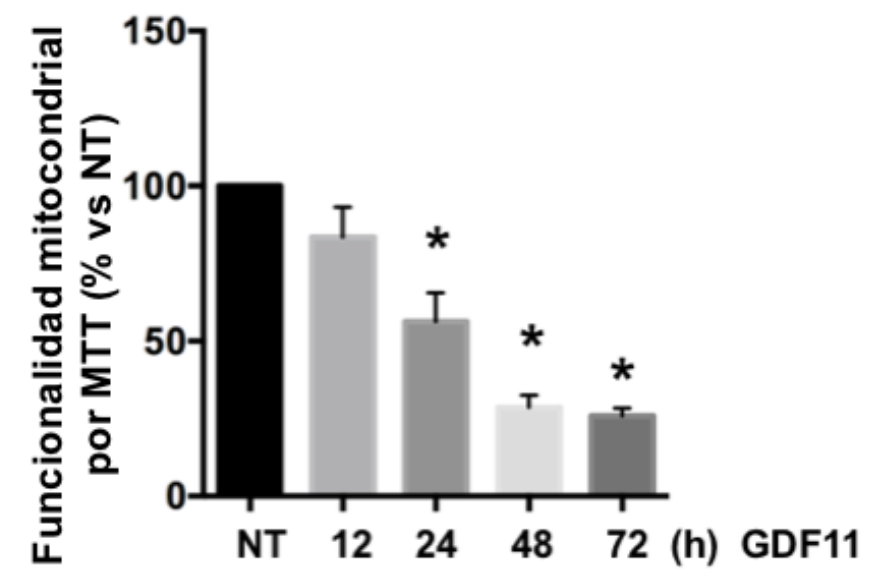

Fig. 7 El GDF11 afecta la funcionalidad mitocondrial de las células de HCC. A) Ensayo de funcionalidad mitocondrial por MTT en la línea celular Huh7 muestra la disminución después del tratamiento con GDF11, viéndose efecto desde las $24 h$, encontrando mayor efecto hasta las $72 \mathrm{~h}$. Cada columna representa el promedio \pm SEM de al menos cuatro experimentos independientes por triplicado. ${ }^{*} p<0.05$ vs NT

Efectos similares fueron encontrados en la línea celular Hep3B, donde al igual que en la otra línea celular, se observa la disminución de la funcionalidad, encontrando la disminución de manera significativa a partir de las 48 h de tratamiento (Fig. 7B). 
B)

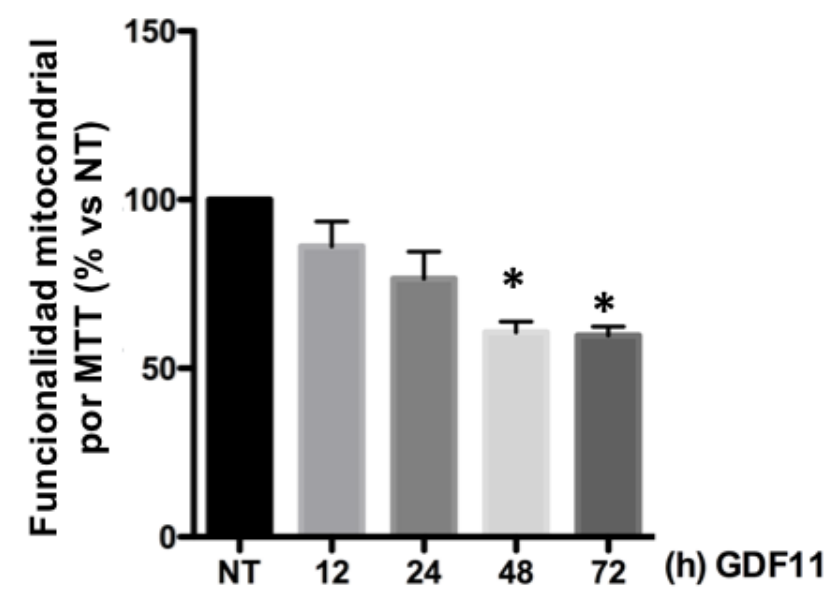

Fig. 7 El GDF11 afecta la funcionalidad mitocondrial de las células de HCC. B) Ensayo de funcionalidad mitocondrial por MTT en la línea celular Hep3B muestra la disminución después del tratamiento con GDF11, viéndose mayor efecto hasta las $72 \mathrm{~h}$. Cada columna representa el promedio \pm SEM de al menos cuatro experimentos independientes por triplicado. ${ }^{*} p<0.05$ vs NT

Nuevamente, los efectos fueron más notorios en la línea celular Huh7, estos efectos pueden deberse al grado de diferenciación que tienen las células, sugiriéndonos que la línea celular Hep3B es de un fenotipo más agresivo en comparación con la línea celular Huh7.

El ensayo de funcionalidad mitocondrial mediante MTT nos sugiere fuertemente que dicho proceso se encuentra comprometido, pero para ganar más certeza sobre los efectos que induce el GDF11 sobre la funcionalidad mitocondrial, específicamente sobre el metabolismo energético, se analizaron parámetros como ECAR, mediante la medición de la producción de lactato, indicándonos los efectos sobre la glucolisis y OCR, el parámetro relacionado con la fosforilación oxidativa, estos parámetros fueron medidos usando el equipo Seahorse Agilent. 
Las células que habían recibido el tratamiento con el GDF11 por $72 \mathrm{~h}$, como se puede observar en la gráfica, se muestra la disminución del parámetro ECAR, observando además una disminución en la respuesta de las células en presencia de glucosa, resultado que además muestra que las células presentan la disminución en el glucolisis, aunado a la disminución en la capacidad glucolítica. Mientras que las células del grupo control muestran una actividad glucolítica mejor, lo cual se relaciona con la capacidad proliferativa alta, una de las principales características de las células cancerosas (Fig. 7C y 7D).

C)

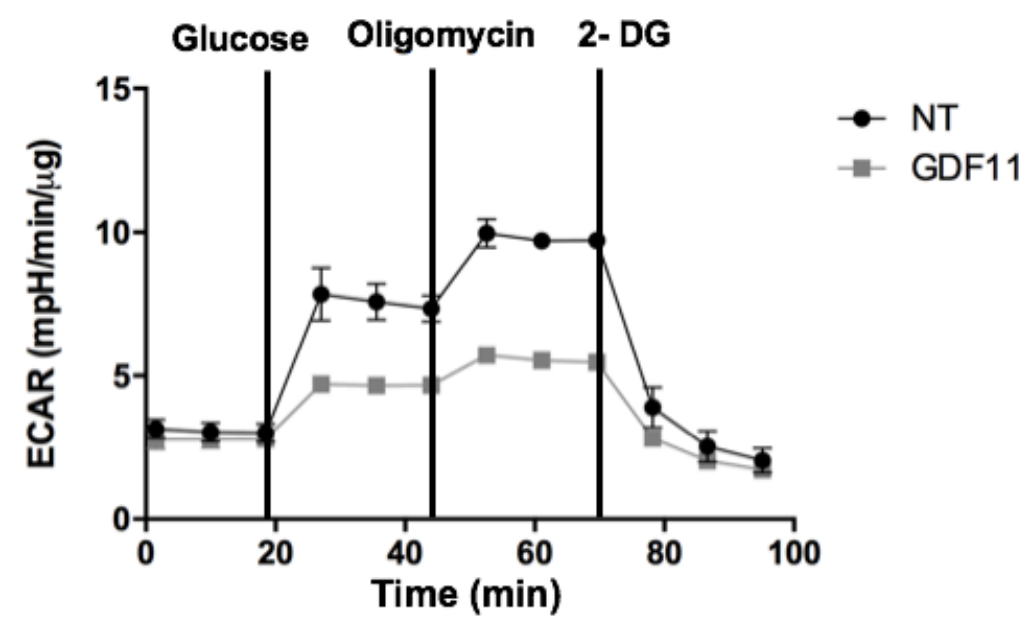

Fig. 7 El GDF11 afecta la funcionalidad mitocondrial de las células de HCC. C) ECAR, determina la producción de lactato y glucolisis en la línea celular Huh7. 
D)

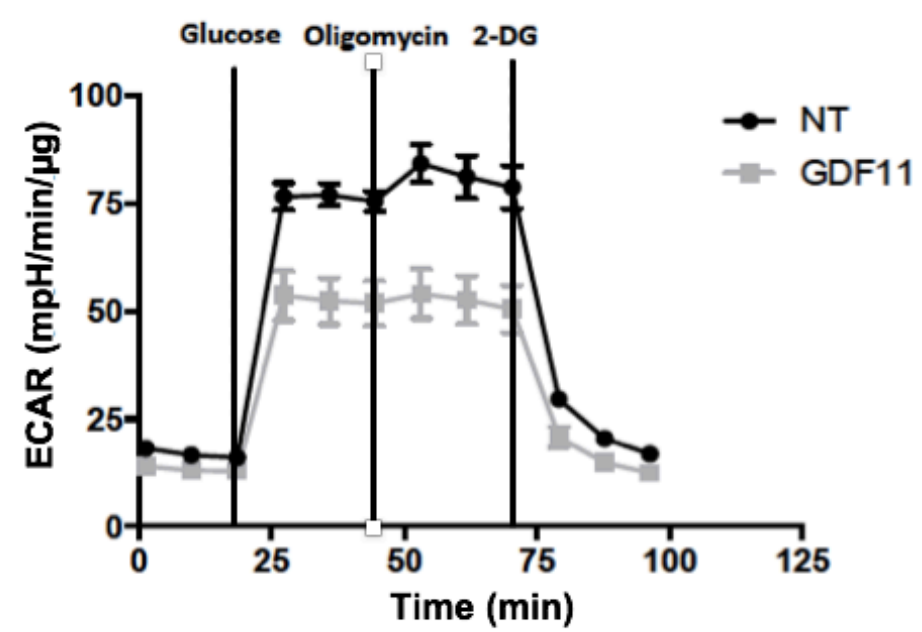

Fig. 7 El GDF11 afecta la funcionalidad mitocondrial de las células de HCC. D) ECAR, determina la producción de lactato y glucolisis en la línea celular Hep3B.

Las mediciones obtenidas del OCR, de las células que fueron tratadas con el GDF11 presentaron una disminución en dicho parámetro comparado con las células que no recibieron el tratamiento. La respiración mitocondrial basal fue normalizada restando el OCR no mitocondrial esto en presencia del inhibidor oligomicina $A$, el cual se observa disminuido de manera significativa en las células tratadas con el GDF11 (Fig. 7E).

E)

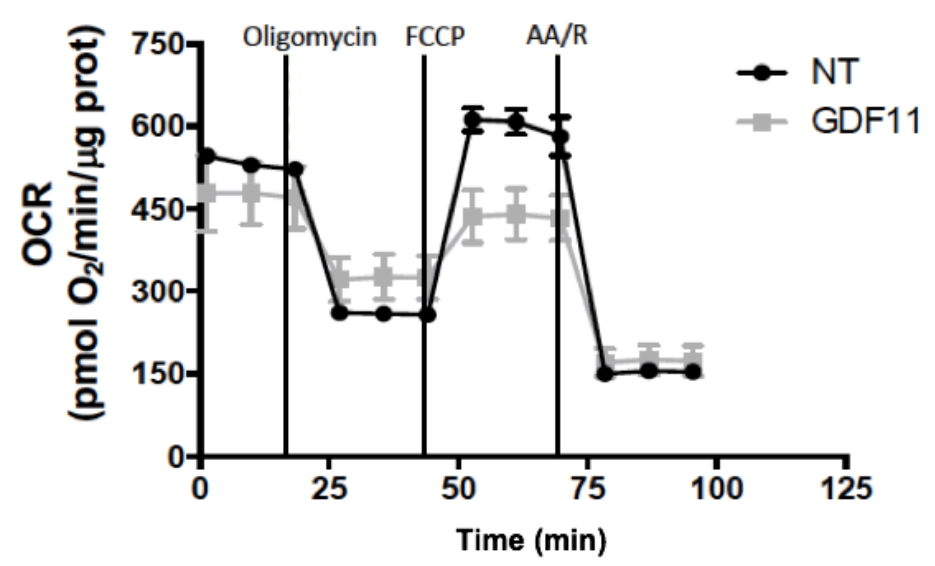

Fig. 7 El GDF11 afecta la funcionalidad mitocondrial de las células de HCC. E) OCR, medición de la fosforilación oxidativa en las células Huh7. 
F)

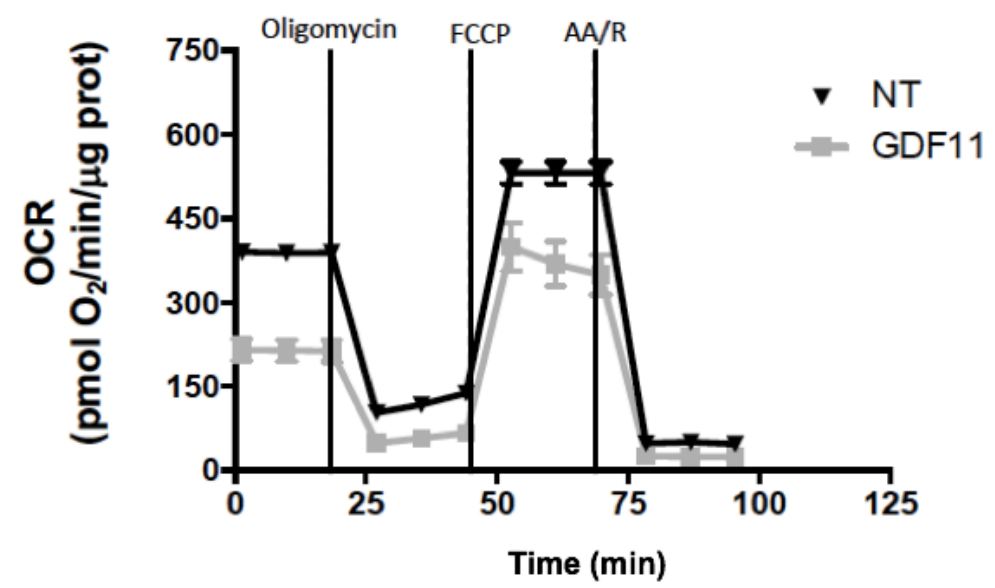

Fig. 7 El GDF11 afecta la funcionalidad mitocondrial de las células de HCC. F) OCR, medición de la fosforilación oxidativa en las células Hep3B.

Estos resultados nos mostraron que el GDF11 está jugando un papel importante en la regulación del metabolismo energético, estos resultados se relacionan con la disminución en la proliferación, debido a que el principal organelo encargado del suministro de energía se encuentra comprometido, si bien, las mitocondrias en cáncer suelen mostrar una menor capacidad energética, el GDF11 está aumentando los efectos de la disfunción mitocondrial.

\subsection{El GDF11 induce cambios transcriptómicos en la línea celular Huh7}

Se realizó un análisis de secuenciación masiva de ARN con la finalidad de obtener un panorama global de los genes regulados de manera diferencial en las células Huh7 después del tratamiento con el GDF11 por 3 días.

Los resultados mostraron que el tratamiento provocó la desregulación de 32 genes, mientras que 101 genes fueron sobreregulados (Fig. 8A y Anexo I). 
Por medio de un análisis no supervisado, mediante un mapa de calor se pudo observar la separación eficiente de ambos grupos (Control contra GDF11) (Fig. 8B).

Finalmente, un análisis de enriquecimiento mediante una ontología genética (GO) evaluada mediante el uso del programa IPA (Ingenuity Pathway Analysis) nos mostró que dentro de las principales rutas alteradas con el tratamiento del GDF11 se encontraban aquellas relacionadas con el metabolismo del colesterol y su regulación, estrés del retículo endoplasmático entre otros procesos (Fig. 8C).

A)

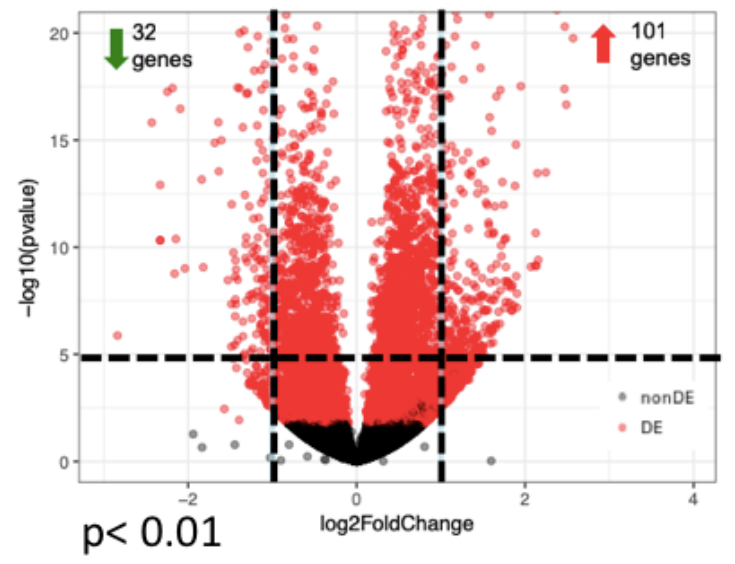


B)

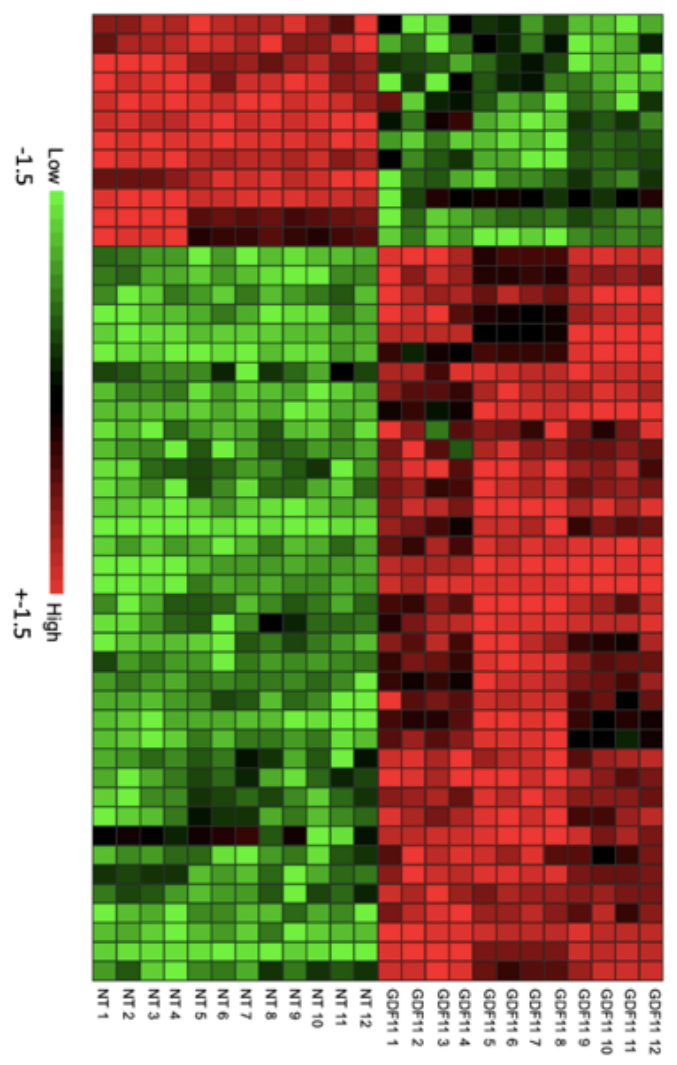

C)

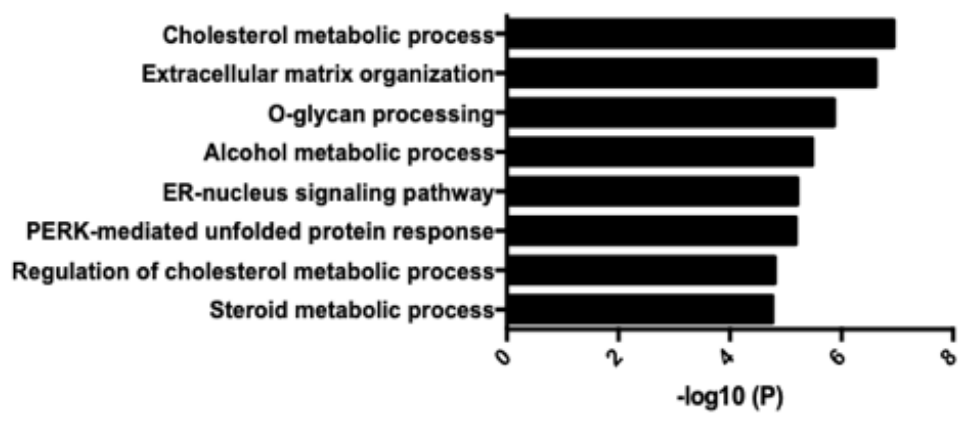

Fig. 8 El GDF11 induce cambios transcriptómicos en la línea celular Huh7. A) Gráfica de volcán. B) Análisis no supervisado (haet map), expresión diferencial entre las células control contra las células tratadas con GDF11 por $72 \mathrm{~h}$. Un total de 133 genes expresados diferencialmente, 32 genes desregulados (en verde) y 101 genes sobreregulados (en rojo). C) Análisis de enriquecimiento. Principales rutas de señalización afectadas por el tratamiento del GDF11 determinado mediante el software IPA. 


\subsection{El GDF11 disminuye la capacidad de formación de esferoides de las células de HCC}

Debido a que los resultados anteriormente presentados sugieren que el GDF11 induce efectos antitumorigénicos, se realizó un ensayo de formación de esferoides. Ambas líneas celulares fueron tratadas con GDF11 cada 24 h por cinco días.

Los resultados muestran que ambas líneas pierden la capacidad de formar esferoides, ya que las células que estuvieron en presencia del factor de crecimiento formaron una menor cantidad de esferoides $339 \%$ en las células Huh7 comparados con las células controles) (Fig. 9A).

A)

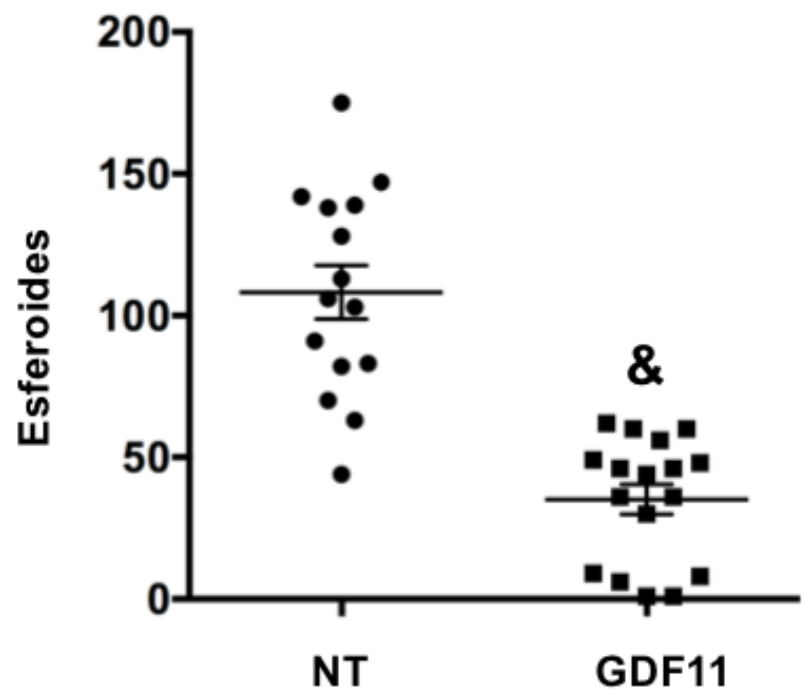

Fig. 9 El GDF11 disminuye la capacidad de formación de esferoides de las células de HCC. A) Ensayo de formación de esferoides muestra que el GDF11 disminuye la formación de esferoides de las células Huh7. Cada punto representa un experimento independiente, se reportó la media \pm SEM de al menos cuatro experimentos independientes por triplicado. \& $p<$ 0.05 vs NT 
Mientras que en las células Hep3B los resultados obtenidos fueron similares ya que esta línea celular en presencia del GDF11 formo una menor cantidad de esferoides (34\% comparados con las células controles) (Fig. 9B).

B)

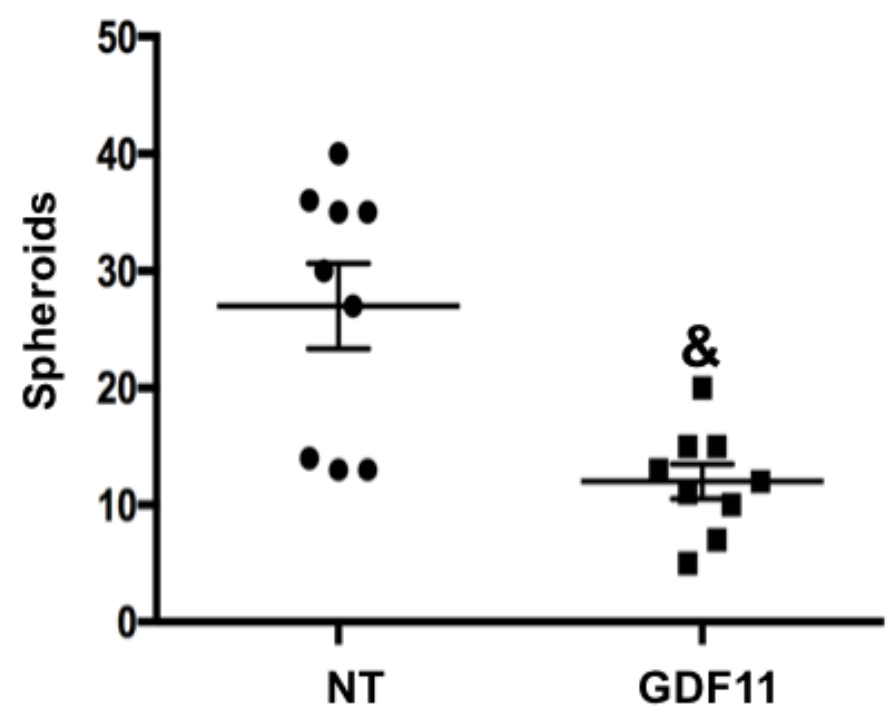

Fig. 9 El GDF11 disminuye la capacidad de formación de esferoides de las células de HCC. B) Ensayo de formación de esferoides muestra que el GDF11 disminuye la formación de esferoides de las células Hep3B. Cada punto representa un experimento independiente, se reportó la media $\pm S E M$ de al menos cuatro experimentos independientes por triplicado. \& $p<$ 0.05 vs NT

También se pudo observar que los esferoides formados de las células que recibieron el tratamiento con el GDF11 eran más pequeños comparados con los esferoides que no recibieron ningún tipo de tratamiento $25 \%$ para las células Huh7 (Fig. 9C) y $40 \%$ para las células Hep3B (Fig. 9D). 
C)
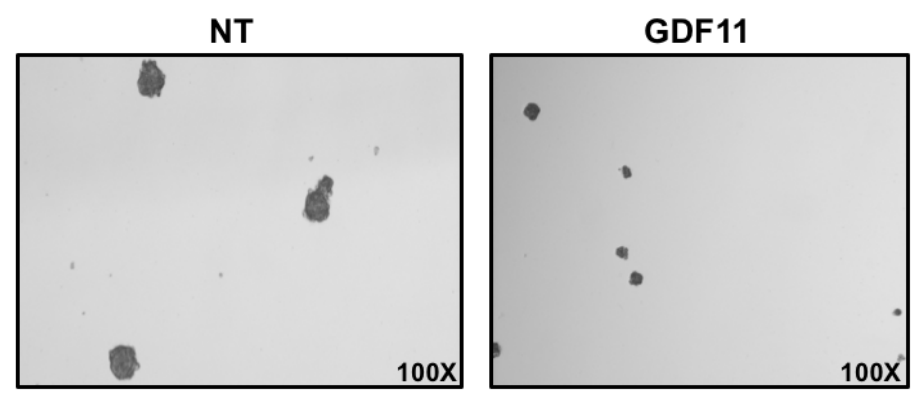

D)
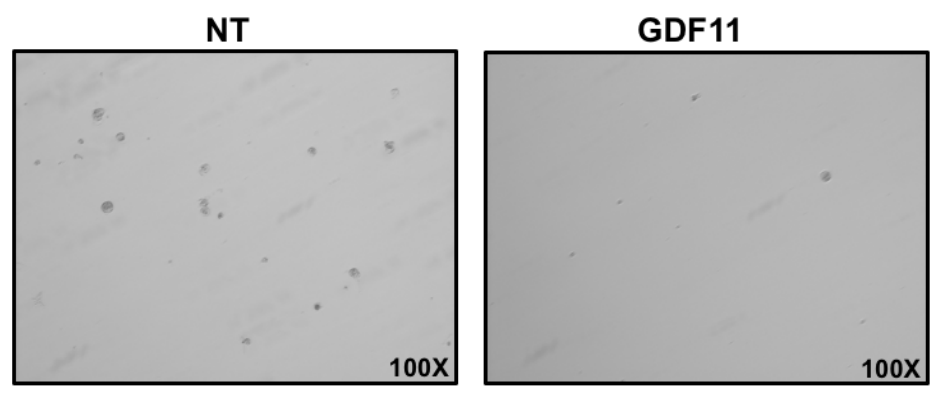

Fig. 9 El GDF11 disminuye la capacidad de formación de esferoides de las células de HCC. C) Imágenes representativas de los esferoides de la línea Huh7 formados después de cinco días. D) Imágenes representativas de los esferoides de la línea Hep3B formados después de cinco días.

\subsection{El GDF11 disminuye la expresión de algunos genes relacionados con} agresividad en las células de HCC

Si bien, con el ensayo de formación de esferoides el resultado nos muestra el efecto antitumorigénico ejercido por el GDF11, se midieron algunos de los principales genes relacionados con agresividad mediante qRT-PCR. Como se puede observar, el tratamiento provoco la disminución de la cantidad de ARN mensajero de CD133, CD24, CK19 y EpCAM, particularmente este último fue disminuido de manera 
significativa solo en la línea celular Hep3B (Fig. 10B) en comparación de la línea celular Huh7, donde no se encontraron cambios de manera significativa (Fig. 10A).

A)
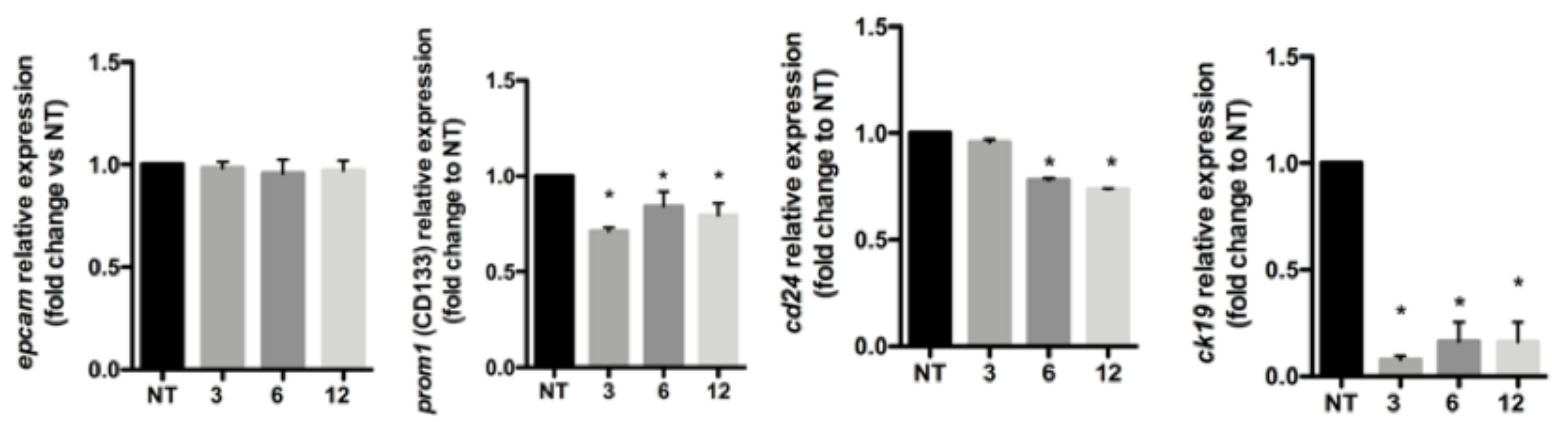

(h) GDF11

B)
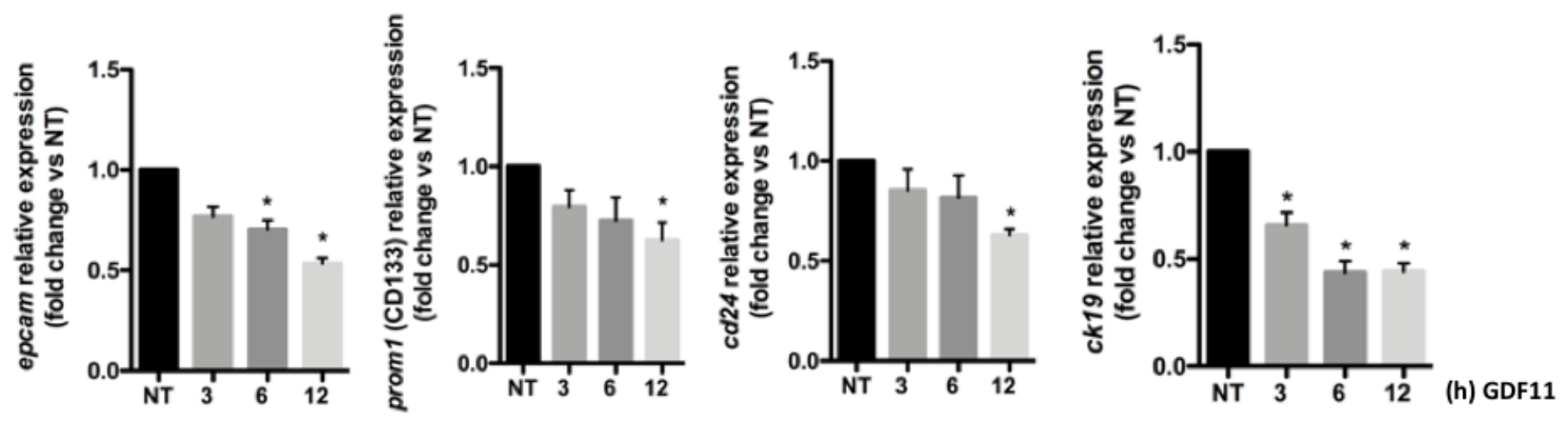

Fig. 10 El GDF11 disminuye la expresión de algunos genes relacionados con agresividad en las células de HCC. A) línea celular Huh7, niveles de ARN mensajero de genes relacionados con agresividad $B$ ) línea celular Hep3B, niveles de ARN mensajero de genes relacionados con agresividad, la expresión de las células no tratadas es reportado como el promedio \pm SEM. *, $p \leq 0.05$ vs $N T$

\subsection{EI GDF11 induce transición mesénquima epitelial}

Uno de los principales puntos a estudiar en cáncer es la capacidad que presentan las células para migrar y hacer metástasis, estos procesos mediados por la transición epitelial a mesenquimal (TEM), donde las células sufren procesos de perdida de marcadores epiteliales, quienes son los encargados de mantener adheridas las células 
a sus sustratos, y con ello la ganancia de marcadores mesenquimales, los cuales se encargan de permitir que las células migren. De acuerdo con el resultado de herida cicatriz, que sugieren también el proceso de migración, se decidió realizar una inminofluorescencia de algunos marcadores del proceso de TEM. Como se puede observar, el marcador Snail, un marcador mesenquimal, se encuentra disminuido con la progresión del tiempo en presencia del GDF11, mientras que, al mismo tiempo, ECadherina, un marcador epitelial se observa aumentado (Fig. 11A).

Para ganar más certeza con el resultado, se usaron otros marcadores, nuevamente, el marcador mesenquimal, $\mathrm{N}$ - Cadherina, se encuentra disminuido y Ocludina, otro de los marcadores epiteliales se observa aumentado (Fig. 11B). Observando, además, que el cambio en las células del proceso mesenquimal a epitelial se da a las $12 \mathrm{~h}$. Por lo que es importante realizar más estudios enfocados en este tiempo. 
A)

\section{GDF11 (h) DAPI Snail E- Cadherina Merge}
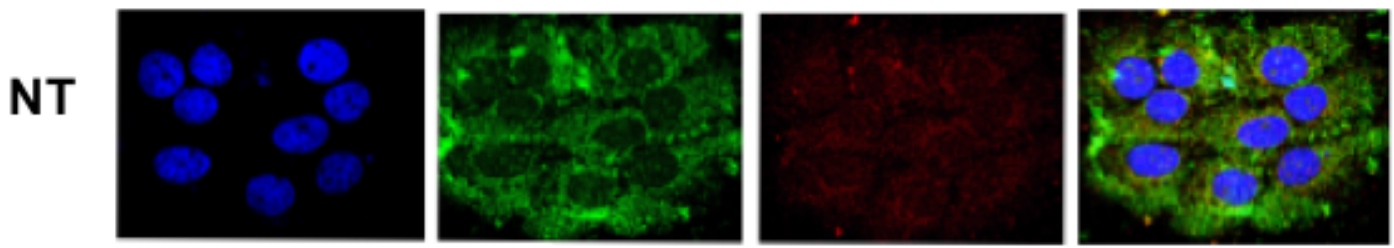

3
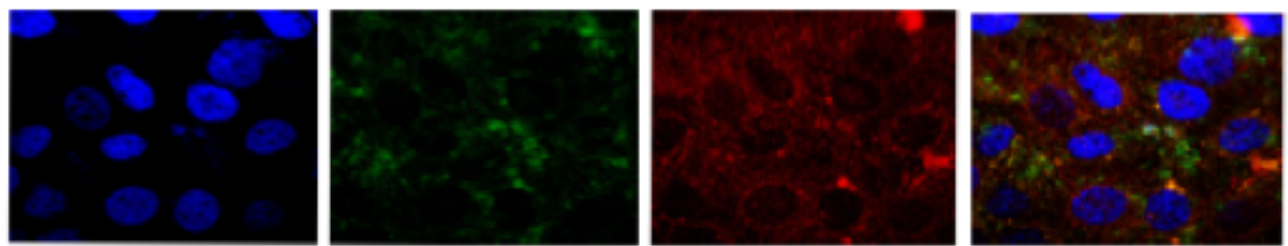

6
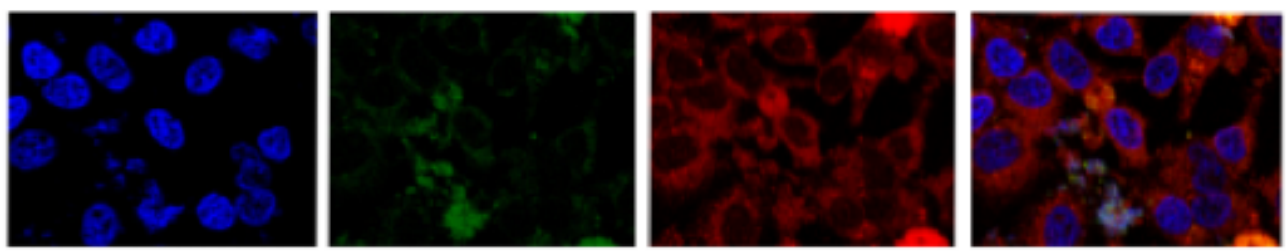

12
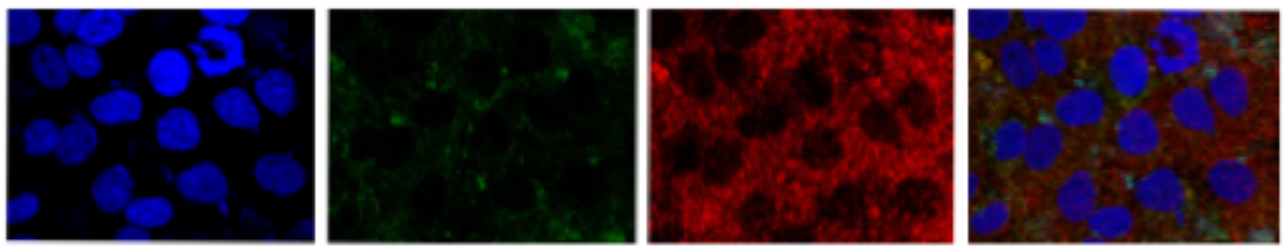

24
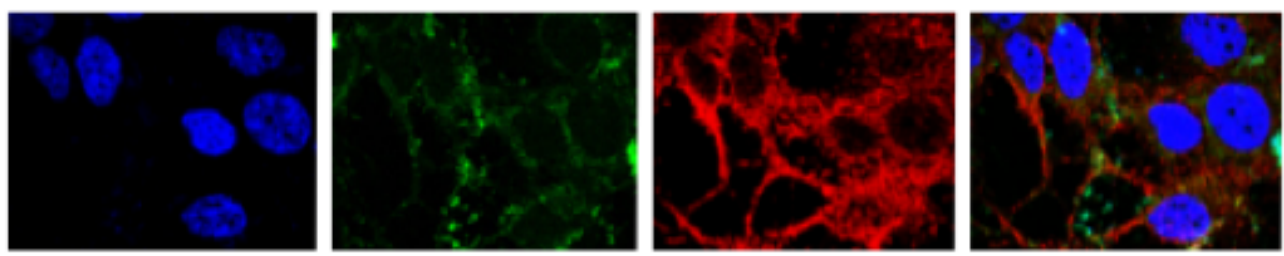

48
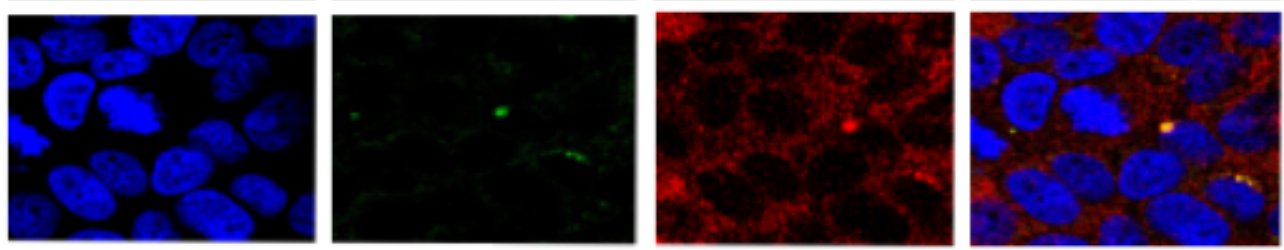

72
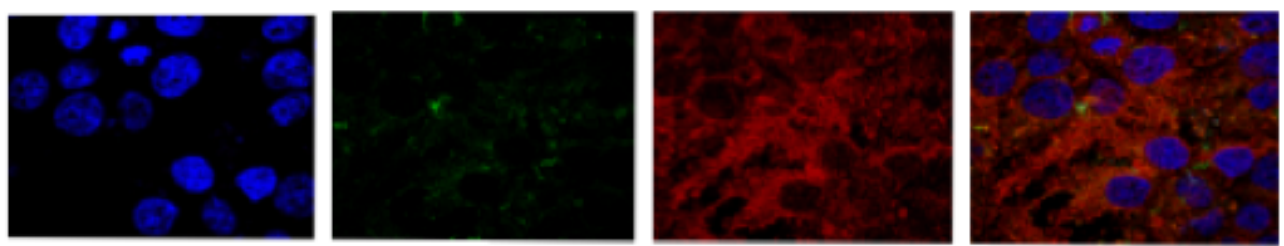

Fig. 11 El GDF11 induce transición mesénquima epitelial. Inmunofluorescencia determinada por microscopia confocal de A) Snail y E-Cadherina. Imagen representativa de al menos tres experimentos independientes. Aumento original 360X. 
B)

\section{GDF11 (h) DAPI N-Cadherina Ocludina Merge}

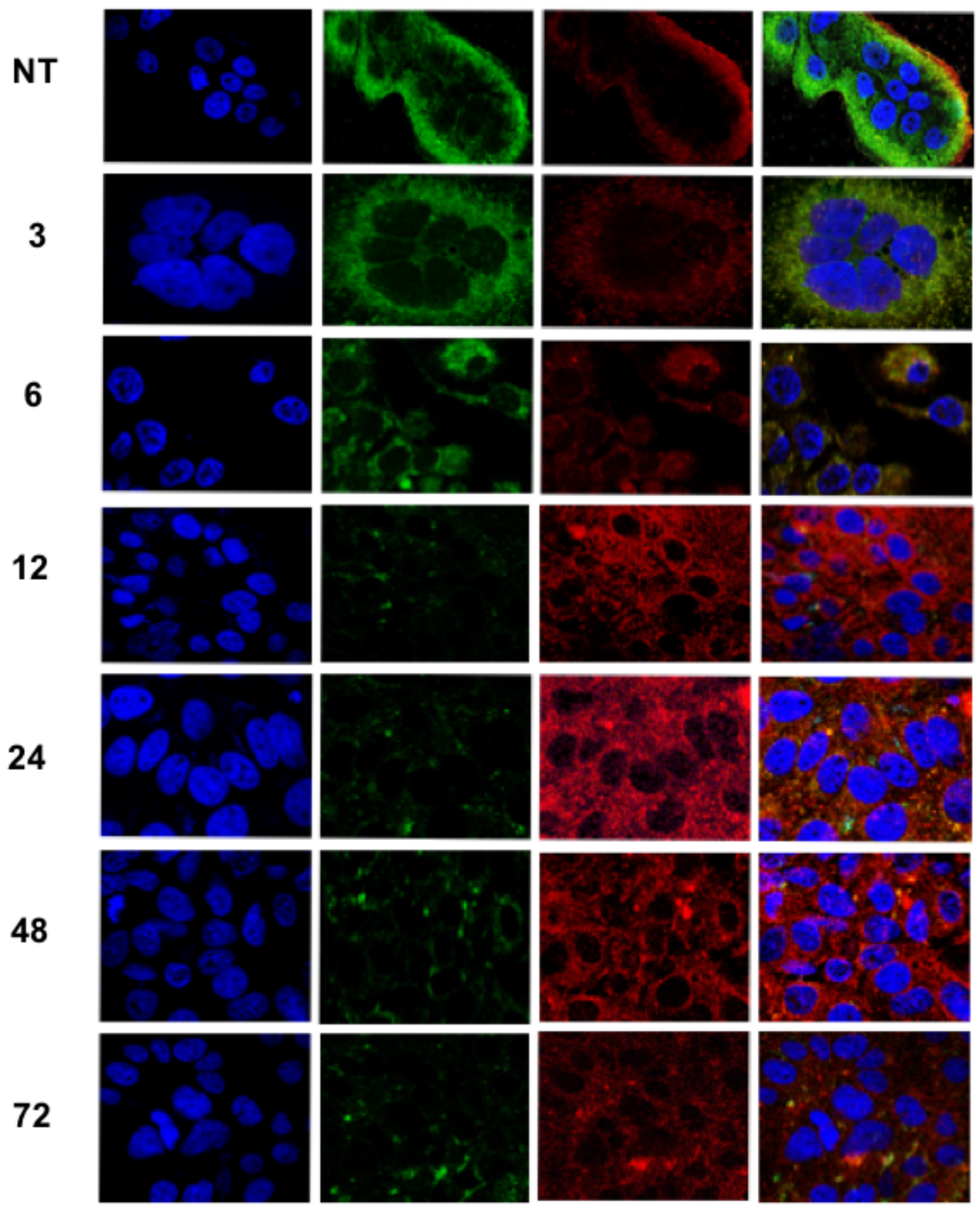

Fig. 11 El GDF11 induce transición mesénquima epitelial. Inmunofluorescencia determinada por microscopia confocal de B) $\mathrm{N}$ - Cadherina y Ocludina. Imagen representativa de al menos tres experimentos independientes. Aumento original 360X. 
Para corroborar los efectos sobre el proceso de TEM, se realizaron ensayos de Western blot de los marcadores usados anteriormente (Fig. 11C). Como se puede observar, se encontraron efectos similares, encontrando nuevamente que los marcadores epiteliales se aumentan con el transcurso del tiempo y los marcadores mesenquimales se ven disminuidos después de 72 h de tratamiento con el GDF11.

C)

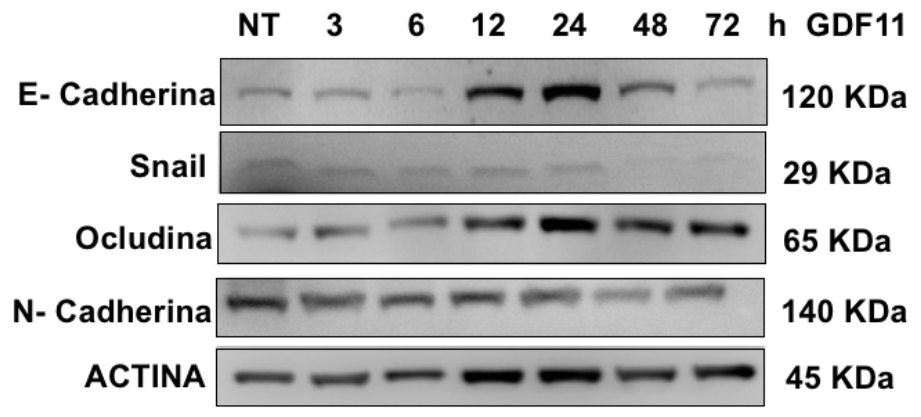

Fig. 11 El GDF11 induce transición mesénquima epitelial. C)Ensayo de Western blot muestra las proteínas implicadas en el proceso de TEM. Imagen representativa de al menos tres experimentos independientes.

Estos resultados nos indican que el tratamiento con el GDF11 está induciendo transición mesénquima epitelial, evitando así el proceso de migración por el cual pasan las células para llevar a cabo una metástasis.

\subsection{EI GDF11 reprime la capacidad de auto renovación de las células de HCC}

Para determinar si los efectos inducidos por el GDF11 se mantenían en las células, se realizó un ensayo de formación de colonias mediante un nuevo diseño experimental, para ello, las líneas celulares se trataron con GDF11 (50ng/ml) cada 24 h por $72 \mathrm{~h}$ en presencia o no de SFB, una vez terminado el tratamiento, las células fueron 
despegadas y sembradas nuevamente para la realización de experimentos extras, dichos experimentos se realizaron sin la presencia del GDF11, estos fueron llevados hasta 10 días con la finalidad de observar los efectos que había inducido el factor de crecimiento y determinar si estos permanecen en las células una vez retirado el tratamiento.

Los resultados obtenidos mostraron que las células Huh7 con el tratamiento previo de GDF11 no lograron recuperar su capacidad para proliferar observando un menor número de colonias formadas comparado con las células que no recibieron el tratamiento, sin encontrar diferencias significativas en aquellas células que recibieron el tratamiento en presencia o no del SFB (Fig. 12A y 12B).

A)

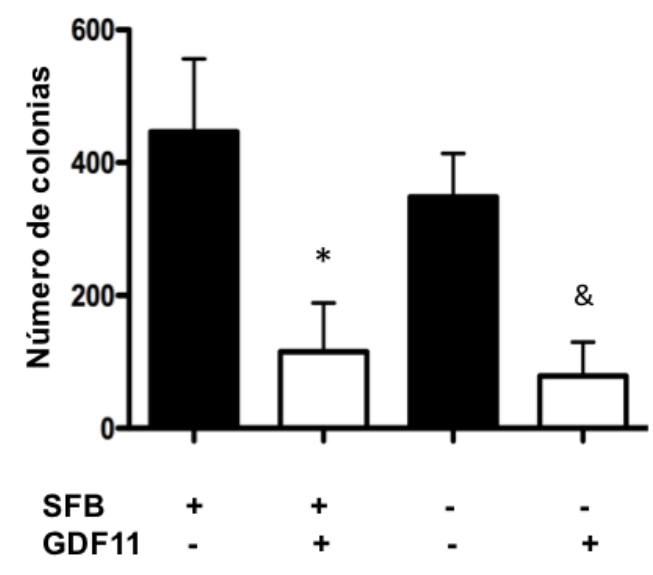

B)

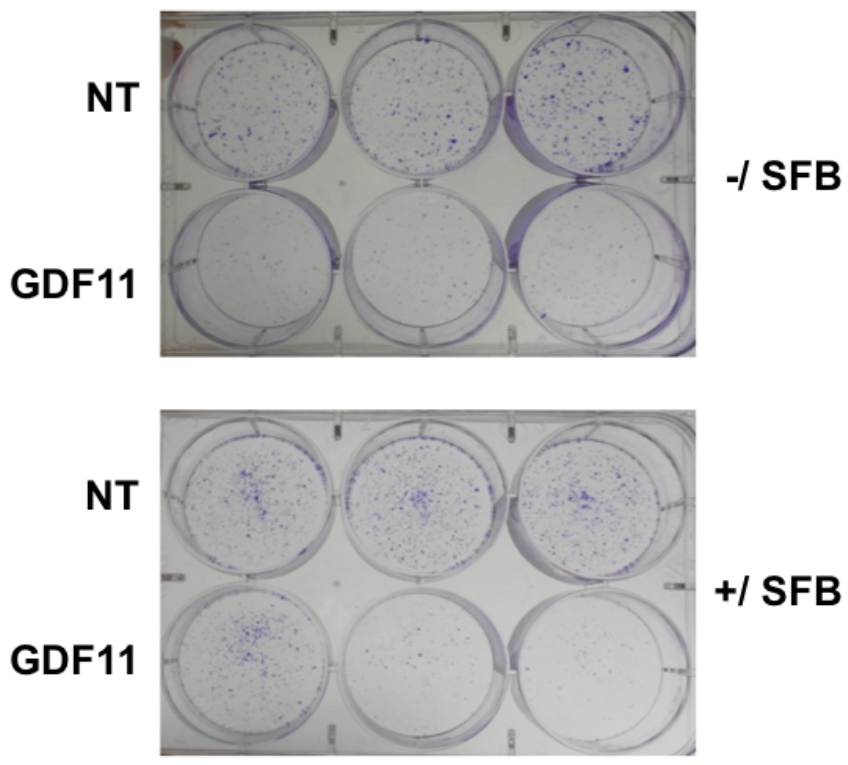

Fig.12 El GDF11 reprime la capacidad de autorenovación de las células de HCC. A) El resultado muestras que las células Huh7 que recibieron el tratamiento con el GDF11 por $72 \mathrm{~h}$ no recuperan su capacidad de formar colonias. B) Imagen representativa de las colonias. Cada columna representa el promedio $\pm S E M$ de al menos cuatro experimentos independientes por triplicado. ${ }^{*} p<0.05$ vs NT (+/SFB), \& $p<0.05$ vs NT (-/SFB). 
En el caso de las células Hep3B, el resultado obtenido fue similar, ya que las células que recibieron el tratamiento perdieron su capacidad de formar colonias, sin embargo, los efectos fueron más notorios cuando las células recibieron el tratamiento en presencia de SFB (Fig. 12C y 12D).

C)

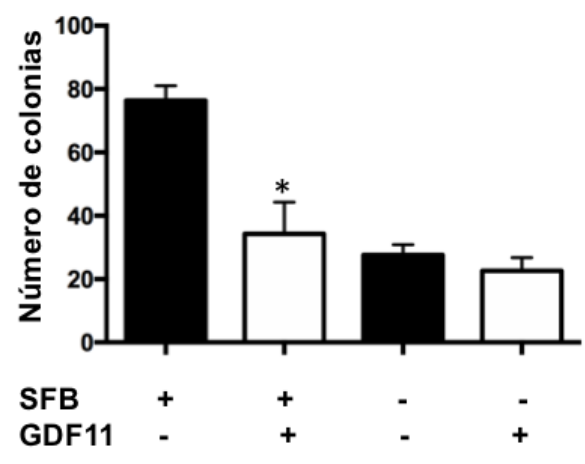

D)

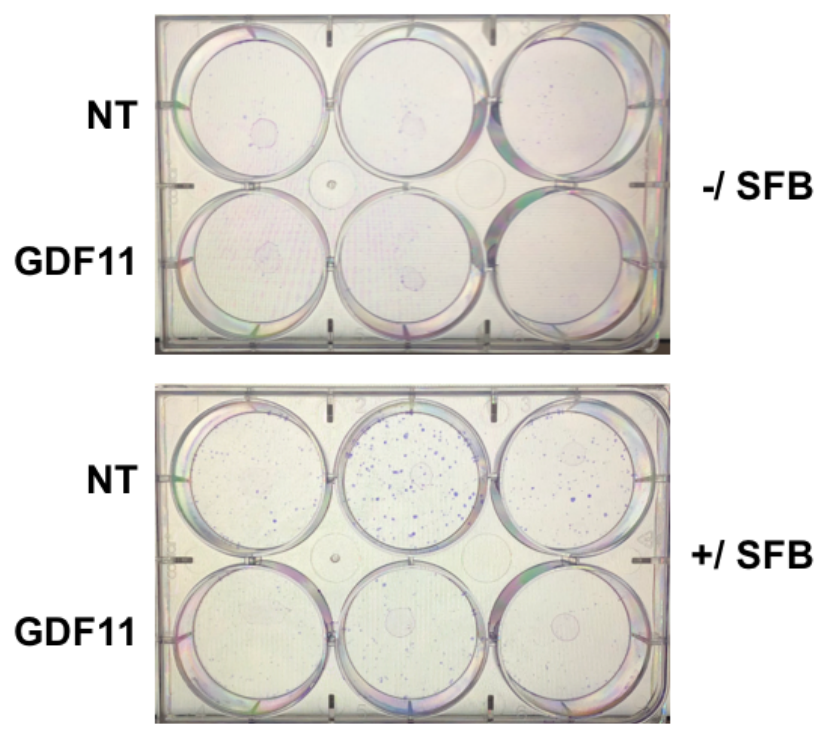

Fig. 12 El GDF11 reprime la capacidad de autorenovación de las células de HCC. C) El resultado muestras que las células Hep3B que recibieron el tratamiento con el GDF11 por $72 h$ no recuperan su capacidad de formar colonias. D) Imagen representativa de las colonias. Cada columna representa el promedio $\pm S E M$ de al menos cuatro experimentos independientes por triplicado. ${ }^{*} p<0.05$ vs NT (+/SFB)

Para corroborar los efectos observados en el ensayo de formación de colonias se realizó nuevamente un ensayo de formación de esferoides con las células que habían recibido el tratamiento del GDF11 por 3 días, el experimento se realizó por 10 días sin que las células continuaran en presencia del estímulo del factor de crecimiento.

Como se puede observar, ambas líneas celulares que fueron tratadas previamente perdieron su capacidad para formar esferoides, indicando nuevamente que los efectos 
que induce el GDF11 son antitumorigénicos además de preservarse en las células después de 10 días de ausencia del GDF11, indicando que el efecto que induce este factor de crecimiento no es transiente (Fig. 12E - 12H).

E)

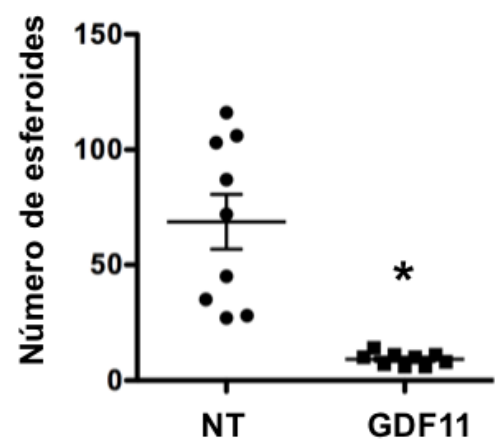

G)

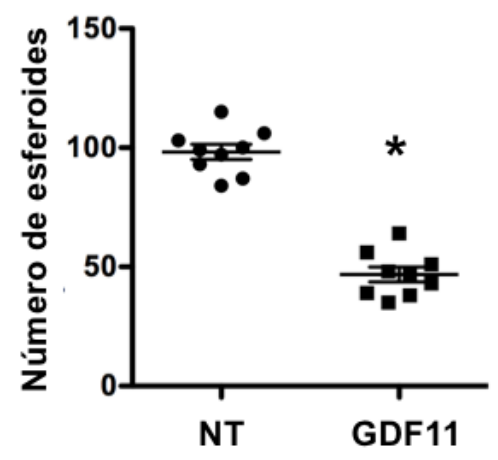

F)

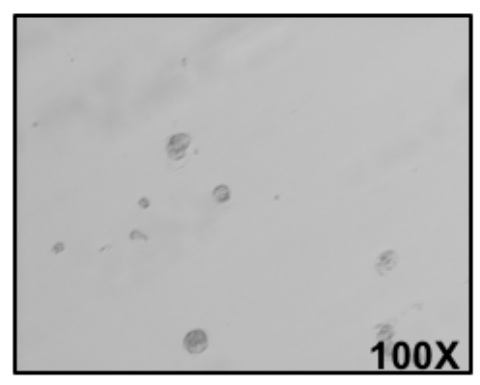

NT

H)

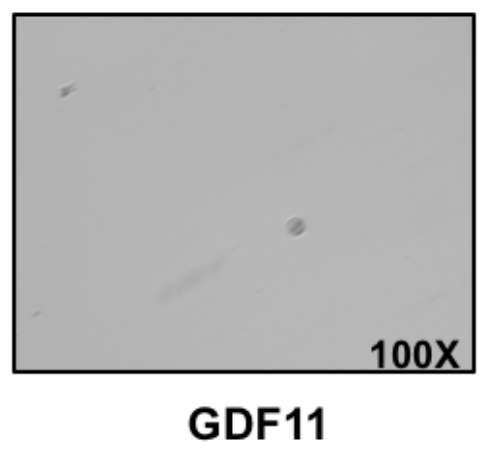

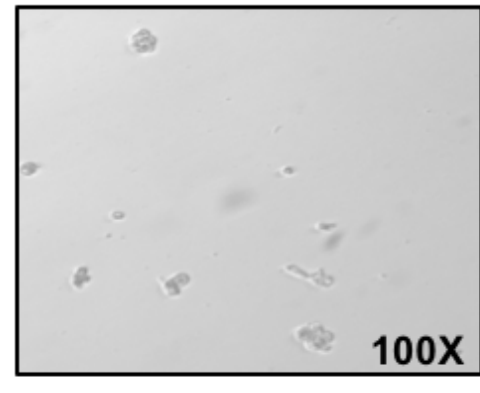

NT

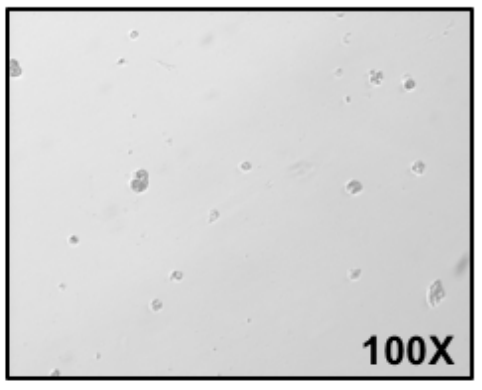

GDF11

Fig. 12 El GDF11 reprime la capacidad de autorenovación de las células de HCC. E) y G) Ensayo de formación de formación de esferoides muestra que el GDF11 disminuye la formación de esferoides de las células que habían recibido el tratamiento por 72 . F) y H) Imágenes representativas de los esferoides de las células que habían recibido el tratamiento por $72 \mathrm{~h}$. Cada punto representa un experimento independiente, se reportó la media \pm SEM de al menos cuatro experimentos independientes por triplicado. \& $p<0.05$ vs NT. Imágenes representativas de los esferoides de la línea Hep3B formados después de cinco días. 


\subsection{EI GDF11 disminuye la migración de las células de HCC}

Para corroborar el efecto del GDF11 sobre el proceso de migración y ganar más certeza, se realizó un ensaño de migración usando el modelo de membrana corioalantoidea (CAM) de embriones de pollo. Para ellos se utilizaron huevos fértiles, a los cuales se le transplantaron $1 \times 10^{6}$ de células Huh7 tratadas previamente o no con GDF11 por $72 \mathrm{~h}$ y se colocaron sobre la CAM de los embriones. La figura 13A muestra la morfología normal de la CAM, sin la presencia de células, como un control. El circulo amarillo muestra la posición donde fueron colocadas las células. Los huevos con las células fueron incubados a $37^{\circ} \mathrm{C}$, después de dos y cuatro días de haber colocado las células sobre la CAM, esta fue removida y embebida en parafina para la realización de los cortes y proseguir con los ensayos de inmunofluorescencia microscopia confocal. 
A)

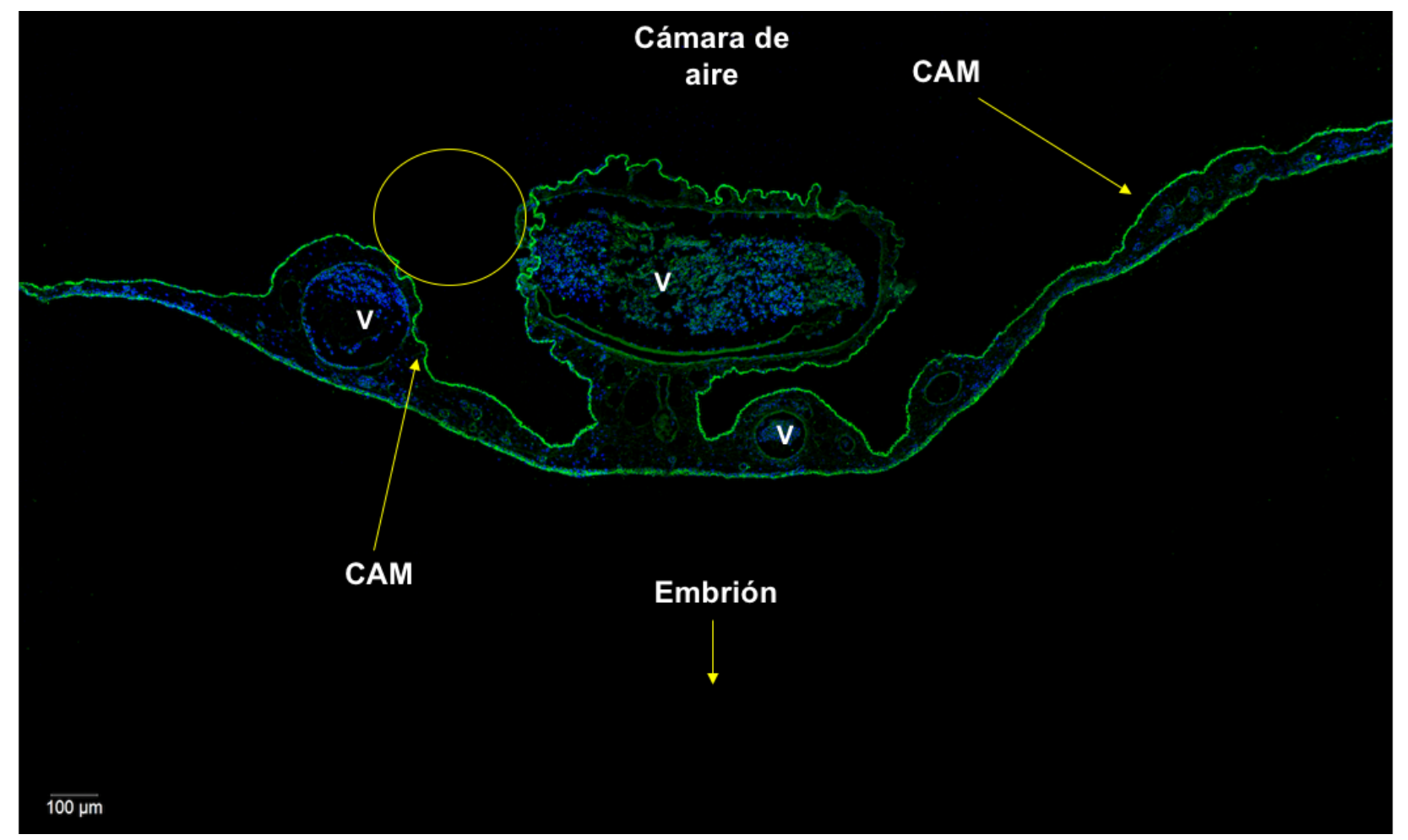

Fig. 13 El GDF11 disminuye la migración de las células de HCC. A) Morfología normal de la CAM. Imagen representativa de al menos tres experimentos independientes. 
B)

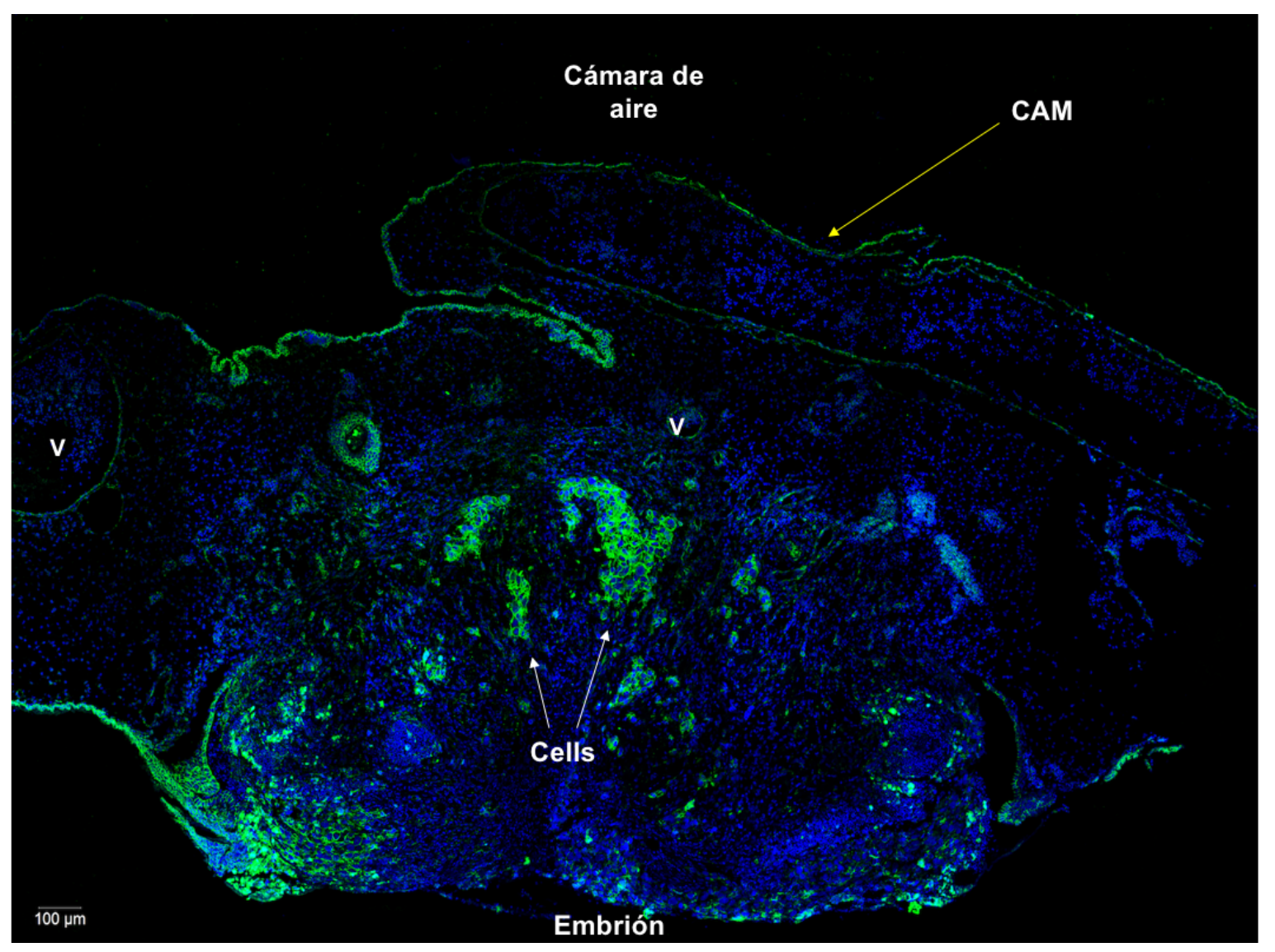

Fig. 13 El GDF11 disminuye la migración de las células de HCC. B) Membrana con las células sin tratamiento, muestra la migración de las células. Imagen representativa de al menos tres experimentos independientes. 
C)

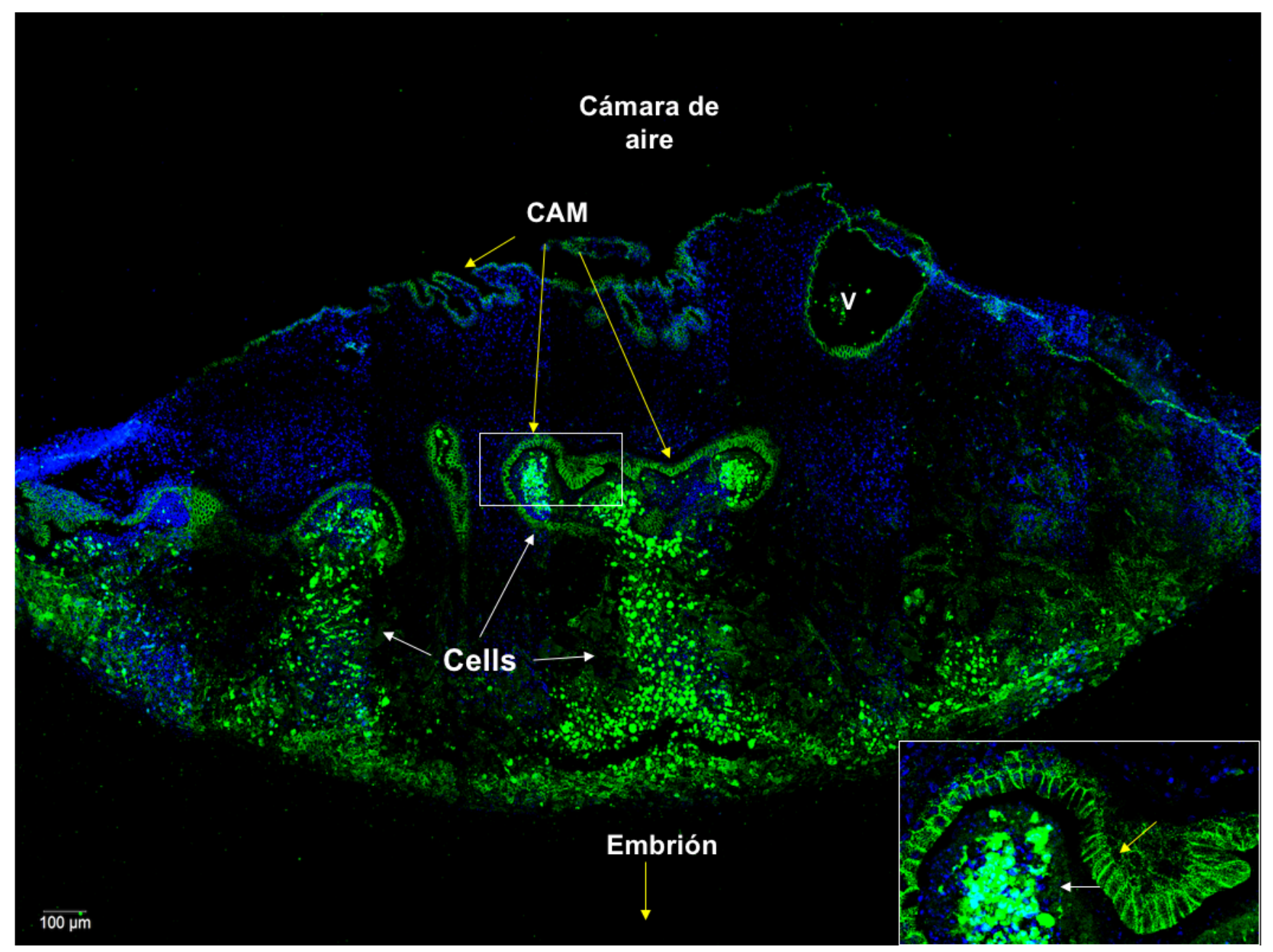

Fig. 13 El GDF11 disminuye la migración de las células de HCC. C) Membrana con células tratadas con GDF11, se observan las células retenidas. Imagen representativa de al menos tres experimentos independientes.

Con la finalidad de analizar el proceso de invasión, se prosiguió a analizar las muestras de dos días de incubación. Los análisis microscópicos de las muestras de la CAM revelaron que la mayoría de las células sin el tratamiento habían desaparecido (Fig. 13B), en comparación con las células que habían recibido el GDF11, las cuales, como se puede observar en la figura $13 \mathrm{C}$ aún se mantienen contenidas. 
Después de haber transcurridos los dos días de incubación con las células, se pudo observar que los embriones habían muerto, este resultado solo pudo observarse en los embriones que contenían las células que no habían recibido el tratamiento con el GDF11, ya que los embriones con las células que recibieron el tratamiento permanecieron vivos hasta que el experimento termino (Fig. 13D)

D)

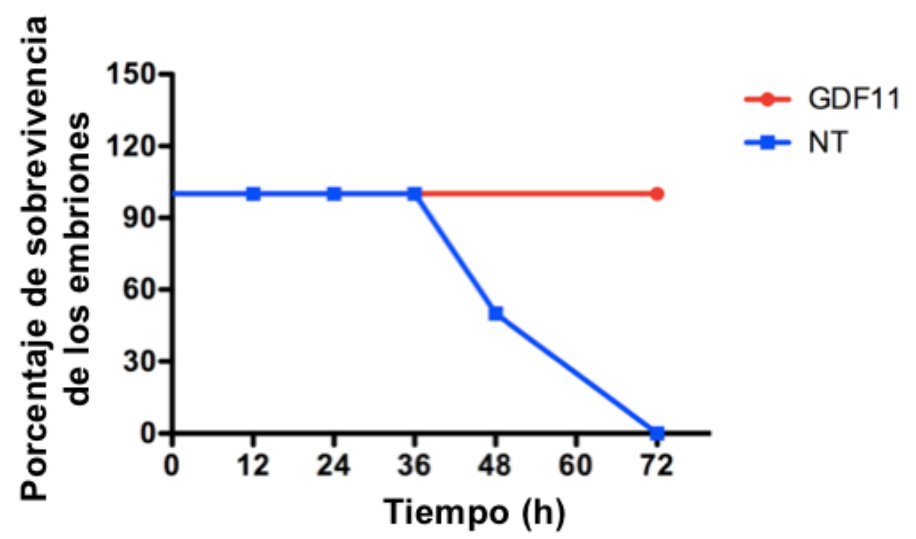

Fig. 13 El GDF11 disminuye la migración de las células de HCC. D) Gráfica de sobrevivencia de los embriones, muestra que las células sin el tratamiento provoco la muerte de los embriones en comparación con los embriones que recibieron las células tratadas, los cuales se mantiene vivos hasta el final del experimento.

Las zonas de la CAM cercanas a las células se puede observar una mayor expresión de beta catenina (Fig. 13C) (flechas amarillas), posiblemente este efecto se deba a una respuesta desplegada de las células por el tratamiento con el GDF11, el cual siguiere ser un efecto de reprogramación celular, este efecto no pudo ser localizado en las muestras de las CAM con las células sin el tratamiento, este resultado sugiere un proceso de degradación de la membrana, lo cual da inicio al proceso de migración, este resultado se relaciona con las imágenes de las muestras de los cuatro días, donde 
la mayoría de las células habían migrado. Además, de mostrarnos el inicio del proceso de migración de las células in vivo.

Con la finalidad de observar el proceso completo de migración, se realizaron cortes de muestras después de cuatro días de incubación, como se puede observar en la figura 13E, se muestran algunas células disgregadas, lo cual nos indica que las células han migrado, mientras que en la figura $13 \mathrm{~F}$ se pueden observar las células que recibieron el GDF11 compactadas, lo que nos indica que las células no han migrado.

E)

F)
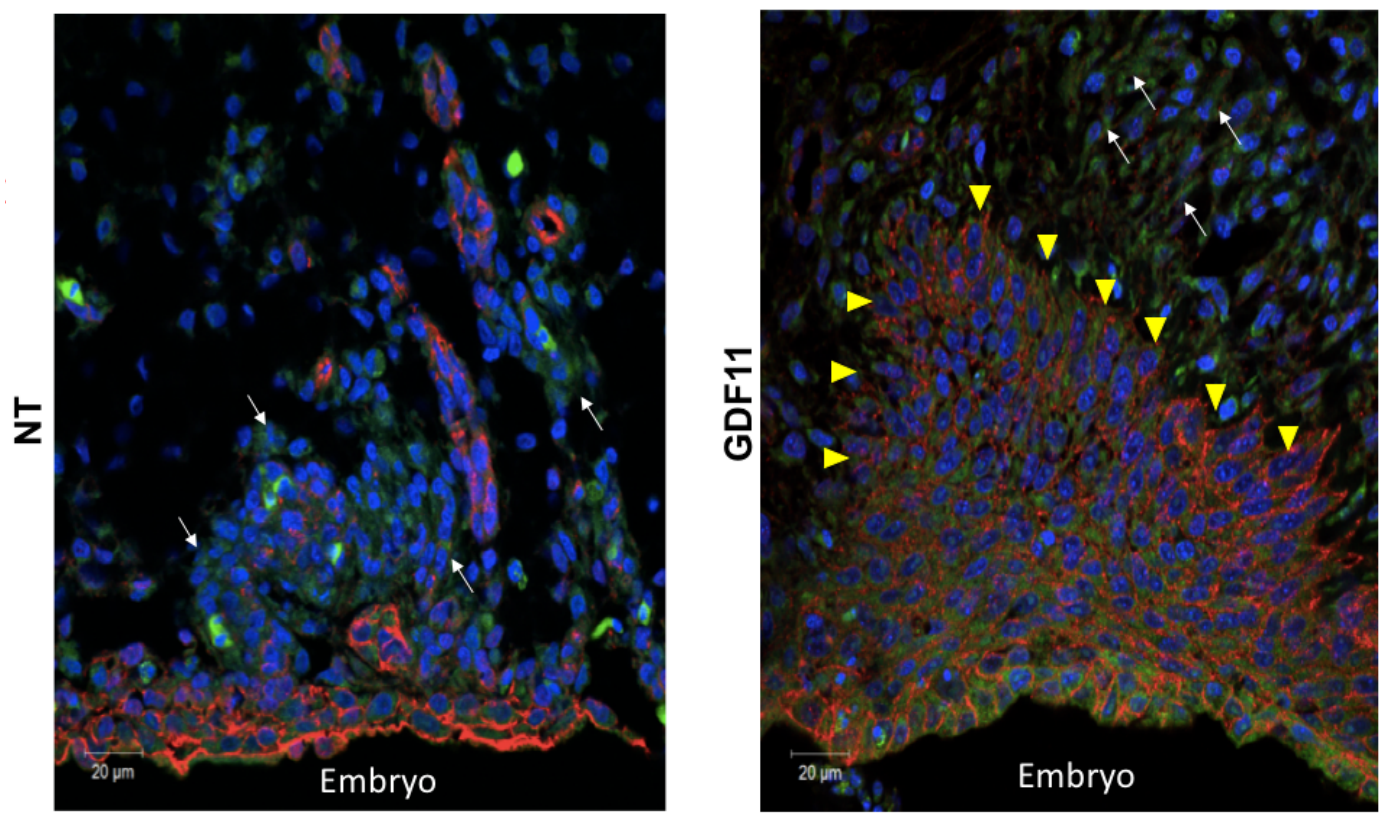

Fig. 13 El GDF11 disminuye la migración de las células de HCC. E) Muestras de 4 días de incubación, se observan pocos vestigios de células debido al proceso de migración. F) Muestras de 4 días de incubación, se observan células retenidas en la membrana. Imágenes representativas de al menos tres experimentos independientes.

Con la finalidad de corroborar que las células habían migrado, se realizaron cortes de las zonas distales de la membrana. En la figura $13 G$ se pueden observar algunas células, demostrando que estas habían llevado a cabo el proceso de migración. 
Mientras que en la figura $13 \mathrm{H}$ no se logran observar células en esta zona, nuevamente, indicando que el tratamiento con el GDF11 induce la disminución de los procesos de migración celular.

G)

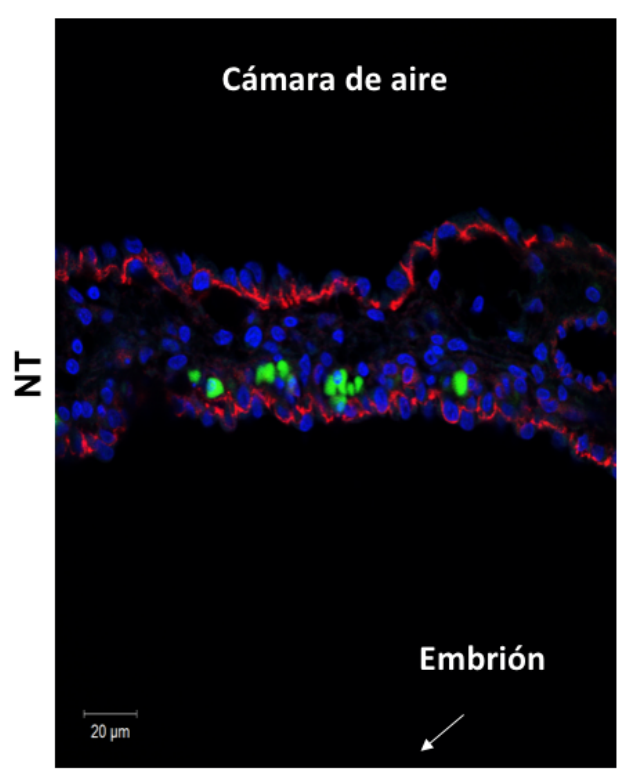

H)

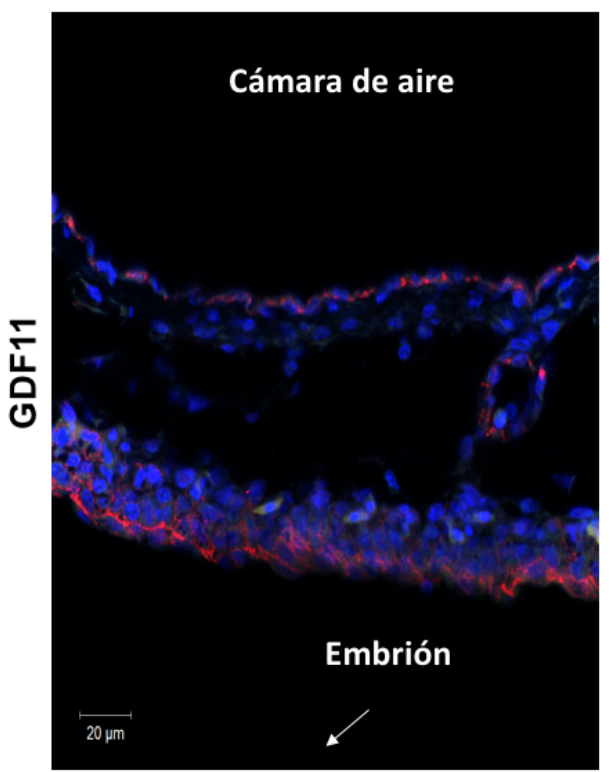

Fig. 13 El GDF11 disminuye la migración de las células de HCC. G) Zona distal de la membrana, se observa la presencia de las células no tratadas migrando. H) Zona distal de la membrana, no se observa la presencia de las células que fueron tratadas previamente con el GDF11. Imágenes representativas de al menos tres experimentos independientes.

Con la finalidad de determinar el estado en el que se encontraban las células una vez colocadas en el embrión, se realizó una tinción con el marcador Ki67, como se muestra en la figura 13I, las células controles son positivas para la tinción, lo cual nos indica que las células una vez colocadas en el embrión son capaces de proliferar, mientras que las células que habían recibido el tratamiento con el GDF11 siguen arrestadas, impidiendo el proceso de proliferación, corroborando los resultados anteriores (Fig. 13J). La figura 13K muestra la densitometría de las imágenes teñidas con Ki67. 
l)

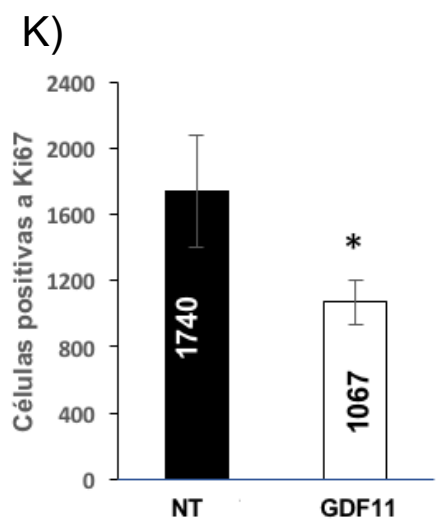

J)
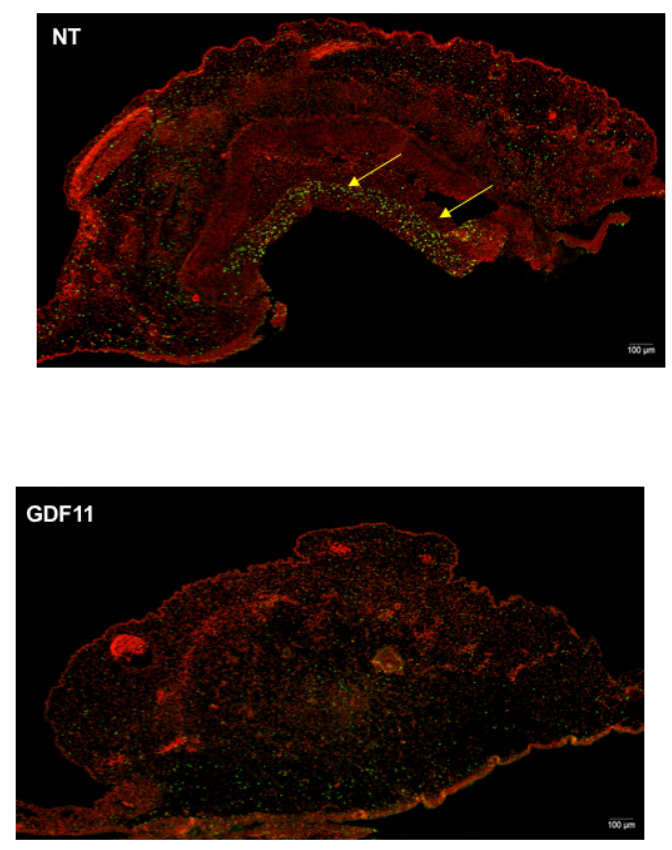

Fig. 13 El GDF11 disminuye la proliferación de las células de HCC. I) Tinción de Ki67, muestra la proliferación de las células control en la CAM de los embriones de pollo. J) Tinción de Ki67, muestra la proliferación de las células que recibieron el GDF11 en las cuales la proliferación esta disminuida en la CAM de los embriones de pollo. K) Densitometría de la tinción de KI67. Imágenes representativas de al menos tres experimentos independientes.

\subsection{EI GDF11 disminuye la formación de esferoides en otras líneas de cáncer}

Con la finalidad de analizar los efectos antitumorigénicos ejercidos por el GDF11 en las líneas de HCC y determinar que este efecto no era solo en las líneas usadas, se realizó el ensayo de formación de esferoides usando otras líneas de cáncer HepG2 (Fig. 14A), una línea de hepatoblastoma humano, Hepa1-6 (Fig. 14B), una línea de cáncer de hígado de ratón, SNU-182 (Fig. 14C), otra línea de cáncer de hígado humano, una línea de cáncer de mama, MDA-MB-231 (Fig. 14D) y finalmente una línea de cáncer de páncreas, CAPAN1 (Fig. 14E). 
A)

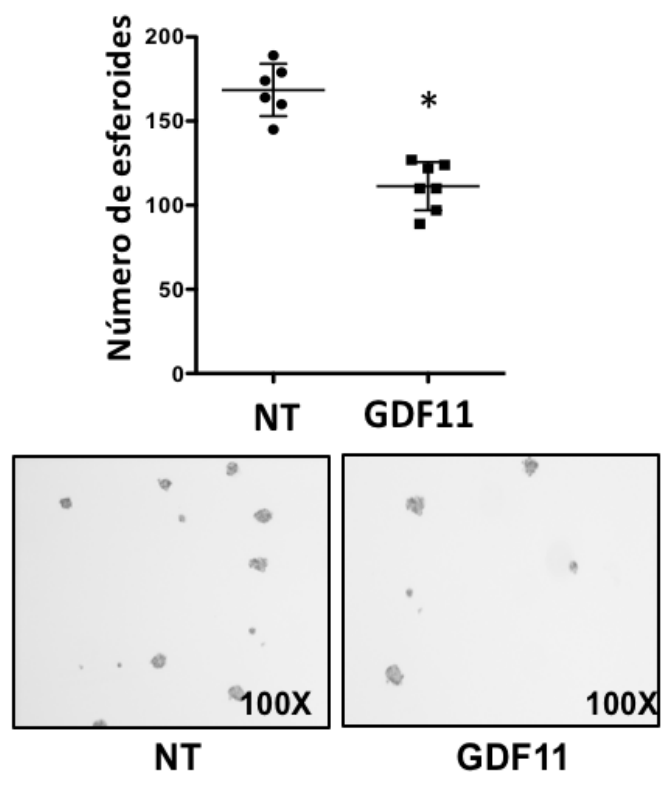

C)
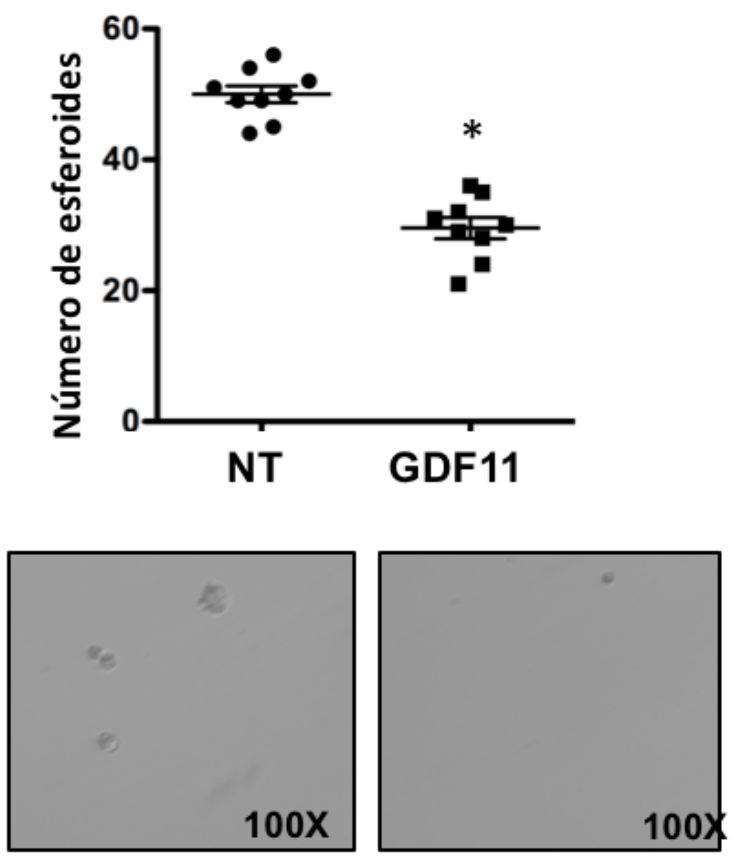

NT
B)
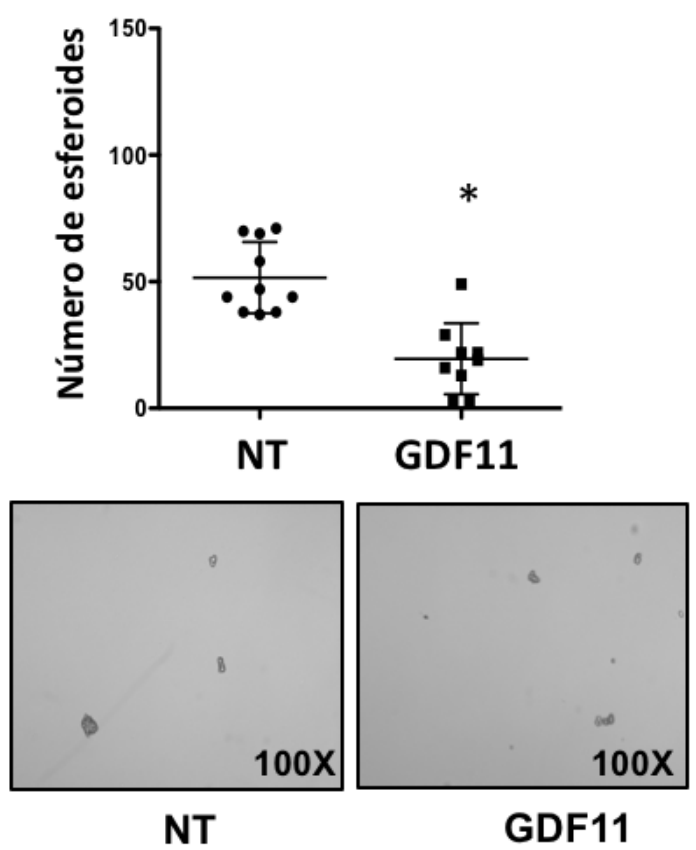

D)
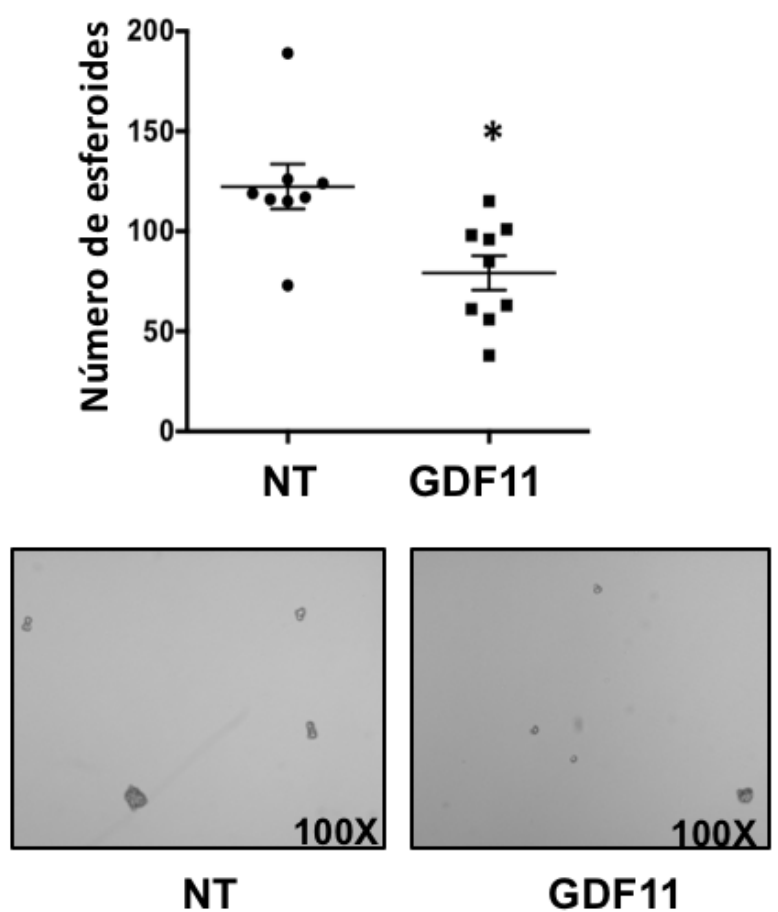
E)

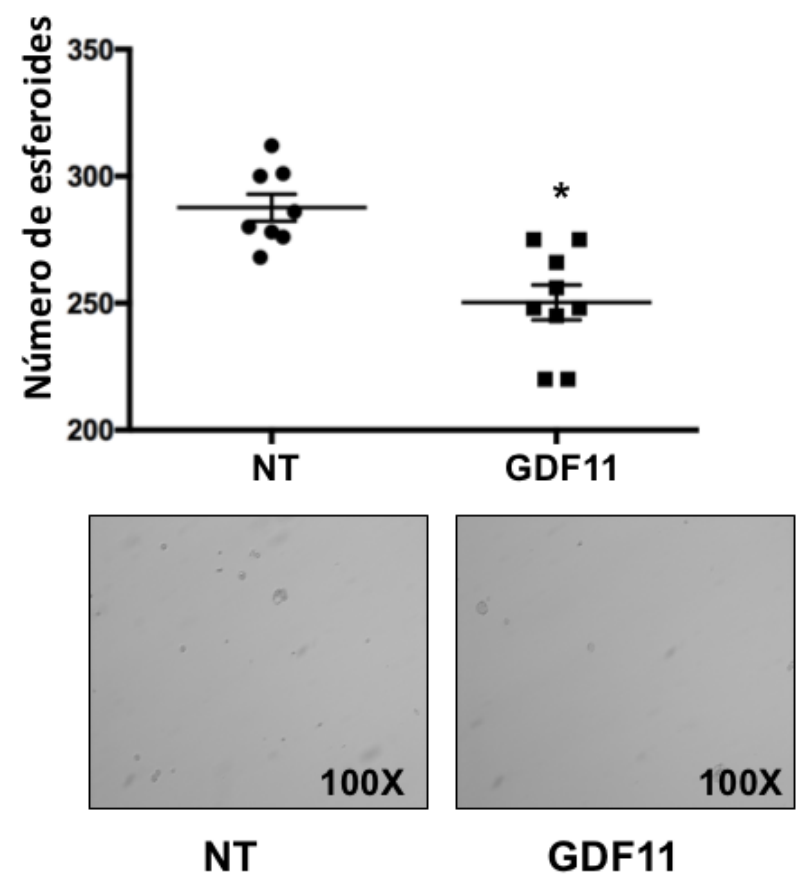

Fig. 14 El GDF11 disminuye la formación de esferoides en otras líneas de cáncer.

A) - E) Ensayo de formación de esferoides muestra que el GDF11 disminuye la formación de esferoides en otras líneas derivadas de cáncer. Cada punto representa un experimento independiente, se reportó la media \pm SEM de al menos cuatro experimentos independientes por triplicado. \& $p<0.05$ vs NT. Imágenes representativas de los esferoides de otras líneas de cáncer.

Las líneas celulares fueron tratadas con GDF11(50 ng/ml) cada 24 h por cinco días. Como se puede observar, en todas las líneas celulares se observaron efectos similares a los encontrados en las líneas Huh7 y Hep3B, donde el tratamiento provoco un menor número de esferoides formados.

Este resultado nos sugiere nuevamente que el efecto que induce el GDF11 es principalmente sobre las células que presentan un fenotipo troncal, en el caso de las células de cáncer, este proceso ocurre aunado al grado de agresividad que presentan las células. 


\subsection{El GDF11 activa la señalización de ERK1/2}

Finalmente, para estudiar cual es el mecanismo que despliega el GDF11 y por el cual las células derivadas de HCC están disminuyendo su proliferación celular, se analizó mediante Western blot el estado de la proteína ERK, un miembro de la familia de las MAPK, quien se ha reportado que juega un papel importante durante la progresión del cáncer.

Si bien, en la línea celular Huh7 no se logró detectar algún cambio (Fig. 15A), en la línea celular Hep3B se logró apreciar la activación de ERK1/2 a partir de los 5 minutos y su inactivación a partir de los 15 minutos (Fig. 15B).

Este resultado nos sugiere que el GDF11 está afectando la señalización mediada por ERK, provocando así la disminución en la proliferación celular.

A)

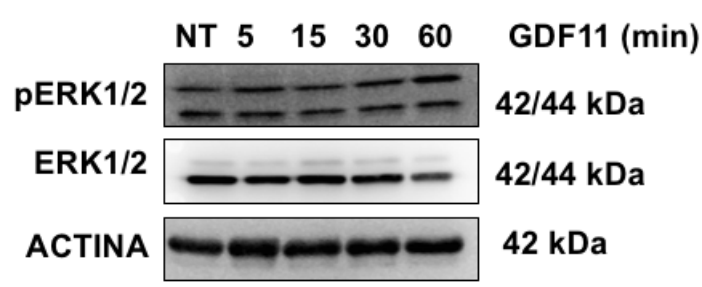

B)

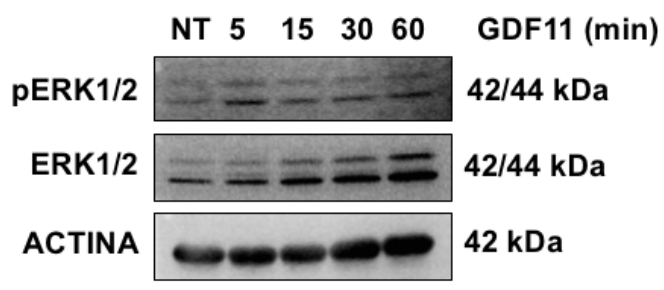

Fig. 15 El GDF11 activa la señalización de ERK1/2. Ensayo de Western blot muestra la activación de ERK1/2. Imágenes representativas de al menos tres experimentos independientes. 


\section{Discusión}

El cáncer de hígado es una de las principales causas de muerte por cáncer a nivel mundial, según lo reportado por el NIH en su "Anual Report to the Nation of the Status of Cancer, Part I: National Cancer Statistic" en 2018, la tasa de incidencia y de mortalidad por esta patología ha ido en aumento en los últimos años.

Una de las principales causas a este aumento en las cifras es debido a que la detección de dicha patología suele ser en etapas avanzadas y esto es debido a la falta de marcadores específicos.

Una de las alternativas para el tratamiento del cáncer de hígado es mediante la intervención quirúrgica para realizar un trasplante de dicho órgano, sin embrago, esta alternativa terapéutica difícilmente suele ser una opción viable, y esto es debido a la falta de donadores.

El uso de tratamientos convencionales como la quimioterapia y radioterapia tienen efectos prometedores como tratamiento contra el cáncer, sin embargo, estos efectos solo son presentados en las etapas tempranas de dicha patología, además de ser tratamientos altamente invasivos en los pacientes, por tal motivo, la calidad de vida a la que se enfrentan suele ser mala.

La búsqueda de nuevas alternativas terapéuticas o marcadores específicos para la detección temprana de dicha enfermedad es uno de los principales objetivos en los que nos encontramos trabajando, con la finalidad de proporcionar tratamientos que no sean invasivos y sean efectivos. 
La familia del TGF- $\beta$ es uno de los principales factores de crecimiento que se han estudiado en cáncer, debido a los efectos que se han reportado que induce dicho factor de crecimiento. Entre los efectos reportados en cáncer, se ha demostrados que el TGF- $\beta$ provoca efectos citotóxicos sobre las células transformadas, además de inducir efectos citoestáticos.

El GDF11 es un miembro de la familia del TGF- $\beta$, el cual se ha vinculado con procesos de regeneración muscular, esto mediante la modulación de procesos relacionados con la proliferación y la diferenciación celular. Estos efectos inducidos por el GDF11 principalmente se llevan a cabo en células troncales y estas son las características que presentan las células que conforman los tumores en etapas avanzadas.

Los resultados demostraron que el GDF11 estaba afectando a las dos líneas celulares provenientes de un cáncer de hígado humano, esto mediante la activación de las principales proteínas implicadas en las rutas de señalización canónica de las familias a las que pertenece el GDF11.

Como se pudo observar, en la línea celular Huh7 hay activación de las proteínas Smad2 y Smad3 mientras que las proteínas Smad 1/5 no muestra cambios, lo que sugiere que los efectos encontrados en la línea celular Huh7 es mediada por la ruta canónica del TGF- $\beta$, además de sugerir que dicha línea celular solo cuenta con los receptores encargados de activar las proteínas Smad antes mencionadas.

En el caso de la línea celular Hep3B, se pudo observar resultados similares a los encontrados en la línea Huh7, la activación de las proteínas Smad2 y Smad3, pero sorprendentemente, también se observó activación de las proteínas Smad1/5, esto 
nos sugiere que los resultados encontrados en esta línea celular no tienen preferencia por alguna ruta de la familia a la que pertenece el GDF11. Este resultado también sugiere la posibilidad de la presencia de los receptores canónicos para el TGF- $\beta$ y la BMP en la línea Hep3B.

Otro de los efectos que se encontró con el tratamiento del GDF11 fue la disminución de la proliferación de las dos líneas celulares, sin embargo, estos efectos fueron más contundentes en la línea Huh7, donde en presencia o no de SFB la proliferación disminuyó de manera significativa hasta las 72 h con el tratamiento.

Mientras que en la línea celular Hep3B, el efecto más contundente se vio en el grupo que recibió el tratamiento con el SFB. Estos efectos fueron corroborados mediante las proteínas que se encargan de regular el ciclo celular, observando que el GDF11 provoca la desregulación de los principales reguladores positivos de dicho proceso y a su vez, la sobreregulación de uno de los reguladores negativos el ciclo como es p27. Una de las posibles razones por lo cual la proliferación se está afectando, es debido a que el GDF11 está afectando la señalización de una de las principales rutas de señalización que participan en la progresión del cáncer, mediante el aumento en la proliferación celular. Como se pudo observar, el GDF11 está impactando sobre la activación de ERK, quien después de 15 minutos está disminuyendo su activación sin encontrar su activación nuevamente incluso 60 minutos después del tratamiento con el factor de crecimiento.

Si bien, el GDF11 no estaba induciendo efectos citotóxicos sobre las células, ya que la viabilidad se encontraba sin cambios, si se encontraba afectado de alguna manera 
a las células, lo cual se observó mediante la disminución de la proliferación, por tal motivo se decidió estudiar el metabolismo de las células con el tratamiento, esto mediante el ensayo de MTT y el uso del Seahorse, los resultados mostraron que las células en presencia del factor de crecimiento presentan una alteración sobre el metabolismo de lípidos, específicamente sobre el metabolismo del colesterol, lo cual se observó después de la realización de la secuenciación de ARN, estos resultados pueden explicar porque las células disminuyen su proliferación, ya que una de las principales rutas de señalización que se encargan de proveer a las células de energía se encuentran alteradas. Además, se observó que la presencia del GDF11 provoca la alteración de 133 genes, de los cuales 101 se sobreexpresaron y 32 fueron reprimidos. Como se observó en los resultados de los esferoides, el GDF11 está induciendo la disminución tanto en número como en tamaño de los esferoides, esto nos indica que el tratamiento está induciendo efectos antitumorigénicos en ambas líneas celulares de cáncer de hígado, además de encontrar que el GDF11 provoca la disminución de los principales genes relacionados con agresividad, específicamente con procesos de diferenciación, lo cual corrobora que el GDF11, en condiciones normales participa en los procesos de diferenciación celular como se ha reportado anteriormente (Egerman et al., 2015; Sinha et al., 2014), encontrando específicamente en cáncer la disminución de los genes usados como marcadores de agresividad.

El GDF11 participa en los procesos de migración celular, esto se debe principalmente a que dicho factor de crecimiento provoca la disminución de marcadores mesenquimales, quienes se encargan de permitir que las células puedan migrar, a su vez, aumentan los marcadores epiteliales, quienes se encargan de mantener 
adheridas las células, por lo que este resultado contradice lo reportado anteriormente (Pons et al., 2018; Williams et al., 2013) quienes indican que el GDF11 induce la progresión de la migración celular, encontrando además que el factor de crecimiento provoca la disminución del marcador E-Cadherina.

Estos resultados fueron corroborados mediante el ensayo de migración usando el modelo de la CAM, donde observamos que las células en presencia del GDF11 pierden sus capacidades para migrar, corroboran el ensayo de herida cicatriz, que fuertemente nos sugirió una alteración en el proceso de migración.

Se pudo observar también, que las células una vez colocadas dentro de los embriones, donde por el proceso de desarrollo en el que se encuentran los embriones existe una producción elevada de factores de crecimiento, aun así, las células que habían recibido el tratamiento con el GDF11 no lograron recuperar sus capacidades proliferativas, comparadas con las células controles.

Los efectos inducidos por el GDF11 no son transientes, ya que las células que recibieron el tratamiento por 72 h no recuperaron su capacidad de proliferación, este resultado se observó en el ensayo de clonogenicidad y de formación de esferoides, donde después de 10 días sin la presencia del GDF11 continúan de alguna manera arrestadas.

Si bien, los resultados muestran el efecto antitumorigénico ejercido por el GDF11, mediante un análisis de secuenciación de ARN se pudo observar la expresión diferencial de algunos genes, entre ellos se observaron alteraciones en genes relacionados con el metabolismo del colesterol, lo cual explica los efectos observados, 
debido a que el colesterol es una de las principales moléculas encargadas de proveer energía a las células además de un incremento en la resistencia a la muerte celular. Finalmente, los efectos que fueron encontrados en las líneas celulares de HCC se observaron también en otras líneas derivadas de diferentes tipos de cáncer, encontrando que el tratamiento con el GDF11 provoco la disminución en la formación de esferoides. Estos resultados nos corroboran una vez más que el principal blanco del GDF11 son las células troncales, en el caso específico de las células cancerosas, éstas durante su proceso de progresión, adquieren características similares a las células troncales, este proceso está estrechamente relacionado con el grado de agresividad que presentan las células cancerosas.

En conclusión, el GDF11 induce efectos antitumorigénicos en las células derivadas de cáncer de hígado, mediante la desregulación de proteínas encargadas de regular la progresión del ciclo celular, reflejándose en la disminución de la proliferación de las células. Además, el tratamiento con el GDF11 provoca la disminución de las principales características de agresividad que presentan las células, como son la disminución en la migración celular, la disminución de genes relacionados con agresividad y por último alteraciones en el metabolismo energético. 


\section{Referencias}

Bajikar, S. S., Wang, C. C., Borten, M. A., Pereira, E. J., Atkins, K. A., \& Janes, K. A. (2017). Tumor-Suppressor Inactivation of GDF11 Occurs by Precursor Sequestration in Triple-Negative Breast Cancer. Dev Cell, 43(4), 418-435 e413. Calvisi, D. F., Wang, C., Ho, C., Ladu, S., Lee, S. A., Mattu, S., Destefanis, G., Delogu, S., Zimmermann, A., Ericsson, J., Brozzetti, S., Staniscia, T., Chen, X., Dombrowski, F., \& Evert, M. (2011). Increased lipogenesis, induced by AKTmTORC1-RPS6 signaling, promotes development of human hepatocellular carcinoma. Gastroenterology, 140(3), 1071-1083.

Cargnello, M., \& Roux, P. P. (2011). Activation and function of the MAPKs and their substrates, the MAPK-activated protein kinases. Microbiol Mol Biol Rev, 75(1), 50-83.

Chang, L., \& Karin, M. (2001). Mammalian MAP kinase signalling cascades. Nature, 410(6824), 37-40.

Che, L., Pilo, M. G., Cigliano, A., Latte, G., Simile, M. M., Ribback, S., Dombrowski, F., Evert, M., Chen, X., \& Calvisi, D. F. (2017). Oncogene dependent requirement of fatty acid synthase in hepatocellular carcinoma. Cell Cycle, 16(6), 499-507.

Chen, Z., Gibson, T. B., Robinson, F., Silvestro, L., Pearson, G., Xu, B., Wright, A., Vanderbilt, C., \& Cobb, M. H. (2001). MAP kinases. Chem Rev, 101(8), 24492476.

Clavijo-Cornejo, D., Enriquez-Cortina, C., Lopez-Reyes, A., Dominguez-Perez, M., Nuno, N., Dominguez-Meraz, M., Bucio, L., Souza, V., Factor, V. M., Thorgeirsson, S. S., Gutierrez-Ruiz, M. C., \& Gomez-Quiroz, L. E. (2013). Biphasic regulation of the NADPH oxidase by HGF/c-Met signaling pathway in primary mouse hepatocytes. Biochimie, 95(6), 1177-1184.

Cronin, K. A., Lake, A. J., Scott, S., Sherman, R. L., Noone, A. M., Howlader, N., Henley, S. J., Anderson, R. N., Firth, A. U., Ma, J., Kohler, B. A., \& Jemal, A. (2018). Annual Report to the Nation on the Status of Cancer, part I: National cancer statistics. Cancer, 124(13), 2785-2800.

Czauderna, C., Palestino-Dominguez, M., Castven, D., Becker, D., Zanon-Rodriguez, L., Hajduk, J., Mahn, F. L., Herr, M., Strand, D., Strand, S., Heilmann-Heimbach, S., Gomez-Quiroz, L. E., Worns, M. A., Galle, P. R., \& Marquardt, J. U. (2018). Ginkgo biloba induces different gene expression signatures and oncogenic pathways in malignant and non-malignant cells of the liver. PLoS One, 13(12), e0209067.

Egerman, M. A., Cadena, S. M., Gilbert, J. A., Meyer, A., Nelson, H. N., Swalley, S. E., Mallozzi, C., Jacobi, C., Jennings, L. L., Clay, I., Laurent, G., Ma, S., Brachat, S., Lach-Trifilieff, E., Shavlakadze, T., Trendelenburg, A. U., Brack, A. S., \& Glass, D. J. (2015). GDF11 Increases with Age and Inhibits Skeletal Muscle Regeneration. Cell Metab, 22(1), 164-174.

Enriquez-Cortina, C., Almonte-Becerril, M., Clavijo-Cornejo, D., Palestino-Dominguez, M., Bello-Monroy, O., Nuno, N., Lopez, A., Bucio, L., Souza, V., HernandezPando, R., Munoz, L., Gutierrez-Ruiz, M. C., \& Gomez-Quiroz, L. E. (2013). 
Hepatocyte growth factor protects against isoniazid/rifampicin-induced oxidative liver damage. Toxicol Sci, 135(1), 26-36.

Esquela, A. F., \& Lee, S. J. (2003). Regulation of metanephric kidney development by growth/differentiation factor 11. Dev Biol, 257(2), 356-370.

Essalmani, R., Zaid, A., Marcinkiewicz, J., Chamberland, A., Pasquato, A., Seidah, N. G., \& Prat, A. (2008). In vivo functions of the proprotein convertase PC5/6 during mouse development: Gdf11 is a likely substrate. Proc Natl Acad Sci U $S A$, 105(15), 5750-5755.

Ferlay, J., Soerjomataram, I., Dikshit, R., Eser, S., Mathers, C., Rebelo, M., Parkin, D. M., Forman, D., \& Bray, F. (2015). Cancer incidence and mortality worldwide: sources, methods and major patterns in GLOBOCAN 2012. Int J Cancer, 136(5), E359-386.

Finkenzeller, G., Stark, G. B., \& Strassburg, S. (2015). Growth differentiation factor 11 supports migration and sprouting of endothelial progenitor cells. J Surg Res, 198(1), 50-56.

Gaunt, S. J., George, M., \& Paul, Y. L. (2013). Direct activation of a mouse Hoxd11 axial expression enhancer by Gdf11/Smad signalling. Dev Biol, 383(1), 52-60.

Ge, G., Hopkins, D. R., Ho, W. B., \& Greenspan, D. S. (2005). GDF11 forms a bone morphogenetic protein 1-activated latent complex that can modulate nerve growth factor-induced differentiation of PC12 cells. Mol Cell Biol, 25(14), 58465858.

Geest, C. R., \& Coffer, P. J. (2009). MAPK signaling pathways in the regulation of hematopoiesis. J Leukoc Biol, 86(2), 237-250.

Gokoffski, K. K., Wu, H. H., Beites, C. L., Kim, J., Kim, E. J., Matzuk, M. M., Johnson, J. E., Lander, A. D., \& Calof, A. L. (2011). Activin and GDF11 collaborate in feedback control of neuroepithelial stem cell proliferation and fate. Development, 138(19), 4131-4142.

Gollob, J. A., Wilhelm, S., Carter, C., \& Kelley, S. L. (2006). Role of Raf kinase in cancer: therapeutic potential of targeting the Raf/MEK/ERK signal transduction pathway. Semin Oncol, 33(4), 392-406.

Gomez-Quiroz, L. E., Seo, D., Lee, Y. H., Kitade, M., Gaiser, T., Gillen, M., Lee, S. B., Gutierrez-Ruiz, M. C., Conner, E. A., Factor, V. M., Thorgeirsson, S. S., \& Marquardt, J. U. (2016). Loss of c-Met signaling sensitizes hepatocytes to lipotoxicity and induces cholestatic liver damage by aggravating oxidative stress. Toxicology, 361-362, 39-48.

Gutiérrez Ruiz, M., Bucio, L., Souza, V., Miranda Labra, R., \& Gómez Quiroz, L. (2014). El hígado. Pretextos y Contextos (M. H. Coria Ed. 1 ed.). Ciudad de México: UAM-I.

Hanahan, D., \& Weinberg, R. A. (2011). Hallmarks of cancer: the next generation. Cell, 144(5), 646-674.

Jimenez-Salazar, J. E., Posadas-Rodriguez, P., Lazzarini-Lechuga, R. C., Luna-Lopez, A., Zentella-Dehesa, A., Gomez-Quiroz, L. E., Konigsberg, M., DominguezGomez, G., \& Damian-Matsumura, P. (2014). Membrane-initiated estradiol signaling of epithelial-mesenchymal transition-associated mechanisms through 
regulation of tight junctions in human breast cancer cells. Horm Cancer, 5(3), 161-173.

Kaposi-Novak, P., Lee, J. S., Gomez-Quiroz, L., Coulouarn, C., Factor, V. M., \& Thorgeirsson, S. S. (2006). Met-regulated expression signature defines a subset of human hepatocellular carcinomas with poor prognosis and aggressive phenotype. J Clin Invest, 116(6), 1582-1595.

Leppa, S., \& Bohmann, D. (1999). Diverse functions of JNK signaling and c-Jun in stress response and apoptosis. Oncogene, 18(45), 6158-6162.

Liu, P., Ge, M., Hu, J., Li, X., Che, L., Sun, K., Cheng, L., Huang, Y., Pilo, M. G., Cigliano, A., Pes, G. M., Pascale, R. M., Brozzetti, S., Vidili, G., Porcu, A., Cossu, A., Palmieri, G., Sini, M. C., Ribback, S., Dombrowski, F., Tao, J., Calvisi, D. F., Chen, L., \& Chen, X. (2017). A functional mammalian target of rapamycin complex 1 signaling is indispensable for c-Myc-driven hepatocarcinogenesis. Hepatology, 66(1), 167-181.

Lu, Z., \& Xu, S. (2006). ERK1/2 MAP kinases in cell survival and apoptosis. IUBMB Life, 58(11), 621-631.

Mandal, R., Becker, S., \& Strebhardt, K. (2016). Stamping out RAF and MEK1/2 to inhibit the ERK1/2 pathway: an emerging threat to anticancer therapy. Oncogene, 35(20), 2547-2561.

Mandal, R., Raab, M., Matthess, Y., Becker, S., Knecht, R., \& Strebhardt, K. (2014). pERK 1/2 inhibit Caspase-8 induced apoptosis in cancer cells by phosphorylating it in a cell cycle specific manner. Mol Oncol, 8(2), 232-249.

Marquardt, J. U., Seo, D., Gomez-Quiroz, L. E., Uchida, K., Gillen, M. C., Kitade, M., Kaposi-Novak, P., Conner, E. A., Factor, V. M., \& Thorgeirsson, S. S. (2012). Loss of c-Met accelerates development of liver fibrosis in response to $\mathrm{CCl}(4)$ exposure through deregulation of multiple molecular pathways. Biochim Biophys Acta, 1822(6), 942-951.

Massague, J. (2012). TGFbeta signalling in context. Nat Rev Mol Cell Biol, 13(10), 616630.

McPherron, A. C., Lawler, A. M., \& Lee, S. J. (1999). Regulation of anterior/posterior patterning of the axial skeleton by growth/differentiation factor 11. Nat Genet, 22(3), 260-264.

Menendez, J. A., \& Lupu, R. (2007). Fatty acid synthase and the lipogenic phenotype in cancer pathogenesis. Nat Rev Cancer, 7(10), 763-777.

Moon, H., Ju, H. L., Chung, S. I., Cho, K. J., Eun, J. W., Nam, S. W., Han, K. H., Calvisi, D. F., \& Ro, S. W. (2017). Transforming Growth Factor-beta Promotes Liver Tumorigenesis in Mice via Up-regulation of Snail. Gastroenterology, 153(5), 1378-1391 e1376.

Morales, A., Mari, M., Garcia-Ruiz, C., Colell, A., \& Fernandez-Checa, J. C. (2012). Hepatocarcinogenesis and ceramide/cholesterol metabolism. Anticancer Agents Med Chem, 12(4), 364-375.

Nakagawa, Y. (1996). Effects of dicoumarol on cytotoxicity caused by tertbutylhydroquinone in isolated rat hepatocytes. Toxicol Lett, 84(2), 63-68. 
Nakashima, M., Toyono, T., Akamine, A., \& Joyner, A. (1999). Expression of growth/differentiation factor 11, a new member of the BMP/TGFbeta superfamily during mouse embryogenesis. Mech Dev, 80(2), 185-189.

Ning, J., Zhao, Y., Ye, Y., \& Yu, J. (2019). Opposing roles and potential antagonistic mechanism between TGF-beta and BMP pathways: Implications for cancer progression. EBioMedicine, 41, 702-710.

Perez-Aguilar, B., Vidal, C. J., Palomec, G., Garcia-Dolores, F., Gutierrez-Ruiz, M. C., Bucio, L., Gomez-Olivares, J. L., \& Gomez-Quiroz, L. E. (2015). Acetylcholinesterase is associated with a decrease in cell proliferation of hepatocellular carcinoma cells. Biochim Biophys Acta, 1852(7), 1380-1387.

Pons, M., Koniaris, L. G., Moe, S. M., Gutierrez, J. C., Esquela-Kerscher, A., \& Zimmers, T. A. (2018). GDF11 induces kidney fibrosis, renal cell epithelial-tomesenchymal transition, and kidney dysfunction and failure. Surgery, 164(2), 262-273.

Quigley, J. P., \& Armstrong, P. B. (1998). Tumor cell intravasation alu-cidated: the chick embryo opens the window. Cell, 94(3), 281-284.

Ribatti, D. (2017). The chick embryo chorioallantoic membrane (CAM) assay. Reprod Toxicol, 70, 97-101.

Roberts, P. J., \& Der, C. J. (2007). Targeting the Raf-MEK-ERK mitogen-activated protein kinase cascade for the treatment of cancer. Oncogene, 26(22), 32913310.

Sinha, M., Jang, Y. C., Oh, J., Khong, D., Wu, E. Y., Manohar, R., Miller, C., Regalado, S. G., Loffredo, F. S., Pancoast, J. R., Hirshman, M. F., Lebowitz, J., Shadrach, J. L., Cerletti, M., Kim, M. J., Serwold, T., Goodyear, L. J., Rosner, B., Lee, R. T., \& Wagers, A. J. (2014). Restoring systemic GDF11 levels reverses agerelated dysfunction in mouse skeletal muscle. Science, 344(6184), 649-652.

Sinning, M., Letelier, R., Rosas, C., Fuenzalida, M., \& Lemus, D. (2012). Angiogenic potential of the cerebrospinal fluid (CSF) of patients with high-grade gliomas measured with the chick embryo chorioallantoic membrane assay (CAM). Biol Res, 45(2), 135-138.

Walker, R. G., Czepnik, M., Goebel, E. J., McCoy, J. C., Vujic, A., Cho, M., Oh, J., Aykul, S., Walton, K. L., Schang, G., Bernard, D. J., Hinck, A. P., Harrison, C. A., Martinez-Hackert, E., Wagers, A. J., Lee, R. T., \& Thompson, T. B. (2017). Structural basis for potency differences between GDF8 and GDF11. BMC Biol, 15(1), 19.

Wallner, C., Drysch, M., Becerikli, M., Jaurich, H., Wagner, J. M., Dittfeld, S., Nagler, J., Harati, K., Dadras, M., Philippou, S., Lehnhardt, M., \& Behr, B. (2018). Interaction with the GDF8/11 pathway reveals treatment options for adenocarcinoma of the breast. Breast, 37, 134-141.

Williams, G., Zentar, M. P., Gajendra, S., Sonego, M., Doherty, P., \& Lalli, G. (2013). Transcriptional basis for the inhibition of neural stem cell proliferation and migration by the TGFbeta-family member GDF11. PLoS One, 8(11), e78478.

Yokoe, T., Ohmachi, T., Inoue, H., Mimori, K., Tanaka, F., Kusunoki, M., \& Mori, M. (2007). Clinical significance of growth differentiation factor 11 in colorectal cancer. Int J Oncol, 31(5), 1097-1101. 
Zhang, J., Yamada, O., Kida, S., Matsushita, Y., \& Hattori, T. (2016). Down-regulation of osteopontin mediates a novel mechanism underlying the cytostatic activity of TGF-beta. Cell Oncol (Dordr), 39(2), 119-128.

Zhang, Y., Alexander, P. B., \& Wang, X. F. (2017). TGF-beta Family Signaling in the Control of Cell Proliferation and Survival. Cold Spring Harb Perspect Biol, 9(4).

Zhang, Y., Shao, J., Wang, Z., Yang, T., Liu, S., Liu, Y., Fan, X., \& Ye, W. (2015). Growth differentiation factor 11 is a protective factor for osteoblastogenesis by targeting PPARgamma. Gene, 557(2), 209-214.

Zhang, Y. H., Cheng, F., Du, X. T., Gao, J. L., Xiao, X. L., Li, N., Li, S. L., \& Dong de, L. (2016). GDF11/BMP11 activates both smad1/5/8 and smad2/3 signals but shows no significant effect on proliferation and migration of human umbilical vein endothelial cells. Oncotarget, 7(11), 12063-12074. 


\section{Anexos}

\subsection{Anexo I}

Genes diferencialmente expresados por RNA-seq de células Huh7 no tratadas vs células tratadas con GDF11 por 72h.

\begin{tabular}{|l|r|r|}
\hline Gene Symbol & log2FoldChange & \multicolumn{1}{c|}{ pvalue } \\
\hline LGALS14 & 3.921469019 & $3.53 \mathrm{E}-261$ \\
\hline LEFTY2 & 3.687024639 & $1.06 \mathrm{E}-26$ \\
\hline LGI4 & 3.490888727 & $8.56 \mathrm{E}-35$ \\
\hline COMP & 2.747552515 & $9.82 \mathrm{E}-25$ \\
\hline NPNT & 2.713387978 & $5.13 \mathrm{E}-232$ \\
\hline ADAMTS16 & 2.647553308 & $1.30 \mathrm{E}-45$ \\
\hline PREX2 & 2.569974521 & $1.75 \mathrm{E}-20$ \\
\hline TNNI2 & 2.488468809 & $2.20 \mathrm{E}-17$ \\
\hline CYP27C1 & 2.470734906 & $5.01 \mathrm{E}-21$ \\
\hline LAMP3 & 2.466356076 & $4.10 \mathrm{E}-18$ \\
\hline INHBE & 2.452467137 & $6.39 \mathrm{E}-48$ \\
\hline LOXL4 & 2.428604852 & $2.17 \mathrm{E}-198$ \\
\hline SLC2A3 & 2.376173926 & $8.30 \mathrm{E}-22$ \\
\hline UACA & 2.37336341 & $1.85 \mathrm{E}-216$ \\
\hline HOXD10 & 2.341004559 & $1.93 \mathrm{E}-34$ \\
\hline ANGPTL2 & 2.339207786 & $4.82 \mathrm{E}-36$ \\
\hline PNCK & 2.338519511 & $1.09 \mathrm{E}-22$ \\
\hline DPYSL3 & 2.324217136 & $7.81 \mathrm{E}-39$ \\
\hline TMPRSS6 & 2.284219761 & $5.99 \mathrm{E}-35$ \\
\hline FXYD3 & 2.246128235 & $3.23 \mathrm{E}-14$ \\
\hline ROCK1P1 & 2.236023786 & $1.63 \mathrm{E}-57$ \\
\hline FBN1 & 2.187855546 & $5.76 \mathrm{E}-33$ \\
\hline ABCA5 & 2.180522535 & $4.23 \mathrm{E}-87$ \\
\hline NCF2 & 2.165376117 & $1.69 \mathrm{E}-42$ \\
\hline MUC4 & 2.154113058 & $3.96 \mathrm{E}-10$ \\
\hline BRINP2 & 2.145535665 & $4.69 \mathrm{E}-35$ \\
\hline IGF2 & 2.145324365 & $3.52 \mathrm{E}-14$ \\
\hline ELN & 2.135058095 & $7.67 \mathrm{E}-10$ \\
\hline MUC6 & 2.124994446 & $2.19 \mathrm{E}-11$ \\
\hline & & \\
\hline
\end{tabular}




\begin{tabular}{|l|r|r|}
\hline CCDC114 & 2.117616995 & $7.32 \mathrm{E}-10$ \\
\hline FCRLA & 2.068443888 & $8.20 \mathrm{E}-10$ \\
\hline TBX15 & 2.035915515 & $1.00 \mathrm{E}-30$ \\
\hline AKR1D1 & 2.022713664 & $3.31 \mathrm{E}-32$ \\
\hline HERPUD1 & 2.01607821 & $4.49 \mathrm{E}-47$ \\
\hline H2AFY2 & 2.009538684 & $5.22 \mathrm{E}-42$ \\
\hline HSPA5 & 1.949514938 & $3.02 \mathrm{E}-18$ \\
\hline MAP4K4 & 1.920309378 & $4.85 \mathrm{E}-145$ \\
\hline CPA6 & 1.90940687 & $3.76 \mathrm{E}-41$ \\
\hline KSR2 & 1.902561407 & $1.45 \mathrm{E}-08$ \\
\hline NFASC & 1.894703438 & $2.23 \mathrm{E}-09$ \\
\hline DNAH17 & 1.891291946 & $1.63 \mathrm{E}-15$ \\
\hline MUC12 & 1.88025976 & $1.38 \mathrm{E}-13$ \\
\hline NEBL & 1.877571261 & $4.53 \mathrm{E}-23$ \\
\hline PALMD & 1.873603078 & $1.82 \mathrm{E}-43$ \\
\hline BIRC7 & 1.861189535 & $5.29 \mathrm{E}-08$ \\
\hline ADAM18 & 1.845354175 & $9.14 \mathrm{E}-08$ \\
\hline THSD7B & 1.836839641 & $7.64 \mathrm{E}-09$ \\
\hline CACNA1I & 1.807888686 & $4.57 \mathrm{E}-09$ \\
\hline MUC16 & 1.788859558 & $3.84 \mathrm{E}-09$ \\
\hline HOXD11 & 1.770701533 & $8.34 \mathrm{E}-10$ \\
\hline HAO2 & 1.769695508 & $3.80 \mathrm{E}-11$ \\
\hline HR & 1.768831463 & $3.54 \mathrm{E}-08$ \\
\hline SCARA5 & 1.756851385 & $6.87 \mathrm{E}-08$ \\
\hline TNR & 1.755585331 & $3.91 \mathrm{E}-09$ \\
\hline VLDLR & 1.745466075 & $5.29 \mathrm{E}-44$ \\
\hline LGR5 & 1.743793568 & $6.26 \mathrm{E}-36$ \\
\hline FAT2 & 1.730028538 & $9.07 \mathrm{E}-14$ \\
\hline TMIE & 1.715156511 & $8.26 \mathrm{E}-11$ \\
\hline COL3A1 & 1.707350978 & $4.57 \mathrm{E}-18$ \\
\hline CRMP1 & 1.707206198 & $1.03 \mathrm{E}-08$ \\
\hline LINC00626 & 1.702047953 & $3.77 \mathrm{E}-07$ \\
\hline COL6A3 & 1.684020112 & $1.04 \mathrm{E}-07$ \\
\hline NRP2 & 1.658978033 & $9.19 \mathrm{E}-18$ \\
\hline VAT1L & 1.658095383 & $8.47 \mathrm{E}-28$ \\
\hline SLC38A4 & 1.657462088 & $7.81 \mathrm{E}-61$ \\
\hline TFCP2L1 & 1.657241066 & $1.69 \mathrm{E}-08$ \\
\hline
\end{tabular}




\begin{tabular}{|l|r|r|}
\hline RYR1 & 1.65532021 & $3.85 \mathrm{E}-07$ \\
\hline CTCFL & 1.651149779 & $3.91 \mathrm{E}-09$ \\
\hline SLC17A2 & 1.647355437 & $5.96 \mathrm{E}-07$ \\
\hline DDIT3 & 1.642562624 & $2.27 \mathrm{E}-22$ \\
\hline ERICH2 & 1.641813038 & $1.25 \mathrm{E}-12$ \\
\hline MUC17 & 1.633344068 & $2.94 \mathrm{E}-08$ \\
\hline INHBC & 1.628561448 & $2.00 \mathrm{E}-11$ \\
\hline RASGRF1 & 1.621020225 & $2.83 \mathrm{E}-06$ \\
\hline TSPAN2 & 1.620255918 & $2.39 \mathrm{E}-11$ \\
\hline GRAMD1B & 1.619594262 & $4.80 \mathrm{E}-07$ \\
\hline USH2A & 1.610606432 & $1.09 \mathrm{E}-24$ \\
\hline LOC100505570 & 1.607861636 & $7.57 \mathrm{E}-07$ \\
\hline EGFLAM & 1.604269324 & $1.00 \mathrm{E}-06$ \\
\hline SYT12 & 1.60131133 & $3.69 \mathrm{E}-16$ \\
\hline ADGRG1 & 1.595839165 & $1.01 \mathrm{E}-09$ \\
\hline SDAD1P1 & 1.595801649 & $2.96 \mathrm{E}-08$ \\
\hline PLOD2 & 1.588643143 & $1.21 \mathrm{E}-46$ \\
\hline AKAP9 & 1.586904882 & $8.35 \mathrm{E}-35$ \\
\hline CD244 & 1.584133714 & $3.22 \mathrm{E}-06$ \\
\hline GRIN2B & 1.583927447 & $4.44 \mathrm{E}-09$ \\
\hline NODAL & 1.579142937 & $6.48 \mathrm{E}-07$ \\
\hline SPOCK3 & 1.575663235 & $1.33 \mathrm{E}-21$ \\
\hline ARG1 & 1.570875587 & $9.63 \mathrm{E}-12$ \\
\hline MUC5B & 1.568495098 & $1.13 \mathrm{E}-06$ \\
\hline SSUH2 & 1.567813132 & $2.40 \mathrm{E}-11$ \\
\hline SLC17A1 & 1.56688722 & $6.87 \mathrm{E}-12$ \\
\hline DDIT4 & 1.550565301 & $1.10 \mathrm{E}-12$ \\
\hline DCDC1 & 1.535536328 & $8.26 \mathrm{E}-13$ \\
\hline LINC00607 & 1.535457271 & $9.33 \mathrm{E}-08$ \\
\hline ESRP1 & 1.52514354 & $9.88 \mathrm{E}-15$ \\
\hline COL4A4 & 1.524387072 & $4.95 \mathrm{E}-07$ \\
\hline HPX & 1.516843773 & $1.96 \mathrm{E}-13$ \\
\hline SUSD4 & 1.514676264 & $9.53 \mathrm{E}-08$ \\
\hline LOC101927476 & 1.504933399 & $4.12 \mathrm{E}-06$ \\
\hline TGM2 & 1.503268181 & $3.89 \mathrm{E}-24$ \\
\hline GDA & -1.528488074 & $3.00 \mathrm{E}-41$ \\
\hline NQO1 & -1.532507828 & $2.55 \mathrm{E}-38$ \\
\hline
\end{tabular}




\begin{tabular}{|l|r|r|}
\hline CEBPD & -1.559862342 & $8.04 \mathrm{E}-25$ \\
\hline RNU1-4 & -1.569737269 & 0.003581296 \\
\hline HMGCS1 & -1.572736881 & $4.05 \mathrm{E}-28$ \\
\hline DHCR7 & -1.604743325 & $1.02 \mathrm{E}-15$ \\
\hline ID3 & -1.635236286 & $2.89 \mathrm{E}-14$ \\
\hline FASN & -1.640033605 & $1.47 \mathrm{E}-16$ \\
\hline LDLR & -1.660673068 & $4.87 \mathrm{E}-32$ \\
\hline UCA1 & -1.683039475 & $1.35 \mathrm{E}-15$ \\
\hline GPX2 & -1.72467583 & $1.97 \mathrm{E}-40$ \\
\hline AGR2 & -1.726754148 & $5.96 \mathrm{E}-35$ \\
\hline RELN & -1.732237464 & $2.98 \mathrm{E}-46$ \\
\hline C4BPA & -1.736620543 & $2.49 \mathrm{E}-22$ \\
\hline SLPI & -1.819627376 & $8.63 \mathrm{E}-10$ \\
\hline PCSK9 & -1.837419153 & $7.00 \mathrm{E}-14$ \\
\hline DUSP5 & -1.891144348 & $3.21 \mathrm{E}-52$ \\
\hline REG1A & -1.985463268 & $7.09 \mathrm{E}-23$ \\
\hline INSIG1 & -1.993474499 & $2.30 \mathrm{E}-32$ \\
\hline SERPINC1 & -2.037707054 & $9.74 \mathrm{E}-10$ \\
\hline PIGR & -2.144615136 & $4.15 \mathrm{E}-11$ \\
\hline SAA1 & -2.159203684 & $1.72 \mathrm{E}-09$ \\
\hline RAMP1 & -2.184992954 & $3.79 \mathrm{E}-18$ \\
\hline CEACAM7 & -2.246612681 & $5.49 \mathrm{E}-18$ \\
\hline CEACAM6 & -2.328163629 & $4.73 \mathrm{E}-11$ \\
\hline LYZ & -2.332004714 & $1.23 \mathrm{E}-13$ \\
\hline MAGEA11 & -2.335203017 & $4.74 \mathrm{E}-11$ \\
\hline FJX1 & -2.431089774 & $1.53 \mathrm{E}-16$ \\
\hline PCDH20 & -2.554797019 & $4.66 \mathrm{E}-45$ \\
\hline NTS & -2.668937049 & $4.98 \mathrm{E}-75$ \\
\hline PI3 & -2.716861907 & $1.79 \mathrm{E}-28$ \\
\hline CXCL5 & -2.954990498 & $2.30 \mathrm{E}-132$ \\
\hline & & \\
\hline
\end{tabular}




\subsection{Anexo II}

\section{Artículos producto de la investigación}

1. GDF11 exhibits tumor suppressive properties in hepatocellular carcinoma cells by restricting clonal expansion and invasion. Monserrat GerardoRamírez, Roberto Lazzarini-Lechuga, Javier Esteban Jiménez-Salazar, Sharik Hernández-Rizo, Arturo Simoni-Nieves, Carmen García-Ruiz, Jorlos Carlos Fernández-Checa, Jens U. Marquardt, Cedric Coulouarn, María Concepción Gutiérrez-Ruiz, Benjamín Pérez-Aguilar, Luis E. Gomez-Quiroz. Biochemica et Biophysica Acta-Molecular Basis of Disease. 2019.

2. GDF11 implications in cancer biology and metabolism. Facts and controversies. Arturo Simoni-Nieves, Monserrat Gerardo-Ramírez, Gibrán PedrazaVázquez, Lisette Chávez-Rodríguez, Leticia Bucio, Verónica Souza, Roxana U Miranda-Labra, Luis E. Gomez-Quiroz, María Concepción Gutiérrez-Ruiz. Frontiers in Oncology, 2019.

3. La homeostasis lipídica en la progresión del cáncer hepático. Monserrat Gerardo-Ramírez, Benjamín Pérez-Aguilar, María Concepción GutiérrezRuiz, Luis Enrique Gómez-Quiroz, Contactos, Revista de educación en ciencias e ingeniería. No. 102, pp 5-13, Octubre-Diciembre del 2016.

4. La tuberculosis y la resistencia a fármacos, en tiempos del cambio climático. Nuevos retos para una infección antigua. Oscar Bello Monroy, Alejandro Escobedo Calvario, Monserrat Gerardo-Ramírez, Roxana Uri Miranda Labra, María Concepción Gutiérrez-Ruiz, Rogelio Hernández Pando, Luis Enrique Gómez-Quiroz Contactos, Revista de educación en ciencias e ingeniería. No. 106, pp 28-36, Octubre-Diciembre del 2017.

5. Typhus, yellow fever and Medicine in Mexico during the French intervention. Monserrat Gerardo-Ramirez, Jesús Zavaleta Castro, Luis Enrique GómezQuiroz. Gaceta Medica de México. 2018;154(1):111-117. 


\title{
GDF11 exhibits tumor suppressive properties in hepatocellular carcinoma cells by restricting clonal expansion and invasion
}

\author{
Monserrat Gerardo-Ramírez ${ }^{\mathrm{a}, \mathrm{b}}$, Roberto Lazzarini-Lechuga ${ }^{\mathrm{c}}$, Sharik Hernández-Rizo ${ }^{\mathrm{a}, \mathrm{b}}$, \\ Javier Esteban Jiménez-Salazar ${ }^{\mathrm{c}}$, Arturo Simoni-Nieves ${ }^{\mathrm{a}, \mathrm{b}}$, Carmen García-Ruiz ${ }^{\mathrm{d}}$, \\ José Carlos Fernández-Checa ${ }^{\mathrm{d}}$, Jens U. Marquardt ${ }^{\mathrm{e}}$, Cedric Coulouarn ${ }^{\mathrm{f}}$, \\ María Concepción Gutiérrez-Ruiz ${ }^{\mathrm{b}, \mathrm{g}}$, Benjamín Pérez-Aguilar ${ }^{\mathrm{b}, 1}$, Luis E. Gomez-Quiroz ${ }^{\mathrm{b}, \mathrm{g}, *, 1}$ \\ ${ }^{a}$ Posgrado en Biología Experimental, DCBS, Universidad Autónoma Metropolitana-Iztapalapa, Mexico City, Mexico \\ ${ }^{\mathrm{b}}$ Departamento de Ciencias de la Salud, Universidad Autónoma Metropolitana-Iztapalapa, Mexico City, Mexico \\ ${ }^{\mathrm{c}}$ Departamento de Biología de la Reproducción, Universidad Autónoma Metropolitana-Iztapalapa, Mexico City, Mexico \\ ${ }^{\mathrm{d}}$ Department of Cell Death and Proliferation, Instituto de Investigaciones Biomédicas de Barcelona, CSIC, Liver Unit, Hospital Clinic, IDIBPAS and CIBERehd, Barcelona, \\ Spain \\ e 1st Department of Medicine, University Medical Center, Johannes Gutenberg University Mainz, Langenbeckstrasse 1, 55131 Mainz, Germany \\ ${ }^{\mathrm{f}}$ INSERM, Inra, University of Rennes, UMR 1241, Nutrition Metabolisms and Cancer, Rennes, France \\ ${ }^{\mathrm{g}}$ Laboratorio de Medicina Experimental, Unidad de Medicina Translacional, Instituto de Investigaciones Biomédicas, UNAM/Instituto Nacional de Cardiología Ignacio \\ Chavez, Mexico City, Mexico
}

\section{A R T I C L E IN F O}

\section{Keywords:}

GDF11

Huh7 cells

HCC

Cell cycle

Liver cancer

Hep3B cells

\begin{abstract}
A B S T R A C T
Growth differentiation factor 11 (GDF11) has been characterized as a key regulator of differentiation in cells that retain stemness features, despite some controversies in age-related studies. GDF11 has been poorly investigated in cancer, particularly in those with stemness capacity, such as hepatocellular carcinoma (HCC), one of the most aggressive cancers worldwide. Here, we focused on investigating the effects of GDF11 in liver cancer cells. GDF11 treatment significantly reduced proliferation, colony and spheroid formation in HCC cell lines. Consistently, down-regulation of CDK6, cyclin D1, cyclin A, and concomitant upregulation of p27 was observed after $24 \mathrm{~h}$ of treatment. Interestingly, cell viability was unchanged, but cell functionality was compromised. These effects were potentially induced by the expression of E-cadherin and occludin, as well as Snail and Ncadherin repression, in a time-dependent manner. Furthermore, GDF11 treatment for $72 \mathrm{~h}$ induced that cells were incapable of sustaining colony and sphere capacity in the absent of GDF11, up to 5 days, indicating that the effect of GDF11 on self-renewal capacity is not transient. Finally, in vivo invasion studies revealed a significant decrease in cell migration of hepatocellular carcinoma cells treated with GDF11 associated to a decreased proliferation judged by Ki67 staining. Data show that exogenous GDF11 displays tumor suppressor properties in HCC cells.
\end{abstract}

\section{Introduction}

Liver diseases represent one of the main challenges in public health. Changes in human habits tend to increase the prevalence of severe liver diseases, such as steatohepatitis, cirrhosis, viral hepatitis and liver cancer [1]. Hepatocellular carcinoma (HCC) is one of the most prevalent and aggressive tumor worldwide with high rate of postsurgical recurrence [2-4], and despite the outstanding progress made in the last decade in identifying new therapeutic approaches to target canonical proliferation and survival pathways, the potential use of non-canonical molecules and the molecular basis of their anti-proliferating activity are currently being studied directed to provide new therapeutic targets [5].

Growth differentiation factor 11 (GDF11) is a member of the subfamily of the bone morphogenic proteins, and of the superfamily of the transforming growth factor beta (TGF- $\beta$ ). GDF11 is critical for organogenesis and development, particularly for skeletal system. Knock-out for mouse Gdf11, or for the furin-like convertase (Pcsk5), which activates GDF11 to a mature form, results in skeletal development defects

\footnotetext{
* Corresponding author at: Departamento de Ciencias de la Salud, Universidad Autónoma Metropolitana Iztapalapa, Av. San Rafael Atlixco 186, Col. Vicentina, Iztapalapa, 09340 Mexico City, Mexico.

E-mail address: legq@xanum.uam.mx (L.E. Gomez-Quiroz).

${ }^{1}$ Shared Senior authorship.
} 
and lethality in uterus $[6,7]$.

Recently, some controversies have emerged about the effects of GDF11 in rejuvenation process [8]. While some groups report that GDF11 expression reduces with age, and its restoration induces proliferation and differentiation of progenitor cells (satellite cells) in the skeletal [9] and cardiac muscle [10], reversing the age-related hypertrophy, others state that GDF11 significantly inhibits muscle regeneration and decreases satellite cell expansion in mice [11,12]. This debating question is also associated with the great similarity of GDF11 with myostatin (or GDF8) and the poor specificity of some commercial antibodies [13]. Aside of these controversial functions of GDF11 in agerelated disorders, both outlooks have in common that cells, with some stemness properties, are targeted by the GDF11, notably in development process [14-16].

Given that cancer cells, with stemness features, are recognized as key therapeutic target, due to their capacity of sustained proliferation and migration, possibly driving tumor progression and resistance to treatment, we aimed at figure out the effects of GDF11 in HCC-derived cell lines. Although some studies revealed that GDF11 expression correlates with poor prognosis in colorectal [17] and breast cancer [18], it has been poorly studied in this kind of disease. Recently, Bajikar and collaborators [19] reported that GDF11 exerts tumor suppressive functions in triple-negative breast cancer cells. Loss of function of GDF11 in breast cancer has been notably related to deficient maturation due to the convertase PCSK5, which activates bioactive GDF11 from its immature form. The present study is the first one related to liver cancer and provides evidence that GDF11 could be a good candidate for new therapeutic options.

\section{Materials and methods}

\subsection{Cell culture}

Huh7, Hep3B, Hepa1-6, HepG2, SNU-182 and MDA-MB-231 cell lines were obtained from the American Type Culture Collection (ATCC, Manassas, VA, USA). Cells were cultured in William's medium supplemented with $10 \%$ fetal bovine serum (FBS, Hy-Clone, Logan, UT, USA), $100 \mathrm{U} / \mathrm{ml}$ ampicillin and $100 \mu \mathrm{g} / \mathrm{ml}$ streptomycin (Thermo Fisher Scientific, Waltham, MA, USA). Cells were maintained at $37^{\circ} \mathrm{C}$ in a $5 \%$ $\mathrm{CO}_{2}$ and $90 \%$ humidity atmosphere. Cells were plated in plastic culture bottles (Sigma-Aldrich, Saint Louis, MO, USA). All cell lines were mycoplasma free.

\subsection{Main experimental design}

Cells were exposed to $50 \mathrm{ng} / \mathrm{ml}$ GDF11 [20] for different times. GDF11 was added to culture media every $24 \mathrm{~h}$ and cells were recovered after $72 \mathrm{~h}$ for experiments, as depicted in Supplementary Fig. 1A.

In order to determine whether GDF11 effects are not transient, and remain after growth factor withdrawal, we performed additional experiments, in which cells were treated every $24 \mathrm{~h}$ up to $72 \mathrm{~h}$, then harvested and re-plated without GDF11. Spheroid and colony formation were evaluated up to 5 days in the absent of GDF11 (Supplementary Fig. 1B).

\subsection{Western blotting}

Western blot was conducted as we previously reported [21]. PVDF membranes were probed with specific antibodies as described in the Supplementary Table 1. Horseradish peroxidase-conjugated antibodies were used according to the primary antibodies. Blots were exposed using Super Signal West Pico Chemiluminescent substrate (Pierce Biotechnology, USA). Signal was detected using Gel Logic 2500 (Kodak, Rochester, NY, USA).

\subsection{Immunofluorescence assays}

Immunofluorescence was conducted as previously reported [22], briefly, cells were treated for different times with GDF11, and then fixed with $4 \%$ paraformaldehyde in phosphate-buffered saline (PBS). Samples were permeabilized with $0.01 \%$ (v/v) Triton-X 100 for $30 \mathrm{~min}$ and blocked with $3 \%(\mathrm{w} / \mathrm{v})$ bovine serum albumin (BSA) in PBS for $30 \mathrm{~min}$ and subsequently incubated with primary antibodies anti-occludin (Santa Cruz Biotechnology 81812, dilution 1:100), anti-snail (Santa Cruz Biotechnology 28199, dilution 1:100), anti-E-cadherin (Santa Cruz Biotechnology 21791, dilution 1:100) and anti-N-cadherin (Santa Cruz Biotechnology 59987, dilution 1:100). Nuclei were counterstained with $1 \mu \mathrm{g} / \mathrm{ml} \mathrm{4',6-diamidino-2-phenylindole} \mathrm{(DAPI)} \mathrm{(Sigma-}$ Aldrich). Images were obtained using a multi-photon confocal microscope (Carl Zeiss LSM-780 NLO, Oberkochen, Germany).

\subsection{Cell proliferation}

Cell proliferation was addressed by CCK- 8 kit (Dojindo Lab, Kumamoto, Japan), following manufacturer's instructions.

\subsection{Spheroid formation}

Cells were seeded in six-well low attachment plates (MilliporeSigma, Saint Louis MO, USA). The cultures were supplemented every $24 \mathrm{~h}$ with $50 \mathrm{ng} / \mathrm{ml}$ of GDF11 for five days. The spheroids were counted and photographed using an inverted microscope Carl Zeiss VERT.A1.

\subsection{Wound-healing assay}

Cells were seeded in six-well plates to approximately $90 \%$ of confluency. In each well a couple of wounds were created with a $20 \mu \mathrm{l}$ pipette tip. Plates were washed three times with PBS to remove detached cells. Subsequently, media were added supplemented or not with FBS in presence or absent of GDF11.

The healing response was monitored every $24 \mathrm{~h}$ up to $72 \mathrm{~h}$ when photography register was performed.

\subsection{Cell functionality by MTT assay}

Cell functionality was addressed by the 3-(4,5-dimethylthiazol-2yl)-2,5-diphenyltetrazolium bromide (MTT) test, using the Vybrant MTT Cell Proliferation Assay Kit (Thermo Fisher Scientific), following manufacturer's instructions.

\subsection{Clonogenic assay}

After $72 \mathrm{~h}$ under GDF11 treatment, $1 \times 10^{3}$ cells were seeded into 6well plates in triplicate and maintained in GDF11-free media, in presence or absent of FBS. After 10 days, colonies were stained with crystal violet, photographed and counted.

\subsection{Invasion study using a chick embryo chorioallantoic membrane (CAM) assay}

Chick embryo CAM model was used to study invasion properties, following previous method reported by our group and others [23-25]. Briefly, ten fertile chick (Gallus domesticus) eggs (ALPES SA Farms, Puebla, Mexico) were randomly separated in two groups. Eggs were incubated at $37.8^{\circ} \mathrm{C}$ and $60 \%$ humidity up to $22 \mathrm{HH}$ of embryo stage development. Then, shells were wiped with $70 \%$ ethanol, and $1 \mathrm{~cm}^{2}$ window was done. The vitelline membrane was dissected and $1 \times 10^{6}$ cells, treated or not with GDF11 for $72 \mathrm{~h}$ and labeled with vibrant CFDA SE cell tracer kit (Thermo Fisher Scientific), were introduced onto the CAM, in the convergence of two blood vessels, using $30 \mu \mathrm{l}$ of Matrigel (Sigma-Aldrich) as substrate. The window in the shells was covered 
A)
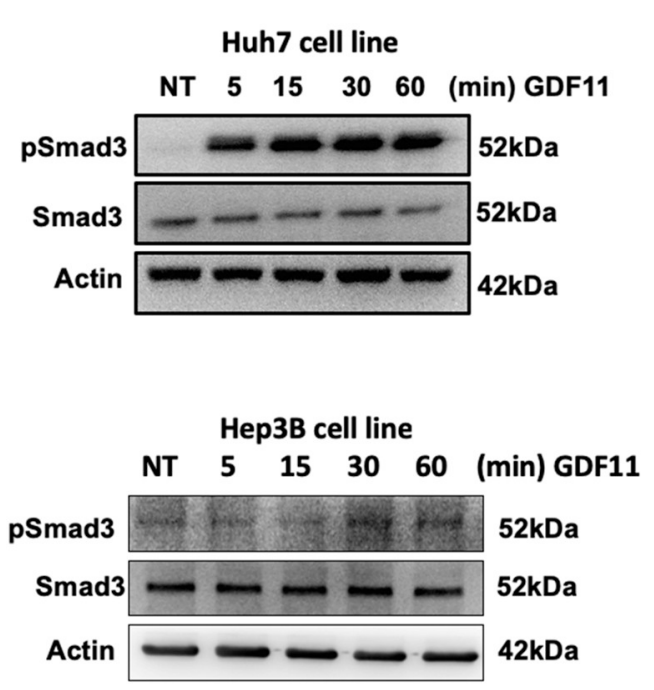

C)
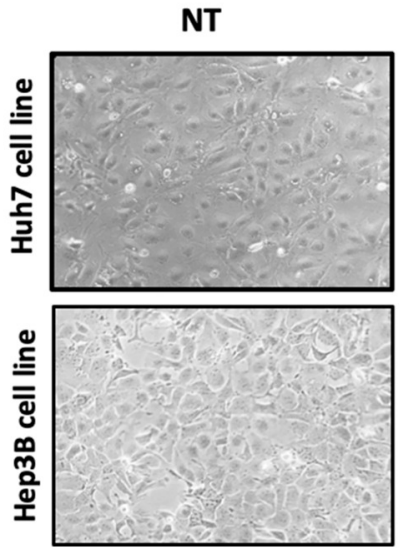

B)
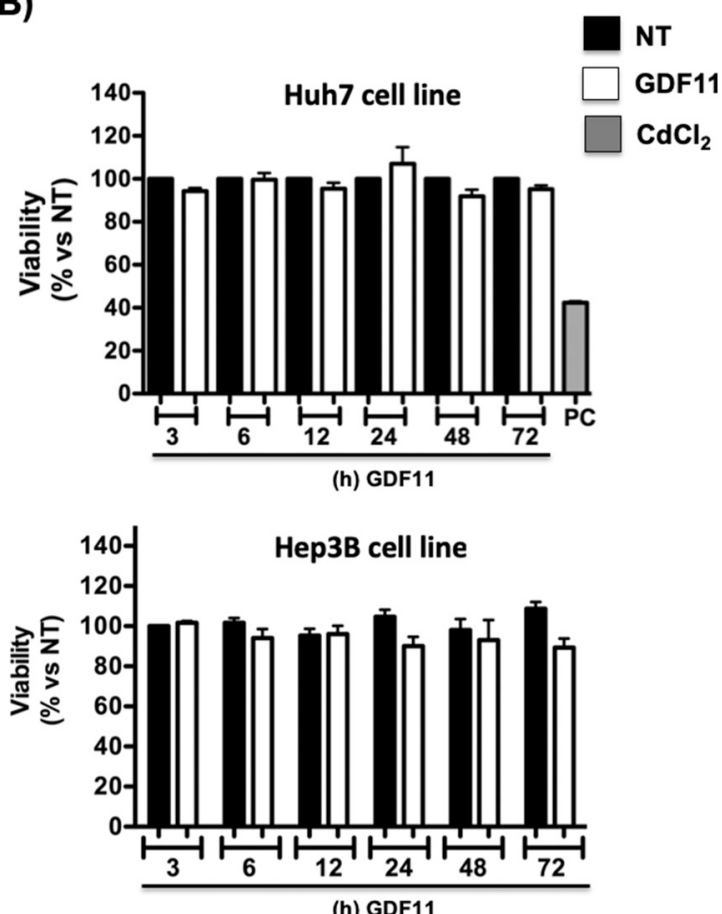

(h) GDF11
GDF11 (72h)
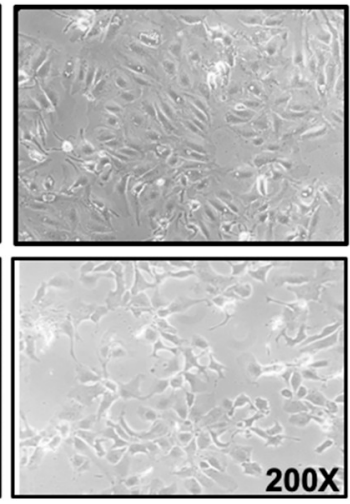

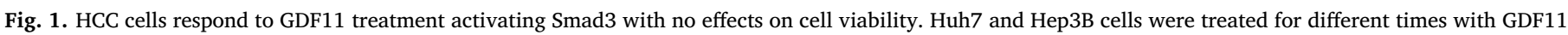

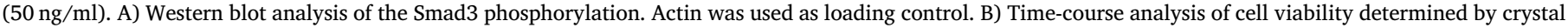

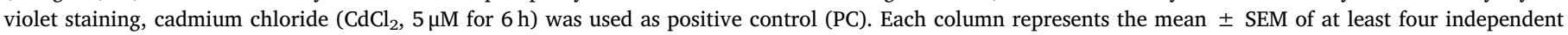

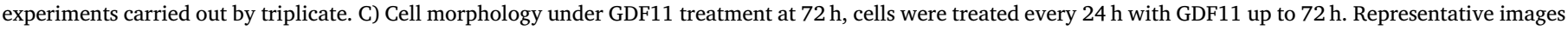
of at least four independent experiments. Original magnification $200 \times$.

with sterile adhesive tape and eggs were incubated as above for 2 and 4 days. CAM were recovered and immediately fixed with $4 \%$ paraformaldehyde in PBS. Paraffin sections $(5 \mu \mathrm{m})$ were obtained for immunofluorescence using anti-beta-catenin antibody (Cell Signaling \# 9562). Proliferation was addressed by immunofluorescence using anti-Ki67 antibody (abcam 15580; dilution 1:100). Nuclei were counterstained with $1 \mu \mathrm{g} / \mathrm{ml}$ DAPI. Images were acquired using a multiphoton confocal microscope (Carl Zeiss LSM-780 NLO).

\subsection{Real-time quantitative reverse transcriptase-polymerase chain reaction ( $q R T-P C R)$}

One $\mu \mathrm{g}$ total RNA was reverse transcribed in $20 \mu \mathrm{l}$ reaction volume with a SuperScript (Invitrogen Corp.) first-strand synthesis kit according to the manufacturer's instructions. Oligonucleotide primers were designed using Primer3 v.0.4.0 (http://frodo.wi.mit.edu/ primer3/) as describe [26]. The qRT-PCR analysis was performed with a CFX96 Touch (Bio-Rad) thermal cycler in a 96-well reaction plate. The $10 \mu \mathrm{l}$ PCR reaction mix contained $5 \mu 12 \times$ SYBR Green PCR Master Mix (Bio-Rad), $200 \mathrm{nM}$ of each primer, and $1 \mu \mathrm{cDNA}$ template. Reactions were incubated for $10 \mathrm{~min}$ at $95^{\circ} \mathrm{C}$ followed by 40 cycles of $30 \mathrm{~s}$ at $95^{\circ} \mathrm{C}$ and $60 \mathrm{~s}$ at specific primer temperature. The expression level of ribosomal protein S18 (rs18) was used as reference. Relative gene expression levels were calculated using the formula $2^{(-\Delta \Delta \mathrm{Ct})}$. Primer sequences are listed in Supplementary Table 2.

\subsection{Protein quantification}

The protein content was determined by using the bicinchoninic acid method (BCA, Pierce, Thermo Fisher Scientific), following the manufacturer's instructions. 


\subsection{Statistical analysis}

The results are presented as the average of at least three independent experiments. A One-way ANOVA followed by Tukey post- test was performed for the analysis of cell viability, mitochondrial functionality by MTT, number of spheroids and number of colonies in cell sensitization experiments whit GDF11. t-Student test was performed for the analysis of the numbers of spheroids.

A)

Serum free

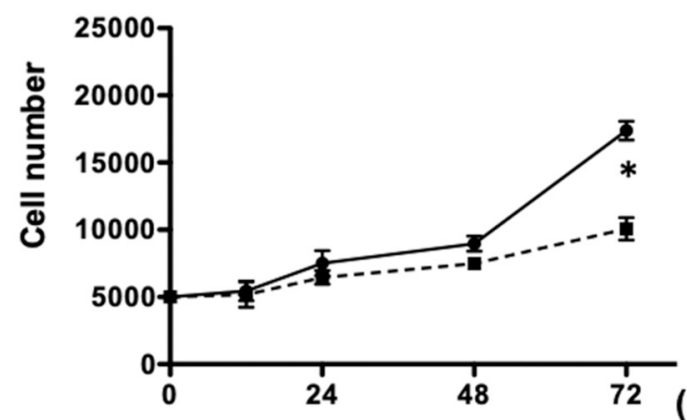

(h) GDF11
FBS

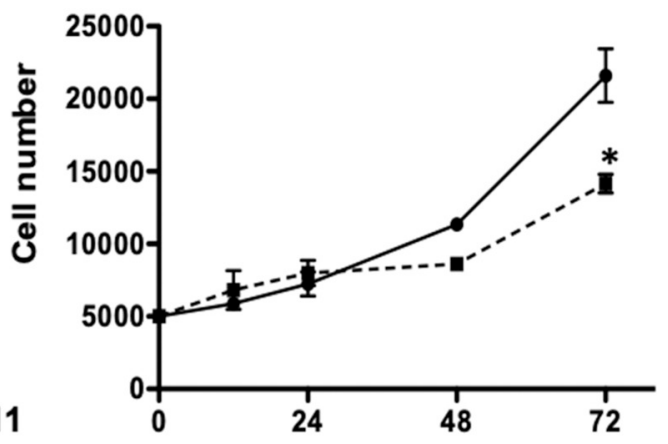

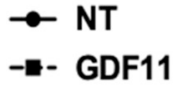

(h) GDF11

B)
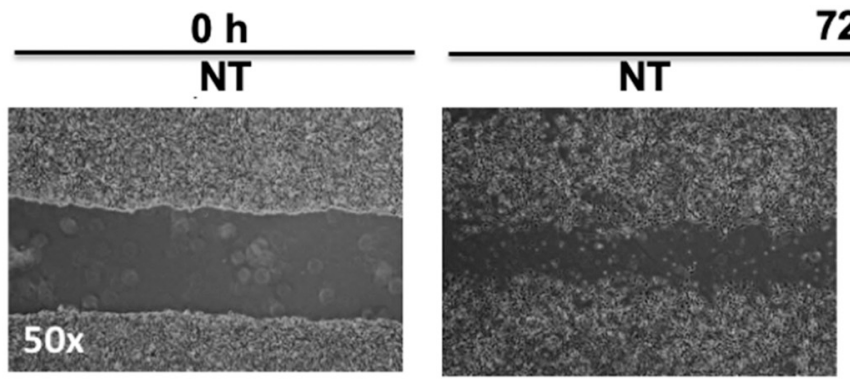

$72 \mathrm{~h}$

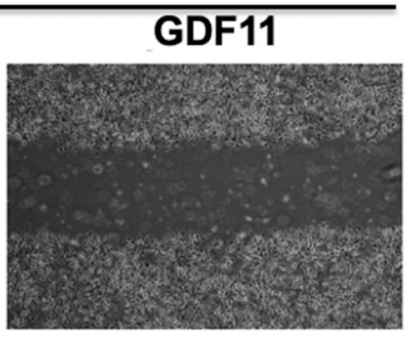

C)
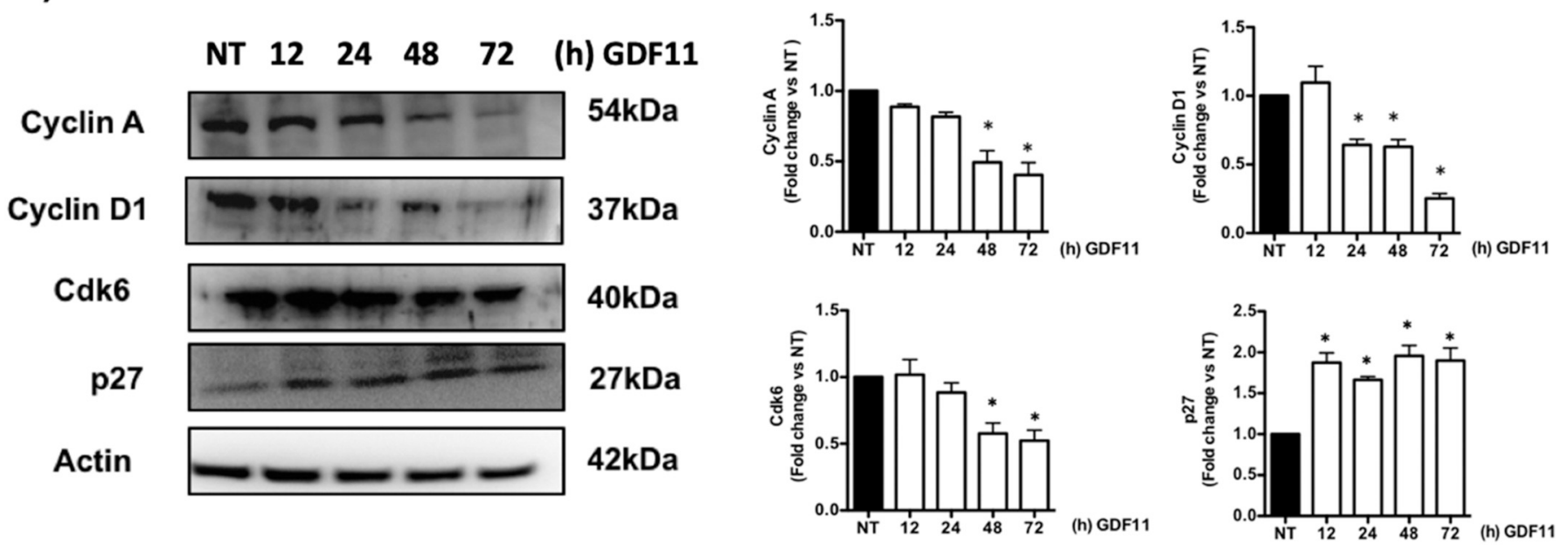

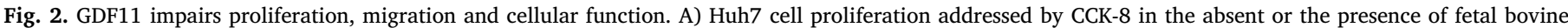

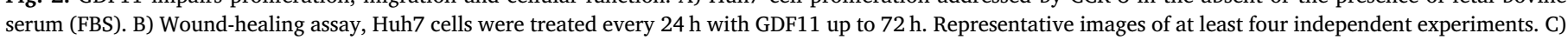

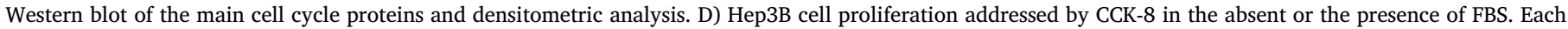

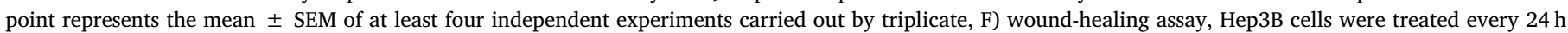

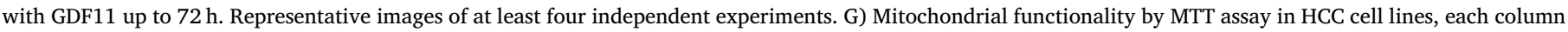

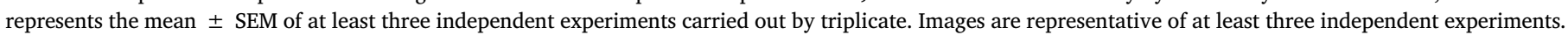
$*, p \leq 0.05$ vs NT cells at $72 \mathrm{~h}$. 
D)
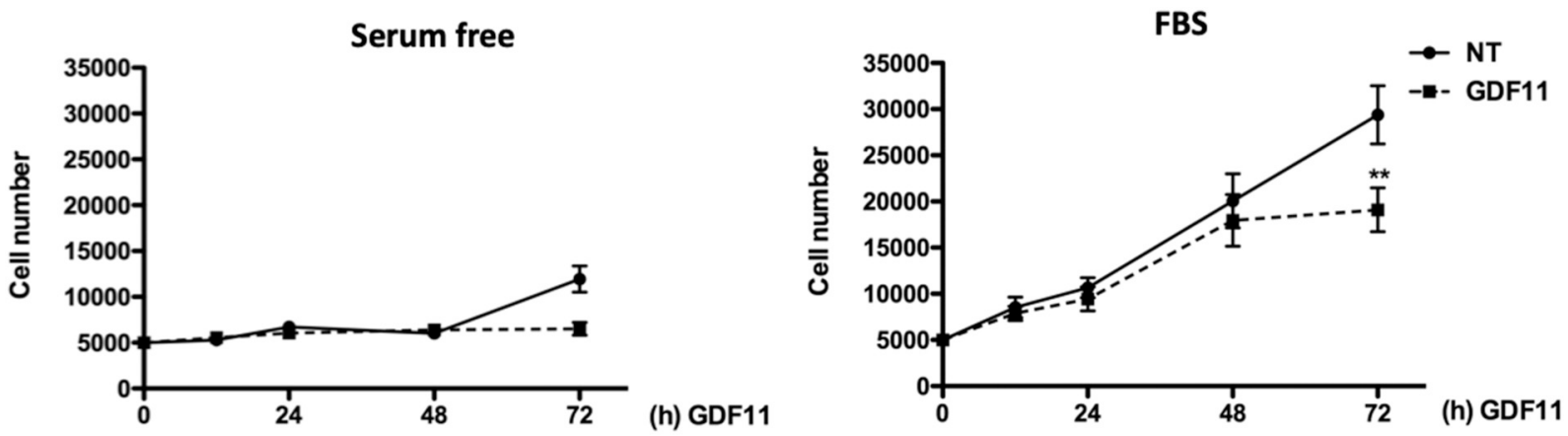

F)

$\mathbf{O h}$

$72 \mathrm{~h}$
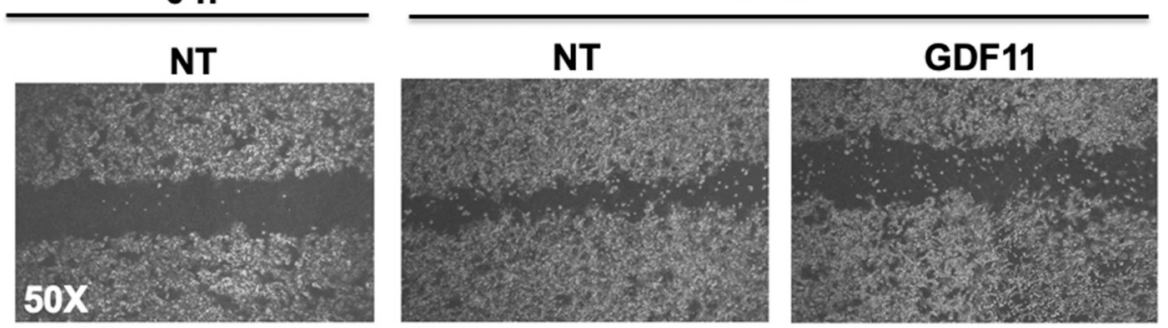

G)
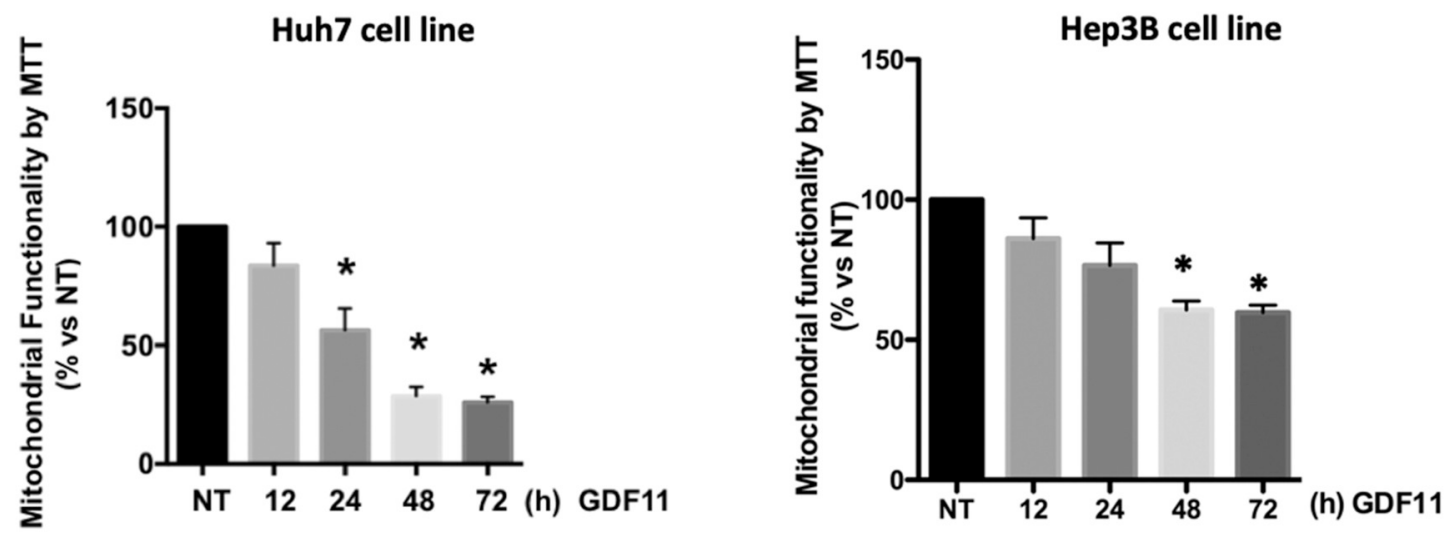

Fig. 2. (continued)

\section{Results}

\subsection{HCC cells respond to GDF11 treatment by activating Smad3}

To figure out whether HCC-derived cells respond to GDF11, Huh7 and Hep3B cells were treated with $50 \mathrm{ng} / \mathrm{ml}$ GDF11 up to $60 \mathrm{~min}$. Activation of the canonical signaling pathway was addressed by immunoblot of Smad3. Fig. 1A shows that Smad3 is rapidly activated by phosphorylation $5 \mathrm{~min}$, in Huh7 cell line, and $30 \mathrm{~min}$ in Hep3B cell line, after GDF11 treatment. Activation remains up to $60 \mathrm{~min}$. To explore impact in cell viability, Huh7 and Hep3B cells were treated at different times with GDF11. Time-course analysis up to $72 \mathrm{~h}$ of treatment demonstrates that GDF11 has no significant impact on cell viability (Fig. 1B), while $\mathrm{CdCl}_{2}(5 \mu \mathrm{M}, 6 \mathrm{~h})$, used as a positive control, reduces cell viability. In addition, morphology inspection of cell culture at $72 \mathrm{~h}$ revealed small changes in cells, including a flat-like phenotype and a decrease in cell density in both cell lines (Fig. 1C).

\subsection{GDF11 impairs cell proliferation and cycle progression}

Next, we decided to address cell proliferation; although no significant effect was observed on cell viability, GDF11 was shown to decrease Huh7 cell proliferation starting after $48 \mathrm{~h}$ GDF11 treatment and being statistically significantly at $72 \mathrm{~h}$ in the absence or presence of FBS (Fig. 2A), which was used as a competitor. In addition, a woundhealing assay revealed an impaired repair process at $72 \mathrm{~h}$ under GDF11 treatment compared with untreated cells (Fig. 2B). The analysis of the content of key cell cycle proteins shows that positive regulators such as Cyclin A, Cyclin D1 and CDK6 decreases in a time dependent manner, while $\mathrm{CDK}$ inhibitor p27 increases (Fig. 2C). Consistent with results observed in Huh7 cells, Hep3B cells under GDF11 treatment showed similar effects in cell proliferation (Fig. 2D) and wound-healing assay (Fig. 2F). Although viability was not affected in both HCC-derived cell lines, cell functionality, evaluated by MTT assay was significantly decreased starting after $24 \mathrm{~h}$ of treatment, in Huh7 cells, and $48 \mathrm{~h}$ in 


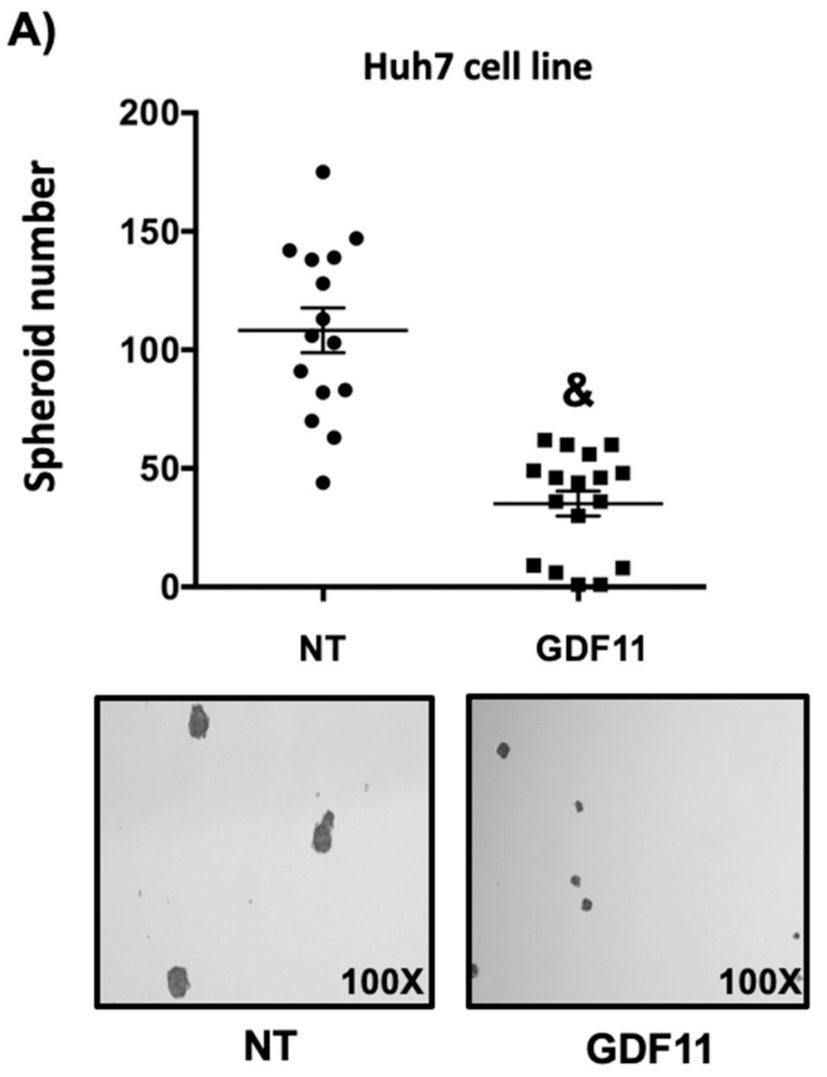

\author{
Hep3B cell line
}

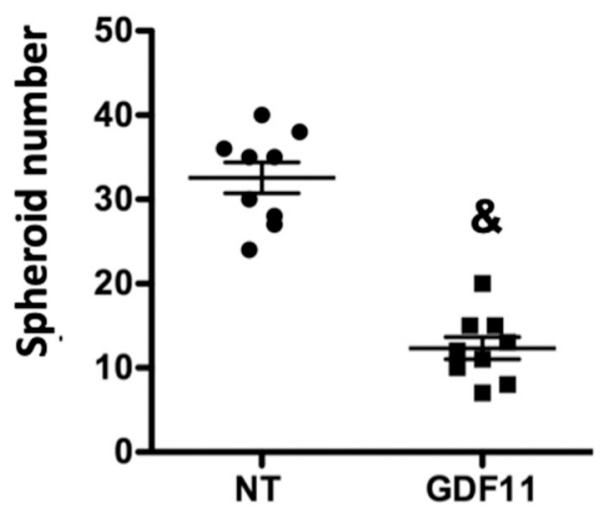

B)
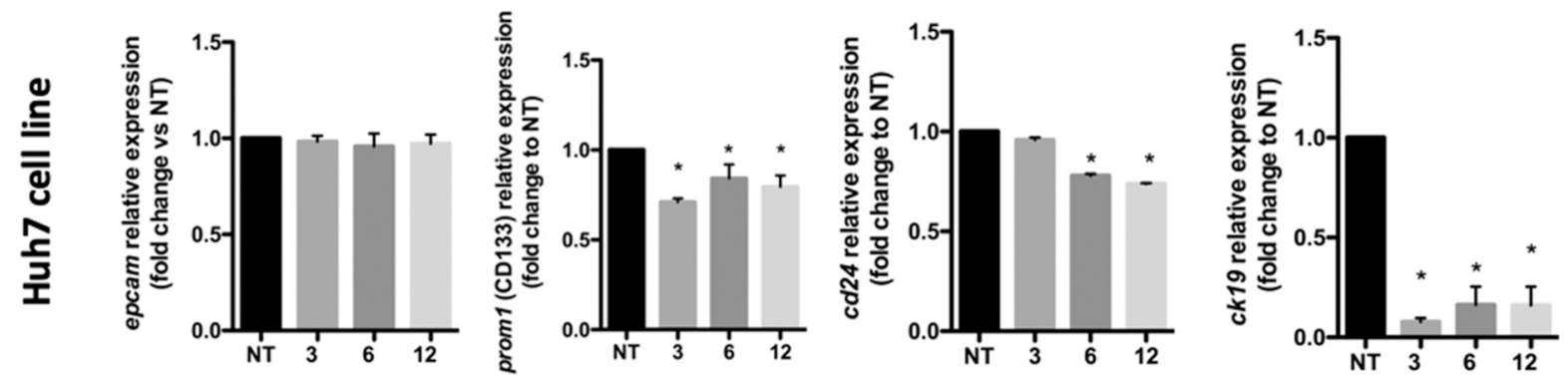

$100 x$
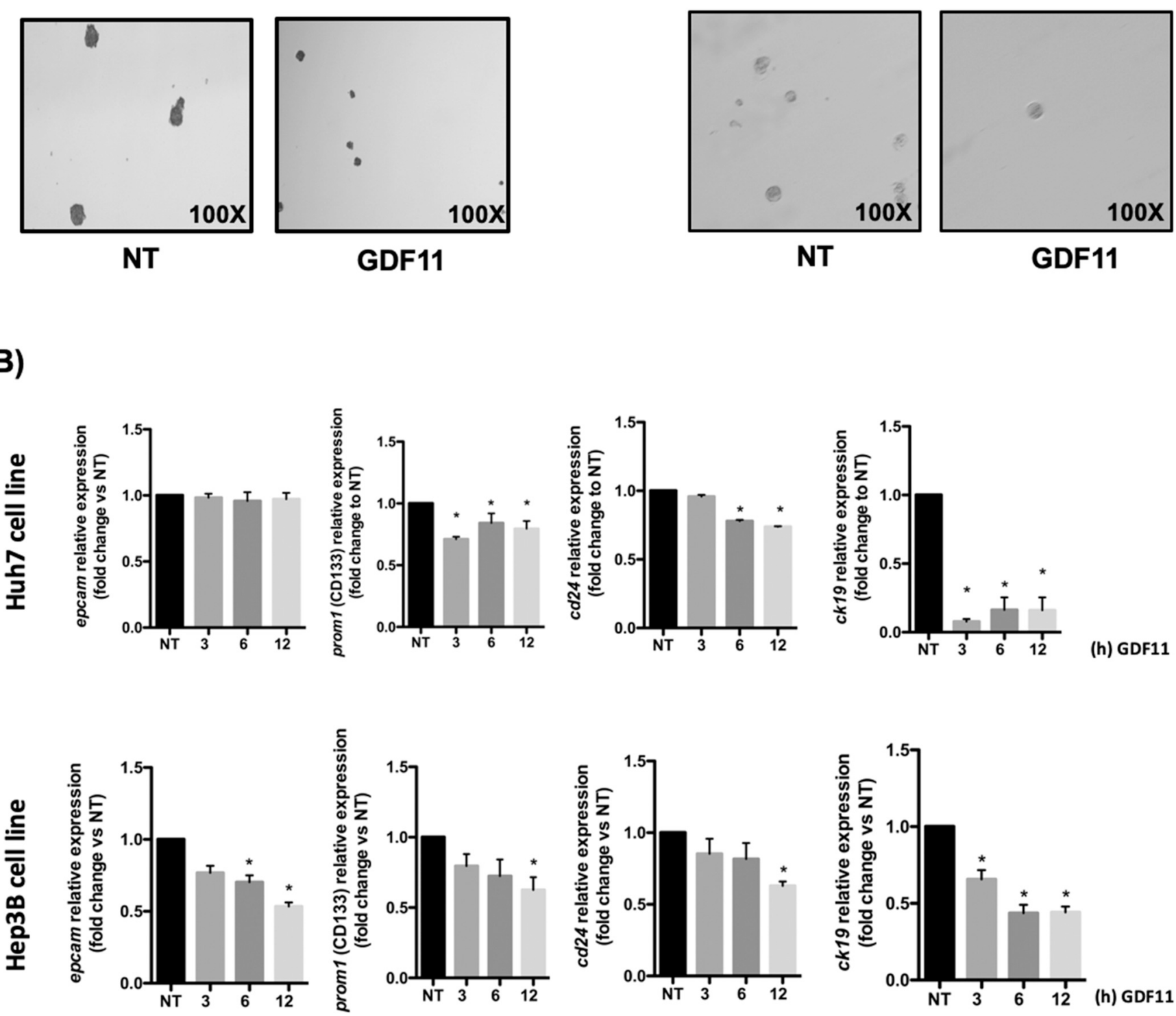

(h) GDF11

Fig. 3. GDF11 decreases spheroid formation capacity and the expression of genes related to aggressiveness. A) Spheroid counting at $72 \mathrm{~h}$, Huh7 and Hep3B cells were treated every $24 \mathrm{~h}$ with GDF11 $(50 \mathrm{ng} / \mathrm{ml})$ up to $72 \mathrm{~h}$, each point represents an independent experiment, we reported the median \pm SEM of at least ten independent experiments. Images are representative of at least ten independent experiments, original magnification $100 \times . \&, p \leq 0.05$ vs NT cells at $72 \mathrm{~h}$. B) Messenger RNA levels of key genes related to cancer aggressiveness, relative expression to not treated (NT) cells is demonstrated as means \pm SEM. *, $p \leq 0.05$ vs NT cells. 
Hep3B cells, explaining the effects observed in proliferation and wound-healing (Fig. 2G).

\subsection{GDF11 decreases spheroid formation capacity and the expression of} genes related to aggressiveness

Previous results strongly suggest that GDF11 exerts tumor suppressive effects. To gain more evidence, we performed studies of spheroid formation under GDF11 treatment every $24 \mathrm{~h}$ for 5 days. Cells treated with GDF11 exhibited fewer spheroids at day 5 (39\%, in Huh7 cells; and 34\% in Hep3B), as compared with untreated cells at the same time (Fig. 3A). Even more, spheroids observed under the GDF11 treatment were smaller (25\% in Huh7 cells; and $40 \%$ in Hep3B) than those formed in the absent of treatment.

The analysis of the expression of some of the key well-characterized markers of cancer cell aggressiveness, revealed an increment of

A)

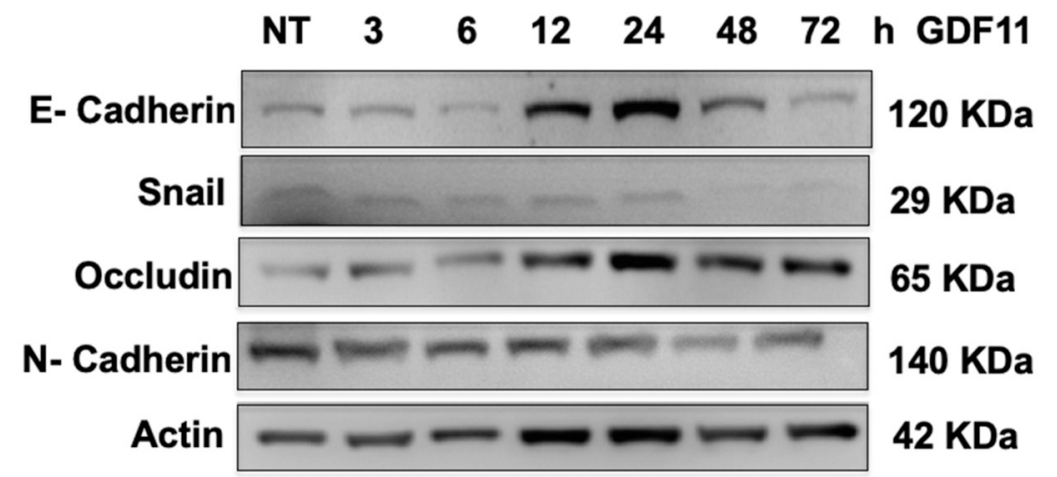

B)
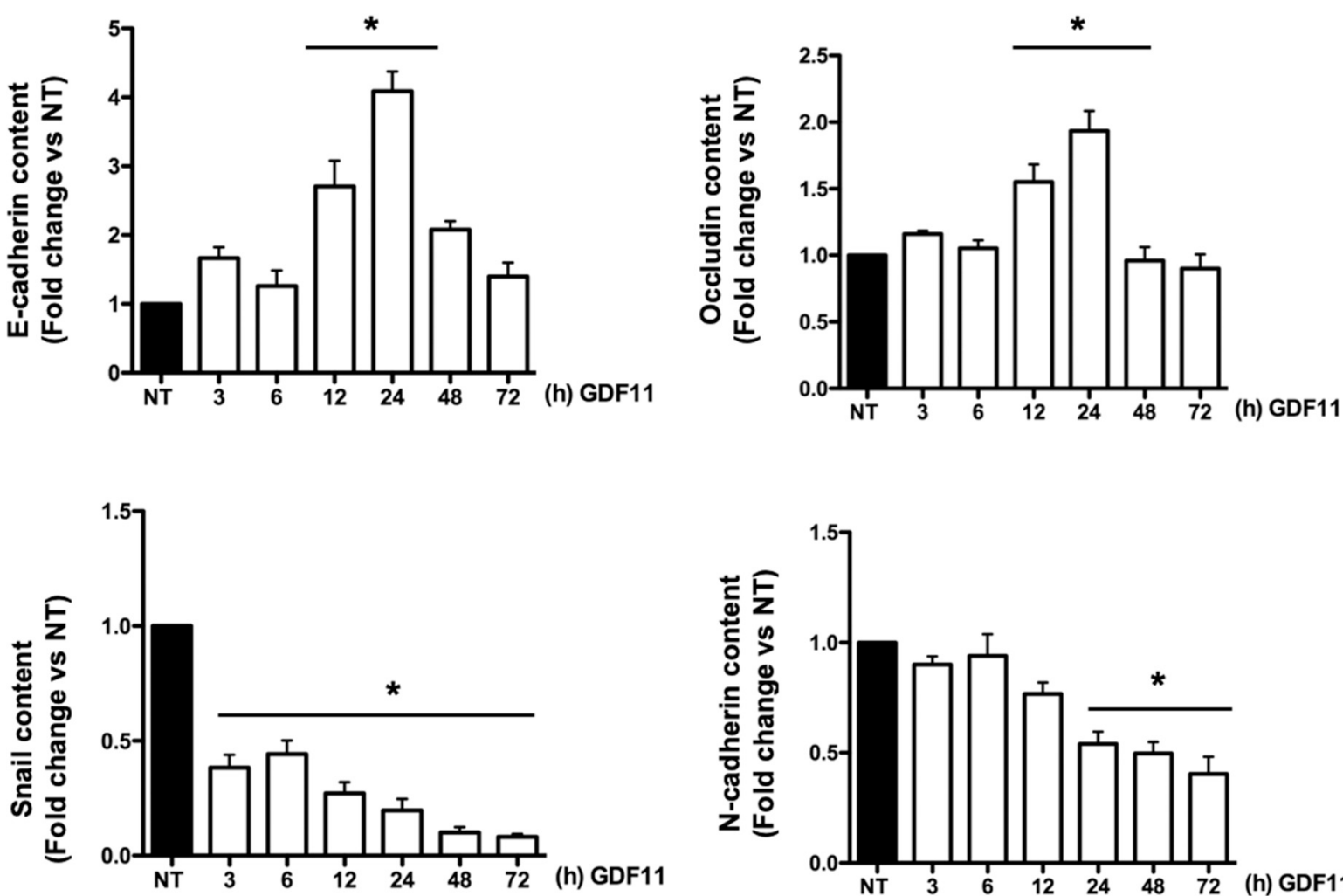

(h) GDF11

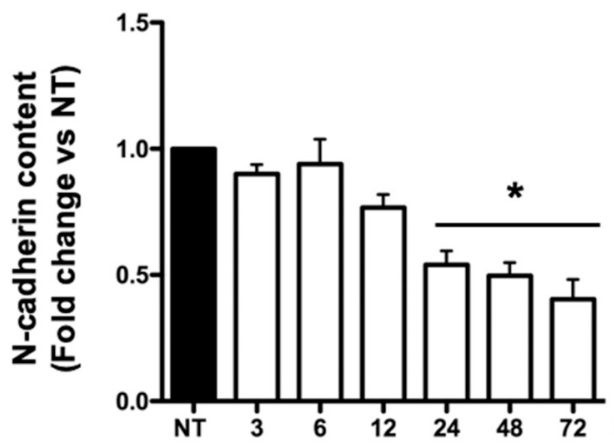

(h) GDF11

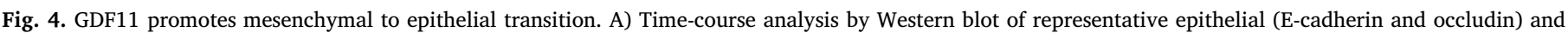

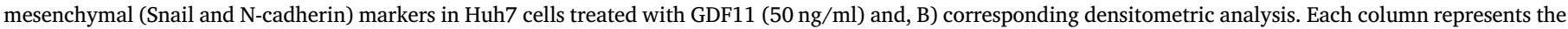

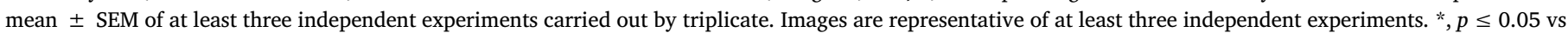

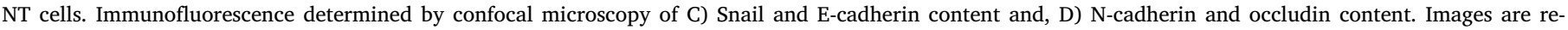
presentative of at least three independent experiments. Original magnification $360 \times$. 
C)

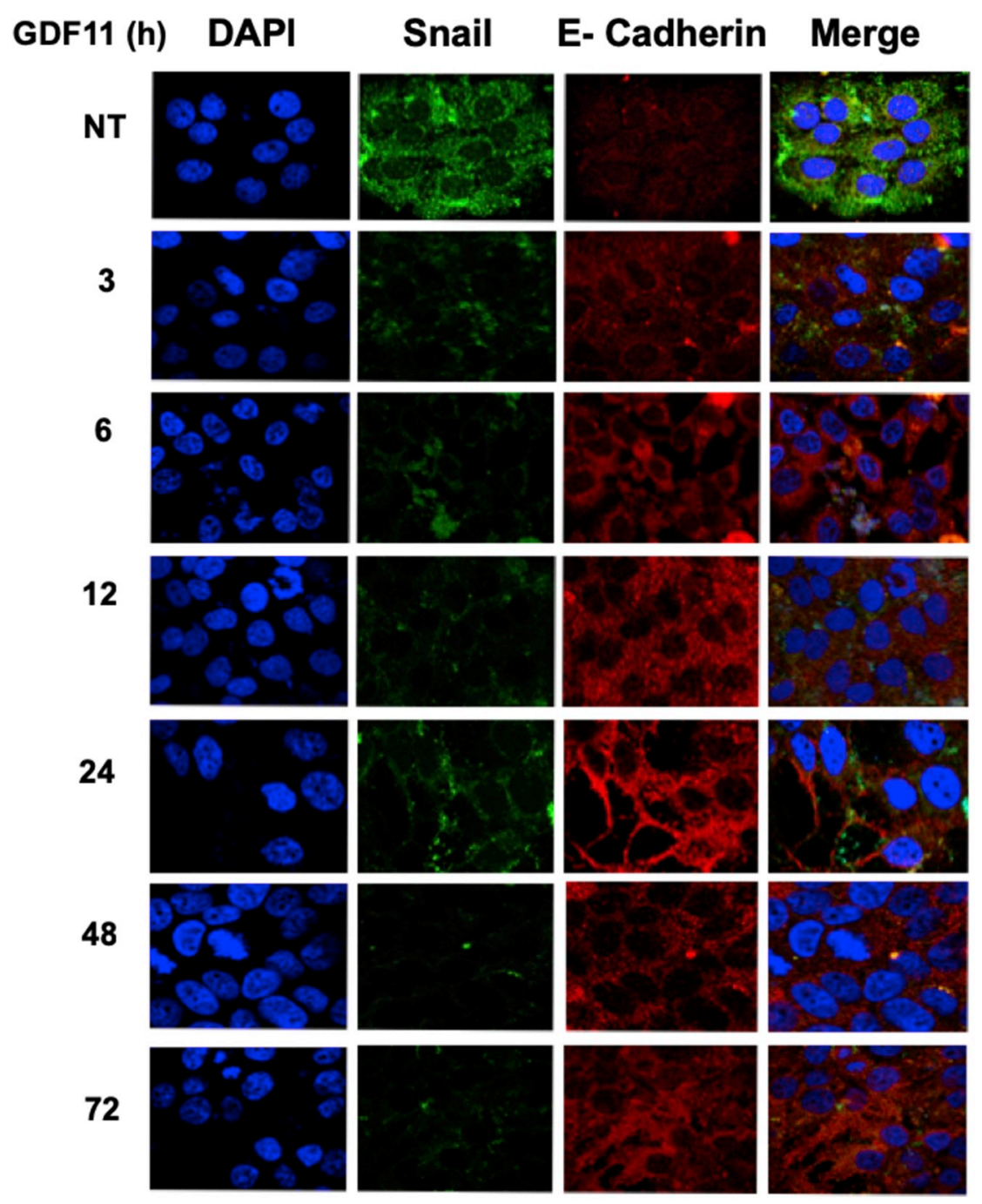

Fig. 4. (continued)

messenger RNA of CD133, CD24, CK19 and EpCAM particularly, the last one was significantly diminished only in Hep3B with no changes in Huh7 cells (Fig. 3B).

\subsection{GDF11 promotes mesenchymal epithelial transition}

Next, we decided to address the expression of some mesenchymal and epithelial key markers in cells under GDF11 treatment. The immunoblot revealed a decrement of mesenchymal markers, such as Snail and $\mathrm{N}$-cadherin, and the increment of epithelial markers, such as occludin and E-cadherin, in a time-dependent manner (Fig. 4A and B), interestingly mesenchymal markers remain below levels of not treated cells, while epithelial markers decrement peaked at $24 \mathrm{~h}$ and then decreased to control values. To gain more confidence of these data, we analyzed the content of these proteins by immunofluorescence, Fig. 4C and D show the colocalization of Snail and E-cadherin; and N-cadherin and occludin, respectively, in both cases the expression of the mesenchymal proteins (Snail or N-cadherin) was considerably diminished, and the epithelial ones was increased, confirming the immunoblot experiments. Similar results were obtained in Hep3B exhibiting an increment in the expression of E-cadherin and occludin, and decrement in $\mathrm{N}$-cadherin, in a time-dependent manner (Supplementary Fig. 2).
3.5. The effects elicited by GDF11 for $72 \mathrm{~h}$ of treatment remain in the absence of the factor

To figure out whether the effects displayed by GDF11 induce a longlasting or a transient cellular reprograming, cells were treated with GDF11 every $24 \mathrm{~h}$ for three days then, cells were harvested and processed to explore the capacity of colony and spheroid formation for five days, in presence or absence of serum as competitor. Fig. 5A shown that Huh7 cells treated with GDF11 remarkably decreased the ability to form colonies, in the presence or absence of FBS. Similarly, spheroid formation was significantly diminished in both cell lines (Fig. 5B and C), interestingly a better effect was observed in Huh7 cell line practically abrogating the spheroid formation capacity. Serum supplementation in the media did not rescue cells from the static phenotype (Supplementary Fig. 3), but the number of spheroids were different in the presence or absent of FBS in NT cells. Reprogramming experiments showed that cells exposed to GDF11 were unable of sustaining their colony and sphere forming capacity, indicating that the effect of GDF11 on self-renewal capacity is not transient.

\subsection{GDF11 impairs invasion capacity}

To address one of the key hallmarks of malignancy, we assayed 
D)

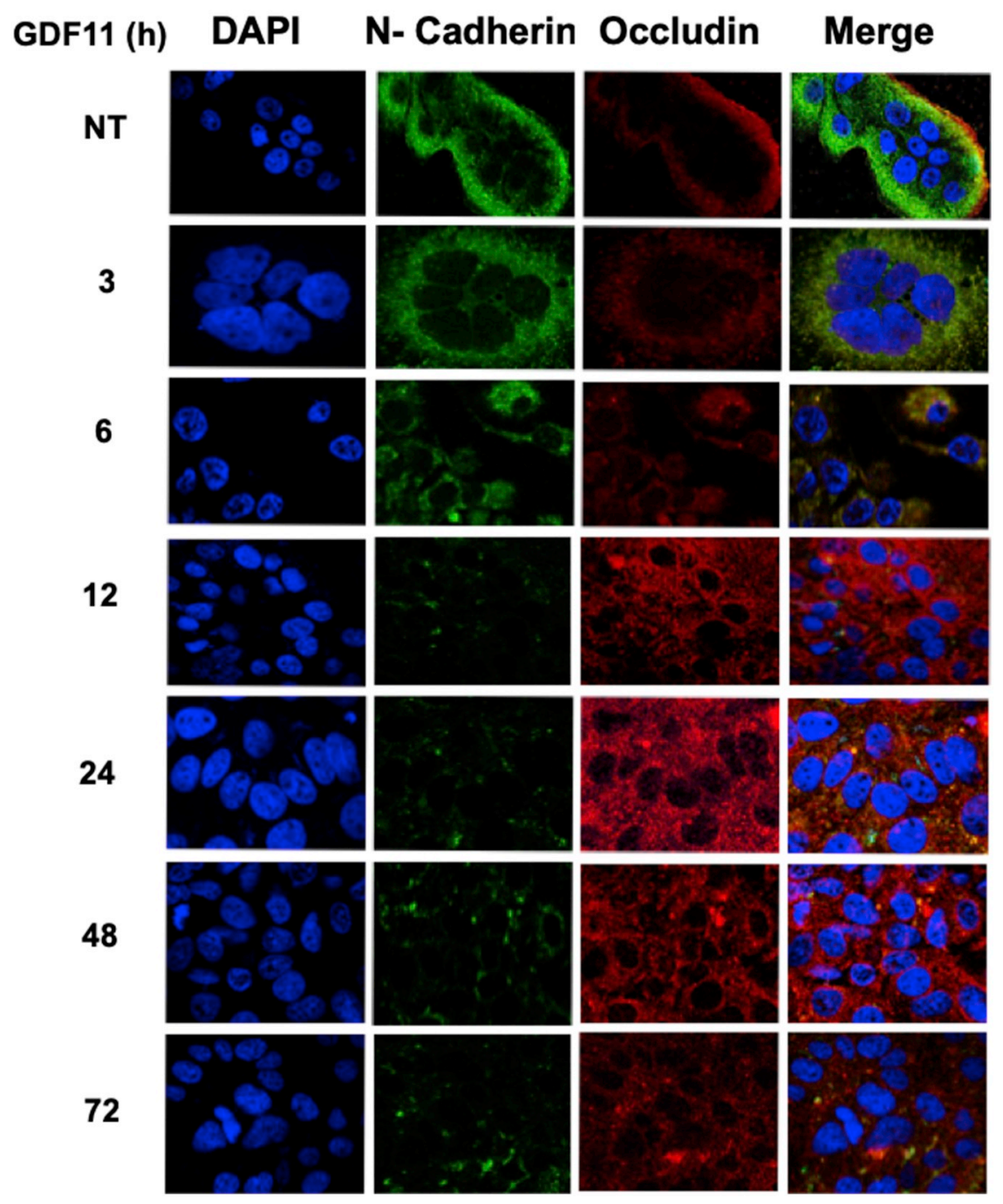

Fig. 4. (continued)

invasion property in cells treated or not with GDF11. $1 \times 10^{6}$ cells were grafted in the CAM of the chick embryo (Fig. 6A). Fig. 6C shows the complete control CAM with no cells, in order to observe normal morphology of the CAM. Cells were grafted in the area labeled with the yellow circle; the eggshell was covered with sterile tape. After two or four days of incubation at $37^{\circ} \mathrm{C}$, the CAM was recovered fixed and paraffin embedded for immunofluorescence and confocal microscopy. We started exploring the effect at day four; at this time we observed embryo lethality only with not treated cells (Fig. 6B). Microscopy inspection revealed few disaggregated not treated cells remaining in the grafted zone (Supplementary Fig. 4A, white arrows), and some cells were observed in the distal zone of the CAM (green cells), indicating an ongoing invasion process (Supplementary Fig. 4C). The same experimental setting with GDF11 treated cells revealed some significant compacted aggregates of cells (Supplementary Fig. 4B, yellow arrow heads), and some of them in transit (Supplementary Fig. 4B, white arrows). No cell was detected in the distal CAM (Supplementary Fig. 4D). Remarkably, chick embryos in the eggs inoculated with GDF11 treated cells were still alive (Fig. 6B).

In order to analyze the invasion process at an early time point, we decided to incubate the eggs only for two days. Microscopic analysis of the complete CAM revealed that most of the untreated cells were gone (Fig. 6D). In fact, some of chick embryo dies also at this time, however, cells treated for three days with GDF11 remained covered by the CAM and cell localization suggests an attempt of migration, but most of the cells still there (Fig. 6E). The CAM zones near to the cell cumulous strongly express beta catenin (yellow arrow, and figure inset), probably as a response to Huh7 cells reprograming induced by GDF11; in comparison, beta catenin expression in CAM with non-treated cells, was weak, suggesting degradation. In order to address the cell proliferation status in the invasion experiment, we proceeded to detect Ki67 protein content by immunofluorescence; Fig. $6 \mathrm{~F}$ shows more proliferating cells in CAM grafted with not treated Huh7 cells comparing with those under GDF11 treatment; remarkably, Ki67 positive cells were more abundant in the lower zone of the CAM, indicating more proliferative capacity (yellow arrow; Fig. 6F).

To corroborate the GDF11-induced invasion restriction, we performed the CAM experiment using Hep3B cells. The results depicted in Supplementary Fig. 3E show disaggregated not treated cells in the engraftment zone, cells seems to be disabled to form cell to cell interactions, in comparison with GDF11 treated cells that exhibited a well compacted cell cumulous with well defined cell interactions, the vascular zone exhibited not treated cells in blood vessels, effect that was absent in GDF11-treated cells, interestingly, the tumor was well delimited (white arrows, Supplementary Fig. 4), suggesting that treated cells were able to degrade the basal membrane, as observed in an in situ 
A)

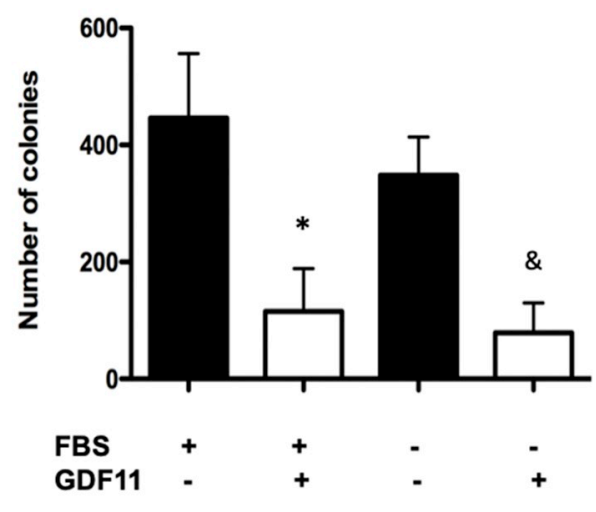

B)
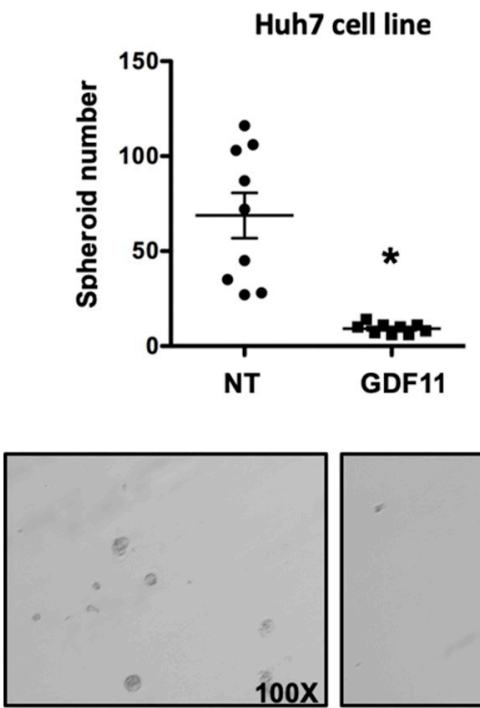

NT
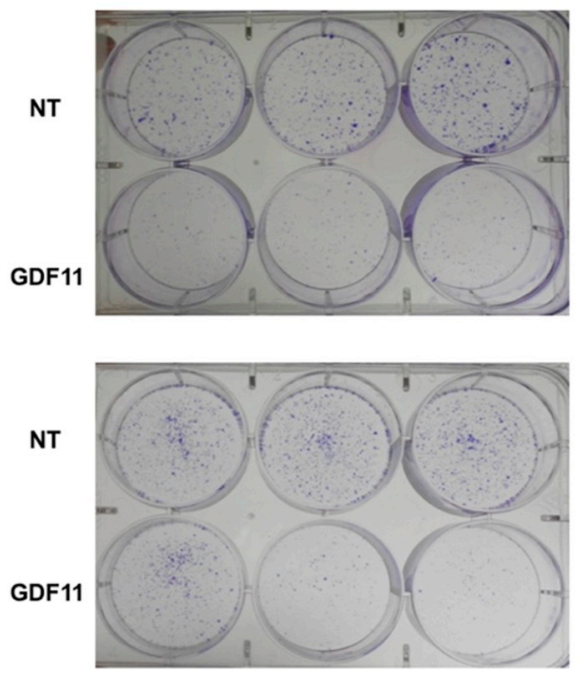

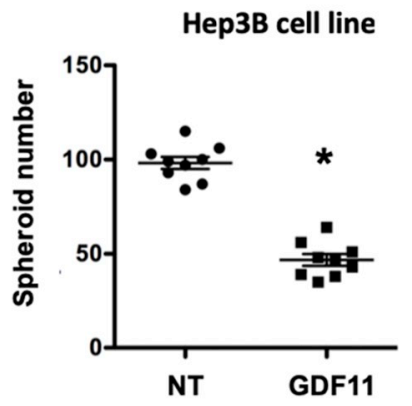

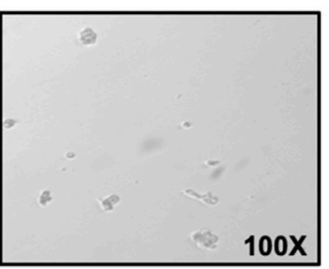

NT

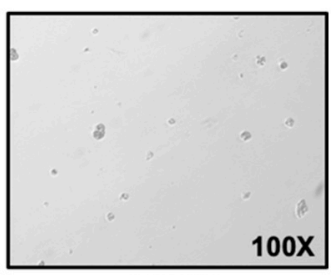

GDF11

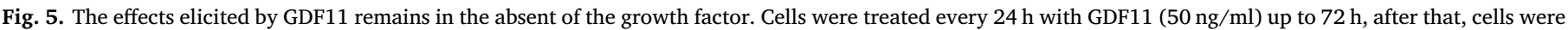

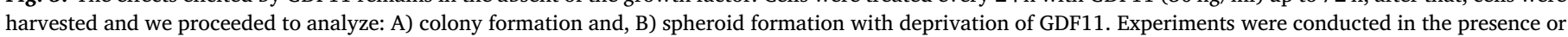

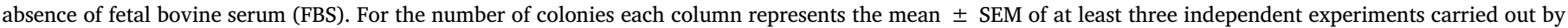

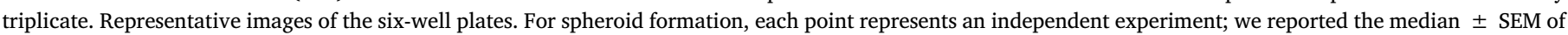
at least nine independent experiments. ${ }^{*}, p \leq 0.05$ vs NT cells in presence of FBS ( + FBS); ${ }^{*}, p \leq 0.05$ vs NT cells in the absence of FBS ( - FBS).

tumor. The distal zone in the experiment with not treated cells shows many disaggregated cells in the CAM, in comparison of the GDF11 experiment with few cells; remarkably, the size of this zone was thicker than that with not treated cells. Thus, these data strongly suggest that GDF11 significantly reduces invasive property.

\subsection{GDF11 decreases spheroid formation in other cancer cell lines}

Finally, to corroborate that the tumor suppressive effects displayed by GDF11 are not restricted to Huh7 and Hep3B cell line, we treated for three days the human hepatoma cell line HepG2 (Fig. 7A), the mouse HCC cell line Hepa1-6 (Fig. 7B), the human breast cancer cell line MDA-231 (Fig. 7C), and the human HCC cell line SNU-182. In all cases, GDF11 significantly decreases spheroid-forming capacity, suggesting a conserved effect among cancer cells with some stemness phenotype.

\section{Discussion}

HCC accounts for $90 \%$ of primary liver cancer, with increasing new cases every year, raising a warning worldwide [4,27]. Although, some therapeutic options are currently well established, such as sorafenib administration for advanced tumors, local ablation or resection, these options only provide some limited benefits in terms of patient survival. Besides, liver transplantation remains a great challenge due to the limited number of donors.

Investigation of signaling pathways involved in the control of proliferation, survival or the metabolism of cancer cells is crucial to define novel alternative therapeutic approaches. 


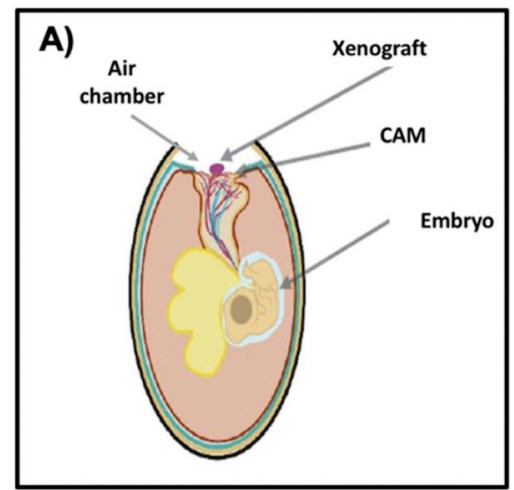

B)

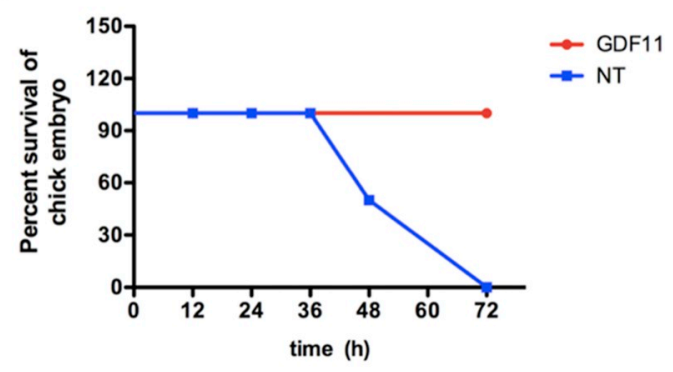

C)
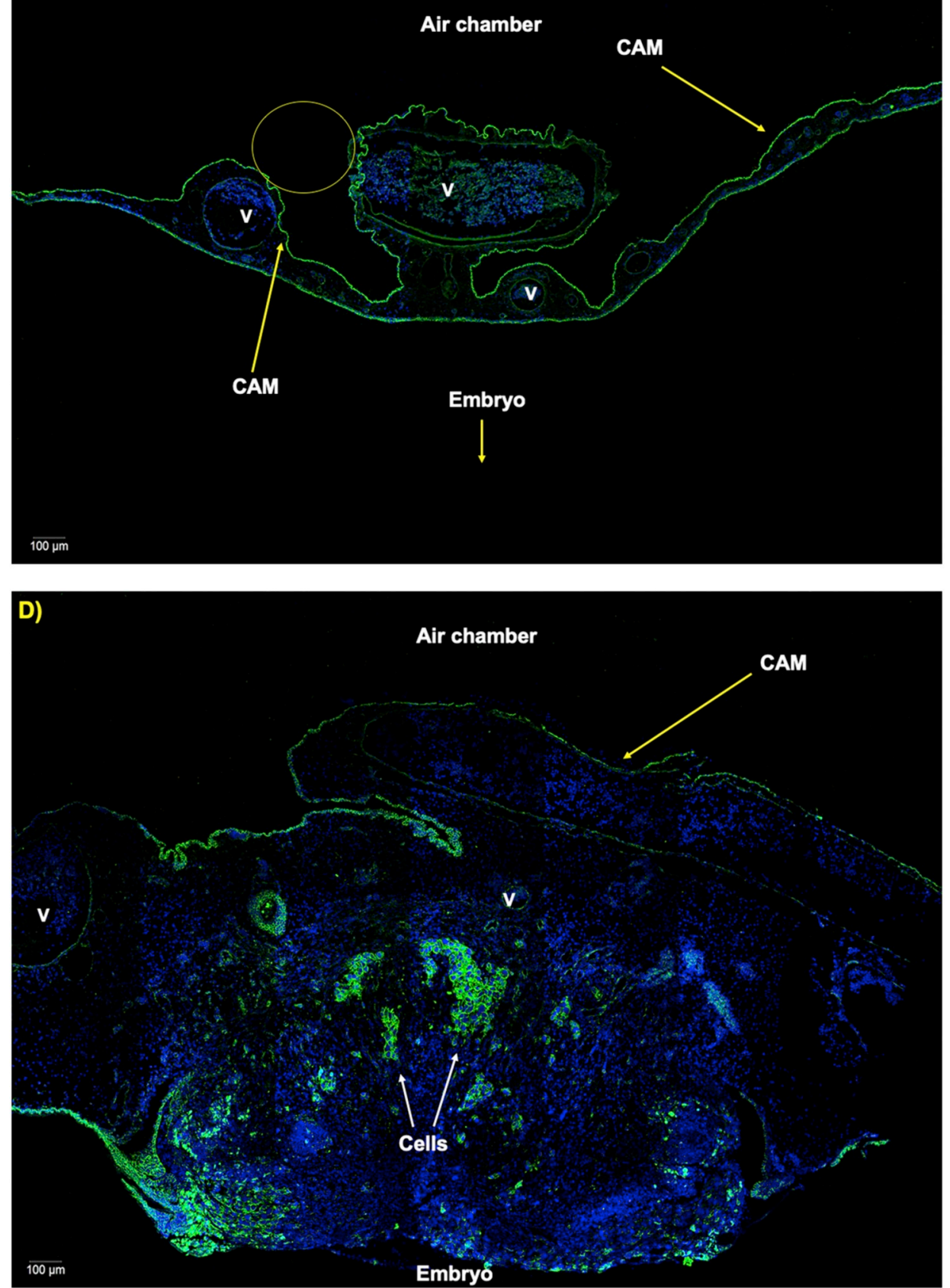


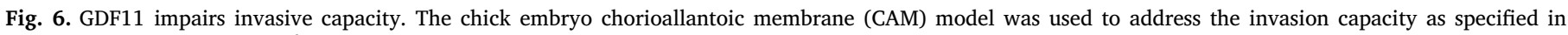

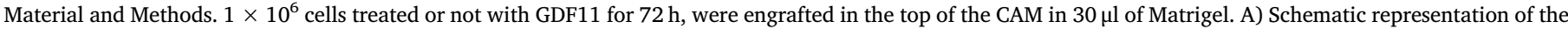

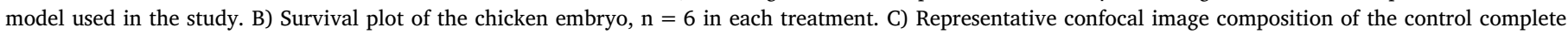

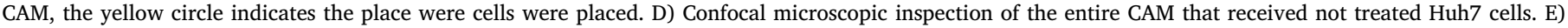

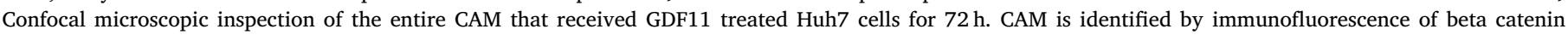

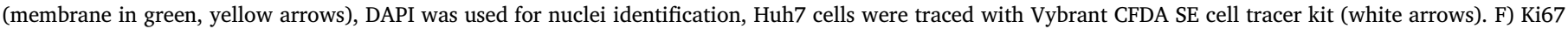

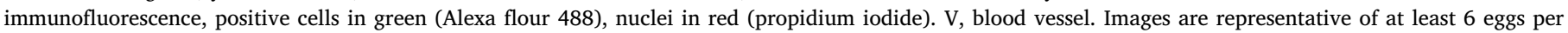
condition.

GDF11, a relatively new member of the TGF- $\beta$ superfamily, has been showed to display biological effects in a wide range of cell types. It is particularly interesting that most of the cells that respond to GDF11 exhibit some degree of stemness phenotype $[9,20]$. Along this characteristic, we hypothesized that this growth factor could exert some effects in HCC-derived cell lines, particularly in those retaining stemness features. It was reported that Huh7 cell line expresses some of the key stemness markers, such as Nanog, Oct 4 or Sox 2 . It has been also reported that increased expression of these genes in Huh7 cells is related to the increment of stemness [28,29], particularly when cells are forming spheroids [30]. The first evidence that Huh7 and Hep3B cells respond to GDF11 was the activation of one of the canonical signal transducers, specifically the phosphorylation of Smad3 [11,20], which was strongly detected after $5 \mathrm{~min}$ of GDF11 treatment in the case of Huh7 and, at $30 \mathrm{~min}$ in Hep3B cells, and remained activated along $60 \mathrm{~min}$ (Fig. 1A). It is well-characterized that some members of the TGF- $\beta$ display effects in epithelial cells that modulate survival or proliferation [31]. Interestingly, we found that viability is unaffected up to $72 \mathrm{~h}$ under GDF11 treatment (Fig. 1B), with no outward changes in cell phenotype. However, cell proliferation is clearly diminished at $72 \mathrm{~h}$, in presence or not, of the proliferative action of FBS (Fig. 2A and D), suggesting cytostatic effects similar to those observed with other members of the TGF- $\beta$ family. Indeed, it is reported that TGF- $\beta$ by itself, displays cytostatic and apoptotic functions that restrain cell growth, avoiding the hyperproliferative disorders, even in Huh7 and Hep3B cells $[32,33]$. This novel effect, elicited by GDF11 in liver cancer cells, confirms the well-conserved cytostatic effect in the TGF- $\beta$ family, as exemplified by the analysis of the content of the main cell cycle regulating proteins; cyclins A and D1, and cdk6 were downregulated, and p27 was overexpressed, these effects being particularly evident at $72 \mathrm{~h}$ (Fig. 2C). Similarly, GDF11 significantly attenuated the proliferation of the neural stem cell line Cor-1, downregulating key positive cell cycle proteins [20]. In addition, this work by Williams and collaborators showed that cell migration is impaired by GDF11 as we also observed (Fig. 2B and F).

Based in the fact that stemness feature is increasing in spheroid or 3D culture, particularly in cells used in this study [29,30], we observed that the number and the size of spheroids decreased in the presence of GDF11 at $72 \mathrm{~h}$ of repeated treatment $(50 \mathrm{ng} / \mathrm{ml}$, every $24 \mathrm{~h})$ in both HCC cell lines. We found similar effects in HepG2 (Fig. 7A), a human hepatoma cell line capable to form spheroids as well [30], and in SNU182, another human HCC cell line from a high aggressive tumor. Interestingly, when comparing the human liver cancer cell lines, GDF11 displayed greater effects in Huh7 and Hep3B than in HepG2, although, in the last one, decrement in sphere formation was statistically significant, confirming the preference of GDF11 on cells with stemness feature. Similar results were reported by Bajikar and collaborators in triple negative breast cancer cell lines [19], even more, Hepa1-6, MDAMB-231 and SNU-182 cell lines presented similar effects with some differences in the number of spheroids, but in all cases with significant changes (Fig. 7).

To gain more evidence, we performed the analysis of the messenger RNA levels of key molecular markers for aggressive cancers and stemness (Fig. 3B), cytokeratin 19 (ck19) has been closely related to poor prognosis and high recurrence in HCC [34], the effect on ck19 expression, induced by GDF11, was the most relevant, in terms of absolute values comparing with NT cells, prom1 (CD133) and epcam (EPCAM) also are well characterized stemness markers, being CD133 most significant in stages I, while the prognostic role of EpCAM is more effective in advanced stages [35], interestingly, the effect of GDF11 in epcam expression was different in the HCC cell lines studied here, Huh7 cells did not respond to the GDF11 treatment exhibiting no changes in the expression, however, Hep3B, which a more aggressive cell line, diminished the expression since $6 \mathrm{~h}$ of treatment, supporting the findings by Chang and coworkers [35]. These results strongly suggest that GDF11 antitumorigenic properties are more relevant in advanced tumors. Finally, cd24 is another well-known marker for stemness and aggressive HCC [36], our data clearly show a decrement since $6 \mathrm{~h}$ in Huh7 and at $12 \mathrm{~h}$ in Hep3B, once again the difference in stemness capacity is evident in both cell lines, but in both cases GDF11 displays antitumorigenic effects.

The analysis of mesenchymal and epithelial markers revealed a clear GDF11-induced mesenchymal to epithelial transition phenotype. A time-dependent decrement in the expression of mesenchymal-related proteins such as Snail and N-cadherin, and increased of epithelial markers, such as E-cadherin and occludin (Fig. 4) [37], was confirmed by Western blot and immunofluorescence. The gain of an epithelial phenotype was simultaneously associated to a significant decrease in colony and spheroid formation capacity (Fig. 5), and to a decreased capacity in invasion (Fig. 6), as addressed by the CAM assay. Interestingly, in the CAM assay we observed a degradation of the basal membrane, a key condition for invasion in the experiment using not treated cells, and in the case of the experiment with GDF11 treated cells the membrane was preserved suggesting a distinctive phenotype of an in situ tumor, in addition treated cells were presented forming cumulous, probably because the increment of E-cadherin expression (Fig. 4 and Supplementary Fig. 2).

All these data clearly show that GDF11 induces an anti-tumor response in HCC cells, directed to decreases aggressiveness by attempting reverse the mesenchymal to epithelial phenotype.

The decrement of the invasive phenotype was also found in triple negative breast cancer cell lines [19]. The effect was associated to an increase in the expression of E-cadherin, supporting our findings in HCC-derived cells. Importantly, we reported that GDF11 effects were not transient, and may evoke a cellular reprograming in HCC cells. Indeed, treatment for $72 \mathrm{~h}$ with GDF11 sustained the effects even five days in culture in the absent of GDF11.

Although, a low frequency of mutations in GDF11 and a significant enrichment in the convertase PCSK5 locus have been reported in breast cancer [19], we did not find significant presence of mutations in those genes in HCC according to The Cancer Genome Atlas (TCGA, data not shown). However, in human HCC the expression level of GDF11 observed no changes, but in cholangiocellular carcinoma (CCC), significant differences were found increasing 1.55-fold change in tumors versus normal tissue (Supplementary Fig. 5), (36 patients for CCC and 371 for HCC; https://portal.gdc.cancer.gov and http://firebrowse.org), in the case of PCSK5 gene expression the TCGA reports significant changes in both HCC and CCC (1.56-fold and 2.31-fold change versus normal tissue.

These data suggest that changes in basal expression in GDF11 and PCSK5 genes, are rare events in HCC and probably not responsible to the loss of function of GDF11, maybe some epigenetic silencing mechanism could be related to loss of function of GDF11. Nevertheless, we clearly demonstrated that recombinant human GDF11 induces an 


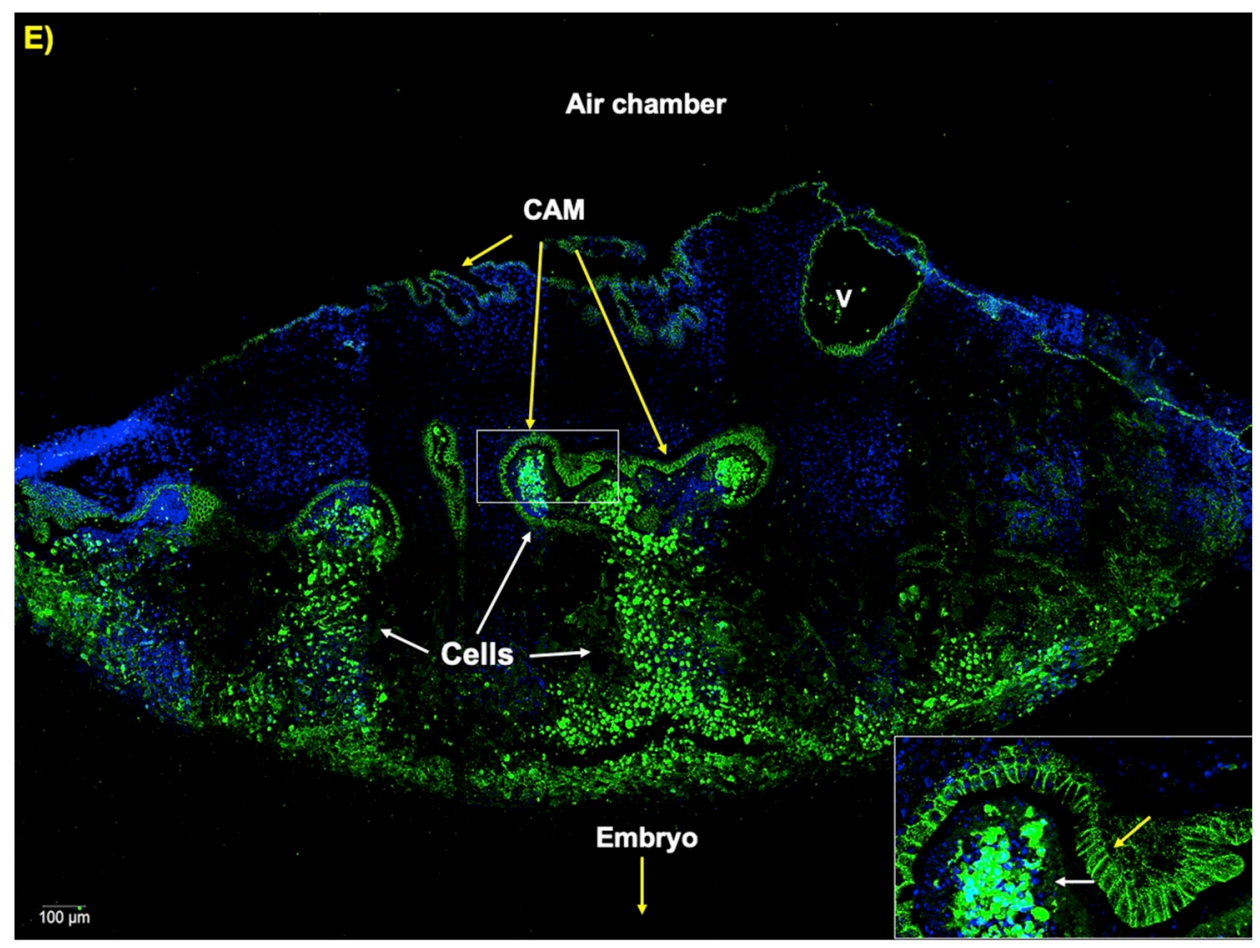

F)
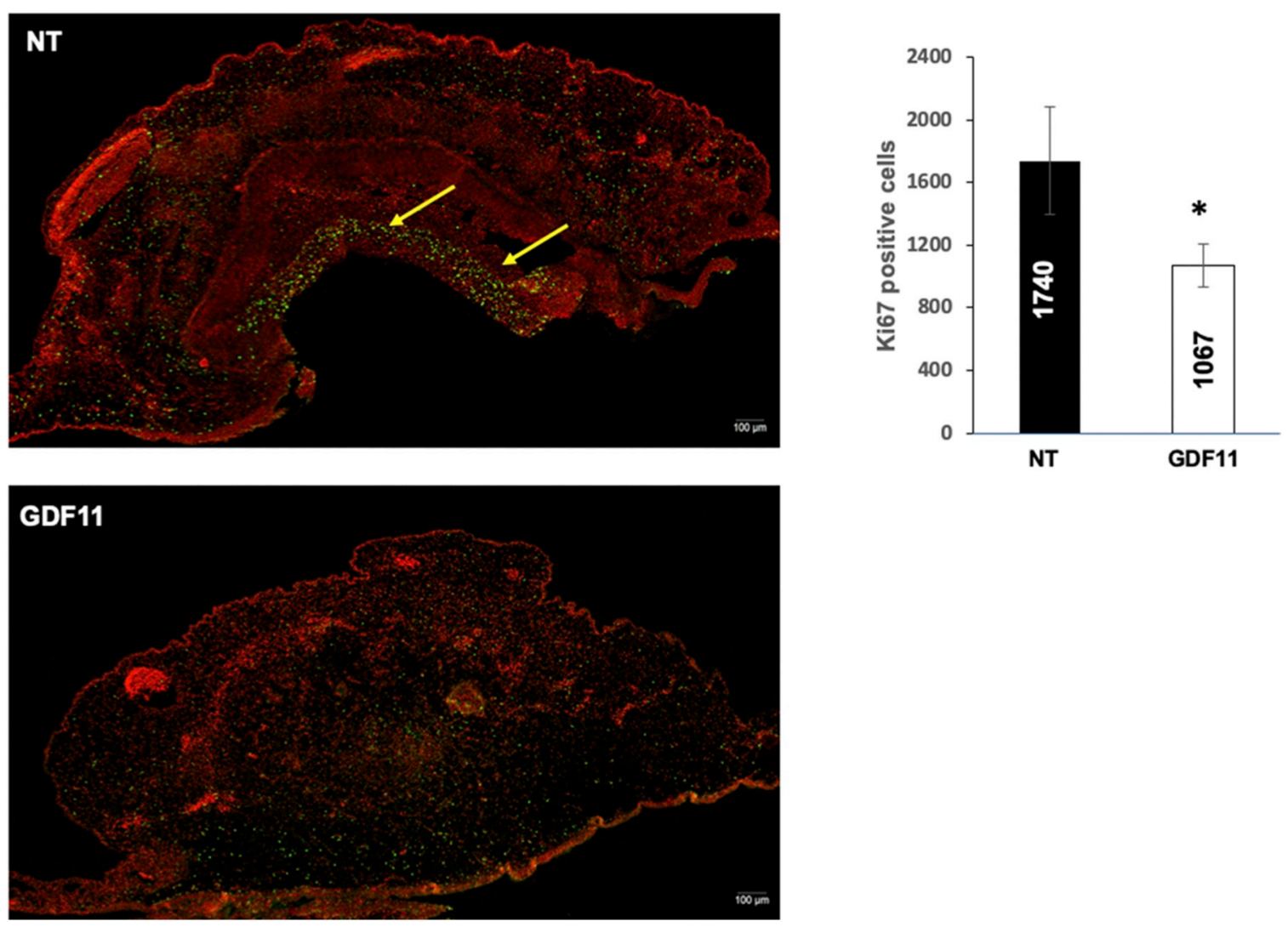

Fig. 6. (continued) 
A)

HepG2 cell line
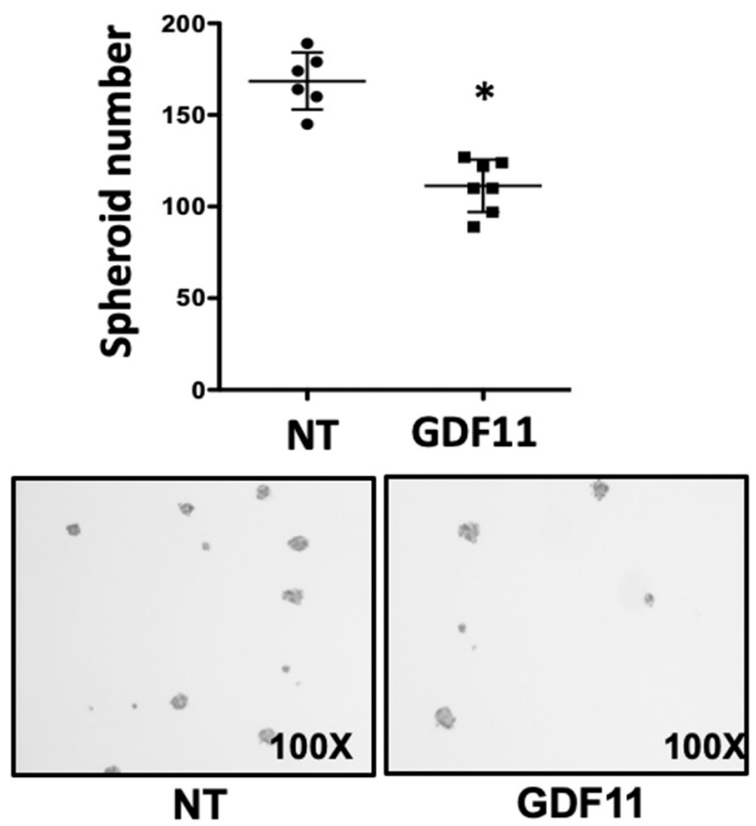

C)

MDA-MB-231 breast cancer cell line
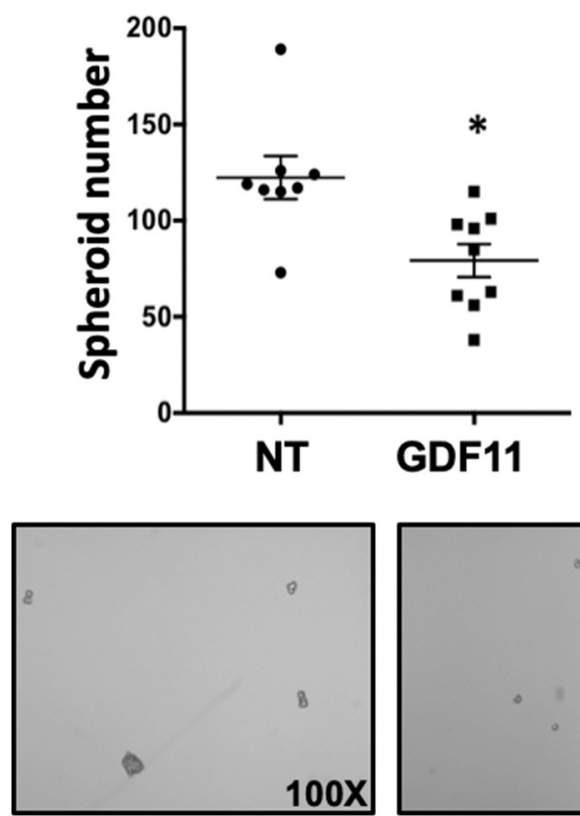

NT
B)

\section{Hepa1-6 cell line}
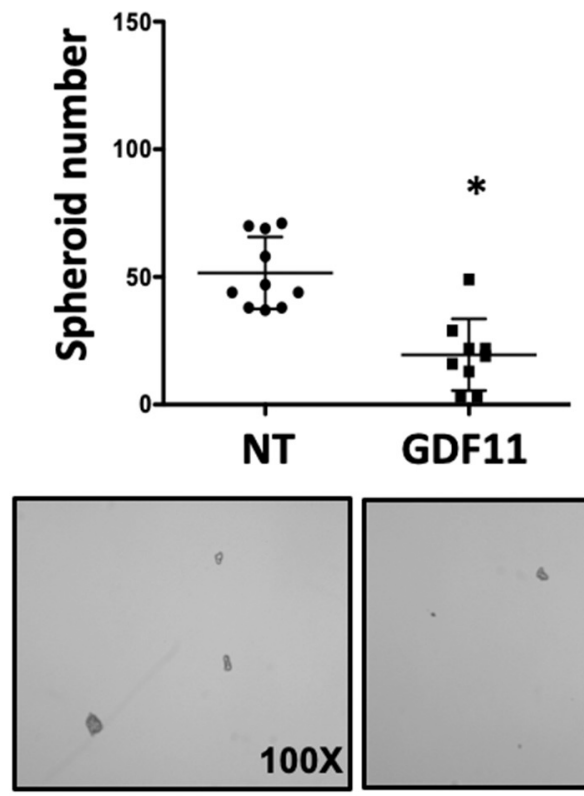

NT

$100 \mathrm{X}$

GDF11

D)

SNU-182 cell line
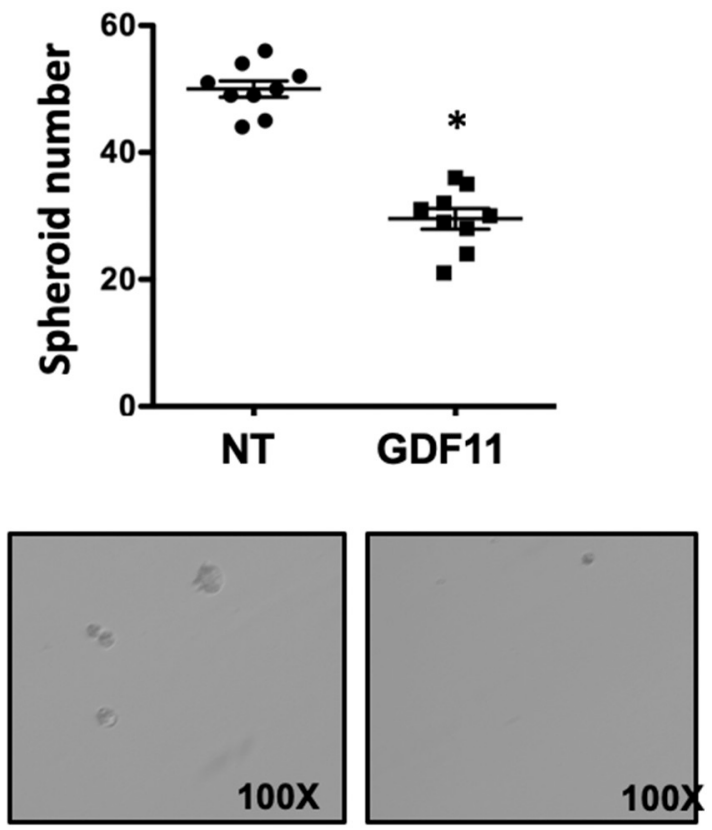

GDF11

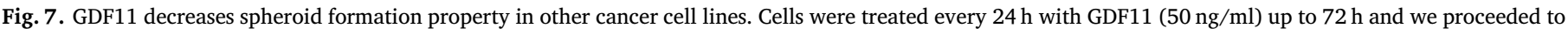

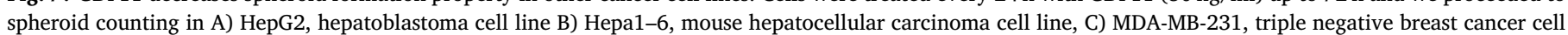

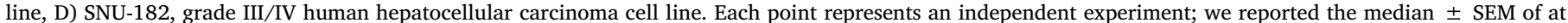
least six independent experiments. ${ }^{*}, p \leq 0.05$ vs NT cells at $72 \mathrm{~h}$. 
antitumorigenic effect with no relevance in cell death, but lessening aggressiveness by promoting a cytostatic phenotype and repressing invasion.

In conclusion, we are reporting tumor suppressive properties of GDF11 in HCC-derived cells restricting self-renewal capacity, setting GDF11 as a good candidate for therapy and biomarker in liver cancer.

\section{Conflicts of interest}

The authors declare no conflict of interest.

\section{Transparency document}

The Transparency document associated with this article can be found, in online version.

\section{Acknowledgements}

This work was partially funded by a grant from the Consejo Nacional de Ciencia y Tecnología (CONACYT; CB-252942 and Fronteras de la Ciencia-1320) and Universidad Autónoma Metropolitana. We thank the confocal core units of the Universidad Autonoma Metropolitana Iztapalapa, and Instituto Nacional de Cancerología de Mexico, for the assistance. MGR, SHR, ASN are scholarship holders from Conacyt.

\section{Appendix A. Supplementary data}

Supplementary data to this article can be found online at https:// doi.org/10.1016/j.bbadis.2019.03.003.

\section{References}

[1] N. Mendez-Sanchez, E. Garcia-Villegas, B. Merino-Zeferino, S. Ochoa-Cruz, A.R. Villa, H. Madrigal, R.A. Kobashi-Margain, Y. Gutierrez-Grobe, N. ChavezTapia, G. Ponciano-Rodriguez, M. Uribe, Liver diseases in Mexico and their associated mortality trends from 2000 to 2007: a retrospective study of the nation and the federal states, Ann. Hepatol. 9 (2010) 428-438.

[2] A. Forner, J.M. Llovet, J. Bruix, Hepatocellular carcinoma, Lancet 379 (2012) $1245-1255$.

[3] P. Kaposi-Novak, J.S. Lee, L. Gomez-Quiroz, C. Coulouarn, V.M. Factor, S.S. Thorgeirsson, Met-regulated expression signature defines a subset of human hepatocellular carcinomas with poor prognosis and aggressive phenotype, J. Clin. Invest. 116 (2006) 1582-1595.

[4] J. Ferlay, I. Soerjomataram, R. Dikshit, S. Eser, C. Mathers, M. Rebelo, D.M. Parkin, D. Forman, F. Bray, Cancer incidence and mortality worldwide: sources, methods and major patterns in GLOBOCAN 2012, Int. J. Cancer 136 (2015) E359-E386.

[5] J. Bruix, M. Colombo, Hepatocellular carcinoma: current state of the art in diagnosis and treatment, Best Pract. Res. Clin. Gastroenterol. 28 (2014) 751.

[6] A.C. McPherron, A.M. Lawler, S.J. Lee, Regulation of anterior/posterior patterning of the axial skeleton by growth/differentiation factor 11, Nat. Genet. 22 (1999) 260-264.

[7] R. Essalmani, A. Zaid, J. Marcinkiewicz, A. Chamberland, A. Pasquato, N.G. Seidah, A. Prat, In vivo functions of the proprotein convertase PC5/6 during mouse development: Gdf11 is a likely substrate, Proc. Natl. Acad. Sci. U. S. A. 105 (2008) $5750-5755$

[8] C.E. Brun, M.A. Rudnicki, GDF11 and the mythical fountain of youth, Cell Metab. 22 (2015) 54-56.

[9] M. Sinha, Y.C. Jang, J. Oh, D. Khong, E.Y. Wu, R. Manohar, C. Miller, S.G. Regalado, F.S. Loffredo, J.R. Pancoast, M.F. Hirshman, J. Lebowitz, J.L. Shadrach, M. Cerletti, M.J. Kim, T. Serwold, L.J. Goodyear, B. Rosner, R.T. Lee, A.J. Wagers, Restoring systemic GDF11 levels reverses age-related dysfunction in mouse skeletal muscle, Science 344 (2014) 649-652.

[10] F.S. Loffredo, M.L. Steinhauser, S.M. Jay, J. Gannon, J.R. Pancoast, P. Yalamanchi, M. Sinha, C. Dall'Osso, D. Khong, J.L. Shadrach, C.M. Miller, B.S. Singer, A. Stewart, N. Psychogios, R.E. Gerszten, A.J. Hartigan, M.J. Kim, T. Serwold, A.J. Wagers, R.T. Lee, Growth differentiation factor 11 is a circulating factor that reverses agerelated cardiac hypertrophy, Cell 153 (2013) 828-839.

[11] M.A. Egerman, S.M. Cadena, J.A. Gilbert, A. Meyer, H.N. Nelson, S.E. Swalley, C. Mallozzi, C. Jacobi, L.L. Jennings, I. Clay, G. Laurent, S. Ma, S. Brachat, E. LachTrifilieff, T. Shavlakadze, A.U. Trendelenburg, A.S. Brack, D.J. Glass, GDF11 increases with age and inhibits skeletal muscle regeneration, Cell Metab. 22 (2015) 164-174.
[12] D.J. Glass, Elevated GDF11 is a risk factor for age-related frailty and disease in humans, Cell Metab. 24 (2016) 7-8.

[13] M.J. Schafer, E.J. Atkinson, P.M. Vanderboom, B. Kotajarvi, T.A. White, M.M. Moore, C.J. Bruce, K.L. Greason, R.M. Suri, S. Khosla, J.D. Miller, H.R. Bergen 3rd, N.K. LeBrasseur, Quantification of GDF11 and myostatin in human aging and cardiovascular disease, Cell Metab. 23 (2016) 1207-1215.

[14] G. Finkenzeller, G.B. Stark, S. Strassburg, Growth differentiation factor 11 supports migration and sprouting of endothelial progenitor cells, J. Surg. Res. 198 (2015) $50-56$.

[15] F. Jeanplong, S.J. Falconer, J.M. Oldham, N.J. Maqbool, M. Thomas, A. Hennebry, C.D. McMahon, Identification and expression of a novel transcript of the growth and differentiation factor-11 gene, Mol. Cell. Biochem. 390 (2014) 9-18.

[16] K.K. Gokoffski, H.H. Wu, C.L. Beites, J. Kim, E.J. Kim, M.M. Matzuk, J.E. Johnson, A.D. Lander, A.L. Calof, Activin and GDF11 collaborate in feedback control of neuroepithelial stem cell proliferation and fate, Development 138 (2011) 4131-4142.

[17] T. Yokoe, T. Ohmachi, H. Inoue, K. Mimori, F. Tanaka, M. Kusunoki, M. Mori, Clinical significance of growth differentiation factor 11 in colorectal cancer, Int. J. Oncol. 31 (2007) 1097-1101.

[18] C. Wallner, M. Drysch, M. Becerikli, H. Jaurich, J.M. Wagner, S. Dittfeld, J. Nagler, K. Harati, M. Dadras, S. Philippou, M. Lehnhardt, B. Behr, Interaction with the GDF8/11 pathway reveals treatment options for adenocarcinoma of the breast, Breast 37 (2018) 134-141.

[19] S.S. Bajikar, C.C. Wang, M.A. Borten, E.J. Pereira, K.A. Atkins, K.A. Janes, Tumorsuppressor inactivation of GDF11 occurs by precursor sequestration in triple-negative breast cancer, Dev. Cell 43 (2017) 418-435 e413.

[20] G. Williams, M.P. Zentar, S. Gajendra, M. Sonego, P. Doherty, G. Lalli, Transcriptional basis for the inhibition of neural stem cell proliferation and migration by the TGFbeta-family member GDF11, PLoS One 8 (2013) e78478.

[21] C. Enriquez-Cortina, M. Almonte-Becerril, D. Clavijo-Cornejo, M. PalestinoDominguez, O. Bello-Monroy, N. Nuno, A. Lopez, L. Bucio, V. Souza, R. HernandezPando, L. Munoz, M.C. Gutierrez-Ruiz, L.E. Gomez-Quiroz, Hepatocyte growth factor protects against isoniazid/rifampicin-induced oxidative liver damage, Toxicological sciences: an official journal of the Society of Toxicology 135 (2013) 26-36.

[22] J.U. Marquardt, D. Seo, L.E. Gomez-Quiroz, K. Uchida, M.C. Gillen, M. Kitade, P. Kaposi-Novak, E.A. Conner, V.M. Factor, S.S. Thorgeirsson, Loss of c-Met accelerates development of liver fibrosis in response to $\mathrm{CCl}(4)$ exposure through deregulation of multiple molecular pathways, Biochim. Biophys. Acta 1822 (2012) 942-951.

[23] J.P. Quigley, P.B. Armstrong, Tumor cell intravasation alu-cidated: the chick embryo opens the window, Cell 94 (1998) 281-284.

[24] D. Ribatti, The chick embryo chorioallantoic membrane (CAM) assay, Reprod. Toxicol. 70 (2017) 97-101.

[25] R. Lazzarini-Lechuga, O. Alcantar-Ramirez, R. Jaime-Cruz, L. Gómez-Quiroz, Efecto teratogénico de nanopartículas de oro de $20 \mathrm{~nm}$ durante la septación cardiaca, Munod Nano 7 (2014) 69-77.

[26] C. Czauderna, M. Palestino-Dominguez, D. Castven, D. Becker, L. Zanon-Rodriguez, J. Hajduk, F.L. Mahn, M. Herr, D. Strand, S. Strand, S. Heilmann-Heimbach, L.E. Gomez-Quiroz, M.A. Worns, P.R. Galle, J.U. Marquardt, Ginkgo biloba induces different gene expression signatures and oncogenic pathways in malignant and nonmalignant cells of the liver, PLoS One 13 (2018) e0209067.

[27] A. Jemal, E.M. Ward, C.J. Johnson, K.A. Cronin, J. Ma, B. Ryerson, A. Mariotto, A.J. Lake, R. Wilson, R.L. Sherman, R.N. Anderson, S.J. Henley, B.A. Kohler, L. Penberthy, E.J. Feuer, H.K. Weir, Annual report to the nation on the status of cancer, 1975-2014, featuring survival, J. Natl. Cancer Inst. 109 (2017).

[28] L. Ghisolfi, A.C. Keates, X. Hu, D.K. Lee, C.J. Li, Ionizing radiation induces stemness in cancer cells, PLoS One 7 (2012) e43628.

[29] H. Hirschfield, C.B. Bian, T. Higashi, S. Nakagawa, T.Z. Zeleke, V.D. Nair, B.C. Fuchs, Y. Hoshida, In vitro modeling of hepatocellular carcinoma molecular subtypes for anti-cancer drug assessment, Exp. Mol. Med. 50 (2018) e419.

[30] H.S. Seol, S.E. Lee, J.S. Song, J.K. Rhee, S.R. Singh, S. Chang, S.J. Jang, Complement proteins C7 and CFH control the stemness of liver cancer cells via LSF-1, Cancer Lett. 372 (2016) 24-35.

[31] Y. Zhang, P.B. Alexander, X.F. Wang, TGF-beta family signaling in the control of cell proliferation and survival, Cold Spring Harb. Perspect. Biol. 9 (2017).

[32] P.M. Siegel, J. Massague, Cytostatic and apoptotic actions of TGF-beta in homeostasis and cancer, Nat. Rev. Cancer 3 (2003) 807-821.

[33] J. Zhang, O. Yamada, S. Kida, Y. Matsushita, T. Hattori, Down-regulation of osteopontin mediates a novel mechanism underlying the cytostatic activity of TGFbeta, Cell Oncol (Dordr) 39 (2016) 119-128.

[34] C.W. Lee, S.E. Lin, H.I. Tsai, P.J. Su, C.H. Hsieh, Y.C. Kuo, C.M. Sung, C.Y. Lin, C.N. Tsai, M.C. Yu, Cadherin 17 is related to recurrence and poor prognosis of cytokeratin 19-positive hepatocellular carcinoma, Oncol. Lett. 15 (2018) 559-567.

[35] A.W. Chan, J.H. Tong, S.L. Chan, P.B. Lai, K.F. To, Expression of stemness markers (CD133 and EpCAM) in prognostication of hepatocellular carcinoma, Histopathology 64 (2014) 935-950.

[36] Y. Li, R. Wang, S. Xiong, X. Wang, Z. Zhao, S. Bai, Y. Wang, Y. Zhao, B. Cheng, Cancer-associated fibroblasts promote the stemness of CD24(+) liver cells via paracrine signaling, J Mol Med (Berl) 97 (2019) 243-255.

[37] W. Chengye, T. Yu, S. Ping, S. Deguang, W. Keyun, W. Yan, Z. Rixin, L. Rui, G. Zhenming, Y. Mingliang, W. Liming, Metformin reverses bFGF-induced epithelial-mesenchymal transition in HCC cells, Oncotarget 8 (2017) 104247-104257. 


\title{
GDF11 Implications in Cancer Biology and Metabolism. Facts and Controversies
}

\author{
Arturo Simoni-Nieves ${ }^{1,2}$, Monserrat Gerardo-Ramírez ${ }^{1,2}$, Gibrán Pedraza-Vázquez ${ }^{1,2}$, \\ Lisette Chávez-Rodríguez ${ }^{1,2}$, Leticia Bucio ${ }^{2,3}$, Verónica Souza ${ }^{2,3}$, \\ Roxana U. Miranda-Labra ${ }^{2,3}$, Luis E. Gomez-Quiroz ${ }^{2,3 *}$ and \\ María Concepción Gutiérrez-Ruiz ${ }^{2,3 *}$
}

${ }^{1}$ Posgrado en Biología Experimental, DCBS, Universidad Autónoma Metropolitana-Iztapalapa, Mexico City, Mexico, ${ }^{2}$ Laboratorio de Fisiología Celular y Biología Molecular, Departamento de Ciencias de la Salud, Universidad Autónoma Metropolitana-Iztapalapa, Mexico City, Mexico, ${ }^{3}$ Laboratorio de Medicina Experimental, Unidad de Medicina Translacional, Instituto de Investigaciones Biomédicas, UNAM/Instituto Nacional de Cardiología Ignacio Chavez, Mexico City, Mexico

OPEN ACCESS

Edited by:

Antonio Giuseppe Naccarato,

University of Pisa, Italy

Reviewed by:

Prospero Civita

Brain Tumor Research Center,

United Kingdom

Sujit Kumar Bhutia,

National Institute of Technology

Rourkela, India

${ }^{*}$ Correspondence:

Luis E. Gomez-Quiroz

legq@xanum.uam.mx

María Concepción Gutiérrez-Ruiz

mcgr@xanum.uam.mx

Specialty section:

This article was submitted to

Cancer Metabolism

a section of the journal

Frontiers in Oncology

Received: 10 August 2019 Accepted: 24 September 2019

Published: 15 October 2019

Citation:

Simoni-Nieves A, Gerardo-Ramírez M Pedraza-Vázquez $G$,

Chávez-Rodríguez L, Bucio L,

Souza V, Miranda-Labra RU,

Gomez-Quiroz LE and

Gutiérrez-Ruiz MC (2019) GDF11

Implications in Cancer Biology and Metabolism. Facts and Controversies.

Front. Oncol. 9:1039.

doi: 10.3389/fonc.2019.01039
Growth Differentiation Factor 11 (GDF11), a member of the super family of the Transforming Growth Factor $\beta$, has gained more attention in the last few years due to numerous reports regarding its functions in other systems, which are different to those related to differentiation and embryonic development, such as age-related muscle dysfunction, skin biology, metabolism, and cancer. GDF11 is expressed in many tissues, including skeletal muscle, pancreas, kidney, nervous system, and retina, among others. GDF11 circulating levels and protein content in tissues are quite variable and are affected by pathological conditions or age. Although, GDF11 biology had a lot of controversies, must of them are only misunderstandings regarding the variability of its responses, which are independent of the tissue, grade of cellular differentiation or pathologies. A blunt fact regarding GDF11 biology is that its target cells have stemness feature, a property that could be found in certain adult cells in health and in disease, such as cancer cells. This review is focused to present and analyze the recent findings in the emerging research field of GDF11 function in cancer and metabolism, and discusses the controversies surrounding the biology of this atypical growth factor.

Keywords: GDF11, PCSK5, cancer, liver, HCC, metabolism

\section{INTRODUCTION}

On May 2013 the research groups, led by doctors Amy J. Wagers and Richard T. Lee, published outstanding work suggesting that the growth differentiation factor 11 (GDF11) could be a good candidate for the age-related heart hypertrophy reversion observed in the model of heterochronic parabiosis (1). One year later, on May 2014, Science journal published a couple of works by the same research team at Harvard University, unveiling that systemic injection of the GDF11 reverses agerelated dysfunction in skeletal muscle (2) and vascular and neurogenic function in the brain (3). Both reports were astonishing, particularly because myostatin, also known as GDF8, shares high structural homology with GDF11, but GDF8 induces exactly the contrary effect, muscle growth inhibition (4). At that moment, GDF11 was called "the rejuvenation factor," a term taken by a commentary note published by Jocelyn Kaiser in the same number of the Science journal (5), and Karoline E. Brun published another similar commentary in Cell journal entitle "GDF11 and the Mythical Fountain of Youth" (6). 
The findings, beyond this unfortunate motto, revealed that GDF11 could exert functions in adult systems, in addition of those characterized in embryonic and fetal tissues. The works by the groups of doctors Wagers and Lee provided evidence that the main target cells are those with certain stemness phenotype, such as the satellite cells in the muscle, which are the progenitor ones for new functional muscle cells.

If GDF11 targets cells with stemness capacity, then many cancer cells should be targeted by this growth factor.

Many cancer cells gain stemness capacity and this correlates with aggressiveness and poor prognosis. The findings raised by the group of doctors, Wagers and Lee, position cancer cells as a target of GDF11 since they proved that stemness is a key condition for GDF11 effect. However, the results could be opposite depending of the cancer cell origin, metabolic status, or the stage of the cancer. We must wait for incoming works in the next few years, perhaps months, revealing a more precise mechanism regarding these apparent controversies in cancer and metabolism.

This work is focused to review the general knowledge of GDF11, and its functions in cancer biology and metabolism, taking into consideration recent findings in the specialized literature and in the public databases and scientific online resources.

\section{GDF11 AN ATYPICAL TGF- $\beta$ FAMILY MEMBER}

GDF11 (also known as Bone Morphogenetic Protein, BMP11), is a member of the super family of the Transforming Growth Factor beta (TGF- $\beta$ ) and a subfamily of the BMP which is widely secreted in many species, including mouse, rat and human, and it is accepted as a key factor in embryo development, particularly in the anterior/posterior patterning (7-9).

GDF11 was identified by McPherron et al. in 1999, who cloned the human and mouse GDF11 and characterized its function in pattering the axial skeleton (9). Two years prior, the same group also discovered and characterized the GDF8 (10).

In humans, GDF11 gene is located in chromosome 12 (12q13.2, forward strand, Ensembl accession number: ENSG00000135414). Two splice variants products have been identified, according to Ensembl (Figure 1), the first one, GDF11201 is a 8657 bp RNA, formed by three coding exons, generating a 407 amino acids protein, and the second one, GDF11-202, is a 1,258 bp, formed by three exons generating a 380 amino acids protein (11). Jeanplong (12) reported another RNA splice variant determined as GDF-11 $\Delta \mathrm{Ex} 11$, characterized by the absence of exon 1, and composed for exon 2 and 3 with transcriptional initiation in intron $1(4,701 \mathrm{bp})$. It is predicted this variant could be regulated by transcription factors, such as some myogenic factors (MRF, Myf5, MyoD, Myogenin, and MRF4), Pax3, NF1, AP1, among others (12), suggesting that it could be involved in muscle development and/or repair as reported in other work (2). Interestingly, the promoter of GDF11 could also be activated by trichostatin A (13), an inhibitor of histone deacetylases (HDAC), suggesting a clear epigenetic regulation of the GDF11 gene expression; HDAC3 regulates zebrafish liver development by modulating GDF11. The overexpression of HDAC3 increases liver size, while the increase of GDF11 expression induces a small size liver; interestingly, the knockdown of GDF11 did not induce any relevant change in liver morphology. The role of HDAC3 in GDF11 function in liver development is likely a direct control over the hepatocyte precursor (hepatoblast) proliferation, as observed in HCC-derived cells (14), but this must be deeply addressed.

GDF11 mRNA is translated in a precursor protein (Figure 2), which is processed by specific proteases generating the mature GDF11 (C-terminal, $12.5 \mathrm{kDa}$ ) and the pro-domain $(\mathrm{N}$ terminal, $30.1 \mathrm{kDa})$. GDF11 shares $89 \%$ amino acid sequence homology with GDF8, however GDF8 expression in human tissues is restricted to cardiac and skeletal muscle (1), while GDF11 is practically expressed in all tissues (15). Although there is high homology between mature GDF8 and GDF11, the pro-domains of both proteins share only $54 \%$ homology. The pro-domain is fundamental for proper protein folding, disulfide bond formation and exportation of the homodimers (16), suggesting differences in posttranslational process.

The protein convertase subtilisin/kexin 5 (PCSK5) is one of the main acting proteins on GDF11, activating the mature GDF11 by proteolytic process at basic sites of the pro-domain (17). The elimination of PCSK5 in the mouse embryo was associated with abnormal expression of Hlxb9 and Hox genes, two well-known GDF11 target genes, generating defects in the anteroposterior patterning and strongly proposing a relationship with GDF11 functions $(7,8)$.

In humans, GDF11 is expressed in practically all tissues, but is particularly relevant in the brain (hippocampus), the kidneys, the endometrium, and the heart muscle; while the liver is the organ with the lowest expression $(1,15,18)$.

\section{THE SIGNAL TRANSDUCTION}

As a member of the BMP family, GDF11 uses the canonical receptors and the SMAD proteins for signaling. The GDF11 dimer (a disulfide-linked homodimer of carboxy-terminal fragments) binds the activin receptors type II A or B (ActRIIA, ActRIIB), proteins with serine/threonine kinase activity; leading to the recruitment and transphosphorylation of two type I serine/threonine kinase receptors, also known as activinlike kinase receptors (ALK), particularly the 4, 5, or 7 (19, 20). The activated ALK receptor phosphorylates and activates the receptor-regulated SMAD (R-SAMD). GDF11 particularly transduces by using SMAD2 and $3(14,21)$, and some reports also propose the participation of SMAD1, 5 and 8 (22). The RSMAD dimer recruits the co-SMAD, SMAD4, to form a trimeric complex, which eventually translocates to the nucleus for gene expression regulation (23). Although the signal transduction of the TGF- $\beta$ family might seem simple, it is highly regulated by extracellular and intracellular mechanisms. Inside the cell, the regulation can occur at the membrane or in the cytosol, during nuclear translocation and DNA biding, at this level, is a 
A

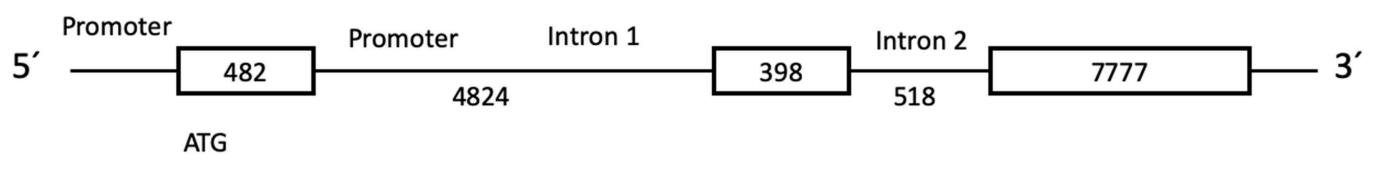

B
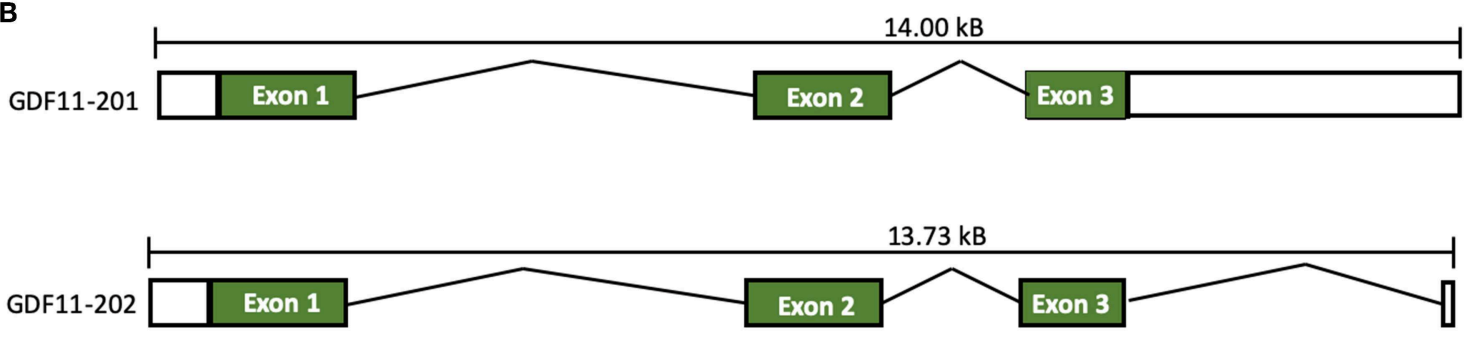

\begin{tabular}{|c|c|c|c|c|c|}
\hline $\begin{array}{c}\text { Name } \\
\text { Splice Variant }\end{array}$ & $\begin{array}{c}\text { Ensambl trasncript } \\
\text { number }\end{array}$ & bp & Protein & $\begin{array}{c}\text { Ensambl protein } \\
\text { number }\end{array}$ & Biotype \\
\hline GDF11-201 & ENST00000257868.9 & 8657 & $\begin{array}{c}407 \mathrm{aa} \\
45.1 \mathrm{KDa}\end{array}$ & ENSP00000257868.5 & Protein coding \\
\hline GDF11-202 & ENST00000546799.1 & 1258 & $\begin{array}{c}380 \mathrm{aa} \\
42.2 \mathrm{KDa}\end{array}$ & ENSP00000448390.1 & Protein coding \\
\hline
\end{tabular}

FIGURE 1 | Schematic representation of GDF11 gene and mRNA. (A) Gdf11 gene and (B) Gdf11 transcripts and table with the two transcripts specifications according to Ensembl (www.ensembl.org, ENSG00000135414.9) and Jeanplog 2014.

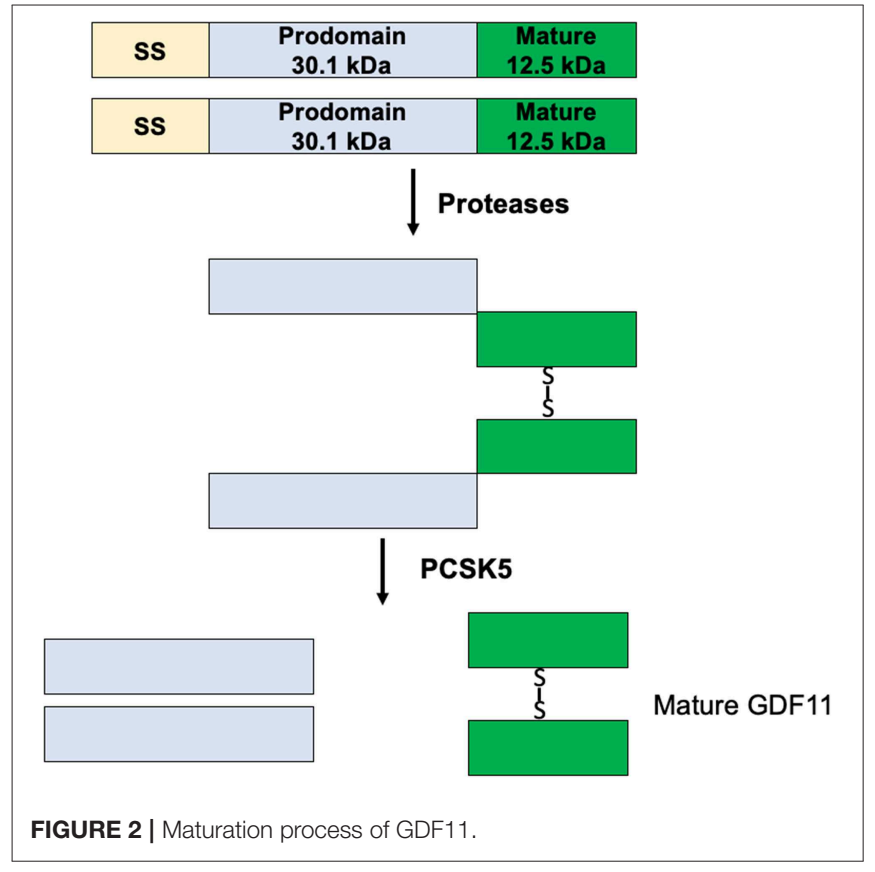

tetrameric complex because the interaction with a fourth protein component or partner (24) (Figure 3).

GDF11 can also transduce by non-canonical pathways. Mitogen activated protein kinase (MAPK) is perhaps the main non-SMAD pathway controlled by the growth factor, activating routes such as p38, AKT, and JNK $(25,26)$, however, in some cases, inhibiting the activation of JNK or NF- $\kappa \mathrm{B}$ (27) depending of the cell lineage. Further, it has been described that the family can also transduce by MAPKKK7 [also known as TGF$\beta$ activated kinase 1 (TAK1)] via MEK6 (28-30). TAK1 is part of a signaling complex formed by TAK1 binding protein 1 (TAB1) and with either TAB2 or TAB3 (31). TAK1 complex follows an intricate mechanism of activation involving the tumor necrosis factor receptor-associated factor (TRAF) 2 or 6 , adaptor proteins with non-conventional activity of E3 ubiquitin ligase. TRAF proteins exert regulation over TAB2 or 3. Finally, the autophosphorylation of TAK1 leads to the activation of its downstream targets, particularly members of the MAPK and $\mathrm{NF}-\kappa \mathrm{B}$ signaling pathways (32).

Negative regulation of the GDF11-mediated signaling can also occur at different levels. Extracellularly, GDF11 can be negatively regulated by the interaction with many proteins such as follistatin $(33,34)$, GDF-associated serum protein-1 (GASP-1), GASP-2 (35), decorin and follistatin-like 3, among others (4). Follistatin, a secreted glycoprotein, binds GDF11 and inhibits its interaction with ActRIIB. Follistatin is the main extracellular inhibitor of GDF11, and is transcriptionally regulated by the same GDF11 signaling, indicating that the signal transduction is restricted by a negative feedback mechanism (36).

The BMP and activin membrane-bound inhibitor (BAMBI), a co-receptor that is not functional due to it lacks cytosolic domain, has been suggested to be another negative regulator in plasma membrane, but that still remains to be confirmed (19).

In the cytosol, GDF11 follows the canonical negative regulation of the family. It has been reported that GDF11 is regulated by SMAD7 (37) and SMAD6 (19). The SMAD specific E3 ubiquitin protein ligase 2 (SMURF2) also displays negative regulation of the signaling pathway (28). Negative-regulation 

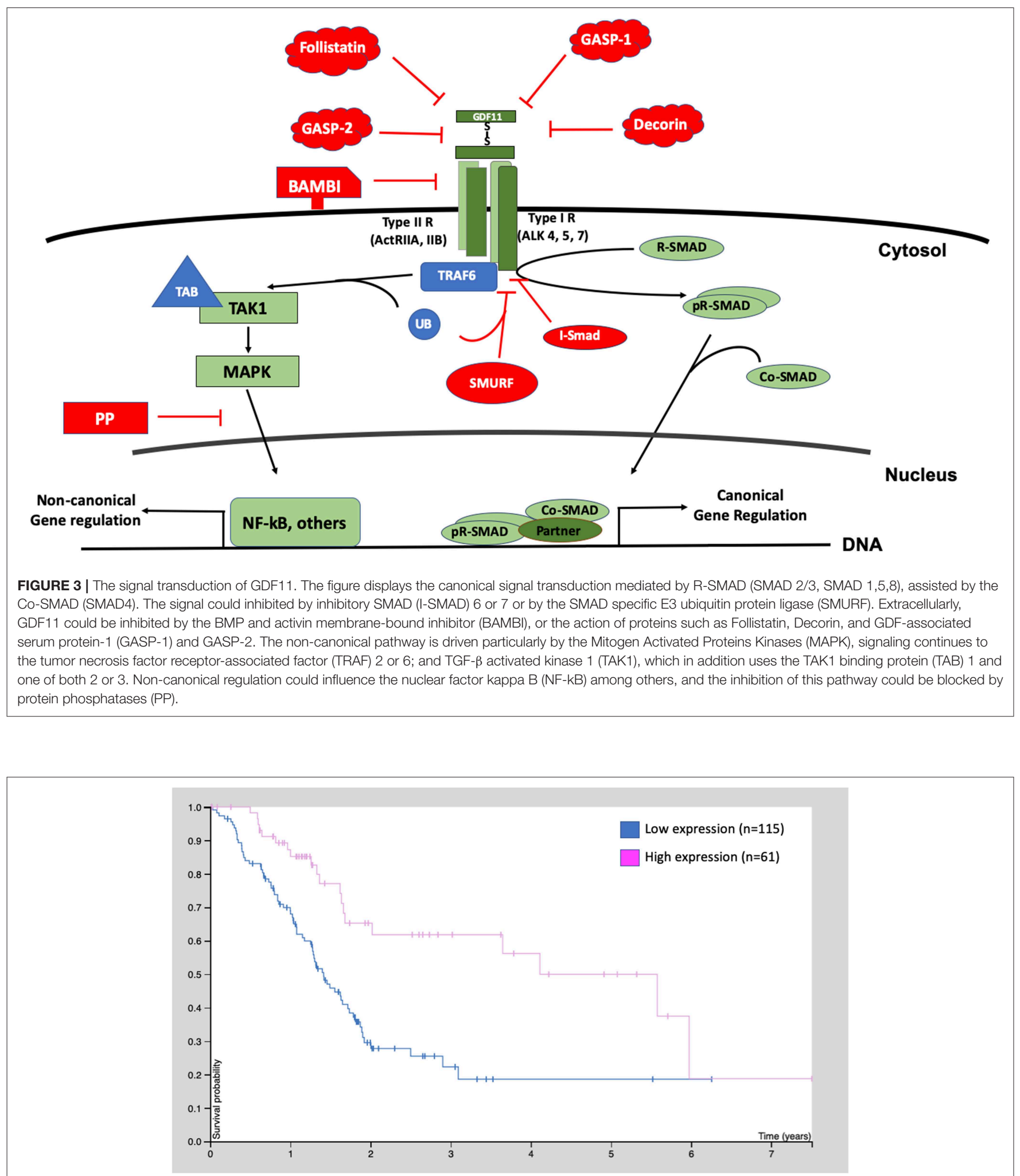

FIGURE 4 | Kaplan-Meier survival curve of 176 patients with pancreatic cancer. Patients were classified as low GDF11 expression and high GDF11 expression, $p<$ 0.001 , according to the human protein atlas (www.proteinatlas.org/ENSG00000135414-GDF11/pathology). 
of the non-canonical pathway is driven by specific protein phosphatases (PP), such as PPC1, among others.

\section{DEVELOPMENT AND AGED-RELATED FUNCTION}

Although GDF11 was identified in 1999 (9), as previously mentioned, in 2014 the growth factor was transiently located in the "Sancta sanctorum" of the "miraculous" molecule, when the laboratory of Amy Wagers (2) reported that GDF11 was responsible for the skeletal muscle regeneration in mice heterochronic parabiosis. A profound controversy arose regarding the rejuvenating property of GDF11; some groups stated that this property is displayed by the growth factor (1$3,38)$, while others reported the opposite effect (39-42), as previously mentioned. To have a good point of view regarding this debate, we suggest a deep view of cited works and commentaries regarding the controversy $(3,5,6,19,42,43)$.

Regardless of this disagreement, there is no doubt about the GDF11 function in differentiation and embryonic development, particularly in anterior/posterior axial skeleton (9) and brain function (44), which are nicely reviewed elsewhere $(19,45,46)$.

\section{GDF11 VS. GDF8 AND THE RACE FOR THE DISCOVERY OF THE REJUVENATION PROPERTIES}

GDF11 and GDF8 are close related members of the activins subclass in the TGF- $\beta$ superfamily. Sharing $90 \%$ of their amino acid sequence $(38,47)$, these two proteins have been a technical challenge for antibody manufacturers and, therefore, protagonists of one of the most controversial studies in recent years $(29,39,48-50)$, regarding to the issue of GDF11 being the protein responsible for "rejuvenation" of aged organisms $(1,2)$, as previously mentioned.

The race from the discovery of the rejuvenation properties of GDF11 to the following debate of the antibody specificity led to a deeper structural analysis of these proteins and the interaction with their receptor. Due to the similarities of $\sim 90 \%$ of sequence identity of the C-terminal signaling domain between GDF11 and GDF8, their mature form is nearly identical, which causes these proteins to share the same activin type II receptor (38).

Although they are indeed similar in their monomeric form, in fact these proteins are thought to have opposite functions, where GDF11 works as a muscle generator in embryogenesis (9) but GDF8 acts as a muscle mass inhibitor $(10,51)$, which may be the result of the final homodimer structure. Thus, it is important to understand that the GDF11 and GDF8 homodimer formation leads to a different conformation that allows them to interact with the same receptor in a unique and specific way. It is reported that both homodimers are linked by a single disulfide bond in an antiparallel conformation, but the flexibility in the relative orientations generated by the differences in their structure are determinant for the quaternary structure variations that lead to a distinctive biological response $(47,52)$.
It has also been reported that GDF11 has a stronger affinity for the receptor than GDF8 (38) and that it is more dependent on direct receptor contacts (53), but there is also an issue with crystal structures of both proteins. Human myostatin alone has not been reported and the available structures are bound to extracellular antagonists (follistatin and follistatin-like 3$)(54,55)$, which have been compared to a small-angle X-ray scattering (SAXS) analysis to determine the mechanism of activation (52). On the other hand, human GDF11 structure has been resolved in recent years (47), thus, it is possible to discover the real impact of the structure of both proteins in future, at which point we can begin to uncover exactly what makes the responses so different.

\section{GDF11 EFFECTS IN CANCER BIOLOGY}

An emerging field of research is the impact of GDF11 in cancer biology. Most of the cancer cells, particularly those with high aggressiveness, retain or recover stemness capacity, placing them as a potential target of $\operatorname{GDF} 11(14,23)$.

There exist some controversies in cancer biology as well; in some cases GDF11 induces clear tumor suppressive properties $(14,23)$, and in others it is the opposite $(56,57)$. Once again, the versatility displayed by this growth factor depends of cell progeny, grade of differentiation or transformation.

\section{LIVER CANCER}

We recently published work describing how GDF11 induces tumor suppressive properties in human hepatocellular carcinoma-derived cells, Huh7 and Hep3B cell lines, restricting spheroid formation and clonogenic capacity, an effect that is also observed in other liver cancer cell lines (SNU-182, Hepa1-6, and HepG2), decreasing proliferation, motogenesis, and invasion. These characteristics were associated with transcriptional repression of cyclin D1 and $\mathrm{A}$, and the overexpression of p27 (14). GDF11 effects, on hepatic cell proliferation, have been found in liver development, where GDF11 targets the hepatoblast, the hepatocyte precursor $(13,58)$.

Remarkably, the invasion experiments using the chick embryo chorioallantoic membrane $(\mathrm{CAM})$ model $(14,59)$ revealed a static phenotype in Huh7 cells treated for $72 \mathrm{~h}$ with GDF11 $(50 \mathrm{ng} / \mathrm{ml})$, an outcome well-correlated with a decrease in cell migration and proliferation. Furthermore, GDF11 treated cells were incapable of sustaining colony and sphere capacity in the absence of GDF11, up to 5 days, indicating that the effect of GDF11 on self-renewal capacity is not transient, suggesting a reprogramming effect.

Similar results were obtained in the hepatoblastoma cell lines, HepG2 and SMMC-7721: the treatment with GDF11 up to $72 \mathrm{~h}$ reduced cell viability. Although SMMC-7721 cells are probably a HELA-derivative cell line, the effect was also present (60). This report also provides preliminary evidence that the expression of GDF11 was significantly lower in cancerous tissue rather than in normal liver.

Outstandingly, GDF11 was capable of decreasing aggressiveness-associated markers in Huh7 and Hep3B cells, 
producing a deregulation in the expression of Epcam, promo1 (CD133), $c d 24$, and $c k 19$, that was associated with the repression of Snail and $\mathrm{N}$-cadherin, and the overexpression of occluding and E-cadherin, strongly indicating a mesenchymal to epithelial transition (14).

It is interesting that, under normal conditions, liver cells, which are the poorest in GDF11 production, are highly responsive to GDF11 in the context of cancer could be relevant in terms of a possible use of GDF11 for treatment. The work by Gerardo-Ramírez clearly showed that all HCC cells used in the study responded to the exogenous GDF11 treatment, decreasing all aggressiveness-associated markers. Interestingly, the effects in HCC cells were differentiated, and it was dependent of the stemness capacity, being more responsive to Hep3B cells, which express fewer stemness markers compared to Huh7 cells. Supporting this statement, in liver development GDF11 has been related to inhibition of liver growth, mainly targeting proliferation of hepatoblast, the cell precursor or mature hepatocytes by a mechanism involving HDAC3, which inhibits the expression of GDF11 as proven by Farooq and collaborators (58). This work clearly demonstrates that GDF11 targets hepatic cells with stemness features, not necessarily those observed in cancer, but in the normal liver, particularly in development.

\section{BREAST CANCER}

Similarly, Bajikar et al. (23) identified a tumor-suppressive role of GDF11 in a triple-negative breast cancer (TNBC). These cells, under 3D culture, heterogeneously express GDF11 and very low levels of GDF8, as well as the main canonical receptors, such as ALK4, and ALK5, among other protein machinery required for a proper signal transduction. This clearly indicates that breast epithelial cells express the required components to recognize GDF11 as an autocrine or paracrine stimulus (23). GDF11 also induced a decrease in number and size of the spheroids and generated more-compacted structures by the increment in Ecadherin, as observed in liver cancer cell lines, and GDF11 treatment induces a cell-cell adhesion preventing metastasis phenomena $(14,23)$.

Authors also found a defective GDF11 maturation and secretion in seven of nine studied TNBC cell lines. The linker was the convertase PCSK5, in which a deficiency was found in the TNBC cells, inducing the extracellular accumulation of the immature proGDF11 and, for instance, loss in the bioactivity of GDF11. This mechanism was also observed in mice; the lack of Pcsk5 in Apc ${ }^{\mathrm{min} /+}$ animals (61) increases adenocarcinoma formation in the small intestine, decreasing the survival $(23,62)$, which demonstrates a clear function in tandem of GDF11 and PCSK5 to induce the tumor suppressive properties. In fact, the restoration of the PCSK5 activity in the TNBC cells suppresses lung metastasis (23).

Another work by Wallner et al. (63) revealed that superphysiological levels of GDF11 $(2 \mu \mathrm{g} / \mathrm{ml})$ could provide advantages in chemotherapy in breast adenocarcinoma, inducing a decrement in the migrative capacity of MCF-7 cells in a scratch assay. Similar findings were observed in the presence of follistatin $(2 \mu \mathrm{g} / \mathrm{ml})$, while GDF8 $(2 \mu \mathrm{g} / \mathrm{ml})$ induced cell death at the same time. This study also showed that GDF11 is expressed in low grade adenocarcinoma tissue (G1), but lower levels in G3 tissue were found, and it was correlated with high expression of follistatin in G1, suggesting an inhibitory effect of GDF11 at higher levels of differentiation, which is consistent with the idea that high aggressiveness in cancer associates with less GDF11 function, confirming the tumor suppressive capacity of GDF11.

\section{PANCREATIC CANCER}

Pancreatic cancer (PC) represents one of the most lethal cancers worldwide (64). It has been reported that GDF11 is downregulated in PC tissue, compared with surrounding tissue, and pancreatic cell lines exhibit a low expression of the growth factor (65). This group also reported that, in a cohort of 63 PC patients, those with high GDF11 expression had significantly better survival rates in comparison with those with low GDF11 expression. These effects were related to decreased proliferation, migration and invasion, and these observations are in agreement with those reported in HCC and TNBC. GDF11 is also capable of inducing apoptosis in PC cell lines (65).

Similarly, the human protein atlas (https://www.proteinatlas. org) provides evidence from 176 patients: those with high GDF11 expression $(n=61)$ exhibited better survival rates, compared with those with low expression $(n=115, p<0.001)$ (Figure 4). These observations strongly suggest that GDF11 could also exert tumor suppressive properties that should be deeply addressed to gain confidence, particularly the effect of exogenous active GDF11 (18).

Interestingly, another member of the family GDF15 is directly correlated with poor survival in PC patients, and it is proposed as a better marker than CA-125 (66), again raising the atypical functions of this growth factor.

As observed in HCC, in PC, the targets of GDF11 are poorly differentiated cells. In the mouse embryo, GDF11 is expressed in the pancreatic epithelium, at embryonic day E12-E14 (67), as it happens in the liver, but in GDF11 $1-$ - animals the pancreas size are 2 -fold smaller than wild type.

In the context of the educated guess that cells with some stemness phenotype respond to GDF11, even in cancer, it has been proven that GDF11 negatively regulates $\mathrm{NGN}^{+}$progenitor cells and GDF11 induces $\beta$-cell differentiation (68), supporting the role of GDF11 in metabolism. Under this context, GDF11 exerts its functions in pancreatic cells with stemness phenotype.

\section{COLORECTAL CANCER}

In 130 patients with colorectal cancer (CRC), the expression of GDF11 was significantly higher compared with normal tissue (56). The classification of the patient cohort in low and high GDF11 expression revealed that those patients with high levels of GDF11 showed a higher frequency of lymph node metastasis, more deaths and lower survival. The study suggests that GDF11 could be a prognostic biomarker in patients with this disease. 


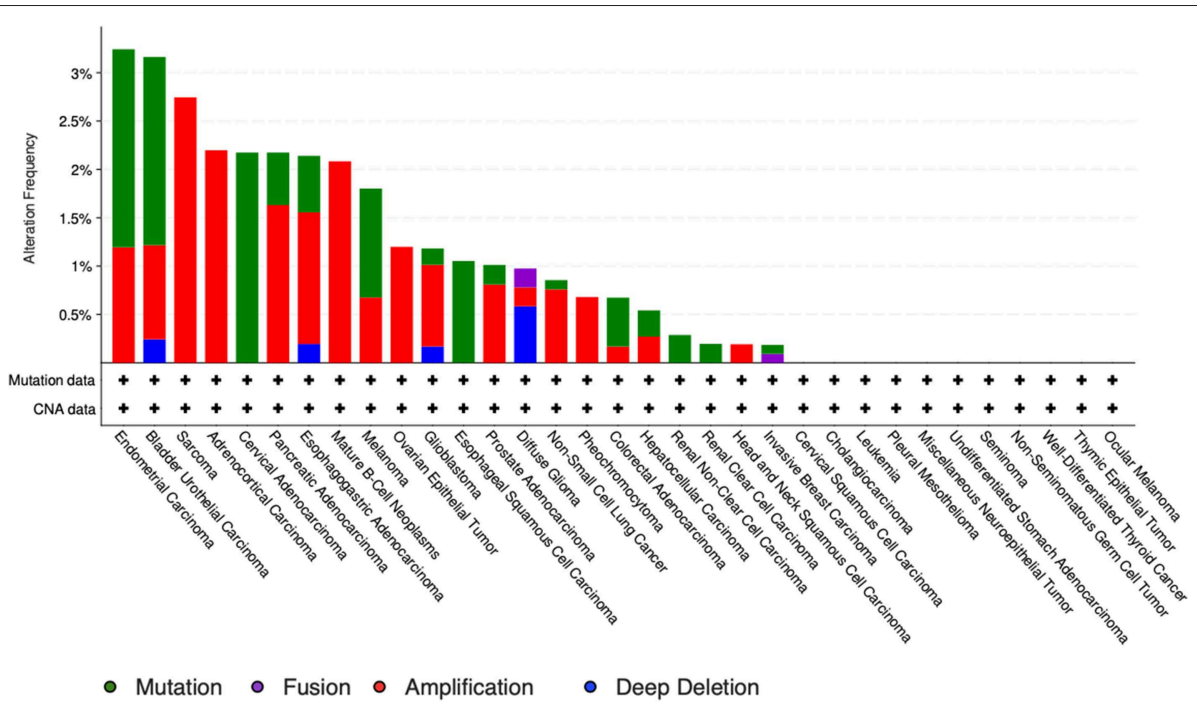

FIGURE 5 | Genomic alterations in Gdf11 gene. Alteration frequency by type of cancer according to cBioportal for cancer genomics (https://www.cbioportal.org).

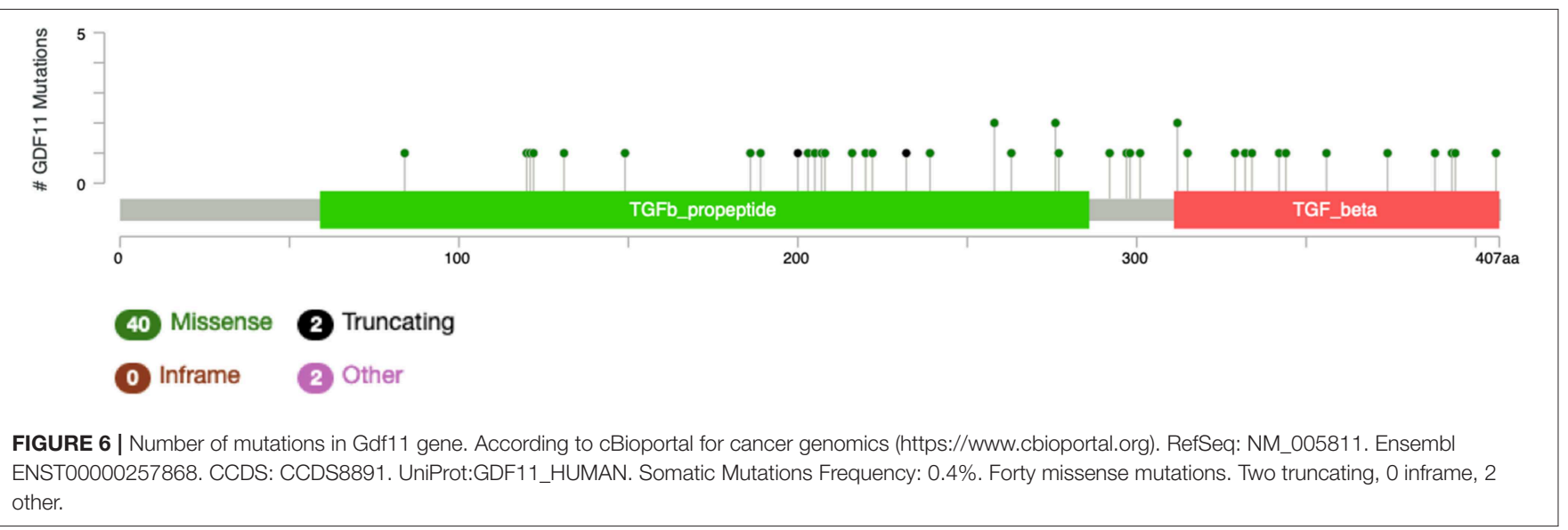

It is known that lymphangiogenesis is a fundamental phenomenon for colorectal cancer dissemination (69). Recently, Ungaro and collaborators reported that the microenvironment in the lymphatic vessels provides support to the tumor-derived cells by manipulating the production of extracellular matrix proteins and soluble factors, such as cytokines and growth factors (70). Whole transcriptomic analysis addressed by RNA-seq of isolated human intestinal lymphatic endothelial cells (HILEC) from surgically resected CRC and healthy corresponding controls, revealed that among those genes differentially expressed, GDF11 was observed as a significant increment with high statistical confidence. CACO-2 cells demonstrated high proliferation in coculture with CRC-HILEC, but the GDF11 silencing by siRNA abrogated this effect indicating a tumor promotion role of GDF11 in CRC. Interestingly, GDF11 was expressed not only in lymphatic vessels in CRC, but also in normal tissue (69). The study also provides evidence of a direct correlation of GDF11 expression and tumor stage, confirming in this particular cancer that GDF11 expression could be a marker of tumor progression (70), and also raises mechanistic evidence that microenvironment in the lymphatic vessel could play a pivotal role in metastasis by local production of GDF11.

\section{OTHER TYPES OF CANCER}

Some reports have pointed to the pro-tumorigenic properties of GDF11, with major or minor confidence of rigorous scientific approach.

In oral squamous cell carcinoma, Qin and coauthors (57) showed that in a small patient cohort GDF11 expression is positively correlated with aggressiveness, finding a higher expression in metastatic oral cancer $(n=19)$ in comparison with non-metastatic oral cancer $(n=15)$. Authors also sustain that GDF11 induced epithelial to mesenchymal transition by downregulating epithelial markers such as E-cadherin, and the overexpression of vimentin or metalloproteinase 9.

In uveal melanoma, GDF11 expression was significantly upregulated compared with surrounding tissue, the expression 


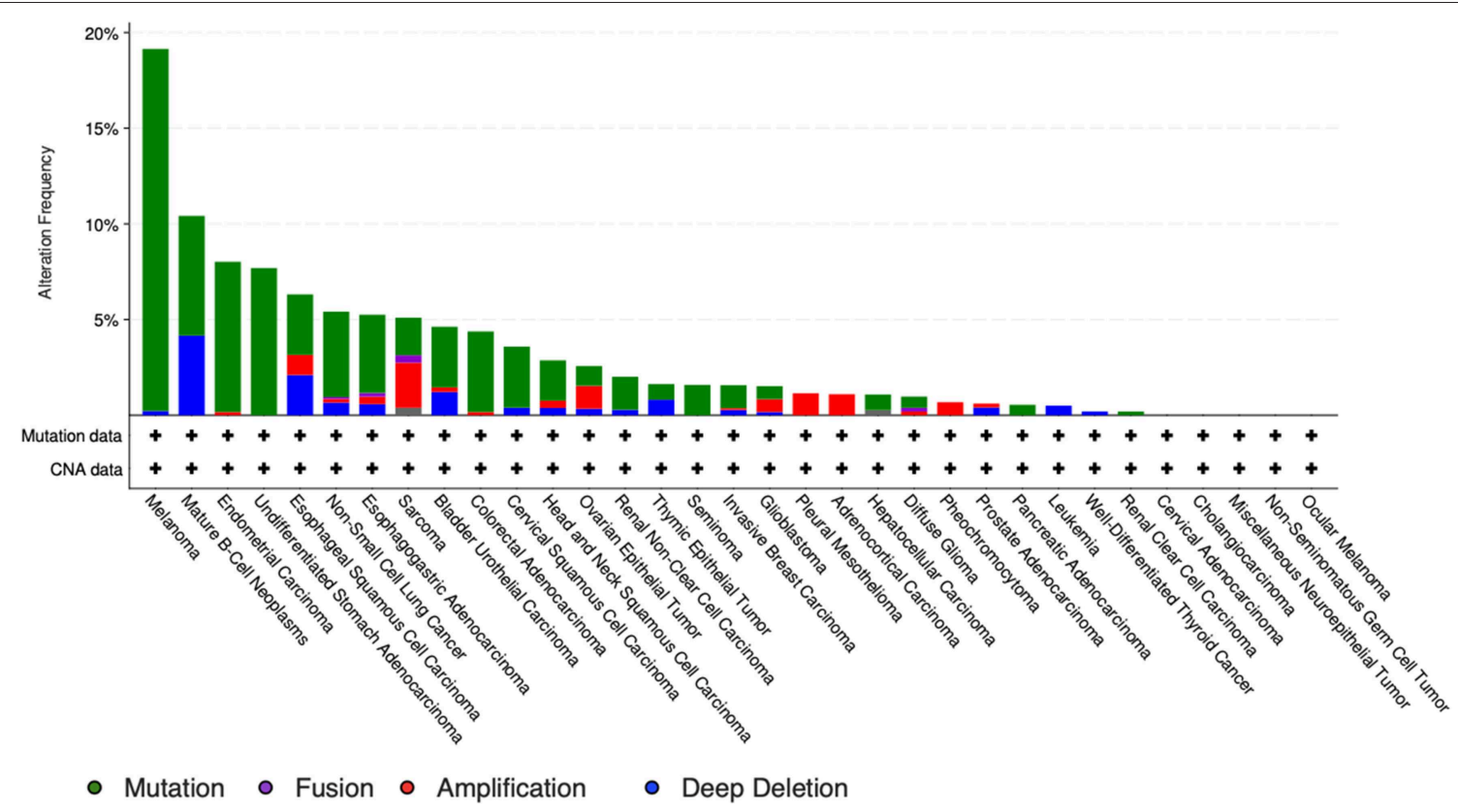

FIGURE 7 | Genomic alterations in Pcsk5 gene. Alteration frequency by type of cancer according to cBioportal for cancer genomics (https://www.cbioportal.org).

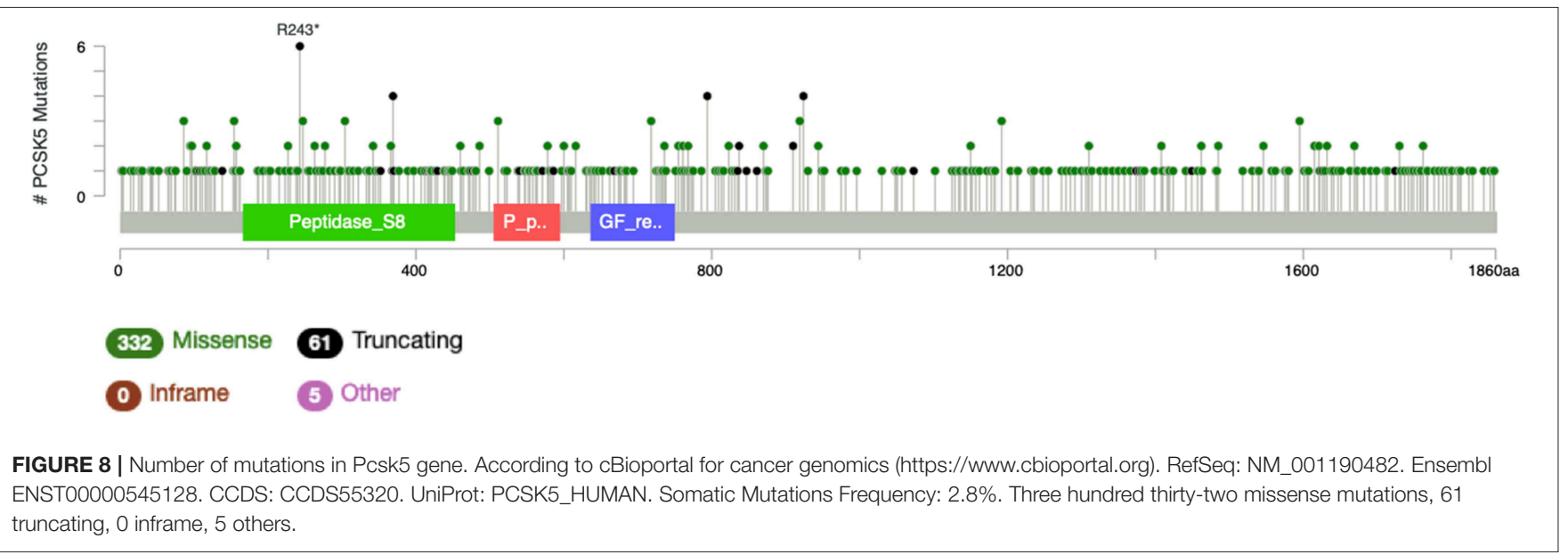

was higher in stage IV and substantially greater in the deceased cases regarding living cases (71). The multivariate analysis confirmed that GDF11 is an independent prognostic indicator of unfavorable overall survival.

\section{GDF11 AND PCSK MUTATIONS}

The study by Liu et al. (71) also showed that no relevant mutations were observed in the GDF11 gene in fact. The cBioportal for cancer genomics web site (https://www.cbioportal. org) indicates that GDF11 is altered in $1 \%$ of database patients. Figure 4 shows the alteration frequency in Gdf11 gene in some cancers, and Figure 5 depicts the number of somatic mutations, most of which are missense (72). It seems that mutations in the Gdf11 gene are not the main consequence in those cancers where
GDF11 is a prognostic factor, which increases research interest in transcriptional and post-translational regulation.

It is particularly relevant to consider the convertase PCSK5, a key regulator of GDF11 activity. Pcsk5 gene presents a high frequency of genomic alterations in 3\% of the patients, according to cBioportal, being particularly relevant in melanoma, endometrial carcinoma, and stomach adenocarcinoma, among others (Figure 6). Missense mutations are particularly observed in the peptidase transcript (Figure 7) (72). As proven remarkably by the team of doctor Kevin A. Janes (23), maturation of bioactive GDF11 is defective in TNBC due to insufficient PCSK5 activity but, as shown, the frequency of mutations appear not to be related with the flaw (Figure 8). Once again, transcriptional and post-translational regulation should be considered in future research. 
TABLE 1 | Overview of cancer cell lines or tissue from patients with differential effect of GDF11, as tumor suppressive or tumor promotion protein.

\begin{tabular}{|c|c|c|c|c|}
\hline Cancer & Cell/Tissue & $\begin{array}{c}\text { Tumor } \\
\text { suppressive }\end{array}$ & $\begin{array}{c}\text { Tumor } \\
\text { promotion }\end{array}$ & References \\
\hline Liver & $\begin{array}{l}\text { Huh7 } \\
\text { Hep3B } \\
\text { SNU-182 } \\
\text { Hepa1-6 HepG2 }\end{array}$ & $x$ & & (14) \\
\hline Liver & $\begin{array}{l}\text { HepG2 } \\
\text { SMMC-7721 } \\
\text { and } \\
\text { tissue }\end{array}$ & $x$ & & (60) \\
\hline Breast & $\begin{array}{l}\text { MDA-MB-231 } \\
\text { MDA-MB-468 } \\
\text { and } \\
\text { tissue }\end{array}$ & $x$ & & (23) \\
\hline Breast & MCF-7 & $x$ & & (63) \\
\hline Pancreas & $\begin{array}{l}\text { PANC-1 } \\
\text { CFPAC-1 } \\
\text { Tissue }\end{array}$ & $x$ & & (65) \\
\hline Colorectal & Tissue & & $X$ & (56) \\
\hline Colorectal & Tissue & & $x$ & (70) \\
\hline Colorectal & CACO-2 & & $x$ & (69) \\
\hline $\begin{array}{l}\text { Oral squamous } \\
\text { cell carcinoma }\end{array}$ & Tissue & & $x$ & $(57)$ \\
\hline $\begin{array}{l}\text { Uveal } \\
\text { melanoma }\end{array}$ & Tissue & & $x$ & (71) \\
\hline
\end{tabular}

\section{EFFECTS OF GDF11 AS METABOLISM REGULATOR}

The impact of GDF11 in the development of pancreas implies that the growth factor could exert some metabolic regulation on this organ in the adult, particularly in the endocrine pancreas (67). Dichmann and coauthors found that in the gdf $11^{-/-}$ mouse, the maturation and number of $\beta$ - and $\alpha$-cells are normal, however, another group led by Harmon reported that the gdf $11^{-/-}$mouse exhibited impairment maturation of $\beta$-cells and an increment in $\alpha$-cells, which could produce glucagon in comparison with the wild type mouse (68). This controversy, which is not unusual, must be addressed, but makes it clear that GDF11 could be inducing effects in the metabolism mediated by the pancreas.

Recently, a work by Anon-Hidalgo et al. (73) reported a convincing study associating the circulating levels of GDF11 with thyroid-stimulating hormone (TSH) in humans. The study showed subjects with high or normal levels of TSH present high level contents of GDF11, compared with patients with low levels of TSH. This finding could be due to the fact that other members of the family, such as GDF8 and GDF15, are regulators of the energy homeostasis $(74,75)$. Anon-Hidalgo team states that it could be related to a regulation of TSH by GDF11, or GDF11 could be positively regulated by TSH or any other thyroid hormones (73).

Luo et al. published that GDF11 decreased lipid content in human mesenchymal stem cells and the mouse 3T3-L1 cell line.
This was associated with the repression of adipogenic genes, such as the transcription factors Pparg, Cebpa, and the executer proteins Plp, Cd36, Plin1, Adipoq, among others, in a mechanism associated to the canonical signal transduction mediated by SMAD2/3 (76). The report provides evidence that GDF11 could exert control over lipid content in unclear fashion. The role of GDF11 in lipid homeostasis could be directed to lipid uptake or efflux, intervening in lipogenic or lipolysis pathways, or lipid removal by autophagy, but data provided by Luo et al. suggest an intervention in lipogenesis. Interestingly, obese mice fed with a high lipid diet present significantly decreased circulating GDF11 levels, compared with mice under low fat diet (77). The mRNA and protein content of GDF11 in skeletal muscle from mice under the high fat diet correlated with the serum content of the growth factor, exhibiting lower expression and protein content, compared with animals under low fat diet. Furthermore, palmitate treatment in the mouse-derived myoblast cell line, C2C12, decreases GDF11 expression. However, the GDF11 did not ameliorate the palmitate-induced insulin resistance and GDF11 treatment did not change expression of Glut4 or Irs-1.

The evidence sustains the metabolic intervention by GDF11, at least in terms of lipid homeostasis, and again in cells with stemness features. This could be relevant in cancer, since lipid overload is one of the main characteristics required for a proper cancer cell proliferation $(78,79)$. In fact, it is reported that GDF11 impairs mitochondrial function in cancer cell lines, particularly in HCC-derived cells (14). The impact of GDF11 in the central metabolic organelle could explain the tumor suppressive properties exerted by the growth factor. Mitochondria provide essential intermediaries required for cell proliferation: driving redox and calcium homeostasis, coordinating energy supply and mediating cell survival; all of which are fundamental for all cells, and particularly for transformed ones (80). A report by Hernandez-Rizo and collaborators states that GDF11 restricts cell proliferation in hepatic tumor cells through glycolysis and lipid metabolism impairment (81). In agreement with these findings, GarridoMoreno et al. (82) recently reported that GDF11 prevents cardiomyocyte hypertrophy by preserving the communication between the mitochondria and sarcoplasmic reticulum and calcium mobility, preserving oxidative mitochondria metabolism by a mechanism mediated by the maintenance of mitochondrial cytosolic calcium buffering capacity.

Although the evidence of GDF11 regulation of the energetic and lipid metabolism is limited, it clearly indicates an effect tending to maintain the cellular energetic homeostasis. More research is required to characterize the mechanism underlying metabolic regulation by the growth factor, particularly in cancer cells.

\section{CONCLUDING REMARKS AND FUTURE PROSPECTIVE}

GDF11 is an intriguing non-conventional growth factor, perhaps the most fascinating new member of the TGF- $\beta$ superfamily. It transduces, as practically all members, by the canonical 
SMAD and non-canonical MAPK pathways, but its functions can be quite variable, even contradictory, depending of the cell lineage, tissue (Table 1), or even age. This raises a complex body of physiological control, which could also differ in health or disease. GDF11 displays a versatile response that must be fully characterized, due to it representing an interesting point of intervention in many diseases or physiological conditions, particularly in cancer. It is remarkable that one of the main characteristics in GDF11 target cells, in normal or pathological conditions, is the stemness capacity. The effects exerted by the growth factor in cancer have begun to be characterized with greater scientific rigor and mechanistic approaches.

Perhaps it is time that GDF11, due to its diverse functionality, constitutes its own subfamily as an atypical and versatile member of the TGF- $\beta$ family.

We must be cautious to oversimplify its functions. The controversies found clearly indicate that GDF11 displays particular activities depending of cell type, grade of differentiation, and pathological or normal conditions. This remarkable atypical member of the TGF- $\beta$ family must be carefully studied in clear and well-controlled biological systems.

\section{REFERENCES}

1. Loffredo FS, Steinhauser ML, Jay SM, Gannon J, Pancoast JR, Yalamanchi $\mathrm{P}$, et al. Growth differentiation factor 11 is a circulating factor that reverses age-related cardiac hypertrophy. Cell. (2013) 153:828-39. doi: 10.1016/j.cell.2013.04.015

2. Sinha M, Jang YC, Oh J, Khong D, Wu EY, Manohar R, et al. Restoring systemic GDF11 levels reverses age-related dysfunction in mouse skeletal muscle. Science. (2014) 344:649-52. doi: 10.1126/science.1251152

3. Katsimpardi L, Litterman NK, Schein PA, Miller CM, Loffredo FS, Wojtkiewicz GR, et al. Vascular and neurogenic rejuvenation of the aging mouse brain by young systemic factors. Science. (2014) 344:630-4. doi: $10.1126 /$ science.1251141

4. Walker RG, Poggioli T, Katsimpardi L, Buchanan SM, Oh J, Wattrus S, et al. Biochemistry and biology of GDF11 and myostatin: similarities, differences, and questions for future investigation. Circ Res. (2016) 118:1125-41; discussion 1142. doi: 10.1161/CIRCRESAHA.116.3 08391

5. Kaiser J. Aging. 'Rejuvenation factor' in blood turns back the clock in old mice. Science. (2014) 344:570-1. doi: 10.1126/science.344.6 184.570

6. Brun CE, Rudnicki MA. GDF11 and the mythical fountain of youth. Cell Metab. (2015) 22:54-6. doi: 10.1016/j.cmet.2015.05.009

7. Lee YJ, McPherron A, Choe S, Sakai Y, Chandraratna RA, Lee SJ, et al. Growth differentiation factor 11 signaling controls retinoic acid activity for axial vertebral development. Dev Biol. (2010) 347:195-203. doi: 10.1016/j.ydbio.2010.08.022

8. Tsuda T, Iwai N, Deguchi E, Kimura O, Ono S, Furukawa T, et al. PCSK5 and GDF11 expression in the hindgut region of mouse embryos with anorectal malformations. Eur J Pediatr Surg. (2011) 21:238-41. doi: 10.1055/s-0031-1273691

9. McPherron AC, Lawler AM, Lee SJ. Regulation of anterior/posterior patterning of the axial skeleton by growth/differentiation factor 11. Nat Genet. (1999) 22:260-4. doi: 10.1038/10320

10. McPherron AC, Lawler AM, Lee SJ. Regulation of skeletal muscle mass in mice by a new TGF-beta superfamily member. Nature. (1997) 387:83-90. doi: $10.1038 / 387083 \mathrm{a} 0$

11. Hunt SE, McLaren W, Gil L, Thormann A, Schuilenburg H, Sheppard D, et al. Ensembl variation resources. Database. (2018) 2018:bay119. doi: $10.1093 /$ database/bay119
The knowledge, regarding GDF11, will surely be increased in the next few years. The mechanism of action in each particular cancer or cell type must be elucidated to clarify these controversies, and perhaps they will stop being such, thanks to the mechanistic enlightenments obtained in the incoming research in the field.

\section{AUTHOR CONTRIBUTIONS}

AS-N, MG-R, GP-V, and LC-R conception and preparation of the manuscript. LB, VS, and RM-L reviewed and corrected the manuscript. MCG-R and LG-Q final review of the manuscript and financial support.

\section{FUNDING}

This work was partially funded by a grant from the Consejo Nacional de Ciencia y Tecnología (CONACYT): CB-252942; Fronteras de la Ciencia 1320; Apoyo al Fortalecimiento y Desarrollo de la Infraestructura 2017-280788, and Universidad Autonoma Metropolitana. We thank Frida Gomez-Cuevas for the assistance in the preparation of the manuscript.

12. Jeanplong F, Falconer SJ, Oldham JM, Maqbool NJ, Thomas M, Hennebry A, et al. Identification and expression of a novel transcript of the growth and differentiation factor-11 gene. Mol Cell Biochem. (2014) 390:9-18. doi: 10.1007/s11010-013-1949-3

13. Zhang X, Wharton W, Yuan Z, Tsai SC, Olashaw N, Seto E. Activation of the growth-differentiation factor 11 gene by the histone deacetylase (HDAC) inhibitor trichostatin A and repression by HDAC3. Mol Cell Biol. (2004) 24:5106-18. doi: 10.1128/MCB.24.12.5106-5118.2004

14. Gerardo-Ramirez M, Lazzarini-Lechuga R, Hernandez-Rizo S, JimenezSalazar JE, Simoni-Nieves A, Garcia-Ruiz C, et al. GDF11 exhibits tumor suppressive properties in hepatocellular carcinoma cells by restricting clonal expansion and invasion. Biochim Biophys Acta Mol Basis Dis. (2019) 1865:1540-54. doi: 10.1016/j.bbadis.2019.03.003

15. Uhlen M, Fagerberg L, Hallstrom BM, Lindskog C, Oksvold P, Mardinoglu A, et al. Proteomics. Tissue-based map of the human proteome. Science. (2015) 347:1260419. doi: 10.1126/science. 1260419

16. Gray AM, Mason AJ. Requirement for activin A and transforming growth factor-beta 1 pro-regions in homodimer assembly. Science. (1990) 247:132830. doi: 10.1126/science. 2315700

17. Essalmani R, Zaid A, Marcinkiewicz J, Chamberland A, Pasquato A, Seidah $\mathrm{NG}$, et al. In vivo functions of the proprotein convertase PC5/6 during mouse development: Gdf11 is a likely substrate. Proc Natl Acad Sci USA. (2008) 105:5750-5. doi: 10.1073/pnas.0709428105

18. Uhlen M, Zhang C, Lee S, Sjostedt E, Fagerberg L, Bidkhori G, et al. A pathology atlas of the human cancer transcriptome. Science. (2017) 357:eaan2507. doi: 10.1126/science.aan2507

19. Jamaiyar A, Wan W, Janota DM, Enrick MK, Chilian WM, Yin L. The versatility and paradox of GDF 11. Pharmacol Ther. (2017) 175:28-34. doi: 10.1016/j.pharmthera.2017.02.032

20. Andersson O, Reissmann E, Ibanez CF. Growth differentiation factor 11 signals through the transforming growth factor-beta receptor ALK5 to regionalize the anterior-posterior axis. EMBO Rep. (2006) 7:831-7. doi: 10.1038/sj.embor.7400752

21. Gaunt SJ, George M, Paul YL. Direct activation of a mouse Hoxd11 axial expression enhancer by Gdf11/Smad signalling. Dev Biol. (2013) 383:52-60. doi: 10.1016/j.ydbio.2013.08.025

22. Zhang YH, Cheng F, Du XT, Gao JL, Xiao XL, Li N, et al. GDF11/BMP11 activates both smad1/5/8 and smad2/3 signals but shows no significant effect on proliferation and migration of human umbilical vein endothelial cells. Oncotarget. (2016) 7:12063-74. doi: 10.18632/oncotarget.10664 
23. Bajikar SS, Wang CC, Borten MA, Pereira EJ, Atkins KA, Janes KA. Tumorsuppressor inactivation of GDF11 occurs by precursor sequestration in triple-negative breast cancer. Dev Cell. (2017) 43:418-35 e13. doi: 10.1016/j.devcel.2017.10.027

24. Hata A, Chen YG. TGF-beta signaling from receptors to smads. Cold Spring Harb Perspect Biol. (2016) 8:a022061. doi: 10.1101/cshperspect.a022061

25. Wang Z, Dou M, Liu F, Jiang P, Ye S, Ma L, et al. GDF11 induces differentiation and apoptosis and inhibits migration of C17.2 neural stem cells via modulating MAPK signaling pathway. PeerJ. (2018) 6:e5524. doi: $10.7717 /$ peerj. 5524

26. Demontis F, Patel VK, Swindell WR, Perrimon N. Intertissue control of the nucleolus via a myokine-dependent longevity pathway. Cell Rep. (2014) 7:1481-94. doi: 10.1016/j.celrep.2014.05.001

27. Mei W, Xiang G, Li Y, Li H, Xiang L, Lu J, et al. GDF11 protects against endothelial injury and reduces atherosclerotic lesion formation in apolipoprotein e-null mice. Mol Ther. (2016) 24:1926-38. doi: $10.1038 / \mathrm{mt} .2016 .160$

28. van Wijk B, Moorman AF, van den Hoff MJ. Role of bone morphogenetic proteins in cardiac differentiation. Cardiovasc Res. (2007) 74:244-55. doi: 10.1016/j.cardiores.2006.11.022

29. Hammers DW, Merscham-Banda M, Hsiao JY, Engst S, Hartman JJ, Sweeney HL. Supraphysiological levels of GDF11 induce striated muscle atrophy. EMBO Mol Med. (2017) 9:531-44. doi: 10.15252/emmm. 201607231

30. Hindi SM, Sato S, Xiong G, Bohnert KR, Gibb AA, Gallot YS, et al. TAK1 regulates skeletal muscle mass and mitochondrial function. JCI Insight. (2018) 3:98441. doi: 10.1172/jci.insight.98441

31. Mihaly SR, Ninomiya-Tsuji J, Morioka S. TAK1 control of cell death. Cell Death Differ. (2014) 21:1667-76. doi: 10.1038/cdd.2014.123

32. Wang C, Deng L, Hong M, Akkaraju GR, Inoue J, Chen ZJ. TAK1 is a ubiquitin-dependent kinase of MKK and IKK. Nature. (2001) 412:346-51. doi: $10.1038 / 35085597$

33. Fife E, Kostka J, Kroc L, Guligowska A, Piglowska M, Soltysik B, et al. Relationship of muscle function to circulating myostatin, follistatin and GDF11 in older women and men. BMC Geriatr. (2018) 18:200. doi: 10.1186/s12877-018-0888-y

34. Schneyer AL, Sidis Y, Gulati A, Sun JL, Keutmann H, Krasney PA. Differential antagonism of activin, myostatin and growth and differentiation factor 11 by wild-type and mutant follistatin. Endocrinology. (2008) 149:4589-95. doi: 10.1210/en.2008-0259

35. Lee YS, Lee SJ. Regulation of GDF-11 and myostatin activity by GASP-1 and GASP-2. Proc Natl Acad Sci USA. (2013) 110:E3713-22. doi: 10.1073/pnas.1309907110

36. Gamer LW, Cox KA, Small C, Rosen V. Gdf11 is a negative regulator of chondrogenesis and myogenesis in the developing chick limb. Dev Biol. (2001) 229:407-20. doi: 10.1006/dbio.2000.9981

37. Smart NG, Apelqvist AA, Gu X, Harmon EB, Topper JN, MacDonald RJ, et al. Conditional expression of Smad7 in pancreatic beta cells disrupts TGF-beta signaling and induces reversible diabetes mellitus. PLoS Biol. (2006) 4:e39. doi: 10.1371/journal.pbio.0040039

38. Walker RG, Czepnik M, Goebel EJ, McCoy JC, Vujic A, Cho M, et al. Structural basis for potency differences between GDF8 and GDF11. BMC Biol. (2017) 15:19. doi: 10.1186/s12915-017-0350-1

39. Egerman MA, Cadena SM, Gilbert JA, Meyer A, Nelson HN, Swalley SE, et al. GDF11 increases with age and inhibits skeletal muscle regeneration. Cell Metab. (2015) 22:164-74. doi: 10.1016/j.cmet.2015.05.010

40. Glass DJ. Elevated GDF11 is a risk factor for age-related frailty and disease in humans. Cell Metab. (2016) 24:7-8. doi: 10.1016/j.cmet.2016.06.017

41. Zhao L, Zhang S, Cui J, Huang W, Wang J, Su F, et al. TERT assists GDF11 to rejuvenate senescent VEGFR2(+)/CD133(+) cells in elderly patients with myocardial infarction. Lab Invest. (2019). doi: 10.1038/s41374-019-0290-1. [Epub ahead of print].

42. Egerman MA, Glass DJ. The role of GDF11 in aging and skeletal muscle, cardiac and bone homeostasis. Crit Rev Biochem Mol Biol. (2019) 54:174-83. doi: 10.1080/10409238.2019.1610722

43. Fan X, Gaur U, Sun L, Yang D, Yang M. The growth differentiation factor 11 (GDF11) and myostatin (MSTN) in tissue specific aging. Mech Ageing Dev. (2017) 164:108-12. doi: 10.1016/j.mad.2017.04.009
44. Gokoffski KK, Wu HH, Beites CL, Kim J, Kim EJ, Matzuk MM, et al. Activin and GDF11 collaborate in feedback control of neuroepithelial stem cell proliferation and fate. Development. (2011) 138:4131-42. doi: 10.1242/dev.065870

45. Zhang Y, Wei Y, Liu D, Liu F, Li X, Pan L, et al. Role of growth differentiation factor 11 in development, physiology and disease. Oncotarget. (2017) 8:8160416. doi: 10.18632/oncotarget.20258

46. Gad JM, Tam PP. Axis development: the mouse becomes a dachshund. Curr Biol. (1999) 9:R783-6. doi: 10.1016/S0960-9822(00)80013-5

47. Padyana AK, Vaidialingam B, Hayes DB, Gupta P, Franti M, Farrow NA. Crystal structure of human GDF11. Acta Crystallogr F Struct Biol Commun. (2016) 72:160-4. doi: 10.1107/S2053230X16001588

48. Jones JE, Cadena SM, Gong C, Wang X, Chen Z, Wang SX, et al. Supraphysiologic administration of GDF11 induces cachexia in part by upregulating GDF15. Cell Rep. (2018) 22:1522-30. doi: 10.1016/j.celrep.2018.01.044

49. Zimmers TA, Jiang Y, Wang M, Liang TW, Rupert JE, Au ED, et al. Exogenous GDF11 induces cardiac and skeletal muscle dysfunction and wasting. Basic Res Cardiol. (2017) 112:48. doi: 10.1007/s00395-017-0642-1

50. Hinken AC, Powers JM, Luo G, Holt JA, Billin AN, Russell AJ. Lack of evidence for GDF11 as a rejuvenator of aged skeletal muscle satellite cells. Aging Cell. (2016) 15:582-4. doi: 10.1111/acel.12475

51. McPherron AC, Lee SJ. Double muscling in cattle due to mutations in the myostatin gene. Proc Natl Acad Sci USA. (1997) 94:12457-61. doi: 10.1073/pnas.94.23.12457

52. Walker RG, McCoy JC, Czepnik M, Mills MJ, Hagg A, Walton KL, et al. Molecular characterization of latent GDF8 reveals mechanisms of activation. Proc Natl Acad Sci USA. (2018) 115:E866-75. doi: 10.1073/pnas.1714622115

53. Goebel EJ, Corpina RA, Hinck CS, Czepnik M, Castonguay R, Grenha R, et al. Structural characterization of an activin class ternary receptor complex reveals a third paradigm for receptor specificity. Proc Natl Acad Sci USA. (2019) 116:15505-13. doi: 10.1073/pnas.1906253116

54. Cash JN, Angerman EB, Kattamuri C, Nolan K, Zhao H, Sidis Y, et al. Structure of myostatin.follistatin-like 3: N-terminal domains of follistatintype molecules exhibit alternate modes of binding. J Biol Chem. (2012) 287:1043-53. doi: 10.1074/jbc.M111.270801

55. Cash JN, Rejon CA, McPherron AC, Bernard DJ, Thompson TB. The structure of myostatin:follistatin 288: insights into receptor utilization and heparin binding. EMBO J. (2009) 28:2662-76. doi: 10.1038/emboj.2009.205

56. Yokoe $\mathrm{T}$, Ohmachi $\mathrm{T}$, Inoue $\mathrm{H}$, Mimori $\mathrm{K}$, Tanaka $\mathrm{F}$, Kusunoki M, et al. Clinical significance of growth differentiation factor 11 in colorectal cancer. Int J Oncol. (2007) 31:1097-101. doi: 10.3892/ijo.31.5.1097

57. Qin X, Kuang H, Chen L, Wei S, Yu D, Liang F. Coexpression of growth differentiation factor 11 and reactive oxygen species in metastatic oral cancer and its role in inducing the epithelial to mesenchymal transition. Oral Surg Oral Med Oral Pathol Oral Radiol. (2017) 123:697-706. doi: 10.1016/j.oooo.2017.03.010

58. Farooq M, Sulochana KN, Pan X, To J, Sheng D, Gong Z, et al. Histone deacetylase 3 (hdac3) is specifically required for liver development in zebrafish. Dev Biol. (2008) 317:336-53. doi: 10.1016/j.ydbio.2008. 02.034

59. Lazzarini-Lechuga $\mathrm{R}$, Alcantar-Ramirez O, Jaime-Cruz R, GómezQuiroz L. Efecto teratogénico de nanopartículas de oro de $20 \mathrm{~nm}$ durante la septación cardiaca. Mundo Nano. (2014) 7:69-77. doi: 10.22201/ceiich.24485691e.2014.13.48710

60. Zhang YH, Pan LH, Pang Y, Yang JX, Lv MJ, Liu F, et al. GDF11/BMP11 as a novel tumor marker for liver cancer. Exp Ther Med. (2018) 15:3495-500. doi: 10.3892/etm.2018.5861

61. Su LK, Kinzler KW, Vogelstein B, Preisinger AC, Moser AR, Luongo C, et al. Multiple intestinal neoplasia caused by a mutation in the murine homolog of the APC gene. Science. (1992) 256:668-70. doi: 10.1126/science.1350108

62. Sun X, Essalmani R, Seidah NG, Prat A. The proprotein convertase PC5/6 is protective against intestinal tumorigenesis: in vivo mouse model. Mol Cancer. (2009) 8:73. doi: 10.1186/1476-4598-8-73

63. Wallner C, Drysch M, Becerikli M, Jaurich H, Wagner JM, Dittfeld $\mathrm{S}$, et al. Interaction with the GDF8/11 pathway reveals treatment options for adenocarcinoma of the breast. Breast. (2018) 37:134-41. doi: 10.1016/j.breast.2017.11.010 
64. Jemal A, Ward EM, Johnson CJ, Cronin KA, Ma J, Ryerson B, et al. Annual report to the nation on the status of cancer, 1975-2014, featuring survival. $J$ Natl Cancer Inst. (2017) 109:djx030. doi: 10.1093/jnci/djx030

65. Liu Y, Shao L, Chen K, Wang Z, Wang J, Jing W, et al. GDF11 restrains tumor growth by promoting apoptosis in pancreatic cancer. Onco Targets Ther. (2018) 11:8371-9. doi: 10.2147/OTT.S181792

66. Hogendorf P, Durczynski A, Skulimowski A, Kumor A, Poznanska G, Strzelczyk J. Growth differentiation factor (GDF-15) concentration combined with Ca125 levels in serum is superior to commonly used cancer biomarkers in differentiation of pancreatic mass. Cancer Biomark. (2018) 21:505-11. doi: $10.3233 / \mathrm{CBM}-170203$

67. Dichmann DS, Yassin H, Serup P. Analysis of pancreatic endocrine development in GDF11-deficient mice. Dev Dyn. (2006) 235:3016-25. doi: 10.1002/dvdy.20953

68. Harmon EB, Apelqvist AA, Smart NG, Gu X, Osborne DH, Kim SK. GDF11 modulates NGN3+ islet progenitor cell number and promotes beta-cell differentiation in pancreas development. Development. (2004) 131:6163-74. doi: 10.1242/dev.01535

69. Barresi V, Reggiani-Bonetti L, Di Gregorio C, De Leon MP, Barresi G. Lymphatic vessel density and its prognostic value in stage I colorectal carcinoma. J Clin Pathol. (2011) 64:6-12. doi: 10.1136/jcp.2010. 083550

70. Ungaro F, Colombo P, Massimino L, Ugolini GS, Correale C, Rasponi M, et al. Lymphatic endothelium contributes to colorectal cancer growth via the soluble matrisome component GDF11. Int J Cancer. (2019) 145:1913-20. doi: 10.1002/ijc.32286

71. Liu X, Zhang Q, Fan C, Tian J, Liu X, Li G. GDF11 upregulation independently predicts shorter overall-survival of uveal melanoma. PLoS ONE. (2019) 14:e0214073. doi: 10.1371/journal.pone.0214073

72. Gao J, Aksoy BA, Dogrusoz U, Dresdner G, Gross B, Sumer SO, et al. Integrative analysis of complex cancer genomics and clinical profiles using the cBioPortal. Sci Signal. (2013) 6:pl1. doi: 10.1126/scisignal.2004088

73. Anon-Hidalgo J, Catalan V, Rodriguez A, Ramirez B, Idoate-Bayon A, Silva C, et al. Circulating concentrations of GDF11 are positively associated with TSH levels in humans. J Clin Med. (2019) 8:E878. doi: 10.3390/jcm8060878

74. Zamani N, Brown CW. Emerging roles for the transforming growth factor\{beta\} superfamily in regulating adiposity and energy expenditure. Endocr Rev. (2011) 32:387-403. doi: 10.1210/er.2010-0018

75. Hsu JY, Crawley S, Chen M, Ayupova DA, Lindhout DA, Higbee J, et al. Nonhomeostatic body weight regulation through a brainstem-restricted receptor for GDF15. Nature. (2017) 550:255-9. doi: 10.1038/nature24042
76. Luo H, Guo Y, Liu Y, Wang Y, Zheng R, Ban Y, et al. Growth differentiation factor 11 inhibits adipogenic differentiation by activating TGFbeta/Smad signalling pathway. Cell Prolif. (2019) 52:e12631. doi: 10.1111/cpr. 12631

77. Jing YY, Li D, Wu F, Gong LL, Li R. GDF11 does not improve the palmitate induced insulin resistance in C2C12. Eur Rev Med Pharmacol Sci. (2017) 21:1795-802.

78. Dominguez-Perez M, Simoni-Nieves A, Rosales P, Nuno-Lambarri N, RosasLemus M, Souza V, et al. Cholesterol burden in the liver induces mitochondrial dynamic changes and resistance to apoptosis. J Cell Physiol. (2019) 234:721323. doi: $10.1002 /$ jcp. 27474

79. Calvisi DF, Wang C, Ho C, Ladu S, Lee SA, Mattu S, et al. Increased lipogenesis, induced by AKT-mTORC1-RPS6 signaling, promotes development of human hepatocellular carcinoma. Gastroenterology. (2011) 140:1071-83. doi: 10.1053/j.gastro.2010.12.006

80. Porporato PE, Filigheddu N, Pedro JMB, Kroemer G, Galluzzi L. Mitochondrial metabolism and cancer. Cell Res. (2018) 28:265-80. doi: $10.1038 /$ cr.2017.155

81. Hernandez-Rizo S, Gerardo-Ramirez M, Fucho R, Perez-Aguilar B, Gomez-Quiroz LE, Fernandez-Checa JC, et al. Growth differentiation factor 11 (GDF11) restricts cell proliferation in hepatic tumor cells through glycolysis and lipid metabolism. Ann Hepatol. (2018) 17:683. doi: 10.5604/01.3001.0012.0962

82. Garrido-Moreno V, Diaz-Vegas A, Lopez-Crisosto C, Troncoso MF, Navarro-Marquez M, Garcia L, et al. GDF-11 prevents cardiomyocyte hypertrophy by maintaining the sarcoplasmic reticulum-mitochondria communication. Pharmacol Res. (2019) 146:104273. doi: 10.1016/j.phrs.2019. 104273

Conflict of Interest: The authors declare that the research was conducted in the absence of any commercial or financial relationships that could be construed as a potential conflict of interest.

Copyright (c) 2019 Simoni-Nieves, Gerardo-Ramírez, Pedraza-Vázquez, ChávezRodríguez, Bucio, Souza, Miranda-Labra, Gomez-Quiroz and Gutiérrez-Ruiz. This is an open-access article distributed under the terms of the Creative Commons Attribution License (CC BY). The use, distribution or reproduction in other forums is permitted, provided the original author(s) and the copyright owner(s) are credited and that the original publication in this journal is cited, in accordance with accepted academic practice. No use, distribution or reproduction is permitted which does not comply with these terms. 

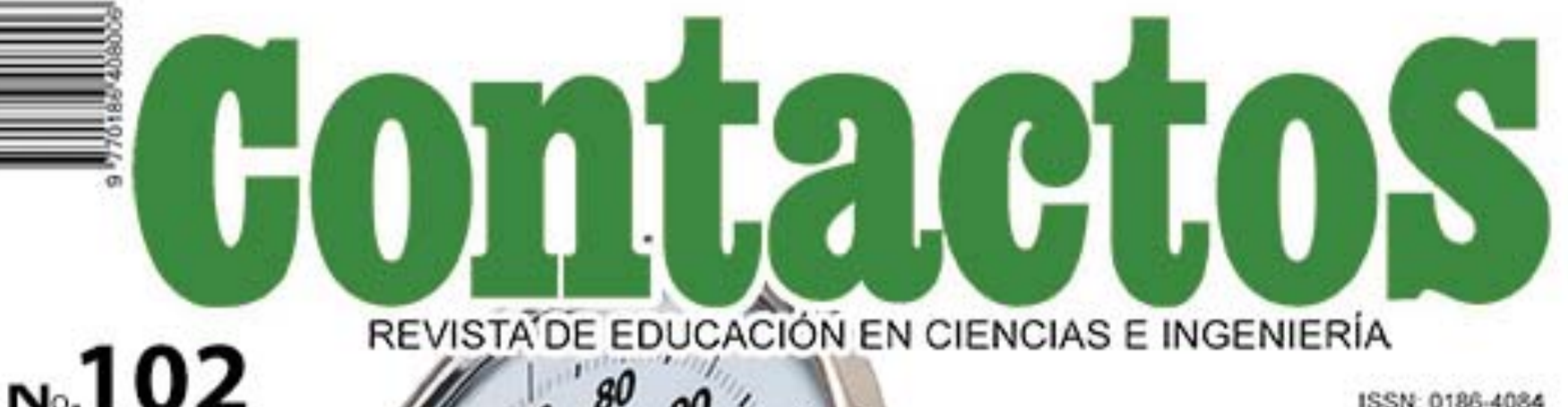

№.102
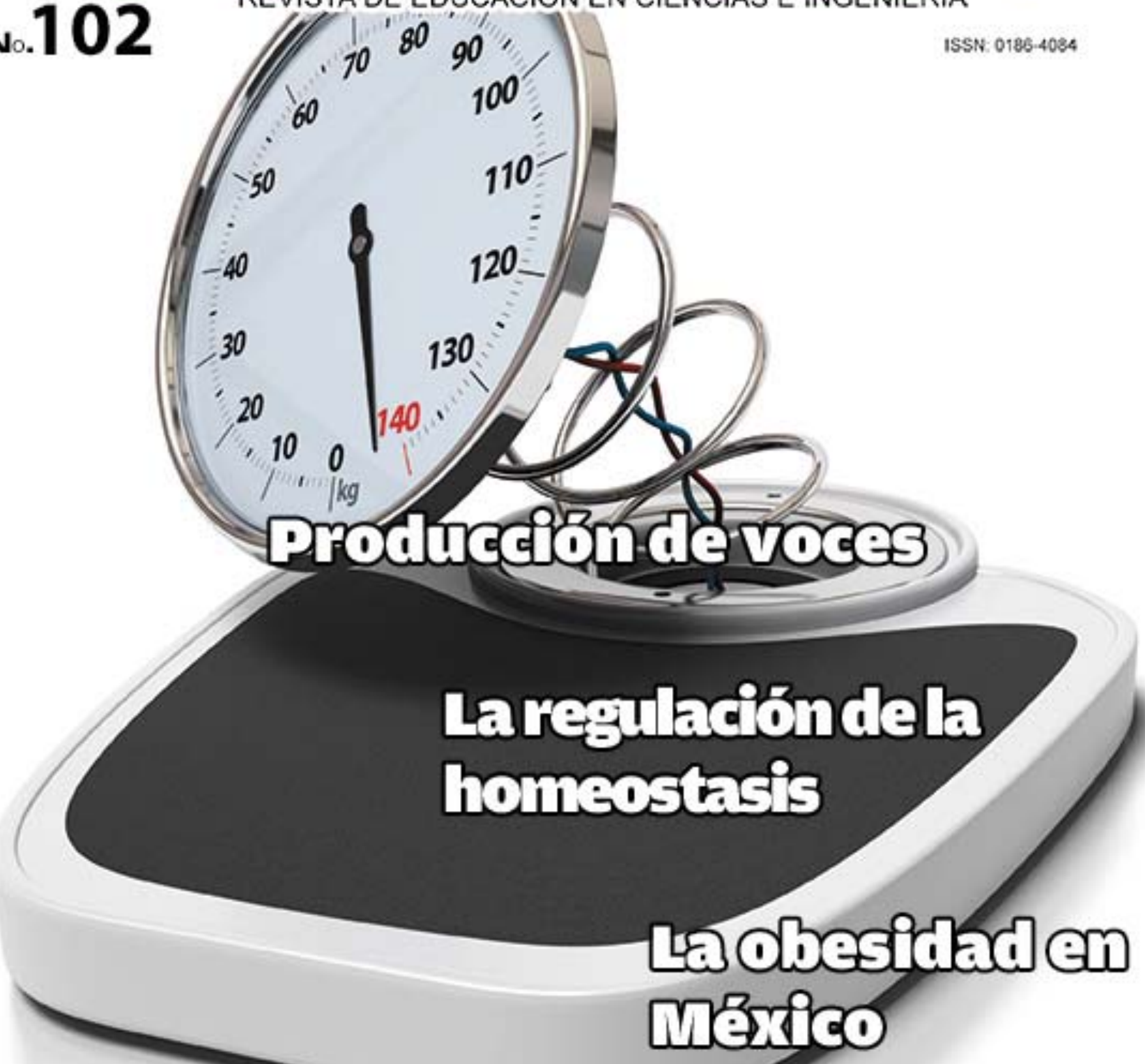


\section{Contenido}

\section{ContactoS No. 102, Octubre-Diciembre 2016}

\author{
Editorial

Ediorial \\ La homeostasis lipfdica en la progresión del \\ cincer hepático \\ Monserrat Gererdo-Ramirez \\ Benjamin Pérez-Aguilar \\ Mería Concepción \\ Gutiérrez-Ruiz \\ Luis Enrique Gómen-Quiroz* \\ Sistema de rastreo por Geolocalización con \\ base en un Microcontrolador y GoogleMaps \\ Jorge López Ortega \\ Julién López Mertínez \\ Gabriel Eduardo Gercie Rojas
}

Obesidad y Sobrepeso en Mérico

Alma E. Martinez Licona

Benjamin Benlenga Magaña
5

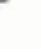

Marvin Coto-Jiménea

John Godderd-Cloee

Fabiole M. Martinea-Lioona

DE VIANDAS Y BREBAJES

La cocina griega

Elancio "Kaneho" Almasara

14

Chef pragmátioo

Los Codices Mayas

53

34

42

21 Rubén Tello Herzera

ContactoS en la WEB

Lea los artículos publicadoe en ContactoS en

http://www.izt.uam.mx/contactoe 


\author{
casa abierta al tiempo \\ ÍNDICE DE REVISTAS MEXICANAS \\ CONACY DEDIVULCACIÓN CIENTIFIICAY YECNOLÓGICA \\ Rector General \\ Dr. Salvador Vega y León. \\ Secretario General \\ Mtro. Norberto Manjarez Álvarez. \\ UNIDAD IZTAPALAPA \\ Rector \\ Dr. José Octavio Nateras Domínguez. \\ Secretario \\ Dr. Miguel Ángel Gómez Fonseca. \\ Director de la División de Ciencias Básicas \\ e Ingeniería \\ Dr. Gilberto Córdoba Herrera. \\ Directora de la División de Ciencias Biológicas y \\ de la Salud \\ Dra. Edith Ponce Alquicira. \\ ContactoS: \\ Consejo Editorial: Dr. José Antonio Nateras \\ Domínguez Dr. Miguel Ángel Gómez Fonseca, \\ Dr. Gilberto Córdoba Herrera, Dra. Edith Ponce \\ Alquicira \\ UAM-Iztapalapa \\ Editor en jefe: MC. Alma Edith Martínez Licona. \\ Comité Editorial por CBS: \\ Dra. Edith Arenas Ríos, Dra. Laura Josefina \\ Pérez Flores, Dr. Pedro Luis Valverde Padilla, \\ Por CBI: \\ Dr. Hugo Ávila Paredes, \\ Por la Universidad Iberoamericana Mtro. Adolfo \\ G. Fink-Pastrana.
}

Contactos REVISTA DE EDUCACIÓN EN CIENCIAS E INGENIERÍA 3a. Época, No. 102, Octubre-Diciembre 2016, es una publicación trimestral, editada por la Univesidad Autónoma Metropolitana a través de la unidad Iztapalapa, División de Ciencias Básicas e Ingeniería y División de Ciencias Biológicas y de la Salud. Prolongación Canal de Miramontes 3855, Col. Ex-Hacienda San Juan de Dios, Delegación Tlalpan, C.P. 14387, México, D.F. y Av. San Rafael Atlixco No. 186, Edificio E-317, Colonia Vicentina, Delegación Iztapalapa, C.P. 09340, México, D.F., Tel. 5804-4606. Página Web de la revista: http://www.izt.uam.mx/contactos y correo electrónico: cts@xanum.uam.mx: Editora responsable MC. Alma Edith Martínez Licona, Certificado de Reserva de Derechos al Uso Exclusivo de Título No. 04-2013-042212044000203, ISSN en trámite, ambos otorgados por el Insituto Nacional del Derecho de Autor. Responsable de la última actualización de este número, Mtra. Alma E. Martinez Licona; Unidad Iztapalapa, División de CBI y CBS; fecha de última modificación: 25 de Agosto de 2017. Tamaño de archivo 7.3 MB.

Los artículos publicados en ContactoS son sometidos a arbitraje; para ello se requiere enviar el original del trabajo en algún procesador de texto a doble espacio, dos copias claras del mismo y un archivo del artículo. Toda correspondencia deberá enviarse a:

\author{
Comité Editorial de la Revista ContactoS, \\ UAM-Iztapalapa, E-317, Tel/Fax. 5804-4606 \\ Av. San Rafael Atlixco No. 186, C.P. 09340, México, D.F. \\ apartado postal 55-534 \\ http://www.izt.uam.mx e-mail cts@xanum.uam.mx
}

Para suscripciones enviar cheque o giro postal a nombre de: Universidad Autónoma Metropolitana, indicando claramente; nombre, dirección y números que comprende la suscripción. suscripción anual (4 números) \$ 80.00 M.N. En el extranjero 60 Dls. U.S., a partir de 1995. 
La homeostasis lipídica en la progresión del cáncer hepático

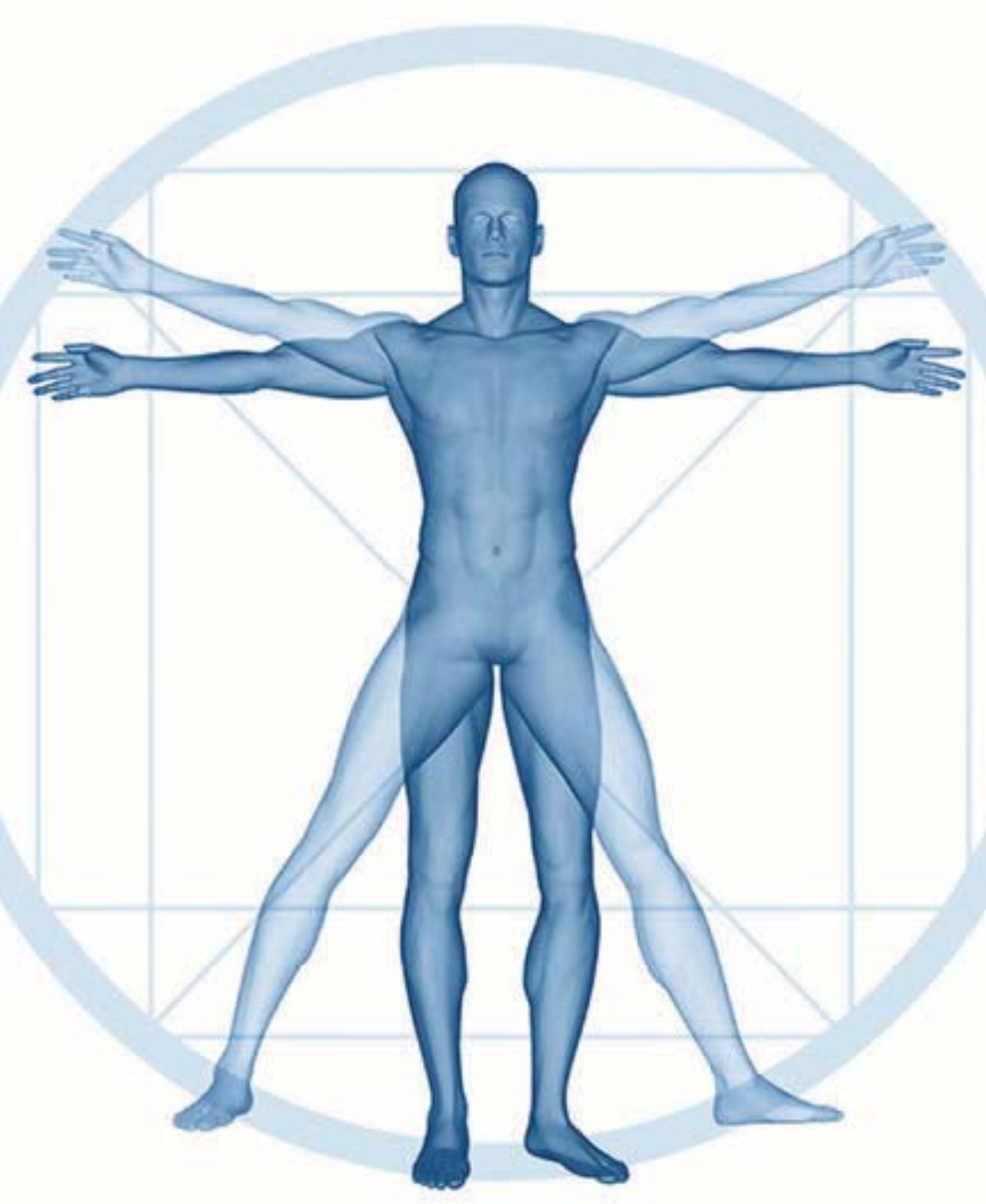

Monserrat Gerardo-Ramirez, Benjamin Pérez-Aguilar, Maria Concepción Gutiérrez-Ruiz, Luis Enrique Gómez-Quiroz Laboratorio de Fisiología Celular, Departamento de Ciencias de la Salud, UAM Iztapalapa. 
Resumen

El carcinoma hepatocelular (HCC) se está posicionando como un serio problema de salud pública tanto en México, como a nivel mundial. Estos tumores hepáticos suelen ser muy agresivos y de mal pronóstico, y su detección en etapas tempranas sigue siendo un reto para los clínicos. En gran medida las características agresivas de las células de los HCC están gobernadas por la disponibilidad en combustibles e intermediarios estructurales que le permitan a la célula cancerosa tener ventajas con respecto al resto del tejido. La homeostasis de lípidos ha sido identificada como un factor relevante para la sobrevivencia, proliferación y resistencia a fármacos, por lo que nuevos blancos terapéuticos pueden ser identificados en las rutas de señalización y metabólicas, claves de la homeostasis lipidica.

\begin{abstract}
Hepatocellular carcinoma (HCC) is has been positioning as a key public health problem in Mexico and worldwide. This tumors use to present and aggressive phenotype and patients use to have poor prognosis, the early diagnosis continues as a big challenge for clinicians. The aggressive phenotype is driven by the energy and molecular intermediaries' availability conferring to cancer cells advantages regarding non transformed cells. Lipid homeostasis has been identified as a key hallmark for survival, proliferation and drug resistance for cancer cells, new therapeutic targets could be identified in the signal transductions and metabolic pathways related to lipogenesis.
\end{abstract}

\section{Palabras clave. Cáncer, Lípidos, Ácidos grasos, Colesterol}

Keywords. Cancer, lipids, free fatty acids, cholesterol

\section{Introducción}

El cáncer es un grupo de más de cien enfermedades caracterizadas por la presencia de células con desórdenes proliferativos, con una alta capacidad de sobrevivencia, de adaptación y de autonomía, que le permite escapar de cualquier tipo de control que pueda ejercer el sistema (Perez-Aguilar et al., 2015).

Entre los cánceres que más preocupan y ocupan a los sistemas de salud en el mundo se encuentra el cáncer de hígado, el HCC actualmente representa el quinto lugar de muertes a nivel internacional (Bruix et al., 2004). En gran medida el HCC representa un reto debido a su diagnóstico tardio que genera la pérdida de opciones quirúrgicas, ocasionando su alta mortalidad.

Por lo anterior es fundamental la búsqueda de nuevas opciones terapéuticas que tiendan a su control, por lo que el conocimiento de los procesos moleculares que permiten la adaptación y sobrevivencia de la célula cancerosa pueden representar posibles blancos de intervención terapéutica.

La célula cancerosa representa el mejor ejemplo de adaptación biológica, sin duda Darwin estaría orgulloso de ello. La adaptación le permite sobrevivir ante constantes agresiones llevadas a cabo por el propio sistema, así como por las terapias encaminadas a su eliminación. Para lograrlo; resulta fundamental tener buenas reservas de energia que puedan ser movilizadas rápidamente, con buen rendimiento $\mathrm{y}$ con relativa facilidad. Con base a lo anterior, los lípidos representan una de las mejores opciones que tiene la celula transformada para sobrevivir.

La regulación de la ruta de sintesis de novo de los ácidos grasos y colesterol, tanto a nivel de expresión de los genes relacionados con ella, su actividad enzimática, asi como de las rutas de 
señalización que los controlan, se posicionan como ejes importantes para el escape de la célula cancerosa de los mecanismos que tienden a eliminarlas, por lo que hasta cierto punto, muchas proteínas relacionadas con la homeostasis lipídica se ubican ya como genes promotores de tumores $y$, en cierta forma, como potenciales blancos de terapias dirigidas a controlar a este grupo de enfermedades.

La presente revisión pretende exponer los aspectos generales de la regulación en la sintesis y degradación de lípidos, así como su metabolismo y su papel en la progresión del $\mathrm{HCC}$.

\section{El contexto bioquimico}

En condiciones normales una célula cubre sus requerimientos energéticos con procesos metabólicos bien definidos, es decir, tiende a ocupar su energía oxidando moléculas simples, empezando por el mismo ATP, y pasando por varios intermedianos hidrocarbonados, como es el caso de la glucosa, hasta llegar a los ácidos grasos y, eventualmente, proteinas.

Las células, particularmente las hepáticas, almacenan la energía excedente como triglicéridos, si bien los hepatocitos no son células especializadas para tal función, lo hacen de manera importante, y la pérdida de esta regulación puede conducir al órgano a la enfermedad por una acumulación excesiva de lípidos, patología conocida como esteatosis (Gutierrez Ruiz et al., 2012).

Sin lugar a dudas, la molécula más importante para el control de lo anteriormente expuesto es el acetil coenzima A ( $\mathrm{Ac}-\mathrm{Co} \mathrm{A}$ ), que es el intermediario bioquímico central en varios procesos tanto catabólicos como anabólicos.

El Ac-CoA es generado, de manera canónica, a partir de piruvato, que a su vez, proviene de la glicólisis, o ruta de oxidación de la glucosa, sin embargo no es la úmica fuente, y este puede ser generado por otras vías (Shi et al., 2015), por lo que Ac-CoA se posiciona como la molécula central en el metabolismo celular (Figura 1). Posteriormente la molécula puede tomar diversos caminos que van desde su completa oxidación, en el ciclo de los ácidos tricarboxilicos o ciclo de Krebs, hasta su uso como precursor en la sintesis de lípidos, desde ácidos grasos, hasta colesterol o residuos hidrofóbicos fundamentales para la función celular como el ácido prenilico, que es fundamental para el correcto funcionamiento de proteinas relacionadas con la proliferación celular como la proteina Ras.

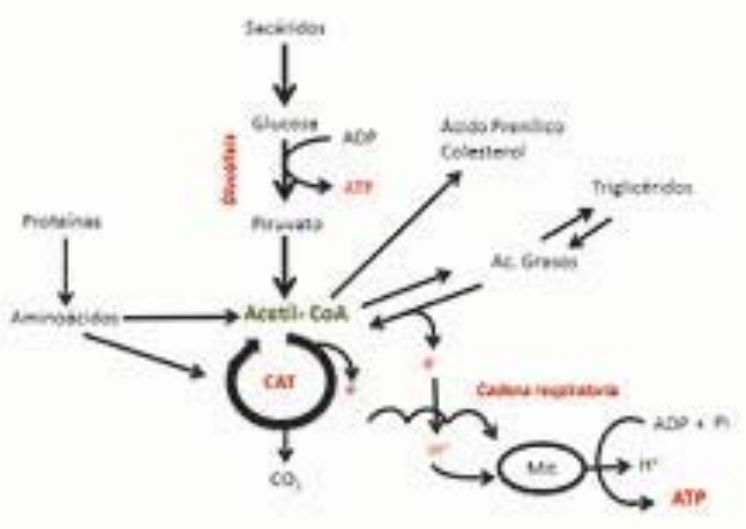

En condiciones normales el Ac-CoA es producido, segín el caso, por la ATP-citrato liasa o por la Acetil-CoA sintasa.

Los niveles elevados de Ac-CoA estimula la activación de dos factores de transcripción conocidos como proteína de unión a los elementos de respuesta a esteroles (SREBP) el 1 y el 2 (Xu et al., 2013).

Estos factores de transcripción regulan la expresión de varios genes relacionados con la biosintesis de lípidos. SREBP1 está relacionado con la biosintesis de ácidos grasos, triglicéridos 
y fosfolipidos, mientras que SREBP2 con la síntesis de colesterol y otros intermediarios derivados de la ruta del mevalonato (Figura 2).

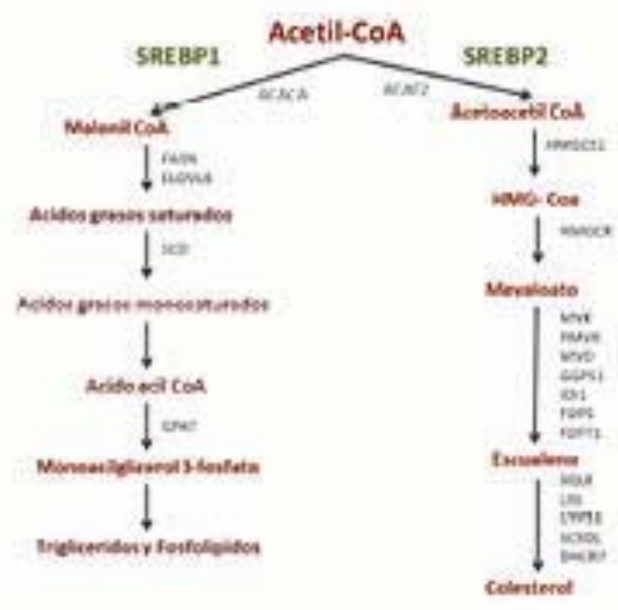

\section{La ruta del mevalonato}

SREBP2 regula genes relacionados con la biosintesis del colesterol, entre ellos están los que codifican para la hidroxi-metil-glutarilCoA reductasa (HMG-CoAR), la mevalonato cinasa (MVK), la escualeno sintasa (SQS), entre otras, que eventualmente y por sus reacciones secuenciales y acopladas, permiten la sintesis del colesterol (Ikonen, 2008).

LA HMG-CoAR es la enzima limitante en la ruta, dirigiendo el paso de su sustrato HMG$\mathrm{CoA}$ a mevalonato en un proceso facilitado por el consumo de NADPH, por lo que el acoplamiento de otras rutas como la de las pentosas fosfato resulta fundamental para que el proceso de sintesis progrese, ya que es en ésta donde se produce éste poder reductor necesario para el proceso (Figura 3).

El colesterol es un lípido fundamental para el buen funcionamiento de la cellula, es requerido para una correcta fluidez de la membrana plasmática, además regula la función de las balsas lipídicas que permiten la adecuada función de los receptores membranales; es el precursor de varias hormonas, sales biliares, entre otras funciones. Si bien el colesterol resulta fundamental para la homeostasis celular, su incremento, particularmente en la mitocondria, genera un mal funcionamiento celular que conduce al estrés oxidante y a la sensibilización a la apoptosis mediada por factores citotóxicos como el factor de necrosis tumoral (TNF) alfa (Mari et al., 2006).

El colesterol no es un lipido del cual se disponga para la obtención de energía, si no para aspectos estructurales y funcionales como se ha mencionado.

\section{Los ácidos grasos y los lípidos neutros.}

Esta ruta estáregulada, en términos de expresión, por el factor de transcripción SREBP1. Sus principales genes blanco son aquellos que codifican para la ácido graso sintasa (FASN), la adenosina trifosfato liasa (ACLY), la acetil CoA carboxilasa (ACAC), la esteroil-CoA desaturasa (SCD) entre otras. Las enzimas reguladas por SREBP1 están implicadas en procesos como la sintesis de ácidos grasos, la formación de lípidos neutros como los triglicéridos (TG), o lípidos especializados como los fosfolípidos. En el proceso bioquímico se requiere también de poder reductor en su forma de NADPH.

Como se ha mencionado el NADPH proviene de rutas como la de las pentosas fosfato, en una reacción catalizada por la glucosa 6 fosfato deshidrogenasa, pero también puede ser generado por la enzima málica y la 6-fosfogluconato deshidrogenasa.

A diferencia del colesterol, como es bien sabido, los ácidos grasos y su presentación esterificada en forma de TG, tiene como finalidad central el aporte energético, ya que su oxidación produce una buena cantidad de ATP al regresar a su intermediario biosintético, el Ac-CoA, a las rutas de oxidación que culminan en el ciclo de los ácidos tricarboxilicos y en la cadena 
respiratoria donde se oxida el NADH y el

$\mathrm{FADH}_{2}$ que provee la succinato deshidrogenasa

(Figura 1) (Gutiérrez-Ruiz et al., 2013)
Si bien es sabido que muchas células cancerosas impiden el funcionamiento mitocondrial, y

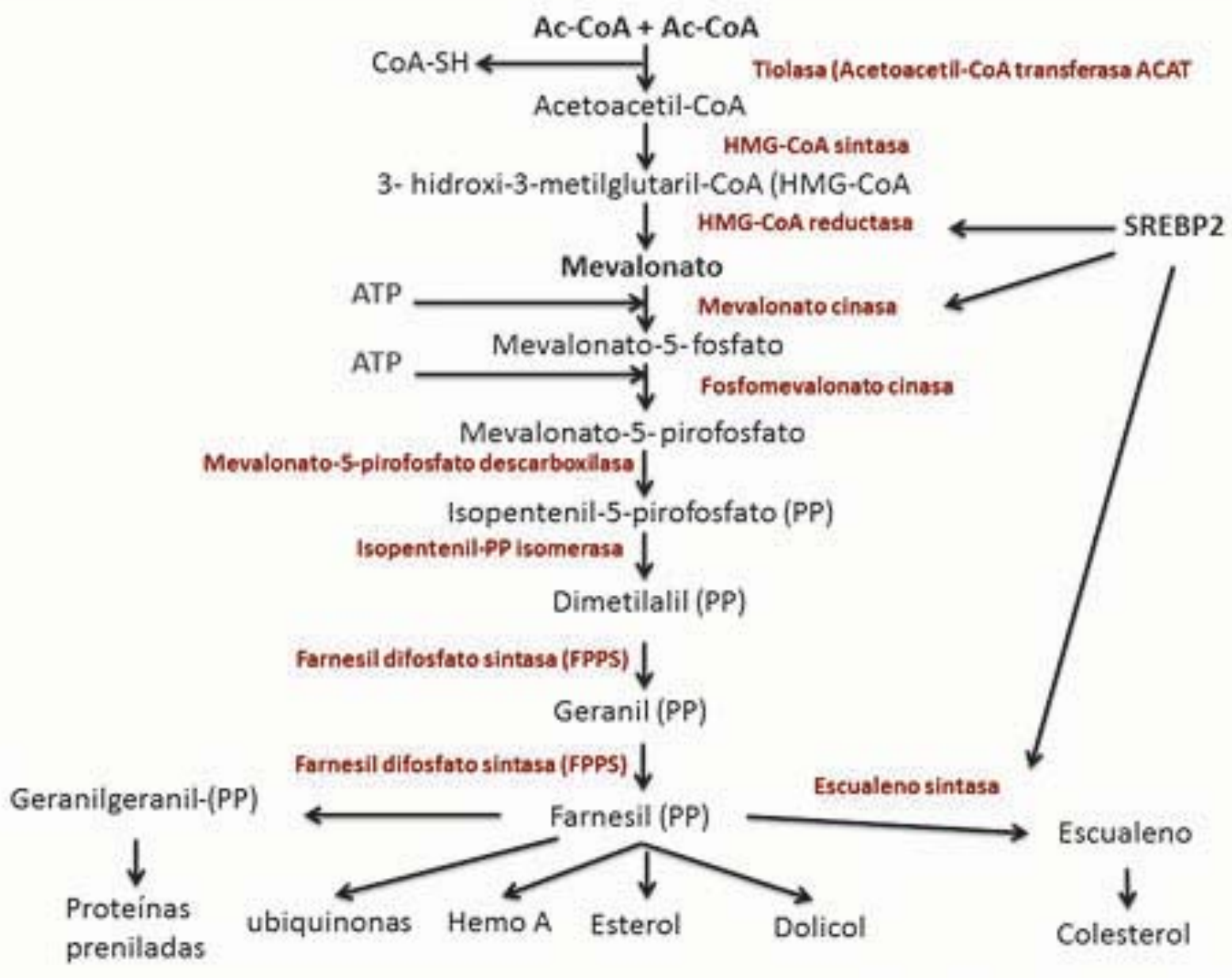

Funcionalidad mitocondrial y la oxidación de los ácidos grasos

En gran medida la oxidación de los ácidos grasos representa la principal fuente de energia para la célula. Si bien existen varias formas de llevar a cabo el proceso la más importante es la oxidación beta en la mitocondria, donde el ácido graso en su forma conjugada con la CoA ingresa a una secuencia de reacciones acopladas que producen $\mathrm{NADH}+\mathrm{H}$ y $\mathrm{FADH}_{2}$ que son procesados en la cadena respiratoria donde eventualmente producen fuerza protón motriz que es usada por el complejo $\mathrm{V}$ para producir el ATP. pasan a ser más dependientes de la glucólisis que de la mitocondria para la obtención de ATP, se sabe también que en algunos casos, como en el higado, las células cancerosas pueden ubicar a la ATP sintasa en la membrana plasmática, representando una excelente estrategia para evadir el impedimento mitocondrial (Ma et al., 2010).

La sobrecarga de colesterol en la mitocondria, mediado por el incremento en la sintesis de novo de dicho lípido, pareciera ser uno de los mecanismos para inducir disrupción mitocondrial (Morales et al., 2012), siendo uno de sus objetivos evitar la salida al citoplasma del citocromo $\mathrm{C}$, uno de los principales inductores 
de apoptosis, pero teniendo como consecuencia la pérdida de la función oxidante de los lípidos. El regulador maestro de las rutas de degradación de ácidos grasos es la proteína cinasa activada por AMP (AMPK).

AMPK es un complejo heterotrimérico que contiene una subunidad catalítica (alfa) y dos regulatorias (beta y gama) (Grahame Hardie, 2014). La enzima regula post-traduccionalmente a varias proteínas del metabolismo, por ejemplo, fosforila a la ACC y a la FASN inactivándolas y permitiendo la beta oxidación. Estimula la localización de transportadores de glucosa (GLUT) 1 y 4 en membrana plasmática, inhibe a la HMG-CoAR por lo que impide la sintesis de colesterol, entre muchas otras actividades más (Grahame Hardie, 2014), por lo que AMPK se sitúa en el centro del control metabólico a nivel de eventos post-traduccionales.

\section{La homeostasis lipídica en la célula cancerosa.}

Es bien conocido que las demandas de energía de una célula cancerosa son elevadas, paradójicamente esto va acompañado de varias restricciones que, en teoría deberían de afectar la movilización de reservas energéticas, por ejemplo la falta de oxigeno (hipoxia) en ciertas células de tumores sólidos, o la deficiencia de nutrientes, sin embargo la célula transformada posee mecanismos, aún no del todo caracterizados, que dirigen la optimización molecular de los procesos y rutas que controlan la homeostasis lipidica.

Se sabe que en varias enfermedades como la diabetes, la esteatohepatitis y el cáncer existe una lipogénesis aberrante, que en gran medida representa, en las fases tardías del cáncer, una fuente de lípidos necesarios para la construcción de membranas en las células proliferantes, - intermediarios para modificaciones posttraduccionales, como el caso de Ras y otras GTPasas pequeñas, todo esto, como se menciona, en el contexto de una alta tasa de proliferación (Menendez et al., 2007).

Molecularmente hablando, la célula cancerosa presenta un incremento transcripcional de proteínas relacionadas con la lipogénesis, tanto de ácidos grasos y triglicéridos, como de colesterol, siendo las mejor caracterizadas ACLY,ACAC, FASN, SCD-1, la enzima málica, HMG-CoAR, MVK, SQS, entre otras, todasellas llevan a un incremento en la sintesis de ácidos grasos como de colesterol (Calvisi et al., 2011; Menendez, et al., 2007). Lo anterior es posible gracias a que también existe un incremento en el contenido y activación de los factores de transcripción que regulan la expresión génica de las enzimas lipogénicas como SREBP1, CREBP2 y ChREBP, entre otros, así como la inactivación de los reguladores de la lipólisis como AMPK (Calvisi, et al., 2011).

Se ha observado que las células de los HCC presentan una elevada expresión de enzimas relacionadas con la sintesis de novo de ácidos grasos como FASN, SCD-1, o de colesterol, como la HMG-CoAR (Calvisi, et al., 2011). En el tejido circundante al tumor, que si bien no se puede considerar sano, si marca una contraste en términos de diferenciación con respecto al tumor, se ha observado una menor expresión de estas enzimas, pero aún se presenta elevado cuando se compara con tejido sano, por lo que la progresión de un cáncer podría ser estimado en términos de la expresión de las enzimas lipogénicas, (figura 1), más interesante es aún el hecho de que se ha observado que pacientes con $\mathrm{HCC}$ más agresivos y con mal pronóstico, presentaron una sobre expresión mayor de dichas enzimas en comparación con aquellos que tuvieron $\mathrm{HCC}$ con mejor pronóstico y mayor sobrevivencia, por lo que además la expresión de enzimas lipogénicas o la represión de las lipoliticas, podrian ser indicadoras de evolución de la enfermedad en pacientes (Calvisi, et al., 2011). 
ACLY, ME, SCD-1, HMGCOAR, MVK, SQS,

La validación de lo anterior se hace patente cuando varias de estas enzimas son eliminadas genéticamente $o$ con inhibidores químicos en

así como la activación de SREBP1, y SREBP2 (Figura 4).

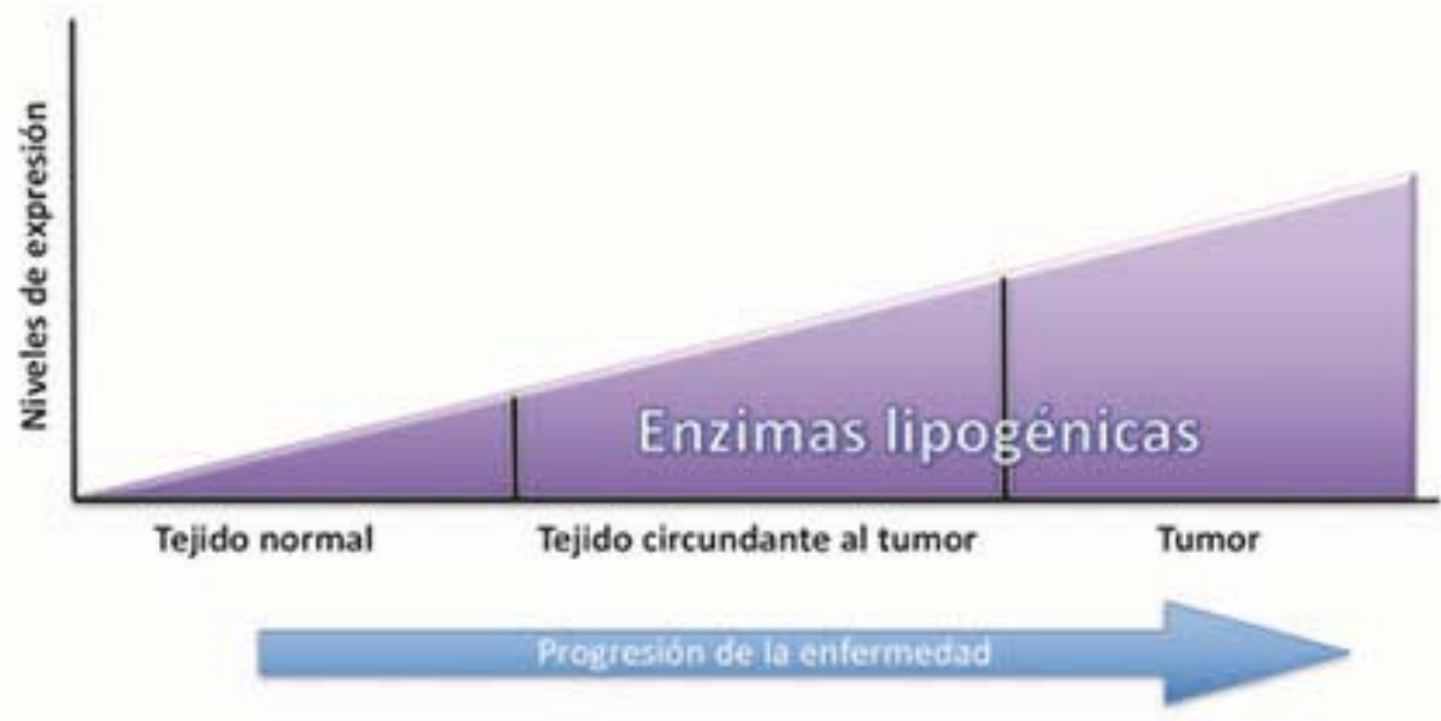

líneas celulares de $\mathrm{HCC}$, las cuales disminuyen su proliferación in vitro asi como la capacidad para formar tumores in vivo (Hanai et al., 2012; Hatzivassiliou et al., 2005; Menendez, et al., 2007).

En un estudio reciente se demostró que la progresión del HCC y su pronóstico está estrechamente relacionado con la lipogénesis, en los tres niveles moleculares, en la expresión génica de enzimas relacionadas, en la activación de factores de transcripción y en la presentación fenotípica (Calvisi, et al., 2011).

La división clinica de muestras de pacientes con sobrevivencia pobre (CP) y con sobrevivencia buena (CB), en relación con tejido normal (NL) y tejido circundante (SL) mostró un efecto en la expresión de las enzimas lipogénicas dependiente de lo avanzado de la enfermedad, tomando como ejemplo la expresión de FASN se observó un contenido basal en NL, que se incrementó moderadamente en SL y CB y significativamente en $\mathrm{CP}$; resultados similares se encontraron en otras enzimas como ACAC,

\section{Señalización lipogénica}

En condiciones normales la ruta de la cinasa del 3 fosfoinositol (PI3K), de la proteína cinasa B (Alkt) y del blanco de la rapamicina en mamimefors (mTOR), conocida como PI3K/ Akt/mTOR, es iniciada canónicamente por receptores a factores de crecimiento que tras ser activados reclutan a PI3K quien fosforila al fosfatidil inositol difosfato $\left(\mathrm{PIP}_{2}\right.$ ), para activarlo en su forma trifosfatada $\left(\mathrm{PIP}_{3}\right.$ ). El $\mathrm{PIP}_{3}$ se une a los dominios homólogos de Pleckstrina de proteinas como Akt, quien además es fosforilada por cinasas específicas como la dependiente de fosfoinositidos (PDK), para su total actividad. Akt tiene como blancos una gran diversidad de sustratos, que van desde proteína que regulan proliferación, sobrevivencia, motogénesis, y de manera especial, metabolismo. Esta vertiente está estrechamente ligada a mTOR, quien está relacionada con proteinas como RPS6 quien conecta con la regulación lipogénica (Liu et al., 2014).

El uso de herramientas de ingeniería genética como vectores que permiten, por un lado, la 
sobreexpresión en el contenido de una forma activa de Akt (AKTtg) o la expresión de un RNA de interferencia contra Akt (siRNA AKT), ha comprobado la sobre activación de mTOR, FASN, ACLY. ACAC, SCD-1 y la desregulación de AMPK alfa, beta y gama, en el caso de AKTtg; por el contrario, el silenciamiento indujo exactamente el efecto opuesto, permitiendo la expresión y activación de AMPK y por ende eventos de lipólisis. Al llevar el vector AKTtg a hígados de ratones de experimentación, por medio de inyección hidrodinámica, se indujeron tumores con un fenotipo agresivo que presentaban, además de la esperada sobreexpresión de Akt, la acumulación de lípidos fue evidente, asociada a la elevación de las proteínas lipogénicas.

El conocimiento generado por el uso de modelos experimentales tanto in vitro como in vivo permite acercar los fenómenos al ser humano. Se ha corroborado que la lipogénesis aberrante se presenta, tal y como en los animales, en tumores humanos, dejando patente la importancia de la investigación básica como acercamiento a los fenómenos que afectan a los humanos (Calvisi, et al., 2011).

Finalmente y con base en lo expuesto, en investigaciones realizadas en el laboratorio de fisiologia celular de la Universidad Autónoma Metropolitana se ha realizado estudios que demuestran que la sobrecarga lipídica, particularmente de colesterol, generada por una dieta hipercolesterolémica (HC, $2 \%$ colesterol) (Gutierrez Ruiz, et al., 2012) induce un mayor daño al DNA y promueve la generación de más tumores de mayor tamaño en ratones sometidos a la dieta $\mathrm{HC}$ y con dietilnitrosamina (DEN), además de ello se ha encontrado mayor vascularización y metástasis en estos ratones que en aquellos solo tratados con el DEN (Datos no publicados).

\section{Conclusión}

La homeostasis lipidica se coloca como un escenario el cual debe ser considerado con mayor atención en la investigación básica con la finalidad de ubicar puntos de intervención terapéutica que al ser interferidos puedan coadyuvar en el tratamiento del cáncer. La ruta del mevalonato reviste particular importancia dado que va dirigida hacia varios puntos de regulación de la célula cancerosa, como la sobrevivencia, la proliferación, el metabolismo, entre otros.

\section{Agradecimientos}

El artículo fue escrito con apoyo del CONACYT Fronteras de la Ciencia 2015-2-1320, CB252942 y SEP-PRODEP-913026-1461211, Universidad Autónoma Metropolitana Iztapalapa

\section{Referencias}

Bruix, J., Boix, L., Sala, M., and Llovet, J. M. (2004). Focus on hepatocellular carcinoma. Cancer cell 5(3), 215-9.

Calvisi, D. F., Wang, C., Ho, C., Ladu, S., Lee, S. A., Mattu, S., Destefanis, G., Delogu, S., Zimmermann, A., Ericsson, J., Brozzetti, S., Staniscia, T., Chen, X., Dombrowski, F., and Evert, M. (2011). Increased lipogenesis, induced by AKT-mTORC1-RPS6 signaling, promotes development of human hepatocellular carcinoma. Gastroenterology 140(3), 1071-83.

Grahame Hardie, D. (2014). AMP-activated protein kinase: a key regulator of energy balance with many roles in human disease. Journal of internal medicine 276(6), 543-59.

Gutierrez Ruiz, M. C., Dominguez Perez, M., Rodriguez Gonzalez, S., Nuno Lambarri, N., Licona Retama, C., and Gomez-Quiroz, 
L. E. (2012). [High cholesterol diet modifies the repaining effect of the hepatocyte growth factor]. Gaceta medica de Mexico 148(3), 23642.

Gutiérrez-Ruiz, M., Palestino-Dominguez, M., Dominguez-Pérez, M., Nuño Lámbarri, N., Souza, V., Bucio, L., and Gomez-Quiroz, L. (2013). La hepatotoxicidad de los lípidos no esterificados en el proceso de daño reparación. In Hepatología de la Ciencia Básica a la Aplicación Clínica (G. H. MS, Ed.) Eds.), Vol. 1. ZarPra.

Hanai, J., Doro, N., Sasaki, A. T., Kobayashi, S., Cantley, L. C., Seth, P., and Sukhatme, V. P. (2012). Inhibition of lung cancer growth: ATP citrate lyase knockdown and statin treatment leads to dual blockade of mitogen-activated protein kinase (MAPK) and phosphatidylinositol-3-kinase (PI3K) AKT pathways. Journal of cellular physiology 227(4), 1709-20.

Hatzivassiliou, G., Zhao, F., Bauer, D. E., Andreadis, C., Shaw, A. N., Dhanak, D., Hingorani, S. R., Tuveson, D. A., and Thompson, C. B. (2005). ATP citrate lyase inhibition can suppress tumor cell growth. Cancer cell 8(4), 311-21.

Ikonen, E. (2008). Cellular cholesterol trafficking and compartmentalization. Nature reviews. Molecular cell biology 9(2), 125-38.

Liu, X., Chhipa, R. R., Pooya, S., Wortman, M., Yachyshin, S., Chow, L. M., Kumar, A., Zhou, X., Sun, Y., Quinn, B., McPherson, C., Wamick, R. E., Kendler, A., Giri, S., Poels, J., Norga, K., Viollet, B., Grabowski, G. A., and Dasgupta, B. (2014). Discrete mechanisms of mTOR and cell cycle regulation by AMPK agonists independent of AMPK. Proceedings of the National Academy of Sciences of the United States of America 111(4), E435-44.
Ma, Z., Cao, M., Liu, Y., He, Y., Wang, Y., Yang, C., Wang, W., Du, Y., Zhou, M., and Gao, F. (2010). Mitochondrial F1FoATP synthase translocates to cell surface in hepatocytes and has high activity in tumor-like acidic and hypoxic environment. Acta Biochim Biophys Sin (Shanghai) 42(8), 530-7. Mari, M., Caballero, F., Colell, A., Morales, A., Caballeria, J., Fernandez, A., Enrich, C., Fernandez-Checa, J. C., and Garcia-Ruiz, C. (2006). Mitochondrial free cholesterol loading sensitizes to TNF- and Fas-mediated steatohepatitis. Cell metabolism 4(3), 185-98.

Menendez, J. A., and Lupu, R. (2007). Fatty acid synthase and the lipogenic phenotype in cancer pathogenesis. Nature reviews. Cancer 7(10), 763-77.

Morales, A., Mari, M., Garcia-Ruiz, C., Colell, A., and Fernandez-Checa, J. C. (2012). Hepatocarcinogenesis and ceramide/ cholesterol metabolism. Anti-cancer agents in medicinal chemistry 12(4), 364-75.

Perez-Aguilar, B., Vidal, C. J., Palomec, G., Garcia-Dolores, F., Gutierrez-Ruiz, M. C., Bucio, L., Gomez-Olivares, J. L., and GomezQuiroz, L. E. (2015). Acetylcholinesterase is associated with a decrease in cell proliferation of hepatocellular carcinoma cells. Biochimica et biophysica acta 1852(7), 1380-7.

Shi, L., and Tu, B. P. (2015). Acetyl-CoA and the regulation of metabolism: mechanisms and consequences. Current opinion in cell biology 33C, 125-131.

Xu, X., So, J. S., Park, J. G., and Lee, A. H. (2013). Transcriptional control of hepatic lipid metabolism by SREBP and ChREBP. Seminars in liver disease 33(4), 301-11. 


\title{
Typhus, yellow fever and Medicine in Mexico during the French intervention
}

Monserrat Gerardo-Ramírez¹, Jesús Zavaleta-Castro² and Luis Enrique Gómez-Quiroz ${ }^{1}$

${ }^{1}$ Department of Health Sciences, Universidad Autónoma Metropolitana Iztapalapa, Ciudad de México; 'Instituto Estatal de Documentación de Morelos, Cuernavaca, Mor., Mexico

\begin{abstract}
French intervention in Mexico (1861-1867) is particularly full of episodes of patriotic heroism in terms of military, politic and, even, religious affairs, however this history is also rich in episodes related to diseases and the evolution of Mexican scientific medicine practice, epidemics such as typhus (nowadays knows as rickettsiosis), yellow fever, or cholera. Principally, this context outlined the Mexican history and influenced the course of the nation. The epidemics served as fertile land for the development of medicine science leading by prominent physicians, particularly by doctor Miguel Francisco Jiménez.
\end{abstract}

KEY WORDS: Typhus. Yellow fever. French intervention. General Zaragoza. Maximilian of Habsburg.

\section{Introduction}

"Immense, extremely painful, perhaps irreparable, is the loss just suffered by the Republic", expressed Francisco Zarco that Saturday at the San Fernando Cemetery, before Ignacio Zaragoza's grave. Five days before, the morning of September 8, 1862, the hero of the $5^{\text {th }}$ of May battle had died as a consequence of typhus. After his victory over the French troops in Puebla, he contracted the disease when he passed by the Acultzingo Peaks, where he had paid visit to wounded and sick soldiers. General Zaragoza was assisted by Doctor Juan N. Navarro, who had been expressly sent by President Benito Juárez, and expired in the presence of his mother and one of his sisters ${ }^{1}$,

Four months prior, on May 5, Zaragoza had informed about the victory of the Mexican army over the invading forces in Puebla. On the military briefing, he highlighted "the behavior of my brave comrades", since "the glorious event that just has taken place shows their spirit and, by itself, recommends them" as patriots. When referring to the French army, he recognized that it "has fought with great bravery", in spite that "its general in chief has behaved awkwardly in the attack" to the city of Puebla. "National arms [...] have covered themselves with glory", concluded Zaragoza².

The period encompassed by the French intervention, since the landing of the European troops (1861) until Maximilian of Habsburg execution (1867), is with no doubt one of the most fascinating in the country's history. Beyond the warlike and political part, the presence of several diseases, such as typhus and yellow fever, shaped our nation; ironically, it is also a period where Mexican medicine arises with scientific bases thanks to French medicine.

\section{Typhus}

The year before the French intervention, Benito Juárez García, as president of the Republic, had issued the Foreign Debt Suspension Decree (July 17,

\author{
Correspondence: \\ Luis E. Gómez-Quiroz \\ Departamento de Ciencias de la Salud \\ Universidad Autónoma Metropolitana Iztapalapa \\ Av. San Rafael Atlixco, 186 \\ Col. Vicentina, Del. Iztapalapa \\ C.P. 09340, Ciudad de México, México \\ E-mail: legq@xanum.uam.mx
}

Date of reception: 02-11-2016

Date of acceptance: 02-11-2016

DOI://dx.doi.org/10.24875/GMM.M18000119
Gac Med Mex. 2018;154:88-93

Contents available at PubMed www.gacetamedicademexico.com 
1861), by means of which he cancelled "for a term of two years all payments, including those assigned to the debt contracted in London and to foreign conventions" ${ }^{\prime \prime}$. The rejection to this provision by the English and French governments was immediate, with the Spanish government joining in. As a consequence, on October 31, the Tripartite Convention was signed in London, which implied the shipment of "combined sea and land forces" to the Mexican territory in order to force it to pay its debts ${ }^{3}$.

Typhus is a disease that caused many problems in Mexico throughout its history. It is caused by a very particular type of bacteria of the rickettsia family, which was precisely discovered in Mexico by Doctor Howard Taylor Ricketts during the 1909 epidemic (Fig. 1), and that was to cause his death by the disease he was studying in May $1910^{4}$. The bacterium is transmitted by infected lice that excrete the microorganism in the feces, which is introduced in the wound left by the insect when the person scratches him/ herself as a consequence of the bite.

The word "typhus" derives from Greek typhus, which means "stupor". It is an infectious disease caused by bacteria such as Rickettsia typhi or Rickettsia prowazekii that often is mistaken with typhoid fever, which is caused by other bacterium, Salmonella typhi. In those times, there was much confusion and patients were often misdiagnosed, until Dr. Jiménez made it clear, as will be later explained.

It's not hard to imagine the scenario in the country for these epidemics to occur: overcrowding, poverty and lack of hydric and hygienic resources made for the disease to considerably spread. As previously mentioned, these were, to a large extent, the conditions prevailing in the country even before the Frenchmen arrival, and which worsened during the interventionist period.

The advance of epidemics may have worsened perhaps by the natural chaos caused, administratively, by the Reform Laws; for example, in February 1861, President Juárez decreed the secularization of hospitals and welfare establishments, which had been managed by the Catholic Church until then, and at the same time, to put order in these services, already in hands of the State, the Directorate General of Public Welfare Funds was created as a branch of the Ministry of the Interior. The institutions that were left under the control of this directorate included the Divino Salvador Hospital and La Cuna foundling house, and many other hospital institutions that one way or another were administered by the Church with experience ${ }^{5}$.

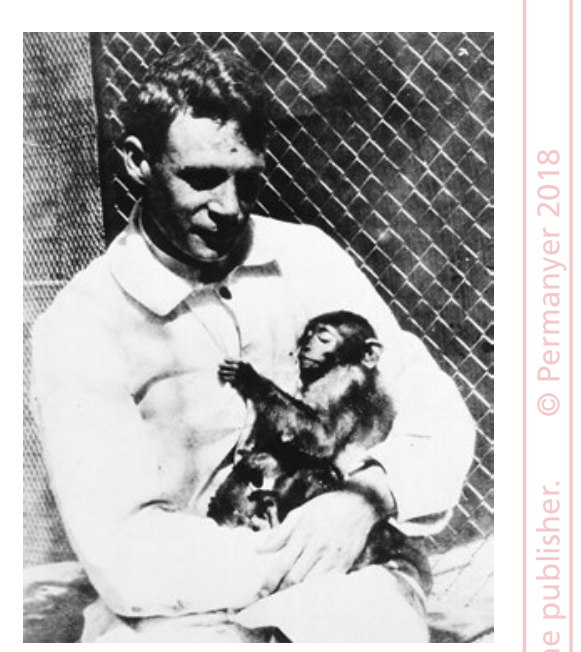

Figure 1. Picture of Doctor Howard Taylor Ricketts with one of his experimental animals (The National Library of Medicine, $\mathrm{NIH}$ ).

The relationship between lack of economic resources and the development of the disease can have, perhaps, as the greatest example, General Ignacio Zaragoza's own contagion and death.

Both in Mexico City and in Puebla, cases of typhus occurred in 1848 and continued in 1849. The disease spread from 1857, the year the Liberal Constitution was published, with Ignacio Comonfort being president of the Republic, to 1859. The same happened in 1861, 1862 (year of the $5^{\text {th }}$ of May Battle) and 1867 (year of the $2^{\text {nd }}$ of April Battle), as a consequence of "movements of military and civilian groups in conditions of insufficient hygienic means", which affected the Mexican troops that had been victorious in Puebla. Not only General Zaragoza, but also "many of his soldiers" and officers died as typhus victims.

After the victory of the Eastern Army over the French troops, communication between General Zaragoza and President Juárez was constant; there was no telegram in which General Zaragoza didn't ask for economic resources for the support of the army, not only in terms of food supplies, but also for the care of endemic diseases that, together with the invading army, attacked the national troops.

The inhabitants of the city of Puebla, far from cooperating, represented a certain obstacle. Such was the case that General Zaragoza himself reported on May 9: "this execrable city that I have not set on fire because there are innocent creatures in it... As for money, there is nothing to be done here, because these people are mean in general, and especially very indolent and selfish... Burning Puebla would be a good thing. It is in mourning due to the event of the $5^{\text {th }}$. It's sad to say this, but it is a shameful truth"'. Terrible the 
report given by the General about heroic Puebla inhabitants' attitude.

On September 1, 1862, General Zaragoza started experiencing symptoms of the infection, particularly high fever, and he was therefore sent to his station in Puebla. A few months before, he had received his daughter's visit, and his wife had died early that same year, to whom he could only provide with 100 pesos for her support, enough for 3 days, which can show the economic situation of the general, and therefore, of the entire Eastern Army. Ignacio Zaragoza died on September 8, 1862, at the age of 33 years, as a consequence of rickettsiosis or typhus ${ }^{7}$, which interrupted the General's brilliant career, which with no doubt could have given even much more to the nation.

"The [federal] government considers General Zaragoza's unexpected death to be a public misfortune", wrote Enrique de Wagner, minister of Prussia in Mexico. "After some days of illness, Zaragoza died of typhus in Puebla, where this epidemic wreaks great havoc, as well as in the entire zone comprised between this city and Orizaba." The Prussian diplomat warned that the French army would be exposed "to great dangers in case of taking the route of all these infested villages and cities", and recommended for "the majority of the forces to be mobilized through Jalapa and Perote, Huamantla, Otumba or San Martín", with the city of Puebla remaining under the protection of "a few thousand men"8.

Interestingly, rickettsioses are constant in warlike processes. In the 1480-1490 Spanish civil war, Christian and Moor troops are known to have been decimated by disease, while similar effects were caused in Napoleon troops in 1812, whereas in World War I, around 100,000 cases occurred in 1914 and 15,000 in 1916. ${ }^{\circ}$. Disease was also key in the plans for Jews elimination in the countries controlled by Nazi Germany, an aspect that is masterfully addressed in Dr. Naomi Baumslag's work ${ }^{4}$.

\section{Yellow fever}

Yellow fever is a disease caused by a virus of the arbovirus family, of the Flavivirus genus, and is transmitted by infected mosquitoes, such as Aedes aegypti (Fig. 2). The disease is characterized by high fever and severe liver damage, which generates jaundice in patients, and hence the term "yellow fever". Once again, a lack of sanitation in contaminated water containers is essential for the reproduction of the mosquito. The disease is currently relatively controlled thanks to

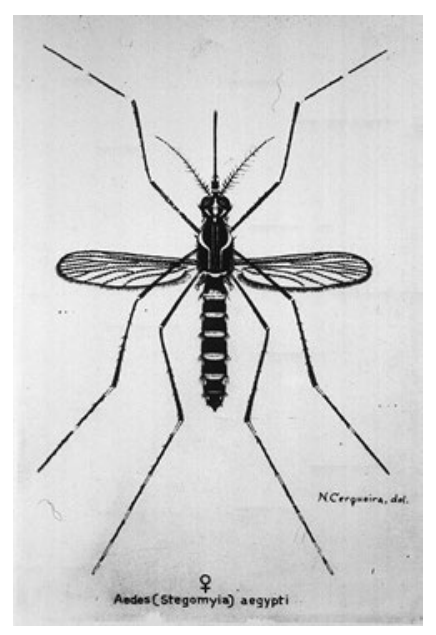

Figure 2. Classic representation of an Aedes (Stegomya) aegypti mosquito (The National Library of Medicine, $\mathrm{NIH}$ ).

vaccines and effective treatments, but in times of the French invasion this wasn't even imagined of.

Yellow fever, or yellow plague, was something that considerably worried invading armies. One of the first reports of this disease, also known as yellow jack, is referred by Jena-Jaques Ampère ${ }^{10}$, when stating that in Mexico there are two completely unbearable things: "la fièvre jaune et les brigands". Ampère's report is overwhelming: "one of the worst inconveniences (is yellow fever)"11.

Spaniards who had first arrived to the Gulf of Mexico coasts were the first victims of this disease, endemic of that region. General Juan Prim, the Spanish commander, a few weeks after having landed, sent around 800 soldiers to hospitals in Cuba for their care. Perhaps President Juárez took advantage of that "natural defense" and played with negotiation time, hoping for the disease to be a natural ally.

The negotiation resulted in the invaders being allowed to advance towards Orizaba, located at 2800 meters above sea level, where the mosquito hardly subsisted. When Spaniards and Englishmen noticed French intentions, they retired and sailed back to their countries, but as previously mentioned, French troops did not.

In 1963, Gloria Grajales published, in the Historia Mexicana journal, quotes from documents of the archive referring the intervention in Mexico by England, France and Spain, which are preserved in the Public Record Office in London. She particularly quotes those related to the French intervention (classification F.O. 97/278, Vol. I, and 97/279, Vol. II, with the title French Expedition) ${ }^{12}$. In said report, at least three entries can be read making reference to the yellow fever 
and to the difficulties the French had to deal with this problem. The first reference, with no date, but reported around August 1862 says: "No date - Arrival of 300 sailors in the Iphigenia frigate; yellow fever contagion in Veracruz" (F.O. 97/278, I, p. 97). Later it refers: "December 4, 1862 - Johnson to Count Russell (No. 1347): About mortality among French troops caused by yellow fever; recruiting of thousand Egyptian blacks to serve in expeditionary forces in Mexico (F.O. 97/278, I, p. 187). And then: Paris, January 6, 1863 - Johnson to Count Russel (No. 20, confidential): About possible reasons to send reinforcements to Mexico, to cover losses caused by disease and death (1500 soldiers and 62 officers dead). Confidential information obtained through captain Hore. Measures taken by the French government to defray the costs of the expedition, etc." (F.O. 97/278, I, pp. 213214). "Memorandum annexed to the previous document: Data obtained through Mister Xavier Raymond about the state of the French army in Mexico. Strong losses caused by yellow fever and other diseases. Roads in bad shape, need for transportation for the Tampico expedition. Monthly expenses for land transportation in Mexico are insufficient. Raymond thinks that the feeling against the expedition is unanimous, etc." (F.O. 97/278, I, pp. 216-218).

The French army was clearly decimated by losses and deaths caused by yellow fever, but information was kept confidential, perhaps in an attempt not to increase the victorious feelings in Mexican troops. Although yellow fever affected the invaders, it did not cause for them to ultimately miss their objective, at least temporarily.

\section{Veracruz, Maximillian and yellow fever}

"Veracruz is a filthy and narrow city, famous for its terrible weather and extreme heat", stated Count Carl Khevenhüller-Metsch, a member of the Austrian volunteer corps that arrived to Mexico to accompany Maximillian of Habsburg. After 3 weeks of journey on the Floride ship, more than 800 men arrived to the Veracruz port on December 7, 1864, where they had to endure $44{ }^{\circ} \mathrm{C}$ at night. Khevenhüller met "German and Austrian doctors who have to be paid the highest homage for their abnegation in times of the yellow fever, this terrible disease that snatches life in a few hours"13. On next day, they continued their journey to the capital of the country, afraid of contagion, given the insalubrious conditions of the port.
On Saturday May 8, 1863, the Novara ship, where Maximillian of Habsburg and his Wife Charlotte of Belgium and their court arrived, dropped anchor in the port of Veracruz. At $4 \mathrm{~h}$ in the morning of Sunday 29, everything was ready "to immediately continue the journey towards the capital, since a prolonged stay in Veracruz was not recommendable, owing to the yellow fever prevailing on that city, which is said to be especially dangerous for those recently arrived"14, stated Wilhelm Knechtel, official botanist of the emperor. However, 2 years later the emperor was to fall ill, with the care of a Mexican specialist being required to treat him.

Maximillian was "affected from the liver and in addition he had been suffering intermittent fevers contracted in one of the trips to warm lands"15. Friedrich Semmeleder, personal doctor of the Austrian, not knowing "too well the special treatment for [these] intermittent fevers", proposed the emperor to "consult with any of the local Mexican physicians who perfectly knew the treatment" against them. He was attended to by the physician Rafael Lucio, "who in those days was already an eminence". Initially, Lucio had resisted to that because "he was a staunch liberal and completely opposed to the imperial regime". Prior to leaving to Cuernavaca, Maximillian wanted to "settle his account with his Mexican doctor, [...] but the wise doctor completely refused receiving a single peso, claiming that having earned the Sovereign's gratitude sufficed him"14.

During the $19^{\text {th }}$ century, yellow fever, typhus, cholera, measles, plague and smallpox epidemic outbreaks added up to more than 70 in the State of Veracruz. Diseases attacked both cities and small villages, with not few of them being decimated. Although yellow fever epidemics were among the most common, "deaths were quantitatively fewer than with smallpox" After 1826 and 1855, 3 yellow fever epidemics occurred in a 5-year period: 1842, 1843 and 1847, the latter in the year of the North American intervention. Between 1850 and 1852 there was another outbreak of the disease, as well as during the French intervention in 1863 and 1867. "Public health in the Veracruz territory [as in other regions in the country] walked hand in hand with the weather and with internal and international fights in defense of sovereignty"16.

\section{State of medicine during the French intervention}

Ironically, the existence of multiple epidemics (in 1864, life expectancy of Mexicans was estimated 
to be 30 years) ${ }^{5}$ was accompanied by fundamental events in the history of medicine during the period the country was occupied by France (1862 to 1867).

On April 18, 1864, the Scientific, Literary and Artistic Commission was founded, and on the $30^{\text {th }}$ of that month, the first meeting of the Medical Sciences Section (later National Academy of Medicine) was carried out. The section was divided in 5 sub-sections: pathology, hygiene, legal medicine and medical statistics, veterinary medicine, medical matters and pharmacology, and physiology and anthropology. The chair was in hands of Doctor Carlos Alberto Ehrmann, and vice-chair was in charge of Doctor Miguel Francisco Jiménez, who was professor at the National School of Medicine. Among other illustrious physicians of those days who were members of the section, Dr. Rafael Lucio and Dr. José María Vértiz can be mentioned ${ }^{17}$. As already mentioned, this time period is with no doubt one of the greatest as regards exemplary physicians and scientists; in addition to the above list, Doctors Lauro Jiménez and Leopoldo Río de la Loza, who made important contributions to pharmacology, should be mentioned, among others.

One of the main accomplishments of the medical section was the publication of Gaceta Médica de México, journal of the scientific commission medical section, which later would be simply Gaceta Médica de México, as until currently is known. The first issue appeared on Thursday September 15, 1864, with its first chairman being Dr. Miguel Francisco Jiménez.

In the first issue, differences between typhus and typhoid fever are precisely discussed in an article written by Dr. Jiménez himself, mentioning that it is an endemic disease in the country and clearly establishing its importance.

\section{Dr. Miguel Francisco Jiménez, amebic hepatic abscess and Mexican scientific medicine}

Dr. Miguel Francisco Jiménez (Fig. 3) is a clear example of growing medical science in the Mexico of the Empire. He was an intelligent and educated man who strongly supported rational and scientific medicine, taking observation, rather than guessing as a basis; he was a strong follower of Auenbrugger and Laennec contributions; he was with no doubt a physician ahead of his time, who applied a scientific view to clinical training and to the entire practice of medicine.

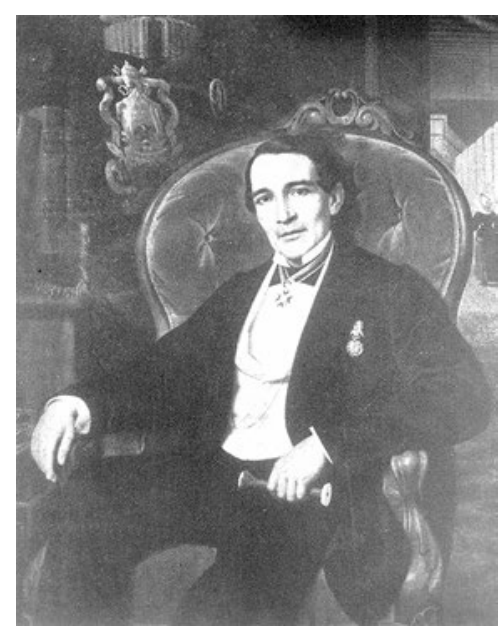

Figure 3. Doctor Miguel Francisco Jiménez.

He was born in Amozoc, Puebla in 1813. He graduated as a physician in 1838 at the Establishment of Medical Sciences, and almost immediately he occupied a post as a professor of pathology, and subsequently anatomy, teachings he offered until his death ${ }^{18}$.

In addition to the studies he carried out to distinguish between typhus and typhoid fever, he did research on other diseases that considerably afflicted the country's population, amebic hepatic abscess, which was very common in Mexico, even since the $16^{\text {th }}$ century.

Amebic hepatic abscess is an accumulation of pus in the liver as a response to the presence of Entamoeba histolytica. The disease is acquired by ingesting water or food contaminated with fecal matter. Once again, the high incidence of this disease speaks of overcrowding, poverty and of the unhealthy conditions of those days. Patients with the disease died regularly, even due to unfortunate medical interventions where a sickle-shaped blade knife was used without anesthesia or asepsis for the treatment not only of hepatic abscess, but for any type of abscess. If the patient didn't die from the disease, he/she died due to infection. This was common until the advance proposed by Dr. Jiménez, consisting in directly surgically intervening by means of a puncture to drain the abscess, which prevented its rupture and dissemination to other organs. It is not hard to imagine that this procedure saved lives and made for patients with the disease to have a better prognosis ${ }^{19}$.

Dr. Jiménez high professional and scientific level deserved the recognition of Maximillian of Habsburg, who invited him to join as one of his personal doctors, together with doctors Federico Semeleder, Samuel Basch and Rafael Lucio Nájera. 
Dr. Jiménez really thought that the arrival of the Empire was something good for the country, not in the plane of conservative exacerbation or apology of the monarchy, but he thought that a new national order could be established that would make the country move towards a better quality of life. In a letter he sent to José María Iglesias he mentions: "I am faithful that a new order could be founded which, being really accepted by everyone, would end once and forever the eternal anarchy that consumes us". Dr. Jiménez died in Mexico City in 1876.

\section{Conclusion}

The period of the French intervention has been one of the most convulsive epochs for the nation, since beyond the armed conflict and occupation, an economic, political and social disaster was experienced, which made for many of the public health problems to be exacerbated, thus affecting all and sundry, as we have seen. However, this is also period of time that marks the beginning of a revolution in medical science in our country by notorious physicians, and although not all of them have been mentioned, we have taken Dr. Francisco Jiménez example as a faithful representative of that generation of medical physicians who, interestingly, were trained in the French school of medicine. Finally, it was also on that period (Thursday September 15, 1864) that Gaceta Médica de Medicina started being published.

\section{Acknowledgements}

This work has been written for diffusion and divulgation purposes and had the support of CONACYT
Ciencia Básica No. 252942, Fronteras de la Ciencia 2015 No. 1320, Instituto Estatal de Documentación del Estado de Morelos and Universidad Autónoma Metropolitana Iztapalapa.

\section{References}

1. Gonzales Lezama R. Del triunfo republicano a la crisis política de 1861. El peor año de la república. Relatos e Historias en México. 2012;45:48-54.

2. Zaragoza I. Parte de Guerra del General Zaragoza. Relatos e Historias en México. 2012;4:68.

3. Porte Petit JM. Antecedentes de la intervención. Primer Congreso Nacional de Historia para el Estudio de la Guerra de Intervención, 1963. Sociedad Mexicana de Geografía y Estadística; 1963.

4. Baumslag N. Medicina asesina. Médicos nazis, experimentación con humanos y tifus. Barcelona: Plataforma Editorial; 2014.

5. Concheiro AA. Cronología médica mexicana. Cinco siglos. México: Siglo XXI; 2010.

6. Florescano E, Malvido E. Ensayos sobre la historia de las epidemias en México. Vol. 1. Instituto Mexicano del Seguro Social; 1982.

7. Rosas A. El patriotismo de Ignacio Zaragoza. Paisaje de la batalla. Relatos e Historias en México. 2012;45:71-6.

8. Díaz L. Versión francesa de México. Informes diplomáticos. 1862-1864. Vol. 3. El Colegio de México; 1965.

9. Peterson RKD. Insects, disease, and military history. The Napoleonic campaigns and historical perception. American Entomologist. 1995;41:147-61.

10. Ampère JJ. Promenade en Amérique. Etats-Unis-Cuba-Mexique. 2 ed. Vol. II. Paris: Michel Levy Freres; 1860.

11. Helguera MM. Posibles antecedentes de la intervención francesa. Historia Mexicana. 1965;15:1-24.

12. Grajales G. Intervención francesa y segundo imperio. Historia Mexicana. 1963;13:284-316

13. Hamann B. Con Maximiliano en México: del diario del príncipe Carl Khevenhüller, 1864-1867. México: FCE; 1992.

14. Knechtel W. Las memorias del jardinero de Maximiliano. Apuntes manuscritos de mis impresiones y experiencias personales en México entre 1864 y 1867. México: Instituto Nacional de Antropología e Historia; 2012.

15. Blasio JL. Maximiliano íntimo. El emperador Maximiliano y su corte. Memorias de un secretario particular. México: Librería de la Vda. de C. Bouret; 1905.

16. Aguilar Sánchez M, Ortiz Escamilla J. Historia general de Veracruz. México: Gobierno del Estado de Veracruz; 2011.

17. Rodríguez Pérez ME. De la Sección Médica a la Academia de Medicina de México: 1864-1880. En: La Academia Nacional de Medicina de México. 150 años de actividad ininterrumpida. México: Intersistemas editores, CONACYT; 2014

18. Martínez Guzmán M. Cuatro médicos personales del emperador Maximiliano de Habsburgo. 1864-1867. Boletín Mexicano de Historia y Filosofía de la Medicina. 2003;6:17-22

19. Fernández del Castillo F. El tratamiento de los abscesos hepáticos antes del doctor Miguel Francisco Jiménez. Gac Med Mex. 1957;87:395-410. 


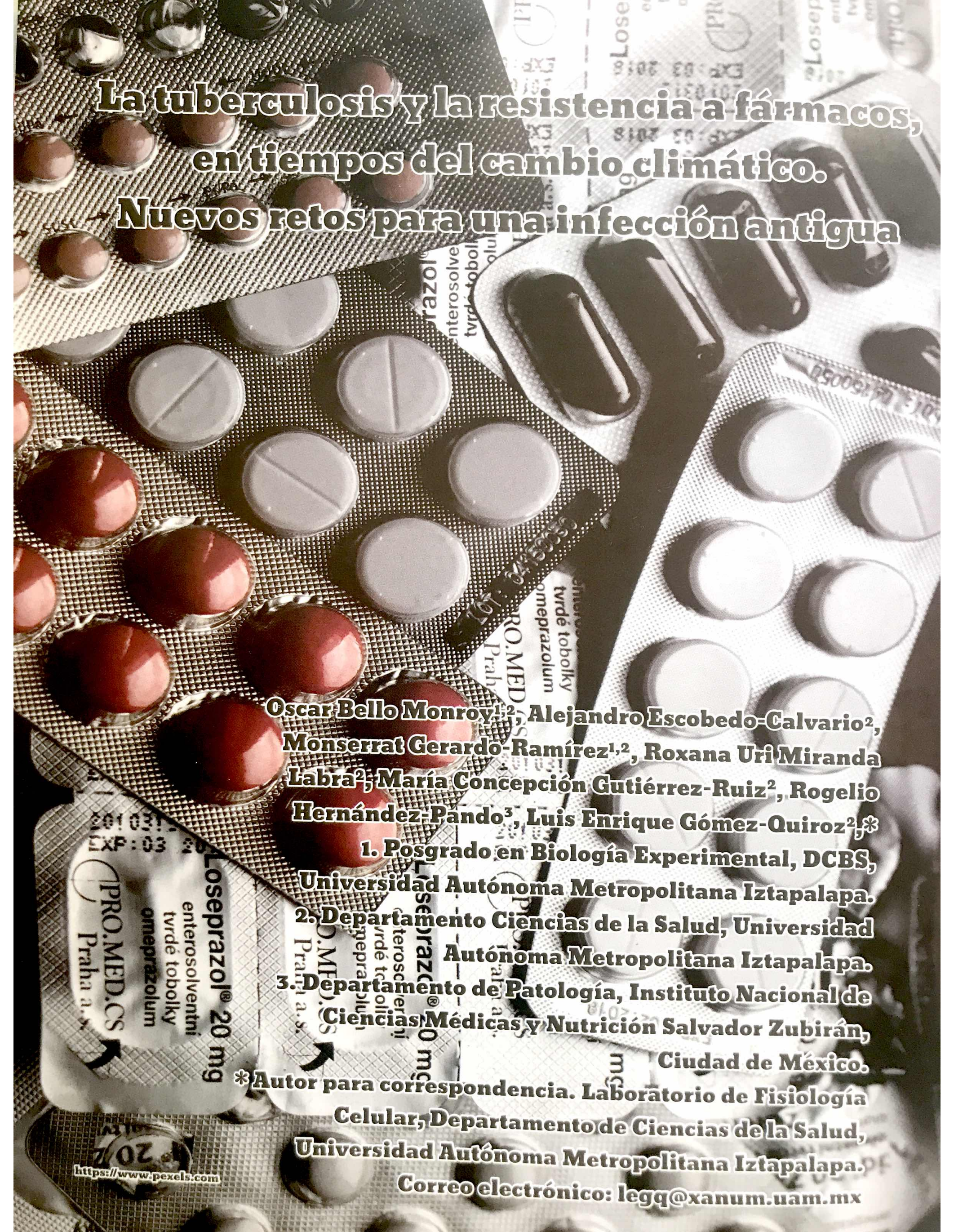




\section{Resumen}

La tuberculosis es un buen ejemplo de enfermedades tristemente célebres, la lista de personajes históricos que padecieron la enfermedad es muy extensa, baste citar solo unos pocos ejemplos para ilustrar: Federico Chopin, Antón Chejov, René Laënnec, Paganini, entre muchos otros, sin mencionar epidemias históricas registradas en los libros que marcaron definitivamente el rumbo de la historia en muchos sentidos.

El cambio climático está transformado la vida en el planeta. Cambios en los patrones de migración de varias especies animales que ponen en peligro su existencia. Los microorganismos están siendo también afectados, no solo aquellos que son transmitidos por insectos, sino también por mamíferos, incluyendo al ser humano.

La tuberculosis, está mostrando cambios que son presumiblemente inducidos por el cambio climático, es difícil tener la evidencia contundente de ello por el momento, pero estudios al respecto ya se conducen en varios países donde la infección es un problema grave de salud pública.

La aparición de cepas que son resistentes a los fármacos de primera línea, están generando la búsqueda de nuevas opciones de tratamiento eficaces, algunas opciones deben tomar en cuenta que la biotransformación de fármacos se realiza en el hígado y que dicho proceso puede comprometer tanto la función del órgano, como la vida del paciente.

Palabras clave: hígado, tuberculosis, resistencia a fármacos, cambio climático

\section{Abstract}

Tuberculosis is a good example of remarkable diseases in history, because many celebrities has suffered this infection with fatal consequences, such as Frédéric Chopin, Anton Chejov, René Laënnec, Niccoló Paganini, among others, even more this disease has been determinant in many social conflicts or wars that has changes the pathways of history.

Climate change is inducing profound changes in the planet. Changes in migration routes of many animal species, jeopardizing their existence. Microorganism have been affected, not only those associated to zoonosis, but mammals and humans as well. Tuberculosis has been exhibiting changes regarding bacillus strains, areas of morbidity and drug resistance, possibly associated to climate change, nowadays, it is quite difficult to address this statement but some research approaches are now in course, particularly in those counties with high incidence.

The rising of multidrug resistance strains of Mycobacterium tuberculosis is generating many concerns regarding the treatment, new therapeutic approaches must be investigated and implemented taking in consideration the liver function because most of the drugs are biotransformed in this organ inducing liver failure and, eventually, decease.

Keywords: liver, tuberculosis, drug resistance, climate change.

\section{Introducción}

El Grupo Intergubernamental de Expertos sobre el Cambio Climático (IPCC, por sus siglas en inglés) ha señalado que las actividades humanas están contribuyendo, de manera significativa, al Calentamiento Global (CG)(Pachauri RK et al., 2015).

La sociedad contemporánea se rehúsa a abandonar, en el mediano plazo, el uso de combustibles fósiles que producen gases con efecto invernadero, en particular el $\mathrm{CO} 2$, que contribuyen fuertemente al CG (Oyhantçabal et al., 2010).

Por otro lado, en países del tercer mundo, el uso de dendrocombustibles continúa siendo la 
forma principal de obtención de energía, particularmente en regiones rurales, donde además contribuye a la deforestación, permitiendo también la generación de gases con efecto invernadero (Schmidt, 2008).

El cambio de uso de suelo, es otro aspecto que incide fuertemente en el cambio climático (CC), generando pérdida de hábitats para plantas y animales, que aunado al $\mathrm{CC}$, está generando problemas de salud pública que están agravándose debido a la poca o casi nula intervención, no solo de las autoridades y gobiernos, sino también de la misma población quien, sin duda, es el principal factor generador del problema (Patzet al., 2004).

En el momento que se finaliza este artículo, (3 de Julio del 2017) se puede fácilmente encontrar en diversos medios de comunicación una serie de notas periodísticas sobre la aparición de brotes infecciosos del virus coxsackie en varios estados del país (García, 2017; Miranda J et al., 2017), se requiere de tiempo y análisis serios para confirmar si estos brotes tienen relación con el CC, (Hii et al., 2011; McIntyre et al., 2017; Paull et al., 2017). Existen reportes que apuntan que la incidencia de la enfermedad llamada "exantema vírico de manos, pies y boca", asociada predominantemente al virus coxsackie A16, tiene incrementos notables en temporadas de calor y lluvias, particularmente en los países asiáticos (Hii, et al., 2011), ¿será que los brotes actuales de ésta enfermedad vírica, están asociados al CC?

\section{Viejos problemas, nuevos paradigmas en el contexto del cambio climático}

Se ha reportado que el cambio climático está generando el incremento en la propagación de enfermedades transmitidas por insectos, entre las que se puede destacar el dengue, la malaria, la enfermedad de Lyme, el virus del oeste del Nilo, la fiebre del Valle Rift, el chikungunya y la fiebre amarilla, entre muchos otros (Oyhantçabal, et al., 2010; Paull, et al., 2017) todavía a finales del 2016 el temor de una pandemia de chikungunya era un tema común entre expertos en epidemiología y líderes de organizaciones de salud, preocupación que traían desde el 2015 (Diaz-Quinonez et al., 2016).

El cambio en el clima está prolongando las estaciones "naturales" de transmisión de enfermedades, alterando la distribución geográfica, entre otros factores; por ejemplo, se prevé una ampliación considerable de las zonas afectadas por la esquistosomiasis en China, una enfermedad transmitida por caracoles (Zhou et al., 2008), los cuales cada vez es más común encontrarlos en regiones en las que anteriormente no se observaban, otra explicación puede ser la falta de sus depredadores que han desaparecido también por elCC.

En el año 2008 se hizo público un documento conocido como 'the Deadly Dozen' donde se alerta sobre una docena de patógenos que, de seguir así las tendencias actuales con el CC, afectará significativamente a animales y personas, impactando en la salud y en la economía mundial (Pandve et al., 2009).

Entre las infecciones emergentes mencionadas en esta lista, se encuentra una que es, tal vez menos obvia, silenciosa, con poca propaganda en televisión u otros medios masivos de comunicación, pero que es, sin lugar a dudas, la más preocupante de todas: la tuberculosis.

\section{Tuberculosis}

Fuera de la región del África subsahariana, la incidencia en la tuberculosis (TB) está disminuyendo, pero está creciendo la preocupación con la aparición de cepas mutifármaco resistentes (MDR) y extensivamente fármaco resistente (XDR). La TB es una enfermedad infecto-contagiosa pulmonar de progresión lenta cuyo agente causal es el bacilo Mycobacterium tuberculosis. El bacilo es un aerobio estricto y prefiere sitios con alta concentración de oxígeno, capaz de 
sobrevivir durante meses en esputo mantenido en un lugar fresco y oscuro, y durante semanas en materiales como alfombras, cadáveres, abonos, papel o ropa, o bien formando parte del polvo. Es resistente al frío, a la congelación y a la desecación por largos periodos de tiempo, su pared celular está compuesta de ácidos micólicos que forman una pared cerosa y gruesa alrededor de la micobacteria, característica que le confiere adaptación ante los cambios climáticos, así como a la entrada de fármacos, debido a la disminución de la permeabilidad celular, lo que obliga un tratamiento costoso y de larga duración. (Barry et al., 1998).

La Organización Mundial de la Salud (WHO, por sus siglas en inglés), establece que la investigación y el desarrollo en TB necesitan mayores inversiones. Cada año mueren más personas de tuberculosis (1.4 millones en 2015) que por la infección del virus de la inmunodeficiencia humana (1.1 millones de muertes); 400,000 mueren por la combinación de ambas infecciones). A pesar de que en la actualidad el número de personas con tuberculosis MDR a nivel mundial asciende a 580,000, los niveles de inversión actuales $(\$ 620$ millones US) en investigación y desarrollo han alcanzado su mínimo desde 2008 (Bridgen et al., 2017). De acuerdo con la WHO, en su informe global sobre tuberculosis (WHO, 2016) en 2015 se estimó que el número de nuevos casos de TB era de 10.4 millones de los cuales el $56 \%$ eran hombres, el $34 \%$ eran mujeres y el $10 \%$ niños, mientras que las coinfecciones de TB y VIH representaron 1.2 millones de casos (11\%), de todos los casos nuevos reportados. En el 2015 murieron 1.8 millones de personas por la infección, de los cuales 400,000 fueron coinfección con el VIH (WHO, 2016).

Según el reporte de 2016, México se encuentra entre los países con una baja incidencia de TB, reportándose 21 casos por cada 100,000 habitantes y una mortalidad casi 20 veces menor que el promedio mundial. Sin embargo, las bajas incidencias de TB en nuestro país se asocian a un alto subregistro, un déficit en el pronóstico y, además muchas personas conviven con enfermos, de los cuales no todos están diagnosticados o bajo tratamiento. Sin embargo, llama la atención que el reporte de la WHO del 2016 se ha agregado a México en la lista de países con alta incidencia de casos de coinfecciones TB/VIH (WHO, 2016), por lo que ello debe generar la atención por parte de las autoridades de salud.

La TB es una enfermedad emergente pues la CENAPRECE ha reportado que el número de casos nuevos en México ha aumentado casi al doble en los últimos 25 años. Además, se estima que un tercio de la población mundial está infectada sin manifestar enfermedad (TB latente), de la cual el 10\% sufrirá TB activa por reactivación de bacterias latentes como consecuencia de la inmunodeficiencia producida por enfermedades como HIV/SIDA o diabetes mellitus tipo 2 (DM-2).

La relación DM-2 con $\mathrm{TB}$ es de gran importancia, pues en comparación con la población sana los diabéticos tienen un riesgo 3 veces mayor de sufrir TB activa y este riesgo es aún mayor en la población joven. La DM-2 es una enfermedad considerada como epidémica en nuestro país y la constante y creciente pobreza de buena parte de nuestra población son elementos cruciales que permiten predecir un mayor número de casos de TB activa en el futuro próximo. De hecho, se calcula que en México de todos los casos de TB activa el 67\% tienen DM-2 lo que corresponde al $11 \%$ de la población total. Es por estos motivos que se considera a la TB y su relación con la DM-2 como un importante problema nacional de salud (Ponce-De-Leon A etal., 2004).

Las estrategias de control de TB, desplegadas por los gobiernos, están enfocadas particularmente a la solución clínica, es decir, por medio de antibióticos, vacunas y acceso a programas e instituciones de salud. Estas acciones no han mostrado efectividad para 
detener a la TB, se requiere de intervenciones sociales y ambientales, las cuales pocas veces se ven contempladas en el sector salud, o en general en programas oficiales.

En términos generales las tasas de muertes se han reducido notablemente, siendo un 90\% menos de muertes asociadas a TB con respecto al 2015, y 80\% de reducción de nuevos casos.

El pronóstico para el paciente con la infección es bueno con antibióticos de primera línea (rifampicina, isoniazida, pirazinamida, etambutol), esto cuando se trata de infecciones con cepas clásicas, pero cada vez se presentan más casos de infecciones con cepas MDR, y XDR las cuales generan cuadros clínicos difíciles de tratar siendo, la mayoría de las veces, letales (Dheda et al., 2017).

\section{La resistencia a fármacos}

Las cepas MDR o XDR, representan una preocupación latente, como se ha mencionado. Se estima que mundialmente el $5 \%$ de los pacientes con tuberculosis están infectados con cepas MDR o XDR, pero entre ellos la tasa de muerte está por arriba del 40\%, 1legando al 60\% cuando la infección es con cepas XDR (WHO, 2016).

Solo 1 de cada 5 pacientes con infección con cepas MDR recibieron tratamiento, y de ellos solo la mitad se curó (WHO, 2016). Lo anterior preocupa aún más debido a que aquellos que recibieron el tratamiento, pero no fueron curados son potencialmente portadores de cepas aún más resistentes.

La tuberculosis MDR es la causada por una cepa que no responde al tratamiento con isoniazida y rifampicina, los dos medicamentos antituberculosos de primera línea más eficaces de que se dispone. La forma MDR se puede tratar y curar con medicamentos de segunda línea. Sin embargo, las opciones de tratamiento de segunda línea son limitadas y requieren quimioterapia de larga duración (hasta de dos años de tratamiento) con fármacos que además de caros son tóxicos, mientras que la TB XDR es una forma más grave de TB, causada por bacterias resistente no solo a la isoniazida y a la rifampicina, sino a cualquiera de los medicamentos antituberculosos de segunda línea más eficaces (fluoroquinolonas y cualquiera de los fármacos inyectables usados en el tratamiento de segunda línea como amikamicina, capreomicina, kanamicina), lo que deja a muchos pacientes sin otras opciones de tratamiento.

¿Cómo puede influenciar el cambio climático la progresión de la tuberculosis, particularmente, las cepas MDR?

Científicos mencionan que enfermedades como la gripe aviar, el ébola, el cólera y la tuberculosis, se propagarán aún más en el mundo como resultado de los cambios en las temperaturas y los niveles de precipitación fluvial. Y tendrán un enorme impacto en la salud humana, como en la naturaleza y las economías del mundo, dice el 'the Deadly Dozen". Asimismo, diferentes factores se suman para el éxito de estas enfermedades, tales como:

Desnutrición. Un buen estado nutricional es fundamental para un sistema inmunológico eficiente que combata la infección, particularmente la deficiencia de vitamina $D$ está asociado fuertemente a la progresión de la enfermedad, particularmente de cepas MDR(Wingfield et al., 2014), se ha documentado que el cambio climático está impactando en nutrición y migración en países asiáticos, con relevancia particularmente en niños (UNICEF, 2011).

Migraciones y hacinamiento. No es secreto que los cambios que conducen a la globalización, los intereses económicos, territoriales y religiosos está conduciendo a la pérdida de arraigo a la tierra, generando migraciones, que pueden ser pequeñas o masivas, como aquellas causadas por conflictos bélico-religiosos como en el caso de Siria 
llevando a serios retos en términos de salud, particularmente en tuberculosis (Cookson et al., 2015).

El hacinamiento es una constante en migraciones masivas de cualquier tipo, condición fundamental para la transmisión del bacilo. En México, esto se observa en regiones como Tijuana que tiene la mayor incidencia de $\mathrm{TB}$, particularmente por el estado en el que viven los migrantes en espera de cruzar la frontera.

Es interesante que los desplazamientos se dan de zonas ecuatoriales a zonas hemisféricas, particularmente hacia el norte (Europa y USA), puede ser que si bien los habitantes de estas zonas ecuatoriales, con radiación solar prácticamente todo el año, sean más resistentes a la TB porque la activación de vitamina D sea adecuada, dicha vitamina depende de fotoactivación para ejercer su efecto(Wingfield, et al., 2014). Al moverse hacia zonas hemisféricas la biodisponibilidad de vitamina $\mathrm{D}$ activa es menor, por menos radiación, y por lo tanto la infección (tal vez latente) se active y manifieste. La tuberculosis induce malnutrición, y la malnutrición condiciona a la tuberculosis (Kant et al., 2015).

Contaminación del aire de interiores, principalmente por la quema de dendrocombustibles, como el carbón o la leña, los cuales siguen siendo la primera opción para la cocción de alimentos y para el calefacción, en muchas regiones pobres del mundo, especialmente en los países con mayor incidencia de la enfermedad, como India y China (Santos et al., 2012). El humo, genera cuadros neumónicos que impiden un buen control para la eliminación de la bacteria en los pulmones de las personas con la infección.

Contaminación de agua. La pérdida de hábitats está generando que especies de animales, silvestres o domesticadas, se acerquen a ciudades en busca de agua y alimento, muchas especies de rumiantes son portadores del bacilo y la posibilidad de que contaminen yacimientos de agua para consumo humano es grande, empiezan a documentarse casos de infección con cepas de Mycobacterium bovis en humanos, representando del 5 al $10 \%$ de los casos totales de TB humana, cabe resaltar que la forma humana puede afectar a animales también, formando así, un circuito de infección constante (Davidson et al., 2017).

Cambio en el uso de suelo se presenta el avance de la urbanización, la construcción de carreteras, agricultura a gran escala, desecación de humedales, entre otros, lo que conduce a la pérdida de biodiversidad, generando que vectores se acerquen más a zonas habitadas. Por otro lado, se pierden también espacios para el cultivo, particularmente para el autoconsumo, en pequeñas comunidades, generando estados de malnutrición, de la cual se aprovechan la infección(Patz, et al., 2004).

El cambio en el uso de suelo está tomando el sitio como el principal factor del resurgimiento de enfermedades infecciosas. Se requieren de estudios sistemáticos para determinar las causas, pero se especula, con cierta razón, que está afectando regímenes alimenticios en poblaciones vulnerables, es importante recordar que la TB es una enfermedad de pobres. El factor nutrición es fundamental para la progresión de la enfermedad, como se ha mencionado. El cambio en el uso de suelo también lleva a la migración, como se ha mencionado, que favorece la transmisión en zonas de baja o nula incidencia.

\section{¿Cuál es el reto? En busca de nuevas opciones terapéuticas}

Desde hace varios años se han reportado nuevas cepas MDR y XDR, incluso se ha reportado que estas cepas están ya mostrando resistencia a nuevos antibióticos como la bedaquilina y delamanid. (Bloemberg et al., 2015). El tratamiento con dosis elevadas de rifampicina y de isoniazida puede ser una buena opción de tratamiento (Chang et al., 2010) pero es sabido 
también que dicho esquema induce daño hepático, particularmente en niños (Donald, 2011), lo cual está asociado a un incremento en casos de muerte, sobre todo en países asiáticos (Kumar et al., 2010). El hígado es el órgano donde los fármacos se biotransforman, y en dicho proceso generan intermediarios altamente tóxicos que pueden inducir, como se ha mencionado, la muerte de un paciente.

Estudios conducidos en nuestro laboratorio en animales de experimentación, han mostrado que el daño hepático inducido por dosis elevadas de fármacos antifímicos puede ser significativamente disminuido, por el cotratamiento con el factor de crecimiento de hepatocitos (HGF, por sus siglas en inglés) lo que lo posiciona como una excelente opción de cotratamiento en pacientes con cepas MDR o XDR (Enriquez-Cortina et al., 2013). Datos obtenidos recientemente muestran que además el HGF es capaz de desplegar efectos diferenciales tanto en hígado como en pulmón en ratones infectados con una cepa MDR, induciendo estrés oxidante en pulmón, fundamental para la eliminación de la bacteria; y reprimiendo la misma respuesta en el hígado, donde las especies reactivas de oxígeno (ROS) representan las principales entidades de daño, incluso el HGF por si solo mostró disminuir notablemente la neumonía observada por la enfermedad, sugiriendo efectos inmunomoduladores (Bello-Monroy et al., 2015).

El tratamiento convencional con los fármacos de primera línea en dosis elevadas en combinación con terapias celulares, al menos experimentalmente, muestra un efecto viable que podría ser llevado a la práctica clínica con resultados prometedores.

\section{Conclusión}

¿Que acciones se debe tomar para contrarrestar, lo más posible, el avance de la TB por el CC? Es importante que se implementen leyes y reglamentos que permitan la conservación y protección de la biodiversidad, aspectos que ha venido empujando fuertemente instituciones como la CONABIO, se deben aplicar nuevos mecanismos de evaluación ambiental, que permita llegar a un consenso a nivel mundial sobre medidas concretas que impacten en CC, con énfasis en enfermedades emergentes, por otro lado se requiere de la participación y capacitación de comunidades rurales para la gestión eficiente de recursos biológicos, que impacten en la conservación de hábitats que beneficien a la comunidad y a las especies animales y vegetales, sin que ello implique pérdida de identidades. Otro aspecto fundamental es que se contemple el cambio del uso de suelo en las políticas de salud, ya que esta presentando un impacto, no solo en tuberculosis, si no en otras infecciones.

La búsqueda de nuevas opciones de tratamiento, más allá de una quimioterapia convencional, puede ser una opción viable que frene el problema, o al menos lo retrase, nuevos enfoques soportados en terapia celular y molecular dirigida en combinación con fármacos, nuevos o convencionales, pudiera rendir buenos frutos.

Es muy claro ya como se ha incrementado los casos de infecciones MDR y XDR; el CC pareciera pues, estar empujando a favor de la enfermedad, como mencionamos, no queda aún del todo claro, pero definitivamente incidir desde ya en el problema con políticas públicas desde los gobiernos, y con conciencia y determinación en la población general, ayudará sin lugar a dudas en detener el problema o al menos, evitar daños que puedan ser históricamente lamentables, por la aparición de cepas incurables.

\section{Agradecimiento}

El presente artículo fue escrito gracias al financiamiento de CONACYT Ciencia Básica \# 252942. 


\section{Referencias}

Bello-Monroy, O., Enriquez-Cortina, C., Souza, V., Miranda Labra R, Gutierrez-Ruiz, M. C., Bucio, L., and Gomez-Quiroz, L. E. (2015). The protective effect of the HGF against the toxicity induced by isoniazid and rifampicin in a moise model of progresivve tuburculosis. . Annals of hepatology 14(4), 580-581.

Bloemberg, G. V., Keller, P. M., Stucki, D., Trauner, A., Borrell, S., Latshang, T., Coscolla, M., Rothe, T., Homke, R., Ritter, C., Feldmann, J., Schulthess, B., Gagneux, S., and Bottger, E. C. (2015). Acquired Resistance to Bedaquiline and Delamanid in Therapy for Tuberculosis. $\mathrm{N}$ Engl.J Med 373(20), 1986-8.

Chang, K. C., and Leung, C. C. (2010). The best approach to reintroducing tuberculosis treatment after hepatotoxicity is still open to debate. Clin Infect Dis 51(3), 366-7; author reply $367-8$.

Cookson, S. T., Abaza, H., Clarke, K. R., Burton, A., Sabrah, N.A., Rumman, K.A., Odeh, N., and Naoum, M. (2015). "Impact of and response to increased tuberculosis prevalence among Syrian refugees compared with Jordanian tuberculosis prevalence: case study of a tuberculosis public health strategy". Confl Health 9, 18.

Davidson, J. A., Loutet, M. G., O'Connor, C., Kearns, C., Smith, R. M., Lalor, M. K., Thomas, H. L., Abubakar, I., and Zenner, D. (2017). Epidemiology of Mycobacterium bovis Disease in Humans in England, Wales, and Northern Ireland, 2002-2014. Emerg Infect Dis 23(3), 377-386.

Dheda, K., Chang, K. C., Guglielmetti, L., Furin, J., Schaaf, H. S., Chesov, D., Esmail, A., and Lange, C. (2017). Clinical management of adults and children with multidrug-resistant and extensively drug-resistant tuberculosis. Clin Microbiol Infect 23(3), 131-140.

Diaz-Quinonez, J. A., Lopez-Martinez, I.,
Torres-Longoria, B., Vazquez-Pichardo, M., Cruz-Ramirez, E., Ramirez-Gonzalez, J. E., Ruiz-Matus, C., and Kuri-Morales, P. (2016). Evidence of the presence of the Zika virus in Mexico since early 2015. Virus Genes 52(6), 855-857.

Donald, P. R. (2011). Antituberculosis druginduced hepatotoxicity in children. Pediatr Rep $3(2), \mathrm{e} 16$.

Enriquez-Cortina, C., Almonte-Becerril, M., Clavijo-Cornejo, D., Palestino-Dominguez, M., Bello-Monroy, O., Nuno, N., Lopez, A., Bucio, L., Souza, V., Hernandez-Pando, R., Munoz, L., Gutierrez-Ruiz, M. C., and Gomez-Quiroz, L. E. (2013). Hepatocyte growth factor protects against isoniazid/rifampicin-induced oxidative liver damage. Toxicol Sci 135(1), 26-36.

García, I. (2017). Se elevan a 143 los casos del virus coxsackie en Oaxaca. In El Universal (doi: Digital ed., Ciudad de México.

Hii, Y. L., Rocklov, J., and Ng, N. (2011). Short term effects of weather on hand, foot and mouth disease. PLoS One 6(2), e16796.

Kant, S., Gupta, H., and Ahluwalia, S. (2015). Significance of nutrition in pulmonary tuberculosis. Crit Rev Food Sci Nutr 55(7), 95563.

Kumar, R., Shalimar, Bhatia, V., Khanal, S., Sreenivas, V., Gupta, S. D., Panda, S. K., and Acharya, S. K. (2010). Antituberculosis therapy-induced acute liver failure: magnitude, profile, prognosis, and predictors of outcome. Hepatology 51(5), 1665-74.

McIntyre, S., Rangel, E. F., Ready, P. D., and Carvalho, B. M. (2017). Species-specific ecological niche modelling predicts different range contractions for Lutzomyia intermedia and a related vector of Leishmania braziliensis following climate change in South America. Parasit Vectors 10(1), 157. 
Miranda J, and Miranda P (2017). El virus coxsackies ataca también a adultos. In El Universal (doi, México.

Oyhantçabal, W., Vitale, E., and Lagarmilla, P. (2010). El cambio climático y su relación con las enfermedades animales y la producción animal. Conf. OIE doi, 169-177.

Pachauri RK, and Meyer L (2015). IPCC, 2014: Cambio climático 2014: Informe de síntesis. Contribución de los Grupos de trabajo I, II y III al Quinto Informe de Evaluación del Grupo Intergubernamental de Expertos sobre el Cambio Climático. 1 ed.

Pandve, H. T., Fernandez, K., Singru, S. A., and Chawla, P. S. (2009). Climate change and the threat of deadly dozen. Indian J Occup Environ Med 13(3), 154.

Patz, J. A., Daszak, P., Tabor, G. M., Aguirre, A. A., Pearl, M., Epstein, J., Wolfe, N. D., Kilpatrick, A. M., Foufopoulos, J., Molyneux, D., Bradley, D. J., Working Group on Land Use, C., and Disease, E. (2004). Unhealthy landscapes: Policy recommendations on land use change and infectious disease emergence. Environ Health Perspect 112(10), 1092-8.

Paull, S. H., Horton, D. E., Ashfaq, M., Rastogi, D., Kramer, L. D., Diffenbaugh, N. S., and Kilpatrick, A. M. (2017). Drought and immunity determine the intensity of West Nile virus epidemics and climate change impacts. Proc Biol Sci 284(1848).

Ponce-De-Leon A, Garcia-Garcia Md M de L, Garcia-Sancho MC, Gomez- Perez FJ, and JL, V.-G. (2004). Tuberculosis and diabetes in southern Mexico. Diabetes care 27, 1584-1590.

Santos, L. G., Pires, G. N., Azeredo Bittencourt, L. R., Tufik, S., and Andersen, M. L. (2012). Chronobiology: relevance for tuberculosis. Tuberculosis (Edinb) 92(4), 293-300.
Schmidt, C. W. (2008). Linking TB and the environment: an overlooked mitigation strategy. Environ Health Perspect 116(11), A478-85.

UNICEF (2011). Children and Climate Change: The impacts of climate change on nutrition and migration

affecting children in Indonesia. 1 ed. UNICEF.

WHO (2016). Global tuberculosis report 2016. 1 ed.

Wingfield, T., Schumacher, S. G., Sandhu, G., Tovar, M. A., Zevallos, K., Baldwin, M. R., Montoya, R., Ramos, E. S., Jongkaewwattana, C., Lewis, J. J., Gilman, R. H., Friedland, J. S., and Evans, C. A. (2014). The seasonality of tuberculosis, sunlight, vitamin D, and household crowding. J Infect Dis 210(5), 774-83.

Zhou, X. N., Yang, G. J., Yang, K., Wang, X. H., Hong, Q. B., Sun, L. P., Malone, J. B., Kristensen, T. K., Bergquist, N. R., and Utzinger, J. (2008). Potential impact of climate change on schistosomiasis transmission in China. Am J Trop Med Hyg 78(2), 188-94. 


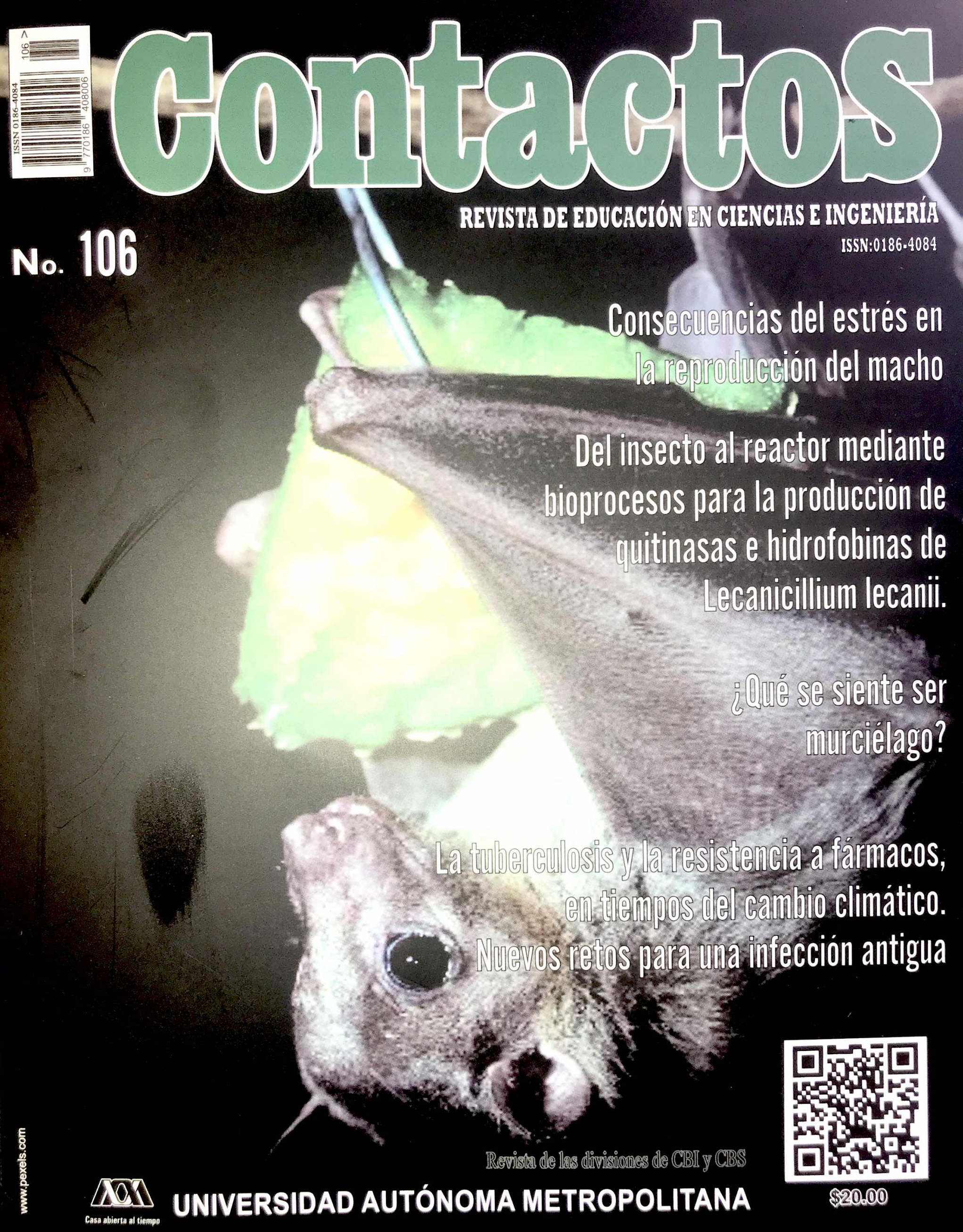




\section{Contenido}

\section{ContactoS No. 106, Octubre Diciembre 2017}

Influencia de la temperatura en la

determinación sexual de peces blancos

y charales (Chirostoma, Atherinopsidae).

Consecuencias del estrés en

la reproducción del macho.

María Cecilia Hernández Rubio,

María del Socorro I. Retana Márquez

Gerardo Figueroa Lucero,

Hortensia Montellano Rosales

Del insecto al reactor mediante

De América para el mundo: el jitomate.

bioprocesos para la producción de

(Solanum lycopersicum L.)

quitinasas e hidrofobinas de

Lecanicillium lecanii.

Zaizy Rocha-Pino y Keiko Shirai

Dra. Laura J. Pérez Flores

El papel de los diversos receptores

¿Qué se siente ser de estrógenos en el cáncer de mama.

murciélago?

Javier Esteban Jiménez-Salazar,

Pablo Damián-Matsumura

Dr. Ricardo López Wilchis

La tuberculosis y la resistencia a fármacos, $\quad 28$

Clasificación de estrés por en tiempos del cambio climático.

Nuevos retos para una infección antigua.

Oscar Bello Monroy, Alejandro Escobedo medio de una red neuronal. F. Daniel Gálvez Sánchez y Alma E. Martínez Licona

-Calvario, Monserrat Gerardo-Ramírez,

Roxana Uri Miranda Labra, María

Concepción Gutiérrez-Ruíz, Rogelio

Hernández-Pando, Luis Enrique Gómez-

Quiroz

ContactoS en la WEB

Lea los artículos publicados en ContactoS en http://www.izt.uam.mx/contactos 


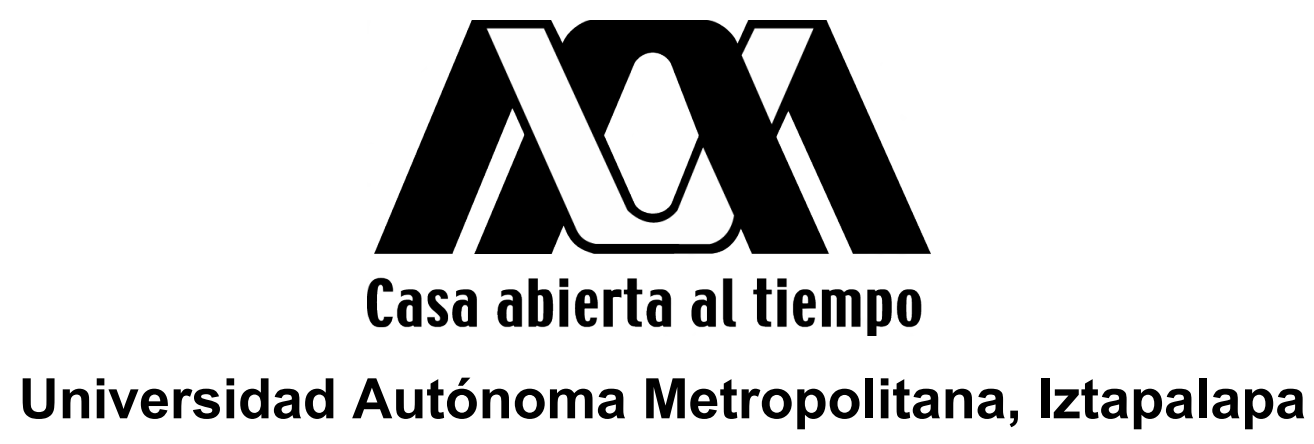

Caracterización de la ruta de señalización activada por el factor de crecimiento y diferenciación 11 (GDF11) y su impacto en la tumorigénesis en hepatocarcinoma humano

TESIS

Para obtener el grado de Maestra en Biología Experimental

Presenta

Biol. Exp. Monserrat Gerardo Ramírez

Comité Tutoral

Dra. María Concepción Gutiérrez Ruiz

Dr. José Carlos Fernández Checa

Dra. Marina Macías Silva 
El programa de Maestría en Biología Experimental de la Universidad Autónoma Metropolitana pertenece al Programa Nacional de Posgrados de Calidad (PNPC) del CONACYT, registro 001481, en el Nivel Consolidado, y cuenta con el apoyo del mismo Consejo, Clave DAFCYT-2003IMPTNNN0020. Número de registro de la beca otorgada por el CONACYT: 633680

Este trabajo estuvo apoyado por los proyectos de CONACYT: CB-252942 y Fronteras de la Ciencia- 1320 siendo responsable de ambos el Dr. Luis Enrique Gómez Quiroz. 
Los miembros del jurado designados por la Comisión Académica del Posgrado en Biología Experimental de la División de Ciencias Biológicas y de la Salud de la Universidad Autónoma Metropolitana- Iztapalapa, abajo firmantes aprobaron la tesis titulada "Caracterización de la ruta de señalización activada por el factor de crecimiento y diferenciación 11 (GDF11) y su impacto en la tumorigénesis en hepatocarcinoma humano" que presenta Monserrat Gerardo Ramírez con fecha de examen el 05 de diciembre del 2019

\section{MIEMBROS DEL JURADO}

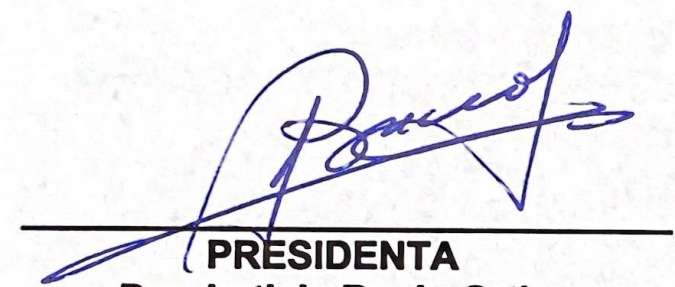

Dra. Leticia Bucio Ortiz

Departamento de Ciencias de la Salud Universidad Autónoma Metropolitana Ciudad de México

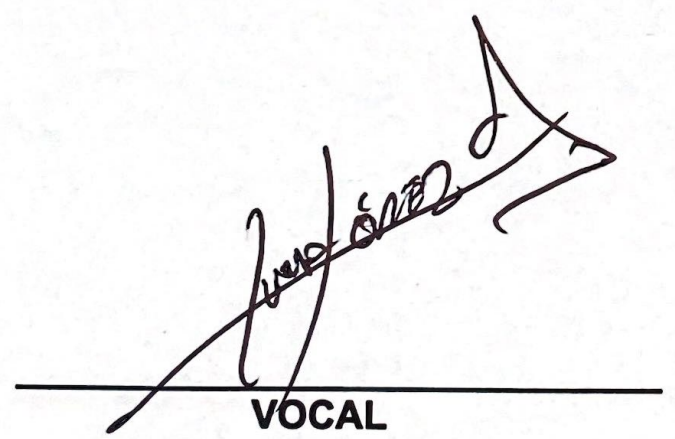

Dr. Armando Luna López Instituto Nacional de Geriatría Ciudad de México

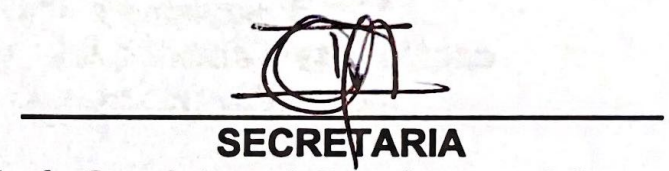

María Guadalupe I. Domínguez Gómez Instituto Nacional de Cancerología Ciudad de México

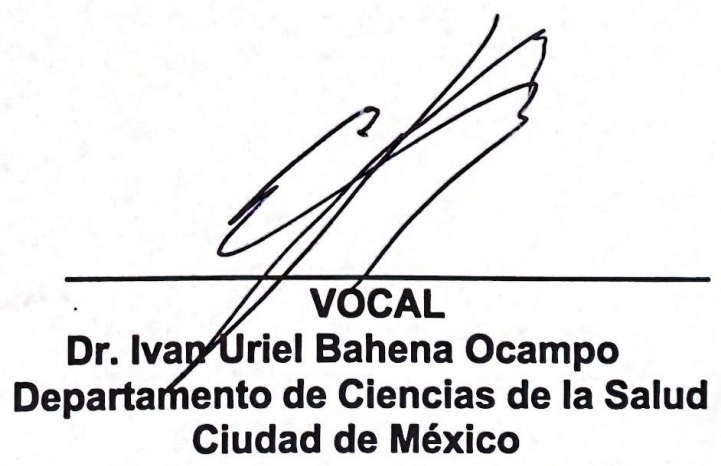




\section{Comité Tutoral}

Directora. Dra. María Concepción Gutiérrez Ruiz

Departamento de Ciencias de la Salud, Universidad Autónoma Metropolitana

Teléfono.5559667520 Correo.mcgr@xanum.uam.mx

Co- director. Dr. José Carlos Fernández Checa

Instituto de Investigaciones Biomédicas de Barcelona, CSIC; Unidad de Hígado,

Hospital Clinic, IDIBAPS y CIBERehd, Barcelona, España.

Doctor Honoris Causa por la Universidad Autónoma Metropolitana

Teléfono. +93-2275709 Correo. checa229@yahoo.com

Asesora. Dra. Marina Macías Silva

Instituto de Fisiología Celular, Universidad Nacional Autónoma de México

Teléfono.5556225729 Correo.mmacias@ifc.unam.mx 


\section{Agradecimientos}

A la Universidad Autónoma Metropolitana, porque fue mi casa de estudios durante este largo tiempo, porque al tener profesores e investigadores de alto nivel me permitieron crecer más.

Al Conacyt, por haberme otorgado la beca que me permitió concluir mis estudios.

A la doctora María Concepción Gutiérrez Ruiz, por ser mi directora de tesis, por su guía y paciencia.

Al doctor José Carlos Fernández Checa, quien también formo parte como codirector de tesis, agradezco también por la oportunidad de haberme dejado trabajar en su laboratorio durante mi estancia en Barcelona.

A la doctora Marina Macías Silva, por ser mi asesora de tesis.

A los miembros del jurado conformado por la doctora Leticia Bucio Ortiz, la doctora María Guadalupe Domínguez Gómez, el doctor Ivan Uriel Bahena Ocampo y al doctor Armando Luna López por los comentarios realizados a la tesis

A la doctora Carmen García Ruiz, del IIBB, por su apoyo durante mi estancia en su laboratorio.

Al doctor Javier Jiménez Salazar y al doctor Roberto Lazzarini, por su apoyo y colaboración durante la realización del proyecto, así como al M en BE Arturo Simoni Nieves, M. en C. Lyssia Castellanos y a la Dra. Elizabeth Tejero por su apoyo en los estudios de RNA-seq.

Al doctor Jens Marquardt, de la Universidad Johannes Gutenberg, Alemania, por su apoyo en la realización de los análisis de RNA- seq.

Al doctor Benjamín Pérez Aguilar, quien formo parte del proyecto durante el desarrollo de este.

Al doctor Luis Enrique Gómez Quiroz, por ser el responsable y líder del proyecto de GDF11, además de ser el encargado de financiarlo, agradezco que me haya dado la oportunidad y la confianza para llevar a cabo esta investigación. 


\section{Agradecimientos}

Al laboratorio de Fisiología Celular (S-351), lugar donde me desarrollé como científica, lugar que me vio crecer y caer algunas veces también, ese espacio que consideré, desde el primer día mi hogar.

A las doctoras que pertenecen al laboratorio, a la Dra. Lety, Dra. Vero y Dra. Roxana por su apoyo.

A la Dra. Conchita, gracias por su apoyo aún cuando me encontraba lejos.

A mis compañeros del laboratorio, por ayudarme, por enseñarme, por hacerme reír y por brindarme su apoyo cuando lo necesitaba (incluso si se trataba de quedarse a trabajar toda la noche) por aquellos experimentos que eran para ayer.

A Benja, quien fue mi maestro, gracias por enseñarme, por tu ayuda, por tu paciencia y por estar ahí cuando me atoraba en los experimentos.

Al Dr. Luis Enrique Gómez Quiroz, no tengo palabras para agradecer todo su apoyo (académico y personal), por ser mi amigo y confidente, por esas platicas mañaneras con una taza de café recién hecho en "la cocina" del lab. acompañado de galletas (algunas veces robadas de mi cajón) y también por las tardes de palomitas de maíz, la herramienta perfecta contra el cansancio de una tarde de trabajo pesado.

Gracias por seguir al pendiente de mi cuando deje el laboratorio y claro por alentarme y apoyarme sabiendo que sería la oportunidad más importante de mi vida y finalmente pero no menos importante...

Gracias también por ser un gran ejemplo por seguir, por ayudarme, por enseñarme y también por soportarme. Agradezco las risas, pero también agradezco los regaños, ya que me forjaron permitiéndome crecer día a día. Gracias, porque usted fue quien vio una chispa en mi para lograr ser un miembro más de su codiciado grupo de trabajo. $Y$ finalmente gracias por enseñarme que "la ciencia es un estilo de vida, no una profesión". 


\section{Dedicatoria}

A mi padre, Federico Gerardo, quien a pesar de la distancia siempre estuvo conmigo, porque me apoyo en todo momento sin cuestionar el futuro por el que estaba trabajando, por alentarme a seguir mis sueños, aun cuando para lograrlos requería de alejarme más de él.

A mi hermano, Edgar Gerardo, quien me apoyo en las decisiones que tomaba, que aun sin vernos diario siempre supe que tú estabas para brindarme una mano y ayudarme a pelear más fuerte para lograr mis objetivos, por celebrar mis batallas ganadas durante esta larga travesía estudiantil, gracias por no dejarme morir sola.

A mi familia, quienes pese a todo se acostumbraron a dejar de verme por el trabajo en el laboratorio, por el apoyo y por el cariño que me brindan día a día, gracias por hacer suyos mis logros y festejarlos como una fiesta nacional.

Una dedicatoria especial a mi madre, Marcela Ramírez, quien tristemente perdió la batalla contra el cáncer, al cual hoy enfrento yo con las mejores herramientas (Ciencia) y con las fuerzas multiplicadas para lograr su control. 


\section{Resumen}

El factor de crecimiento y diferenciación 11 (GDF11) ha sido caracterizado como uno de los principales reguladores de los procesos de diferenciación en células con características troncales a pesar de algunas controversias sobre estudios relacionados con la edad. El GDF11 ha sido pobremente estudiado en patologías como el cáncer, particularmente por las características troncales que presentan las células, principalmente en el carcinoma hepatocelular ( $\mathrm{HCC}$ ), uno de los cánceres más agresivos a nivel mundial. En este trabajo nos propusimos investigar los efectos del GDF11 en las células de cáncer de hígado.

EI GDF11 induce la activación de la ruta de las Smad (Smad2/3) sin activar a las Smad asociadas a la familia de las BMP (Smad1/5) en la línea celular Huh7, pero observamos en la línea celular Hep3B la activación de las proteínas Smad de ambas familias.

El tratamiento con el GDF11 no afecta la viabilidad de las células, pero reduce de manera significativa la proliferación, la formación de esferoides y la formación de colonias en las líneas de HCC.

Se observó también la desregulación de CDK6, Ciclina D1 y Ciclina A y la sobreregulación de p27 después del tratamiento con GDF11. Interesantemente, el tratamiento induce disfunción mitocondrial mediante la disminución de la fosforilación oxidativa (OCR) y la disminución en la capacidad glucolítica (ECAR).

Estos efectos fueron potencialmente inducidos por la expresión de E- Cadherina y Ocludina así como la represión de Snail y N- Cadherina de manera dependiente. 
Además, el tratamiento con el GDF11 por 72 h provoco en las células la disminución en la formación de colonias y de esferoides, estos efectos fueron observados una vez que el tratamiento fue removido dejando las células sin este estímulo hasta por 10 días, indicando que el efecto del GDF11 no es transitorio.

Finalmente, en el ensayo de invasión observamos la disminución de manera significativa en la migración de las células tratadas con GDF11 asociado a la disminución en la proliferación mediante la tinción con Ki67.

Finalmente, nosotros proponemos la activación de ERK1/2 como unos de los principales blancos de la señalización de GDF11 en la disminución en la proliferación. Los datos mostraron que el GDF11 exógeno muestra propiedades supresoras de tumores en las células de HCC. 


\section{Abstract}

Growth differentiation factor 11 (GDF11) has been characterized as a key regulator of differentiation in cells that retain stemness features, despite some controversies in agerelated studies. GDF11 has been poorly investigated in cancer, particularly in those with stemness capacity, such as hepatocellular carcinoma (HCC), one of the most aggressive cancers worldwide. Here, we focused on investigating the effects of GDF11 in liver cancer cells.

GDF11 induced Smad signaling activation (Smad2/3), without activated the BMP associated Smad signaling (Smad 1/5) in Huh7 cell line, but we observe in Hep3B cell line both Smad signaling activated.

GDF11 treatment did not affect the viability but significantly reduced proliferation, colony and spheroid formation in HCC cell lines.

Consistently, down-regulation of CDK6, cyclin D1, cyclin A, and concomitant upregulation of p27 was observed after $24 \mathrm{~h}$ of treatment. Interestingly, GDF11 treatment induce mitochondrial dysfunction by oxidative phosphorylation decrease (OCR) and glycolytic capacity decrease (ECAR).

These effects were potentially induced by the expression of E-cadherin and occludin, as well as Snail and $\mathrm{N}$-cadherin repression, in a time-dependent manner. Furthermore, GDF11 treatment for $72 \mathrm{~h}$ induced that cells were incapable of sustaining colony and sphere capacity in the absent of GDF11, up to 10 days, indicating that the effect of GDF11 on self-renewal capacity is not transient. 
In vivo invasion studies revealed a significant decrease in cell migration of hepatocellular carcinoma cells treated with GDF11 associated to a decreased proliferation judged by Ki67 staining.

Finally, we propose ERK1/2 activation like a principal target for GDF11 signaling in the decrease in the proliferation. Data show that exogenous GDF11 displays tumor suppressor properties in HCC cells. 


\section{Índice}

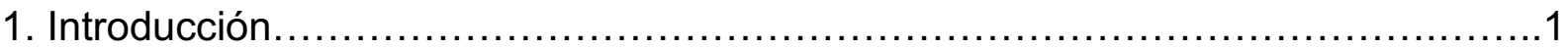

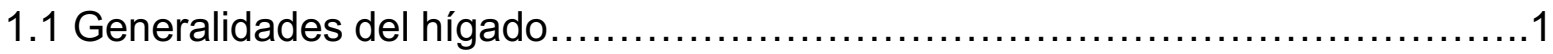

1.2 Principales agentes tóxicos y estadios de daño hepático...........................1

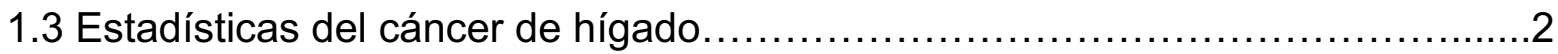

1.4 Características del cáncer hepático...............................................

1.5 El papel de la ruta de las MAPK en el cáncer de hígado..........................

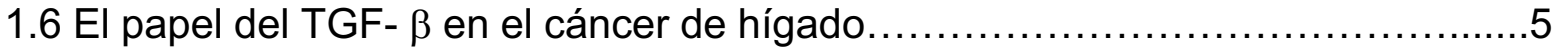

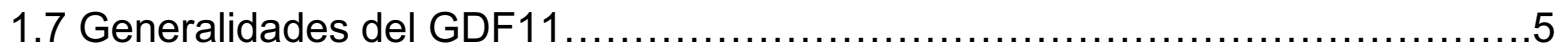

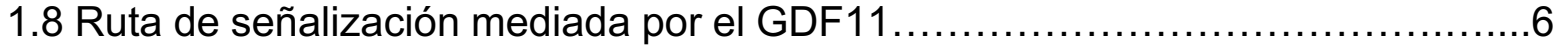

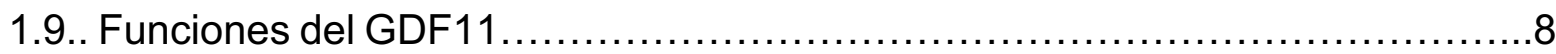

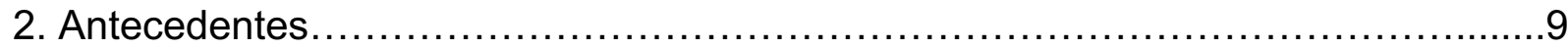

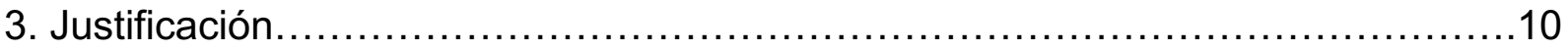

4. Pregunta de investigación.........................................................

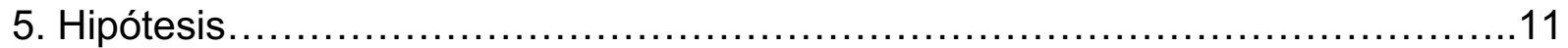

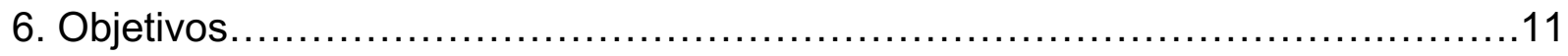

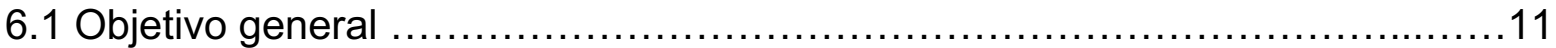

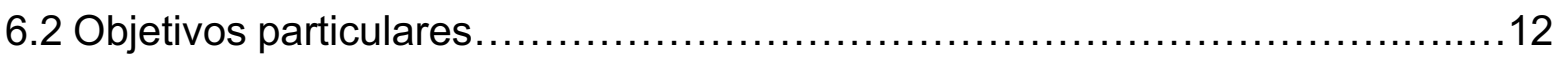

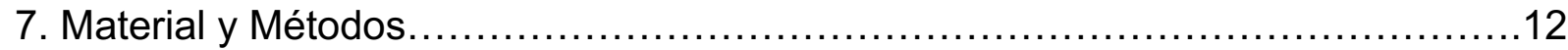

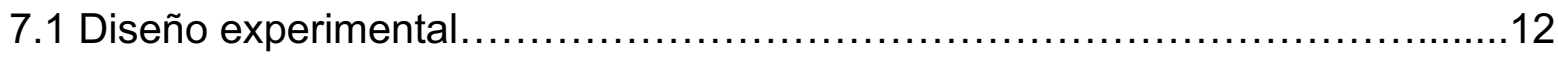

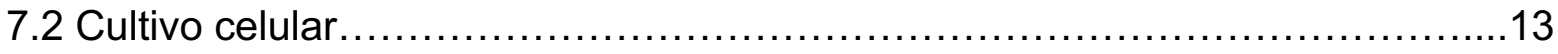

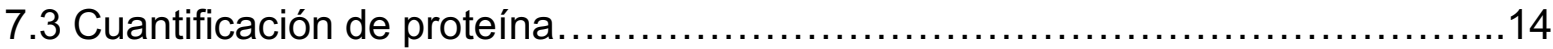




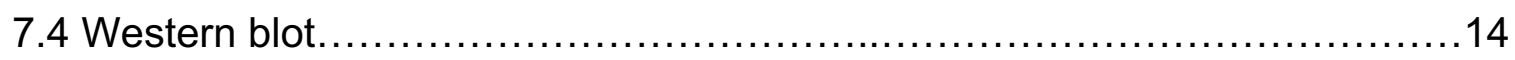

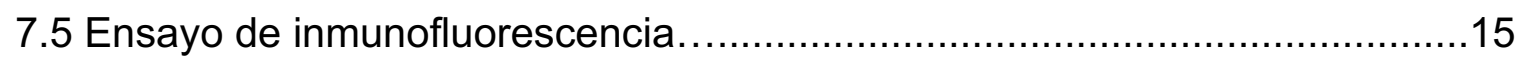

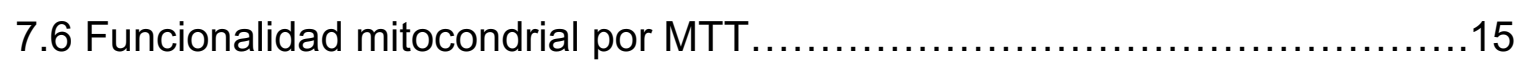

7.7 Determinación en tiempo real del metabolismo mediante

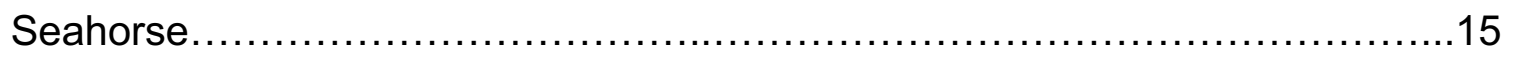

7.8 Estudio de invasión usando el modelo de membrana corioalantoidea

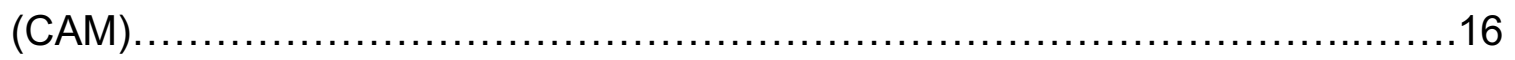

7.9 Reacción en cadena de la polimerasa acoplada a retrotranscripción

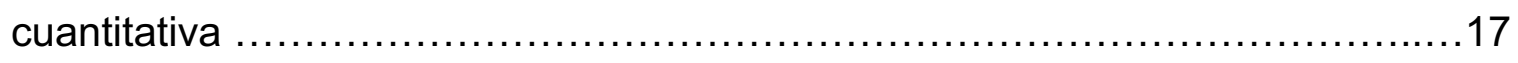

7.10 Ensayo de inmunoprecipitación..........................................17

7.11 Ensayo de proliferación celular.......................................... 18

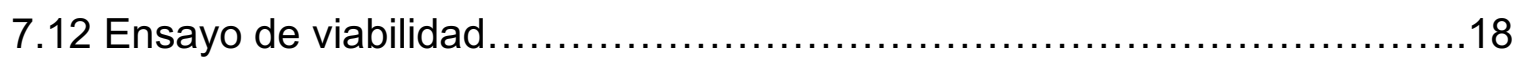

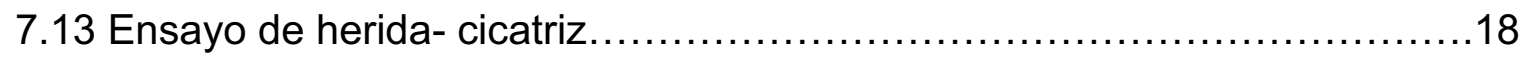

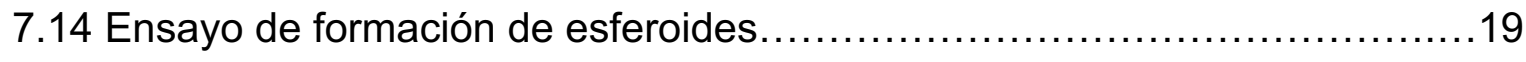

7.15 Ensayo de clonogenicidad.............................................. 19

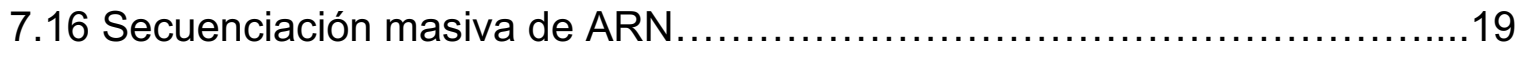

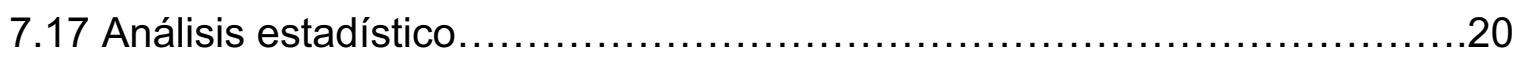

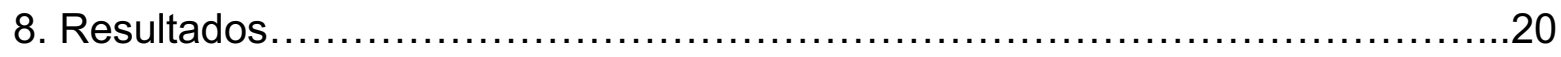

8.1 El GDF11 no afecta la viabilidad de las células de cáncer de

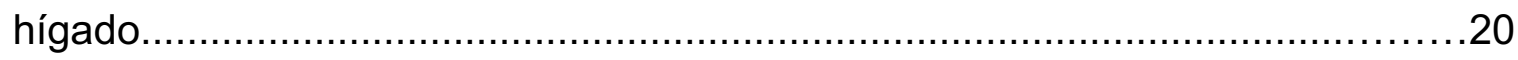

8.2 La línea celular Huh7 presenta los receptores requeridos por el

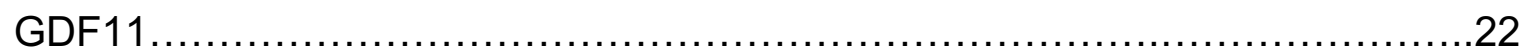


8.3 Las líneas de HCC responden al tratamiento del GDF11 mediante la activación

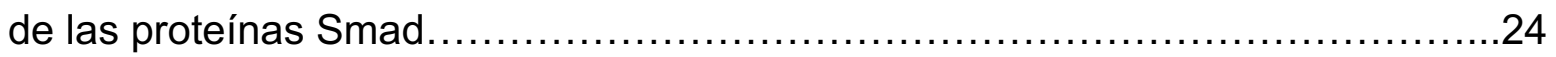

8.4 El GDF11 induce efectos antiproliferativos en las líneas celulares de

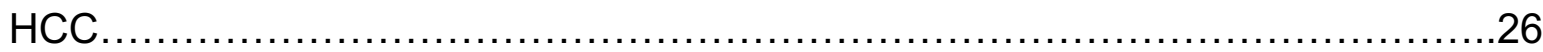

8.5 El GDF11 afecta la funcionalidad mitocondrial de las células de HCC 31

8.6 El GDF11 induce cambios transcriptómicos en la línea celular Huh7. 36 8.7 El GDF11 disminuye la capacidad de formación de esferoides de las células de HCC 39

8.8 El GDF11 disminuye la expresión de algunos genes relacionados con

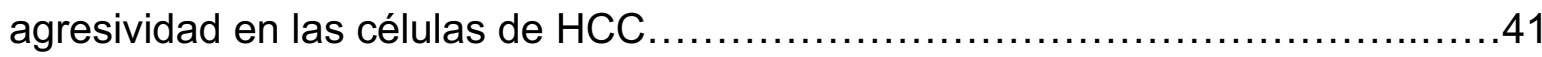

8.9 El GDF11 induce transición mesénquima epitelial............................42 8.10 El GDF11 reprime la capacidad de auto renovación de las células de

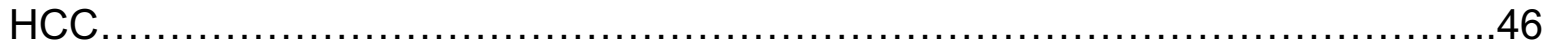

8.11 El GDF11 disminuye la migración de las células de HCC.....................50

8.12 El GDF11 disminuye la formación de esferoides en otras líneas de

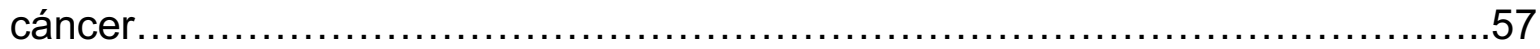

8.13 El GDF11 activa la señalización de ERK1/2 ................................60

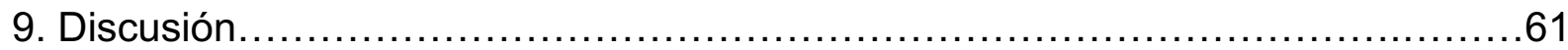

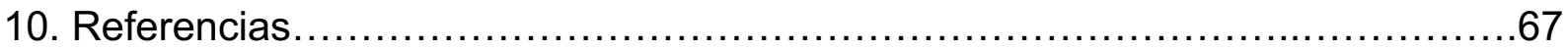

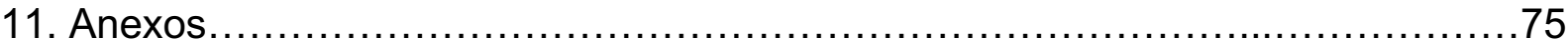




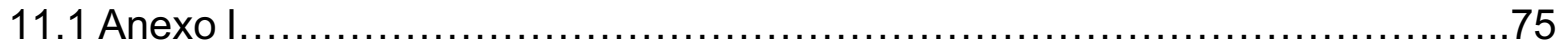

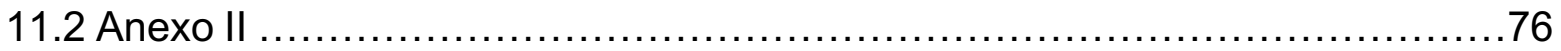




\section{Introducción}

\subsection{Generalidades del hígado}

El hígado es uno de los órganos internos más grande de nuestro cuerpo, tiene un peso promedio de $1.5 \mathrm{~kg}$ en el adulto, en él fluye aproximadamente litro y medio de sangre cada minuto, de ahí su color característico. El hígado realiza más de 500 funciones entre las que están la transformación de los alimentos en energía, la síntesis de factores de coagulación, la eliminación de sustancias tóxicas, produce la bilis que se secreta en el intestino para ayudar a absorber nutrientes que no son hidrosolubles, almacena algunas vitaminas y al glucógeno (un reservorio importante de energía). Aun cuando está especializado para llevar a cabo dichos procesos, es muy susceptible a la agresión que suele comprometer su funcionamiento adecuado.

\subsection{Principales agentes tóxicos y estadios de daño hepático}

Entre los principales agentes que lo afectan se encuentran algunas sustancias toxicas como lo son: el alcohol, fármacos, drogas, exceso de grasas y las infecciones por virus como la hepatitis B y hepatitis C.

Cuando la agresión se vuelve crónica, el órgano puede sufrir una esteatosis, si las agresiones continúan, puede progresar a un proceso de inflamación denominada esteatohepatitis, siguiendo al proceso de fibrosis, cirrosis y culminar finalmente en un hepatocarcinoma celular (HCC, por sus siglas en inglés) (Gutiérrez Ruiz et al., 2014).

El cambio en el estilo de vida de muchas personas está tendiendo a incrementar la prevalencia en las enfermedades hepáticas, como la asociada al consumo de alcohol, la esteatohepatitis no alcohólica y el cáncer hepático. 


\subsection{Estadísticas del cáncer de hígado}

El hepatocarcinoma celular (HCC, por sus siglas en inglés) es uno de los tumores con mayor prevalencia y uno de los más agresivos en todo el mundo, se posiciona como una de las principales causas de muerte por cáncer a nivel mundial (Ferlay et al., 2015; Kaposi-Novak et al., 2006; Liu et al., 2017).

En 2018, el Instituto Nacional del Cáncer en Estados Unidos hizo público en su Reporte Anual de la Nación (Cronin et al., 2018) la incidencia y mortalidad de diversos tipos de cáncer. Sorprendentemente, los datos mostraron que la gran mayoría de los tipos de cáncer han disminuido tanto en la incidencia como en la mortalidad en hombres y mujeres, encontrando que de los 18 tipos de cáncer más comunes en hombres 11 han disminuido y de los 20 tipos más comunes en mujeres 14 han disminuido, lamentablemente, no todos los tipos de canceres siguen la misma tendencia a disminuir, ya que el cáncer de páncreas, encéfalo, algunos relacionados con el sistema nervioso y el cáncer de hígado lejos de disminuir van en aumento.

El Instituto Nacional de Estadística y Geografía INEGI en México (www.inegi.org.mx) reportó en 2015 las cifras de las principales causas de muerte en hombres y mujeres, de las cuales 35,718 muertes registradas fueron causadas por enfermedades relacionadas con el hígado, de las cuales 6,333 muertes fueron por causa de tumores malignos, por lo que, lo posiciona como el tercer tipo de cáncer con mayor índice de mortalidad registrada en dicho año.

Este índice de mortalidad relacionada con enfermedades hepáticas aumenta con la edad, ya que se posiciona como el segundo lugar en hombres con edades entre 30 a 44 años, manteniendo el mismo lugar entre las edades de 45 y 59 años. En hombres 
de 60 años y más, las muertes relacionadas con las enfermedades hepáticas se posicionan como la quinta causa.

Estas cifras se mantienen en mujeres, ya que en edades entre 45 y 59 años esta causa de muerte se posiciona en el tercer lugar y en mujeres mayores a los 60 años las muertes por este padecimiento se posicionan en el sexto lugar (www.inegi.org.mx $)$.

Este incremento en la incidencia y la mortalidad es debido principalmente a la detección en etapas avanzadas de la enfermedad, y son estas etapas donde las terapias no suelen funcionar de manera óptima, por esta razón, en la actualidad uno de los principales objetivos para la ciencia es la búsqueda de nuevas terapias, que sean específicas y eficaces o bien mejoras para la detección temprana del HCC.

\subsection{Características del cáncer hepático}

El HCC se caracteriza por la proliferación descontrolada de los hepatocitos y la acumulación de mutaciones lo que conlleva a desórdenes en diversas rutas de señalización encargadas de modular procesos que confieren a las células cancerosas sobrevivencia, alteración en el metabolismo energético, resistencia a fármacos y capacidad para migrar (Hanahan et al., 2011).

\subsection{El papel de la ruta de las MAPK en el cáncer de hígado}

Una de las rutas que se encuentra afectada en HCC y que se ha reportado que juega un papel esencial es la de la familia de las MAPK (mitogen- activated protein kinase) (Mandal et al., 2016). Esta familia está conformada por aproximadamente 518 miembros y se encuentra ampliamente conservada en los seres vivos (Lu et al., 2006). 
La familia de las MAPK se encuentra orquestando procesos esenciales para las células ya que está implicada en el crecimiento y la diferenciación celular, procesos de mitosis, motilidad celular, metabolismo energético, proliferación, apoptosis, sobrevivencia, procesos de embriogénesis y en la regulación de la expresión de genes (Chen et al., 2001).

Esta ruta actúa mediante una cascada de señalización que implica la activación de intermediarios comenzando por la activación de MAPK3, esta cinasa es la encargada de fosforilar y activar al siguiente intermediario MAPK2 y esta finalmente culmina con la activación de MAPK, quien es la responsable de unirse al núcleo permitiendo la expresión de genes relacionados con los procesos anteriormente mencionados (Chang et al., 2001; Leppa et al., 1999).

Esta familia está conformada por diversos miembros, entre ellos se encuentra ERK (extracellular signal- regulated kinases), JNK y P38 (Lu et al., 2006).

ERK a su vez es una de las principales rutas de señalización debido a que también juega un papel importante en procesos como proliferación celular, diferenciación, progresión del ciclo celular, migración, motilidad, invasión, metástasis e interacción con la matriz celular (Cargnello et al., 2011; Mandal et al., 2016; Mandal et al., 2014; Roberts et al., 2007).

Principalmente la activación de esta ruta se ha relacionado con procesos de agresión como en el caso de la ingesta alta de colesterol (Gomez-Quiroz et al., 2016).

La activación de esta ruta también se lleva a cabo mediante un estímulo derivado de factores de crecimiento como el factor de crecimiento epidermal (EGF), el factor de crecimiento derivado de plaquetas (PDGF), receptores acoplados a proteínas G, 
factores mitogénicos, citocinas y proteínas G. Una vez que llega el estímulo se activará RAS, la cual se va a encargar de la activación de RAF, que a su vez activará a MEK que finalmente activa a ERK (Geest et al., 2009; Mandal et al., 2016; Mandal et al., 2014).

Se ha observado que alteraciones en esta ruta de señalización se encuentra estrechamente ligada con el 30\% de neoplasias (Gollob et al., 2006; Mandal et al., 2016). Hay reportes que indican que el oncogen RAS presenta varias mutaciones, por lo que se está trabajando en el diseño de inhibidores como posible terapia para diversos tipos de cáncer (Gollob et al., 2006).

\subsection{El papel del TGF- $\beta$ en el cáncer de hígado}

Otra de las vías que juega un papel importante en la progresión del cáncer es la de la superfamilia del factor de crecimiento transformante beta (TGF- $\beta$ ) la cual podría considerarse como un posible blanco terapéutico. Sin embargo, dado el papel dual que juega es difícil ya que en etapas tempranas de la enfermedad sus efectos suelen ser citotóxicos, mientras que en etapas avanzadas los principales efectos que suele ejercer sobre el tumor son el crecimiento, procesos de invasión y metástasis, la evasión del sistema inmune entre otros (Moon et al., 2017; Zhang, J. et al., 2016; Zhang et al., 2017).

\subsection{Generalidades del GDF11}

Uno de los miembros de la superfamilia del TGF- $\beta$ es el factor de crecimiento y 
diferenciación 11 (GDF11), quien también se encuentra en la familia de las proteínas morfogenéticas de hueso (BMP), donde es conocido como BMP11 el cual se ha asociado con efectos diferenciales en los distintos linajes celulares, mientras que en unos puede inducir citotoxicidad, en otros, puede iniciar señales de sobrevivencia (Sinha et al., 2014; Zhang et al., 2015; Zhang, Y. H. et al., 2016).

\subsection{Ruta de señalización mediada por el GDF11}

Esta proteína induce su señalización mediante un complejo tetramérico de receptores con actividad de serina treonina cinasa, este complejo de receptores está conformado por dos receptores tipo I a los que pertenecen los receptores ALK y dos receptores tipo II, entre los que se encuentran ACTRII.

Si bien, el GDF11 se encuentra entre dos familias, ambas inducen activación de proteínas Smad de manera distinta y esto se debe al tipo de receptor que se esté activando por el GDF11.

Cuando la activación es mediada por la ruta canónica del TGF- $\beta$, el GDF11 se une a Ios receptores tipo I como ALK4, ALK5 o ALK7 y a receptores tipo II como ACTRIIA o ACTRIIB (Walker et al., 2017; Williams et al., 2013).

Cuando la ruta de señalización es mediada por la familia de las BMP la activación de los receptores es distinta, ya que para esta la ruta va mediada por los receptores ALK1, ALK2, ALK3 y ALK6 (Ning et al., 2019; Zhang, Y. H. et al., 2016).

Una vez que el GDF11 se une a los receptores tipo I, estos se encargan de activar a las proteínas Smad, las cuales también son conocidas como R-Smad, nuevamente, 
según el tipo de receptores que se activen serán las encargadas de activar la ruta de las proteínas Smad, en el caso del TGF- $\beta$, la ruta activada de manera canónica esta mediada por Smad2/3 (Williams et al., 2013), para el caso de las BMP, la ruta canónica de las Smad es vía Smad 1/5 (Zhang, Y. H. et al., 2016) (Fig. 1).

Una vez activadas las proteínas R-Smad una Smad en común (Smad 4), también conocida como Co-Smad, se les une formando así un complejo que se transloca al núcleo para la expresión de diversos genes que se encargan de regular procesos relacionados con el desarrollo, diferenciación, migración y proliferación celular (Finkenzeller et al., 2015; Gaunt et al., 2013; Massague, 2012; Williams et al., 2013).

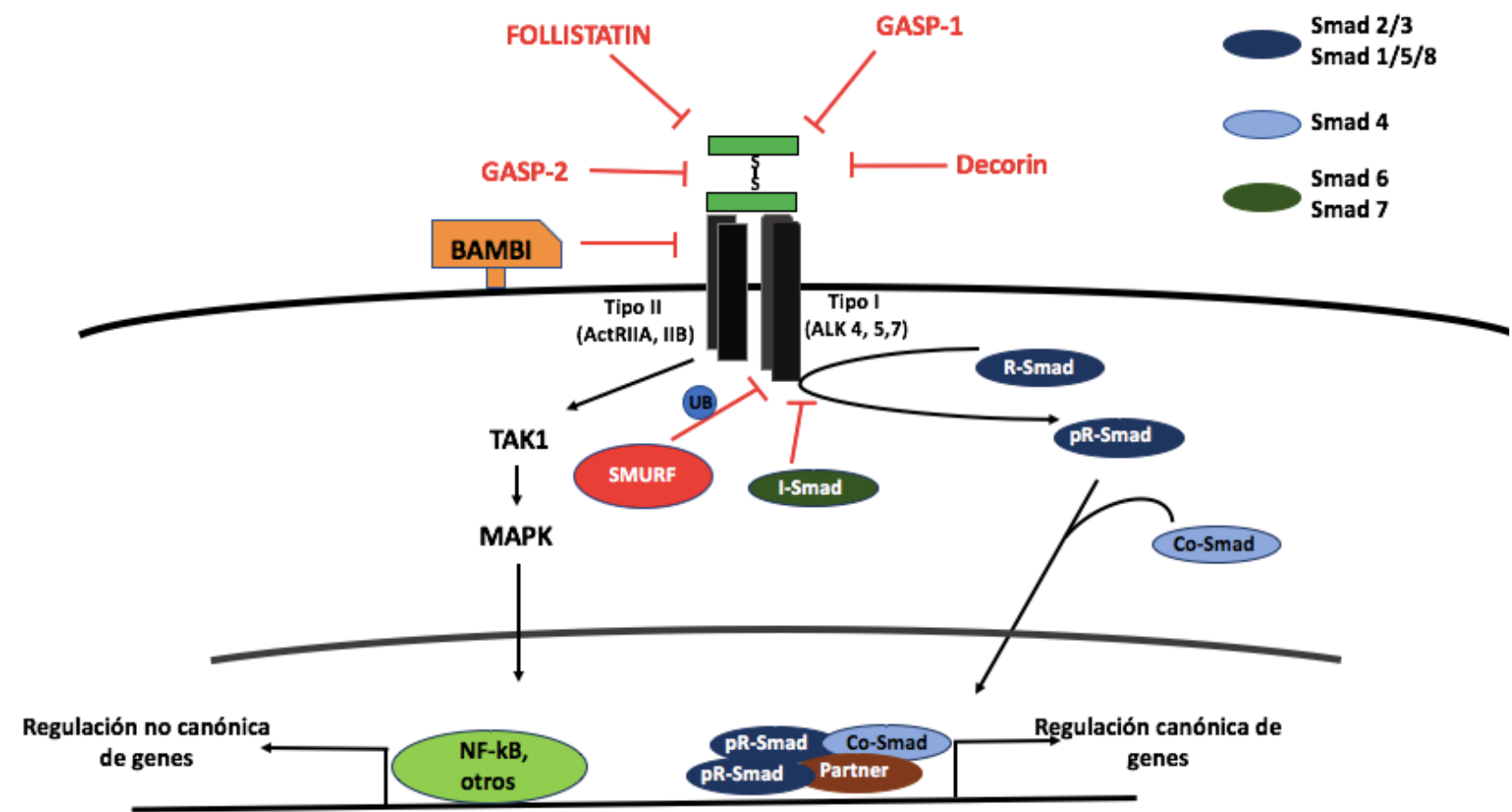

Fig. 1 Ruta de señalización mediada por el GDF11.

Si bien, esta familia se caracteriza por la amplia diversidad de receptores y ligandos, los mencionados para GDF11 tienen respuestas fisiológicas distintas comparadas con 
las respuestas producidas por la unión de otros ligandos con sus receptores correspondientes, sin embargo de las principales respuestas emitidas por GDF11 son las relacionadas con la inhibición de la neurogénesis controlando la expresión de p27, un regulador negativo del ciclo celular que interactúa con las cinasas dependientes de ciclinas, además de regular la expresión de otros genes relacionados con dicho proceso e inhibiendo la proliferación celular, también, suprime la expresión de genes implicados en la migración celular incluyendo FASCIN, LIM y LASP1, ejerce efectos sobre la activación de Hoxd11, un factor de transcripción que juega un papel importante en la morfogénesis de organismos multicelulares (Gaunt et al., 2013; Williams et al., 2013).

\subsection{Funciones del GDF11}

Entre las funciones fisiológicas del GDF11 se encuentran procesos de desarrollo, embriogénesis, diferenciación y organogénesis, regeneración del músculo esquelético, el músculo cardiaco y el sistema neural a partir de células progenitoras; y esto se lleva a cabo mediante el incremento de la proliferación y la diferenciación de las células troncales, las cuales dan origen a más células que, después de su maduración serán las encargadas de sustituir a las células dañadas cuya función se encuentra comprometida devolviendo así a los músculos sus funciones fisiológicas adecuadas (Esquela et al., 2003; McPherron et al., 1999; Nakashima et al., 1999; Sinha et al., 2014). Estos descubrimientos se determinaron mediante el uso del GDF11 recombinante en ratones viejos, donde determinaron que el uso de este factor de 
crecimiento provocó el aumento de la frecuencia de células satélites, lo cual se vio reflejado en el incremento en el mejoramiento muscular (Sinha et al., 2014).

Otro de los efectos que se han demostrado que induce esta molécula son sobre los procesos de invasión y metástasis (Finkenzeller et al., 2015; Ge et al., 2005; Gokoffski et al., 2011; Williams et al., 2013).

\section{Antecedentes}

En 2007, el grupo del Dr. Mori reportó por primera vez la relación existente entre el GDF11 y el cáncer colorectal, donde encontraron un incremento del ARNm del factor de crecimiento en muestras de pacientes con mal pronóstico. Interesantemente, este aumento se hizo más notorio en muestras de pacientes considerados con pobre pronóstico debido a la baja sobrevivencia después de la intervención quirúrgica, por esta razón se relacionó al factor como un posible marcador de agresividad (Yokoe et al., 2007).

En 2017, el grupo del Dr. Bajikar (Bajikar et al., 2017), reportó el efecto antitumorigénico de GDF11 en cáncer de mama humano triple negativo y reportaron que la presencia de dicho factor confería a las células la pérdida de la capacidad migratoria, considerada como una característica de agresividad, debido al aumento de E-cadherina, proteína que se encarga de mantener a las células epiteliales ancladas al sustrato, además, de una disminución en la proliferación celular. Efectos similares se reportaron en ratones a los cuales se le implantaron células MDA- MB- 231, dicho modelo demostró que esta línea celular presenta un aumento en la susceptibilidad a la apoptosis. Al estudiar el mecanismo por el cual se producían estos efectos 
encontraron que se debió principalmente al impedimento de la maduración de GDF11 ya que la convertasa Pcsk5, la cual es la encargada de llevar a cabo este proceso no funcionaba adecuadamente, debido a la presencia de mutaciones principalmente en sus sitios activos. Esto provocó que la célula presentara una acumulación del GDF11 inmaduro en su interior (Bajikar et al., 2017; Essalmani et al., 2008) .

Los resultados anteriores se vieron reforzados por los encontrados en el grupo del Dr. Behr, quien determinó la relación del GDF11 con el cáncer de mama, reportando que las células después del tratamiento con el factor de crecimiento perdieron la capacidad de migrar. Además, encontraron en pacientes con cáncer de mama, con un índice de recaída menor, que los niveles de expresión de GDF11 eran altos (Wallner et al., 2018).

\section{Justificación}

El HCC es una de las principales causas de muerte por cáncer a nivel mundial, mientras que, en México, las defunciones por enfermedades del hígado se posicionan en el tercer lugar, razón por la cual se ha convertido en un serio problema de salud pública. Una de las dificultades para tratar esta patología es debido a su detección tardía ya que esta suele presentarse como un padecimiento asintomático en sus etapas iniciales permitiendo el avance rápido, por lo que cuando se diagnostica, en la mayoría de los casos, las terapias comunes ya no suelen ser efectivas, siendo la principal opción el trasplante del órgano. Sin embargo, esta opción suele ser poco alentadora debido al bajo índice de donación de órganos y al riesgo que presenta. 
Por esta razón, es importante buscar nuevas terapias que sean efectivas, con menor riesgo y menos invasivas para los pacientes.

El GDF11 puede ser una buena opción terapéutica debido a los efectos antitumorales observados in vitro por lo que es importante conocer el mecanismo de acción por el cual actúa dicho factor para inducir tales efectos.

\section{Pregunta de investigación}

¿Cuál es el mecanismo desplegado por el GDF11 en la inducción de sus efectos antitumorigénicos en células de cáncer hepático humano?

\section{Hipótesis}

Por su fenotipo troncal, las células Huh7 y Hep3B responderán al GDF11 induciendo un efecto antitumorigénico medido por la regulación del metabolismo y la transición mesénquima epitelial.

\section{Objetivos}

\subsection{Objetivo general}

Caracterizar el mecanismo por el cual el GDF11 induce efectos antitumorales en células Huh7 y Hep3B derivadas de carcinomas hepatocelular humano. 


\subsection{Objetivos particulares}

- Caracterizar los efectos antitumorigénicos ejercidos por el GDF11 en células Huh7 y Hep3B derivadas de carcinomas hepatocelular humano.

- Determinar la transducción de señales en respuesta al GDF11 en células Huh7 y Hep3B.

- Caracterizar los efectos del GDF11 en la transición mesénquima epitelial.

- Evaluar las propiedades de invasión del GDF11en un modelo de membrana corioalantoidea de embriones de pollo.

- Determinar los efectos transcriptómicos globales que ejerce el GDF11 en células Huh7 por medio de RNA-seq y su relación con el fenotipo celular.

\section{Material y Métodos}

\subsection{Diseño experimental}

Se usó el factor de crecimiento y diferenciación 11 (GDF11) recombinante humano (Peprotech) a una concentración de $50 \mathrm{ng} / \mathrm{ml}$ siguiendo los protocolos (Fig. 2). 

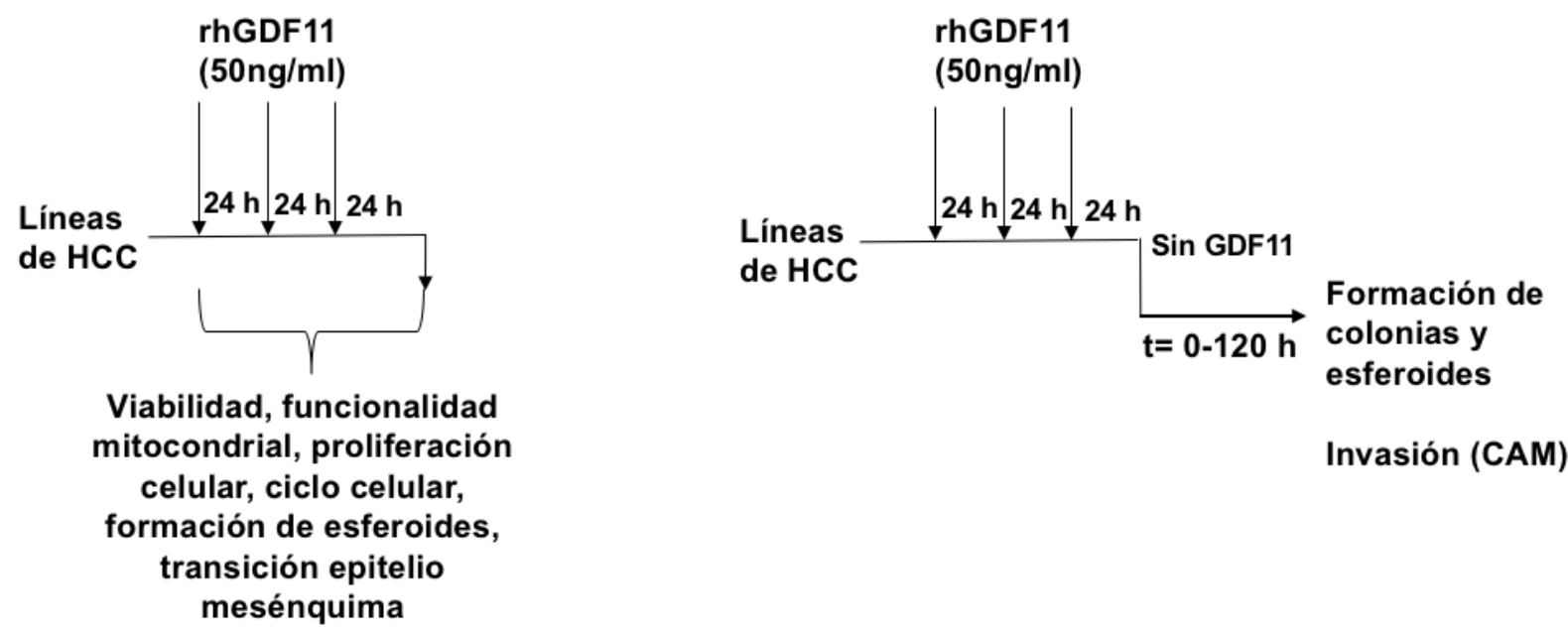

Fig. 2 Diseño experimental del proyecto desarrollado

\subsection{Cultivo celular}

Se usaron las líneas celulares Huh7, Hep3B, HepG2, SNU182 y Hepa1-6 las cuales son derivadas de carcinomas hepatocelulares, MDA-MB-231 derivadas de un carcinoma de mama y CAPAN1 derivada de un cáncer de páncreas. Todas las líneas celulares fueron obtenidas de la ATCC (Manassas, VA, USA). Se cultivaron usando medio Williams (Sigma- Aldrich, USA), con suero fetal bovino (SFB) (Hyclone, USA) al $10 \%$ y antibiótico y antimicótico (Thermo Fisher, USA) al 1\%, las células se mantuvieron al $5 \%$ de $\mathrm{CO}_{2}, 90 \%$ de humedad y $37{ }^{\circ} \mathrm{C}$. Se sembraron en botellas para cultivo de plástico (Costar Inc, USA). Todos los experimentos se realizaron en un

intervalo de pasaje 20-35. Se usó el factor de crecimiento y diferenciación 11 recombinante humano GDF11, (Peprotech Inc, USA) a una concentración de $50 \mathrm{ng} / \mathrm{ml}$ por diferentes intervalos de tiempo. 


\subsection{Cuantificación de proteína}

Se realizó la extracción de proteína usando un buffer de lisis con inhibidores de proteasas (PhosSTOP, Rocher, Complete, Rocher). Se realizó la cuantificación de la proteína mediante el estuche comercial de ácido bicinconínico (BCA, Pierce, Thermo Fisher Scientific) siguiendo el protocolo del fabricante.

\subsection{Western blot}

El western blot se realizó siguiendo el protocolo previamente reportado (EnriquezCortina et al., 2013). Se usó membrana de PVDF (Bio-Rad, USA) con los anticuerpos descritos en la tabla 1. Las membranas fueron expuestas usando Super Signal West Pico Quimioluminiscente (Pierce Biotechnology, USA). Las membranas fueron reveladas usando un Gel Logic 2500 (Kodak, Rochester, NY, USA)

\begin{tabular}{|l|l|l|l|}
\hline Anticuerpo & Dilución & Secundario & Número de catálogo \\
\hline Smad3 & $1: 1000$ & Rabbit & Abcam. Ab40854 \\
\hline pSmad3 & $1: 1000$ & Rabbit & Abcam. Ab52903 \\
\hline Smad2 & $1: 1000$ & Rabbit & Cell Signaling 5339 S \\
\hline pSmad2 & $1: 1000$ & Rabbit & Cell Signaling 3108 S \\
\hline Smad1 & $1: 1000$ & Rabbit & Cell Signaling 6944 S \\
\hline Smad5 & $1: 1000$ & Rabbit & Cell Signaling 12534 S \\
\hline pSmad1/5 & $1: 1000$ & Rabbit & Cell Signaling 9516 S \\
\hline ACVRIIA & $1: 1000$ & Rabbit & Abcam. Ab96793 \\
\hline Cyclin D1 & $1: 200$ & Rabbit & Santa Cruz. Biotechnology sc-753 \\
\hline Cyclin A & $1: 200$ & Rabbit & Santa Cruz. Biotechnology sc-751 \\
\hline Cdk6 & $1: 200$ & Rabbit & Santa Cruz. Biotechnology sc-7181 \\
\hline p27 & $1: 200$ & Rabbit & Santa Cruz. Biotechnology sc-776 \\
\hline Occludin & $1: 200$ & Mouse & Santa Cruz. Biotechnology sc-81812 \\
\hline Snail & $1: 200$ & Rabbit & Santa Cruz. Biotechnology sc-28199 \\
\hline E- Cadherin & $1: 200$ & Mouse & Santa Cruz. Biotechnology sc-21791 \\
\hline N-Cadherin & $1: 200$ & Mouse & Santa Cruz. Biotechnology sc-59987 \\
\hline ERK 1/2 & $1: 1000$ & Rabbit & Cell Signaling 4695 S \\
\hline pERK 1/2 & $1: 1000$ & Rabbit & Cell Signaling 4376 S \\
\hline Actin & $1: 10000$ & Rabbit & Millipore-Sigma A3854
\end{tabular}

Tabla. 1 Lista de anticuerpos 


\subsection{Ensayo de inmunofluorescencia}

Se realizó siguiendo el protocolo descrito (Marquardt et al., 2012). Las células fueron tratadas por diferentes intervalos de tiempo con GDF11 $(50 \mathrm{ng} / \mathrm{ml})$, posteriormente fueron fijadas con paraformaldehido al $4 \%$ en PBS (phosphate buffered saline). Las muestras fueron permeabilizadas con $0.01 \%$ con triton- $X 100$ por 30 min. $y$ bloqueadas con BSA al $3 \%$ por 30 min e incubados con los anticuerpos anti-occludin (Santa Cruz Biotechnology 81812, dilución 1:100), anti-snail (Santa Cruz Biotechnology 28199, dilución 1:100), anti-E-cadherin (Santa Cruz Biotechnology 21791, dilución 1:100) and anti-N-cadherin (Santa Cruz Biotechnology 59987, dilución 1:100). El núcleo fue teñido con DAPI. Las imágenes fueron obtenidas con un microscopio confocal (Carl Zeiss LSM- 780 NLO, Oberkochen, Alemania).

\subsection{Funcionalidad mitocondrial por MTT}

La funcionalidad mitocondrial fue medida usando bromuro de 3-(4,5-dimetiltiazol-2-il)2,5-dimetiltetrazolio mediante un ensayo de funcionalidad mitocondrial comercial (Vybrant MTT cell proliferation assay kit, Thermo Fisher Scientific) siguiendo el protocolo del fabricante.

\subsection{Determinación en tiempo real del metabolismo mediante Seahorse}

La taza del consumo de oxígeno en tiempo real de manera in vivo (OCR) y la taza de acidificación extracelular (ECAR) fue monitoreada mediante el uso del equipo Seahorse XFe24 (Seahorse Bioscience) siguiendo el protocolo estándar. La línea celular Huh7 fue tratada con GDF11 a la concentración reportada anteriormente por 
$48 \mathrm{~h}$ con medio sin SFB. Después de las $48 \mathrm{~h}$ del tratamiento, se obtuvieron 40,000 células fueron sembradas nuevamente en las placas específicas del equipo usando medio con SFB, una vez adheridas las células, se realizó el último tratamiento con GDF11 para completar las 72 h de tratamiento. Para realizar la medición en tiempo real tanto de ECAR como de OCR, las células fueron incubadas con medio de ensayo (XF Base Media) el cual fue suplementado con $2 \mathrm{mM}$ de L-glutamina seguido de una inyección de $10 \mathrm{mM}$ de glucosa, $2 \mathrm{mM}$ de oligomicina y $50 \mathrm{mM}$ de 2-deoxy-glucosa (2DG) (Glycolysis Stress test). El ECAR y el OCR fueron normalizados con el total de proteína.

\subsection{Estudio de invasión usando el modelo de membrana corioalantoidea (CAM)}

Se realizó el experimento siguiendo el protocolo reportado previamente (Quigley et al., 1998; Ribatti, 2017; Sinning et al., 2012). Se usaron huevos fértiles (Granja ALPES SA, Puebla, México), los cuales fueron separados en dos grupos de forma aleatoria. Los huevos fueron incubados a $37.8^{\circ} \mathrm{C}$ y $60 \%$ de humedad, se realizó una ventana sobre el cascaron de $1 \mathrm{~cm}^{2}$. La membrana vitelina fue diseccionada, un millón de células, tratadas y no tratadas con GDF11 por $72 \mathrm{~h}$, fueron trazadas con el colorante comercial vibrant CFDA SE cell tracer kit (Thermo Fisher Scientific) e introducidas en la CAM, entre dos vasos sanguíneos usando $30 \mu \mathrm{l}$ de matrigel (Sigma- Aldrich) como sustrato. La ventana fue cubierta con cinta adhesiva esteril y los huevos fueron incubados por 2 y 4 días. La CAM fue removida e inmediatamente fue fijada con paraformaldehido (4\%) en PBS. Las secciones en parafina fueron usadas para realizar 
las tinciones de inmunofluorescencia. El núcleo fue teñido con DAPI.

Las imágenes fueron obtenidas con un microscopio confocal (Carl Zeiss LSM- 780 NLO, Oberkochen, Alemania).

\subsection{Reacción en cadena de la polimerasa acoplada a retrotranscripción} cuantitativa

$1 \mu \mathrm{g}$ de ARN se transcribió de forma reversa usando $20 \mu \mathrm{l}$ de reacción SuperScript (Invitrogen Corp.) siguiendo el protocolo descrito por el fabricante. Los primers fueron diseñados usando Primer3 v.0.4.0 (http://frodo.wi.mit.edu/primer3/) como se reportó en (Czauderna et al., 2018). El análisis de qRT-PCR fue realizado con un CFX96 Touch (Bio-Rad) termo ciclador de reacción de placas de 96 pozos. $10 \mu$ de reacción fueron mezcladas con $5 \mu \mathrm{l}$ 2X SYBR Green PCR Master Mix (Bio-Rad), 200nM de cada primer y $1 \mu \mathrm{l}$ de cDNA. La reacción fue incubada por $10 \mathrm{~min}$ a $95^{\circ} \mathrm{C}$ seguido de 40 ciclos de 30 s a $95^{\circ} \mathrm{C}$ y 60 s a la temperatura específica del primer. El nivel de expresión de la proteína ribosomal S18 (rs18) se usó como referencia. Los niveles de expresión relativos de los genes fueron calculados usando la formula $2^{(-\Delta \Delta \mathrm{Ct})}$.

\subsection{Ensayo de inmunoprecipitación}

Se realizó siguiendo el protocolo reportado (Clavijo-Cornejo et al., 2013). Se usó la línea celular Huh7 y el GDF11 (50 ng/ml) por diferentes periodos de tiempo. Se usó el anticuerpo pSer/Thr (Abcam 17464), ACVIIA (Abcam 96793) para detectar el receptor en su forma activa. 


\subsection{Ensayo de proliferación celular}

Se realizó siguiendo el protocolo reportado (Perez-Aguilar et al., 2015). Se sembraron las líneas celulares en placas de 96 pozos estériles. Se usó el GDF11 (50 ng/ml) y se incubo por diferentes tiempos en presencia o no de SFB. La proliferación celular se midió mediante el reactivo cck-8 (Dojindo Lab, Kumamoto, Japón) siguiendo las recomendaciones del fabricante.

\subsection{Ensayo de viabilidad}

Se realizó siguiendo el protocolo reportado por (Nakagawa, 1996). Se sembraron las líneas celulares en placas de 96 pozos estériles. Se usó el GDF11 (50 ng/ml) a diferentes tiempos en presencia o no de SFB. La viabilidad celular se midió por medio de la absorbancia obtenida del cristal violeta una vez extraído con SDS.

\subsection{Ensayo de herida- cicatriz}

Se realizó el ensayo siguiendo lo reportado por (Jimenez-Salazar et al., 2014). Se sembraron las líneas células a una confluencia de $90 \%$ aproximadamente en platos de cultivo de $3 \mathrm{~cm}$. Se realizaron dos heridas usando una punta de pipetas de 1-200 $\mu \mathrm{L}$ estéril. Se realizaron lavados de forma delicada con PBS con la finalidad de remover las células no adheridas después de la realización de la herida. Las heridas realizadas fueron monitoreadas cada $24 \mathrm{~h}$. Se usó el GDF11 (50 ng/ml) por $72 \mathrm{~h}$ en presencia o no de SFB. Finalmente, una vez terminado el experimento se tomaron fotografías. 


\subsection{Ensayo de formación de esferoides}

Este ensayo se realizó siguiendo el protocolo reportado por (Perez-Aguilar et al., 2015). Se sembraron las líneas celulares en placas de baja adherencia. Se usó el GDF11 (50 ng/ml) por cinco días. Una vez terminado el tratamiento se contaron los esferoides y se tomaron fotos.

\subsection{Ensayo de clonogenicidad}

Se sembraron las líneas celulares en platos de cultivo de $6 \mathrm{~cm}$. Se usó el GDF11 (50 $\mathrm{ng} / \mathrm{ml}$ ) por $72 \mathrm{~h}$ en presencia o no de SFB. Transcurrido el tiempo, las células fueron despegadas usando tripsina y se sembraron 1000 células en placas de 6 pozos usando medio Williams con suero, pero sin la presencia del factor de crecimiento por 10 días. Al finalizar el experimento las colonias fueron teñidas con cristal violeta y se realizó el conteo de estas.

\subsection{Secuenciación masiva de ARN}

La extracción del ARN se realizó utilizando el reactivo Trizol (Thermo Fisher Scientific) siguiendo las instrucciones del fabricante.

La cantidad de ARN y la pureza se estimó utilizando un espectrofotómetro Nanodrop ND-2000c (NanoDrop Technologies, Wilmington, DE) y la integridad fue evaluada por Agilent 2100 Bioanalyzer (Agilent, Palo Alto, CA). La secuenciación del ARN se realizó utilizando la plataforma de Illumina HiSeq4000, los resultados fueron guardados en la base de datos de Bioproject. 
Las lecturas sin procesar se filtraron mediante la eliminación de secuencias adaptadoras, contaminación y calidad de lectura. Las lecturas se mapearon usando la secuencia de referencia del genoma humano (GRCh37.82) usando HISAT2 (hisat22.0.2-beta) seguido de un resumen de lectura con featureCounts (subread-1.5.0-p1). Los parámetros para el análisis de expresión diferencial fueron la tasa de descubrimiento falso (FDR) igual a 0.5 , valor $p<0.001$ y cambio de registro de pliegue de -1.5 a 1.5. Todos los análisis de datos se realizaron utilizando el lenguaje de programación $\mathrm{R}$ y paquetes relacionados. La matriz de salida de featureCounts se ingresó en el paquete Bioconductor DESeq2 para análisis de expresión diferencial.

\subsection{Análisis estadístico}

Cada experimento se llevó a cabo por triplicado en al menos tres experimentos independientes. El análisis estadístico de los resultados obtenidos se realizó mediante el análisis de varianza (ANOVA) seguido por la prueba no paramétrica Tukey para el análisis de viabilidad, funcionalidad mitocondrial mediante MTT, número de esferoides y número de colonias. La prueba t-student fue realizada para el análisis del número de esferoides.

\section{Resultados}

\subsection{EI GDF11 no afecta la viabilidad de las células de cáncer de hígado}

Debido a que el GDF11 es un miembro de la familia del TGF- $\beta$ y a dicha familia se le han atribuido efectos citotóxicos sobre las células transformadas, esto principalmente 
en etapas avanzadas del cáncer, se evaluó el impacto del GDF11 sobre la viabilidad celular, las células Huh7 y Hep3B fueron tratadas con GDF11 (50 ng/ml) por diferentes intervalos de tiempo.

Como se observa en los resultados, ambas líneas celulares no se vieron afectadas después del tratamiento, sin encontrar cambios significativos incluso $72 \mathrm{~h}$ en presencia del tratamiento (Fig. 3A y 3B)

A)

\section{Línea celular Huh7}

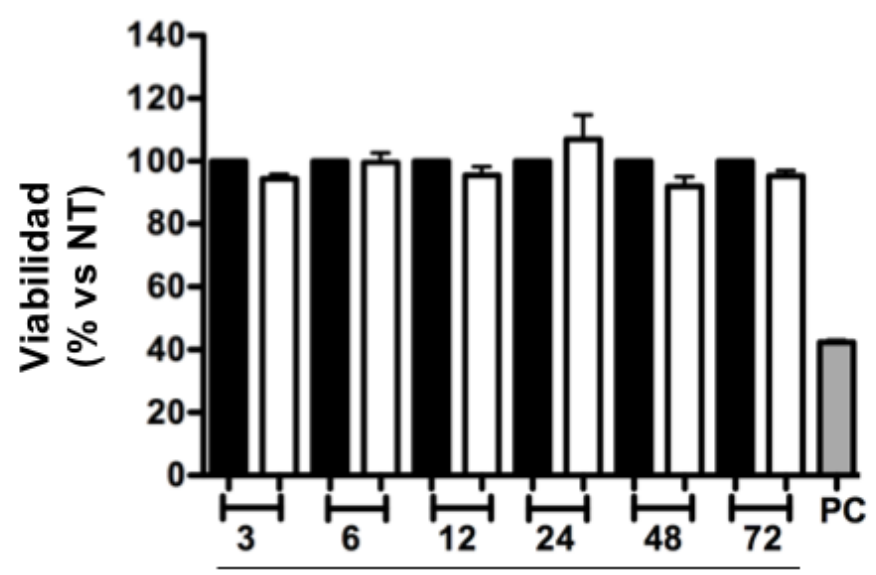

(h) GDF11 
B)

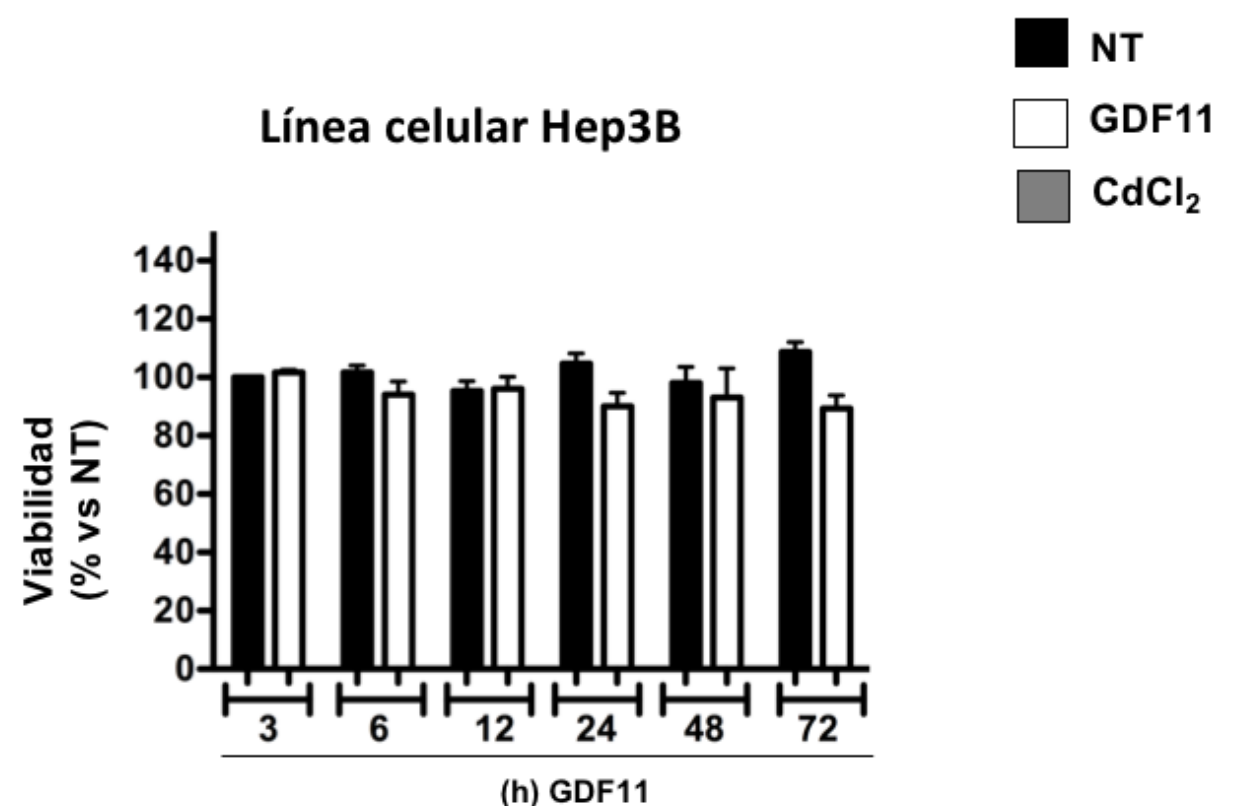

Fig. 3A y 3B El GDF11 no afecta la viabilidad de las células de cáncer de hígado. Ensayo de viabilidad celular determinado mediante cristal violeta. Se usó $\mathrm{CdCl}_{2}$ (5 $\mu \mathrm{M}$ por 6h) como control positivo (PC). Cada columna representa el promedio \pm SEM de al menos cuatro experimentos independientes por triplicado.

\subsection{La línea celular Huh7 presenta los receptores requeridos por el GDF11}

Como se pudo observar, el GDF11 no está afectando la viabilidad celular, por lo que se determinó evaluar cuales eran los receptores implicados en la señalización mediada por el factor de crecimiento. Mediante Western blot se observaron dos de los principales receptores reportados para el GDF11, ALK5, como uno de los receptores tipo I y ACTRIIA como uno de los receptores tipo II.

El resultado muestra que la línea celular Huh7 cuenta con ambos receptores del GDF11 (Fig. 4A) 
A)

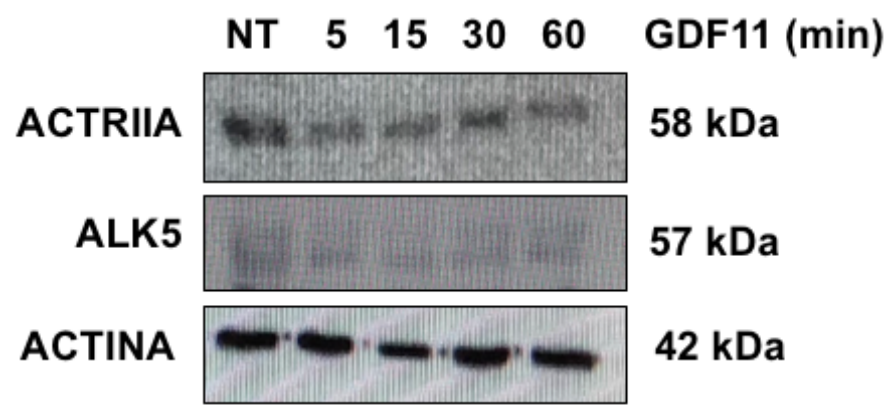

Fig. 4A La línea celular Huh7 presenta los receptores requeridos por el GDF11. Ensayo de Western blot muestra la presencia de los principales receptores usados por el GDF11. Se usó actina como control de carga.

Con la finalidad de estudiar el comportamiento de los receptores en la línea celular Huh7, se realizó un ensayo de inmunoprecipitación, el resultado muestra que el tratamiento con el GDF11 permite la activación del receptor (Fig. 4B).

B)

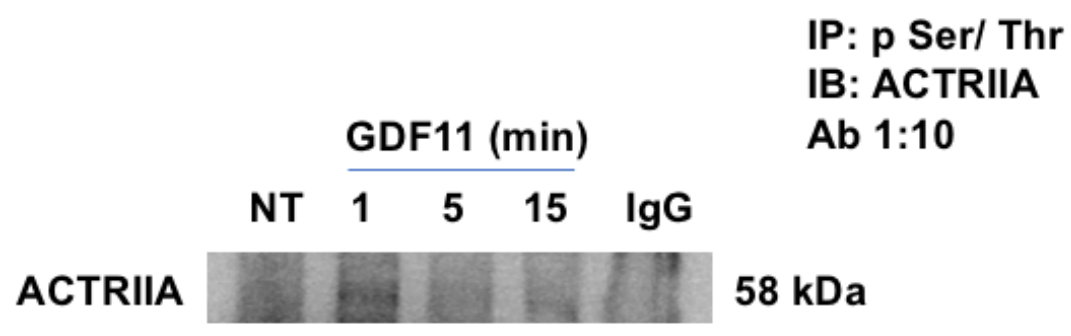

Fig. 4B La línea celular Huh7 presenta los receptores requeridos por el GDF11. Ensayo de Inmunoprecipitación, muestra activación del receptor ACTRIIA. Imagen representativa de al menos tres experimentos independientes. 


\subsection{Las líneas de HCC responden al tratamiento del GDF11 mediante la activación de las proteínas Smad}

Debido a que el GDF11 es un miembro de la superfamilia del TGF- $\beta$ y de la familia de las BMP, a continuación, se evaluó cuál de las vías canónicas de ambas familias se encontraban implicadas en los procesos observados por el GDF11 mediante su activación.

Se realizó un ensayo de Western blot para determinar las proteínas Smad activadas en la línea celular Huh7. Los resultados muestran la activación de las proteínas Smad2 y Smad3 a partir de los 5 minutos del tratamiento, esta ruta es activada de manera canónica por el TGF- $\beta$. Sin embargo, las proteínas río abajo de la familia de las BMP (Smad1 y Smad5) no participan en la señalización del GDF11 en la línea celular Huh7 ya que estas no muestran cambios después de la administración del factor de crecimiento, encontrando, además, la activación de ambas proteínas en el grupo control (Fig. 5A). En la línea celular Hep3B la activación de las proteínas Smad2 y Smad3 es a partir de los 15 minutos después de la administración del GDF11, sin embargo, también se observa la activación de las proteínas Smad1 y Smad5 a los

mismos tiempos que las proteínas canónicas de la familia del TGF- $\beta$, este resultado sugiere que la línea celular Hep3B induce efectos utilizando las dos rutas canónicas del GDF11 sin mostrar alguna preferencia por la señalización de ambas familias (Fig. $5 B)$. 
A)

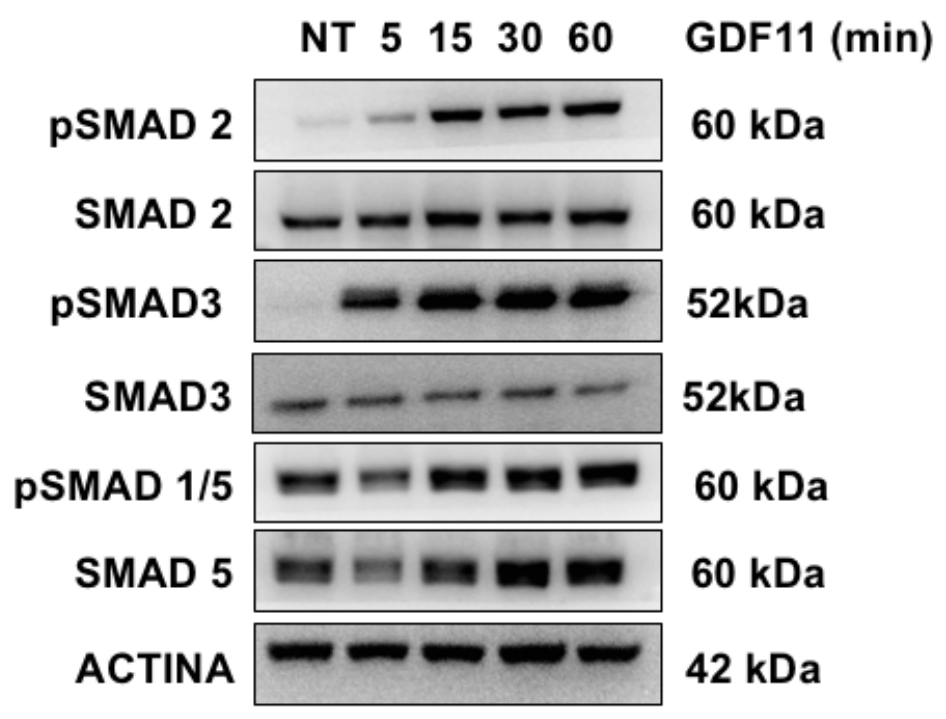

Fig. 5 Las líneas de HCC responden al tratamiento del GDF11 mediante la activación de las proteínas Smad. A) Ensayo de Western blot muestra la activación de las proteínas Smad2/3 sin encontrar cambios en la activación de las proteínas Smad1/5 en la línea celular Huh7. Imágenes representativas de al menos tres experimentos independientes.

B)

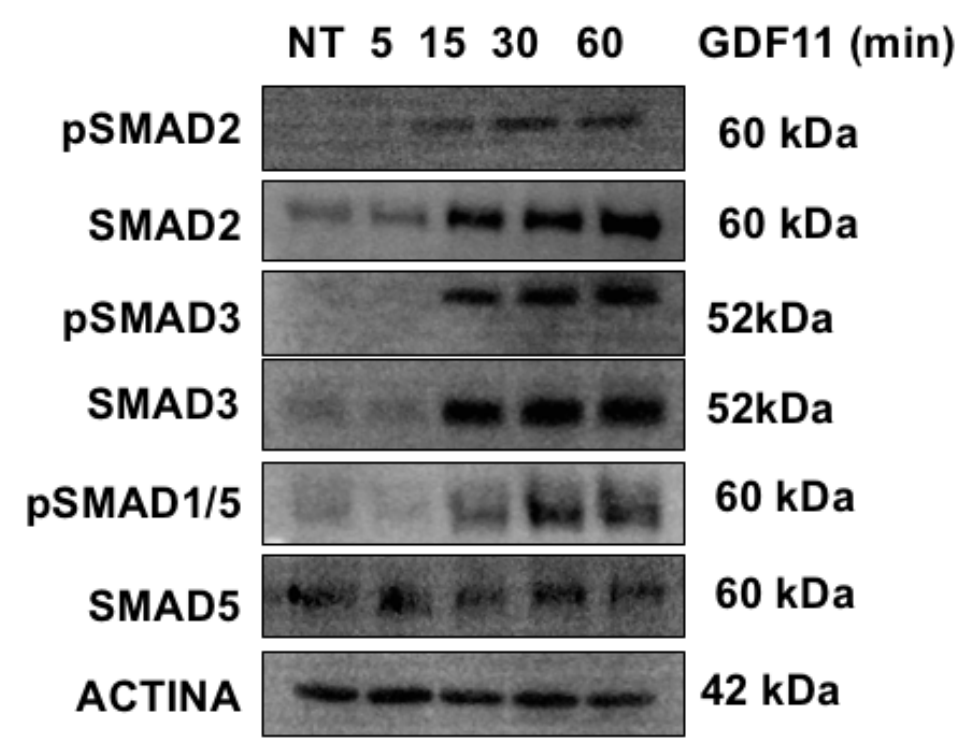

Fig. 5 Las líneas de HCC responden al tratamiento del GDF11 mediante la activación de las proteínas Smad. B) Ensayo de Western blot muestra la activación de las proteínas Smad2/3 además de la activación de las proteínas Smad1/5 en la línea celular Hep3B. Imágenes representativas de al menos tres experimentos independientes. 


\subsection{EI GDF11 induce efectos antiproliferativos en las líneas celulares de HCC}

Posteriormente se evaluó el efecto del GDF11 sobre la proliferación, si bien, resultados anteriores mostraron que no había efectos sobre la viabilidad se evaluó sí el tratamiento afectaba la proliferación de las líneas provenientes de un cáncer de hígado humano.

Los resultados muestran que el GDF11 disminuye la proliferación en ambas líneas celulares, encontrando que en las células Huh7 disminuye la proliferación de manera significativa hasta las $72 \mathrm{~h}$ de tratamiento, estos experimentos se realizaron en presencia o no de SFB, el cual fue utilizado como un agente mitogénico, permitiendo así la progresión acelerada de la proliferación celular (Fig. 6A y 6B).

A)

-/SFB

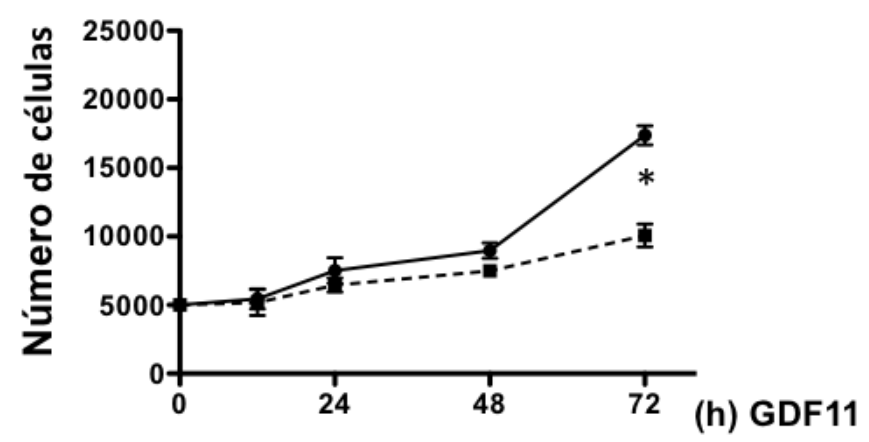


B)
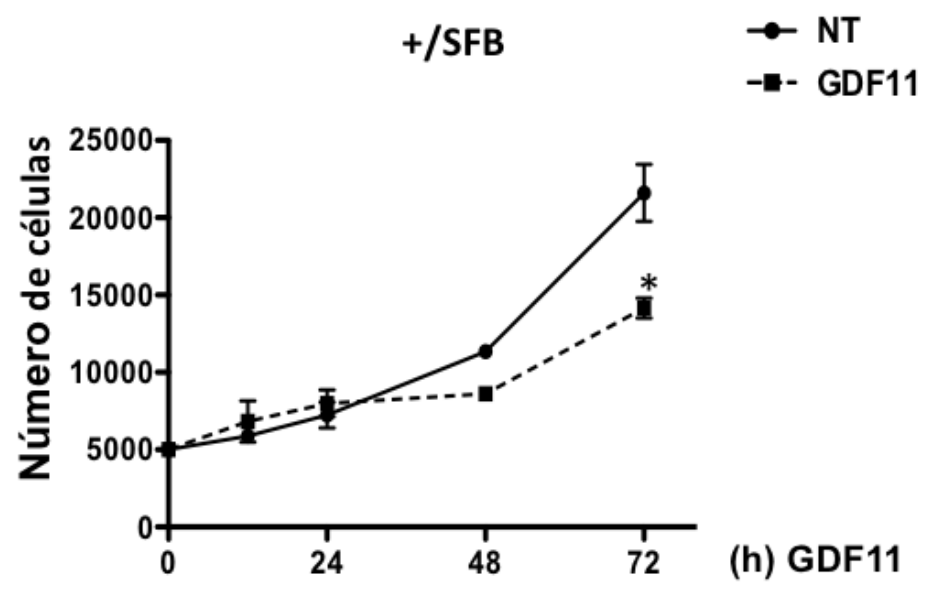

Fig. 6 EI GDF11 induce efectos antiproliferativos en las líneas celulares de HCC. A) Ensayo de proliferación celular muestra que el GDF11 induce la disminución de la proliferación sin la presencia de SFB. B) Ensayo de proliferación en presencia de SFB en la línea celular Huh7. Cada punto representa el promedio \pm SEM de al menos cuatro experimentos independientes por triplicado. ${ }^{*} p<0.05$ vs NT

Efectos similares fueron observados en las células Hep3B, donde la disminución en la proliferación se vio reflejada después de $72 \mathrm{~h}$ con el tratamiento, nuevamente, estos resultados se realizaron en presencia o no de SFB (Fig. 6C y 6D). Si bien, en ambos grupos (-/SFB, +/SFB) se observó disminución en la proliferación, los resultados fueron significativos cuando el experimento se realizó en presencia de SFB. 
C)

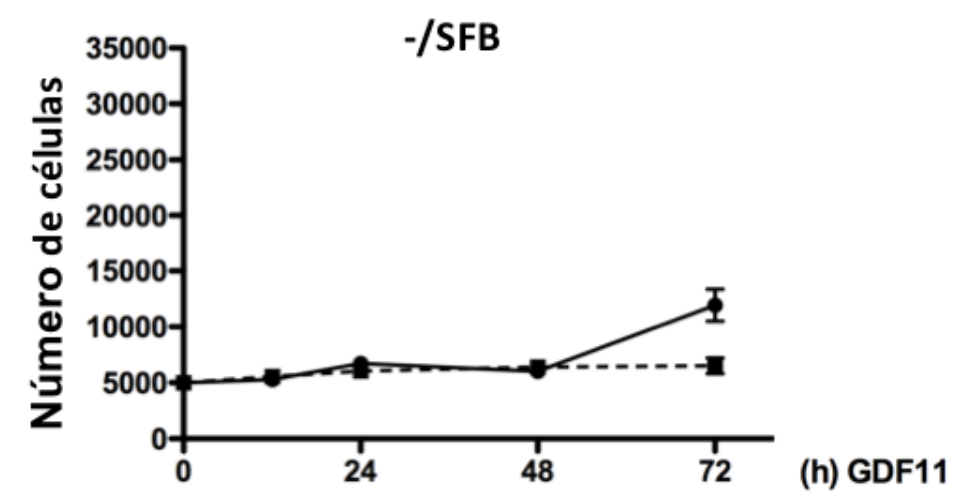

D)

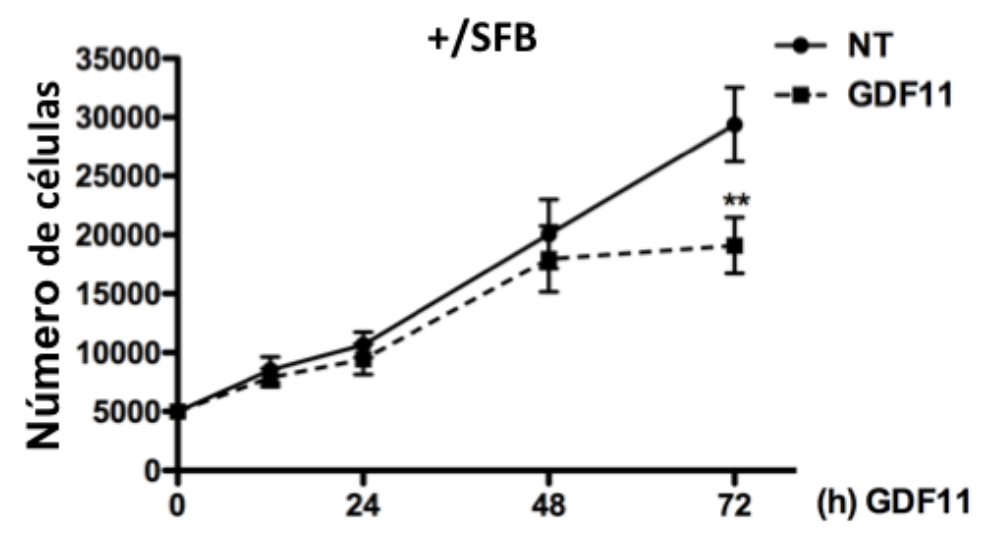

Fig. 6 El GDF11 induce efectos antiproliferativos en las líneas celulares de HCC. C) Ensayo de proliferación celular muestra que el GDF11 induce la disminución de la proliferación sin la presencia de SFB. D) Ensayo de proliferación en presencia de SFB en la línea celular Huh7. Cada punto representa el promedio $\pm S E M$ de al menos cuatro experimentos independientes por triplicado. ${ }^{* *} p<0.05$ vs NT

A continuación, se realizó además un ensayo de herida cicatriz con la finalidad de observar de manera indirecta los efectos sobre la proliferación celular, ya que dicho ensayo nos sugiere además afectos sobre la migración. Como se puede observar en las imágenes, ambas líneas celulares que estuvieron en presencia del GDF11 disminuyeron de manera notoria el cierre de la herida realizada comparada con las 
células control, las cuales, como se puede observar, después de $72 \mathrm{~h}$ la herida realizada estaba cerrada en su gran mayoría, observando efectos similares a la herida realizada en el tiempo cero (Fig. 6E y 6F).

E)
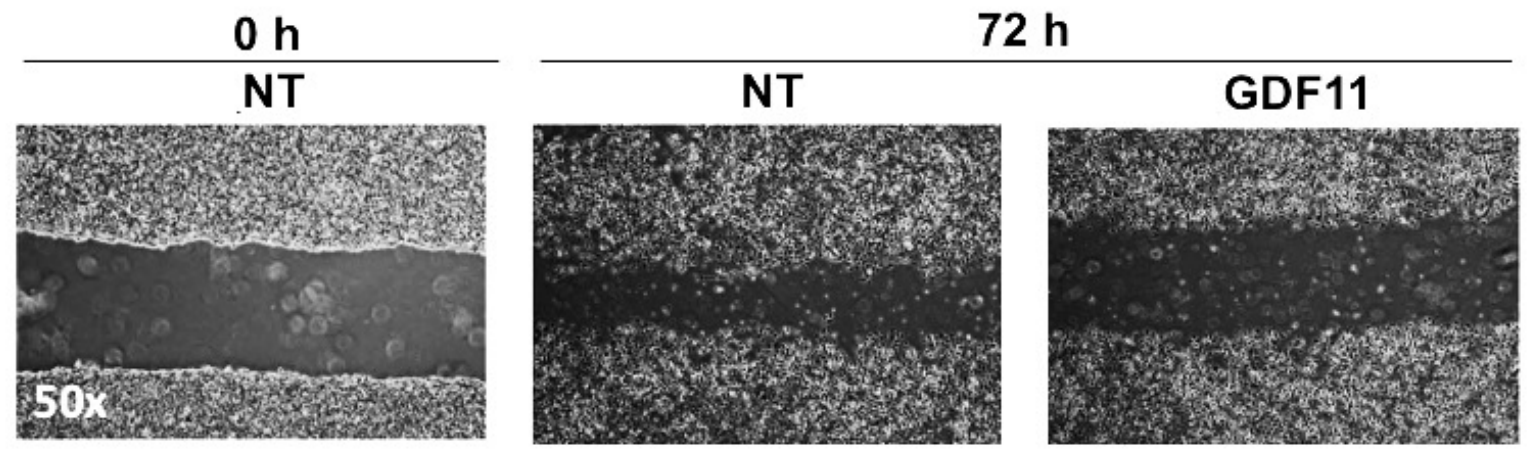

Fig. 6 EI GDF11 induce efectos antiproliferativos en las líneas celulares de HCC. E) Ensayo de herida cicatriz muestras que el tratamiento con el GDF11 retrasa el cierre de la herida en la línea celular Huh7. Imágenes representativas de al menos tres experimentos independientes.

F)

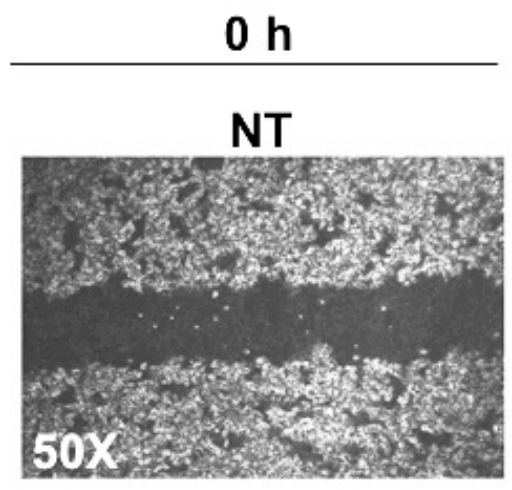

$72 \mathrm{~h}$

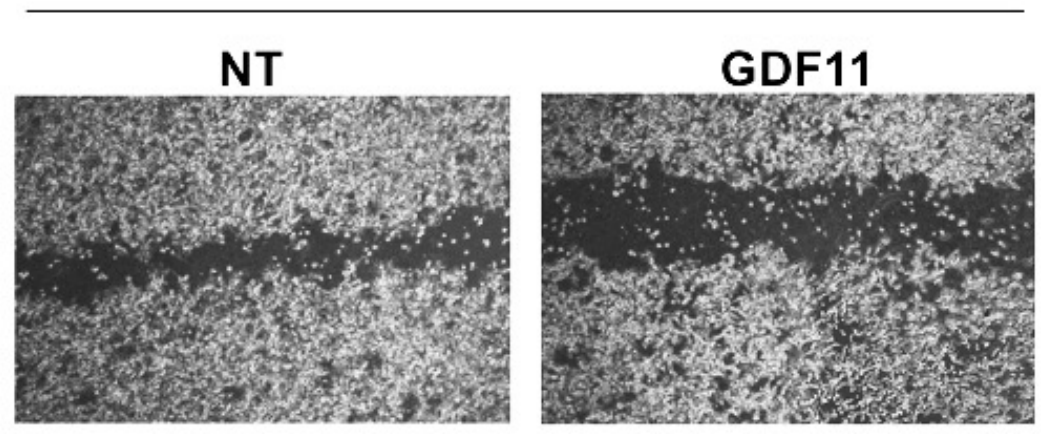

Fig. 6 El GDF11 induce efectos antiproliferativos en las líneas celulares de HCC. F) Ensayo de herida cicatriz muestras que el tratamiento con el GDF11 retrasa el cierre de la herida en la línea celular Hep3B. Imágenes representativas de al menos tres experimentos independientes. 
Para corroborar el efecto de la disminución en la proliferación celular y el cierre del ensayo de herida cicatriz, se decidió observar mediante un ensayo de Western blot algunas proteínas implicadas en la regulación del ciclo celular. Como se puede observar, algunas de las principales proteínas que se encargan de regular de manera positiva, permitiendo la progresión del ciclo celular, como ciclina A, ciclina D1 y la cinasa dependiente de ciclina (cdk6) se encuentran disminuidas después del tratamiento con el GDF11 en el transcurso del tiempo, observándose un mayor efecto después de $72 \mathrm{~h}$ con el tratamiento, mientras que la proteína p27, uno de los reguladores negativos del ciclo celular se encuentra aumentado con el tiempo.

Este resultado nos sugiere porque la proliferación se encontró disminuida (Fig. 6G y $6 \mathrm{H})$.

G)

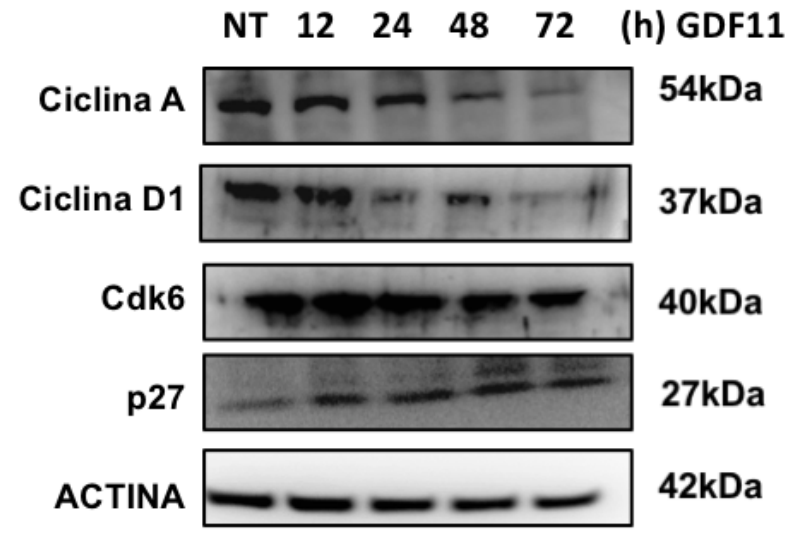


H)
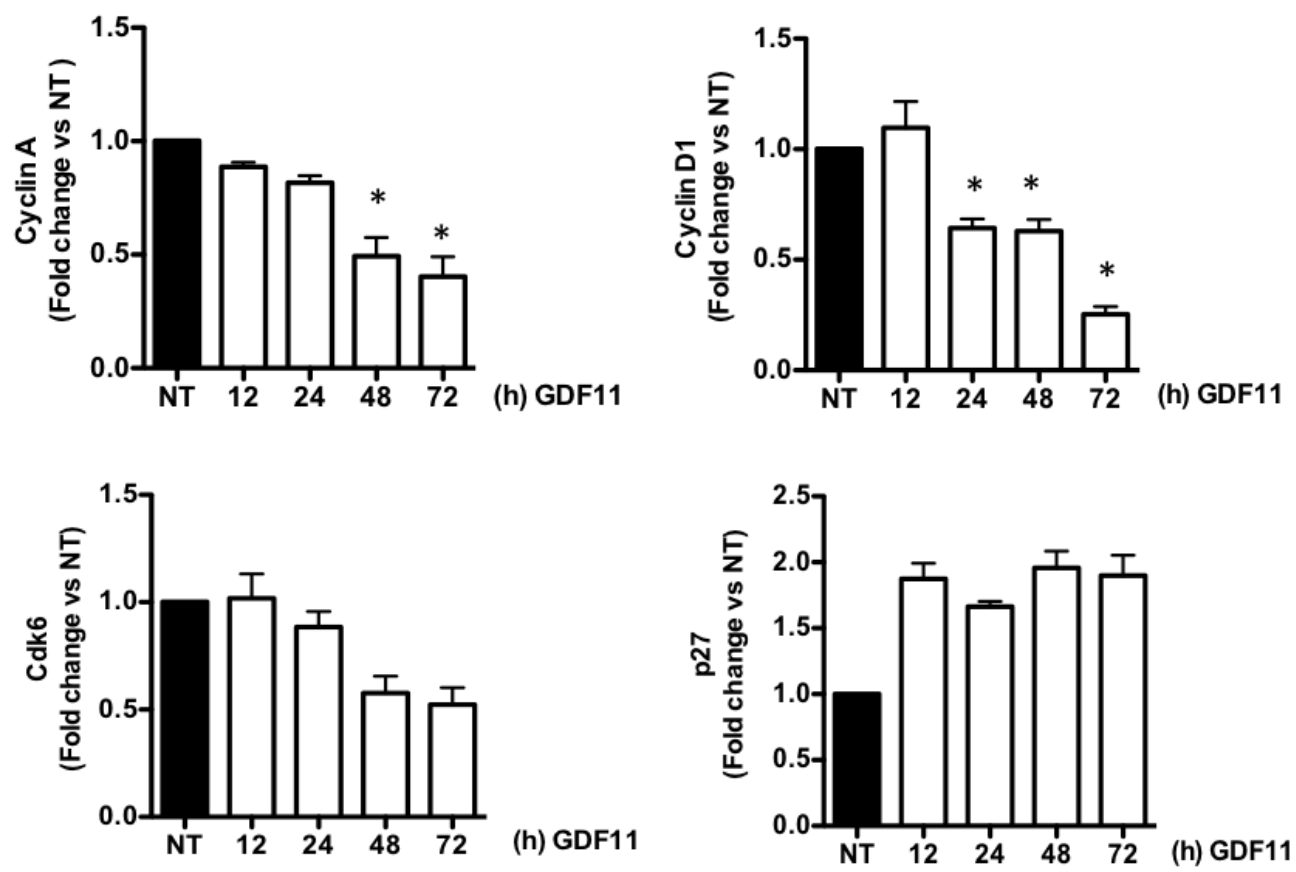

Fig. 6 El GDF11 induce efectos antiproliferativos en las líneas celulares de HCC. G) Ensayo de Western blot muestra la disminución de las principales proteínas regulatorias del ciclo celular y la sobreactivación de $p 27$, regulador negativo del ciclo celular, en la línea celular Huh7. H) Densitometría de las imágenes del ensayo de Western blot. Imagen representativa de al menos tres experimentos independientes.

\subsection{EI GDF11 afecta la funcionalidad mitocondrial de las células de HCC}

Si bien, el GDF11 no estaba afectando la viabilidad celular, pero si estaba afectando la proliferación, se decidió evaluar la funcionalidad mitocondrial por MTT de las células derivadas de HCC.

Como se puede observar, el tratamiento con el GDF11 provoco la disminución de la funcionalidad mitocondrial de la línea celular Huh7, observándose la diferencia de manera significativa a partir de las $24 \mathrm{~h}$ en presencia del tratamiento y observándose 
el punto con mayor efecto después de las $72 \mathrm{~h}$ en presencia del tratamiento en comparación con las células que no recibieron el tratamiento (Fig. 7A).

A)

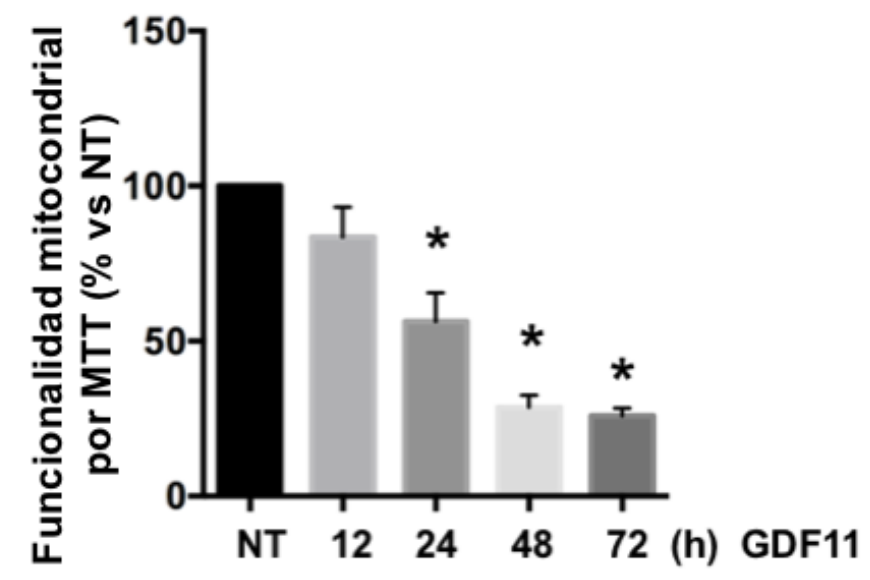

Fig. 7 El GDF11 afecta la funcionalidad mitocondrial de las células de HCC. A) Ensayo de funcionalidad mitocondrial por MTT en la línea celular Huh7 muestra la disminución después del tratamiento con GDF11, viéndose efecto desde las $24 h$, encontrando mayor efecto hasta las $72 \mathrm{~h}$. Cada columna representa el promedio \pm SEM de al menos cuatro experimentos independientes por triplicado. ${ }^{*} p<0.05$ vs NT

Efectos similares fueron encontrados en la línea celular Hep3B, donde al igual que en la otra línea celular, se observa la disminución de la funcionalidad, encontrando la disminución de manera significativa a partir de las 48 h de tratamiento (Fig. 7B). 
B)

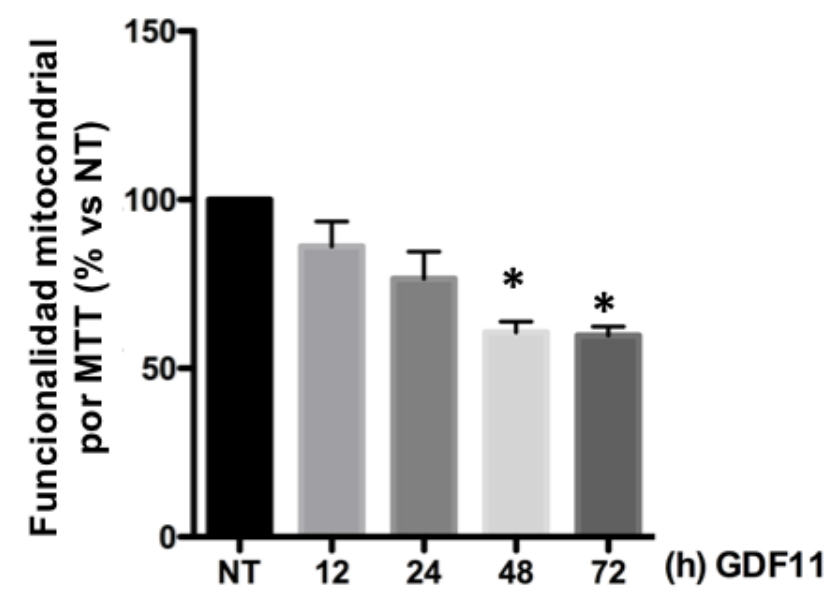

Fig. 7 El GDF11 afecta la funcionalidad mitocondrial de las células de HCC. B) Ensayo de funcionalidad mitocondrial por MTT en la línea celular Hep3B muestra la disminución después del tratamiento con GDF11, viéndose mayor efecto hasta las $72 \mathrm{~h}$. Cada columna representa el promedio \pm SEM de al menos cuatro experimentos independientes por triplicado. ${ }^{*} p<0.05$ vs NT

Nuevamente, los efectos fueron más notorios en la línea celular Huh7, estos efectos pueden deberse al grado de diferenciación que tienen las células, sugiriéndonos que la línea celular Hep3B es de un fenotipo más agresivo en comparación con la línea celular Huh7.

El ensayo de funcionalidad mitocondrial mediante MTT nos sugiere fuertemente que dicho proceso se encuentra comprometido, pero para ganar más certeza sobre los efectos que induce el GDF11 sobre la funcionalidad mitocondrial, específicamente sobre el metabolismo energético, se analizaron parámetros como ECAR, mediante la medición de la producción de lactato, indicándonos los efectos sobre la glucolisis y OCR, el parámetro relacionado con la fosforilación oxidativa, estos parámetros fueron medidos usando el equipo Seahorse Agilent. 
Las células que habían recibido el tratamiento con el GDF11 por $72 \mathrm{~h}$, como se puede observar en la gráfica, se muestra la disminución del parámetro ECAR, observando además una disminución en la respuesta de las células en presencia de glucosa, resultado que además muestra que las células presentan la disminución en el glucolisis, aunado a la disminución en la capacidad glucolítica. Mientras que las células del grupo control muestran una actividad glucolítica mejor, lo cual se relaciona con la capacidad proliferativa alta, una de las principales características de las células cancerosas (Fig. 7C y 7D).

C)

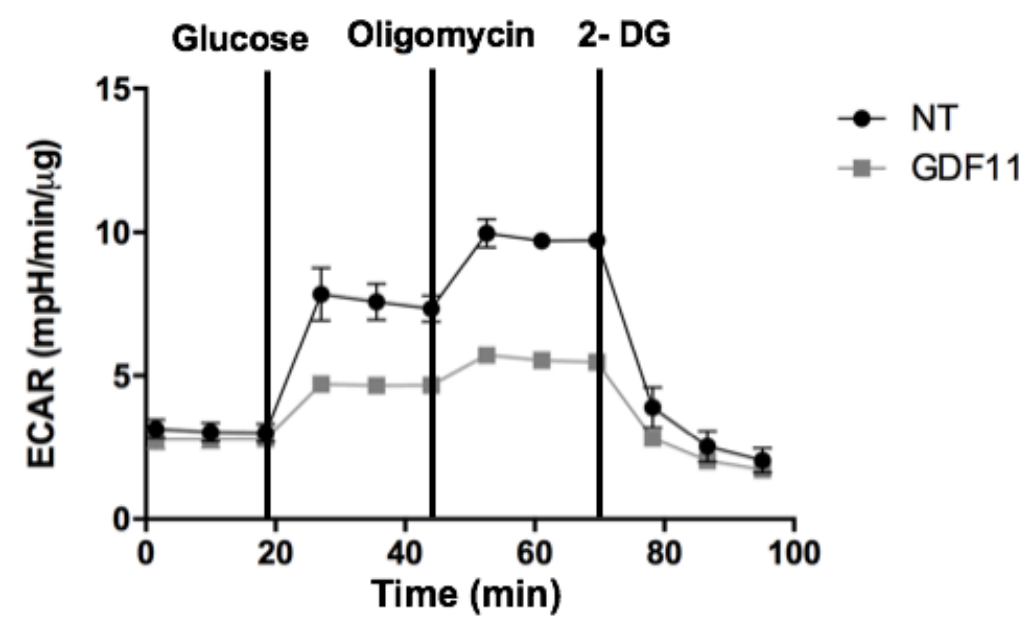

Fig. 7 El GDF11 afecta la funcionalidad mitocondrial de las células de HCC. C) ECAR, determina la producción de lactato y glucolisis en la línea celular Huh7. 
D)

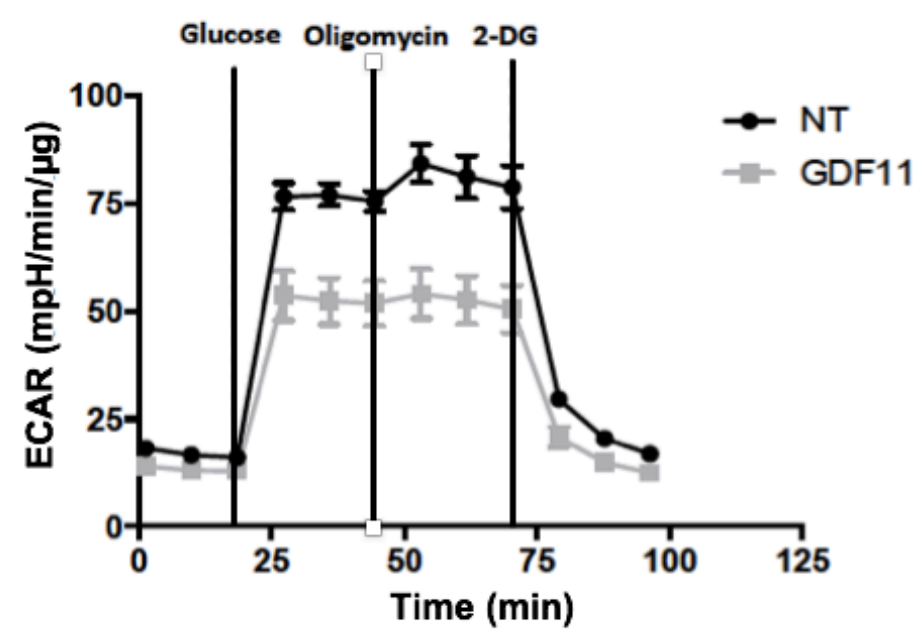

Fig. 7 El GDF11 afecta la funcionalidad mitocondrial de las células de HCC. D) ECAR, determina la producción de lactato y glucolisis en la línea celular Hep3B.

Las mediciones obtenidas del OCR, de las células que fueron tratadas con el GDF11 presentaron una disminución en dicho parámetro comparado con las células que no recibieron el tratamiento. La respiración mitocondrial basal fue normalizada restando el OCR no mitocondrial esto en presencia del inhibidor oligomicina $A$, el cual se observa disminuido de manera significativa en las células tratadas con el GDF11 (Fig. 7E).

E)

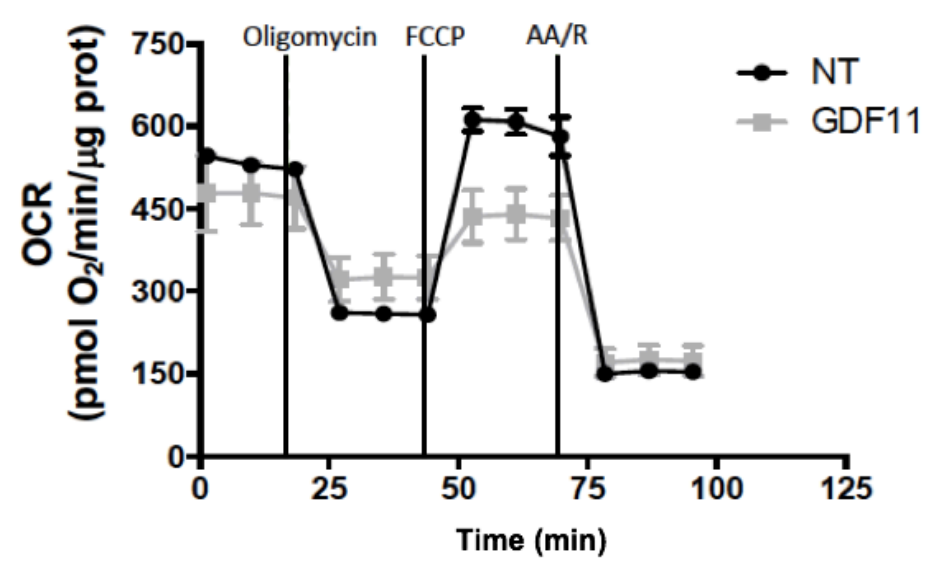

Fig. 7 El GDF11 afecta la funcionalidad mitocondrial de las células de HCC. E) OCR, medición de la fosforilación oxidativa en las células Huh7. 
F)

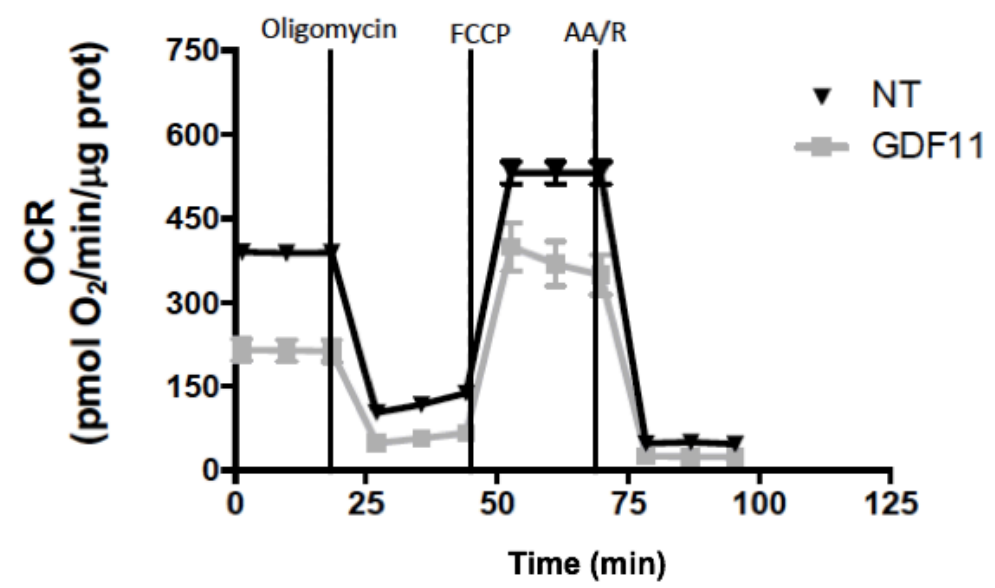

Fig. 7 El GDF11 afecta la funcionalidad mitocondrial de las células de HCC. F) OCR, medición de la fosforilación oxidativa en las células Hep3B.

Estos resultados nos mostraron que el GDF11 está jugando un papel importante en la regulación del metabolismo energético, estos resultados se relacionan con la disminución en la proliferación, debido a que el principal organelo encargado del suministro de energía se encuentra comprometido, si bien, las mitocondrias en cáncer suelen mostrar una menor capacidad energética, el GDF11 está aumentando los efectos de la disfunción mitocondrial.

\subsection{El GDF11 induce cambios transcriptómicos en la línea celular Huh7}

Se realizó un análisis de secuenciación masiva de ARN con la finalidad de obtener un panorama global de los genes regulados de manera diferencial en las células Huh7 después del tratamiento con el GDF11 por 3 días.

Los resultados mostraron que el tratamiento provocó la desregulación de 32 genes, mientras que 101 genes fueron sobreregulados (Fig. 8A y Anexo I). 
Por medio de un análisis no supervisado, mediante un mapa de calor se pudo observar la separación eficiente de ambos grupos (Control contra GDF11) (Fig. 8B).

Finalmente, un análisis de enriquecimiento mediante una ontología genética (GO) evaluada mediante el uso del programa IPA (Ingenuity Pathway Analysis) nos mostró que dentro de las principales rutas alteradas con el tratamiento del GDF11 se encontraban aquellas relacionadas con el metabolismo del colesterol y su regulación, estrés del retículo endoplasmático entre otros procesos (Fig. 8C).

A)

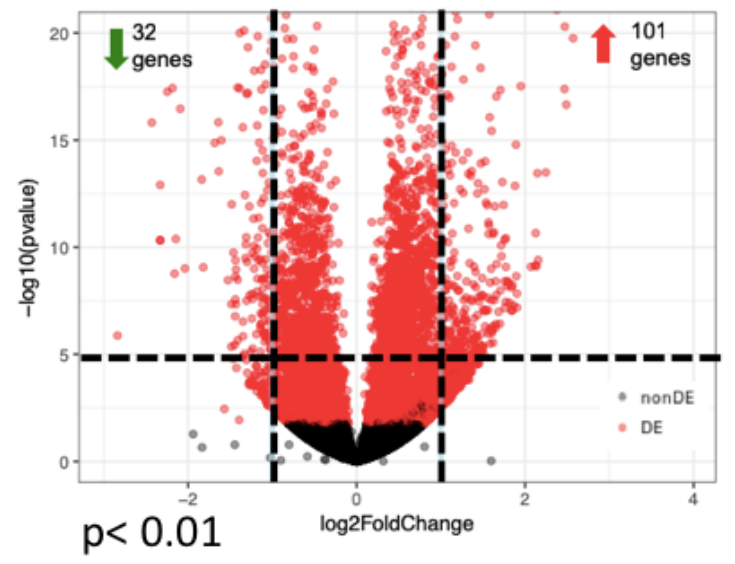


B)

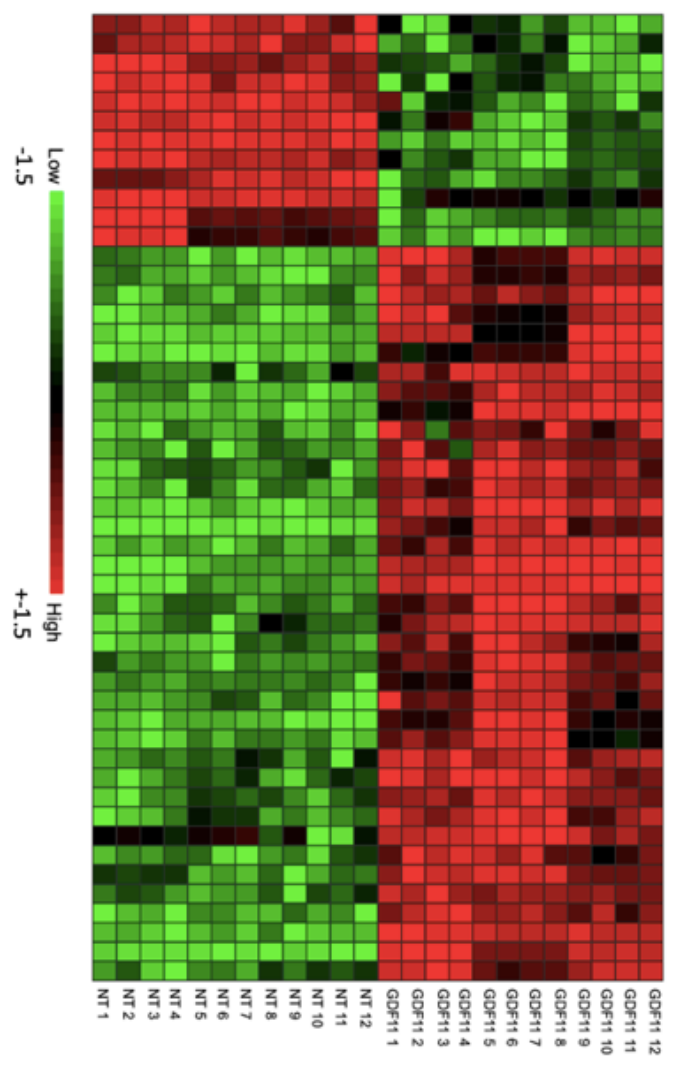

C)

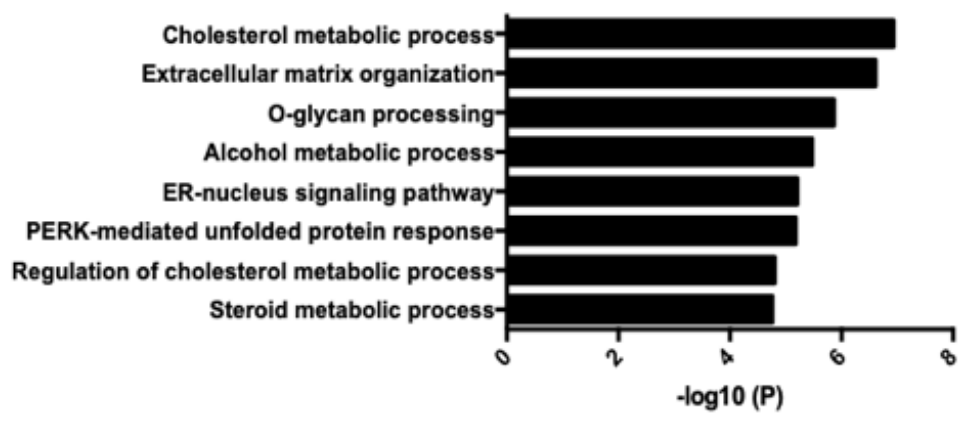

Fig. 8 El GDF11 induce cambios transcriptómicos en la línea celular Huh7. A) Gráfica de volcán. B) Análisis no supervisado (haet map), expresión diferencial entre las células control contra las células tratadas con GDF11 por $72 \mathrm{~h}$. Un total de 133 genes expresados diferencialmente, 32 genes desregulados (en verde) y 101 genes sobreregulados (en rojo). C) Análisis de enriquecimiento. Principales rutas de señalización afectadas por el tratamiento del GDF11 determinado mediante el software IPA. 


\subsection{El GDF11 disminuye la capacidad de formación de esferoides de las células de HCC}

Debido a que los resultados anteriormente presentados sugieren que el GDF11 induce efectos antitumorigénicos, se realizó un ensayo de formación de esferoides. Ambas líneas celulares fueron tratadas con GDF11 cada 24 h por cinco días.

Los resultados muestran que ambas líneas pierden la capacidad de formar esferoides, ya que las células que estuvieron en presencia del factor de crecimiento formaron una menor cantidad de esferoides $339 \%$ en las células Huh7 comparados con las células controles) (Fig. 9A).

A)

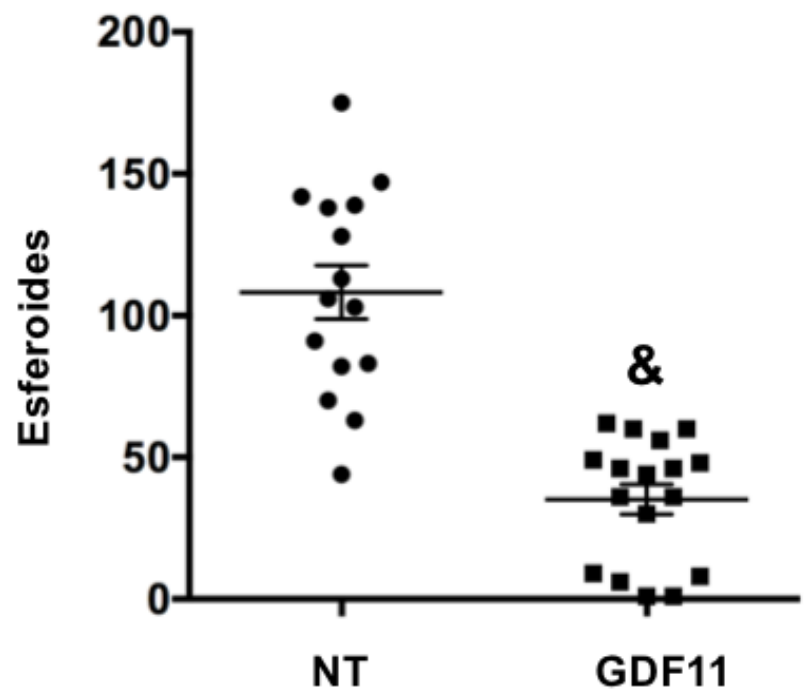

Fig. 9 El GDF11 disminuye la capacidad de formación de esferoides de las células de HCC. A) Ensayo de formación de esferoides muestra que el GDF11 disminuye la formación de esferoides de las células Huh7. Cada punto representa un experimento independiente, se reportó la media \pm SEM de al menos cuatro experimentos independientes por triplicado. \& $p<$ 0.05 vs NT 
Mientras que en las células Hep3B los resultados obtenidos fueron similares ya que esta línea celular en presencia del GDF11 formo una menor cantidad de esferoides (34\% comparados con las células controles) (Fig. 9B).

B)

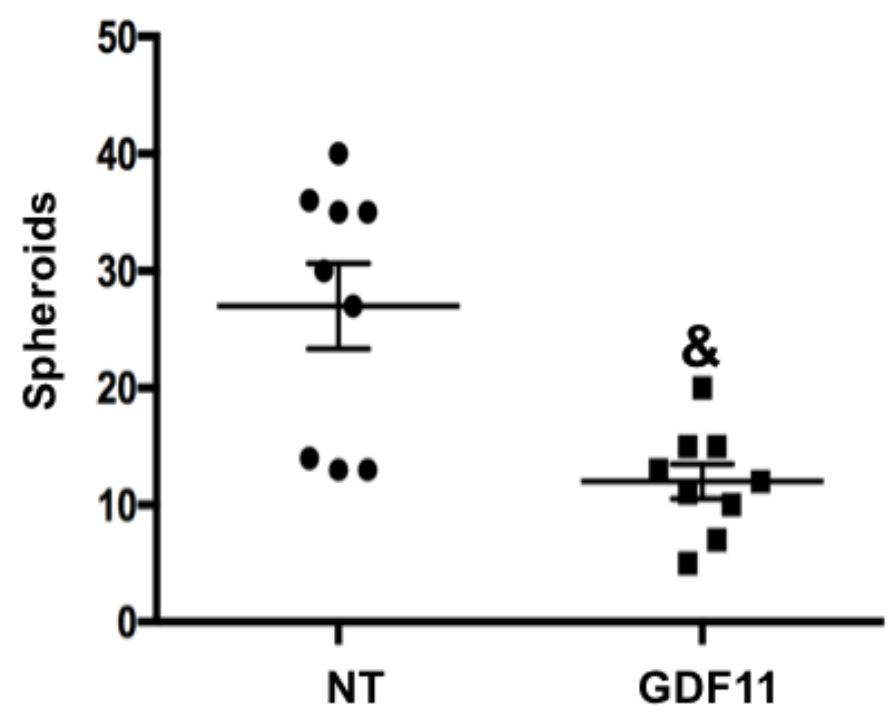

Fig. 9 El GDF11 disminuye la capacidad de formación de esferoides de las células de HCC. B) Ensayo de formación de esferoides muestra que el GDF11 disminuye la formación de esferoides de las células Hep3B. Cada punto representa un experimento independiente, se reportó la media $\pm S E M$ de al menos cuatro experimentos independientes por triplicado. \& $p<$ 0.05 vs NT

También se pudo observar que los esferoides formados de las células que recibieron el tratamiento con el GDF11 eran más pequeños comparados con los esferoides que no recibieron ningún tipo de tratamiento $25 \%$ para las células Huh7 (Fig. 9C) y $40 \%$ para las células Hep3B (Fig. 9D). 
C)
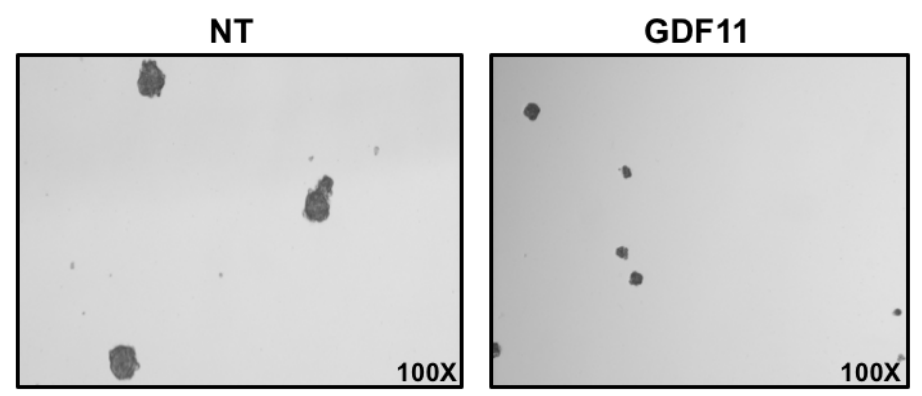

D)
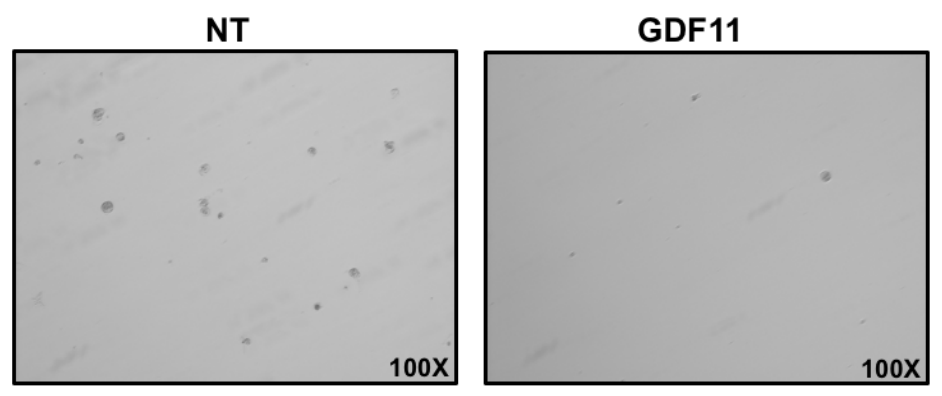

Fig. 9 El GDF11 disminuye la capacidad de formación de esferoides de las células de HCC. C) Imágenes representativas de los esferoides de la línea Huh7 formados después de cinco días. D) Imágenes representativas de los esferoides de la línea Hep3B formados después de cinco días.

\subsection{El GDF11 disminuye la expresión de algunos genes relacionados con} agresividad en las células de HCC

Si bien, con el ensayo de formación de esferoides el resultado nos muestra el efecto antitumorigénico ejercido por el GDF11, se midieron algunos de los principales genes relacionados con agresividad mediante qRT-PCR. Como se puede observar, el tratamiento provoco la disminución de la cantidad de ARN mensajero de CD133, CD24, CK19 y EpCAM, particularmente este último fue disminuido de manera 
significativa solo en la línea celular Hep3B (Fig. 10B) en comparación de la línea celular Huh7, donde no se encontraron cambios de manera significativa (Fig. 10A).

A)
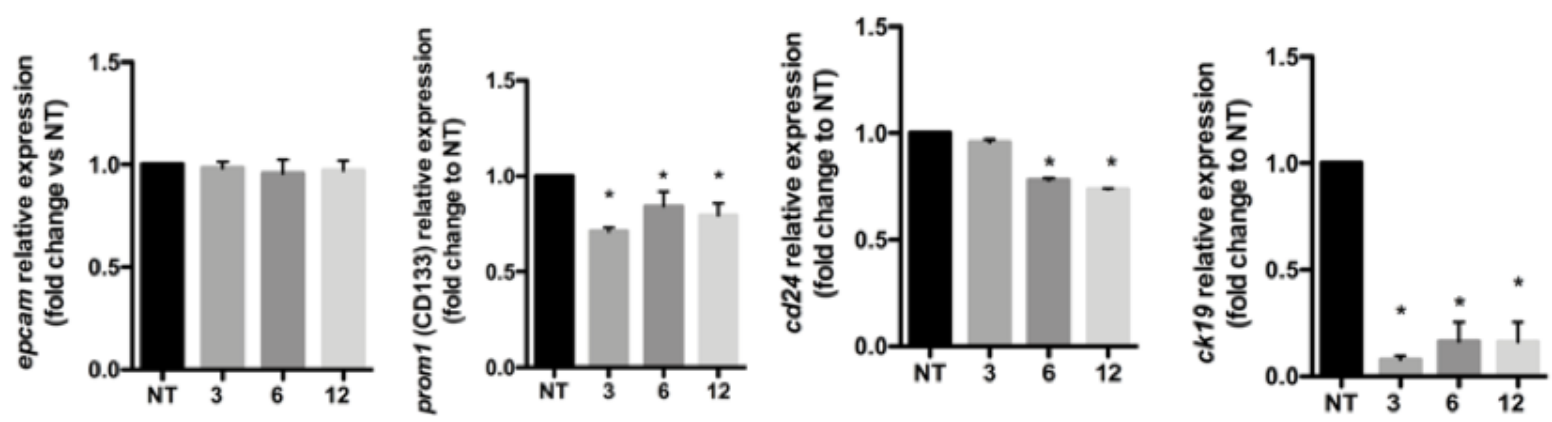

(h) GDF11

B)
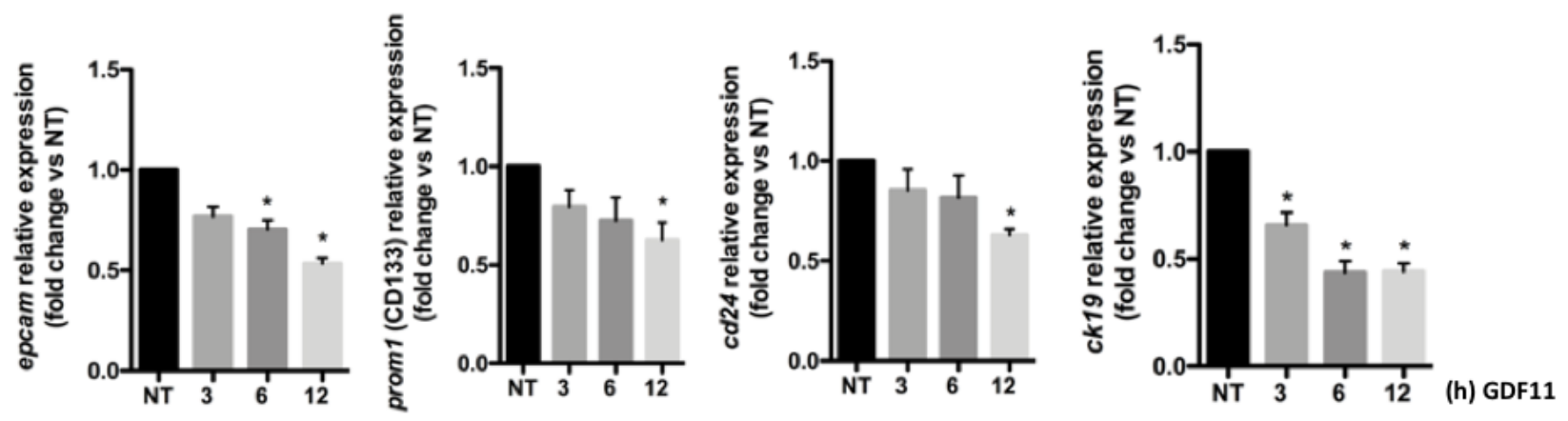

Fig. 10 El GDF11 disminuye la expresión de algunos genes relacionados con agresividad en las células de HCC. A) línea celular Huh7, niveles de ARN mensajero de genes relacionados con agresividad $B$ ) línea celular Hep3B, niveles de ARN mensajero de genes relacionados con agresividad, la expresión de las células no tratadas es reportado como el promedio \pm SEM. *, $p \leq 0.05$ vs $N T$

\subsection{EI GDF11 induce transición mesénquima epitelial}

Uno de los principales puntos a estudiar en cáncer es la capacidad que presentan las células para migrar y hacer metástasis, estos procesos mediados por la transición epitelial a mesenquimal (TEM), donde las células sufren procesos de perdida de marcadores epiteliales, quienes son los encargados de mantener adheridas las células 
a sus sustratos, y con ello la ganancia de marcadores mesenquimales, los cuales se encargan de permitir que las células migren. De acuerdo con el resultado de herida cicatriz, que sugieren también el proceso de migración, se decidió realizar una inminofluorescencia de algunos marcadores del proceso de TEM. Como se puede observar, el marcador Snail, un marcador mesenquimal, se encuentra disminuido con la progresión del tiempo en presencia del GDF11, mientras que, al mismo tiempo, ECadherina, un marcador epitelial se observa aumentado (Fig. 11A).

Para ganar más certeza con el resultado, se usaron otros marcadores, nuevamente, el marcador mesenquimal, $\mathrm{N}$ - Cadherina, se encuentra disminuido y Ocludina, otro de los marcadores epiteliales se observa aumentado (Fig. 11B). Observando, además, que el cambio en las células del proceso mesenquimal a epitelial se da a las $12 \mathrm{~h}$. Por lo que es importante realizar más estudios enfocados en este tiempo. 
A)

\section{GDF11 (h) DAPI Snail E- Cadherina Merge}
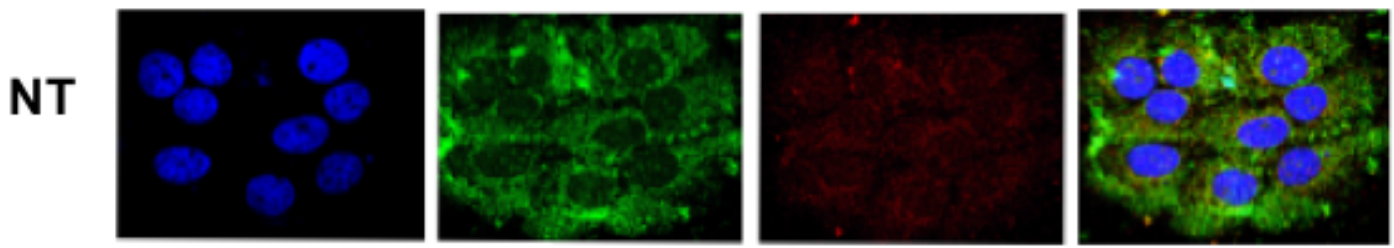

3
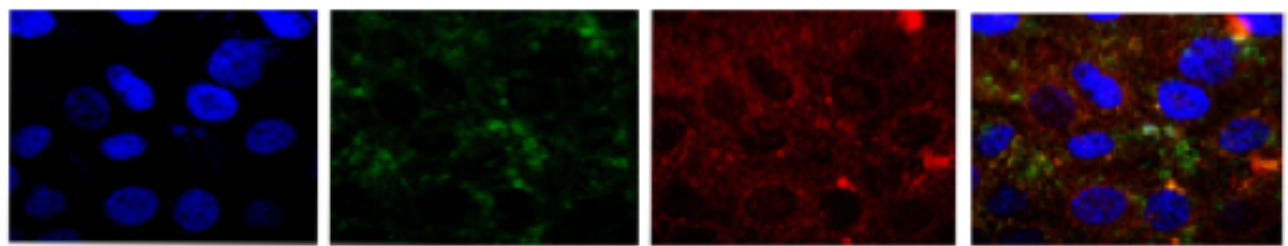

6
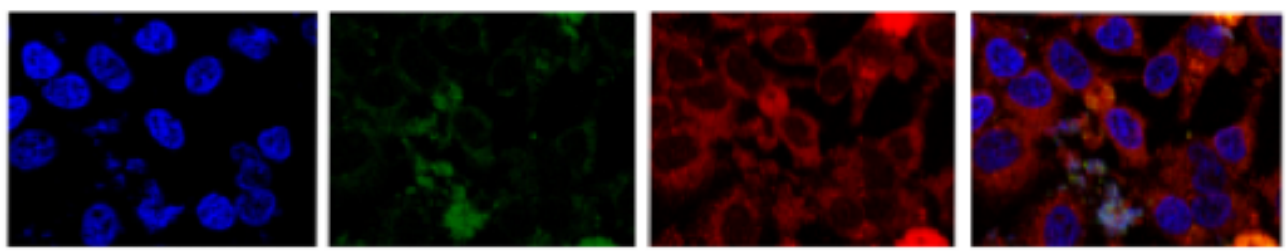

12
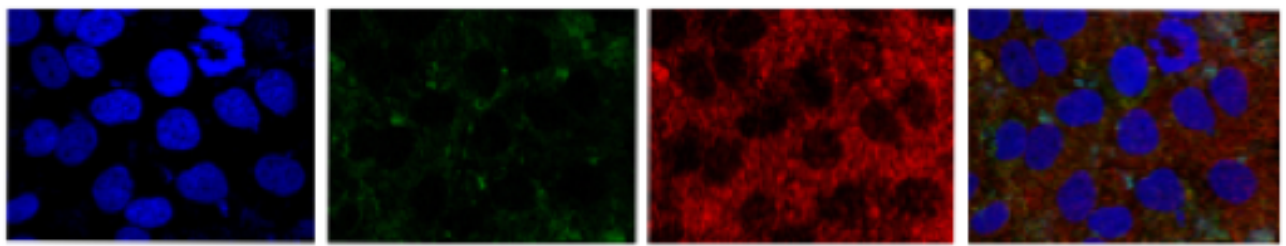

24
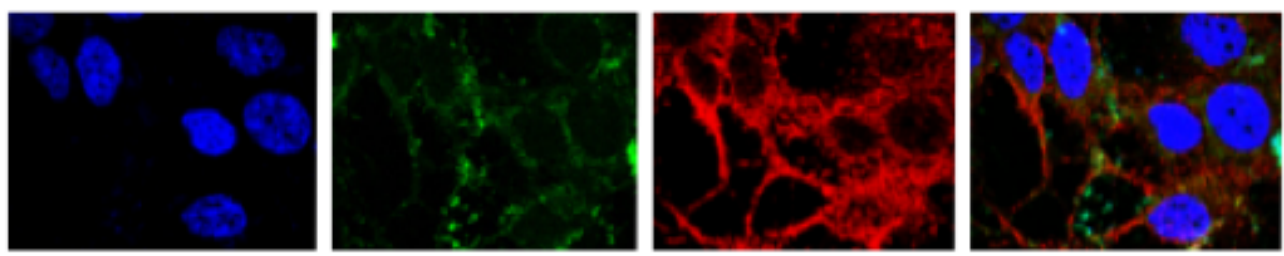

48
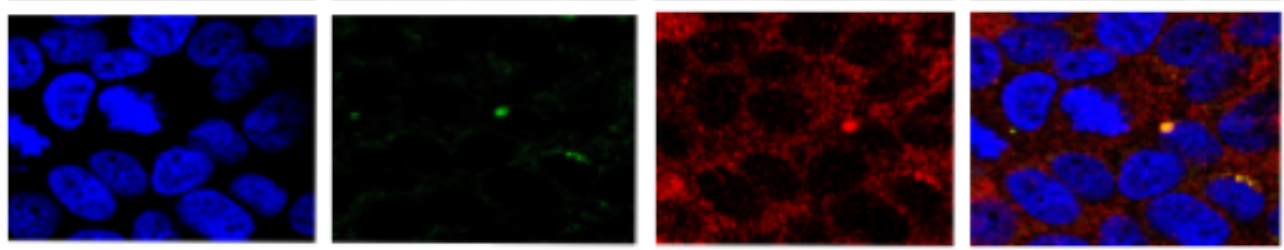

72
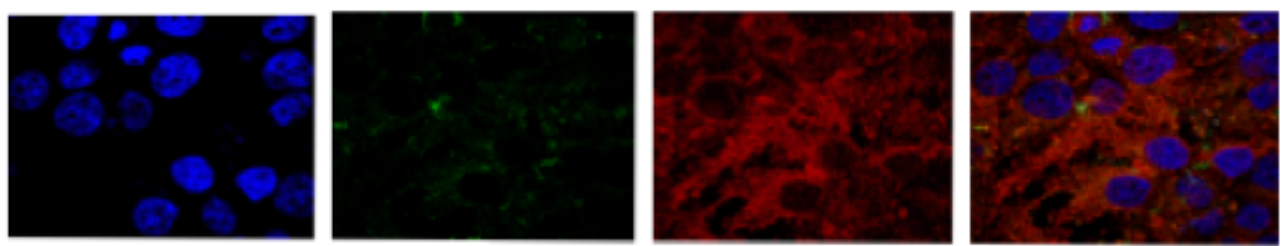

Fig. 11 El GDF11 induce transición mesénquima epitelial. Inmunofluorescencia determinada por microscopia confocal de A) Snail y E-Cadherina. Imagen representativa de al menos tres experimentos independientes. Aumento original 360X. 
B)

\section{GDF11 (h) DAPI N-Cadherina Ocludina Merge}

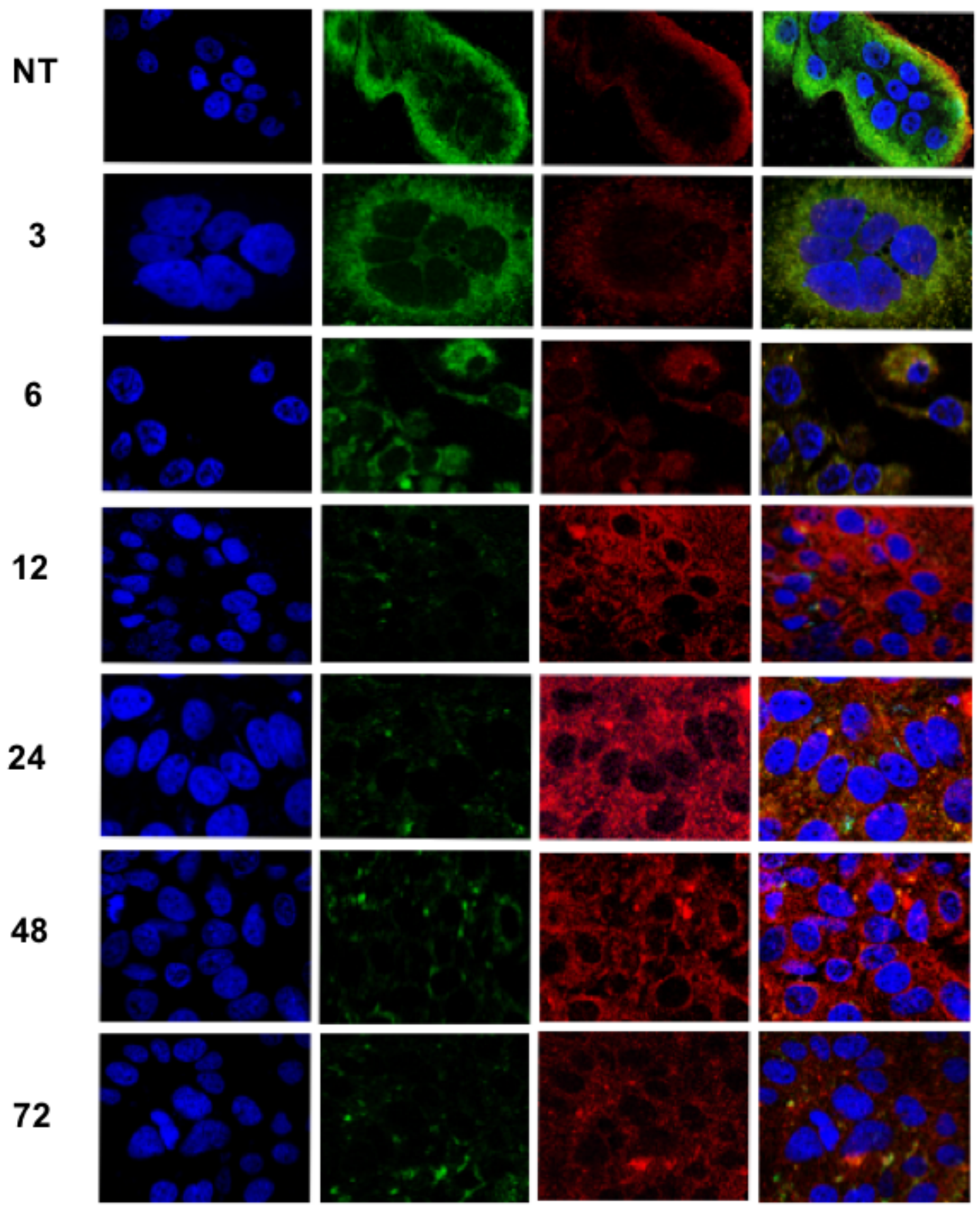

Fig. 11 El GDF11 induce transición mesénquima epitelial. Inmunofluorescencia determinada por microscopia confocal de B) $\mathrm{N}$ - Cadherina y Ocludina. Imagen representativa de al menos tres experimentos independientes. Aumento original 360X. 
Para corroborar los efectos sobre el proceso de TEM, se realizaron ensayos de Western blot de los marcadores usados anteriormente (Fig. 11C). Como se puede observar, se encontraron efectos similares, encontrando nuevamente que los marcadores epiteliales se aumentan con el transcurso del tiempo y los marcadores mesenquimales se ven disminuidos después de 72 h de tratamiento con el GDF11.

C)

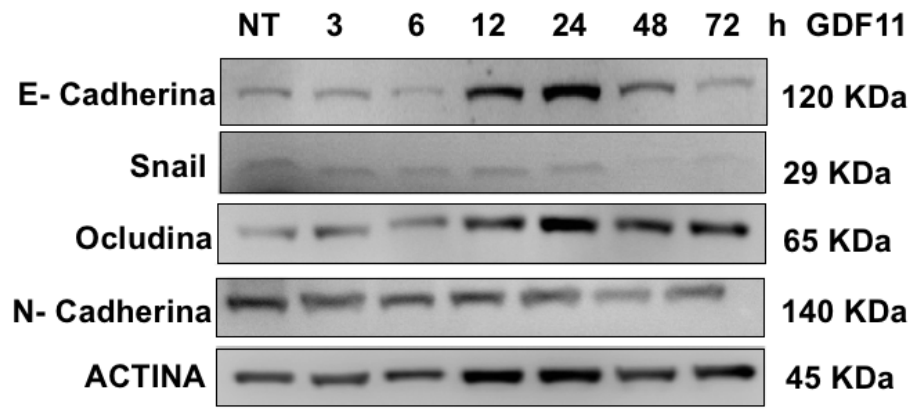

Fig. 11 El GDF11 induce transición mesénquima epitelial. C)Ensayo de Western blot muestra las proteínas implicadas en el proceso de TEM. Imagen representativa de al menos tres experimentos independientes.

Estos resultados nos indican que el tratamiento con el GDF11 está induciendo transición mesénquima epitelial, evitando así el proceso de migración por el cual pasan las células para llevar a cabo una metástasis.

\subsection{EI GDF11 reprime la capacidad de auto renovación de las células de HCC}

Para determinar si los efectos inducidos por el GDF11 se mantenían en las células, se realizó un ensayo de formación de colonias mediante un nuevo diseño experimental, para ello, las líneas celulares se trataron con GDF11 (50ng/ml) cada 24 h por $72 \mathrm{~h}$ en presencia o no de SFB, una vez terminado el tratamiento, las células fueron 
despegadas y sembradas nuevamente para la realización de experimentos extras, dichos experimentos se realizaron sin la presencia del GDF11, estos fueron llevados hasta 10 días con la finalidad de observar los efectos que había inducido el factor de crecimiento y determinar si estos permanecen en las células una vez retirado el tratamiento.

Los resultados obtenidos mostraron que las células Huh7 con el tratamiento previo de GDF11 no lograron recuperar su capacidad para proliferar observando un menor número de colonias formadas comparado con las células que no recibieron el tratamiento, sin encontrar diferencias significativas en aquellas células que recibieron el tratamiento en presencia o no del SFB (Fig. 12A y 12B).

A)

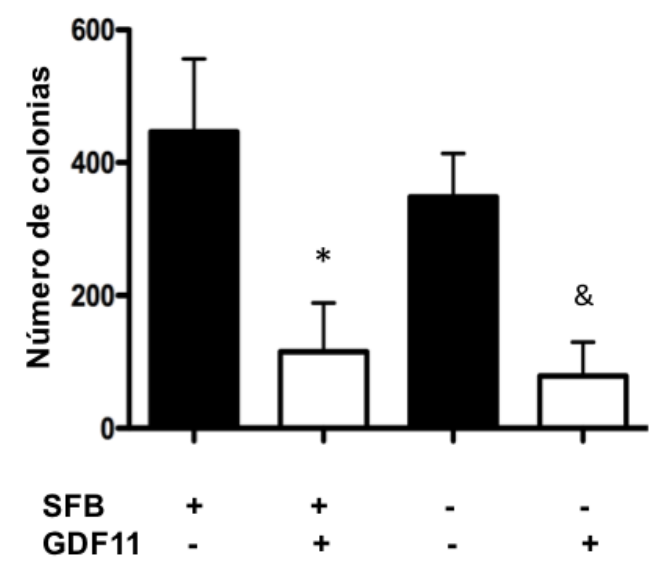

B)

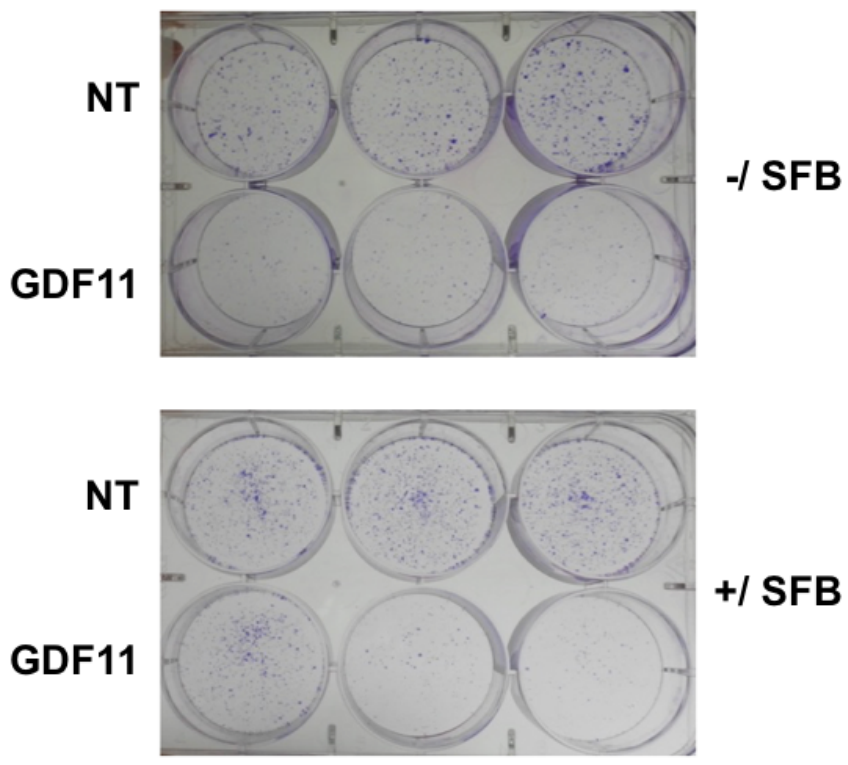

Fig.12 El GDF11 reprime la capacidad de autorenovación de las células de HCC. A) El resultado muestras que las células Huh7 que recibieron el tratamiento con el GDF11 por $72 \mathrm{~h}$ no recuperan su capacidad de formar colonias. B) Imagen representativa de las colonias. Cada columna representa el promedio $\pm S E M$ de al menos cuatro experimentos independientes por triplicado. ${ }^{*} p<0.05$ vs NT (+/SFB), \& $p<0.05$ vs NT (-/SFB). 
En el caso de las células Hep3B, el resultado obtenido fue similar, ya que las células que recibieron el tratamiento perdieron su capacidad de formar colonias, sin embargo, los efectos fueron más notorios cuando las células recibieron el tratamiento en presencia de SFB (Fig. 12C y 12D).

C)

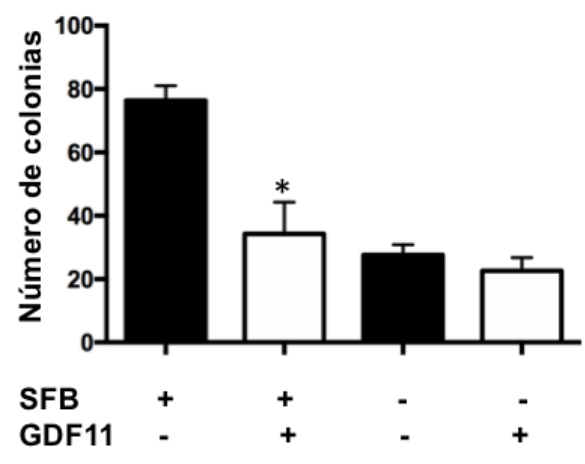

D)

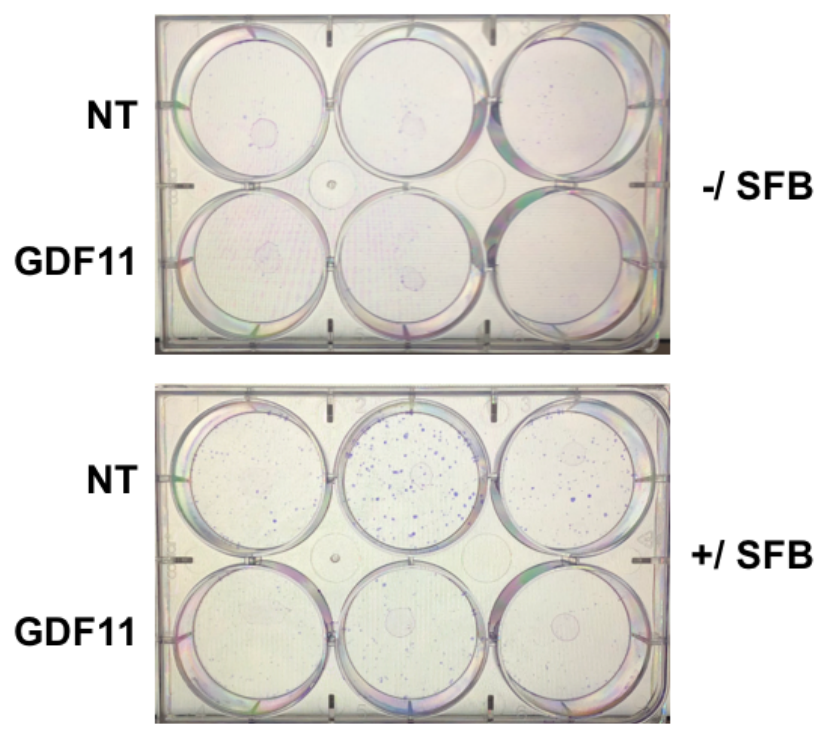

Fig. 12 El GDF11 reprime la capacidad de autorenovación de las células de HCC. C) El resultado muestras que las células Hep3B que recibieron el tratamiento con el GDF11 por $72 h$ no recuperan su capacidad de formar colonias. D) Imagen representativa de las colonias. Cada columna representa el promedio $\pm S E M$ de al menos cuatro experimentos independientes por triplicado. ${ }^{*} p<0.05$ vs NT (+/SFB)

Para corroborar los efectos observados en el ensayo de formación de colonias se realizó nuevamente un ensayo de formación de esferoides con las células que habían recibido el tratamiento del GDF11 por 3 días, el experimento se realizó por 10 días sin que las células continuaran en presencia del estímulo del factor de crecimiento.

Como se puede observar, ambas líneas celulares que fueron tratadas previamente perdieron su capacidad para formar esferoides, indicando nuevamente que los efectos 
que induce el GDF11 son antitumorigénicos además de preservarse en las células después de 10 días de ausencia del GDF11, indicando que el efecto que induce este factor de crecimiento no es transiente (Fig. 12E - 12H).

E)

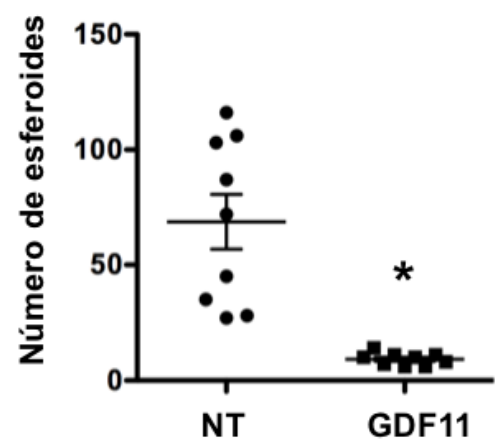

G)

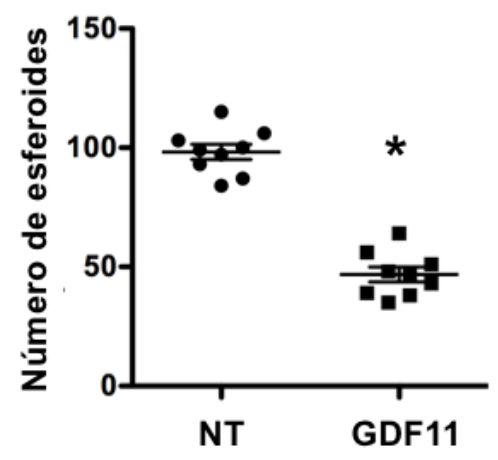

F)

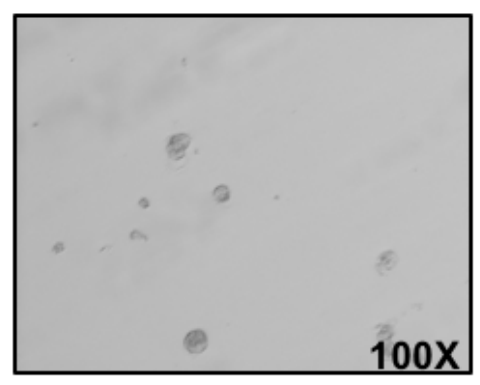

NT

H)

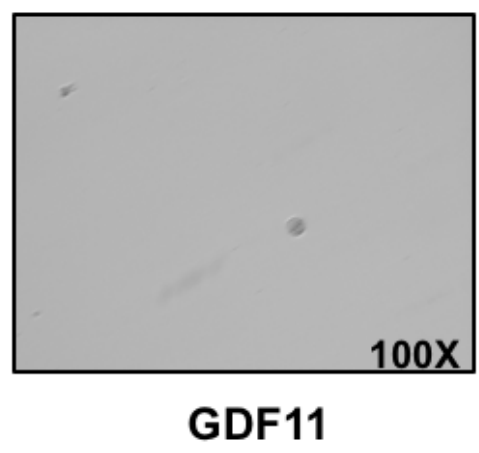

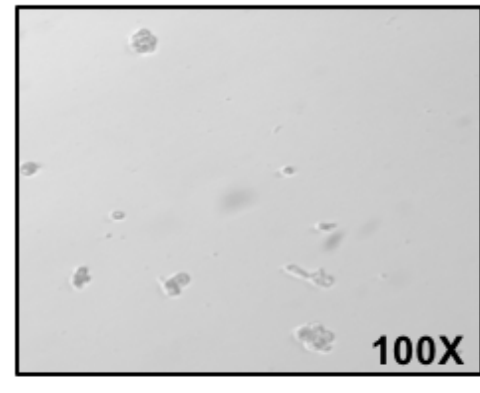

NT

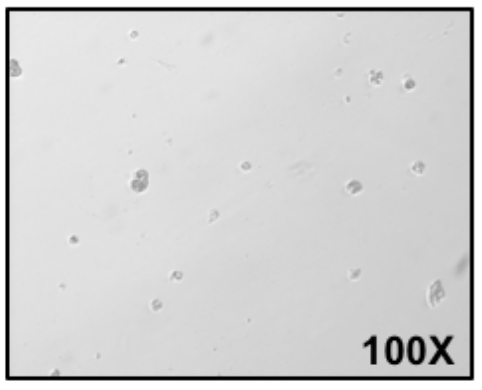

GDF11

Fig. 12 El GDF11 reprime la capacidad de autorenovación de las células de HCC. E) y G) Ensayo de formación de formación de esferoides muestra que el GDF11 disminuye la formación de esferoides de las células que habían recibido el tratamiento por 72 . F) y H) Imágenes representativas de los esferoides de las células que habían recibido el tratamiento por $72 \mathrm{~h}$. Cada punto representa un experimento independiente, se reportó la media \pm SEM de al menos cuatro experimentos independientes por triplicado. \& $p<0.05$ vs NT. Imágenes representativas de los esferoides de la línea Hep3B formados después de cinco días. 


\subsection{EI GDF11 disminuye la migración de las células de HCC}

Para corroborar el efecto del GDF11 sobre el proceso de migración y ganar más certeza, se realizó un ensaño de migración usando el modelo de membrana corioalantoidea (CAM) de embriones de pollo. Para ellos se utilizaron huevos fértiles, a los cuales se le transplantaron $1 \times 10^{6}$ de células Huh7 tratadas previamente o no con GDF11 por $72 \mathrm{~h}$ y se colocaron sobre la CAM de los embriones. La figura 13A muestra la morfología normal de la CAM, sin la presencia de células, como un control. El circulo amarillo muestra la posición donde fueron colocadas las células. Los huevos con las células fueron incubados a $37^{\circ} \mathrm{C}$, después de dos y cuatro días de haber colocado las células sobre la CAM, esta fue removida y embebida en parafina para la realización de los cortes y proseguir con los ensayos de inmunofluorescencia microscopia confocal. 
A)

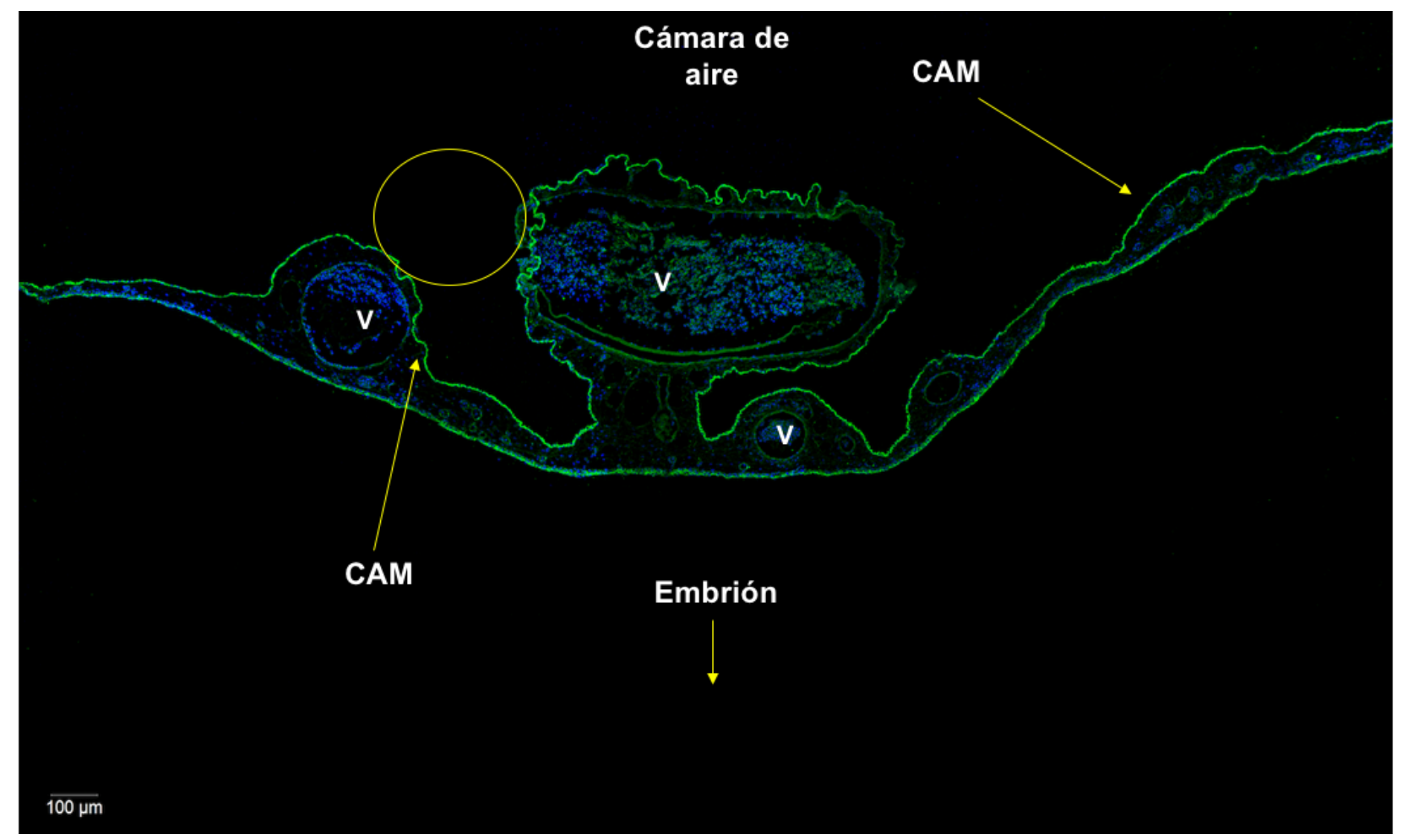

Fig. 13 El GDF11 disminuye la migración de las células de HCC. A) Morfología normal de la CAM. Imagen representativa de al menos tres experimentos independientes. 
B)

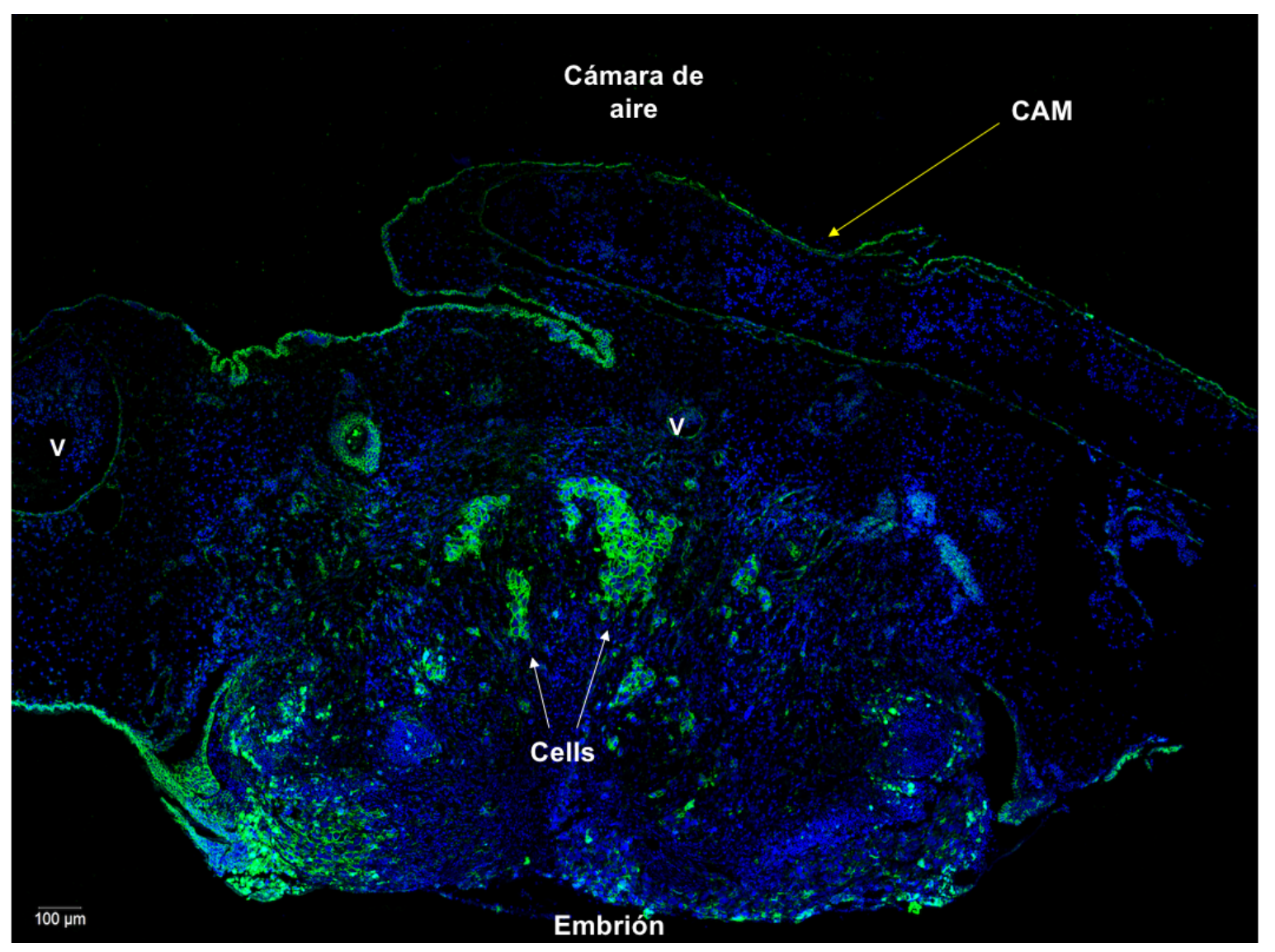

Fig. 13 El GDF11 disminuye la migración de las células de HCC. B) Membrana con las células sin tratamiento, muestra la migración de las células. Imagen representativa de al menos tres experimentos independientes. 
C)

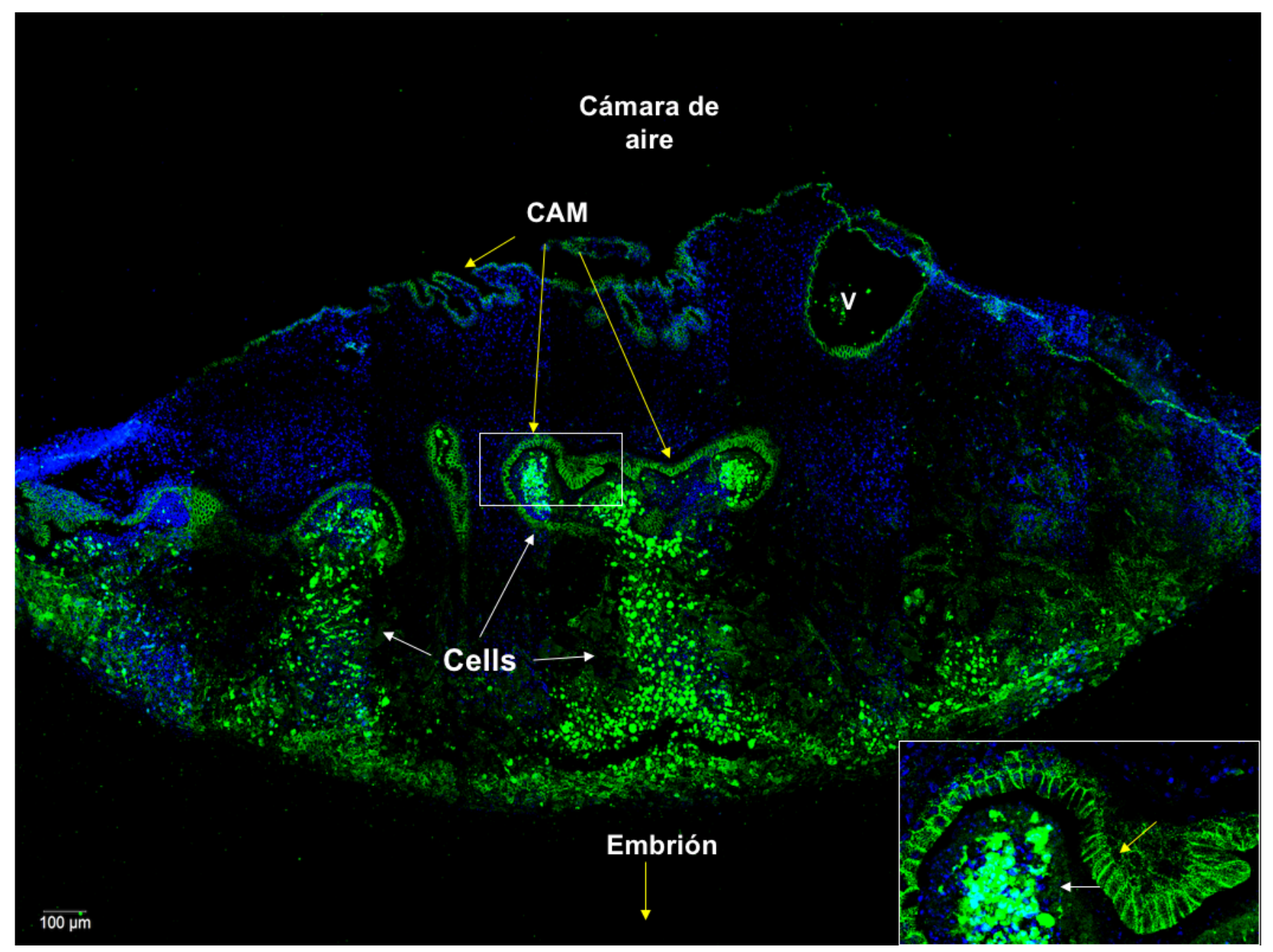

Fig. 13 El GDF11 disminuye la migración de las células de HCC. C) Membrana con células tratadas con GDF11, se observan las células retenidas. Imagen representativa de al menos tres experimentos independientes.

Con la finalidad de analizar el proceso de invasión, se prosiguió a analizar las muestras de dos días de incubación. Los análisis microscópicos de las muestras de la CAM revelaron que la mayoría de las células sin el tratamiento habían desaparecido (Fig. 13B), en comparación con las células que habían recibido el GDF11, las cuales, como se puede observar en la figura $13 \mathrm{C}$ aún se mantienen contenidas. 
Después de haber transcurridos los dos días de incubación con las células, se pudo observar que los embriones habían muerto, este resultado solo pudo observarse en los embriones que contenían las células que no habían recibido el tratamiento con el GDF11, ya que los embriones con las células que recibieron el tratamiento permanecieron vivos hasta que el experimento termino (Fig. 13D)

D)

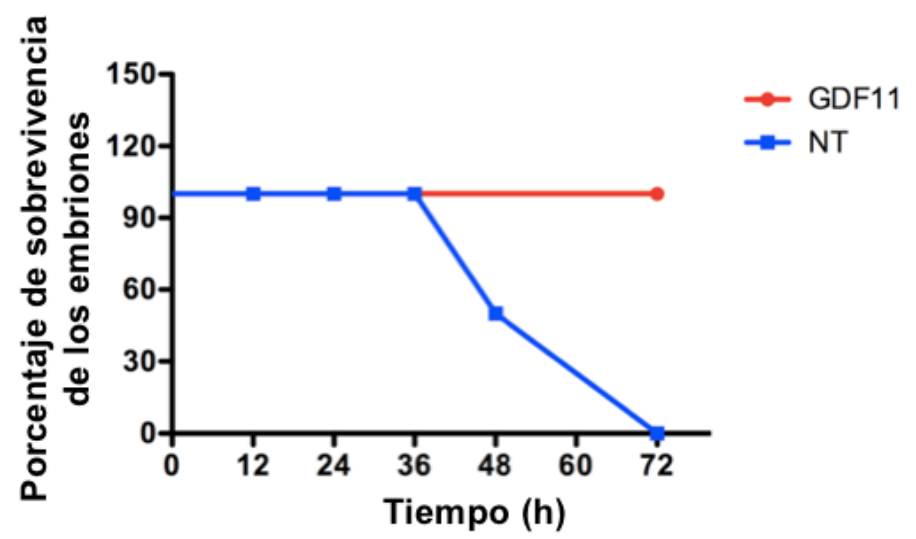

Fig. 13 El GDF11 disminuye la migración de las células de HCC. D) Gráfica de sobrevivencia de los embriones, muestra que las células sin el tratamiento provoco la muerte de los embriones en comparación con los embriones que recibieron las células tratadas, los cuales se mantiene vivos hasta el final del experimento.

Las zonas de la CAM cercanas a las células se puede observar una mayor expresión de beta catenina (Fig. 13C) (flechas amarillas), posiblemente este efecto se deba a una respuesta desplegada de las células por el tratamiento con el GDF11, el cual siguiere ser un efecto de reprogramación celular, este efecto no pudo ser localizado en las muestras de las CAM con las células sin el tratamiento, este resultado sugiere un proceso de degradación de la membrana, lo cual da inicio al proceso de migración, este resultado se relaciona con las imágenes de las muestras de los cuatro días, donde 
la mayoría de las células habían migrado. Además, de mostrarnos el inicio del proceso de migración de las células in vivo.

Con la finalidad de observar el proceso completo de migración, se realizaron cortes de muestras después de cuatro días de incubación, como se puede observar en la figura 13E, se muestran algunas células disgregadas, lo cual nos indica que las células han migrado, mientras que en la figura $13 \mathrm{~F}$ se pueden observar las células que recibieron el GDF11 compactadas, lo que nos indica que las células no han migrado.

E)

F)
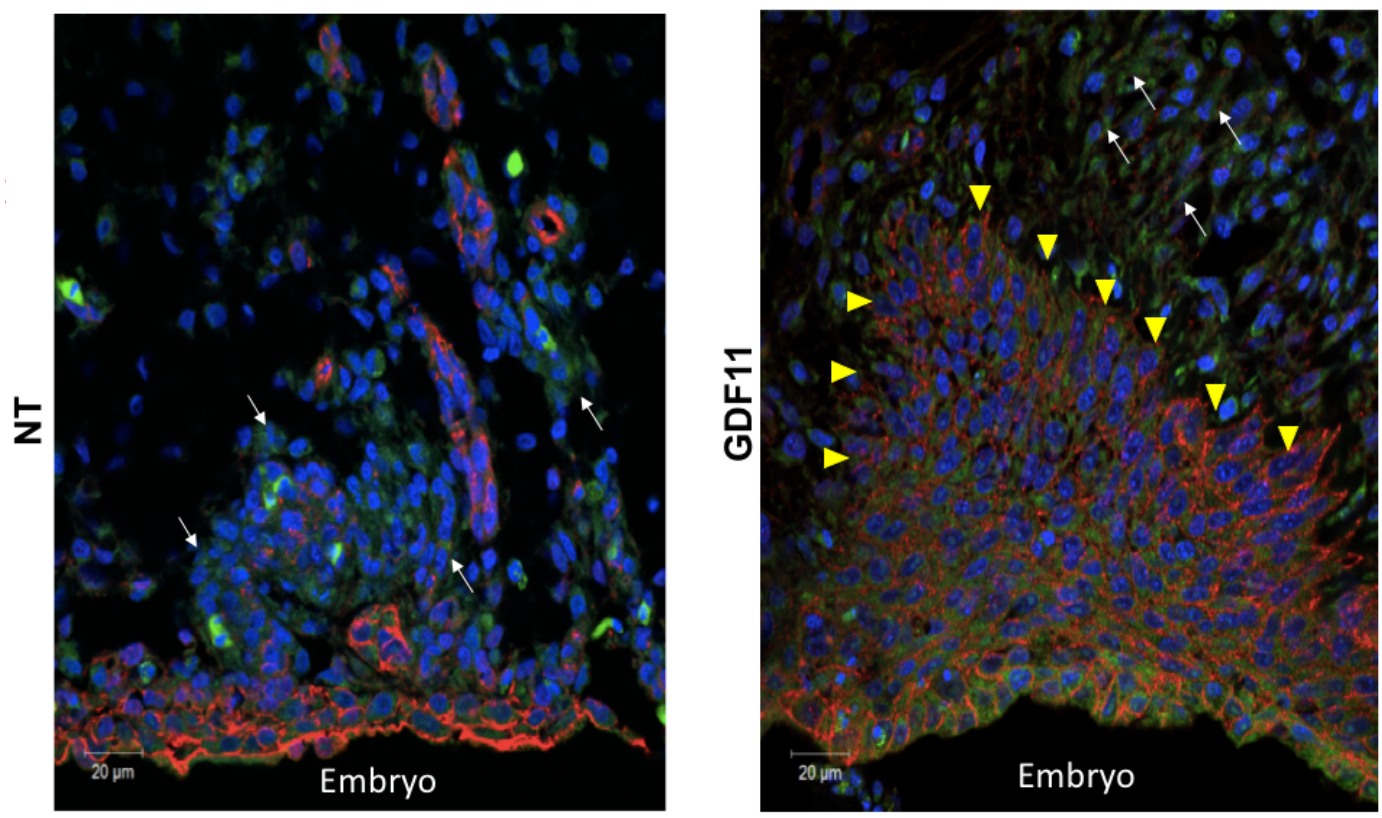

Fig. 13 El GDF11 disminuye la migración de las células de HCC. E) Muestras de 4 días de incubación, se observan pocos vestigios de células debido al proceso de migración. F) Muestras de 4 días de incubación, se observan células retenidas en la membrana. Imágenes representativas de al menos tres experimentos independientes.

Con la finalidad de corroborar que las células habían migrado, se realizaron cortes de las zonas distales de la membrana. En la figura $13 G$ se pueden observar algunas células, demostrando que estas habían llevado a cabo el proceso de migración. 
Mientras que en la figura $13 \mathrm{H}$ no se logran observar células en esta zona, nuevamente, indicando que el tratamiento con el GDF11 induce la disminución de los procesos de migración celular.

G)

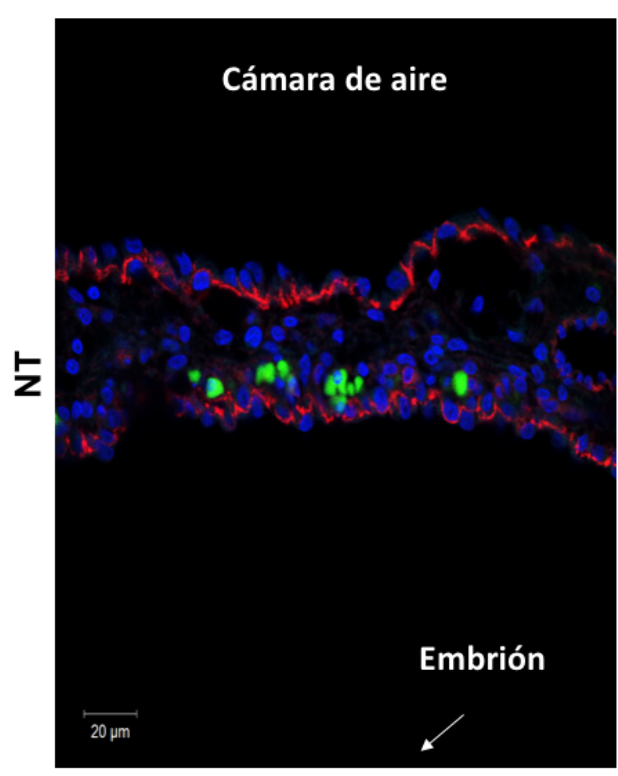

H)

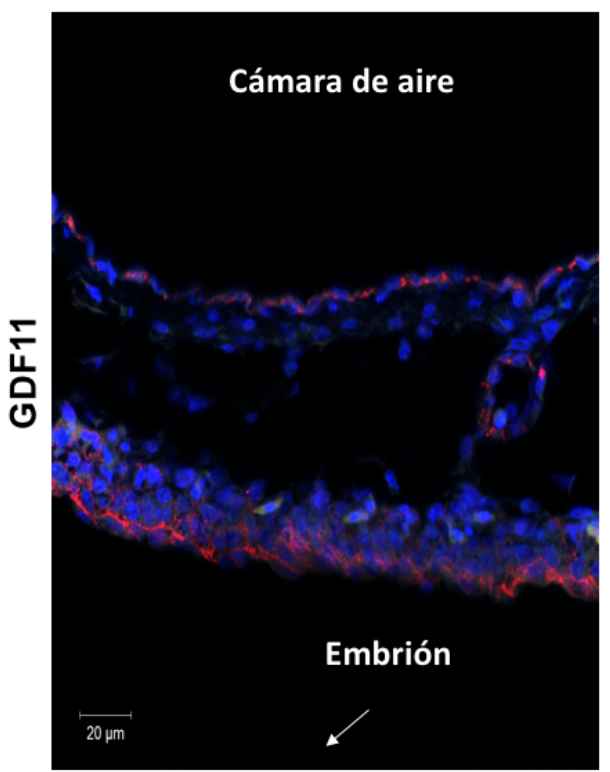

Fig. 13 El GDF11 disminuye la migración de las células de HCC. G) Zona distal de la membrana, se observa la presencia de las células no tratadas migrando. H) Zona distal de la membrana, no se observa la presencia de las células que fueron tratadas previamente con el GDF11. Imágenes representativas de al menos tres experimentos independientes.

Con la finalidad de determinar el estado en el que se encontraban las células una vez colocadas en el embrión, se realizó una tinción con el marcador Ki67, como se muestra en la figura 13I, las células controles son positivas para la tinción, lo cual nos indica que las células una vez colocadas en el embrión son capaces de proliferar, mientras que las células que habían recibido el tratamiento con el GDF11 siguen arrestadas, impidiendo el proceso de proliferación, corroborando los resultados anteriores (Fig. 13J). La figura 13K muestra la densitometría de las imágenes teñidas con Ki67. 
l)

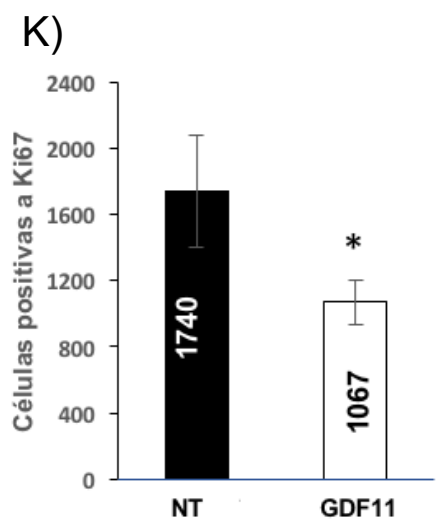

J)
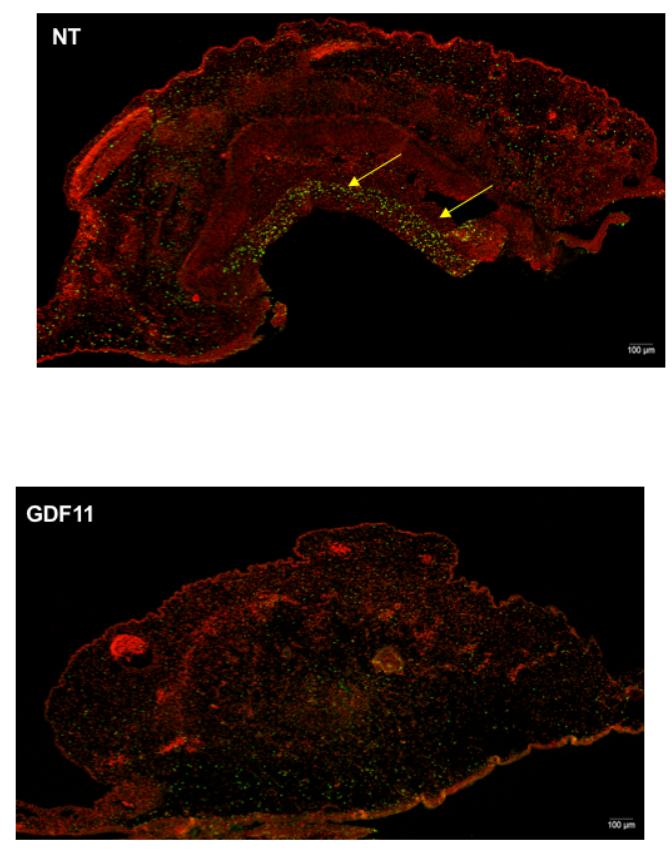

Fig. 13 El GDF11 disminuye la proliferación de las células de HCC. I) Tinción de Ki67, muestra la proliferación de las células control en la CAM de los embriones de pollo. J) Tinción de Ki67, muestra la proliferación de las células que recibieron el GDF11 en las cuales la proliferación esta disminuida en la CAM de los embriones de pollo. K) Densitometría de la tinción de KI67. Imágenes representativas de al menos tres experimentos independientes.

\subsection{EI GDF11 disminuye la formación de esferoides en otras líneas de cáncer}

Con la finalidad de analizar los efectos antitumorigénicos ejercidos por el GDF11 en las líneas de HCC y determinar que este efecto no era solo en las líneas usadas, se realizó el ensayo de formación de esferoides usando otras líneas de cáncer HepG2 (Fig. 14A), una línea de hepatoblastoma humano, Hepa1-6 (Fig. 14B), una línea de cáncer de hígado de ratón, SNU-182 (Fig. 14C), otra línea de cáncer de hígado humano, una línea de cáncer de mama, MDA-MB-231 (Fig. 14D) y finalmente una línea de cáncer de páncreas, CAPAN1 (Fig. 14E). 
A)

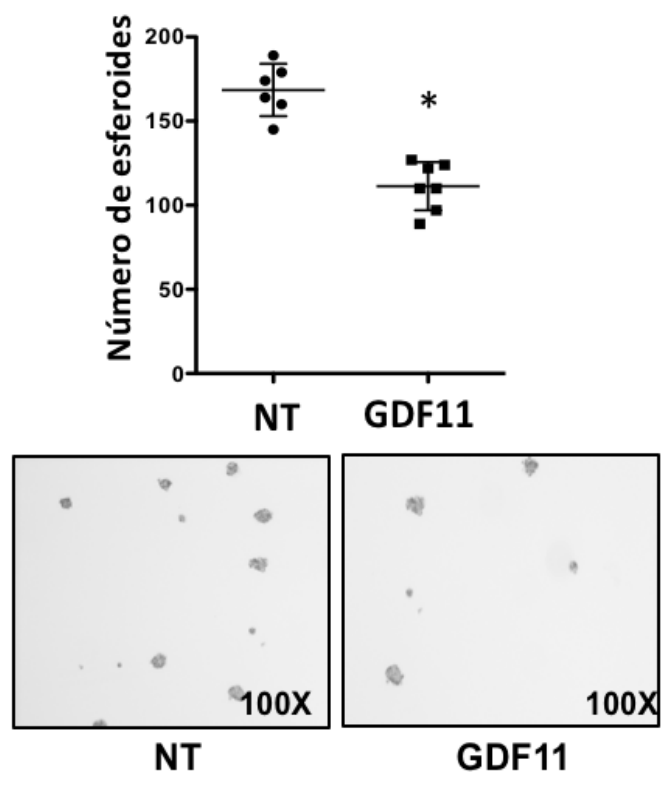

C)
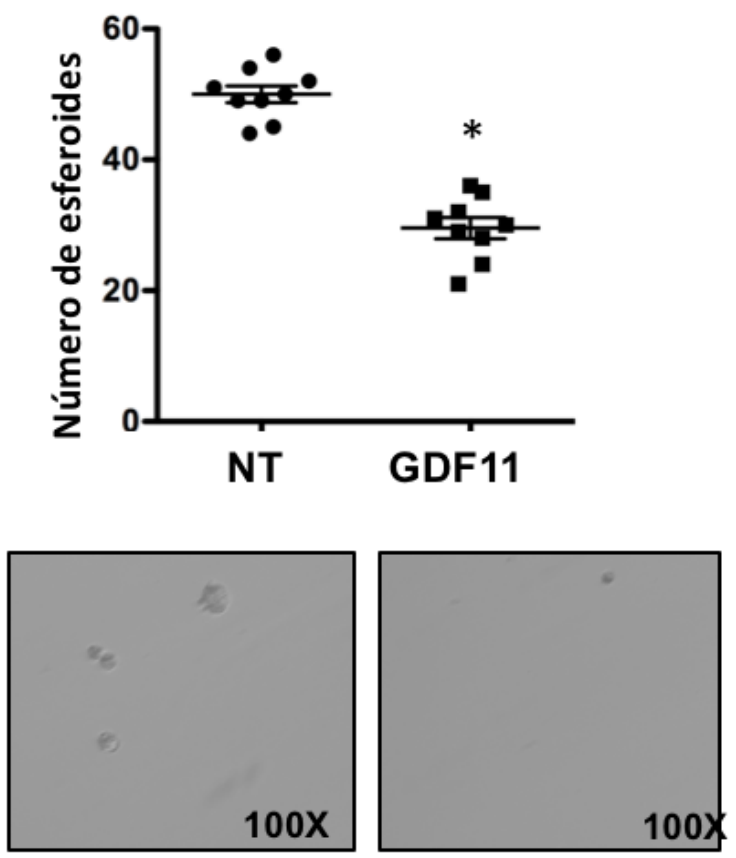

NT
B)
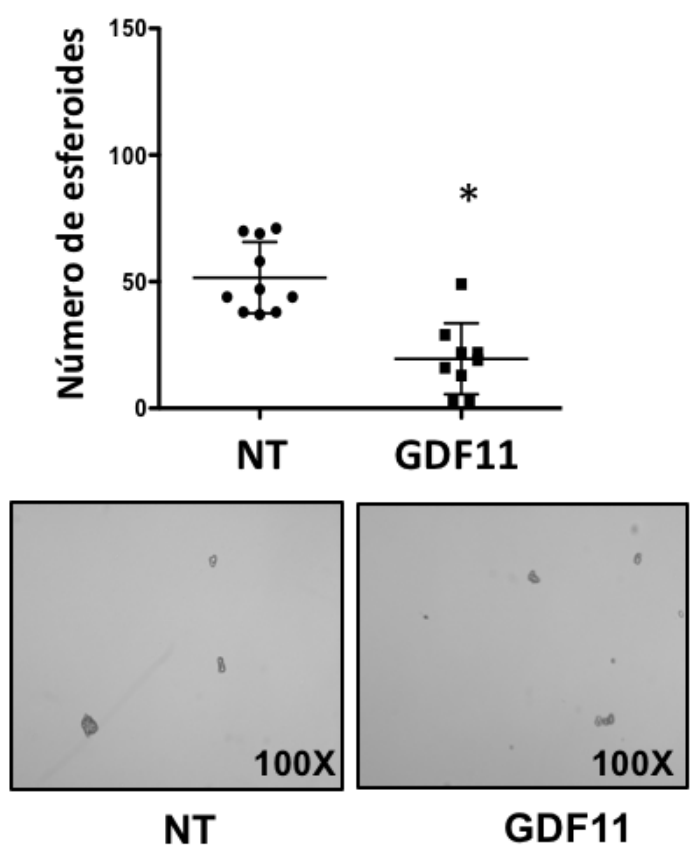

D)
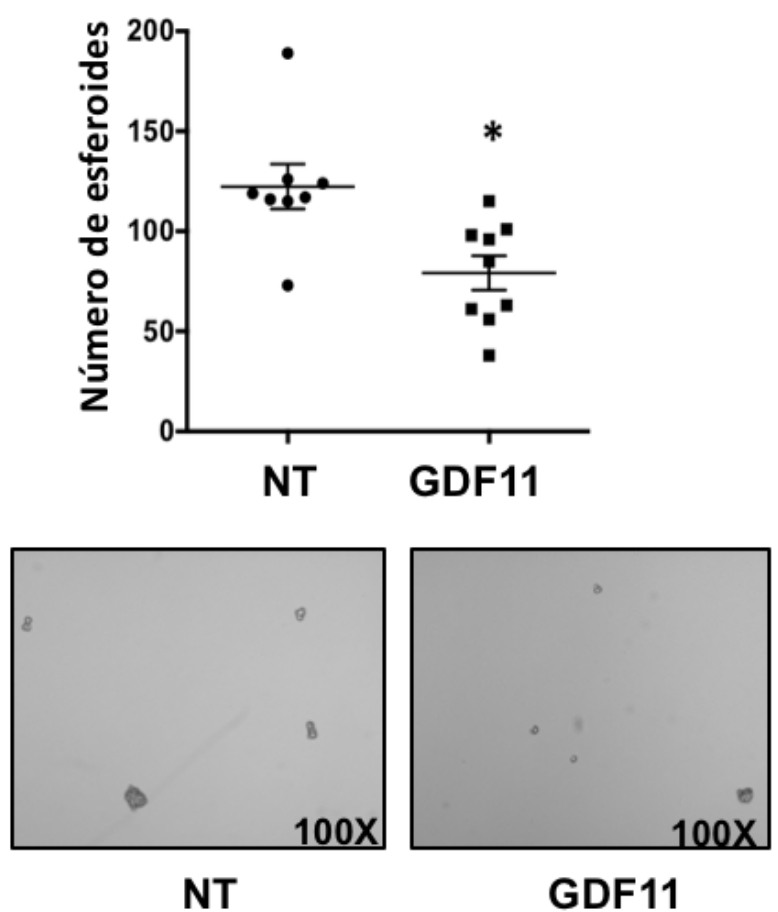
E)

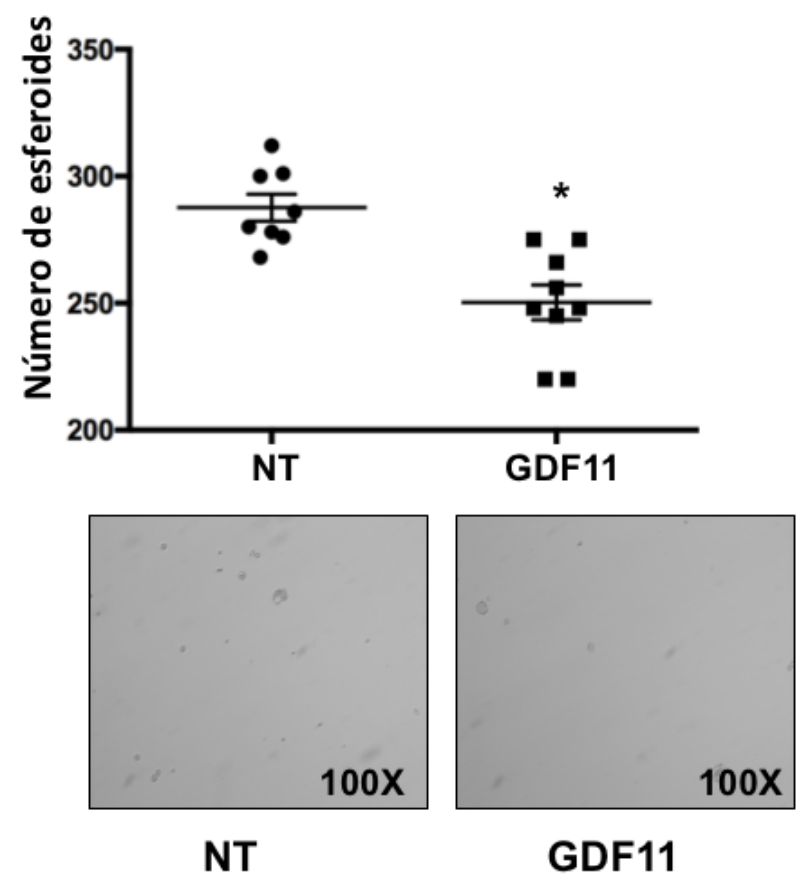

Fig. 14 El GDF11 disminuye la formación de esferoides en otras líneas de cáncer.

A) - E) Ensayo de formación de esferoides muestra que el GDF11 disminuye la formación de esferoides en otras líneas derivadas de cáncer. Cada punto representa un experimento independiente, se reportó la media \pm SEM de al menos cuatro experimentos independientes por triplicado. \& $p<0.05$ vs NT. Imágenes representativas de los esferoides de otras líneas de cáncer.

Las líneas celulares fueron tratadas con GDF11(50 ng/ml) cada 24 h por cinco días. Como se puede observar, en todas las líneas celulares se observaron efectos similares a los encontrados en las líneas Huh7 y Hep3B, donde el tratamiento provoco un menor número de esferoides formados.

Este resultado nos sugiere nuevamente que el efecto que induce el GDF11 es principalmente sobre las células que presentan un fenotipo troncal, en el caso de las células de cáncer, este proceso ocurre aunado al grado de agresividad que presentan las células. 


\subsection{El GDF11 activa la señalización de ERK1/2}

Finalmente, para estudiar cual es el mecanismo que despliega el GDF11 y por el cual las células derivadas de HCC están disminuyendo su proliferación celular, se analizó mediante Western blot el estado de la proteína ERK, un miembro de la familia de las MAPK, quien se ha reportado que juega un papel importante durante la progresión del cáncer.

Si bien, en la línea celular Huh7 no se logró detectar algún cambio (Fig. 15A), en la línea celular Hep3B se logró apreciar la activación de ERK1/2 a partir de los 5 minutos y su inactivación a partir de los 15 minutos (Fig. 15B).

Este resultado nos sugiere que el GDF11 está afectando la señalización mediada por ERK, provocando así la disminución en la proliferación celular.

A)

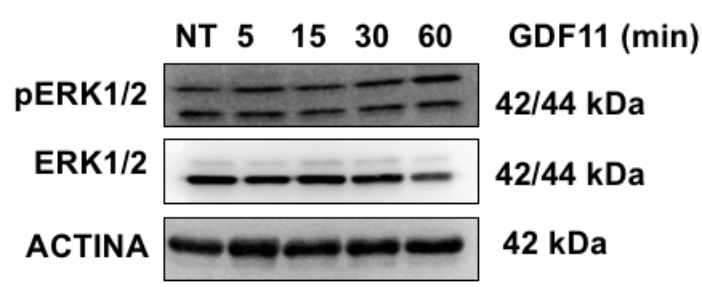

B)

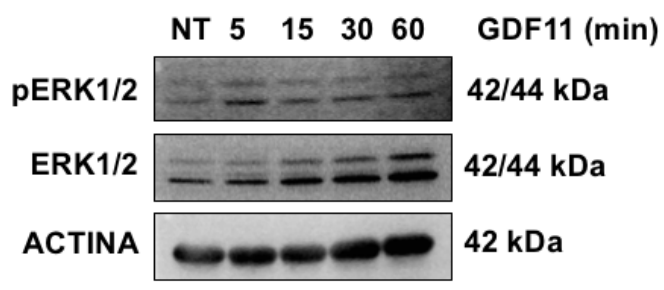

Fig. 15 El GDF11 activa la señalización de ERK1/2. Ensayo de Western blot muestra la activación de ERK1/2. Imágenes representativas de al menos tres experimentos independientes. 


\section{Discusión}

El cáncer de hígado es una de las principales causas de muerte por cáncer a nivel mundial, según lo reportado por el NIH en su "Anual Report to the Nation of the Status of Cancer, Part I: National Cancer Statistic" en 2018, la tasa de incidencia y de mortalidad por esta patología ha ido en aumento en los últimos años.

Una de las principales causas a este aumento en las cifras es debido a que la detección de dicha patología suele ser en etapas avanzadas y esto es debido a la falta de marcadores específicos.

Una de las alternativas para el tratamiento del cáncer de hígado es mediante la intervención quirúrgica para realizar un trasplante de dicho órgano, sin embrago, esta alternativa terapéutica difícilmente suele ser una opción viable, y esto es debido a la falta de donadores.

El uso de tratamientos convencionales como la quimioterapia y radioterapia tienen efectos prometedores como tratamiento contra el cáncer, sin embargo, estos efectos solo son presentados en las etapas tempranas de dicha patología, además de ser tratamientos altamente invasivos en los pacientes, por tal motivo, la calidad de vida a la que se enfrentan suele ser mala.

La búsqueda de nuevas alternativas terapéuticas o marcadores específicos para la detección temprana de dicha enfermedad es uno de los principales objetivos en los que nos encontramos trabajando, con la finalidad de proporcionar tratamientos que no sean invasivos y sean efectivos. 
La familia del TGF- $\beta$ es uno de los principales factores de crecimiento que se han estudiado en cáncer, debido a los efectos que se han reportado que induce dicho factor de crecimiento. Entre los efectos reportados en cáncer, se ha demostrados que el TGF- $\beta$ provoca efectos citotóxicos sobre las células transformadas, además de inducir efectos citoestáticos.

El GDF11 es un miembro de la familia del TGF- $\beta$, el cual se ha vinculado con procesos de regeneración muscular, esto mediante la modulación de procesos relacionados con la proliferación y la diferenciación celular. Estos efectos inducidos por el GDF11 principalmente se llevan a cabo en células troncales y estas son las características que presentan las células que conforman los tumores en etapas avanzadas.

Los resultados demostraron que el GDF11 estaba afectando a las dos líneas celulares provenientes de un cáncer de hígado humano, esto mediante la activación de las principales proteínas implicadas en las rutas de señalización canónica de las familias a las que pertenece el GDF11.

Como se pudo observar, en la línea celular Huh7 hay activación de las proteínas Smad2 y Smad3 mientras que las proteínas Smad 1/5 no muestra cambios, lo que sugiere que los efectos encontrados en la línea celular Huh7 es mediada por la ruta canónica del TGF- $\beta$, además de sugerir que dicha línea celular solo cuenta con los receptores encargados de activar las proteínas Smad antes mencionadas.

En el caso de la línea celular Hep3B, se pudo observar resultados similares a los encontrados en la línea Huh7, la activación de las proteínas Smad2 y Smad3, pero sorprendentemente, también se observó activación de las proteínas Smad1/5, esto 
nos sugiere que los resultados encontrados en esta línea celular no tienen preferencia por alguna ruta de la familia a la que pertenece el GDF11. Este resultado también sugiere la posibilidad de la presencia de los receptores canónicos para el TGF- $\beta$ y la BMP en la línea Hep3B.

Otro de los efectos que se encontró con el tratamiento del GDF11 fue la disminución de la proliferación de las dos líneas celulares, sin embargo, estos efectos fueron más contundentes en la línea Huh7, donde en presencia o no de SFB la proliferación disminuyó de manera significativa hasta las 72 h con el tratamiento.

Mientras que en la línea celular Hep3B, el efecto más contundente se vio en el grupo que recibió el tratamiento con el SFB. Estos efectos fueron corroborados mediante las proteínas que se encargan de regular el ciclo celular, observando que el GDF11 provoca la desregulación de los principales reguladores positivos de dicho proceso y a su vez, la sobreregulación de uno de los reguladores negativos el ciclo como es p27. Una de las posibles razones por lo cual la proliferación se está afectando, es debido a que el GDF11 está afectando la señalización de una de las principales rutas de señalización que participan en la progresión del cáncer, mediante el aumento en la proliferación celular. Como se pudo observar, el GDF11 está impactando sobre la activación de ERK, quien después de 15 minutos está disminuyendo su activación sin encontrar su activación nuevamente incluso 60 minutos después del tratamiento con el factor de crecimiento.

Si bien, el GDF11 no estaba induciendo efectos citotóxicos sobre las células, ya que la viabilidad se encontraba sin cambios, si se encontraba afectado de alguna manera 
a las células, lo cual se observó mediante la disminución de la proliferación, por tal motivo se decidió estudiar el metabolismo de las células con el tratamiento, esto mediante el ensayo de MTT y el uso del Seahorse, los resultados mostraron que las células en presencia del factor de crecimiento presentan una alteración sobre el metabolismo de lípidos, específicamente sobre el metabolismo del colesterol, lo cual se observó después de la realización de la secuenciación de ARN, estos resultados pueden explicar porque las células disminuyen su proliferación, ya que una de las principales rutas de señalización que se encargan de proveer a las células de energía se encuentran alteradas. Además, se observó que la presencia del GDF11 provoca la alteración de 133 genes, de los cuales 101 se sobreexpresaron y 32 fueron reprimidos. Como se observó en los resultados de los esferoides, el GDF11 está induciendo la disminución tanto en número como en tamaño de los esferoides, esto nos indica que el tratamiento está induciendo efectos antitumorigénicos en ambas líneas celulares de cáncer de hígado, además de encontrar que el GDF11 provoca la disminución de los principales genes relacionados con agresividad, específicamente con procesos de diferenciación, lo cual corrobora que el GDF11, en condiciones normales participa en los procesos de diferenciación celular como se ha reportado anteriormente (Egerman et al., 2015; Sinha et al., 2014), encontrando específicamente en cáncer la disminución de los genes usados como marcadores de agresividad.

El GDF11 participa en los procesos de migración celular, esto se debe principalmente a que dicho factor de crecimiento provoca la disminución de marcadores mesenquimales, quienes se encargan de permitir que las células puedan migrar, a su vez, aumentan los marcadores epiteliales, quienes se encargan de mantener 
adheridas las células, por lo que este resultado contradice lo reportado anteriormente (Pons et al., 2018; Williams et al., 2013) quienes indican que el GDF11 induce la progresión de la migración celular, encontrando además que el factor de crecimiento provoca la disminución del marcador E-Cadherina.

Estos resultados fueron corroborados mediante el ensayo de migración usando el modelo de la CAM, donde observamos que las células en presencia del GDF11 pierden sus capacidades para migrar, corroboran el ensayo de herida cicatriz, que fuertemente nos sugirió una alteración en el proceso de migración.

Se pudo observar también, que las células una vez colocadas dentro de los embriones, donde por el proceso de desarrollo en el que se encuentran los embriones existe una producción elevada de factores de crecimiento, aun así, las células que habían recibido el tratamiento con el GDF11 no lograron recuperar sus capacidades proliferativas, comparadas con las células controles.

Los efectos inducidos por el GDF11 no son transientes, ya que las células que recibieron el tratamiento por 72 h no recuperaron su capacidad de proliferación, este resultado se observó en el ensayo de clonogenicidad y de formación de esferoides, donde después de 10 días sin la presencia del GDF11 continúan de alguna manera arrestadas.

Si bien, los resultados muestran el efecto antitumorigénico ejercido por el GDF11, mediante un análisis de secuenciación de ARN se pudo observar la expresión diferencial de algunos genes, entre ellos se observaron alteraciones en genes relacionados con el metabolismo del colesterol, lo cual explica los efectos observados, 
debido a que el colesterol es una de las principales moléculas encargadas de proveer energía a las células además de un incremento en la resistencia a la muerte celular. Finalmente, los efectos que fueron encontrados en las líneas celulares de HCC se observaron también en otras líneas derivadas de diferentes tipos de cáncer, encontrando que el tratamiento con el GDF11 provoco la disminución en la formación de esferoides. Estos resultados nos corroboran una vez más que el principal blanco del GDF11 son las células troncales, en el caso específico de las células cancerosas, éstas durante su proceso de progresión, adquieren características similares a las células troncales, este proceso está estrechamente relacionado con el grado de agresividad que presentan las células cancerosas.

En conclusión, el GDF11 induce efectos antitumorigénicos en las células derivadas de cáncer de hígado, mediante la desregulación de proteínas encargadas de regular la progresión del ciclo celular, reflejándose en la disminución de la proliferación de las células. Además, el tratamiento con el GDF11 provoca la disminución de las principales características de agresividad que presentan las células, como son la disminución en la migración celular, la disminución de genes relacionados con agresividad y por último alteraciones en el metabolismo energético. 


\section{Referencias}

Bajikar, S. S., Wang, C. C., Borten, M. A., Pereira, E. J., Atkins, K. A., \& Janes, K. A. (2017). Tumor-Suppressor Inactivation of GDF11 Occurs by Precursor Sequestration in Triple-Negative Breast Cancer. Dev Cell, 43(4), 418-435 e413. Calvisi, D. F., Wang, C., Ho, C., Ladu, S., Lee, S. A., Mattu, S., Destefanis, G., Delogu, S., Zimmermann, A., Ericsson, J., Brozzetti, S., Staniscia, T., Chen, X., Dombrowski, F., \& Evert, M. (2011). Increased lipogenesis, induced by AKTmTORC1-RPS6 signaling, promotes development of human hepatocellular carcinoma. Gastroenterology, 140(3), 1071-1083.

Cargnello, M., \& Roux, P. P. (2011). Activation and function of the MAPKs and their substrates, the MAPK-activated protein kinases. Microbiol Mol Biol Rev, 75(1), 50-83.

Chang, L., \& Karin, M. (2001). Mammalian MAP kinase signalling cascades. Nature, 410(6824), 37-40.

Che, L., Pilo, M. G., Cigliano, A., Latte, G., Simile, M. M., Ribback, S., Dombrowski, F., Evert, M., Chen, X., \& Calvisi, D. F. (2017). Oncogene dependent requirement of fatty acid synthase in hepatocellular carcinoma. Cell Cycle, 16(6), 499-507.

Chen, Z., Gibson, T. B., Robinson, F., Silvestro, L., Pearson, G., Xu, B., Wright, A., Vanderbilt, C., \& Cobb, M. H. (2001). MAP kinases. Chem Rev, 101(8), 24492476.

Clavijo-Cornejo, D., Enriquez-Cortina, C., Lopez-Reyes, A., Dominguez-Perez, M., Nuno, N., Dominguez-Meraz, M., Bucio, L., Souza, V., Factor, V. M., Thorgeirsson, S. S., Gutierrez-Ruiz, M. C., \& Gomez-Quiroz, L. E. (2013). Biphasic regulation of the NADPH oxidase by HGF/c-Met signaling pathway in primary mouse hepatocytes. Biochimie, 95(6), 1177-1184.

Cronin, K. A., Lake, A. J., Scott, S., Sherman, R. L., Noone, A. M., Howlader, N., Henley, S. J., Anderson, R. N., Firth, A. U., Ma, J., Kohler, B. A., \& Jemal, A. (2018). Annual Report to the Nation on the Status of Cancer, part I: National cancer statistics. Cancer, 124(13), 2785-2800.

Czauderna, C., Palestino-Dominguez, M., Castven, D., Becker, D., Zanon-Rodriguez, L., Hajduk, J., Mahn, F. L., Herr, M., Strand, D., Strand, S., Heilmann-Heimbach, S., Gomez-Quiroz, L. E., Worns, M. A., Galle, P. R., \& Marquardt, J. U. (2018). Ginkgo biloba induces different gene expression signatures and oncogenic pathways in malignant and non-malignant cells of the liver. PLoS One, 13(12), e0209067.

Egerman, M. A., Cadena, S. M., Gilbert, J. A., Meyer, A., Nelson, H. N., Swalley, S. E., Mallozzi, C., Jacobi, C., Jennings, L. L., Clay, I., Laurent, G., Ma, S., Brachat, S., Lach-Trifilieff, E., Shavlakadze, T., Trendelenburg, A. U., Brack, A. S., \& Glass, D. J. (2015). GDF11 Increases with Age and Inhibits Skeletal Muscle Regeneration. Cell Metab, 22(1), 164-174.

Enriquez-Cortina, C., Almonte-Becerril, M., Clavijo-Cornejo, D., Palestino-Dominguez, M., Bello-Monroy, O., Nuno, N., Lopez, A., Bucio, L., Souza, V., HernandezPando, R., Munoz, L., Gutierrez-Ruiz, M. C., \& Gomez-Quiroz, L. E. (2013). 
Hepatocyte growth factor protects against isoniazid/rifampicin-induced oxidative liver damage. Toxicol Sci, 135(1), 26-36.

Esquela, A. F., \& Lee, S. J. (2003). Regulation of metanephric kidney development by growth/differentiation factor 11. Dev Biol, 257(2), 356-370.

Essalmani, R., Zaid, A., Marcinkiewicz, J., Chamberland, A., Pasquato, A., Seidah, N. G., \& Prat, A. (2008). In vivo functions of the proprotein convertase PC5/6 during mouse development: Gdf11 is a likely substrate. Proc Natl Acad Sci U $S A$, 105(15), 5750-5755.

Ferlay, J., Soerjomataram, I., Dikshit, R., Eser, S., Mathers, C., Rebelo, M., Parkin, D. M., Forman, D., \& Bray, F. (2015). Cancer incidence and mortality worldwide: sources, methods and major patterns in GLOBOCAN 2012. Int J Cancer, 136(5), E359-386.

Finkenzeller, G., Stark, G. B., \& Strassburg, S. (2015). Growth differentiation factor 11 supports migration and sprouting of endothelial progenitor cells. J Surg Res, 198(1), 50-56.

Gaunt, S. J., George, M., \& Paul, Y. L. (2013). Direct activation of a mouse Hoxd11 axial expression enhancer by Gdf11/Smad signalling. Dev Biol, 383(1), 52-60.

Ge, G., Hopkins, D. R., Ho, W. B., \& Greenspan, D. S. (2005). GDF11 forms a bone morphogenetic protein 1-activated latent complex that can modulate nerve growth factor-induced differentiation of PC12 cells. Mol Cell Biol, 25(14), 58465858.

Geest, C. R., \& Coffer, P. J. (2009). MAPK signaling pathways in the regulation of hematopoiesis. J Leukoc Biol, 86(2), 237-250.

Gokoffski, K. K., Wu, H. H., Beites, C. L., Kim, J., Kim, E. J., Matzuk, M. M., Johnson, J. E., Lander, A. D., \& Calof, A. L. (2011). Activin and GDF11 collaborate in feedback control of neuroepithelial stem cell proliferation and fate. Development, 138(19), 4131-4142.

Gollob, J. A., Wilhelm, S., Carter, C., \& Kelley, S. L. (2006). Role of Raf kinase in cancer: therapeutic potential of targeting the Raf/MEK/ERK signal transduction pathway. Semin Oncol, 33(4), 392-406.

Gomez-Quiroz, L. E., Seo, D., Lee, Y. H., Kitade, M., Gaiser, T., Gillen, M., Lee, S. B., Gutierrez-Ruiz, M. C., Conner, E. A., Factor, V. M., Thorgeirsson, S. S., \& Marquardt, J. U. (2016). Loss of c-Met signaling sensitizes hepatocytes to lipotoxicity and induces cholestatic liver damage by aggravating oxidative stress. Toxicology, 361-362, 39-48.

Gutiérrez Ruiz, M., Bucio, L., Souza, V., Miranda Labra, R., \& Gómez Quiroz, L. (2014). El hígado. Pretextos y Contextos (M. H. Coria Ed. 1 ed.). Ciudad de México: UAM-I.

Hanahan, D., \& Weinberg, R. A. (2011). Hallmarks of cancer: the next generation. Cell, 144(5), 646-674.

Jimenez-Salazar, J. E., Posadas-Rodriguez, P., Lazzarini-Lechuga, R. C., Luna-Lopez, A., Zentella-Dehesa, A., Gomez-Quiroz, L. E., Konigsberg, M., DominguezGomez, G., \& Damian-Matsumura, P. (2014). Membrane-initiated estradiol signaling of epithelial-mesenchymal transition-associated mechanisms through 
regulation of tight junctions in human breast cancer cells. Horm Cancer, 5(3), 161-173.

Kaposi-Novak, P., Lee, J. S., Gomez-Quiroz, L., Coulouarn, C., Factor, V. M., \& Thorgeirsson, S. S. (2006). Met-regulated expression signature defines a subset of human hepatocellular carcinomas with poor prognosis and aggressive phenotype. J Clin Invest, 116(6), 1582-1595.

Leppa, S., \& Bohmann, D. (1999). Diverse functions of JNK signaling and c-Jun in stress response and apoptosis. Oncogene, 18(45), 6158-6162.

Liu, P., Ge, M., Hu, J., Li, X., Che, L., Sun, K., Cheng, L., Huang, Y., Pilo, M. G., Cigliano, A., Pes, G. M., Pascale, R. M., Brozzetti, S., Vidili, G., Porcu, A., Cossu, A., Palmieri, G., Sini, M. C., Ribback, S., Dombrowski, F., Tao, J., Calvisi, D. F., Chen, L., \& Chen, X. (2017). A functional mammalian target of rapamycin complex 1 signaling is indispensable for c-Myc-driven hepatocarcinogenesis. Hepatology, 66(1), 167-181.

Lu, Z., \& Xu, S. (2006). ERK1/2 MAP kinases in cell survival and apoptosis. IUBMB Life, 58(11), 621-631.

Mandal, R., Becker, S., \& Strebhardt, K. (2016). Stamping out RAF and MEK1/2 to inhibit the ERK1/2 pathway: an emerging threat to anticancer therapy. Oncogene, 35(20), 2547-2561.

Mandal, R., Raab, M., Matthess, Y., Becker, S., Knecht, R., \& Strebhardt, K. (2014). pERK 1/2 inhibit Caspase-8 induced apoptosis in cancer cells by phosphorylating it in a cell cycle specific manner. Mol Oncol, 8(2), 232-249.

Marquardt, J. U., Seo, D., Gomez-Quiroz, L. E., Uchida, K., Gillen, M. C., Kitade, M., Kaposi-Novak, P., Conner, E. A., Factor, V. M., \& Thorgeirsson, S. S. (2012). Loss of c-Met accelerates development of liver fibrosis in response to $\mathrm{CCl}(4)$ exposure through deregulation of multiple molecular pathways. Biochim Biophys Acta, 1822(6), 942-951.

Massague, J. (2012). TGFbeta signalling in context. Nat Rev Mol Cell Biol, 13(10), 616630.

McPherron, A. C., Lawler, A. M., \& Lee, S. J. (1999). Regulation of anterior/posterior patterning of the axial skeleton by growth/differentiation factor 11. Nat Genet, 22(3), 260-264.

Menendez, J. A., \& Lupu, R. (2007). Fatty acid synthase and the lipogenic phenotype in cancer pathogenesis. Nat Rev Cancer, 7(10), 763-777.

Moon, H., Ju, H. L., Chung, S. I., Cho, K. J., Eun, J. W., Nam, S. W., Han, K. H., Calvisi, D. F., \& Ro, S. W. (2017). Transforming Growth Factor-beta Promotes Liver Tumorigenesis in Mice via Up-regulation of Snail. Gastroenterology, 153(5), 1378-1391 e1376.

Morales, A., Mari, M., Garcia-Ruiz, C., Colell, A., \& Fernandez-Checa, J. C. (2012). Hepatocarcinogenesis and ceramide/cholesterol metabolism. Anticancer Agents Med Chem, 12(4), 364-375.

Nakagawa, Y. (1996). Effects of dicoumarol on cytotoxicity caused by tertbutylhydroquinone in isolated rat hepatocytes. Toxicol Lett, 84(2), 63-68. 
Nakashima, M., Toyono, T., Akamine, A., \& Joyner, A. (1999). Expression of growth/differentiation factor 11, a new member of the BMP/TGFbeta superfamily during mouse embryogenesis. Mech Dev, 80(2), 185-189.

Ning, J., Zhao, Y., Ye, Y., \& Yu, J. (2019). Opposing roles and potential antagonistic mechanism between TGF-beta and BMP pathways: Implications for cancer progression. EBioMedicine, 41, 702-710.

Perez-Aguilar, B., Vidal, C. J., Palomec, G., Garcia-Dolores, F., Gutierrez-Ruiz, M. C., Bucio, L., Gomez-Olivares, J. L., \& Gomez-Quiroz, L. E. (2015). Acetylcholinesterase is associated with a decrease in cell proliferation of hepatocellular carcinoma cells. Biochim Biophys Acta, 1852(7), 1380-1387.

Pons, M., Koniaris, L. G., Moe, S. M., Gutierrez, J. C., Esquela-Kerscher, A., \& Zimmers, T. A. (2018). GDF11 induces kidney fibrosis, renal cell epithelial-tomesenchymal transition, and kidney dysfunction and failure. Surgery, 164(2), 262-273.

Quigley, J. P., \& Armstrong, P. B. (1998). Tumor cell intravasation alu-cidated: the chick embryo opens the window. Cell, 94(3), 281-284.

Ribatti, D. (2017). The chick embryo chorioallantoic membrane (CAM) assay. Reprod Toxicol, 70, 97-101.

Roberts, P. J., \& Der, C. J. (2007). Targeting the Raf-MEK-ERK mitogen-activated protein kinase cascade for the treatment of cancer. Oncogene, 26(22), 32913310.

Sinha, M., Jang, Y. C., Oh, J., Khong, D., Wu, E. Y., Manohar, R., Miller, C., Regalado, S. G., Loffredo, F. S., Pancoast, J. R., Hirshman, M. F., Lebowitz, J., Shadrach, J. L., Cerletti, M., Kim, M. J., Serwold, T., Goodyear, L. J., Rosner, B., Lee, R. T., \& Wagers, A. J. (2014). Restoring systemic GDF11 levels reverses agerelated dysfunction in mouse skeletal muscle. Science, 344(6184), 649-652.

Sinning, M., Letelier, R., Rosas, C., Fuenzalida, M., \& Lemus, D. (2012). Angiogenic potential of the cerebrospinal fluid (CSF) of patients with high-grade gliomas measured with the chick embryo chorioallantoic membrane assay (CAM). Biol Res, 45(2), 135-138.

Walker, R. G., Czepnik, M., Goebel, E. J., McCoy, J. C., Vujic, A., Cho, M., Oh, J., Aykul, S., Walton, K. L., Schang, G., Bernard, D. J., Hinck, A. P., Harrison, C. A., Martinez-Hackert, E., Wagers, A. J., Lee, R. T., \& Thompson, T. B. (2017). Structural basis for potency differences between GDF8 and GDF11. BMC Biol, 15(1), 19.

Wallner, C., Drysch, M., Becerikli, M., Jaurich, H., Wagner, J. M., Dittfeld, S., Nagler, J., Harati, K., Dadras, M., Philippou, S., Lehnhardt, M., \& Behr, B. (2018). Interaction with the GDF8/11 pathway reveals treatment options for adenocarcinoma of the breast. Breast, 37, 134-141.

Williams, G., Zentar, M. P., Gajendra, S., Sonego, M., Doherty, P., \& Lalli, G. (2013). Transcriptional basis for the inhibition of neural stem cell proliferation and migration by the TGFbeta-family member GDF11. PLoS One, 8(11), e78478.

Yokoe, T., Ohmachi, T., Inoue, H., Mimori, K., Tanaka, F., Kusunoki, M., \& Mori, M. (2007). Clinical significance of growth differentiation factor 11 in colorectal cancer. Int J Oncol, 31(5), 1097-1101. 
Zhang, J., Yamada, O., Kida, S., Matsushita, Y., \& Hattori, T. (2016). Down-regulation of osteopontin mediates a novel mechanism underlying the cytostatic activity of TGF-beta. Cell Oncol (Dordr), 39(2), 119-128.

Zhang, Y., Alexander, P. B., \& Wang, X. F. (2017). TGF-beta Family Signaling in the Control of Cell Proliferation and Survival. Cold Spring Harb Perspect Biol, 9(4).

Zhang, Y., Shao, J., Wang, Z., Yang, T., Liu, S., Liu, Y., Fan, X., \& Ye, W. (2015). Growth differentiation factor 11 is a protective factor for osteoblastogenesis by targeting PPARgamma. Gene, 557(2), 209-214.

Zhang, Y. H., Cheng, F., Du, X. T., Gao, J. L., Xiao, X. L., Li, N., Li, S. L., \& Dong de, L. (2016). GDF11/BMP11 activates both smad1/5/8 and smad2/3 signals but shows no significant effect on proliferation and migration of human umbilical vein endothelial cells. Oncotarget, 7(11), 12063-12074. 


\section{Anexos}

\subsection{Anexo I}

Genes diferencialmente expresados por RNA-seq de células Huh7 no tratadas vs células tratadas con GDF11 por 72h.

\begin{tabular}{|l|r|r|}
\hline Gene Symbol & log2FoldChange & \multicolumn{1}{c|}{ pvalue } \\
\hline LGALS14 & 3.921469019 & $3.53 \mathrm{E}-261$ \\
\hline LEFTY2 & 3.687024639 & $1.06 \mathrm{E}-26$ \\
\hline LGI4 & 3.490888727 & $8.56 \mathrm{E}-35$ \\
\hline COMP & 2.747552515 & $9.82 \mathrm{E}-25$ \\
\hline NPNT & 2.713387978 & $5.13 \mathrm{E}-232$ \\
\hline ADAMTS16 & 2.647553308 & $1.30 \mathrm{E}-45$ \\
\hline PREX2 & 2.569974521 & $1.75 \mathrm{E}-20$ \\
\hline TNNI2 & 2.488468809 & $2.20 \mathrm{E}-17$ \\
\hline CYP27C1 & 2.470734906 & $5.01 \mathrm{E}-21$ \\
\hline LAMP3 & 2.466356076 & $4.10 \mathrm{E}-18$ \\
\hline INHBE & 2.452467137 & $6.39 \mathrm{E}-48$ \\
\hline LOXL4 & 2.428604852 & $2.17 \mathrm{E}-198$ \\
\hline SLC2A3 & 2.376173926 & $8.30 \mathrm{E}-22$ \\
\hline UACA & 2.37336341 & $1.85 \mathrm{E}-216$ \\
\hline HOXD10 & 2.341004559 & $1.93 \mathrm{E}-34$ \\
\hline ANGPTL2 & 2.339207786 & $4.82 \mathrm{E}-36$ \\
\hline PNCK & 2.338519511 & $1.09 \mathrm{E}-22$ \\
\hline DPYSL3 & 2.324217136 & $7.81 \mathrm{E}-39$ \\
\hline TMPRSS6 & 2.284219761 & $5.99 \mathrm{E}-35$ \\
\hline FXYD3 & 2.246128235 & $3.23 \mathrm{E}-14$ \\
\hline ROCK1P1 & 2.236023786 & $1.63 \mathrm{E}-57$ \\
\hline FBN1 & 2.187855546 & $5.76 \mathrm{E}-33$ \\
\hline ABCA5 & 2.180522535 & $4.23 \mathrm{E}-87$ \\
\hline NCF2 & 2.165376117 & $1.69 \mathrm{E}-42$ \\
\hline MUC4 & 2.154113058 & $3.96 \mathrm{E}-10$ \\
\hline BRINP2 & 2.145535665 & $4.69 \mathrm{E}-35$ \\
\hline IGF2 & 2.145324365 & $3.52 \mathrm{E}-14$ \\
\hline ELN & 2.135058095 & $7.67 \mathrm{E}-10$ \\
\hline MUC6 & 2.124994446 & $2.19 \mathrm{E}-11$ \\
\hline & & \\
\hline
\end{tabular}




\begin{tabular}{|l|r|r|}
\hline CCDC114 & 2.117616995 & $7.32 \mathrm{E}-10$ \\
\hline FCRLA & 2.068443888 & $8.20 \mathrm{E}-10$ \\
\hline TBX15 & 2.035915515 & $1.00 \mathrm{E}-30$ \\
\hline AKR1D1 & 2.022713664 & $3.31 \mathrm{E}-32$ \\
\hline HERPUD1 & 2.01607821 & $4.49 \mathrm{E}-47$ \\
\hline H2AFY2 & 2.009538684 & $5.22 \mathrm{E}-42$ \\
\hline HSPA5 & 1.949514938 & $3.02 \mathrm{E}-18$ \\
\hline MAP4K4 & 1.920309378 & $4.85 \mathrm{E}-145$ \\
\hline CPA6 & 1.90940687 & $3.76 \mathrm{E}-41$ \\
\hline KSR2 & 1.902561407 & $1.45 \mathrm{E}-08$ \\
\hline NFASC & 1.894703438 & $2.23 \mathrm{E}-09$ \\
\hline DNAH17 & 1.891291946 & $1.63 \mathrm{E}-15$ \\
\hline MUC12 & 1.88025976 & $1.38 \mathrm{E}-13$ \\
\hline NEBL & 1.877571261 & $4.53 \mathrm{E}-23$ \\
\hline PALMD & 1.873603078 & $1.82 \mathrm{E}-43$ \\
\hline BIRC7 & 1.861189535 & $5.29 \mathrm{E}-08$ \\
\hline ADAM18 & 1.845354175 & $9.14 \mathrm{E}-08$ \\
\hline THSD7B & 1.836839641 & $7.64 \mathrm{E}-09$ \\
\hline CACNA1I & 1.807888686 & $4.57 \mathrm{E}-09$ \\
\hline MUC16 & 1.788859558 & $3.84 \mathrm{E}-09$ \\
\hline HOXD11 & 1.770701533 & $8.34 \mathrm{E}-10$ \\
\hline HAO2 & 1.769695508 & $3.80 \mathrm{E}-11$ \\
\hline HR & 1.768831463 & $3.54 \mathrm{E}-08$ \\
\hline SCARA5 & 1.756851385 & $6.87 \mathrm{E}-08$ \\
\hline TNR & 1.755585331 & $3.91 \mathrm{E}-09$ \\
\hline VLDLR & 1.745466075 & $5.29 \mathrm{E}-44$ \\
\hline LGR5 & 1.743793568 & $6.26 \mathrm{E}-36$ \\
\hline FAT2 & 1.730028538 & $9.07 \mathrm{E}-14$ \\
\hline TMIE & 1.715156511 & $8.26 \mathrm{E}-11$ \\
\hline COL3A1 & 1.707350978 & $4.57 \mathrm{E}-18$ \\
\hline CRMP1 & 1.707206198 & $1.03 \mathrm{E}-08$ \\
\hline LINC00626 & 1.702047953 & $3.77 \mathrm{E}-07$ \\
\hline COL6A3 & 1.684020112 & $1.04 \mathrm{E}-07$ \\
\hline NRP2 & 1.658978033 & $9.19 \mathrm{E}-18$ \\
\hline VAT1L & 1.658095383 & $8.47 \mathrm{E}-28$ \\
\hline SLC38A4 & 1.657462088 & $7.81 \mathrm{E}-61$ \\
\hline TFCP2L1 & 1.657241066 & $1.69 \mathrm{E}-08$ \\
\hline
\end{tabular}




\begin{tabular}{|l|r|r|}
\hline RYR1 & 1.65532021 & $3.85 \mathrm{E}-07$ \\
\hline CTCFL & 1.651149779 & $3.91 \mathrm{E}-09$ \\
\hline SLC17A2 & 1.647355437 & $5.96 \mathrm{E}-07$ \\
\hline DDIT3 & 1.642562624 & $2.27 \mathrm{E}-22$ \\
\hline ERICH2 & 1.641813038 & $1.25 \mathrm{E}-12$ \\
\hline MUC17 & 1.633344068 & $2.94 \mathrm{E}-08$ \\
\hline INHBC & 1.628561448 & $2.00 \mathrm{E}-11$ \\
\hline RASGRF1 & 1.621020225 & $2.83 \mathrm{E}-06$ \\
\hline TSPAN2 & 1.620255918 & $2.39 \mathrm{E}-11$ \\
\hline GRAMD1B & 1.619594262 & $4.80 \mathrm{E}-07$ \\
\hline USH2A & 1.610606432 & $1.09 \mathrm{E}-24$ \\
\hline LOC100505570 & 1.607861636 & $7.57 \mathrm{E}-07$ \\
\hline EGFLAM & 1.604269324 & $1.00 \mathrm{E}-06$ \\
\hline SYT12 & 1.60131133 & $3.69 \mathrm{E}-16$ \\
\hline ADGRG1 & 1.595839165 & $1.01 \mathrm{E}-09$ \\
\hline SDAD1P1 & 1.595801649 & $2.96 \mathrm{E}-08$ \\
\hline PLOD2 & 1.588643143 & $1.21 \mathrm{E}-46$ \\
\hline AKAP9 & 1.586904882 & $8.35 \mathrm{E}-35$ \\
\hline CD244 & 1.584133714 & $3.22 \mathrm{E}-06$ \\
\hline GRIN2B & 1.583927447 & $4.44 \mathrm{E}-09$ \\
\hline NODAL & 1.579142937 & $6.48 \mathrm{E}-07$ \\
\hline SPOCK3 & 1.575663235 & $1.33 \mathrm{E}-21$ \\
\hline ARG1 & 1.570875587 & $9.63 \mathrm{E}-12$ \\
\hline MUC5B & 1.568495098 & $1.13 \mathrm{E}-06$ \\
\hline SSUH2 & 1.567813132 & $2.40 \mathrm{E}-11$ \\
\hline SLC17A1 & 1.56688722 & $6.87 \mathrm{E}-12$ \\
\hline DDIT4 & 1.550565301 & $1.10 \mathrm{E}-12$ \\
\hline DCDC1 & 1.535536328 & $8.26 \mathrm{E}-13$ \\
\hline LINC00607 & 1.535457271 & $9.33 \mathrm{E}-08$ \\
\hline ESRP1 & 1.52514354 & $9.88 \mathrm{E}-15$ \\
\hline COL4A4 & 1.524387072 & $4.95 \mathrm{E}-07$ \\
\hline HPX & 1.516843773 & $1.96 \mathrm{E}-13$ \\
\hline SUSD4 & 1.514676264 & $9.53 \mathrm{E}-08$ \\
\hline LOC101927476 & 1.504933399 & $4.12 \mathrm{E}-06$ \\
\hline TGM2 & 1.503268181 & $3.89 \mathrm{E}-24$ \\
\hline GDA & -1.528488074 & $3.00 \mathrm{E}-41$ \\
\hline NQO1 & -1.532507828 & $2.55 \mathrm{E}-38$ \\
\hline
\end{tabular}




\begin{tabular}{|l|r|r|}
\hline CEBPD & -1.559862342 & $8.04 \mathrm{E}-25$ \\
\hline RNU1-4 & -1.569737269 & 0.003581296 \\
\hline HMGCS1 & -1.572736881 & $4.05 \mathrm{E}-28$ \\
\hline DHCR7 & -1.604743325 & $1.02 \mathrm{E}-15$ \\
\hline ID3 & -1.635236286 & $2.89 \mathrm{E}-14$ \\
\hline FASN & -1.640033605 & $1.47 \mathrm{E}-16$ \\
\hline LDLR & -1.660673068 & $4.87 \mathrm{E}-32$ \\
\hline UCA1 & -1.683039475 & $1.35 \mathrm{E}-15$ \\
\hline GPX2 & -1.72467583 & $1.97 \mathrm{E}-40$ \\
\hline AGR2 & -1.726754148 & $5.96 \mathrm{E}-35$ \\
\hline RELN & -1.732237464 & $2.98 \mathrm{E}-46$ \\
\hline C4BPA & -1.736620543 & $2.49 \mathrm{E}-22$ \\
\hline SLPI & -1.819627376 & $8.63 \mathrm{E}-10$ \\
\hline PCSK9 & -1.837419153 & $7.00 \mathrm{E}-14$ \\
\hline DUSP5 & -1.891144348 & $3.21 \mathrm{E}-52$ \\
\hline REG1A & -1.985463268 & $7.09 \mathrm{E}-23$ \\
\hline INSIG1 & -1.993474499 & $2.30 \mathrm{E}-32$ \\
\hline SERPINC1 & -2.037707054 & $9.74 \mathrm{E}-10$ \\
\hline PIGR & -2.144615136 & $4.15 \mathrm{E}-11$ \\
\hline SAA1 & -2.159203684 & $1.72 \mathrm{E}-09$ \\
\hline RAMP1 & -2.184992954 & $3.79 \mathrm{E}-18$ \\
\hline CEACAM7 & -2.246612681 & $5.49 \mathrm{E}-18$ \\
\hline CEACAM6 & -2.328163629 & $4.73 \mathrm{E}-11$ \\
\hline LYZ & -2.332004714 & $1.23 \mathrm{E}-13$ \\
\hline MAGEA11 & -2.335203017 & $4.74 \mathrm{E}-11$ \\
\hline FJX1 & -2.431089774 & $1.53 \mathrm{E}-16$ \\
\hline PCDH20 & -2.554797019 & $4.66 \mathrm{E}-45$ \\
\hline NTS & -2.668937049 & $4.98 \mathrm{E}-75$ \\
\hline PI3 & -2.716861907 & $1.79 \mathrm{E}-28$ \\
\hline CXCL5 & -2.954990498 & $2.30 \mathrm{E}-132$ \\
\hline & & \\
\hline
\end{tabular}




\subsection{Anexo II}

\section{Artículos producto de la investigación}

1. GDF11 exhibits tumor suppressive properties in hepatocellular carcinoma cells by restricting clonal expansion and invasion. Monserrat GerardoRamírez, Roberto Lazzarini-Lechuga, Javier Esteban Jiménez-Salazar, Sharik Hernández-Rizo, Arturo Simoni-Nieves, Carmen García-Ruiz, Jorlos Carlos Fernández-Checa, Jens U. Marquardt, Cedric Coulouarn, María Concepción Gutiérrez-Ruiz, Benjamín Pérez-Aguilar, Luis E. Gomez-Quiroz. Biochemica et Biophysica Acta-Molecular Basis of Disease. 2019.

2. GDF11 implications in cancer biology and metabolism. Facts and controversies. Arturo Simoni-Nieves, Monserrat Gerardo-Ramírez, Gibrán PedrazaVázquez, Lisette Chávez-Rodríguez, Leticia Bucio, Verónica Souza, Roxana U Miranda-Labra, Luis E. Gomez-Quiroz, María Concepción Gutiérrez-Ruiz. Frontiers in Oncology, 2019.

3. La homeostasis lipídica en la progresión del cáncer hepático. Monserrat Gerardo-Ramírez, Benjamín Pérez-Aguilar, María Concepción GutiérrezRuiz, Luis Enrique Gómez-Quiroz, Contactos, Revista de educación en ciencias e ingeniería. No. 102, pp 5-13, Octubre-Diciembre del 2016.

4. La tuberculosis y la resistencia a fármacos, en tiempos del cambio climático. Nuevos retos para una infección antigua. Oscar Bello Monroy, Alejandro Escobedo Calvario, Monserrat Gerardo-Ramírez, Roxana Uri Miranda Labra, María Concepción Gutiérrez-Ruiz, Rogelio Hernández Pando, Luis Enrique Gómez-Quiroz Contactos, Revista de educación en ciencias e ingeniería. No. 106, pp 28-36, Octubre-Diciembre del 2017.

5. Typhus, yellow fever and Medicine in Mexico during the French intervention. Monserrat Gerardo-Ramirez, Jesús Zavaleta Castro, Luis Enrique GómezQuiroz. Gaceta Medica de México. 2018;154(1):111-117. 


\title{
GDF11 exhibits tumor suppressive properties in hepatocellular carcinoma cells by restricting clonal expansion and invasion
}

\author{
Monserrat Gerardo-Ramírez ${ }^{\mathrm{a}, \mathrm{b}}$, Roberto Lazzarini-Lechuga ${ }^{\mathrm{c}}$, Sharik Hernández-Rizo ${ }^{\mathrm{a}, \mathrm{b}}$, \\ Javier Esteban Jiménez-Salazar ${ }^{\mathrm{c}}$, Arturo Simoni-Nieves ${ }^{\mathrm{a}, \mathrm{b}}$, Carmen García-Ruiz ${ }^{\mathrm{d}}$, \\ José Carlos Fernández-Checa ${ }^{\mathrm{d}}$, Jens U. Marquardt ${ }^{\mathrm{e}}$, Cedric Coulouarn ${ }^{\mathrm{f}}$, \\ María Concepción Gutiérrez-Ruiz ${ }^{\mathrm{b}, \mathrm{g}}$, Benjamín Pérez-Aguilar ${ }^{\mathrm{b}, 1}$, Luis E. Gomez-Quiroz ${ }^{\mathrm{b}, \mathrm{g}, *, 1}$ \\ ${ }^{a}$ Posgrado en Biología Experimental, DCBS, Universidad Autónoma Metropolitana-Iztapalapa, Mexico City, Mexico \\ ${ }^{\mathrm{b}}$ Departamento de Ciencias de la Salud, Universidad Autónoma Metropolitana-Iztapalapa, Mexico City, Mexico \\ ${ }^{\mathrm{c}}$ Departamento de Biología de la Reproducción, Universidad Autónoma Metropolitana-Iztapalapa, Mexico City, Mexico \\ ${ }^{\mathrm{d}}$ Department of Cell Death and Proliferation, Instituto de Investigaciones Biomédicas de Barcelona, CSIC, Liver Unit, Hospital Clinic, IDIBPAS and CIBERehd, Barcelona, \\ Spain \\ e 1st Department of Medicine, University Medical Center, Johannes Gutenberg University Mainz, Langenbeckstrasse 1, 55131 Mainz, Germany \\ ${ }^{\mathrm{f}}$ INSERM, Inra, University of Rennes, UMR 1241, Nutrition Metabolisms and Cancer, Rennes, France \\ ${ }^{\mathrm{g}}$ Laboratorio de Medicina Experimental, Unidad de Medicina Translacional, Instituto de Investigaciones Biomédicas, UNAM/Instituto Nacional de Cardiología Ignacio \\ Chavez, Mexico City, Mexico
}

\section{A R T I C L E IN F O}

\section{Keywords:}

GDF11

Huh7 cells

HCC

Cell cycle

Liver cancer

Hep3B cells

\begin{abstract}
A B S T R A C T
Growth differentiation factor 11 (GDF11) has been characterized as a key regulator of differentiation in cells that retain stemness features, despite some controversies in age-related studies. GDF11 has been poorly investigated in cancer, particularly in those with stemness capacity, such as hepatocellular carcinoma (HCC), one of the most aggressive cancers worldwide. Here, we focused on investigating the effects of GDF11 in liver cancer cells. GDF11 treatment significantly reduced proliferation, colony and spheroid formation in HCC cell lines. Consistently, down-regulation of CDK6, cyclin D1, cyclin A, and concomitant upregulation of p27 was observed after $24 \mathrm{~h}$ of treatment. Interestingly, cell viability was unchanged, but cell functionality was compromised. These effects were potentially induced by the expression of E-cadherin and occludin, as well as Snail and Ncadherin repression, in a time-dependent manner. Furthermore, GDF11 treatment for $72 \mathrm{~h}$ induced that cells were incapable of sustaining colony and sphere capacity in the absent of GDF11, up to 5 days, indicating that the effect of GDF11 on self-renewal capacity is not transient. Finally, in vivo invasion studies revealed a significant decrease in cell migration of hepatocellular carcinoma cells treated with GDF11 associated to a decreased proliferation judged by Ki67 staining. Data show that exogenous GDF11 displays tumor suppressor properties in HCC cells.
\end{abstract}

\section{Introduction}

Liver diseases represent one of the main challenges in public health. Changes in human habits tend to increase the prevalence of severe liver diseases, such as steatohepatitis, cirrhosis, viral hepatitis and liver cancer [1]. Hepatocellular carcinoma (HCC) is one of the most prevalent and aggressive tumor worldwide with high rate of postsurgical recurrence [2-4], and despite the outstanding progress made in the last decade in identifying new therapeutic approaches to target canonical proliferation and survival pathways, the potential use of non-canonical molecules and the molecular basis of their anti-proliferating activity are currently being studied directed to provide new therapeutic targets [5].

Growth differentiation factor 11 (GDF11) is a member of the subfamily of the bone morphogenic proteins, and of the superfamily of the transforming growth factor beta (TGF- $\beta$ ). GDF11 is critical for organogenesis and development, particularly for skeletal system. Knock-out for mouse Gdf11, or for the furin-like convertase (Pcsk5), which activates GDF11 to a mature form, results in skeletal development defects

\footnotetext{
* Corresponding author at: Departamento de Ciencias de la Salud, Universidad Autónoma Metropolitana Iztapalapa, Av. San Rafael Atlixco 186, Col. Vicentina, Iztapalapa, 09340 Mexico City, Mexico.

E-mail address: legq@xanum.uam.mx (L.E. Gomez-Quiroz).

${ }^{1}$ Shared Senior authorship.
} 
and lethality in uterus $[6,7]$.

Recently, some controversies have emerged about the effects of GDF11 in rejuvenation process [8]. While some groups report that GDF11 expression reduces with age, and its restoration induces proliferation and differentiation of progenitor cells (satellite cells) in the skeletal [9] and cardiac muscle [10], reversing the age-related hypertrophy, others state that GDF11 significantly inhibits muscle regeneration and decreases satellite cell expansion in mice [11,12]. This debating question is also associated with the great similarity of GDF11 with myostatin (or GDF8) and the poor specificity of some commercial antibodies [13]. Aside of these controversial functions of GDF11 in agerelated disorders, both outlooks have in common that cells, with some stemness properties, are targeted by the GDF11, notably in development process [14-16].

Given that cancer cells, with stemness features, are recognized as key therapeutic target, due to their capacity of sustained proliferation and migration, possibly driving tumor progression and resistance to treatment, we aimed at figure out the effects of GDF11 in HCC-derived cell lines. Although some studies revealed that GDF11 expression correlates with poor prognosis in colorectal [17] and breast cancer [18], it has been poorly studied in this kind of disease. Recently, Bajikar and collaborators [19] reported that GDF11 exerts tumor suppressive functions in triple-negative breast cancer cells. Loss of function of GDF11 in breast cancer has been notably related to deficient maturation due to the convertase PCSK5, which activates bioactive GDF11 from its immature form. The present study is the first one related to liver cancer and provides evidence that GDF11 could be a good candidate for new therapeutic options.

\section{Materials and methods}

\subsection{Cell culture}

Huh7, Hep3B, Hepa1-6, HepG2, SNU-182 and MDA-MB-231 cell lines were obtained from the American Type Culture Collection (ATCC, Manassas, VA, USA). Cells were cultured in William's medium supplemented with $10 \%$ fetal bovine serum (FBS, Hy-Clone, Logan, UT, USA), $100 \mathrm{U} / \mathrm{ml}$ ampicillin and $100 \mu \mathrm{g} / \mathrm{ml}$ streptomycin (Thermo Fisher Scientific, Waltham, MA, USA). Cells were maintained at $37^{\circ} \mathrm{C}$ in a $5 \%$ $\mathrm{CO}_{2}$ and $90 \%$ humidity atmosphere. Cells were plated in plastic culture bottles (Sigma-Aldrich, Saint Louis, MO, USA). All cell lines were mycoplasma free.

\subsection{Main experimental design}

Cells were exposed to $50 \mathrm{ng} / \mathrm{ml}$ GDF11 [20] for different times. GDF11 was added to culture media every $24 \mathrm{~h}$ and cells were recovered after $72 \mathrm{~h}$ for experiments, as depicted in Supplementary Fig. 1A.

In order to determine whether GDF11 effects are not transient, and remain after growth factor withdrawal, we performed additional experiments, in which cells were treated every $24 \mathrm{~h}$ up to $72 \mathrm{~h}$, then harvested and re-plated without GDF11. Spheroid and colony formation were evaluated up to 5 days in the absent of GDF11 (Supplementary Fig. 1B).

\subsection{Western blotting}

Western blot was conducted as we previously reported [21]. PVDF membranes were probed with specific antibodies as described in the Supplementary Table 1. Horseradish peroxidase-conjugated antibodies were used according to the primary antibodies. Blots were exposed using Super Signal West Pico Chemiluminescent substrate (Pierce Biotechnology, USA). Signal was detected using Gel Logic 2500 (Kodak, Rochester, NY, USA).

\subsection{Immunofluorescence assays}

Immunofluorescence was conducted as previously reported [22], briefly, cells were treated for different times with GDF11, and then fixed with $4 \%$ paraformaldehyde in phosphate-buffered saline (PBS). Samples were permeabilized with $0.01 \%$ (v/v) Triton-X 100 for $30 \mathrm{~min}$ and blocked with $3 \%(\mathrm{w} / \mathrm{v})$ bovine serum albumin (BSA) in PBS for $30 \mathrm{~min}$ and subsequently incubated with primary antibodies anti-occludin (Santa Cruz Biotechnology 81812, dilution 1:100), anti-snail (Santa Cruz Biotechnology 28199, dilution 1:100), anti-E-cadherin (Santa Cruz Biotechnology 21791, dilution 1:100) and anti-N-cadherin (Santa Cruz Biotechnology 59987, dilution 1:100). Nuclei were counterstained with $1 \mu \mathrm{g} / \mathrm{ml} \mathrm{4',6-diamidino-2-phenylindole} \mathrm{(DAPI)} \mathrm{(Sigma-}$ Aldrich). Images were obtained using a multi-photon confocal microscope (Carl Zeiss LSM-780 NLO, Oberkochen, Germany).

\subsection{Cell proliferation}

Cell proliferation was addressed by CCK- 8 kit (Dojindo Lab, Kumamoto, Japan), following manufacturer's instructions.

\subsection{Spheroid formation}

Cells were seeded in six-well low attachment plates (MilliporeSigma, Saint Louis MO, USA). The cultures were supplemented every $24 \mathrm{~h}$ with $50 \mathrm{ng} / \mathrm{ml}$ of GDF11 for five days. The spheroids were counted and photographed using an inverted microscope Carl Zeiss VERT.A1.

\subsection{Wound-healing assay}

Cells were seeded in six-well plates to approximately $90 \%$ of confluency. In each well a couple of wounds were created with a $20 \mu \mathrm{l}$ pipette tip. Plates were washed three times with PBS to remove detached cells. Subsequently, media were added supplemented or not with FBS in presence or absent of GDF11.

The healing response was monitored every $24 \mathrm{~h}$ up to $72 \mathrm{~h}$ when photography register was performed.

\subsection{Cell functionality by MTT assay}

Cell functionality was addressed by the 3-(4,5-dimethylthiazol-2yl)-2,5-diphenyltetrazolium bromide (MTT) test, using the Vybrant MTT Cell Proliferation Assay Kit (Thermo Fisher Scientific), following manufacturer's instructions.

\subsection{Clonogenic assay}

After $72 \mathrm{~h}$ under GDF11 treatment, $1 \times 10^{3}$ cells were seeded into 6well plates in triplicate and maintained in GDF11-free media, in presence or absent of FBS. After 10 days, colonies were stained with crystal violet, photographed and counted.

\subsection{Invasion study using a chick embryo chorioallantoic membrane (CAM) assay}

Chick embryo CAM model was used to study invasion properties, following previous method reported by our group and others [23-25]. Briefly, ten fertile chick (Gallus domesticus) eggs (ALPES SA Farms, Puebla, Mexico) were randomly separated in two groups. Eggs were incubated at $37.8^{\circ} \mathrm{C}$ and $60 \%$ humidity up to $22 \mathrm{HH}$ of embryo stage development. Then, shells were wiped with $70 \%$ ethanol, and $1 \mathrm{~cm}^{2}$ window was done. The vitelline membrane was dissected and $1 \times 10^{6}$ cells, treated or not with GDF11 for $72 \mathrm{~h}$ and labeled with vibrant CFDA SE cell tracer kit (Thermo Fisher Scientific), were introduced onto the CAM, in the convergence of two blood vessels, using $30 \mu \mathrm{l}$ of Matrigel (Sigma-Aldrich) as substrate. The window in the shells was covered 
A)
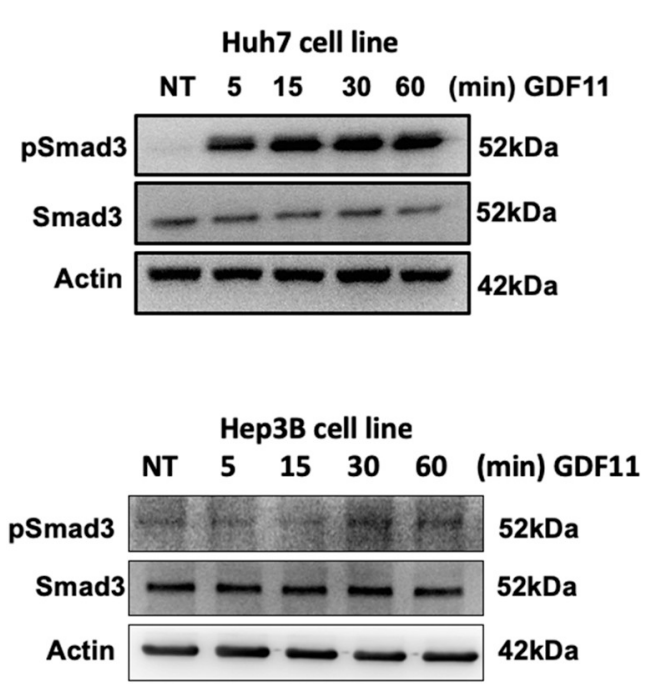

C)
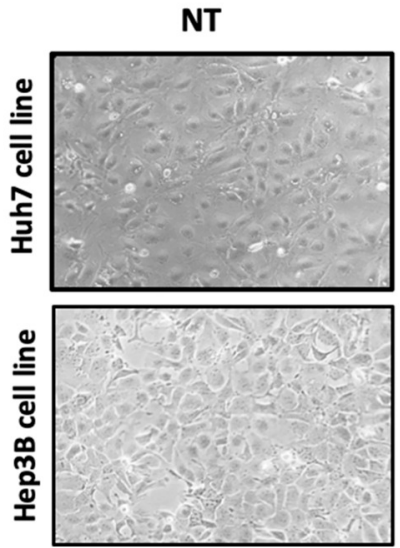

B)
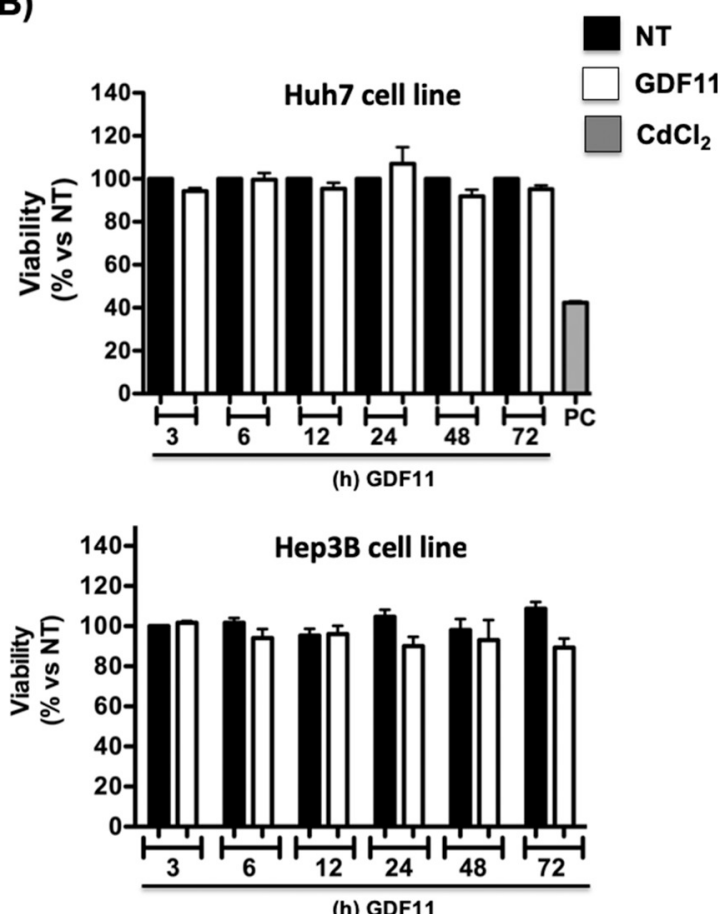

(h) GDF11
GDF11 (72h)
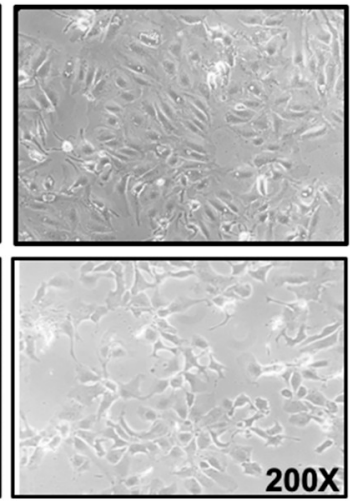

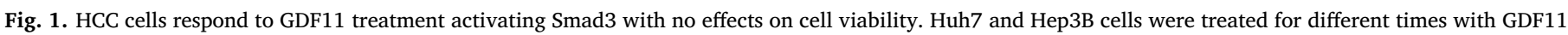

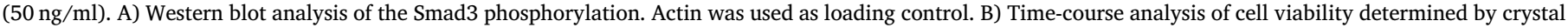

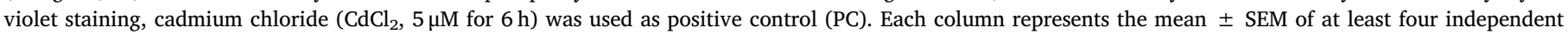

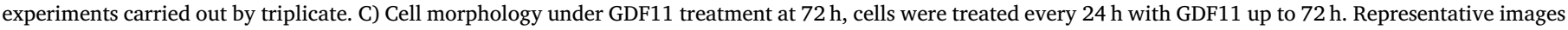
of at least four independent experiments. Original magnification $200 \times$.

with sterile adhesive tape and eggs were incubated as above for 2 and 4 days. CAM were recovered and immediately fixed with $4 \%$ paraformaldehyde in PBS. Paraffin sections $(5 \mu \mathrm{m})$ were obtained for immunofluorescence using anti-beta-catenin antibody (Cell Signaling \# 9562). Proliferation was addressed by immunofluorescence using anti-Ki67 antibody (abcam 15580; dilution 1:100). Nuclei were counterstained with $1 \mu \mathrm{g} / \mathrm{ml}$ DAPI. Images were acquired using a multiphoton confocal microscope (Carl Zeiss LSM-780 NLO).

\subsection{Real-time quantitative reverse transcriptase-polymerase chain reaction ( $q R T-P C R)$}

One $\mu \mathrm{g}$ total RNA was reverse transcribed in $20 \mu \mathrm{l}$ reaction volume with a SuperScript (Invitrogen Corp.) first-strand synthesis kit according to the manufacturer's instructions. Oligonucleotide primers were designed using Primer3 v.0.4.0 (http://frodo.wi.mit.edu/ primer3/) as describe [26]. The qRT-PCR analysis was performed with a CFX96 Touch (Bio-Rad) thermal cycler in a 96-well reaction plate. The $10 \mu \mathrm{l}$ PCR reaction mix contained $5 \mu 12 \times$ SYBR Green PCR Master Mix (Bio-Rad), $200 \mathrm{nM}$ of each primer, and $1 \mu \mathrm{cDNA}$ template. Reactions were incubated for $10 \mathrm{~min}$ at $95^{\circ} \mathrm{C}$ followed by 40 cycles of $30 \mathrm{~s}$ at $95^{\circ} \mathrm{C}$ and $60 \mathrm{~s}$ at specific primer temperature. The expression level of ribosomal protein S18 (rs18) was used as reference. Relative gene expression levels were calculated using the formula $2^{(-\Delta \Delta \mathrm{Ct})}$. Primer sequences are listed in Supplementary Table 2.

\subsection{Protein quantification}

The protein content was determined by using the bicinchoninic acid method (BCA, Pierce, Thermo Fisher Scientific), following the manufacturer's instructions. 


\subsection{Statistical analysis}

The results are presented as the average of at least three independent experiments. A One-way ANOVA followed by Tukey post- test was performed for the analysis of cell viability, mitochondrial functionality by MTT, number of spheroids and number of colonies in cell sensitization experiments whit GDF11. t-Student test was performed for the analysis of the numbers of spheroids.

A)

Serum free

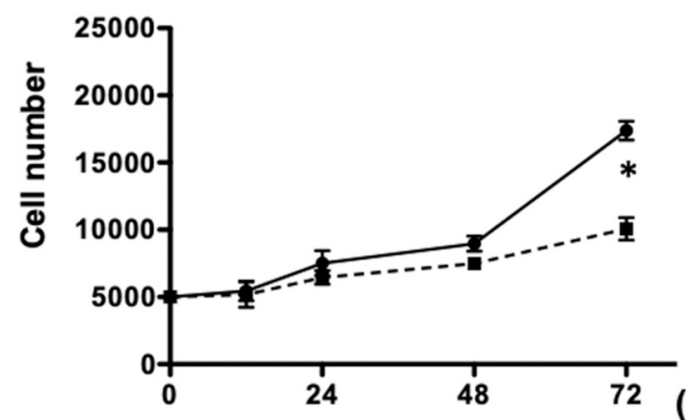

(h) GDF11
FBS

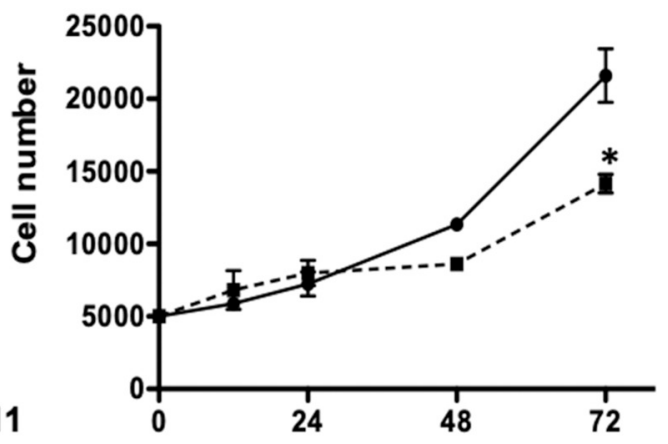

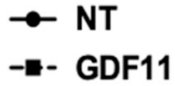

(h) GDF11

B)
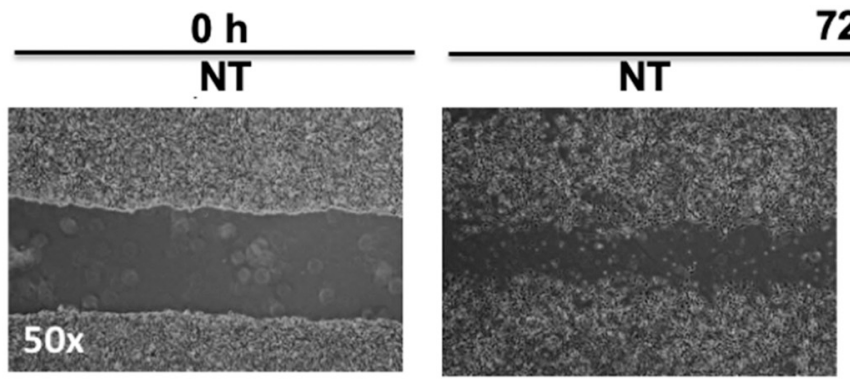

$72 \mathrm{~h}$

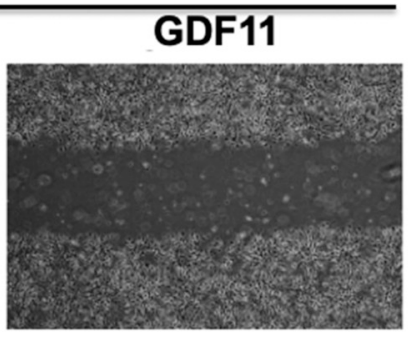

C)
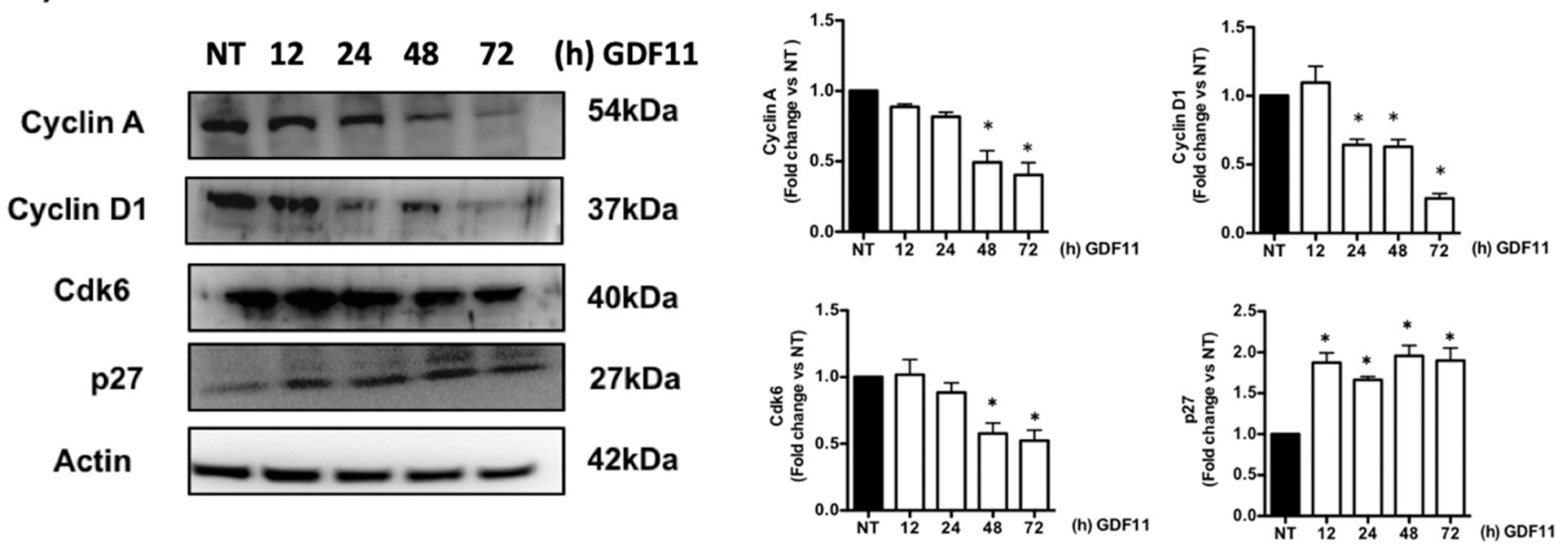

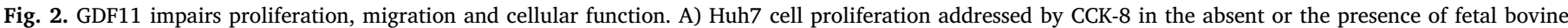

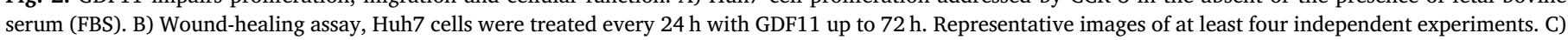

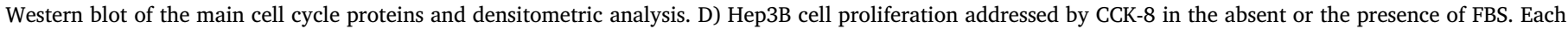

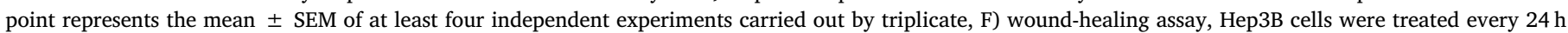

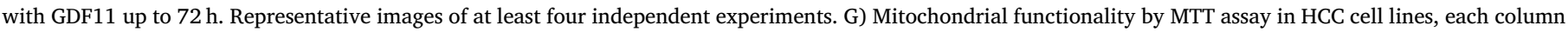

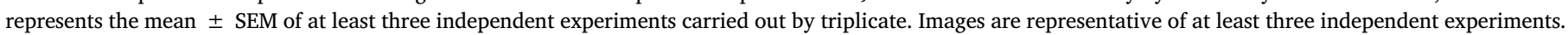
$*, p \leq 0.05$ vs NT cells at $72 \mathrm{~h}$. 
D)
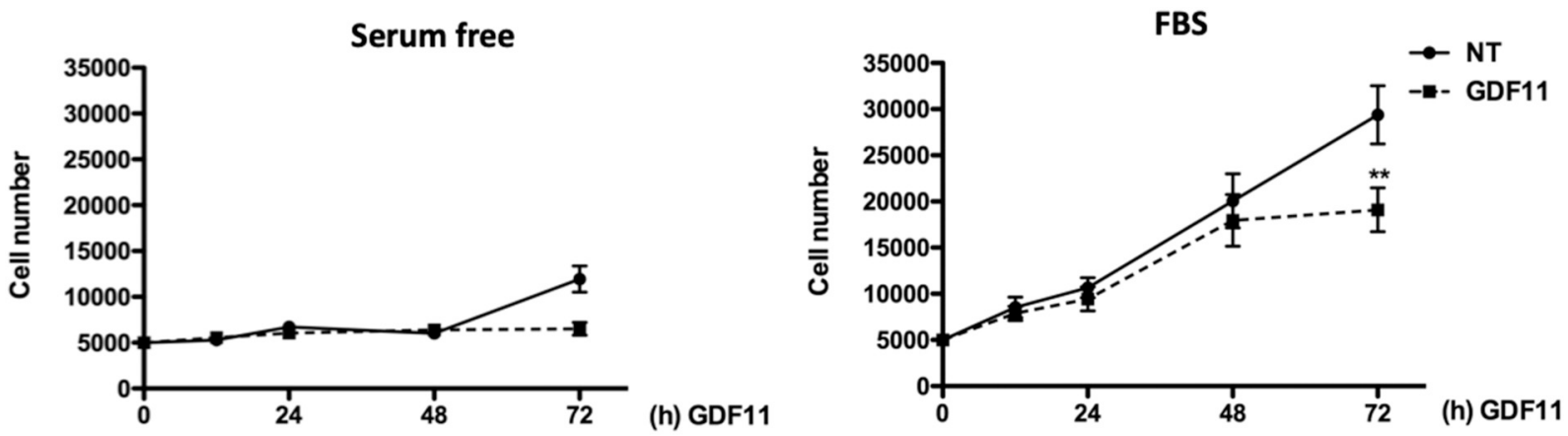

F)

$\mathbf{O h}$

$72 \mathrm{~h}$
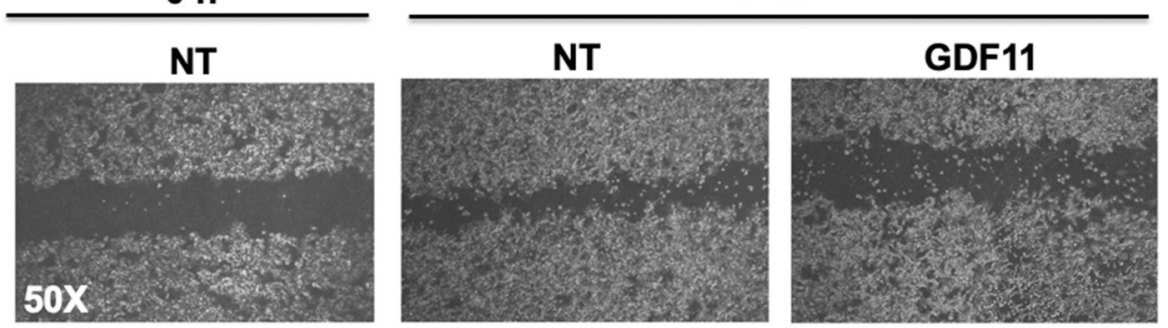

G)
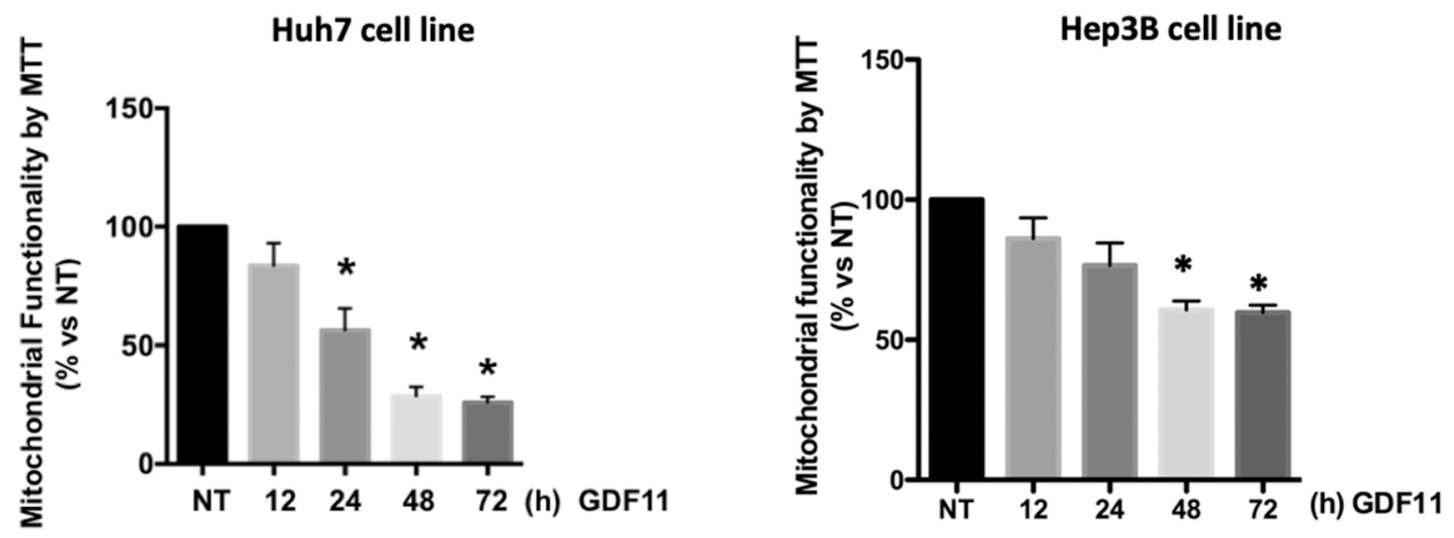

Fig. 2. (continued)

\section{Results}

\subsection{HCC cells respond to GDF11 treatment by activating Smad3}

To figure out whether HCC-derived cells respond to GDF11, Huh7 and Hep3B cells were treated with $50 \mathrm{ng} / \mathrm{ml}$ GDF11 up to $60 \mathrm{~min}$. Activation of the canonical signaling pathway was addressed by immunoblot of Smad3. Fig. 1A shows that Smad3 is rapidly activated by phosphorylation $5 \mathrm{~min}$, in Huh7 cell line, and $30 \mathrm{~min}$ in Hep3B cell line, after GDF11 treatment. Activation remains up to $60 \mathrm{~min}$. To explore impact in cell viability, Huh7 and Hep3B cells were treated at different times with GDF11. Time-course analysis up to $72 \mathrm{~h}$ of treatment demonstrates that GDF11 has no significant impact on cell viability (Fig. 1B), while $\mathrm{CdCl}_{2}(5 \mu \mathrm{M}, 6 \mathrm{~h})$, used as a positive control, reduces cell viability. In addition, morphology inspection of cell culture at $72 \mathrm{~h}$ revealed small changes in cells, including a flat-like phenotype and a decrease in cell density in both cell lines (Fig. 1C).

\subsection{GDF11 impairs cell proliferation and cycle progression}

Next, we decided to address cell proliferation; although no significant effect was observed on cell viability, GDF11 was shown to decrease Huh7 cell proliferation starting after $48 \mathrm{~h}$ GDF11 treatment and being statistically significantly at $72 \mathrm{~h}$ in the absence or presence of FBS (Fig. 2A), which was used as a competitor. In addition, a woundhealing assay revealed an impaired repair process at $72 \mathrm{~h}$ under GDF11 treatment compared with untreated cells (Fig. 2B). The analysis of the content of key cell cycle proteins shows that positive regulators such as Cyclin A, Cyclin D1 and CDK6 decreases in a time dependent manner, while $\mathrm{CDK}$ inhibitor p27 increases (Fig. 2C). Consistent with results observed in Huh7 cells, Hep3B cells under GDF11 treatment showed similar effects in cell proliferation (Fig. 2D) and wound-healing assay (Fig. 2F). Although viability was not affected in both HCC-derived cell lines, cell functionality, evaluated by MTT assay was significantly decreased starting after $24 \mathrm{~h}$ of treatment, in Huh7 cells, and $48 \mathrm{~h}$ in 


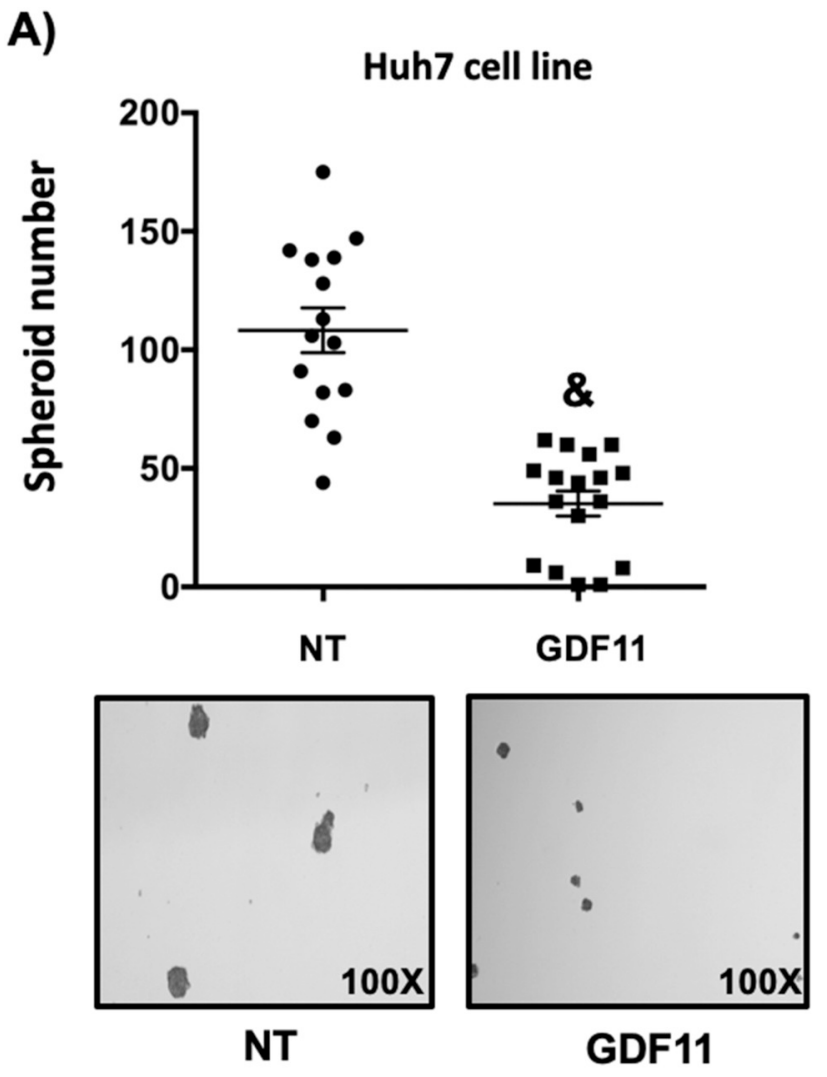

\author{
Hep3B cell line
}

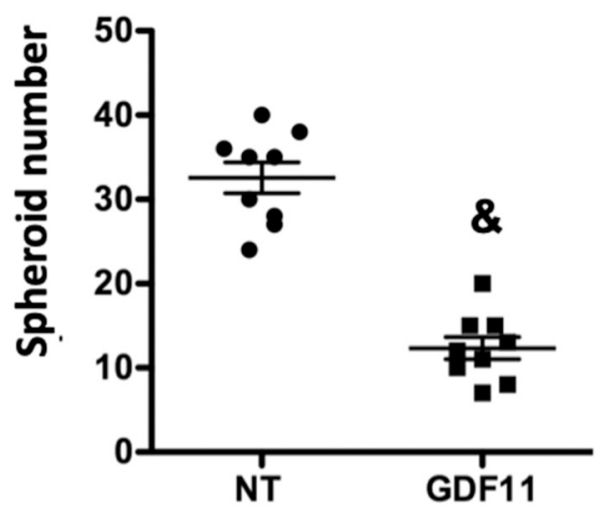

B)
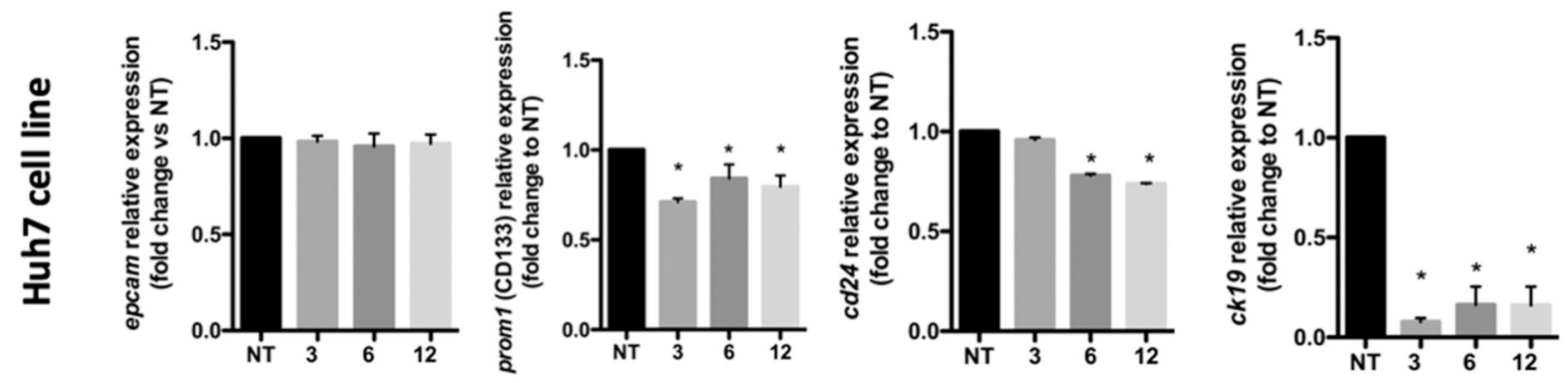

$100 x$
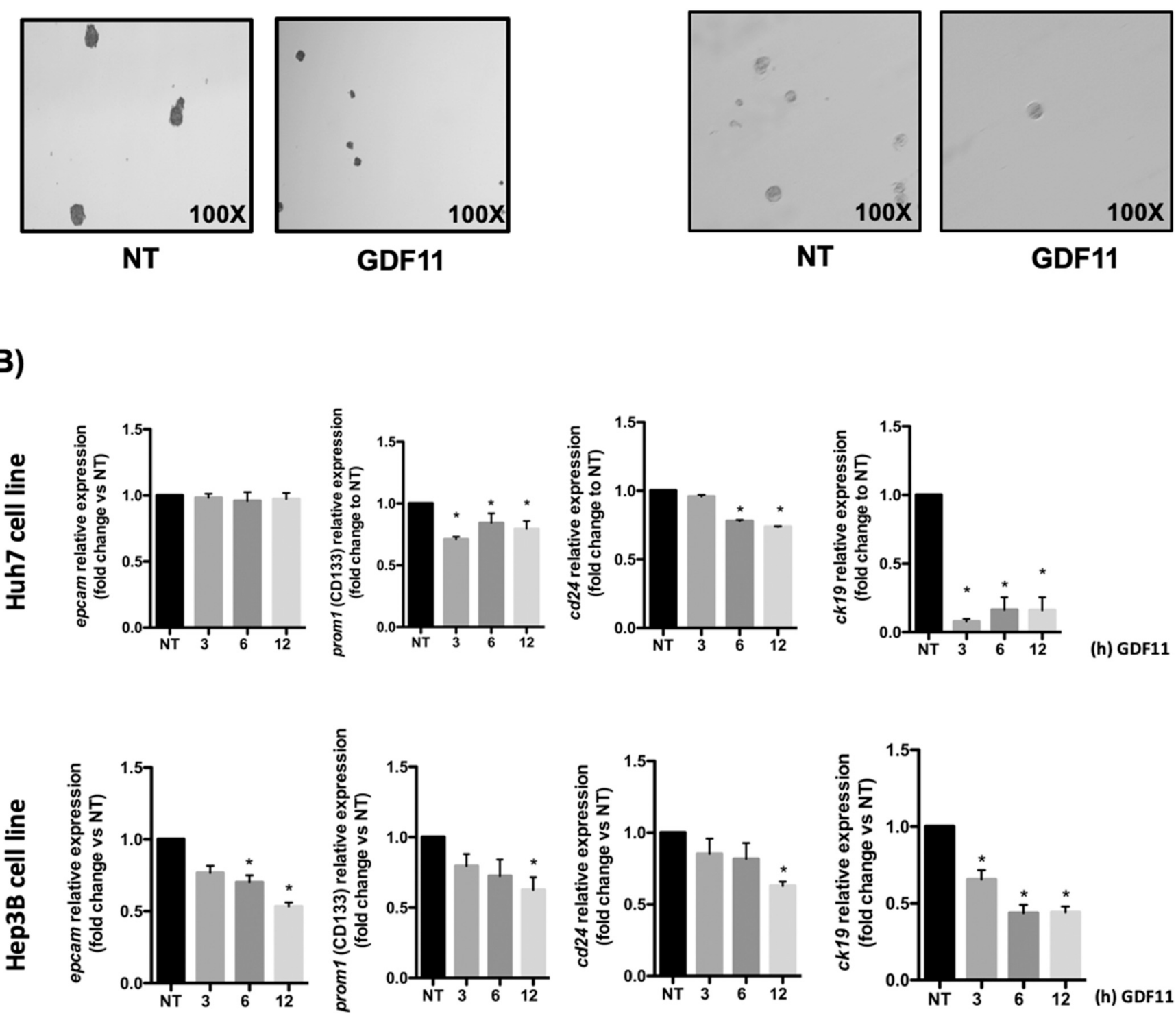

(h) GDF11

Fig. 3. GDF11 decreases spheroid formation capacity and the expression of genes related to aggressiveness. A) Spheroid counting at $72 \mathrm{~h}$, Huh7 and Hep3B cells were treated every $24 \mathrm{~h}$ with GDF11 $(50 \mathrm{ng} / \mathrm{ml})$ up to $72 \mathrm{~h}$, each point represents an independent experiment, we reported the median \pm SEM of at least ten independent experiments. Images are representative of at least ten independent experiments, original magnification $100 \times . \&, p \leq 0.05$ vs NT cells at $72 \mathrm{~h}$. B) Messenger RNA levels of key genes related to cancer aggressiveness, relative expression to not treated (NT) cells is demonstrated as means \pm SEM. *, $p \leq 0.05$ vs NT cells. 
Hep3B cells, explaining the effects observed in proliferation and wound-healing (Fig. 2G).

\subsection{GDF11 decreases spheroid formation capacity and the expression of} genes related to aggressiveness

Previous results strongly suggest that GDF11 exerts tumor suppressive effects. To gain more evidence, we performed studies of spheroid formation under GDF11 treatment every $24 \mathrm{~h}$ for 5 days. Cells treated with GDF11 exhibited fewer spheroids at day 5 (39\%, in Huh7 cells; and 34\% in Hep3B), as compared with untreated cells at the same time (Fig. 3A). Even more, spheroids observed under the GDF11 treatment were smaller (25\% in Huh7 cells; and $40 \%$ in Hep3B) than those formed in the absent of treatment.

The analysis of the expression of some of the key well-characterized markers of cancer cell aggressiveness, revealed an increment of

A)

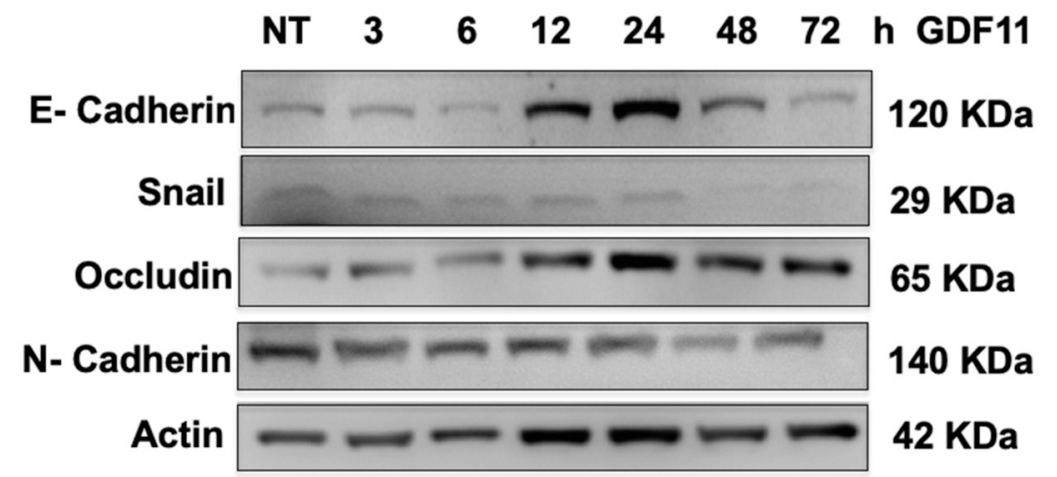

B)
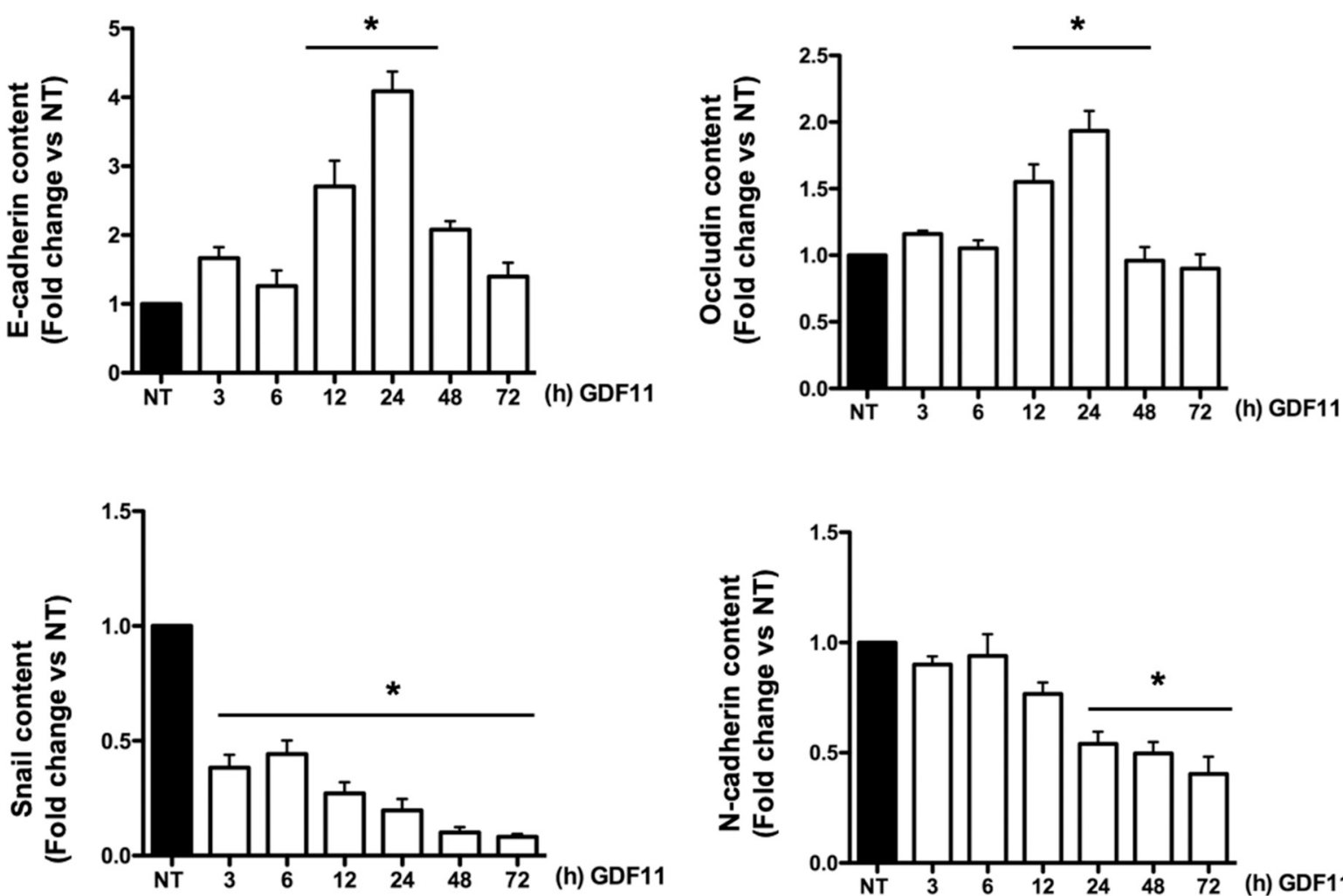

(h) GDF11

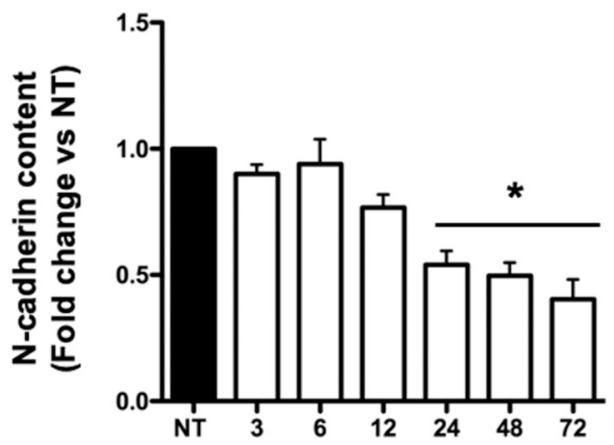

(h) GDF11

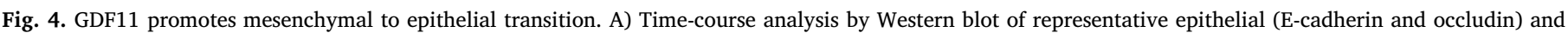

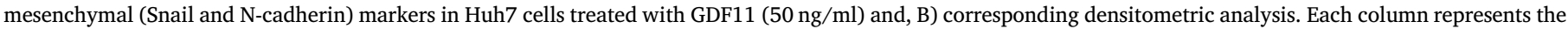

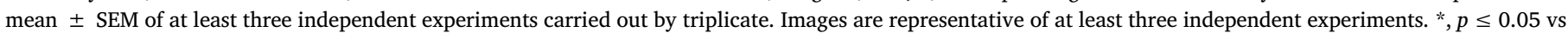

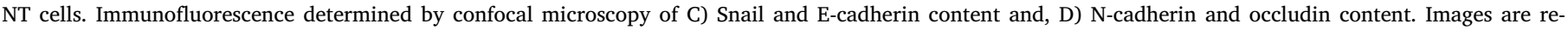
presentative of at least three independent experiments. Original magnification $360 \times$. 
C)

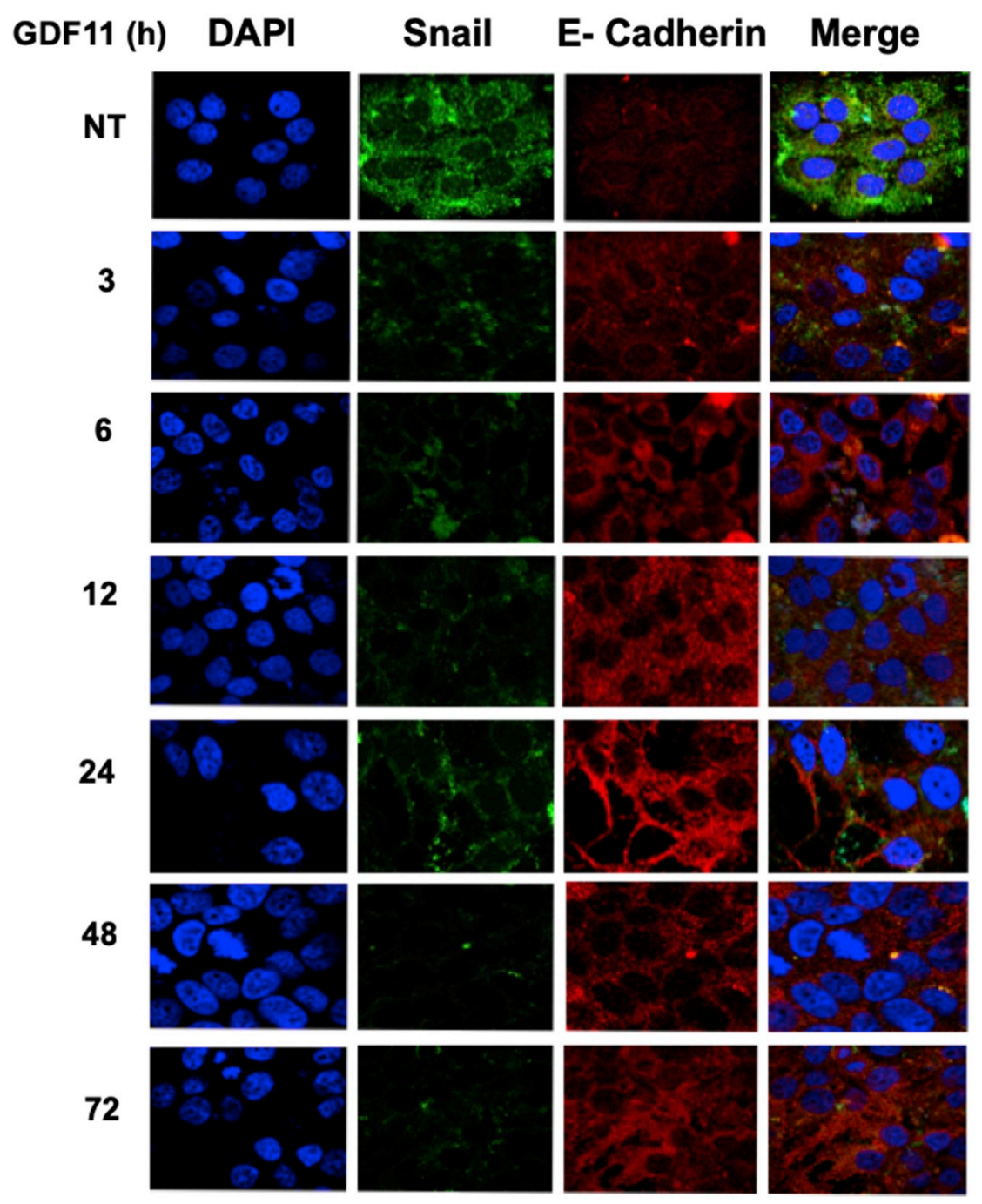

Fig. 4. (continued)

messenger RNA of CD133, CD24, CK19 and EpCAM particularly, the last one was significantly diminished only in Hep3B with no changes in Huh7 cells (Fig. 3B).

\subsection{GDF11 promotes mesenchymal epithelial transition}

Next, we decided to address the expression of some mesenchymal and epithelial key markers in cells under GDF11 treatment. The immunoblot revealed a decrement of mesenchymal markers, such as Snail and $\mathrm{N}$-cadherin, and the increment of epithelial markers, such as occludin and E-cadherin, in a time-dependent manner (Fig. 4A and B), interestingly mesenchymal markers remain below levels of not treated cells, while epithelial markers decrement peaked at $24 \mathrm{~h}$ and then decreased to control values. To gain more confidence of these data, we analyzed the content of these proteins by immunofluorescence, Fig. 4C and D show the colocalization of Snail and E-cadherin; and N-cadherin and occludin, respectively, in both cases the expression of the mesenchymal proteins (Snail or N-cadherin) was considerably diminished, and the epithelial ones was increased, confirming the immunoblot experiments. Similar results were obtained in Hep3B exhibiting an increment in the expression of E-cadherin and occludin, and decrement in $\mathrm{N}$-cadherin, in a time-dependent manner (Supplementary Fig. 2).
3.5. The effects elicited by GDF11 for $72 \mathrm{~h}$ of treatment remain in the absence of the factor

To figure out whether the effects displayed by GDF11 induce a longlasting or a transient cellular reprograming, cells were treated with GDF11 every $24 \mathrm{~h}$ for three days then, cells were harvested and processed to explore the capacity of colony and spheroid formation for five days, in presence or absence of serum as competitor. Fig. 5A shown that Huh7 cells treated with GDF11 remarkably decreased the ability to form colonies, in the presence or absence of FBS. Similarly, spheroid formation was significantly diminished in both cell lines (Fig. 5B and C), interestingly a better effect was observed in Huh7 cell line practically abrogating the spheroid formation capacity. Serum supplementation in the media did not rescue cells from the static phenotype (Supplementary Fig. 3), but the number of spheroids were different in the presence or absent of FBS in NT cells. Reprogramming experiments showed that cells exposed to GDF11 were unable of sustaining their colony and sphere forming capacity, indicating that the effect of GDF11 on self-renewal capacity is not transient.

\subsection{GDF11 impairs invasion capacity}

To address one of the key hallmarks of malignancy, we assayed 
D)

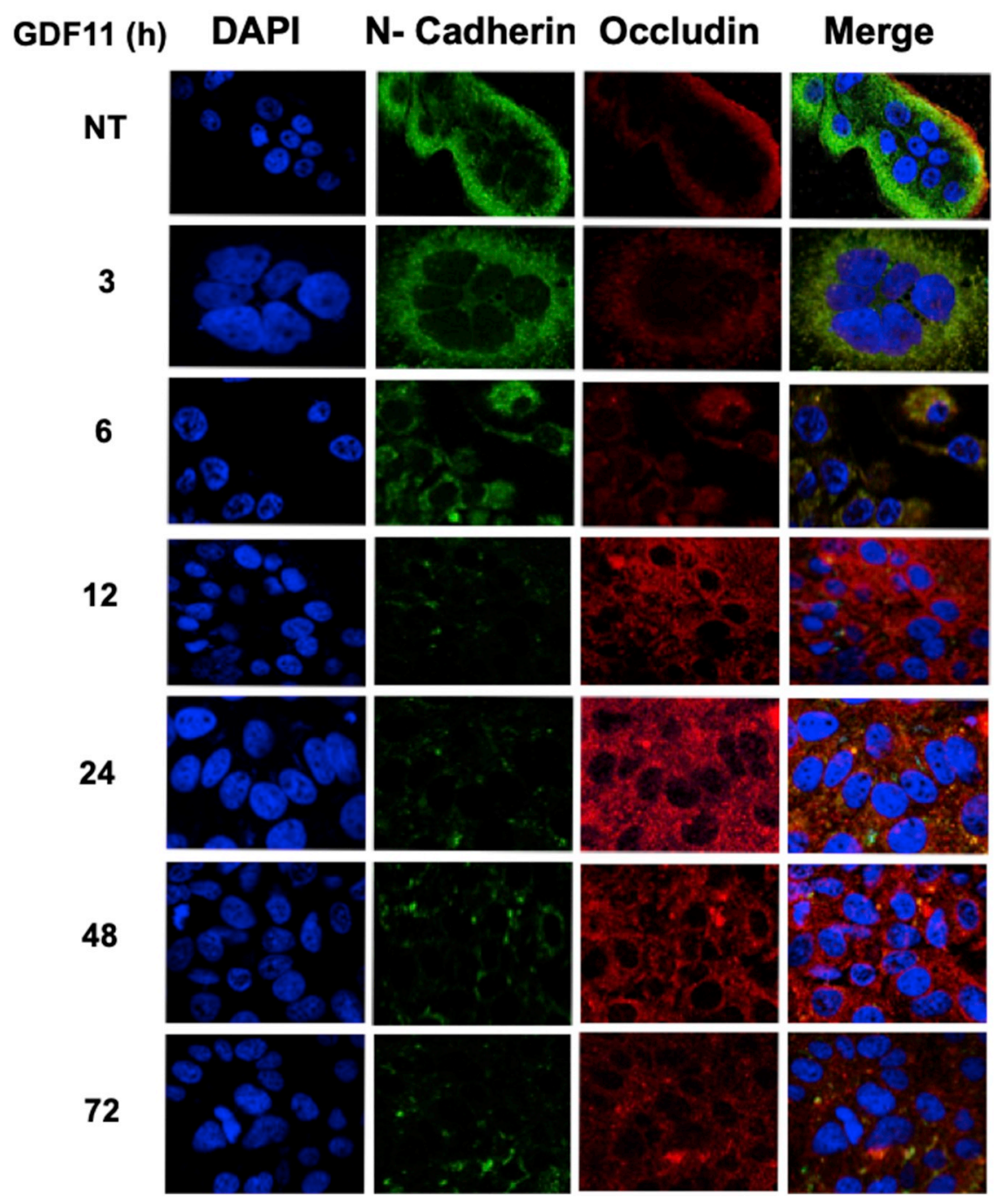

Fig. 4. (continued)

invasion property in cells treated or not with GDF11. $1 \times 10^{6}$ cells were grafted in the CAM of the chick embryo (Fig. 6A). Fig. 6C shows the complete control CAM with no cells, in order to observe normal morphology of the CAM. Cells were grafted in the area labeled with the yellow circle; the eggshell was covered with sterile tape. After two or four days of incubation at $37^{\circ} \mathrm{C}$, the CAM was recovered fixed and paraffin embedded for immunofluorescence and confocal microscopy. We started exploring the effect at day four; at this time we observed embryo lethality only with not treated cells (Fig. 6B). Microscopy inspection revealed few disaggregated not treated cells remaining in the grafted zone (Supplementary Fig. 4A, white arrows), and some cells were observed in the distal zone of the CAM (green cells), indicating an ongoing invasion process (Supplementary Fig. 4C). The same experimental setting with GDF11 treated cells revealed some significant compacted aggregates of cells (Supplementary Fig. 4B, yellow arrow heads), and some of them in transit (Supplementary Fig. 4B, white arrows). No cell was detected in the distal CAM (Supplementary Fig. 4D). Remarkably, chick embryos in the eggs inoculated with GDF11 treated cells were still alive (Fig. 6B).

In order to analyze the invasion process at an early time point, we decided to incubate the eggs only for two days. Microscopic analysis of the complete CAM revealed that most of the untreated cells were gone (Fig. 6D). In fact, some of chick embryo dies also at this time, however, cells treated for three days with GDF11 remained covered by the CAM and cell localization suggests an attempt of migration, but most of the cells still there (Fig. 6E). The CAM zones near to the cell cumulous strongly express beta catenin (yellow arrow, and figure inset), probably as a response to Huh7 cells reprograming induced by GDF11; in comparison, beta catenin expression in CAM with non-treated cells, was weak, suggesting degradation. In order to address the cell proliferation status in the invasion experiment, we proceeded to detect Ki67 protein content by immunofluorescence; Fig. $6 \mathrm{~F}$ shows more proliferating cells in CAM grafted with not treated Huh7 cells comparing with those under GDF11 treatment; remarkably, Ki67 positive cells were more abundant in the lower zone of the CAM, indicating more proliferative capacity (yellow arrow; Fig. 6F).

To corroborate the GDF11-induced invasion restriction, we performed the CAM experiment using Hep3B cells. The results depicted in Supplementary Fig. 3E show disaggregated not treated cells in the engraftment zone, cells seems to be disabled to form cell to cell interactions, in comparison with GDF11 treated cells that exhibited a well compacted cell cumulous with well defined cell interactions, the vascular zone exhibited not treated cells in blood vessels, effect that was absent in GDF11-treated cells, interestingly, the tumor was well delimited (white arrows, Supplementary Fig. 4), suggesting that treated cells were able to degrade the basal membrane, as observed in an in situ 
A)

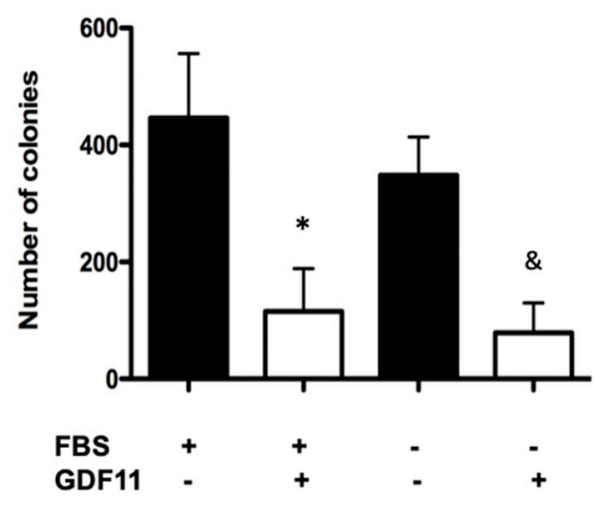

B)
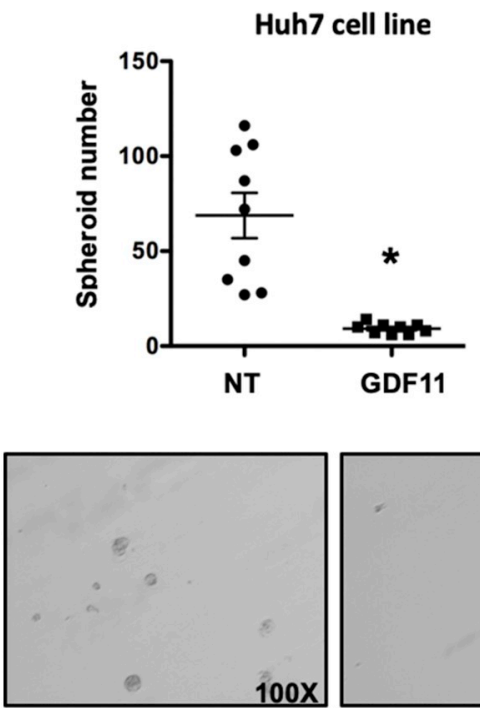

NT
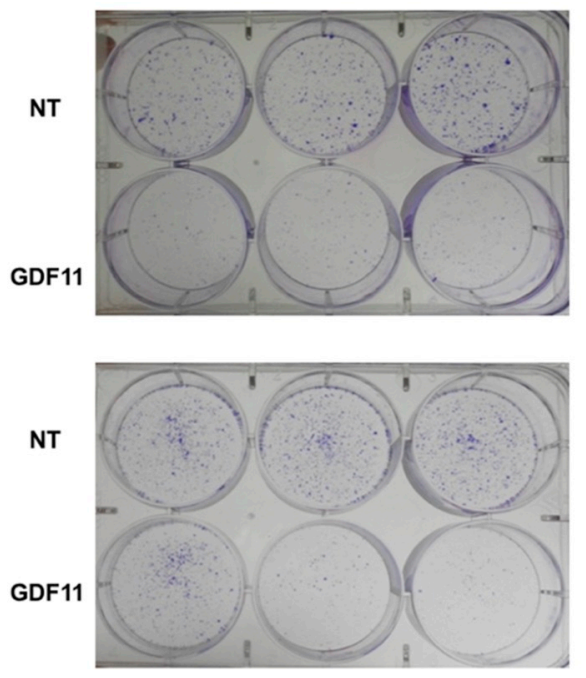

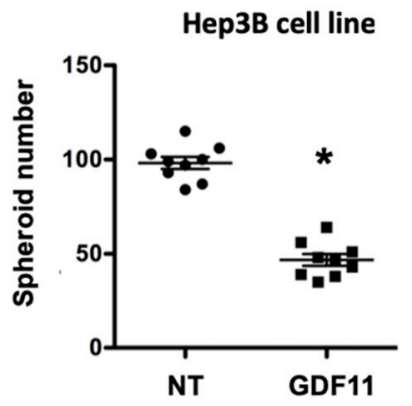

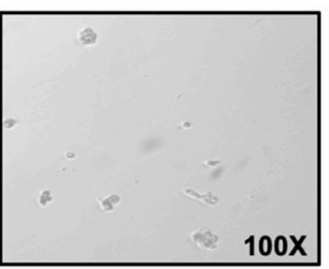

NT

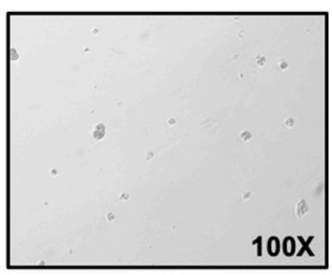

GDF11

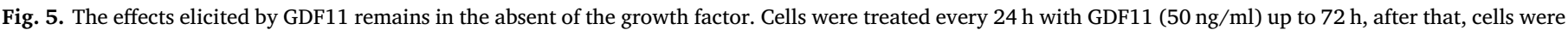

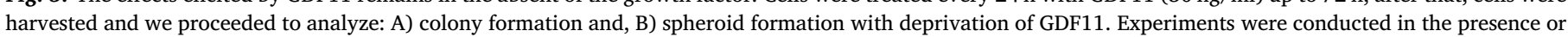

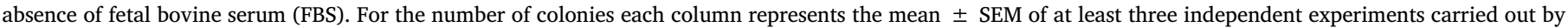

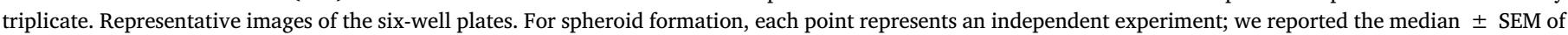
at least nine independent experiments. ${ }^{*}, p \leq 0.05$ vs NT cells in presence of FBS ( + FBS); ${ }^{*}, p \leq 0.05$ vs NT cells in the absence of FBS ( - FBS).

tumor. The distal zone in the experiment with not treated cells shows many disaggregated cells in the CAM, in comparison of the GDF11 experiment with few cells; remarkably, the size of this zone was thicker than that with not treated cells. Thus, these data strongly suggest that GDF11 significantly reduces invasive property.

\subsection{GDF11 decreases spheroid formation in other cancer cell lines}

Finally, to corroborate that the tumor suppressive effects displayed by GDF11 are not restricted to Huh7 and Hep3B cell line, we treated for three days the human hepatoma cell line HepG2 (Fig. 7A), the mouse HCC cell line Hepa1-6 (Fig. 7B), the human breast cancer cell line MDA-231 (Fig. 7C), and the human HCC cell line SNU-182. In all cases, GDF11 significantly decreases spheroid-forming capacity, suggesting a conserved effect among cancer cells with some stemness phenotype.

\section{Discussion}

HCC accounts for $90 \%$ of primary liver cancer, with increasing new cases every year, raising a warning worldwide [4,27]. Although, some therapeutic options are currently well established, such as sorafenib administration for advanced tumors, local ablation or resection, these options only provide some limited benefits in terms of patient survival. Besides, liver transplantation remains a great challenge due to the limited number of donors.

Investigation of signaling pathways involved in the control of proliferation, survival or the metabolism of cancer cells is crucial to define novel alternative therapeutic approaches. 


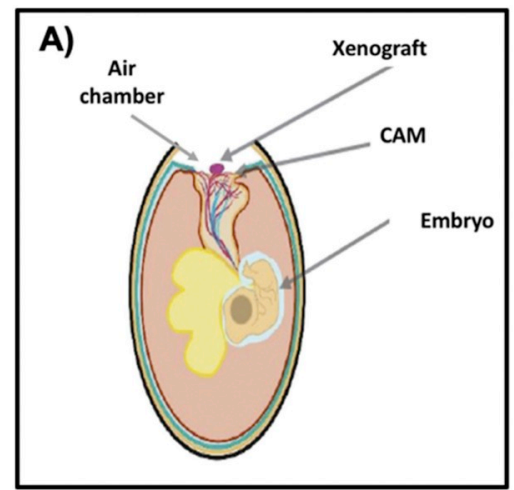

B)

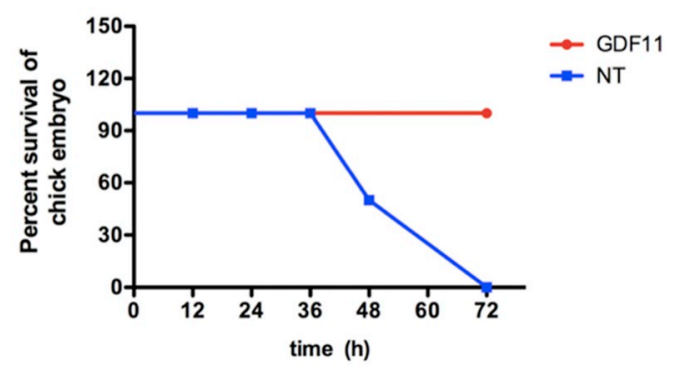

C)
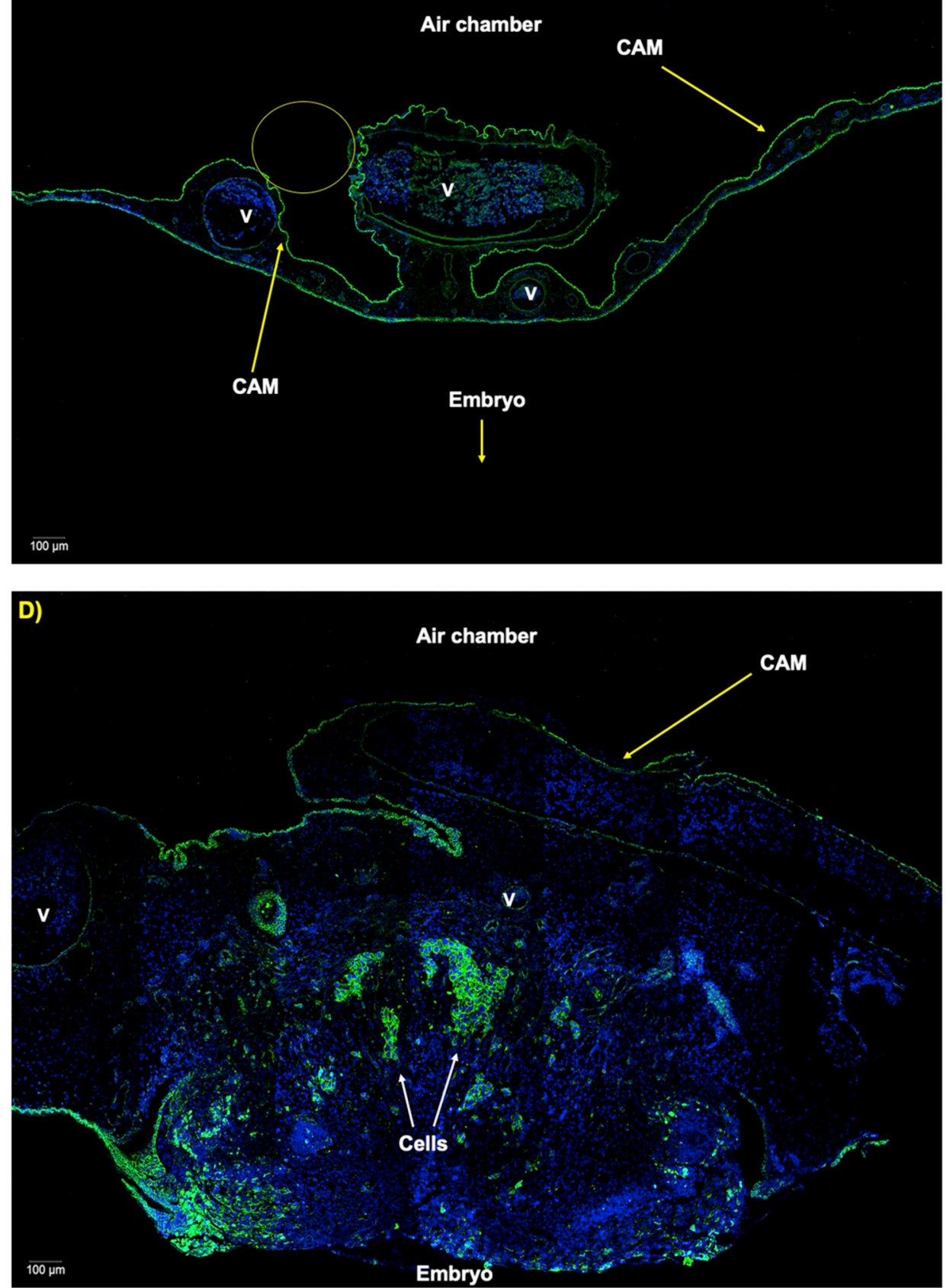


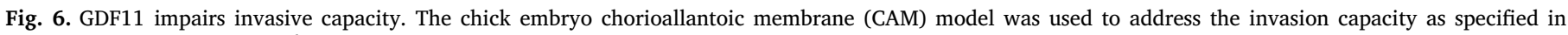

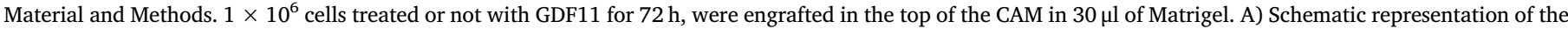

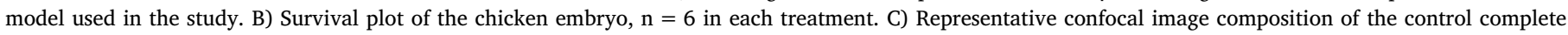

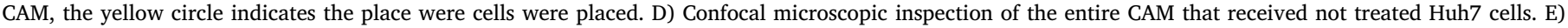

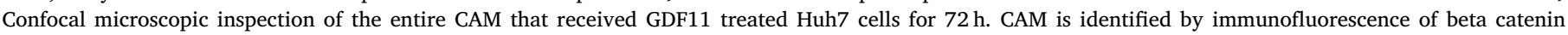

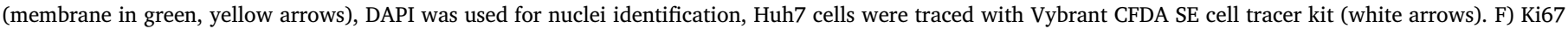

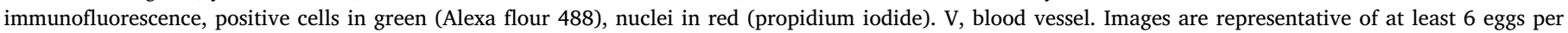
condition.

GDF11, a relatively new member of the TGF- $\beta$ superfamily, has been showed to display biological effects in a wide range of cell types. It is particularly interesting that most of the cells that respond to GDF11 exhibit some degree of stemness phenotype $[9,20]$. Along this characteristic, we hypothesized that this growth factor could exert some effects in HCC-derived cell lines, particularly in those retaining stemness features. It was reported that Huh7 cell line expresses some of the key stemness markers, such as Nanog, Oct 4 or Sox 2 . It has been also reported that increased expression of these genes in Huh7 cells is related to the increment of stemness [28,29], particularly when cells are forming spheroids [30]. The first evidence that Huh7 and Hep3B cells respond to GDF11 was the activation of one of the canonical signal transducers, specifically the phosphorylation of Smad3 [11,20], which was strongly detected after $5 \mathrm{~min}$ of GDF11 treatment in the case of Huh7 and, at $30 \mathrm{~min}$ in Hep3B cells, and remained activated along $60 \mathrm{~min}$ (Fig. 1A). It is well-characterized that some members of the TGF- $\beta$ display effects in epithelial cells that modulate survival or proliferation [31]. Interestingly, we found that viability is unaffected up to $72 \mathrm{~h}$ under GDF11 treatment (Fig. 1B), with no outward changes in cell phenotype. However, cell proliferation is clearly diminished at $72 \mathrm{~h}$, in presence or not, of the proliferative action of FBS (Fig. 2A and D), suggesting cytostatic effects similar to those observed with other members of the TGF- $\beta$ family. Indeed, it is reported that TGF- $\beta$ by itself, displays cytostatic and apoptotic functions that restrain cell growth, avoiding the hyperproliferative disorders, even in Huh7 and Hep3B cells $[32,33]$. This novel effect, elicited by GDF11 in liver cancer cells, confirms the well-conserved cytostatic effect in the TGF- $\beta$ family, as exemplified by the analysis of the content of the main cell cycle regulating proteins; cyclins A and D1, and cdk6 were downregulated, and p27 was overexpressed, these effects being particularly evident at $72 \mathrm{~h}$ (Fig. 2C). Similarly, GDF11 significantly attenuated the proliferation of the neural stem cell line Cor-1, downregulating key positive cell cycle proteins [20]. In addition, this work by Williams and collaborators showed that cell migration is impaired by GDF11 as we also observed (Fig. 2B and F).

Based in the fact that stemness feature is increasing in spheroid or 3D culture, particularly in cells used in this study [29,30], we observed that the number and the size of spheroids decreased in the presence of GDF11 at $72 \mathrm{~h}$ of repeated treatment $(50 \mathrm{ng} / \mathrm{ml}$, every $24 \mathrm{~h})$ in both HCC cell lines. We found similar effects in HepG2 (Fig. 7A), a human hepatoma cell line capable to form spheroids as well [30], and in SNU182, another human HCC cell line from a high aggressive tumor. Interestingly, when comparing the human liver cancer cell lines, GDF11 displayed greater effects in Huh7 and Hep3B than in HepG2, although, in the last one, decrement in sphere formation was statistically significant, confirming the preference of GDF11 on cells with stemness feature. Similar results were reported by Bajikar and collaborators in triple negative breast cancer cell lines [19], even more, Hepa1-6, MDAMB-231 and SNU-182 cell lines presented similar effects with some differences in the number of spheroids, but in all cases with significant changes (Fig. 7).

To gain more evidence, we performed the analysis of the messenger RNA levels of key molecular markers for aggressive cancers and stemness (Fig. 3B), cytokeratin 19 (ck19) has been closely related to poor prognosis and high recurrence in HCC [34], the effect on ck19 expression, induced by GDF11, was the most relevant, in terms of absolute values comparing with NT cells, prom1 (CD133) and epcam (EPCAM) also are well characterized stemness markers, being CD133 most significant in stages I, while the prognostic role of EpCAM is more effective in advanced stages [35], interestingly, the effect of GDF11 in epcam expression was different in the HCC cell lines studied here, Huh7 cells did not respond to the GDF11 treatment exhibiting no changes in the expression, however, Hep3B, which a more aggressive cell line, diminished the expression since $6 \mathrm{~h}$ of treatment, supporting the findings by Chang and coworkers [35]. These results strongly suggest that GDF11 antitumorigenic properties are more relevant in advanced tumors. Finally, cd24 is another well-known marker for stemness and aggressive HCC [36], our data clearly show a decrement since $6 \mathrm{~h}$ in Huh7 and at $12 \mathrm{~h}$ in Hep3B, once again the difference in stemness capacity is evident in both cell lines, but in both cases GDF11 displays antitumorigenic effects.

The analysis of mesenchymal and epithelial markers revealed a clear GDF11-induced mesenchymal to epithelial transition phenotype. A time-dependent decrement in the expression of mesenchymal-related proteins such as Snail and N-cadherin, and increased of epithelial markers, such as E-cadherin and occludin (Fig. 4) [37], was confirmed by Western blot and immunofluorescence. The gain of an epithelial phenotype was simultaneously associated to a significant decrease in colony and spheroid formation capacity (Fig. 5), and to a decreased capacity in invasion (Fig. 6), as addressed by the CAM assay. Interestingly, in the CAM assay we observed a degradation of the basal membrane, a key condition for invasion in the experiment using not treated cells, and in the case of the experiment with GDF11 treated cells the membrane was preserved suggesting a distinctive phenotype of an in situ tumor, in addition treated cells were presented forming cumulous, probably because the increment of E-cadherin expression (Fig. 4 and Supplementary Fig. 2).

All these data clearly show that GDF11 induces an anti-tumor response in HCC cells, directed to decreases aggressiveness by attempting reverse the mesenchymal to epithelial phenotype.

The decrement of the invasive phenotype was also found in triple negative breast cancer cell lines [19]. The effect was associated to an increase in the expression of E-cadherin, supporting our findings in HCC-derived cells. Importantly, we reported that GDF11 effects were not transient, and may evoke a cellular reprograming in HCC cells. Indeed, treatment for $72 \mathrm{~h}$ with GDF11 sustained the effects even five days in culture in the absent of GDF11.

Although, a low frequency of mutations in GDF11 and a significant enrichment in the convertase PCSK5 locus have been reported in breast cancer [19], we did not find significant presence of mutations in those genes in HCC according to The Cancer Genome Atlas (TCGA, data not shown). However, in human HCC the expression level of GDF11 observed no changes, but in cholangiocellular carcinoma (CCC), significant differences were found increasing 1.55-fold change in tumors versus normal tissue (Supplementary Fig. 5), (36 patients for CCC and 371 for HCC; https://portal.gdc.cancer.gov and http://firebrowse.org), in the case of PCSK5 gene expression the TCGA reports significant changes in both HCC and CCC (1.56-fold and 2.31-fold change versus normal tissue.

These data suggest that changes in basal expression in GDF11 and PCSK5 genes, are rare events in HCC and probably not responsible to the loss of function of GDF11, maybe some epigenetic silencing mechanism could be related to loss of function of GDF11. Nevertheless, we clearly demonstrated that recombinant human GDF11 induces an 


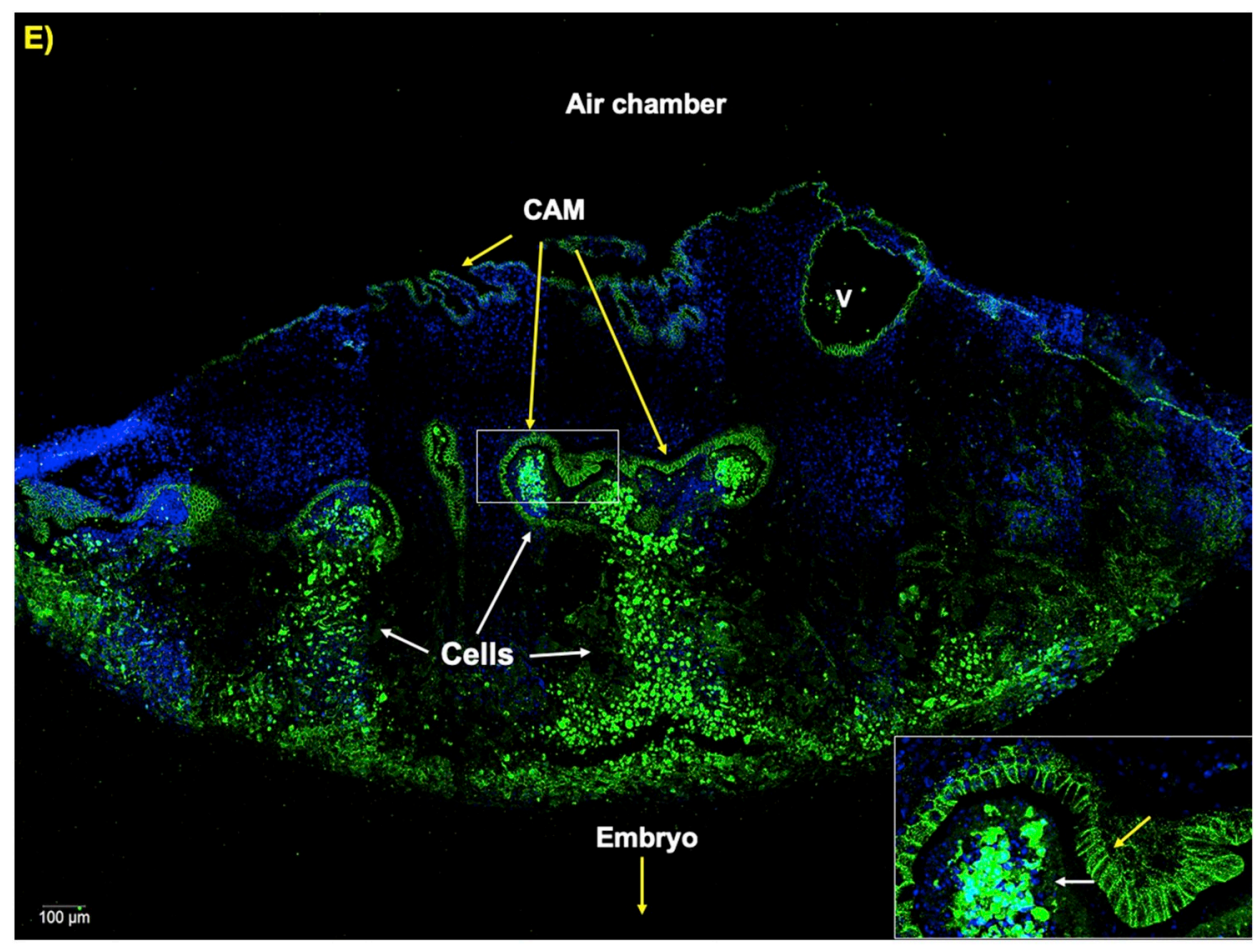

F)
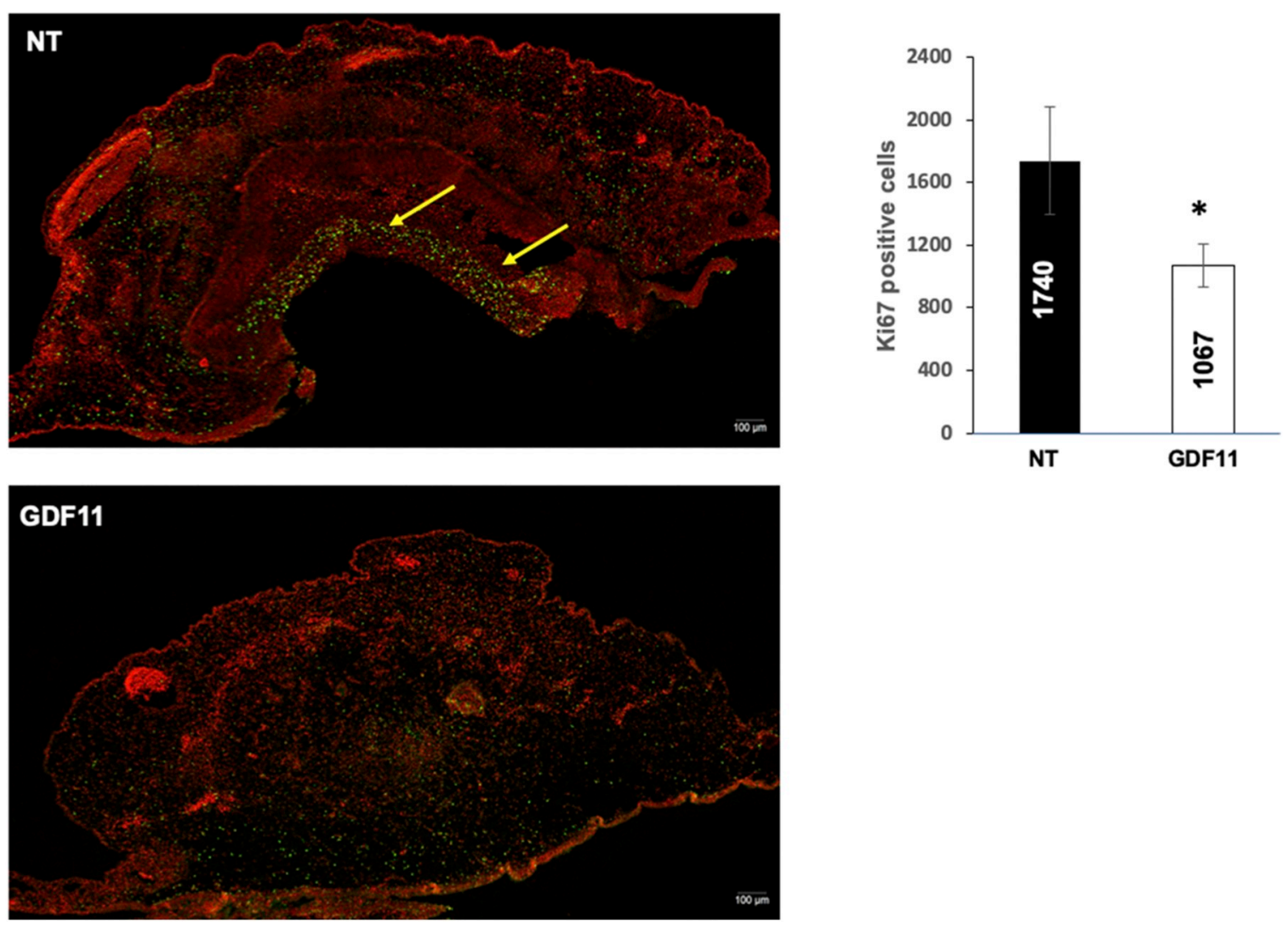

Fig. 6. (continued) 
A)

HepG2 cell line
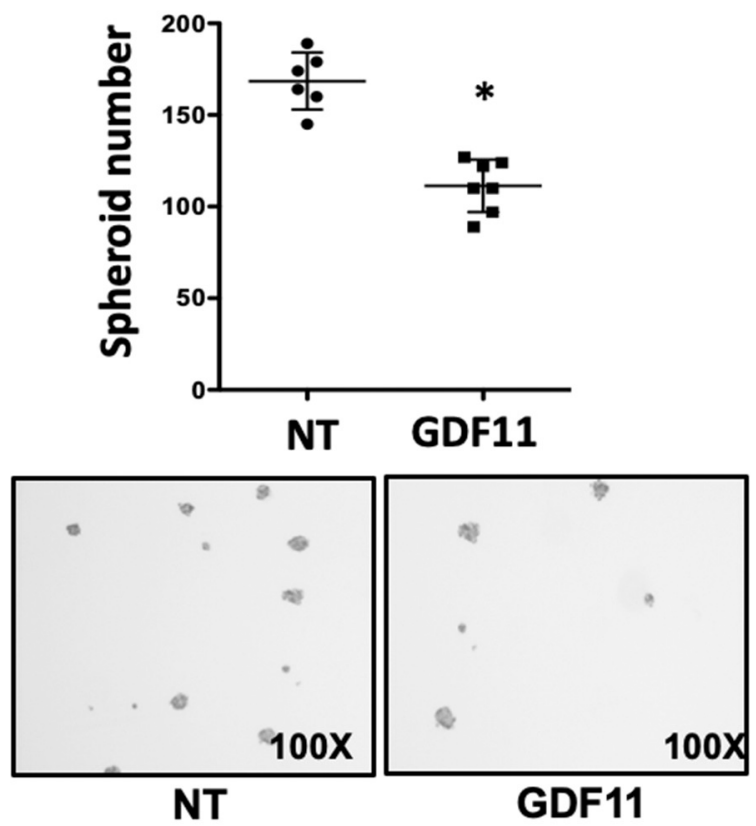

C)

MDA-MB-231 breast cancer cell line
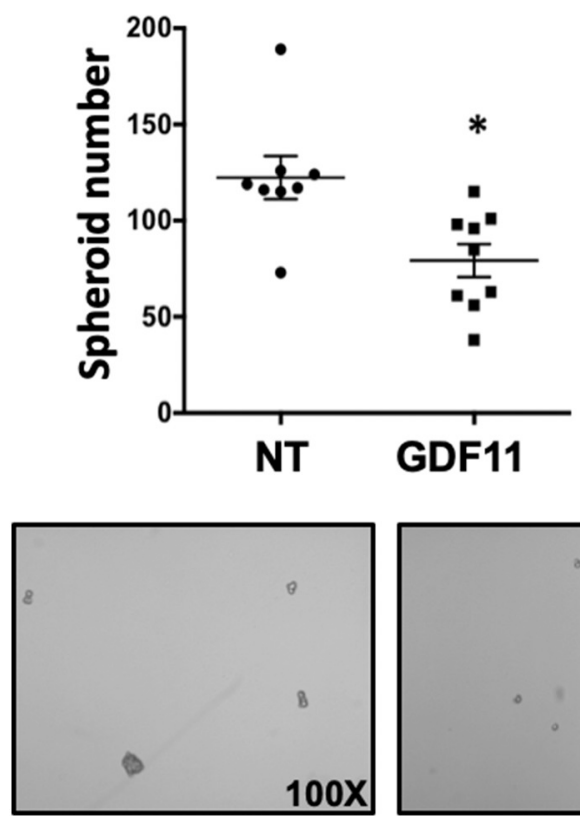

NT
B)

\section{Hepa1-6 cell line}
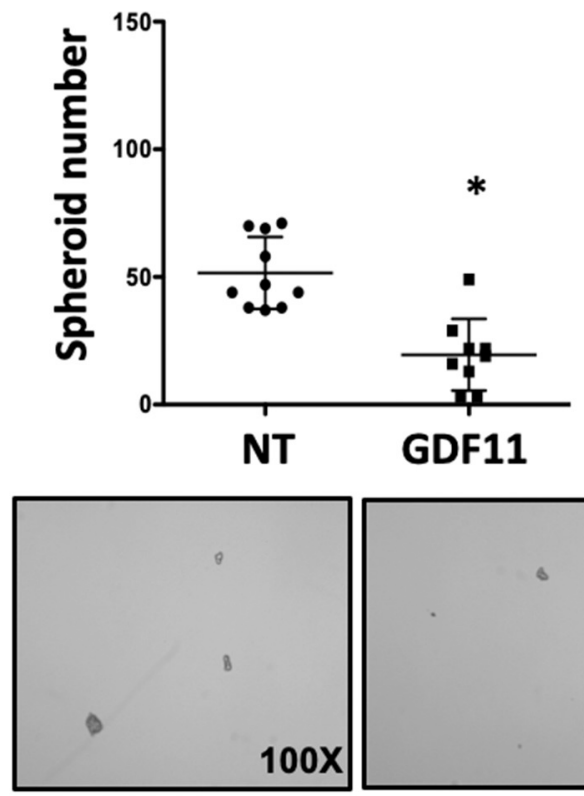

NT

$100 \mathrm{X}$

GDF11

D)

SNU-182 cell line
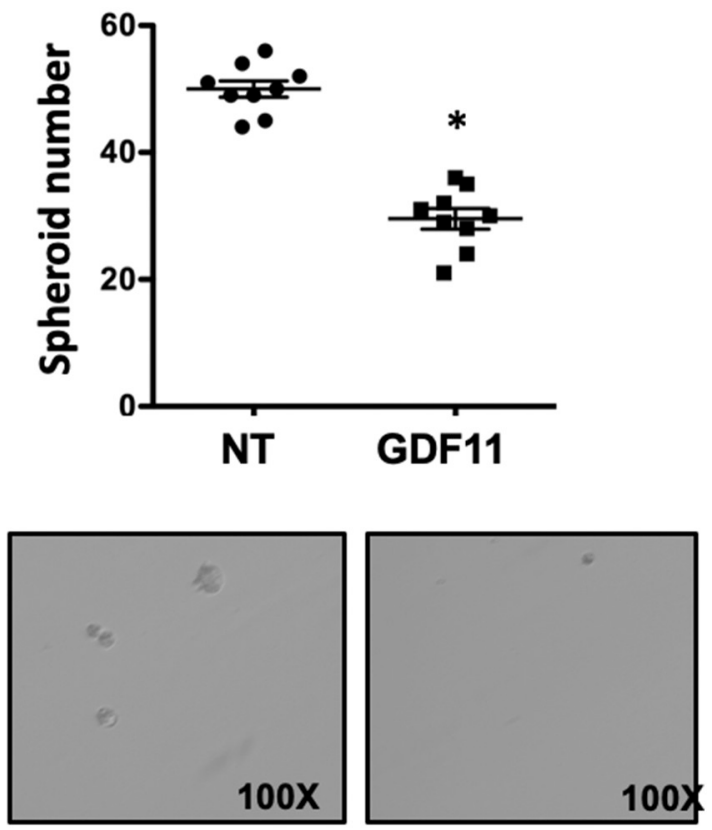

GDF11

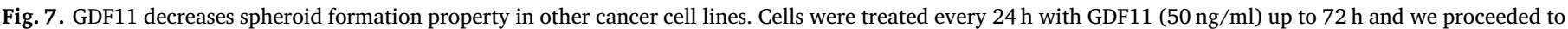

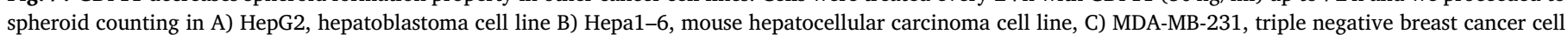

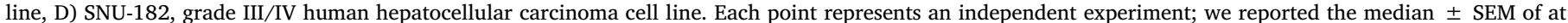
least six independent experiments. ${ }^{*}, p \leq 0.05$ vs NT cells at $72 \mathrm{~h}$. 
antitumorigenic effect with no relevance in cell death, but lessening aggressiveness by promoting a cytostatic phenotype and repressing invasion.

In conclusion, we are reporting tumor suppressive properties of GDF11 in HCC-derived cells restricting self-renewal capacity, setting GDF11 as a good candidate for therapy and biomarker in liver cancer.

\section{Conflicts of interest}

The authors declare no conflict of interest.

\section{Transparency document}

The Transparency document associated with this article can be found, in online version.

\section{Acknowledgements}

This work was partially funded by a grant from the Consejo Nacional de Ciencia y Tecnología (CONACYT; CB-252942 and Fronteras de la Ciencia-1320) and Universidad Autónoma Metropolitana. We thank the confocal core units of the Universidad Autonoma Metropolitana Iztapalapa, and Instituto Nacional de Cancerología de Mexico, for the assistance. MGR, SHR, ASN are scholarship holders from Conacyt.

\section{Appendix A. Supplementary data}

Supplementary data to this article can be found online at https:// doi.org/10.1016/j.bbadis.2019.03.003.

\section{References}

[1] N. Mendez-Sanchez, E. Garcia-Villegas, B. Merino-Zeferino, S. Ochoa-Cruz, A.R. Villa, H. Madrigal, R.A. Kobashi-Margain, Y. Gutierrez-Grobe, N. ChavezTapia, G. Ponciano-Rodriguez, M. Uribe, Liver diseases in Mexico and their associated mortality trends from 2000 to 2007: a retrospective study of the nation and the federal states, Ann. Hepatol. 9 (2010) 428-438.

[2] A. Forner, J.M. Llovet, J. Bruix, Hepatocellular carcinoma, Lancet 379 (2012) $1245-1255$.

[3] P. Kaposi-Novak, J.S. Lee, L. Gomez-Quiroz, C. Coulouarn, V.M. Factor, S.S. Thorgeirsson, Met-regulated expression signature defines a subset of human hepatocellular carcinomas with poor prognosis and aggressive phenotype, J. Clin. Invest. 116 (2006) 1582-1595.

[4] J. Ferlay, I. Soerjomataram, R. Dikshit, S. Eser, C. Mathers, M. Rebelo, D.M. Parkin, D. Forman, F. Bray, Cancer incidence and mortality worldwide: sources, methods and major patterns in GLOBOCAN 2012, Int. J. Cancer 136 (2015) E359-E386.

[5] J. Bruix, M. Colombo, Hepatocellular carcinoma: current state of the art in diagnosis and treatment, Best Pract. Res. Clin. Gastroenterol. 28 (2014) 751.

[6] A.C. McPherron, A.M. Lawler, S.J. Lee, Regulation of anterior/posterior patterning of the axial skeleton by growth/differentiation factor 11, Nat. Genet. 22 (1999) 260-264.

[7] R. Essalmani, A. Zaid, J. Marcinkiewicz, A. Chamberland, A. Pasquato, N.G. Seidah, A. Prat, In vivo functions of the proprotein convertase PC5/6 during mouse development: Gdf11 is a likely substrate, Proc. Natl. Acad. Sci. U. S. A. 105 (2008) $5750-5755$

[8] C.E. Brun, M.A. Rudnicki, GDF11 and the mythical fountain of youth, Cell Metab. 22 (2015) 54-56.

[9] M. Sinha, Y.C. Jang, J. Oh, D. Khong, E.Y. Wu, R. Manohar, C. Miller, S.G. Regalado, F.S. Loffredo, J.R. Pancoast, M.F. Hirshman, J. Lebowitz, J.L. Shadrach, M. Cerletti, M.J. Kim, T. Serwold, L.J. Goodyear, B. Rosner, R.T. Lee, A.J. Wagers, Restoring systemic GDF11 levels reverses age-related dysfunction in mouse skeletal muscle, Science 344 (2014) 649-652.

[10] F.S. Loffredo, M.L. Steinhauser, S.M. Jay, J. Gannon, J.R. Pancoast, P. Yalamanchi, M. Sinha, C. Dall'Osso, D. Khong, J.L. Shadrach, C.M. Miller, B.S. Singer, A. Stewart, N. Psychogios, R.E. Gerszten, A.J. Hartigan, M.J. Kim, T. Serwold, A.J. Wagers, R.T. Lee, Growth differentiation factor 11 is a circulating factor that reverses agerelated cardiac hypertrophy, Cell 153 (2013) 828-839.

[11] M.A. Egerman, S.M. Cadena, J.A. Gilbert, A. Meyer, H.N. Nelson, S.E. Swalley, C. Mallozzi, C. Jacobi, L.L. Jennings, I. Clay, G. Laurent, S. Ma, S. Brachat, E. LachTrifilieff, T. Shavlakadze, A.U. Trendelenburg, A.S. Brack, D.J. Glass, GDF11 increases with age and inhibits skeletal muscle regeneration, Cell Metab. 22 (2015) 164-174.
[12] D.J. Glass, Elevated GDF11 is a risk factor for age-related frailty and disease in humans, Cell Metab. 24 (2016) 7-8.

[13] M.J. Schafer, E.J. Atkinson, P.M. Vanderboom, B. Kotajarvi, T.A. White, M.M. Moore, C.J. Bruce, K.L. Greason, R.M. Suri, S. Khosla, J.D. Miller, H.R. Bergen 3rd, N.K. LeBrasseur, Quantification of GDF11 and myostatin in human aging and cardiovascular disease, Cell Metab. 23 (2016) 1207-1215.

[14] G. Finkenzeller, G.B. Stark, S. Strassburg, Growth differentiation factor 11 supports migration and sprouting of endothelial progenitor cells, J. Surg. Res. 198 (2015) $50-56$.

[15] F. Jeanplong, S.J. Falconer, J.M. Oldham, N.J. Maqbool, M. Thomas, A. Hennebry, C.D. McMahon, Identification and expression of a novel transcript of the growth and differentiation factor-11 gene, Mol. Cell. Biochem. 390 (2014) 9-18.

[16] K.K. Gokoffski, H.H. Wu, C.L. Beites, J. Kim, E.J. Kim, M.M. Matzuk, J.E. Johnson, A.D. Lander, A.L. Calof, Activin and GDF11 collaborate in feedback control of neuroepithelial stem cell proliferation and fate, Development 138 (2011) 4131-4142.

[17] T. Yokoe, T. Ohmachi, H. Inoue, K. Mimori, F. Tanaka, M. Kusunoki, M. Mori, Clinical significance of growth differentiation factor 11 in colorectal cancer, Int. J. Oncol. 31 (2007) 1097-1101.

[18] C. Wallner, M. Drysch, M. Becerikli, H. Jaurich, J.M. Wagner, S. Dittfeld, J. Nagler, K. Harati, M. Dadras, S. Philippou, M. Lehnhardt, B. Behr, Interaction with the GDF8/11 pathway reveals treatment options for adenocarcinoma of the breast, Breast 37 (2018) 134-141.

[19] S.S. Bajikar, C.C. Wang, M.A. Borten, E.J. Pereira, K.A. Atkins, K.A. Janes, Tumorsuppressor inactivation of GDF11 occurs by precursor sequestration in triple-negative breast cancer, Dev. Cell 43 (2017) 418-435 e413.

[20] G. Williams, M.P. Zentar, S. Gajendra, M. Sonego, P. Doherty, G. Lalli, Transcriptional basis for the inhibition of neural stem cell proliferation and migration by the TGFbeta-family member GDF11, PLoS One 8 (2013) e78478.

[21] C. Enriquez-Cortina, M. Almonte-Becerril, D. Clavijo-Cornejo, M. PalestinoDominguez, O. Bello-Monroy, N. Nuno, A. Lopez, L. Bucio, V. Souza, R. HernandezPando, L. Munoz, M.C. Gutierrez-Ruiz, L.E. Gomez-Quiroz, Hepatocyte growth factor protects against isoniazid/rifampicin-induced oxidative liver damage, Toxicological sciences: an official journal of the Society of Toxicology 135 (2013) 26-36.

[22] J.U. Marquardt, D. Seo, L.E. Gomez-Quiroz, K. Uchida, M.C. Gillen, M. Kitade, P. Kaposi-Novak, E.A. Conner, V.M. Factor, S.S. Thorgeirsson, Loss of c-Met accelerates development of liver fibrosis in response to $\mathrm{CCl}(4)$ exposure through deregulation of multiple molecular pathways, Biochim. Biophys. Acta 1822 (2012) 942-951.

[23] J.P. Quigley, P.B. Armstrong, Tumor cell intravasation alu-cidated: the chick embryo opens the window, Cell 94 (1998) 281-284.

[24] D. Ribatti, The chick embryo chorioallantoic membrane (CAM) assay, Reprod. Toxicol. 70 (2017) 97-101.

[25] R. Lazzarini-Lechuga, O. Alcantar-Ramirez, R. Jaime-Cruz, L. Gómez-Quiroz, Efecto teratogénico de nanopartículas de oro de $20 \mathrm{~nm}$ durante la septación cardiaca, Munod Nano 7 (2014) 69-77.

[26] C. Czauderna, M. Palestino-Dominguez, D. Castven, D. Becker, L. Zanon-Rodriguez, J. Hajduk, F.L. Mahn, M. Herr, D. Strand, S. Strand, S. Heilmann-Heimbach, L.E. Gomez-Quiroz, M.A. Worns, P.R. Galle, J.U. Marquardt, Ginkgo biloba induces different gene expression signatures and oncogenic pathways in malignant and nonmalignant cells of the liver, PLoS One 13 (2018) e0209067.

[27] A. Jemal, E.M. Ward, C.J. Johnson, K.A. Cronin, J. Ma, B. Ryerson, A. Mariotto, A.J. Lake, R. Wilson, R.L. Sherman, R.N. Anderson, S.J. Henley, B.A. Kohler, L. Penberthy, E.J. Feuer, H.K. Weir, Annual report to the nation on the status of cancer, 1975-2014, featuring survival, J. Natl. Cancer Inst. 109 (2017).

[28] L. Ghisolfi, A.C. Keates, X. Hu, D.K. Lee, C.J. Li, Ionizing radiation induces stemness in cancer cells, PLoS One 7 (2012) e43628.

[29] H. Hirschfield, C.B. Bian, T. Higashi, S. Nakagawa, T.Z. Zeleke, V.D. Nair, B.C. Fuchs, Y. Hoshida, In vitro modeling of hepatocellular carcinoma molecular subtypes for anti-cancer drug assessment, Exp. Mol. Med. 50 (2018) e419.

[30] H.S. Seol, S.E. Lee, J.S. Song, J.K. Rhee, S.R. Singh, S. Chang, S.J. Jang, Complement proteins C7 and CFH control the stemness of liver cancer cells via LSF-1, Cancer Lett. 372 (2016) 24-35.

[31] Y. Zhang, P.B. Alexander, X.F. Wang, TGF-beta family signaling in the control of cell proliferation and survival, Cold Spring Harb. Perspect. Biol. 9 (2017).

[32] P.M. Siegel, J. Massague, Cytostatic and apoptotic actions of TGF-beta in homeostasis and cancer, Nat. Rev. Cancer 3 (2003) 807-821.

[33] J. Zhang, O. Yamada, S. Kida, Y. Matsushita, T. Hattori, Down-regulation of osteopontin mediates a novel mechanism underlying the cytostatic activity of TGFbeta, Cell Oncol (Dordr) 39 (2016) 119-128.

[34] C.W. Lee, S.E. Lin, H.I. Tsai, P.J. Su, C.H. Hsieh, Y.C. Kuo, C.M. Sung, C.Y. Lin, C.N. Tsai, M.C. Yu, Cadherin 17 is related to recurrence and poor prognosis of cytokeratin 19-positive hepatocellular carcinoma, Oncol. Lett. 15 (2018) 559-567.

[35] A.W. Chan, J.H. Tong, S.L. Chan, P.B. Lai, K.F. To, Expression of stemness markers (CD133 and EpCAM) in prognostication of hepatocellular carcinoma, Histopathology 64 (2014) 935-950.

[36] Y. Li, R. Wang, S. Xiong, X. Wang, Z. Zhao, S. Bai, Y. Wang, Y. Zhao, B. Cheng, Cancer-associated fibroblasts promote the stemness of CD24(+) liver cells via paracrine signaling, J Mol Med (Berl) 97 (2019) 243-255.

[37] W. Chengye, T. Yu, S. Ping, S. Deguang, W. Keyun, W. Yan, Z. Rixin, L. Rui, G. Zhenming, Y. Mingliang, W. Liming, Metformin reverses bFGF-induced epithelial-mesenchymal transition in HCC cells, Oncotarget 8 (2017) 104247-104257. 


\title{
GDF11 Implications in Cancer Biology and Metabolism. Facts and Controversies
}

\author{
Arturo Simoni-Nieves ${ }^{1,2}$, Monserrat Gerardo-Ramírez ${ }^{1,2}$, Gibrán Pedraza-Vázquez ${ }^{1,2}$, \\ Lisette Chávez-Rodríguez ${ }^{1,2}$, Leticia Bucio ${ }^{2,3}$, Verónica Souza ${ }^{2,3}$, \\ Roxana U. Miranda-Labra ${ }^{2,3}$, Luis E. Gomez-Quiroz ${ }^{2,3 *}$ and \\ María Concepción Gutiérrez-Ruiz ${ }^{2,3 *}$
}

${ }^{1}$ Posgrado en Biología Experimental, DCBS, Universidad Autónoma Metropolitana-Iztapalapa, Mexico City, Mexico, ${ }^{2}$ Laboratorio de Fisiología Celular y Biología Molecular, Departamento de Ciencias de la Salud, Universidad Autónoma Metropolitana-Iztapalapa, Mexico City, Mexico, ${ }^{3}$ Laboratorio de Medicina Experimental, Unidad de Medicina Translacional, Instituto de Investigaciones Biomédicas, UNAM/Instituto Nacional de Cardiología Ignacio Chavez, Mexico City, Mexico

OPEN ACCESS

Edited by:

Antonio Giuseppe Naccarato,

University of Pisa, Italy

Reviewed by:

Prospero Civita

Brain Tumor Research Center,

United Kingdom

Sujit Kumar Bhutia,

National Institute of Technology

Rourkela, India

${ }^{*}$ Correspondence:

Luis E. Gomez-Quiroz

legq@xanum.uam.mx

María Concepción Gutiérrez-Ruiz

mcgr@xanum.uam.mx

Specialty section:

This article was submitted to

Cancer Metabolism

a section of the journal

Frontiers in Oncology

Received: 10 August 2019 Accepted: 24 September 2019

Published: 15 October 2019

Citation:

Simoni-Nieves A, Gerardo-Ramírez M Pedraza-Vázquez $G$,

Chávez-Rodríguez L, Bucio L,

Souza V, Miranda-Labra RU,

Gomez-Quiroz LE and

Gutiérrez-Ruiz MC (2019) GDF11

Implications in Cancer Biology and Metabolism. Facts and Controversies.

Front. Oncol. 9:1039.

doi: 10.3389/fonc.2019.01039
Growth Differentiation Factor 11 (GDF11), a member of the super family of the Transforming Growth Factor $\beta$, has gained more attention in the last few years due to numerous reports regarding its functions in other systems, which are different to those related to differentiation and embryonic development, such as age-related muscle dysfunction, skin biology, metabolism, and cancer. GDF11 is expressed in many tissues, including skeletal muscle, pancreas, kidney, nervous system, and retina, among others. GDF11 circulating levels and protein content in tissues are quite variable and are affected by pathological conditions or age. Although, GDF11 biology had a lot of controversies, must of them are only misunderstandings regarding the variability of its responses, which are independent of the tissue, grade of cellular differentiation or pathologies. A blunt fact regarding GDF11 biology is that its target cells have stemness feature, a property that could be found in certain adult cells in health and in disease, such as cancer cells. This review is focused to present and analyze the recent findings in the emerging research field of GDF11 function in cancer and metabolism, and discusses the controversies surrounding the biology of this atypical growth factor.

Keywords: GDF11, PCSK5, cancer, liver, HCC, metabolism

\section{INTRODUCTION}

On May 2013 the research groups, led by doctors Amy J. Wagers and Richard T. Lee, published outstanding work suggesting that the growth differentiation factor 11 (GDF11) could be a good candidate for the age-related heart hypertrophy reversion observed in the model of heterochronic parabiosis (1). One year later, on May 2014, Science journal published a couple of works by the same research team at Harvard University, unveiling that systemic injection of the GDF11 reverses agerelated dysfunction in skeletal muscle (2) and vascular and neurogenic function in the brain (3). Both reports were astonishing, particularly because myostatin, also known as GDF8, shares high structural homology with GDF11, but GDF8 induces exactly the contrary effect, muscle growth inhibition (4). At that moment, GDF11 was called "the rejuvenation factor," a term taken by a commentary note published by Jocelyn Kaiser in the same number of the Science journal (5), and Karoline E. Brun published another similar commentary in Cell journal entitle "GDF11 and the Mythical Fountain of Youth" (6). 
The findings, beyond this unfortunate motto, revealed that GDF11 could exert functions in adult systems, in addition of those characterized in embryonic and fetal tissues. The works by the groups of doctors Wagers and Lee provided evidence that the main target cells are those with certain stemness phenotype, such as the satellite cells in the muscle, which are the progenitor ones for new functional muscle cells.

If GDF11 targets cells with stemness capacity, then many cancer cells should be targeted by this growth factor.

Many cancer cells gain stemness capacity and this correlates with aggressiveness and poor prognosis. The findings raised by the group of doctors, Wagers and Lee, position cancer cells as a target of GDF11 since they proved that stemness is a key condition for GDF11 effect. However, the results could be opposite depending of the cancer cell origin, metabolic status, or the stage of the cancer. We must wait for incoming works in the next few years, perhaps months, revealing a more precise mechanism regarding these apparent controversies in cancer and metabolism.

This work is focused to review the general knowledge of GDF11, and its functions in cancer biology and metabolism, taking into consideration recent findings in the specialized literature and in the public databases and scientific online resources.

\section{GDF11 AN ATYPICAL TGF- $\beta$ FAMILY MEMBER}

GDF11 (also known as Bone Morphogenetic Protein, BMP11), is a member of the super family of the Transforming Growth Factor beta (TGF- $\beta$ ) and a subfamily of the BMP which is widely secreted in many species, including mouse, rat and human, and it is accepted as a key factor in embryo development, particularly in the anterior/posterior patterning (7-9).

GDF11 was identified by McPherron et al. in 1999, who cloned the human and mouse GDF11 and characterized its function in pattering the axial skeleton (9). Two years prior, the same group also discovered and characterized the GDF8 (10).

In humans, GDF11 gene is located in chromosome 12 (12q13.2, forward strand, Ensembl accession number: ENSG00000135414). Two splice variants products have been identified, according to Ensembl (Figure 1), the first one, GDF11201 is a 8657 bp RNA, formed by three coding exons, generating a 407 amino acids protein, and the second one, GDF11-202, is a 1,258 bp, formed by three exons generating a 380 amino acids protein (11). Jeanplong (12) reported another RNA splice variant determined as GDF-11 $\Delta \mathrm{Ex} 11$, characterized by the absence of exon 1, and composed for exon 2 and 3 with transcriptional initiation in intron $1(4,701 \mathrm{bp})$. It is predicted this variant could be regulated by transcription factors, such as some myogenic factors (MRF, Myf5, MyoD, Myogenin, and MRF4), Pax3, NF1, AP1, among others (12), suggesting that it could be involved in muscle development and/or repair as reported in other work (2). Interestingly, the promoter of GDF11 could also be activated by trichostatin A (13), an inhibitor of histone deacetylases (HDAC), suggesting a clear epigenetic regulation of the GDF11 gene expression; HDAC3 regulates zebrafish liver development by modulating GDF11. The overexpression of HDAC3 increases liver size, while the increase of GDF11 expression induces a small size liver; interestingly, the knockdown of GDF11 did not induce any relevant change in liver morphology. The role of HDAC3 in GDF11 function in liver development is likely a direct control over the hepatocyte precursor (hepatoblast) proliferation, as observed in HCC-derived cells (14), but this must be deeply addressed.

GDF11 mRNA is translated in a precursor protein (Figure 2), which is processed by specific proteases generating the mature GDF11 (C-terminal, $12.5 \mathrm{kDa}$ ) and the pro-domain $(\mathrm{N}$ terminal, $30.1 \mathrm{kDa})$. GDF11 shares $89 \%$ amino acid sequence homology with GDF8, however GDF8 expression in human tissues is restricted to cardiac and skeletal muscle (1), while GDF11 is practically expressed in all tissues (15). Although there is high homology between mature GDF8 and GDF11, the pro-domains of both proteins share only $54 \%$ homology. The pro-domain is fundamental for proper protein folding, disulfide bond formation and exportation of the homodimers (16), suggesting differences in posttranslational process.

The protein convertase subtilisin/kexin 5 (PCSK5) is one of the main acting proteins on GDF11, activating the mature GDF11 by proteolytic process at basic sites of the pro-domain (17). The elimination of PCSK5 in the mouse embryo was associated with abnormal expression of Hlxb9 and Hox genes, two well-known GDF11 target genes, generating defects in the anteroposterior patterning and strongly proposing a relationship with GDF11 functions $(7,8)$.

In humans, GDF11 is expressed in practically all tissues, but is particularly relevant in the brain (hippocampus), the kidneys, the endometrium, and the heart muscle; while the liver is the organ with the lowest expression $(1,15,18)$.

\section{THE SIGNAL TRANSDUCTION}

As a member of the BMP family, GDF11 uses the canonical receptors and the SMAD proteins for signaling. The GDF11 dimer (a disulfide-linked homodimer of carboxy-terminal fragments) binds the activin receptors type II A or B (ActRIIA, ActRIIB), proteins with serine/threonine kinase activity; leading to the recruitment and transphosphorylation of two type I serine/threonine kinase receptors, also known as activinlike kinase receptors (ALK), particularly the 4, 5, or 7 (19, 20). The activated ALK receptor phosphorylates and activates the receptor-regulated SMAD (R-SAMD). GDF11 particularly transduces by using SMAD2 and $3(14,21)$, and some reports also propose the participation of SMAD1, 5 and 8 (22). The RSMAD dimer recruits the co-SMAD, SMAD4, to form a trimeric complex, which eventually translocates to the nucleus for gene expression regulation (23). Although the signal transduction of the TGF- $\beta$ family might seem simple, it is highly regulated by extracellular and intracellular mechanisms. Inside the cell, the regulation can occur at the membrane or in the cytosol, during nuclear translocation and DNA biding, at this level, is a 
A

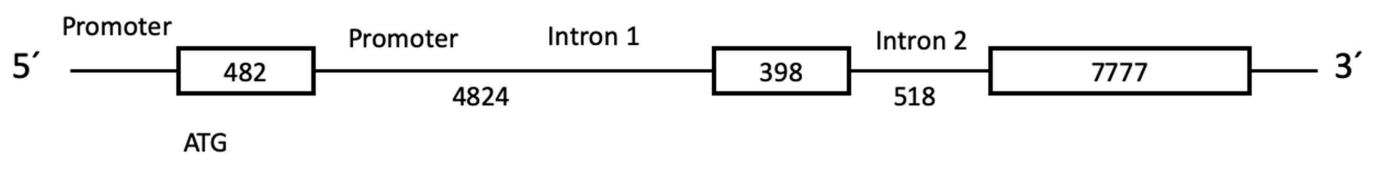

B
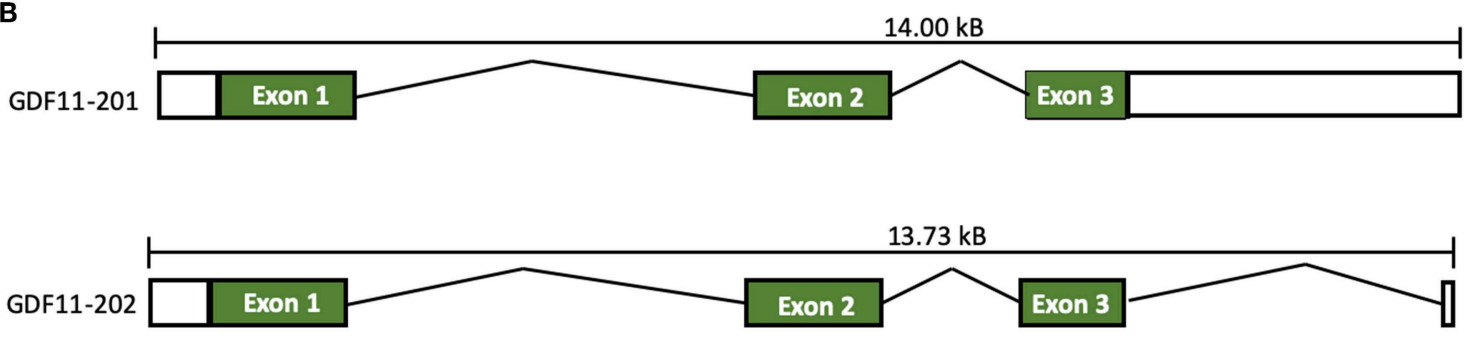

\begin{tabular}{|c|c|c|c|c|c|}
\hline $\begin{array}{c}\text { Name } \\
\text { Splice Variant }\end{array}$ & $\begin{array}{c}\text { Ensambl trasncript } \\
\text { number }\end{array}$ & bp & Protein & $\begin{array}{c}\text { Ensambl protein } \\
\text { number }\end{array}$ & Biotype \\
\hline GDF11-201 & ENST00000257868.9 & 8657 & $\begin{array}{c}407 \mathrm{aa} \\
45.1 \mathrm{KDa}\end{array}$ & ENSP00000257868.5 & Protein coding \\
\hline GDF11-202 & ENST00000546799.1 & 1258 & $\begin{array}{c}380 \mathrm{aa} \\
42.2 \mathrm{KDa}\end{array}$ & ENSP00000448390.1 & Protein coding \\
\hline
\end{tabular}

FIGURE 1 | Schematic representation of GDF11 gene and mRNA. (A) Gdf11 gene and (B) Gdf11 transcripts and table with the two transcripts specifications according to Ensembl (www.ensembl.org, ENSG00000135414.9) and Jeanplog 2014.

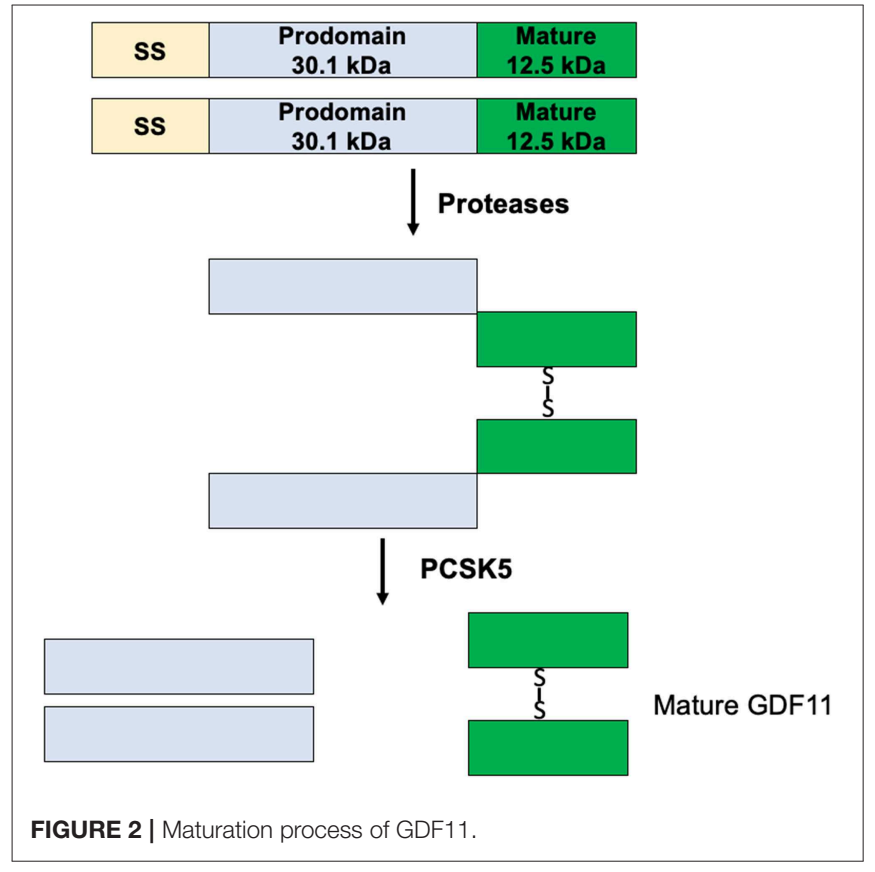

tetrameric complex because the interaction with a fourth protein component or partner (24) (Figure 3).

GDF11 can also transduce by non-canonical pathways. Mitogen activated protein kinase (MAPK) is perhaps the main non-SMAD pathway controlled by the growth factor, activating routes such as p38, AKT, and JNK $(25,26)$, however, in some cases, inhibiting the activation of JNK or NF- $\kappa \mathrm{B}$ (27) depending of the cell lineage. Further, it has been described that the family can also transduce by MAPKKK7 [also known as TGF$\beta$ activated kinase 1 (TAK1)] via MEK6 (28-30). TAK1 is part of a signaling complex formed by TAK1 binding protein 1 (TAB1) and with either TAB2 or TAB3 (31). TAK1 complex follows an intricate mechanism of activation involving the tumor necrosis factor receptor-associated factor (TRAF) 2 or 6 , adaptor proteins with non-conventional activity of E3 ubiquitin ligase. TRAF proteins exert regulation over TAB2 or 3. Finally, the autophosphorylation of TAK1 leads to the activation of its downstream targets, particularly members of the MAPK and $\mathrm{NF}-\kappa \mathrm{B}$ signaling pathways (32).

Negative regulation of the GDF11-mediated signaling can also occur at different levels. Extracellularly, GDF11 can be negatively regulated by the interaction with many proteins such as follistatin $(33,34)$, GDF-associated serum protein-1 (GASP-1), GASP-2 (35), decorin and follistatin-like 3, among others (4). Follistatin, a secreted glycoprotein, binds GDF11 and inhibits its interaction with ActRIIB. Follistatin is the main extracellular inhibitor of GDF11, and is transcriptionally regulated by the same GDF11 signaling, indicating that the signal transduction is restricted by a negative feedback mechanism (36).

The BMP and activin membrane-bound inhibitor (BAMBI), a co-receptor that is not functional due to it lacks cytosolic domain, has been suggested to be another negative regulator in plasma membrane, but that still remains to be confirmed (19).

In the cytosol, GDF11 follows the canonical negative regulation of the family. It has been reported that GDF11 is regulated by SMAD7 (37) and SMAD6 (19). The SMAD specific E3 ubiquitin protein ligase 2 (SMURF2) also displays negative regulation of the signaling pathway (28). Negative-regulation 

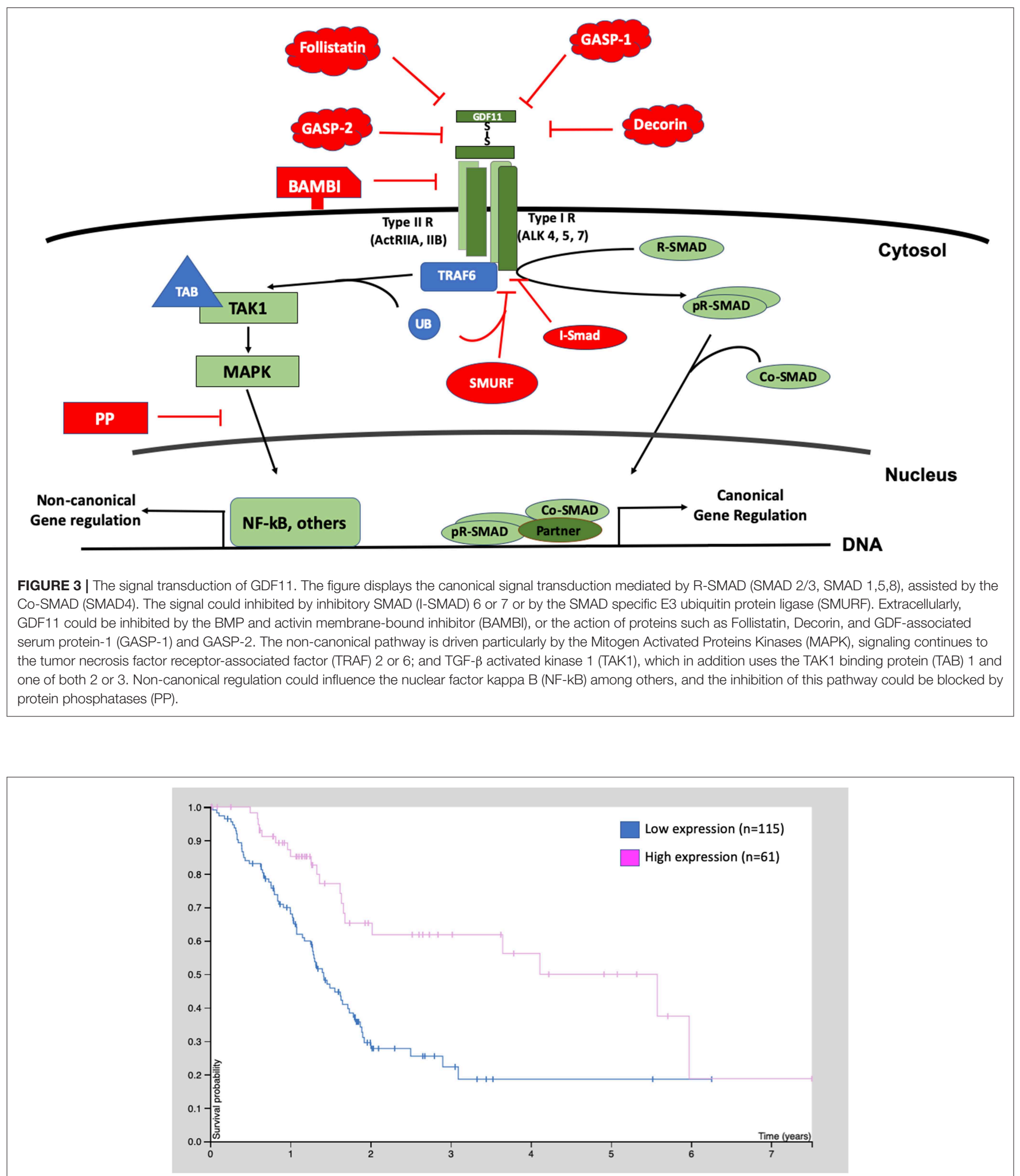

FIGURE 4 | Kaplan-Meier survival curve of 176 patients with pancreatic cancer. Patients were classified as low GDF11 expression and high GDF11 expression, $p<$ 0.001 , according to the human protein atlas (www.proteinatlas.org/ENSG00000135414-GDF11/pathology). 
of the non-canonical pathway is driven by specific protein phosphatases (PP), such as PPC1, among others.

\section{DEVELOPMENT AND AGED-RELATED FUNCTION}

Although GDF11 was identified in 1999 (9), as previously mentioned, in 2014 the growth factor was transiently located in the "Sancta sanctorum" of the "miraculous" molecule, when the laboratory of Amy Wagers (2) reported that GDF11 was responsible for the skeletal muscle regeneration in mice heterochronic parabiosis. A profound controversy arose regarding the rejuvenating property of GDF11; some groups stated that this property is displayed by the growth factor (1$3,38)$, while others reported the opposite effect (39-42), as previously mentioned. To have a good point of view regarding this debate, we suggest a deep view of cited works and commentaries regarding the controversy $(3,5,6,19,42,43)$.

Regardless of this disagreement, there is no doubt about the GDF11 function in differentiation and embryonic development, particularly in anterior/posterior axial skeleton (9) and brain function (44), which are nicely reviewed elsewhere $(19,45,46)$.

\section{GDF11 VS. GDF8 AND THE RACE FOR THE DISCOVERY OF THE REJUVENATION PROPERTIES}

GDF11 and GDF8 are close related members of the activins subclass in the TGF- $\beta$ superfamily. Sharing $90 \%$ of their amino acid sequence $(38,47)$, these two proteins have been a technical challenge for antibody manufacturers and, therefore, protagonists of one of the most controversial studies in recent years $(29,39,48-50)$, regarding to the issue of GDF11 being the protein responsible for "rejuvenation" of aged organisms $(1,2)$, as previously mentioned.

The race from the discovery of the rejuvenation properties of GDF11 to the following debate of the antibody specificity led to a deeper structural analysis of these proteins and the interaction with their receptor. Due to the similarities of $\sim 90 \%$ of sequence identity of the C-terminal signaling domain between GDF11 and GDF8, their mature form is nearly identical, which causes these proteins to share the same activin type II receptor (38).

Although they are indeed similar in their monomeric form, in fact these proteins are thought to have opposite functions, where GDF11 works as a muscle generator in embryogenesis (9) but GDF8 acts as a muscle mass inhibitor $(10,51)$, which may be the result of the final homodimer structure. Thus, it is important to understand that the GDF11 and GDF8 homodimer formation leads to a different conformation that allows them to interact with the same receptor in a unique and specific way. It is reported that both homodimers are linked by a single disulfide bond in an antiparallel conformation, but the flexibility in the relative orientations generated by the differences in their structure are determinant for the quaternary structure variations that lead to a distinctive biological response $(47,52)$.
It has also been reported that GDF11 has a stronger affinity for the receptor than GDF8 (38) and that it is more dependent on direct receptor contacts (53), but there is also an issue with crystal structures of both proteins. Human myostatin alone has not been reported and the available structures are bound to extracellular antagonists (follistatin and follistatin-like 3$)(54,55)$, which have been compared to a small-angle X-ray scattering (SAXS) analysis to determine the mechanism of activation (52). On the other hand, human GDF11 structure has been resolved in recent years (47), thus, it is possible to discover the real impact of the structure of both proteins in future, at which point we can begin to uncover exactly what makes the responses so different.

\section{GDF11 EFFECTS IN CANCER BIOLOGY}

An emerging field of research is the impact of GDF11 in cancer biology. Most of the cancer cells, particularly those with high aggressiveness, retain or recover stemness capacity, placing them as a potential target of $\operatorname{GDF} 11(14,23)$.

There exist some controversies in cancer biology as well; in some cases GDF11 induces clear tumor suppressive properties $(14,23)$, and in others it is the opposite $(56,57)$. Once again, the versatility displayed by this growth factor depends of cell progeny, grade of differentiation or transformation.

\section{LIVER CANCER}

We recently published work describing how GDF11 induces tumor suppressive properties in human hepatocellular carcinoma-derived cells, Huh7 and Hep3B cell lines, restricting spheroid formation and clonogenic capacity, an effect that is also observed in other liver cancer cell lines (SNU-182, Hepa1-6, and HepG2), decreasing proliferation, motogenesis, and invasion. These characteristics were associated with transcriptional repression of cyclin D1 and $\mathrm{A}$, and the overexpression of p27 (14). GDF11 effects, on hepatic cell proliferation, have been found in liver development, where GDF11 targets the hepatoblast, the hepatocyte precursor $(13,58)$.

Remarkably, the invasion experiments using the chick embryo chorioallantoic membrane $(\mathrm{CAM})$ model $(14,59)$ revealed a static phenotype in Huh7 cells treated for $72 \mathrm{~h}$ with GDF11 $(50 \mathrm{ng} / \mathrm{ml})$, an outcome well-correlated with a decrease in cell migration and proliferation. Furthermore, GDF11 treated cells were incapable of sustaining colony and sphere capacity in the absence of GDF11, up to 5 days, indicating that the effect of GDF11 on self-renewal capacity is not transient, suggesting a reprogramming effect.

Similar results were obtained in the hepatoblastoma cell lines, HepG2 and SMMC-7721: the treatment with GDF11 up to $72 \mathrm{~h}$ reduced cell viability. Although SMMC-7721 cells are probably a HELA-derivative cell line, the effect was also present (60). This report also provides preliminary evidence that the expression of GDF11 was significantly lower in cancerous tissue rather than in normal liver.

Outstandingly, GDF11 was capable of decreasing aggressiveness-associated markers in Huh7 and Hep3B cells, 
producing a deregulation in the expression of Epcam, promo1 (CD133), $c d 24$, and $c k 19$, that was associated with the repression of Snail and $\mathrm{N}$-cadherin, and the overexpression of occluding and E-cadherin, strongly indicating a mesenchymal to epithelial transition (14).

It is interesting that, under normal conditions, liver cells, which are the poorest in GDF11 production, are highly responsive to GDF11 in the context of cancer could be relevant in terms of a possible use of GDF11 for treatment. The work by Gerardo-Ramírez clearly showed that all HCC cells used in the study responded to the exogenous GDF11 treatment, decreasing all aggressiveness-associated markers. Interestingly, the effects in HCC cells were differentiated, and it was dependent of the stemness capacity, being more responsive to Hep3B cells, which express fewer stemness markers compared to Huh7 cells. Supporting this statement, in liver development GDF11 has been related to inhibition of liver growth, mainly targeting proliferation of hepatoblast, the cell precursor or mature hepatocytes by a mechanism involving HDAC3, which inhibits the expression of GDF11 as proven by Farooq and collaborators (58). This work clearly demonstrates that GDF11 targets hepatic cells with stemness features, not necessarily those observed in cancer, but in the normal liver, particularly in development.

\section{BREAST CANCER}

Similarly, Bajikar et al. (23) identified a tumor-suppressive role of GDF11 in a triple-negative breast cancer (TNBC). These cells, under 3D culture, heterogeneously express GDF11 and very low levels of GDF8, as well as the main canonical receptors, such as ALK4, and ALK5, among other protein machinery required for a proper signal transduction. This clearly indicates that breast epithelial cells express the required components to recognize GDF11 as an autocrine or paracrine stimulus (23). GDF11 also induced a decrease in number and size of the spheroids and generated more-compacted structures by the increment in Ecadherin, as observed in liver cancer cell lines, and GDF11 treatment induces a cell-cell adhesion preventing metastasis phenomena $(14,23)$.

Authors also found a defective GDF11 maturation and secretion in seven of nine studied TNBC cell lines. The linker was the convertase PCSK5, in which a deficiency was found in the TNBC cells, inducing the extracellular accumulation of the immature proGDF11 and, for instance, loss in the bioactivity of GDF11. This mechanism was also observed in mice; the lack of Pcsk5 in Apc ${ }^{\mathrm{min} /+}$ animals (61) increases adenocarcinoma formation in the small intestine, decreasing the survival $(23,62)$, which demonstrates a clear function in tandem of GDF11 and PCSK5 to induce the tumor suppressive properties. In fact, the restoration of the PCSK5 activity in the TNBC cells suppresses lung metastasis (23).

Another work by Wallner et al. (63) revealed that superphysiological levels of GDF11 $(2 \mu \mathrm{g} / \mathrm{ml})$ could provide advantages in chemotherapy in breast adenocarcinoma, inducing a decrement in the migrative capacity of MCF-7 cells in a scratch assay. Similar findings were observed in the presence of follistatin $(2 \mu \mathrm{g} / \mathrm{ml})$, while GDF8 $(2 \mu \mathrm{g} / \mathrm{ml})$ induced cell death at the same time. This study also showed that GDF11 is expressed in low grade adenocarcinoma tissue (G1), but lower levels in G3 tissue were found, and it was correlated with high expression of follistatin in G1, suggesting an inhibitory effect of GDF11 at higher levels of differentiation, which is consistent with the idea that high aggressiveness in cancer associates with less GDF11 function, confirming the tumor suppressive capacity of GDF11.

\section{PANCREATIC CANCER}

Pancreatic cancer (PC) represents one of the most lethal cancers worldwide (64). It has been reported that GDF11 is downregulated in PC tissue, compared with surrounding tissue, and pancreatic cell lines exhibit a low expression of the growth factor (65). This group also reported that, in a cohort of 63 PC patients, those with high GDF11 expression had significantly better survival rates in comparison with those with low GDF11 expression. These effects were related to decreased proliferation, migration and invasion, and these observations are in agreement with those reported in HCC and TNBC. GDF11 is also capable of inducing apoptosis in PC cell lines (65).

Similarly, the human protein atlas (https://www.proteinatlas. org) provides evidence from 176 patients: those with high GDF11 expression $(n=61)$ exhibited better survival rates, compared with those with low expression $(n=115, p<0.001)$ (Figure 4). These observations strongly suggest that GDF11 could also exert tumor suppressive properties that should be deeply addressed to gain confidence, particularly the effect of exogenous active GDF11 (18).

Interestingly, another member of the family GDF15 is directly correlated with poor survival in PC patients, and it is proposed as a better marker than CA-125 (66), again raising the atypical functions of this growth factor.

As observed in HCC, in PC, the targets of GDF11 are poorly differentiated cells. In the mouse embryo, GDF11 is expressed in the pancreatic epithelium, at embryonic day E12-E14 (67), as it happens in the liver, but in GDF11 $1-$ - animals the pancreas size are 2 -fold smaller than wild type.

In the context of the educated guess that cells with some stemness phenotype respond to GDF11, even in cancer, it has been proven that GDF11 negatively regulates $\mathrm{NGN}^{+}$progenitor cells and GDF11 induces $\beta$-cell differentiation (68), supporting the role of GDF11 in metabolism. Under this context, GDF11 exerts its functions in pancreatic cells with stemness phenotype.

\section{COLORECTAL CANCER}

In 130 patients with colorectal cancer (CRC), the expression of GDF11 was significantly higher compared with normal tissue (56). The classification of the patient cohort in low and high GDF11 expression revealed that those patients with high levels of GDF11 showed a higher frequency of lymph node metastasis, more deaths and lower survival. The study suggests that GDF11 could be a prognostic biomarker in patients with this disease. 


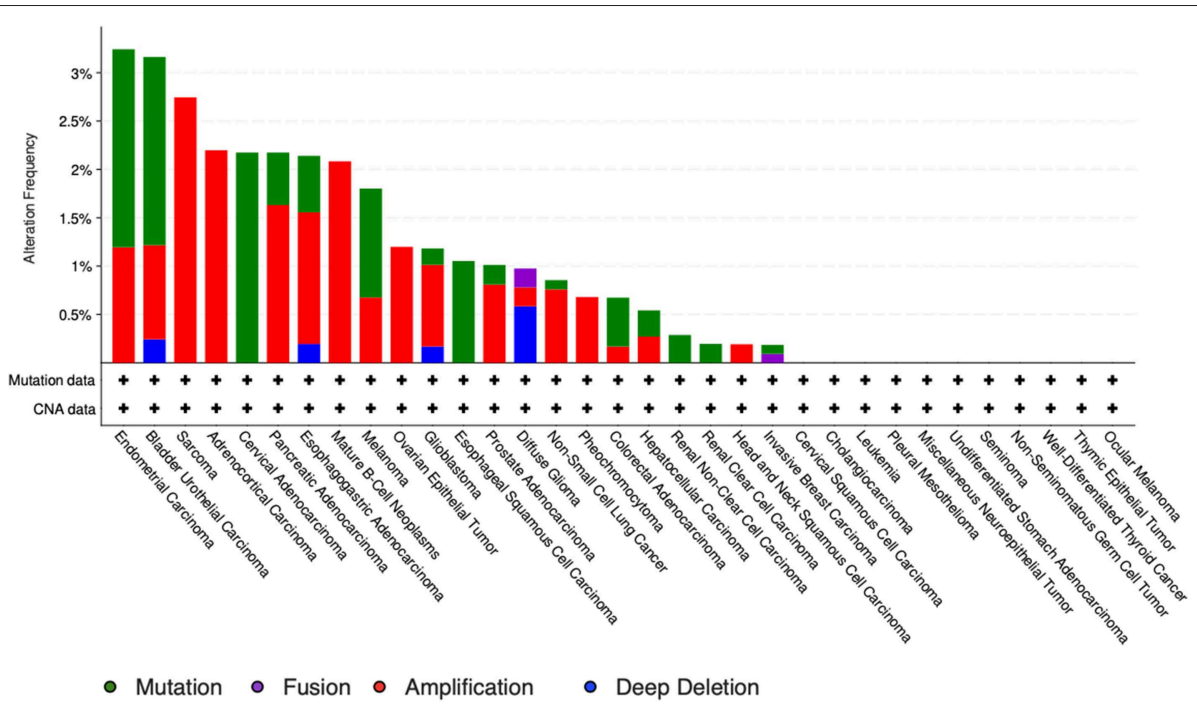

FIGURE 5 | Genomic alterations in Gdf11 gene. Alteration frequency by type of cancer according to cBioportal for cancer genomics (https://www.cbioportal.org).

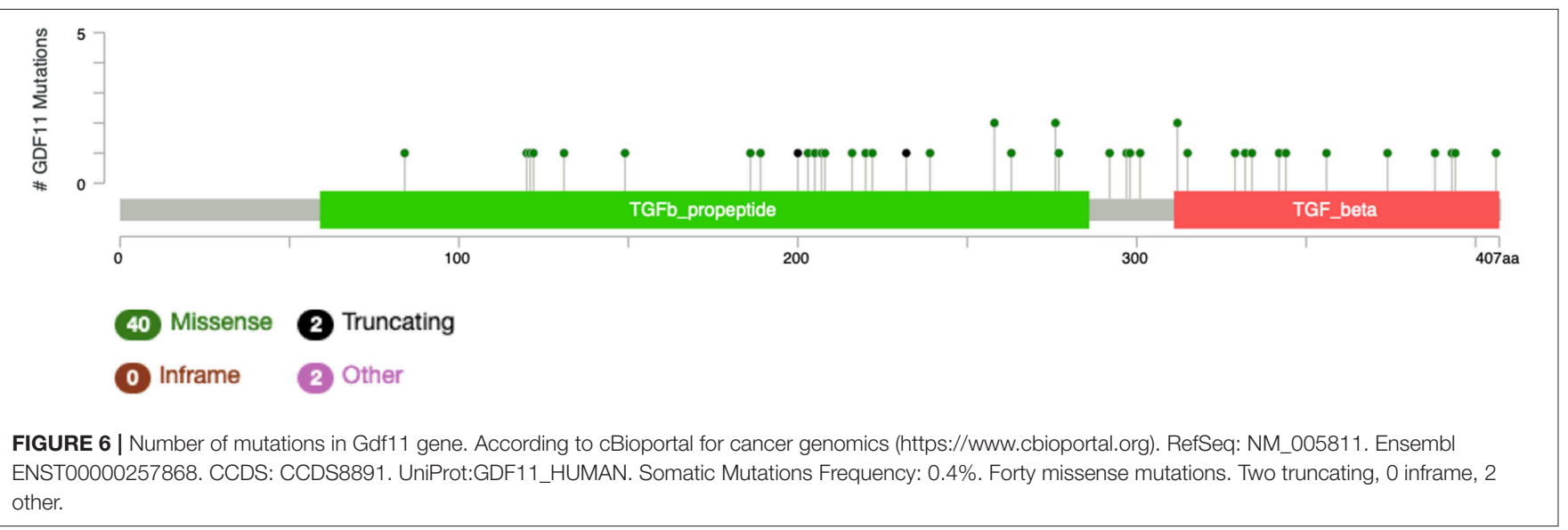

It is known that lymphangiogenesis is a fundamental phenomenon for colorectal cancer dissemination (69). Recently, Ungaro and collaborators reported that the microenvironment in the lymphatic vessels provides support to the tumor-derived cells by manipulating the production of extracellular matrix proteins and soluble factors, such as cytokines and growth factors (70). Whole transcriptomic analysis addressed by RNA-seq of isolated human intestinal lymphatic endothelial cells (HILEC) from surgically resected CRC and healthy corresponding controls, revealed that among those genes differentially expressed, GDF11 was observed as a significant increment with high statistical confidence. CACO-2 cells demonstrated high proliferation in coculture with CRC-HILEC, but the GDF11 silencing by siRNA abrogated this effect indicating a tumor promotion role of GDF11 in CRC. Interestingly, GDF11 was expressed not only in lymphatic vessels in CRC, but also in normal tissue (69). The study also provides evidence of a direct correlation of GDF11 expression and tumor stage, confirming in this particular cancer that GDF11 expression could be a marker of tumor progression (70), and also raises mechanistic evidence that microenvironment in the lymphatic vessel could play a pivotal role in metastasis by local production of GDF11.

\section{OTHER TYPES OF CANCER}

Some reports have pointed to the pro-tumorigenic properties of GDF11, with major or minor confidence of rigorous scientific approach.

In oral squamous cell carcinoma, Qin and coauthors (57) showed that in a small patient cohort GDF11 expression is positively correlated with aggressiveness, finding a higher expression in metastatic oral cancer $(n=19)$ in comparison with non-metastatic oral cancer $(n=15)$. Authors also sustain that GDF11 induced epithelial to mesenchymal transition by downregulating epithelial markers such as E-cadherin, and the overexpression of vimentin or metalloproteinase 9.

In uveal melanoma, GDF11 expression was significantly upregulated compared with surrounding tissue, the expression 


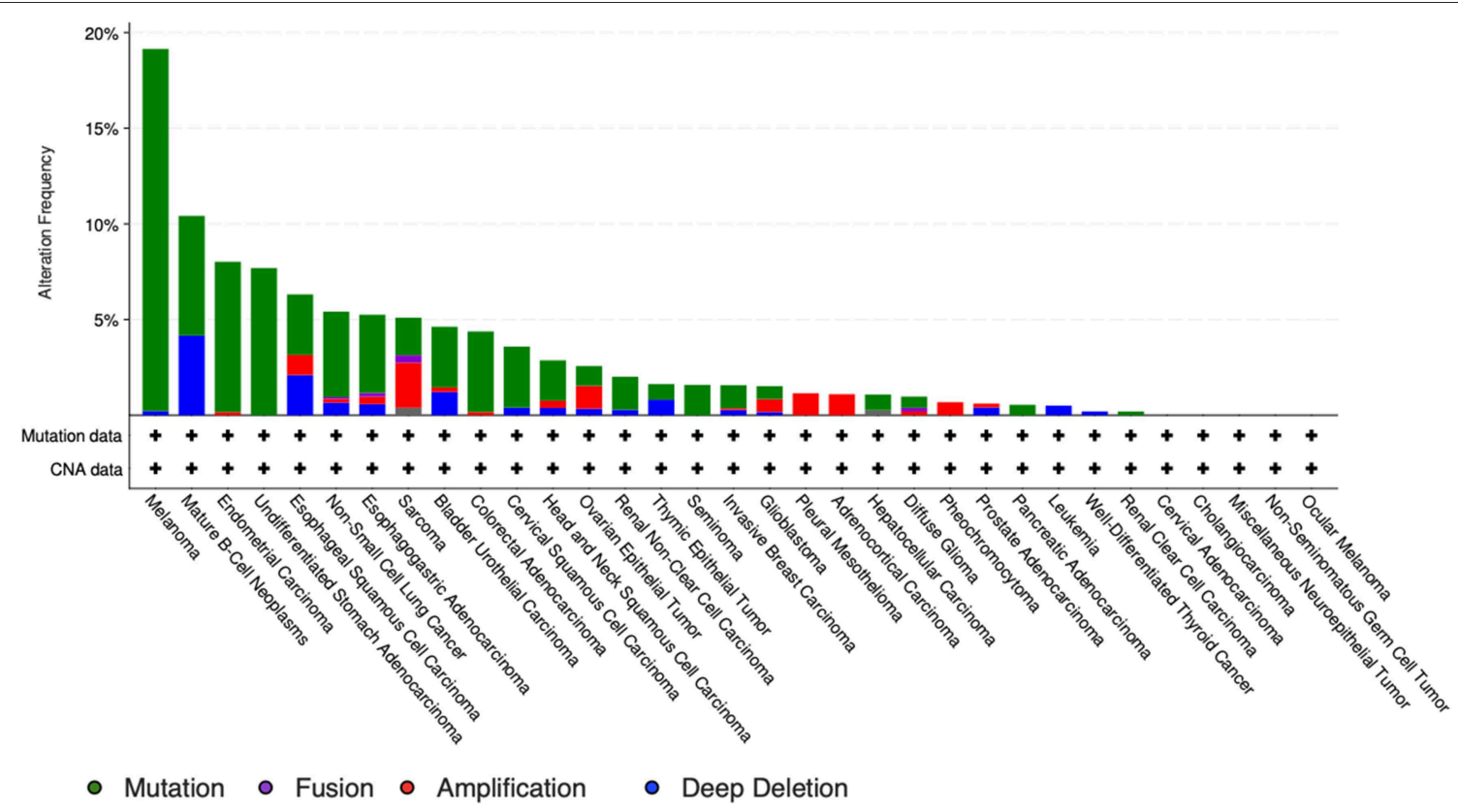

FIGURE 7 | Genomic alterations in Pcsk5 gene. Alteration frequency by type of cancer according to cBioportal for cancer genomics (https://www.cbioportal.org).

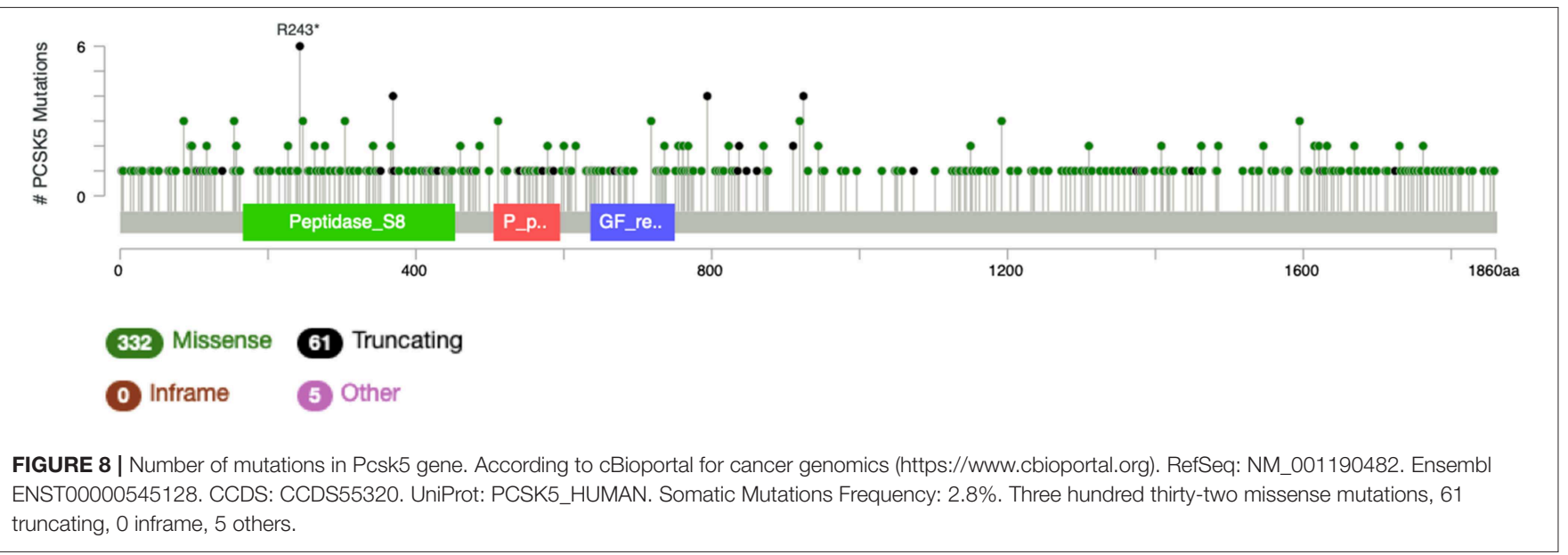

was higher in stage IV and substantially greater in the deceased cases regarding living cases (71). The multivariate analysis confirmed that GDF11 is an independent prognostic indicator of unfavorable overall survival.

\section{GDF11 AND PCSK MUTATIONS}

The study by Liu et al. (71) also showed that no relevant mutations were observed in the GDF11 gene in fact. The cBioportal for cancer genomics web site (https://www.cbioportal. org) indicates that GDF11 is altered in $1 \%$ of database patients. Figure 4 shows the alteration frequency in Gdf11 gene in some cancers, and Figure 5 depicts the number of somatic mutations, most of which are missense (72). It seems that mutations in the Gdf11 gene are not the main consequence in those cancers where
GDF11 is a prognostic factor, which increases research interest in transcriptional and post-translational regulation.

It is particularly relevant to consider the convertase PCSK5, a key regulator of GDF11 activity. Pcsk5 gene presents a high frequency of genomic alterations in 3\% of the patients, according to cBioportal, being particularly relevant in melanoma, endometrial carcinoma, and stomach adenocarcinoma, among others (Figure 6). Missense mutations are particularly observed in the peptidase transcript (Figure 7) (72). As proven remarkably by the team of doctor Kevin A. Janes (23), maturation of bioactive GDF11 is defective in TNBC due to insufficient PCSK5 activity but, as shown, the frequency of mutations appear not to be related with the flaw (Figure 8). Once again, transcriptional and post-translational regulation should be considered in future research. 
TABLE 1 | Overview of cancer cell lines or tissue from patients with differential effect of GDF11, as tumor suppressive or tumor promotion protein.

\begin{tabular}{|c|c|c|c|c|}
\hline Cancer & Cell/Tissue & $\begin{array}{c}\text { Tumor } \\
\text { suppressive }\end{array}$ & $\begin{array}{c}\text { Tumor } \\
\text { promotion }\end{array}$ & References \\
\hline Liver & $\begin{array}{l}\text { Huh7 } \\
\text { Hep3B } \\
\text { SNU-182 } \\
\text { Hepa1-6 HepG2 }\end{array}$ & $x$ & & (14) \\
\hline Liver & $\begin{array}{l}\text { HepG2 } \\
\text { SMMC-7721 } \\
\text { and } \\
\text { tissue }\end{array}$ & $x$ & & (60) \\
\hline Breast & $\begin{array}{l}\text { MDA-MB-231 } \\
\text { MDA-MB-468 } \\
\text { and } \\
\text { tissue }\end{array}$ & $x$ & & (23) \\
\hline Breast & MCF-7 & $x$ & & (63) \\
\hline Pancreas & $\begin{array}{l}\text { PANC-1 } \\
\text { CFPAC-1 } \\
\text { Tissue }\end{array}$ & $x$ & & (65) \\
\hline Colorectal & Tissue & & $X$ & (56) \\
\hline Colorectal & Tissue & & $x$ & (70) \\
\hline Colorectal & CACO-2 & & $x$ & (69) \\
\hline $\begin{array}{l}\text { Oral squamous } \\
\text { cell carcinoma }\end{array}$ & Tissue & & $x$ & $(57)$ \\
\hline $\begin{array}{l}\text { Uveal } \\
\text { melanoma }\end{array}$ & Tissue & & $x$ & (71) \\
\hline
\end{tabular}

\section{EFFECTS OF GDF11 AS METABOLISM REGULATOR}

The impact of GDF11 in the development of pancreas implies that the growth factor could exert some metabolic regulation on this organ in the adult, particularly in the endocrine pancreas (67). Dichmann and coauthors found that in the gdf $11^{-/-}$ mouse, the maturation and number of $\beta$ - and $\alpha$-cells are normal, however, another group led by Harmon reported that the gdf $11^{-/-}$mouse exhibited impairment maturation of $\beta$-cells and an increment in $\alpha$-cells, which could produce glucagon in comparison with the wild type mouse (68). This controversy, which is not unusual, must be addressed, but makes it clear that GDF11 could be inducing effects in the metabolism mediated by the pancreas.

Recently, a work by Anon-Hidalgo et al. (73) reported a convincing study associating the circulating levels of GDF11 with thyroid-stimulating hormone (TSH) in humans. The study showed subjects with high or normal levels of TSH present high level contents of GDF11, compared with patients with low levels of TSH. This finding could be due to the fact that other members of the family, such as GDF8 and GDF15, are regulators of the energy homeostasis $(74,75)$. Anon-Hidalgo team states that it could be related to a regulation of TSH by GDF11, or GDF11 could be positively regulated by TSH or any other thyroid hormones (73).

Luo et al. published that GDF11 decreased lipid content in human mesenchymal stem cells and the mouse 3T3-L1 cell line.
This was associated with the repression of adipogenic genes, such as the transcription factors Pparg, Cebpa, and the executer proteins Plp, Cd36, Plin1, Adipoq, among others, in a mechanism associated to the canonical signal transduction mediated by SMAD2/3 (76). The report provides evidence that GDF11 could exert control over lipid content in unclear fashion. The role of GDF11 in lipid homeostasis could be directed to lipid uptake or efflux, intervening in lipogenic or lipolysis pathways, or lipid removal by autophagy, but data provided by Luo et al. suggest an intervention in lipogenesis. Interestingly, obese mice fed with a high lipid diet present significantly decreased circulating GDF11 levels, compared with mice under low fat diet (77). The mRNA and protein content of GDF11 in skeletal muscle from mice under the high fat diet correlated with the serum content of the growth factor, exhibiting lower expression and protein content, compared with animals under low fat diet. Furthermore, palmitate treatment in the mouse-derived myoblast cell line, C2C12, decreases GDF11 expression. However, the GDF11 did not ameliorate the palmitate-induced insulin resistance and GDF11 treatment did not change expression of Glut4 or Irs-1.

The evidence sustains the metabolic intervention by GDF11, at least in terms of lipid homeostasis, and again in cells with stemness features. This could be relevant in cancer, since lipid overload is one of the main characteristics required for a proper cancer cell proliferation $(78,79)$. In fact, it is reported that GDF11 impairs mitochondrial function in cancer cell lines, particularly in HCC-derived cells (14). The impact of GDF11 in the central metabolic organelle could explain the tumor suppressive properties exerted by the growth factor. Mitochondria provide essential intermediaries required for cell proliferation: driving redox and calcium homeostasis, coordinating energy supply and mediating cell survival; all of which are fundamental for all cells, and particularly for transformed ones (80). A report by Hernandez-Rizo and collaborators states that GDF11 restricts cell proliferation in hepatic tumor cells through glycolysis and lipid metabolism impairment (81). In agreement with these findings, GarridoMoreno et al. (82) recently reported that GDF11 prevents cardiomyocyte hypertrophy by preserving the communication between the mitochondria and sarcoplasmic reticulum and calcium mobility, preserving oxidative mitochondria metabolism by a mechanism mediated by the maintenance of mitochondrial cytosolic calcium buffering capacity.

Although the evidence of GDF11 regulation of the energetic and lipid metabolism is limited, it clearly indicates an effect tending to maintain the cellular energetic homeostasis. More research is required to characterize the mechanism underlying metabolic regulation by the growth factor, particularly in cancer cells.

\section{CONCLUDING REMARKS AND FUTURE PROSPECTIVE}

GDF11 is an intriguing non-conventional growth factor, perhaps the most fascinating new member of the TGF- $\beta$ superfamily. It transduces, as practically all members, by the canonical 
SMAD and non-canonical MAPK pathways, but its functions can be quite variable, even contradictory, depending of the cell lineage, tissue (Table 1), or even age. This raises a complex body of physiological control, which could also differ in health or disease. GDF11 displays a versatile response that must be fully characterized, due to it representing an interesting point of intervention in many diseases or physiological conditions, particularly in cancer. It is remarkable that one of the main characteristics in GDF11 target cells, in normal or pathological conditions, is the stemness capacity. The effects exerted by the growth factor in cancer have begun to be characterized with greater scientific rigor and mechanistic approaches.

Perhaps it is time that GDF11, due to its diverse functionality, constitutes its own subfamily as an atypical and versatile member of the TGF- $\beta$ family.

We must be cautious to oversimplify its functions. The controversies found clearly indicate that GDF11 displays particular activities depending of cell type, grade of differentiation, and pathological or normal conditions. This remarkable atypical member of the TGF- $\beta$ family must be carefully studied in clear and well-controlled biological systems.

\section{REFERENCES}

1. Loffredo FS, Steinhauser ML, Jay SM, Gannon J, Pancoast JR, Yalamanchi $\mathrm{P}$, et al. Growth differentiation factor 11 is a circulating factor that reverses age-related cardiac hypertrophy. Cell. (2013) 153:828-39. doi: 10.1016/j.cell.2013.04.015

2. Sinha M, Jang YC, Oh J, Khong D, Wu EY, Manohar R, et al. Restoring systemic GDF11 levels reverses age-related dysfunction in mouse skeletal muscle. Science. (2014) 344:649-52. doi: 10.1126/science.1251152

3. Katsimpardi L, Litterman NK, Schein PA, Miller CM, Loffredo FS, Wojtkiewicz GR, et al. Vascular and neurogenic rejuvenation of the aging mouse brain by young systemic factors. Science. (2014) 344:630-4. doi: $10.1126 /$ science.1251141

4. Walker RG, Poggioli T, Katsimpardi L, Buchanan SM, Oh J, Wattrus S, et al. Biochemistry and biology of GDF11 and myostatin: similarities, differences, and questions for future investigation. Circ Res. (2016) 118:1125-41; discussion 1142. doi: 10.1161/CIRCRESAHA.116.3 08391

5. Kaiser J. Aging. 'Rejuvenation factor' in blood turns back the clock in old mice. Science. (2014) 344:570-1. doi: 10.1126/science.344.6 184.570

6. Brun CE, Rudnicki MA. GDF11 and the mythical fountain of youth. Cell Metab. (2015) 22:54-6. doi: 10.1016/j.cmet.2015.05.009

7. Lee YJ, McPherron A, Choe S, Sakai Y, Chandraratna RA, Lee SJ, et al. Growth differentiation factor 11 signaling controls retinoic acid activity for axial vertebral development. Dev Biol. (2010) 347:195-203. doi: 10.1016/j.ydbio.2010.08.022

8. Tsuda T, Iwai N, Deguchi E, Kimura O, Ono S, Furukawa T, et al. PCSK5 and GDF11 expression in the hindgut region of mouse embryos with anorectal malformations. Eur J Pediatr Surg. (2011) 21:238-41. doi: 10.1055/s-0031-1273691

9. McPherron AC, Lawler AM, Lee SJ. Regulation of anterior/posterior patterning of the axial skeleton by growth/differentiation factor 11. Nat Genet. (1999) 22:260-4. doi: 10.1038/10320

10. McPherron AC, Lawler AM, Lee SJ. Regulation of skeletal muscle mass in mice by a new TGF-beta superfamily member. Nature. (1997) 387:83-90. doi: $10.1038 / 387083 \mathrm{a} 0$

11. Hunt SE, McLaren W, Gil L, Thormann A, Schuilenburg H, Sheppard D, et al. Ensembl variation resources. Database. (2018) 2018:bay119. doi: $10.1093 /$ database/bay119
The knowledge, regarding GDF11, will surely be increased in the next few years. The mechanism of action in each particular cancer or cell type must be elucidated to clarify these controversies, and perhaps they will stop being such, thanks to the mechanistic enlightenments obtained in the incoming research in the field.

\section{AUTHOR CONTRIBUTIONS}

AS-N, MG-R, GP-V, and LC-R conception and preparation of the manuscript. LB, VS, and RM-L reviewed and corrected the manuscript. MCG-R and LG-Q final review of the manuscript and financial support.

\section{FUNDING}

This work was partially funded by a grant from the Consejo Nacional de Ciencia y Tecnología (CONACYT): CB-252942; Fronteras de la Ciencia 1320; Apoyo al Fortalecimiento y Desarrollo de la Infraestructura 2017-280788, and Universidad Autonoma Metropolitana. We thank Frida Gomez-Cuevas for the assistance in the preparation of the manuscript.

12. Jeanplong F, Falconer SJ, Oldham JM, Maqbool NJ, Thomas M, Hennebry A, et al. Identification and expression of a novel transcript of the growth and differentiation factor-11 gene. Mol Cell Biochem. (2014) 390:9-18. doi: 10.1007/s11010-013-1949-3

13. Zhang X, Wharton W, Yuan Z, Tsai SC, Olashaw N, Seto E. Activation of the growth-differentiation factor 11 gene by the histone deacetylase (HDAC) inhibitor trichostatin A and repression by HDAC3. Mol Cell Biol. (2004) 24:5106-18. doi: 10.1128/MCB.24.12.5106-5118.2004

14. Gerardo-Ramirez M, Lazzarini-Lechuga R, Hernandez-Rizo S, JimenezSalazar JE, Simoni-Nieves A, Garcia-Ruiz C, et al. GDF11 exhibits tumor suppressive properties in hepatocellular carcinoma cells by restricting clonal expansion and invasion. Biochim Biophys Acta Mol Basis Dis. (2019) 1865:1540-54. doi: 10.1016/j.bbadis.2019.03.003

15. Uhlen M, Fagerberg L, Hallstrom BM, Lindskog C, Oksvold P, Mardinoglu A, et al. Proteomics. Tissue-based map of the human proteome. Science. (2015) 347:1260419. doi: 10.1126/science. 1260419

16. Gray AM, Mason AJ. Requirement for activin A and transforming growth factor-beta 1 pro-regions in homodimer assembly. Science. (1990) 247:132830. doi: 10.1126/science. 2315700

17. Essalmani R, Zaid A, Marcinkiewicz J, Chamberland A, Pasquato A, Seidah $\mathrm{NG}$, et al. In vivo functions of the proprotein convertase PC5/6 during mouse development: Gdf11 is a likely substrate. Proc Natl Acad Sci USA. (2008) 105:5750-5. doi: 10.1073/pnas.0709428105

18. Uhlen M, Zhang C, Lee S, Sjostedt E, Fagerberg L, Bidkhori G, et al. A pathology atlas of the human cancer transcriptome. Science. (2017) 357:eaan2507. doi: 10.1126/science.aan2507

19. Jamaiyar A, Wan W, Janota DM, Enrick MK, Chilian WM, Yin L. The versatility and paradox of GDF 11. Pharmacol Ther. (2017) 175:28-34. doi: 10.1016/j.pharmthera.2017.02.032

20. Andersson O, Reissmann E, Ibanez CF. Growth differentiation factor 11 signals through the transforming growth factor-beta receptor ALK5 to regionalize the anterior-posterior axis. EMBO Rep. (2006) 7:831-7. doi: 10.1038/sj.embor.7400752

21. Gaunt SJ, George M, Paul YL. Direct activation of a mouse Hoxd11 axial expression enhancer by Gdf11/Smad signalling. Dev Biol. (2013) 383:52-60. doi: 10.1016/j.ydbio.2013.08.025

22. Zhang YH, Cheng F, Du XT, Gao JL, Xiao XL, Li N, et al. GDF11/BMP11 activates both smad1/5/8 and smad2/3 signals but shows no significant effect on proliferation and migration of human umbilical vein endothelial cells. Oncotarget. (2016) 7:12063-74. doi: 10.18632/oncotarget.10664 
23. Bajikar SS, Wang CC, Borten MA, Pereira EJ, Atkins KA, Janes KA. Tumorsuppressor inactivation of GDF11 occurs by precursor sequestration in triple-negative breast cancer. Dev Cell. (2017) 43:418-35 e13. doi: 10.1016/j.devcel.2017.10.027

24. Hata A, Chen YG. TGF-beta signaling from receptors to smads. Cold Spring Harb Perspect Biol. (2016) 8:a022061. doi: 10.1101/cshperspect.a022061

25. Wang Z, Dou M, Liu F, Jiang P, Ye S, Ma L, et al. GDF11 induces differentiation and apoptosis and inhibits migration of C17.2 neural stem cells via modulating MAPK signaling pathway. PeerJ. (2018) 6:e5524. doi: $10.7717 /$ peerj. 5524

26. Demontis F, Patel VK, Swindell WR, Perrimon N. Intertissue control of the nucleolus via a myokine-dependent longevity pathway. Cell Rep. (2014) 7:1481-94. doi: 10.1016/j.celrep.2014.05.001

27. Mei W, Xiang G, Li Y, Li H, Xiang L, Lu J, et al. GDF11 protects against endothelial injury and reduces atherosclerotic lesion formation in apolipoprotein e-null mice. Mol Ther. (2016) 24:1926-38. doi: $10.1038 / \mathrm{mt} .2016 .160$

28. van Wijk B, Moorman AF, van den Hoff MJ. Role of bone morphogenetic proteins in cardiac differentiation. Cardiovasc Res. (2007) 74:244-55. doi: 10.1016/j.cardiores.2006.11.022

29. Hammers DW, Merscham-Banda M, Hsiao JY, Engst S, Hartman JJ, Sweeney HL. Supraphysiological levels of GDF11 induce striated muscle atrophy. EMBO Mol Med. (2017) 9:531-44. doi: 10.15252/emmm. 201607231

30. Hindi SM, Sato S, Xiong G, Bohnert KR, Gibb AA, Gallot YS, et al. TAK1 regulates skeletal muscle mass and mitochondrial function. JCI Insight. (2018) 3:98441. doi: 10.1172/jci.insight.98441

31. Mihaly SR, Ninomiya-Tsuji J, Morioka S. TAK1 control of cell death. Cell Death Differ. (2014) 21:1667-76. doi: 10.1038/cdd.2014.123

32. Wang C, Deng L, Hong M, Akkaraju GR, Inoue J, Chen ZJ. TAK1 is a ubiquitin-dependent kinase of MKK and IKK. Nature. (2001) 412:346-51. doi: $10.1038 / 35085597$

33. Fife E, Kostka J, Kroc L, Guligowska A, Piglowska M, Soltysik B, et al. Relationship of muscle function to circulating myostatin, follistatin and GDF11 in older women and men. BMC Geriatr. (2018) 18:200. doi: 10.1186/s12877-018-0888-y

34. Schneyer AL, Sidis Y, Gulati A, Sun JL, Keutmann H, Krasney PA. Differential antagonism of activin, myostatin and growth and differentiation factor 11 by wild-type and mutant follistatin. Endocrinology. (2008) 149:4589-95. doi: 10.1210/en.2008-0259

35. Lee YS, Lee SJ. Regulation of GDF-11 and myostatin activity by GASP-1 and GASP-2. Proc Natl Acad Sci USA. (2013) 110:E3713-22. doi: 10.1073/pnas.1309907110

36. Gamer LW, Cox KA, Small C, Rosen V. Gdf11 is a negative regulator of chondrogenesis and myogenesis in the developing chick limb. Dev Biol. (2001) 229:407-20. doi: 10.1006/dbio.2000.9981

37. Smart NG, Apelqvist AA, Gu X, Harmon EB, Topper JN, MacDonald RJ, et al. Conditional expression of Smad7 in pancreatic beta cells disrupts TGF-beta signaling and induces reversible diabetes mellitus. PLoS Biol. (2006) 4:e39. doi: 10.1371/journal.pbio.0040039

38. Walker RG, Czepnik M, Goebel EJ, McCoy JC, Vujic A, Cho M, et al. Structural basis for potency differences between GDF8 and GDF11. BMC Biol. (2017) 15:19. doi: 10.1186/s12915-017-0350-1

39. Egerman MA, Cadena SM, Gilbert JA, Meyer A, Nelson HN, Swalley SE, et al. GDF11 increases with age and inhibits skeletal muscle regeneration. Cell Metab. (2015) 22:164-74. doi: 10.1016/j.cmet.2015.05.010

40. Glass DJ. Elevated GDF11 is a risk factor for age-related frailty and disease in humans. Cell Metab. (2016) 24:7-8. doi: 10.1016/j.cmet.2016.06.017

41. Zhao L, Zhang S, Cui J, Huang W, Wang J, Su F, et al. TERT assists GDF11 to rejuvenate senescent VEGFR2(+)/CD133(+) cells in elderly patients with myocardial infarction. Lab Invest. (2019). doi: 10.1038/s41374-019-0290-1. [Epub ahead of print].

42. Egerman MA, Glass DJ. The role of GDF11 in aging and skeletal muscle, cardiac and bone homeostasis. Crit Rev Biochem Mol Biol. (2019) 54:174-83. doi: 10.1080/10409238.2019.1610722

43. Fan X, Gaur U, Sun L, Yang D, Yang M. The growth differentiation factor 11 (GDF11) and myostatin (MSTN) in tissue specific aging. Mech Ageing Dev. (2017) 164:108-12. doi: 10.1016/j.mad.2017.04.009
44. Gokoffski KK, Wu HH, Beites CL, Kim J, Kim EJ, Matzuk MM, et al. Activin and GDF11 collaborate in feedback control of neuroepithelial stem cell proliferation and fate. Development. (2011) 138:4131-42. doi: 10.1242/dev.065870

45. Zhang Y, Wei Y, Liu D, Liu F, Li X, Pan L, et al. Role of growth differentiation factor 11 in development, physiology and disease. Oncotarget. (2017) 8:8160416. doi: 10.18632/oncotarget.20258

46. Gad JM, Tam PP. Axis development: the mouse becomes a dachshund. Curr Biol. (1999) 9:R783-6. doi: 10.1016/S0960-9822(00)80013-5

47. Padyana AK, Vaidialingam B, Hayes DB, Gupta P, Franti M, Farrow NA. Crystal structure of human GDF11. Acta Crystallogr F Struct Biol Commun. (2016) 72:160-4. doi: 10.1107/S2053230X16001588

48. Jones JE, Cadena SM, Gong C, Wang X, Chen Z, Wang SX, et al. Supraphysiologic administration of GDF11 induces cachexia in part by upregulating GDF15. Cell Rep. (2018) 22:1522-30. doi: 10.1016/j.celrep.2018.01.044

49. Zimmers TA, Jiang Y, Wang M, Liang TW, Rupert JE, Au ED, et al. Exogenous GDF11 induces cardiac and skeletal muscle dysfunction and wasting. Basic Res Cardiol. (2017) 112:48. doi: 10.1007/s00395-017-0642-1

50. Hinken AC, Powers JM, Luo G, Holt JA, Billin AN, Russell AJ. Lack of evidence for GDF11 as a rejuvenator of aged skeletal muscle satellite cells. Aging Cell. (2016) 15:582-4. doi: 10.1111/acel.12475

51. McPherron AC, Lee SJ. Double muscling in cattle due to mutations in the myostatin gene. Proc Natl Acad Sci USA. (1997) 94:12457-61. doi: 10.1073/pnas.94.23.12457

52. Walker RG, McCoy JC, Czepnik M, Mills MJ, Hagg A, Walton KL, et al. Molecular characterization of latent GDF8 reveals mechanisms of activation. Proc Natl Acad Sci USA. (2018) 115:E866-75. doi: 10.1073/pnas.1714622115

53. Goebel EJ, Corpina RA, Hinck CS, Czepnik M, Castonguay R, Grenha R, et al. Structural characterization of an activin class ternary receptor complex reveals a third paradigm for receptor specificity. Proc Natl Acad Sci USA. (2019) 116:15505-13. doi: 10.1073/pnas.1906253116

54. Cash JN, Angerman EB, Kattamuri C, Nolan K, Zhao H, Sidis Y, et al. Structure of myostatin.follistatin-like 3: N-terminal domains of follistatintype molecules exhibit alternate modes of binding. J Biol Chem. (2012) 287:1043-53. doi: 10.1074/jbc.M111.270801

55. Cash JN, Rejon CA, McPherron AC, Bernard DJ, Thompson TB. The structure of myostatin:follistatin 288: insights into receptor utilization and heparin binding. EMBO J. (2009) 28:2662-76. doi: 10.1038/emboj.2009.205

56. Yokoe $\mathrm{T}$, Ohmachi $\mathrm{T}$, Inoue $\mathrm{H}$, Mimori $\mathrm{K}$, Tanaka $\mathrm{F}$, Kusunoki M, et al. Clinical significance of growth differentiation factor 11 in colorectal cancer. Int J Oncol. (2007) 31:1097-101. doi: 10.3892/ijo.31.5.1097

57. Qin X, Kuang H, Chen L, Wei S, Yu D, Liang F. Coexpression of growth differentiation factor 11 and reactive oxygen species in metastatic oral cancer and its role in inducing the epithelial to mesenchymal transition. Oral Surg Oral Med Oral Pathol Oral Radiol. (2017) 123:697-706. doi: 10.1016/j.oooo.2017.03.010

58. Farooq M, Sulochana KN, Pan X, To J, Sheng D, Gong Z, et al. Histone deacetylase 3 (hdac3) is specifically required for liver development in zebrafish. Dev Biol. (2008) 317:336-53. doi: 10.1016/j.ydbio.2008. 02.034

59. Lazzarini-Lechuga $\mathrm{R}$, Alcantar-Ramirez O, Jaime-Cruz R, GómezQuiroz L. Efecto teratogénico de nanopartículas de oro de $20 \mathrm{~nm}$ durante la septación cardiaca. Mundo Nano. (2014) 7:69-77. doi: 10.22201/ceiich.24485691e.2014.13.48710

60. Zhang YH, Pan LH, Pang Y, Yang JX, Lv MJ, Liu F, et al. GDF11/BMP11 as a novel tumor marker for liver cancer. Exp Ther Med. (2018) 15:3495-500. doi: 10.3892/etm.2018.5861

61. Su LK, Kinzler KW, Vogelstein B, Preisinger AC, Moser AR, Luongo C, et al. Multiple intestinal neoplasia caused by a mutation in the murine homolog of the APC gene. Science. (1992) 256:668-70. doi: 10.1126/science.1350108

62. Sun X, Essalmani R, Seidah NG, Prat A. The proprotein convertase PC5/6 is protective against intestinal tumorigenesis: in vivo mouse model. Mol Cancer. (2009) 8:73. doi: 10.1186/1476-4598-8-73

63. Wallner C, Drysch M, Becerikli M, Jaurich H, Wagner JM, Dittfeld $\mathrm{S}$, et al. Interaction with the GDF8/11 pathway reveals treatment options for adenocarcinoma of the breast. Breast. (2018) 37:134-41. doi: 10.1016/j.breast.2017.11.010 
64. Jemal A, Ward EM, Johnson CJ, Cronin KA, Ma J, Ryerson B, et al. Annual report to the nation on the status of cancer, 1975-2014, featuring survival. $J$ Natl Cancer Inst. (2017) 109:djx030. doi: 10.1093/jnci/djx030

65. Liu Y, Shao L, Chen K, Wang Z, Wang J, Jing W, et al. GDF11 restrains tumor growth by promoting apoptosis in pancreatic cancer. Onco Targets Ther. (2018) 11:8371-9. doi: 10.2147/OTT.S181792

66. Hogendorf P, Durczynski A, Skulimowski A, Kumor A, Poznanska G, Strzelczyk J. Growth differentiation factor (GDF-15) concentration combined with Ca125 levels in serum is superior to commonly used cancer biomarkers in differentiation of pancreatic mass. Cancer Biomark. (2018) 21:505-11. doi: $10.3233 / \mathrm{CBM}-170203$

67. Dichmann DS, Yassin H, Serup P. Analysis of pancreatic endocrine development in GDF11-deficient mice. Dev Dyn. (2006) 235:3016-25. doi: 10.1002/dvdy.20953

68. Harmon EB, Apelqvist AA, Smart NG, Gu X, Osborne DH, Kim SK. GDF11 modulates NGN3+ islet progenitor cell number and promotes beta-cell differentiation in pancreas development. Development. (2004) 131:6163-74. doi: 10.1242/dev.01535

69. Barresi V, Reggiani-Bonetti L, Di Gregorio C, De Leon MP, Barresi G. Lymphatic vessel density and its prognostic value in stage I colorectal carcinoma. J Clin Pathol. (2011) 64:6-12. doi: 10.1136/jcp.2010. 083550

70. Ungaro F, Colombo P, Massimino L, Ugolini GS, Correale C, Rasponi M, et al. Lymphatic endothelium contributes to colorectal cancer growth via the soluble matrisome component GDF11. Int J Cancer. (2019) 145:1913-20. doi: 10.1002/ijc.32286

71. Liu X, Zhang Q, Fan C, Tian J, Liu X, Li G. GDF11 upregulation independently predicts shorter overall-survival of uveal melanoma. PLoS ONE. (2019) 14:e0214073. doi: 10.1371/journal.pone.0214073

72. Gao J, Aksoy BA, Dogrusoz U, Dresdner G, Gross B, Sumer SO, et al. Integrative analysis of complex cancer genomics and clinical profiles using the cBioPortal. Sci Signal. (2013) 6:pl1. doi: 10.1126/scisignal.2004088

73. Anon-Hidalgo J, Catalan V, Rodriguez A, Ramirez B, Idoate-Bayon A, Silva C, et al. Circulating concentrations of GDF11 are positively associated with TSH levels in humans. J Clin Med. (2019) 8:E878. doi: 10.3390/jcm8060878

74. Zamani N, Brown CW. Emerging roles for the transforming growth factor\{beta\} superfamily in regulating adiposity and energy expenditure. Endocr Rev. (2011) 32:387-403. doi: 10.1210/er.2010-0018

75. Hsu JY, Crawley S, Chen M, Ayupova DA, Lindhout DA, Higbee J, et al. Nonhomeostatic body weight regulation through a brainstem-restricted receptor for GDF15. Nature. (2017) 550:255-9. doi: 10.1038/nature24042
76. Luo H, Guo Y, Liu Y, Wang Y, Zheng R, Ban Y, et al. Growth differentiation factor 11 inhibits adipogenic differentiation by activating TGFbeta/Smad signalling pathway. Cell Prolif. (2019) 52:e12631. doi: 10.1111/cpr. 12631

77. Jing YY, Li D, Wu F, Gong LL, Li R. GDF11 does not improve the palmitate induced insulin resistance in C2C12. Eur Rev Med Pharmacol Sci. (2017) 21:1795-802.

78. Dominguez-Perez M, Simoni-Nieves A, Rosales P, Nuno-Lambarri N, RosasLemus M, Souza V, et al. Cholesterol burden in the liver induces mitochondrial dynamic changes and resistance to apoptosis. J Cell Physiol. (2019) 234:721323. doi: $10.1002 /$ jcp. 27474

79. Calvisi DF, Wang C, Ho C, Ladu S, Lee SA, Mattu S, et al. Increased lipogenesis, induced by AKT-mTORC1-RPS6 signaling, promotes development of human hepatocellular carcinoma. Gastroenterology. (2011) 140:1071-83. doi: 10.1053/j.gastro.2010.12.006

80. Porporato PE, Filigheddu N, Pedro JMB, Kroemer G, Galluzzi L. Mitochondrial metabolism and cancer. Cell Res. (2018) 28:265-80. doi: $10.1038 /$ cr.2017.155

81. Hernandez-Rizo S, Gerardo-Ramirez M, Fucho R, Perez-Aguilar B, Gomez-Quiroz LE, Fernandez-Checa JC, et al. Growth differentiation factor 11 (GDF11) restricts cell proliferation in hepatic tumor cells through glycolysis and lipid metabolism. Ann Hepatol. (2018) 17:683. doi: 10.5604/01.3001.0012.0962

82. Garrido-Moreno V, Diaz-Vegas A, Lopez-Crisosto C, Troncoso MF, Navarro-Marquez M, Garcia L, et al. GDF-11 prevents cardiomyocyte hypertrophy by maintaining the sarcoplasmic reticulum-mitochondria communication. Pharmacol Res. (2019) 146:104273. doi: 10.1016/j.phrs.2019. 104273

Conflict of Interest: The authors declare that the research was conducted in the absence of any commercial or financial relationships that could be construed as a potential conflict of interest.

Copyright (c) 2019 Simoni-Nieves, Gerardo-Ramírez, Pedraza-Vázquez, ChávezRodríguez, Bucio, Souza, Miranda-Labra, Gomez-Quiroz and Gutiérrez-Ruiz. This is an open-access article distributed under the terms of the Creative Commons Attribution License (CC BY). The use, distribution or reproduction in other forums is permitted, provided the original author(s) and the copyright owner(s) are credited and that the original publication in this journal is cited, in accordance with accepted academic practice. No use, distribution or reproduction is permitted which does not comply with these terms. 

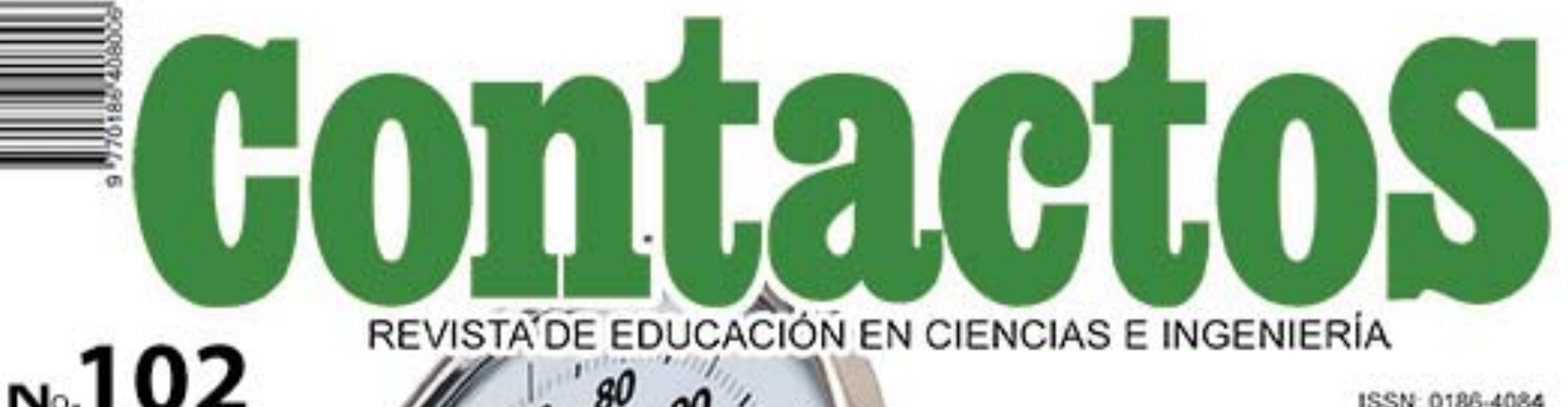

№.102
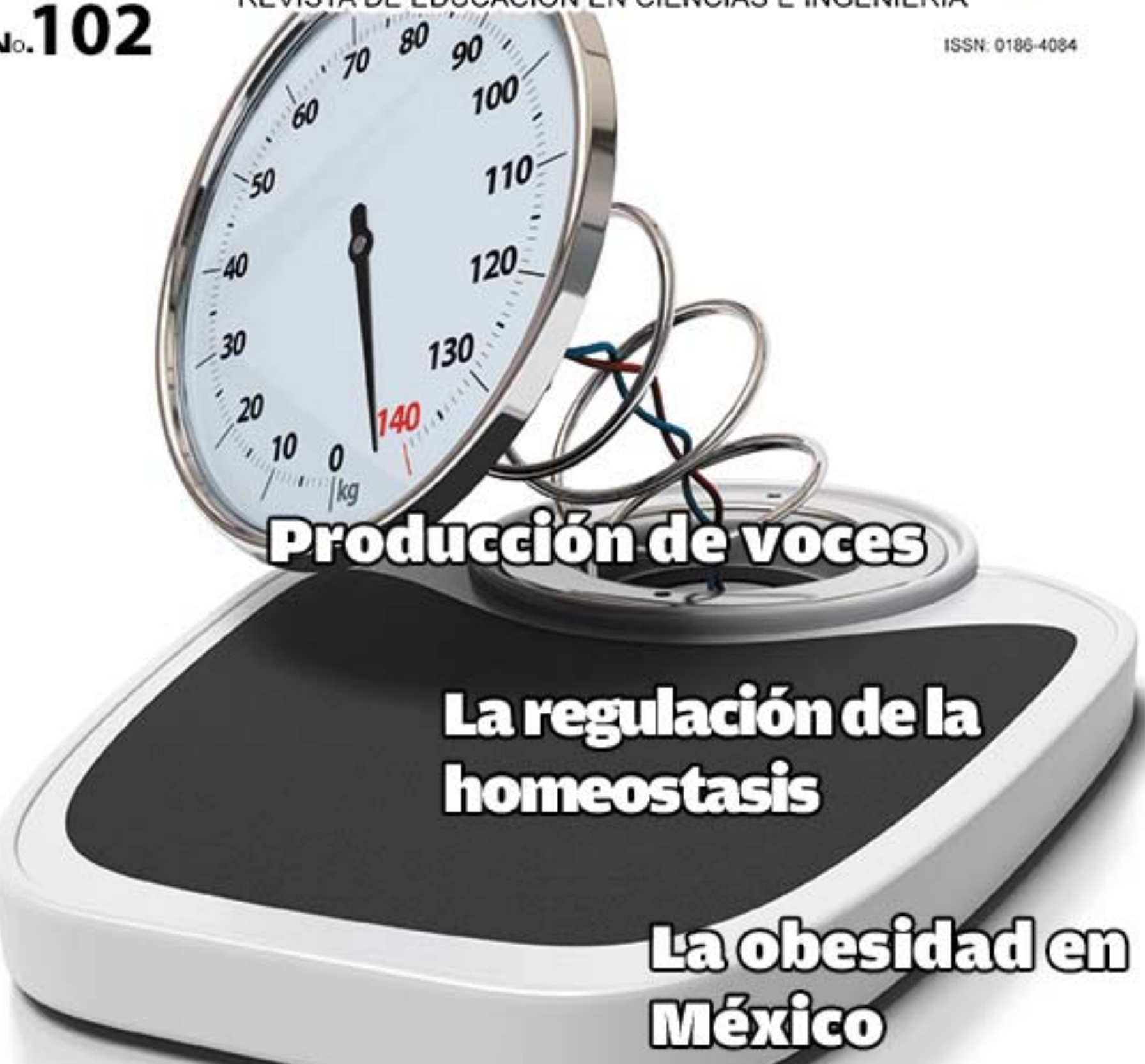


\section{Contenido}

\section{ContactoS No. 102, Octubre-Diciembre 2016}

\author{
Editorial

Ediorial \\ La homeostasis lipfdica en la progresión del \\ cincer hepático \\ Monserrat Gererdo-Ramirez \\ Benjamin Pérez-Aguilar \\ Mería Concepción \\ Gutiérrez-Ruiz \\ Luis Enrique Gómen-Quiroz* \\ Sistema de rastreo por Geolocalización con \\ base en un Microcontrolador y GoogleMaps \\ Jorge López Ortega \\ Julién López Mertínez \\ Gabriel Eduardo Gercie Rojas
}

Obesidad y Sobrepeso en Mérico

Alma E. Martinez Licona

Benjamin Benlenga Magaña
5

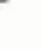

Marvin Coto-Jiménea

John Godderd-Cloee

Fabiole M. Martinea-Lioona

DE VIANDAS Y BREBAJES

La cocina griega

Elancio "Kaneho" Almasara

14

Chef pragmátioo

Los Codices Mayas

53

34

42

21 Rubén Tello Herzera

ContactoS en la WEB

Lea los artículos publicadoe en ContactoS en

http://www.izt.uam.mx/contactoe 


\author{
casa abierta al tiempo \\ ÍNDICE DE REVISTAS MEXICANAS \\ CONACY DEDIVULCACIÓN CIENTIFIICAY YECNOLÓGICA \\ Rector General \\ Dr. Salvador Vega y León. \\ Secretario General \\ Mtro. Norberto Manjarez Álvarez. \\ UNIDAD IZTAPALAPA \\ Rector \\ Dr. José Octavio Nateras Domínguez. \\ Secretario \\ Dr. Miguel Ángel Gómez Fonseca. \\ Director de la División de Ciencias Básicas \\ e Ingeniería \\ Dr. Gilberto Córdoba Herrera. \\ Directora de la División de Ciencias Biológicas y \\ de la Salud \\ Dra. Edith Ponce Alquicira. \\ ContactoS: \\ Consejo Editorial: Dr. José Antonio Nateras \\ Domínguez Dr. Miguel Ángel Gómez Fonseca, \\ Dr. Gilberto Córdoba Herrera, Dra. Edith Ponce \\ Alquicira \\ UAM-Iztapalapa \\ Editor en jefe: MC. Alma Edith Martínez Licona. \\ Comité Editorial por CBS: \\ Dra. Edith Arenas Ríos, Dra. Laura Josefina \\ Pérez Flores, Dr. Pedro Luis Valverde Padilla, \\ Por CBI: \\ Dr. Hugo Ávila Paredes, \\ Por la Universidad Iberoamericana Mtro. Adolfo \\ G. Fink-Pastrana.
}

Contactos REVISTA DE EDUCACIÓN EN CIENCIAS E INGENIERÍA 3a. Época, No. 102, Octubre-Diciembre 2016, es una publicación trimestral, editada por la Univesidad Autónoma Metropolitana a través de la unidad Iztapalapa, División de Ciencias Básicas e Ingeniería y División de Ciencias Biológicas y de la Salud. Prolongación Canal de Miramontes 3855, Col. Ex-Hacienda San Juan de Dios, Delegación Tlalpan, C.P. 14387, México, D.F. y Av. San Rafael Atlixco No. 186, Edificio E-317, Colonia Vicentina, Delegación Iztapalapa, C.P. 09340, México, D.F., Tel. 5804-4606. Página Web de la revista: http://www.izt.uam.mx/contactos y correo electrónico: cts@xanum.uam.mx: Editora responsable MC. Alma Edith Martínez Licona, Certificado de Reserva de Derechos al Uso Exclusivo de Título No. 04-2013-042212044000203, ISSN en trámite, ambos otorgados por el Insituto Nacional del Derecho de Autor. Responsable de la última actualización de este número, Mtra. Alma E. Martinez Licona; Unidad Iztapalapa, División de CBI y CBS; fecha de última modificación: 25 de Agosto de 2017. Tamaño de archivo 7.3 MB.

Los artículos publicados en ContactoS son sometidos a arbitraje; para ello se requiere enviar el original del trabajo en algún procesador de texto a doble espacio, dos copias claras del mismo y un archivo del artículo. Toda correspondencia deberá enviarse a:

\author{
Comité Editorial de la Revista ContactoS, \\ UAM-Iztapalapa, E-317, Tel/Fax. 5804-4606 \\ Av. San Rafael Atlixco No. 186, C.P. 09340, México, D.F. \\ apartado postal 55-534 \\ http://www.izt.uam.mx e-mail cts@xanum.uam.mx
}

Para suscripciones enviar cheque o giro postal a nombre de: Universidad Autónoma Metropolitana, indicando claramente; nombre, dirección y números que comprende la suscripción. suscripción anual (4 números) \$ 80.00 M.N. En el extranjero 60 Dls. U.S., a partir de 1995. 
La homeostasis lipídica en la progresión del cáncer hepático

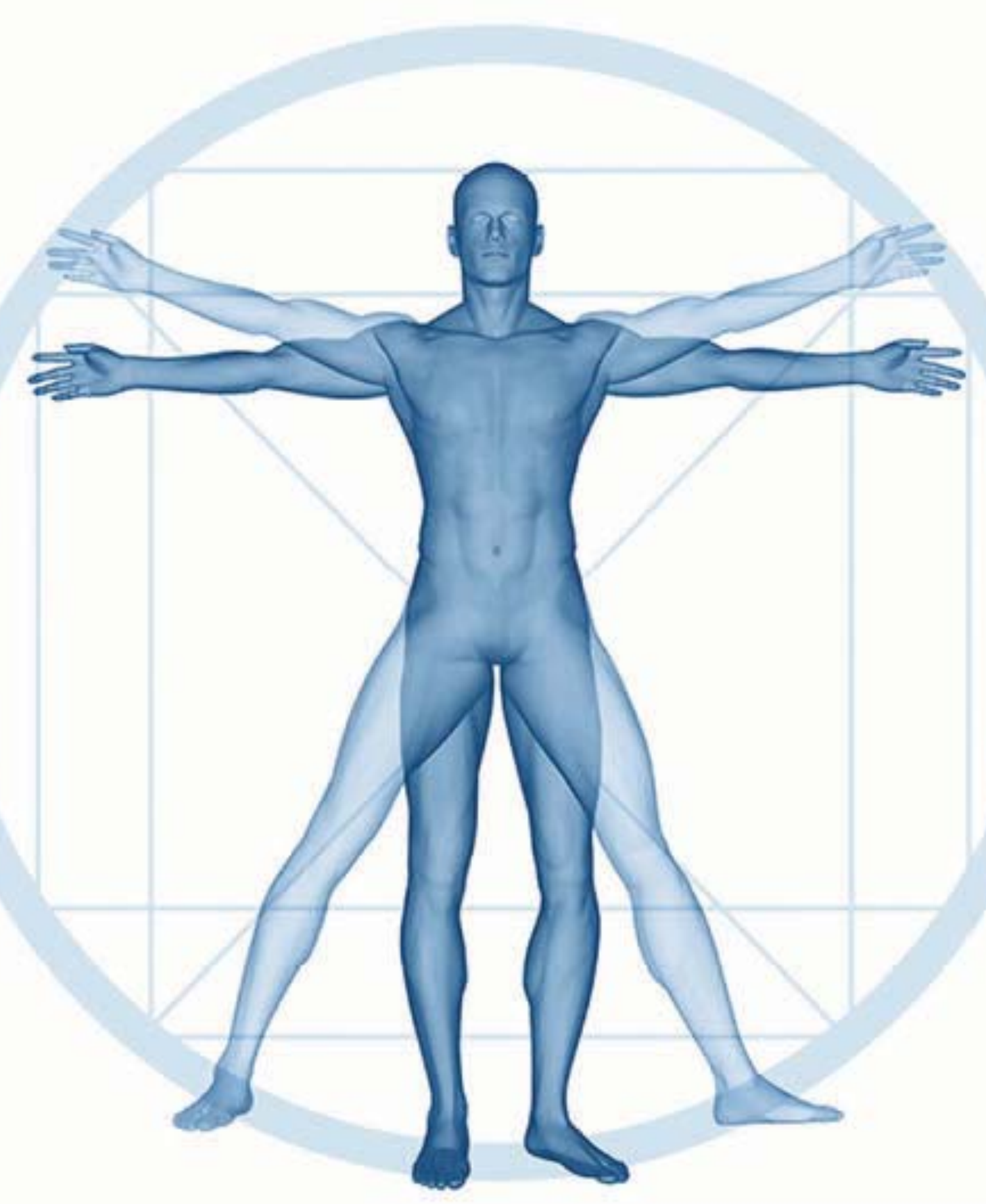

Monserrat Gerardo-Ramirez, Benjamin Pérez-Aguilar, Maria Concepción Gutiérrez-Ruiz, Luis Enrique Gómez-Quiroz Laboratorio de Fisiología Celular, Departamento de Ciencias de la Salud, UAM Iztapalapa. 
Resumen

El carcinoma hepatocelular (HCC) se está posicionando como un serio problema de salud pública tanto en México, como a nivel mundial. Estos tumores hepáticos suelen ser muy agresivos y de mal pronóstico, y su detección en etapas tempranas sigue siendo un reto para los clínicos. En gran medida las características agresivas de las células de los HCC están gobernadas por la disponibilidad en combustibles e intermediarios estructurales que le permitan a la célula cancerosa tener ventajas con respecto al resto del tejido. La homeostasis de lípidos ha sido identificada como un factor relevante para la sobrevivencia, proliferación y resistencia a fármacos, por lo que nuevos blancos terapéuticos pueden ser identificados en las rutas de señalización y metabólicas, claves de la homeostasis lipidica.

\begin{abstract}
Hepatocellular carcinoma (HCC) is has been positioning as a key public health problem in Mexico and worldwide. This tumors use to present and aggressive phenotype and patients use to have poor prognosis, the early diagnosis continues as a big challenge for clinicians. The aggressive phenotype is driven by the energy and molecular intermediaries' availability conferring to cancer cells advantages regarding non transformed cells. Lipid homeostasis has been identified as a key hallmark for survival, proliferation and drug resistance for cancer cells, new therapeutic targets could be identified in the signal transductions and metabolic pathways related to lipogenesis.
\end{abstract}

\section{Palabras clave. Cáncer, Lípidos, Ácidos grasos, Colesterol}

Keywords. Cancer, lipids, free fatty acids, cholesterol

\section{Introducción}

El cáncer es un grupo de más de cien enfermedades caracterizadas por la presencia de células con desórdenes proliferativos, con una alta capacidad de sobrevivencia, de adaptación y de autonomía, que le permite escapar de cualquier tipo de control que pueda ejercer el sistema (Perez-Aguilar et al., 2015).

Entre los cánceres que más preocupan y ocupan a los sistemas de salud en el mundo se encuentra el cáncer de hígado, el HCC actualmente representa el quinto lugar de muertes a nivel internacional (Bruix et al., 2004). En gran medida el HCC representa un reto debido a su diagnóstico tardio que genera la pérdida de opciones quirúrgicas, ocasionando su alta mortalidad.

Por lo anterior es fundamental la búsqueda de nuevas opciones terapéuticas que tiendan a su control, por lo que el conocimiento de los procesos moleculares que permiten la adaptación y sobrevivencia de la célula cancerosa pueden representar posibles blancos de intervención terapéutica.

La célula cancerosa representa el mejor ejemplo de adaptación biológica, sin duda Darwin estaría orgulloso de ello. La adaptación le permite sobrevivir ante constantes agresiones llevadas a cabo por el propio sistema, así como por las terapias encaminadas a su eliminación. Para lograrlo; resulta fundamental tener buenas reservas de energia que puedan ser movilizadas rápidamente, con buen rendimiento $\mathrm{y}$ con relativa facilidad. Con base a lo anterior, los lípidos representan una de las mejores opciones que tiene la celula transformada para sobrevivir.

La regulación de la ruta de sintesis de novo de los ácidos grasos y colesterol, tanto a nivel de expresión de los genes relacionados con ella, su actividad enzimática, asi como de las rutas de 
señalización que los controlan, se posicionan como ejes importantes para el escape de la célula cancerosa de los mecanismos que tienden a eliminarlas, por lo que hasta cierto punto, muchas proteínas relacionadas con la homeostasis lipídica se ubican ya como genes promotores de tumores $y$, en cierta forma, como potenciales blancos de terapias dirigidas a controlar a este grupo de enfermedades.

La presente revisión pretende exponer los aspectos generales de la regulación en la sintesis y degradación de lípidos, así como su metabolismo y su papel en la progresión del $\mathrm{HCC}$.

\section{El contexto bioquimico}

En condiciones normales una célula cubre sus requerimientos energéticos con procesos metabólicos bien definidos, es decir, tiende a ocupar su energía oxidando moléculas simples, empezando por el mismo ATP, y pasando por varios intermedianos hidrocarbonados, como es el caso de la glucosa, hasta llegar a los ácidos grasos y, eventualmente, proteinas.

Las células, particularmente las hepáticas, almacenan la energía excedente como triglicéridos, si bien los hepatocitos no son células especializadas para tal función, lo hacen de manera importante, y la pérdida de esta regulación puede conducir al órgano a la enfermedad por una acumulación excesiva de lípidos, patología conocida como esteatosis (Gutierrez Ruiz et al., 2012).

Sin lugar a dudas, la molécula más importante para el control de lo anteriormente expuesto es el acetil coenzima A ( $\mathrm{Ac}-\mathrm{Co} \mathrm{A}$ ), que es el intermediario bioquímico central en varios procesos tanto catabólicos como anabólicos.

El Ac-CoA es generado, de manera canónica, a partir de piruvato, que a su vez, proviene de la glicólisis, o ruta de oxidación de la glucosa, sin embargo no es la úmica fuente, y este puede ser generado por otras vías (Shi et al., 2015), por lo que Ac-CoA se posiciona como la molécula central en el metabolismo celular (Figura 1). Posteriormente la molécula puede tomar diversos caminos que van desde su completa oxidación, en el ciclo de los ácidos tricarboxilicos o ciclo de Krebs, hasta su uso como precursor en la sintesis de lípidos, desde ácidos grasos, hasta colesterol o residuos hidrofóbicos fundamentales para la función celular como el ácido prenilico, que es fundamental para el correcto funcionamiento de proteinas relacionadas con la proliferación celular como la proteina Ras.

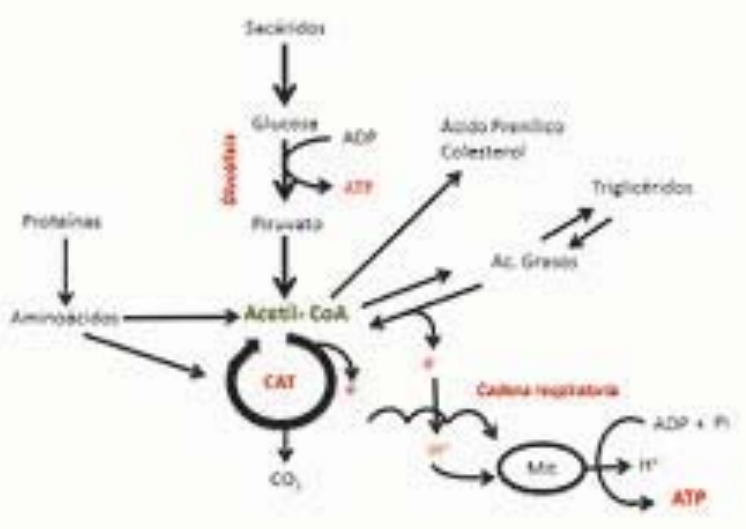

En condiciones normales el Ac-CoA es producido, segín el caso, por la ATP-citrato liasa o por la Acetil-CoA sintasa.

Los niveles elevados de Ac-CoA estimula la activación de dos factores de transcripción conocidos como proteína de unión a los elementos de respuesta a esteroles (SREBP) el 1 y el 2 (Xu et al., 2013).

Estos factores de transcripción regulan la expresión de varios genes relacionados con la biosintesis de lípidos. SREBP1 está relacionado con la biosintesis de ácidos grasos, triglicéridos 
y fosfolipidos, mientras que SREBP2 con la síntesis de colesterol y otros intermediarios derivados de la ruta del mevalonato (Figura 2).

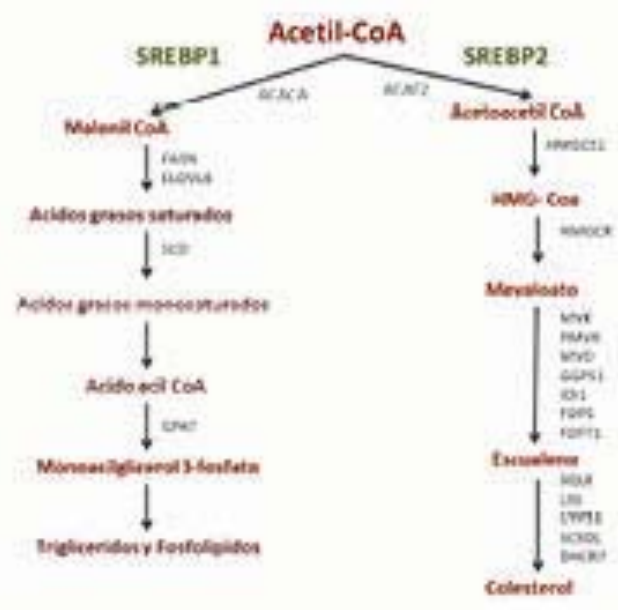

\section{La ruta del mevalonato}

SREBP2 regula genes relacionados con la biosintesis del colesterol, entre ellos están los que codifican para la hidroxi-metil-glutarilCoA reductasa (HMG-CoAR), la mevalonato cinasa (MVK), la escualeno sintasa (SQS), entre otras, que eventualmente y por sus reacciones secuenciales y acopladas, permiten la sintesis del colesterol (Ikonen, 2008).

LA HMG-CoAR es la enzima limitante en la ruta, dirigiendo el paso de su sustrato HMG$\mathrm{CoA}$ a mevalonato en un proceso facilitado por el consumo de NADPH, por lo que el acoplamiento de otras rutas como la de las pentosas fosfato resulta fundamental para que el proceso de sintesis progrese, ya que es en ésta donde se produce éste poder reductor necesario para el proceso (Figura 3).

El colesterol es un lípido fundamental para el buen funcionamiento de la cellula, es requerido para una correcta fluidez de la membrana plasmática, además regula la función de las balsas lipídicas que permiten la adecuada función de los receptores membranales; es el precursor de varias hormonas, sales biliares, entre otras funciones. Si bien el colesterol resulta fundamental para la homeostasis celular, su incremento, particularmente en la mitocondria, genera un mal funcionamiento celular que conduce al estrés oxidante y a la sensibilización a la apoptosis mediada por factores citotóxicos como el factor de necrosis tumoral (TNF) alfa (Mari et al., 2006).

El colesterol no es un lipido del cual se disponga para la obtención de energía, si no para aspectos estructurales y funcionales como se ha mencionado.

\section{Los ácidos grasos y los lípidos neutros.}

Esta ruta estáregulada, en términos de expresión, por el factor de transcripción SREBP1. Sus principales genes blanco son aquellos que codifican para la ácido graso sintasa (FASN), la adenosina trifosfato liasa (ACLY), la acetil CoA carboxilasa (ACAC), la esteroil-CoA desaturasa (SCD) entre otras. Las enzimas reguladas por SREBP1 están implicadas en procesos como la sintesis de ácidos grasos, la formación de lípidos neutros como los triglicéridos (TG), o lípidos especializados como los fosfolípidos. En el proceso bioquímico se requiere también de poder reductor en su forma de NADPH.

Como se ha mencionado el NADPH proviene de rutas como la de las pentosas fosfato, en una reacción catalizada por la glucosa 6 fosfato deshidrogenasa, pero también puede ser generado por la enzima málica y la 6-fosfogluconato deshidrogenasa.

A diferencia del colesterol, como es bien sabido, los ácidos grasos y su presentación esterificada en forma de TG, tiene como finalidad central el aporte energético, ya que su oxidación produce una buena cantidad de ATP al regresar a su intermediario biosintético, el Ac-CoA, a las rutas de oxidación que culminan en el ciclo de los ácidos tricarboxilicos y en la cadena 
respiratoria donde se oxida el NADH y el

$\mathrm{FADH}_{2}$ que provee la succinato deshidrogenasa

(Figura 1) (Gutiérrez-Ruiz et al., 2013)
Si bien es sabido que muchas células cancerosas impiden el funcionamiento mitocondrial, y

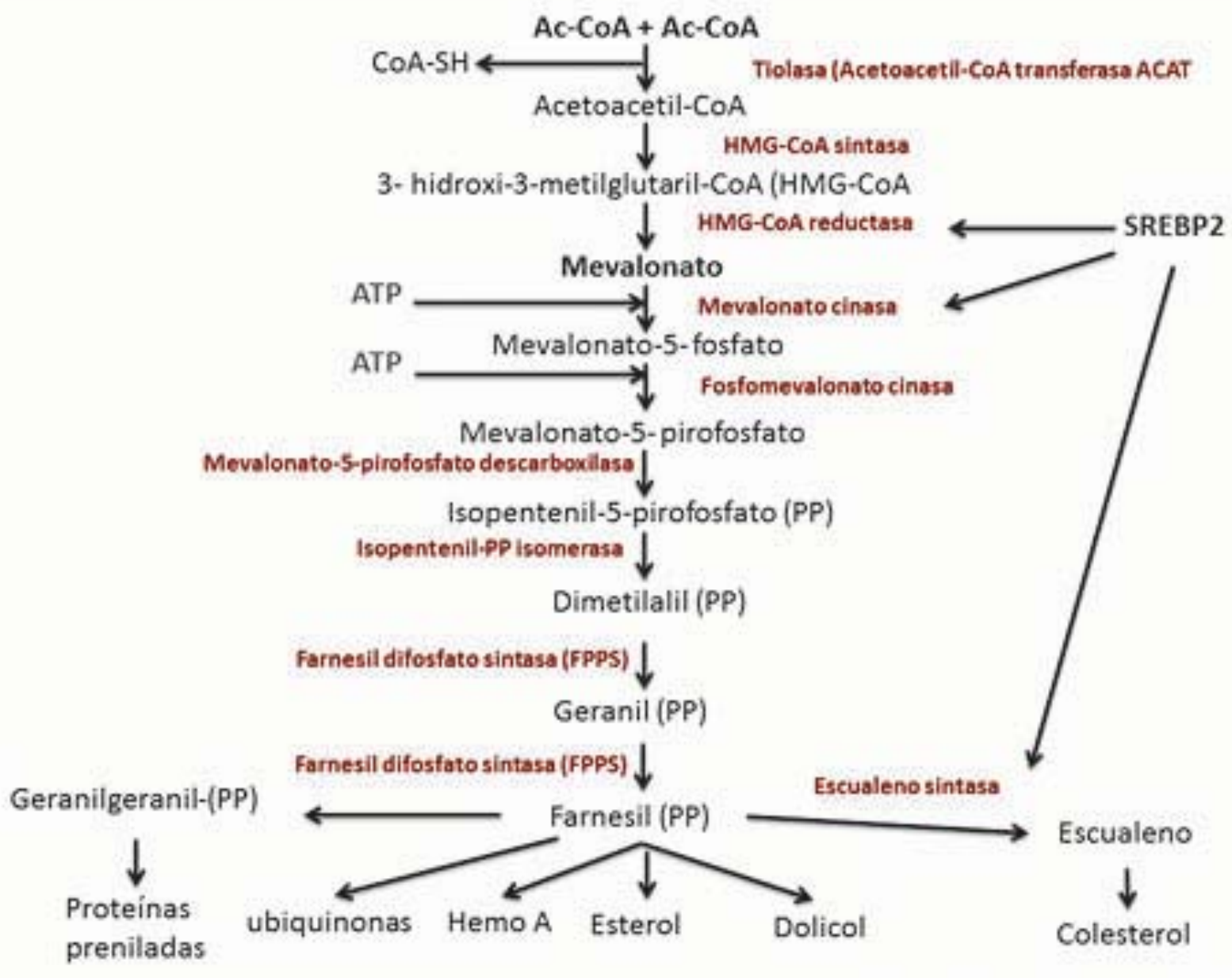

Funcionalidad mitocondrial y la oxidación de los ácidos grasos

En gran medida la oxidación de los ácidos grasos representa la principal fuente de energia para la célula. Si bien existen varias formas de llevar a cabo el proceso la más importante es la oxidación beta en la mitocondria, donde el ácido graso en su forma conjugada con la CoA ingresa a una secuencia de reacciones acopladas que producen $\mathrm{NADH}+\mathrm{H}$ y $\mathrm{FADH}_{2}$ que son procesados en la cadena respiratoria donde eventualmente producen fuerza protón motriz que es usada por el complejo $\mathrm{V}$ para producir el ATP. pasan a ser más dependientes de la glucólisis que de la mitocondria para la obtención de ATP, se sabe también que en algunos casos, como en el higado, las células cancerosas pueden ubicar a la ATP sintasa en la membrana plasmática, representando una excelente estrategia para evadir el impedimento mitocondrial (Ma et al., 2010).

La sobrecarga de colesterol en la mitocondria, mediado por el incremento en la sintesis de novo de dicho lípido, pareciera ser uno de los mecanismos para inducir disrupción mitocondrial (Morales et al., 2012), siendo uno de sus objetivos evitar la salida al citoplasma del citocromo $\mathrm{C}$, uno de los principales inductores 
de apoptosis, pero teniendo como consecuencia la pérdida de la función oxidante de los lípidos. El regulador maestro de las rutas de degradación de ácidos grasos es la proteína cinasa activada por AMP (AMPK).

AMPK es un complejo heterotrimérico que contiene una subunidad catalítica (alfa) y dos regulatorias (beta y gama) (Grahame Hardie, 2014). La enzima regula post-traduccionalmente a varias proteínas del metabolismo, por ejemplo, fosforila a la ACC y a la FASN inactivándolas y permitiendo la beta oxidación. Estimula la localización de transportadores de glucosa (GLUT) 1 y 4 en membrana plasmática, inhibe a la HMG-CoAR por lo que impide la sintesis de colesterol, entre muchas otras actividades más (Grahame Hardie, 2014), por lo que AMPK se sitúa en el centro del control metabólico a nivel de eventos post-traduccionales.

\section{La homeostasis lipídica en la célula cancerosa.}

Es bien conocido que las demandas de energía de una célula cancerosa son elevadas, paradójicamente esto va acompañado de varias restricciones que, en teoría deberían de afectar la movilización de reservas energéticas, por ejemplo la falta de oxigeno (hipoxia) en ciertas células de tumores sólidos, o la deficiencia de nutrientes, sin embargo la célula transformada posee mecanismos, aún no del todo caracterizados, que dirigen la optimización molecular de los procesos y rutas que controlan la homeostasis lipidica.

Se sabe que en varias enfermedades como la diabetes, la esteatohepatitis y el cáncer existe una lipogénesis aberrante, que en gran medida representa, en las fases tardías del cáncer, una fuente de lípidos necesarios para la construcción de membranas en las células proliferantes, - intermediarios para modificaciones posttraduccionales, como el caso de Ras y otras GTPasas pequeñas, todo esto, como se menciona, en el contexto de una alta tasa de proliferación (Menendez et al., 2007).

Molecularmente hablando, la célula cancerosa presenta un incremento transcripcional de proteínas relacionadas con la lipogénesis, tanto de ácidos grasos y triglicéridos, como de colesterol, siendo las mejor caracterizadas ACLY,ACAC, FASN, SCD-1, la enzima málica, HMG-CoAR, MVK, SQS, entre otras, todasellas llevan a un incremento en la sintesis de ácidos grasos como de colesterol (Calvisi et al., 2011; Menendez, et al., 2007). Lo anterior es posible gracias a que también existe un incremento en el contenido y activación de los factores de transcripción que regulan la expresión génica de las enzimas lipogénicas como SREBP1, CREBP2 y ChREBP, entre otros, así como la inactivación de los reguladores de la lipólisis como AMPK (Calvisi, et al., 2011).

Se ha observado que las células de los HCC presentan una elevada expresión de enzimas relacionadas con la sintesis de novo de ácidos grasos como FASN, SCD-1, o de colesterol, como la HMG-CoAR (Calvisi, et al., 2011). En el tejido circundante al tumor, que si bien no se puede considerar sano, si marca una contraste en términos de diferenciación con respecto al tumor, se ha observado una menor expresión de estas enzimas, pero aún se presenta elevado cuando se compara con tejido sano, por lo que la progresión de un cáncer podría ser estimado en términos de la expresión de las enzimas lipogénicas, (figura 1), más interesante es aún el hecho de que se ha observado que pacientes con $\mathrm{HCC}$ más agresivos y con mal pronóstico, presentaron una sobre expresión mayor de dichas enzimas en comparación con aquellos que tuvieron $\mathrm{HCC}$ con mejor pronóstico y mayor sobrevivencia, por lo que además la expresión de enzimas lipogénicas o la represión de las lipoliticas, podrian ser indicadoras de evolución de la enfermedad en pacientes (Calvisi, et al., 2011). 
ACLY, ME, SCD-1, HMGCOAR, MVK, SQS,

La validación de lo anterior se hace patente cuando varias de estas enzimas son eliminadas genéticamente $o$ con inhibidores químicos en

así como la activación de SREBP1, y SREBP2 (Figura 4).

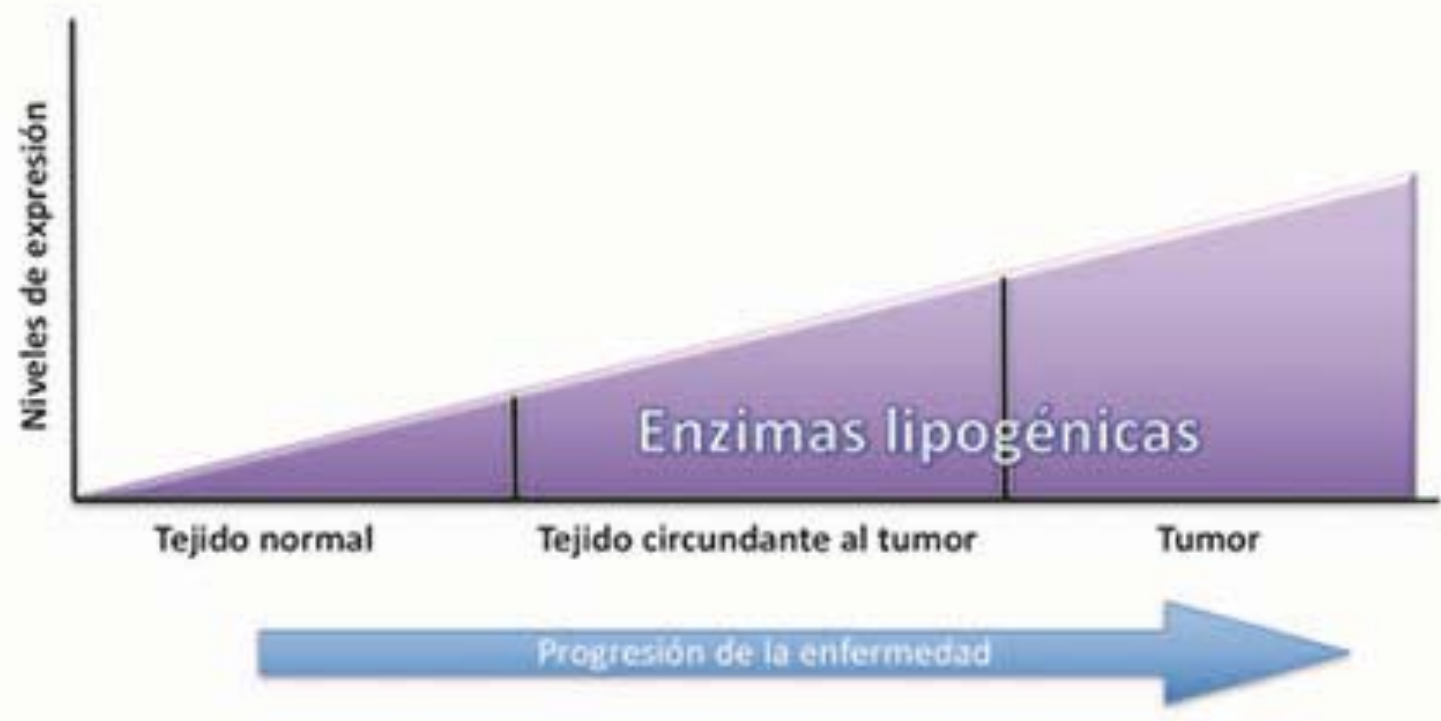

líneas celulares de $\mathrm{HCC}$, las cuales disminuyen su proliferación in vitro asi como la capacidad para formar tumores in vivo (Hanai et al., 2012; Hatzivassiliou et al., 2005; Menendez, et al., 2007).

En un estudio reciente se demostró que la progresión del HCC y su pronóstico está estrechamente relacionado con la lipogénesis, en los tres niveles moleculares, en la expresión génica de enzimas relacionadas, en la activación de factores de transcripción y en la presentación fenotípica (Calvisi, et al., 2011).

La división clinica de muestras de pacientes con sobrevivencia pobre (CP) y con sobrevivencia buena (CB), en relación con tejido normal (NL) y tejido circundante (SL) mostró un efecto en la expresión de las enzimas lipogénicas dependiente de lo avanzado de la enfermedad, tomando como ejemplo la expresión de FASN se observó un contenido basal en NL, que se incrementó moderadamente en SL y CB y significativamente en $\mathrm{CP}$; resultados similares se encontraron en otras enzimas como ACAC,

\section{Señalización lipogénica}

En condiciones normales la ruta de la cinasa del 3 fosfoinositol (PI3K), de la proteína cinasa B (Alkt) y del blanco de la rapamicina en mamimefors (mTOR), conocida como PI3K/ Akt/mTOR, es iniciada canónicamente por receptores a factores de crecimiento que tras ser activados reclutan a PI3K quien fosforila al fosfatidil inositol difosfato $\left(\mathrm{PIP}_{2}\right.$ ), para activarlo en su forma trifosfatada $\left(\mathrm{PIP}_{3}\right.$ ). El $\mathrm{PIP}_{3}$ se une a los dominios homólogos de Pleckstrina de proteinas como Akt, quien además es fosforilada por cinasas específicas como la dependiente de fosfoinositidos (PDK), para su total actividad. Akt tiene como blancos una gran diversidad de sustratos, que van desde proteína que regulan proliferación, sobrevivencia, motogénesis, y de manera especial, metabolismo. Esta vertiente está estrechamente ligada a mTOR, quien está relacionada con proteinas como RPS6 quien conecta con la regulación lipogénica (Liu et al., 2014).

El uso de herramientas de ingeniería genética como vectores que permiten, por un lado, la 
sobreexpresión en el contenido de una forma activa de Akt (AKTtg) o la expresión de un RNA de interferencia contra Akt (siRNA AKT), ha comprobado la sobre activación de mTOR, FASN, ACLY. ACAC, SCD-1 y la desregulación de AMPK alfa, beta y gama, en el caso de AKTtg; por el contrario, el silenciamiento indujo exactamente el efecto opuesto, permitiendo la expresión y activación de AMPK y por ende eventos de lipólisis. Al llevar el vector AKTtg a hígados de ratones de experimentación, por medio de inyección hidrodinámica, se indujeron tumores con un fenotipo agresivo que presentaban, además de la esperada sobreexpresión de Akt, la acumulación de lípidos fue evidente, asociada a la elevación de las proteínas lipogénicas.

El conocimiento generado por el uso de modelos experimentales tanto in vitro como in vivo permite acercar los fenómenos al ser humano. Se ha corroborado que la lipogénesis aberrante se presenta, tal y como en los animales, en tumores humanos, dejando patente la importancia de la investigación básica como acercamiento a los fenómenos que afectan a los humanos (Calvisi, et al., 2011).

Finalmente y con base en lo expuesto, en investigaciones realizadas en el laboratorio de fisiologia celular de la Universidad Autónoma Metropolitana se ha realizado estudios que demuestran que la sobrecarga lipídica, particularmente de colesterol, generada por una dieta hipercolesterolémica (HC, $2 \%$ colesterol) (Gutierrez Ruiz, et al., 2012) induce un mayor daño al DNA y promueve la generación de más tumores de mayor tamaño en ratones sometidos a la dieta $\mathrm{HC}$ y con dietilnitrosamina (DEN), además de ello se ha encontrado mayor vascularización y metástasis en estos ratones que en aquellos solo tratados con el DEN (Datos no publicados).

\section{Conclusión}

La homeostasis lipidica se coloca como un escenario el cual debe ser considerado con mayor atención en la investigación básica con la finalidad de ubicar puntos de intervención terapéutica que al ser interferidos puedan coadyuvar en el tratamiento del cáncer. La ruta del mevalonato reviste particular importancia dado que va dirigida hacia varios puntos de regulación de la célula cancerosa, como la sobrevivencia, la proliferación, el metabolismo, entre otros.

\section{Agradecimientos}

El artículo fue escrito con apoyo del CONACYT Fronteras de la Ciencia 2015-2-1320, CB252942 y SEP-PRODEP-913026-1461211, Universidad Autónoma Metropolitana Iztapalapa

\section{Referencias}

Bruix, J., Boix, L., Sala, M., and Llovet, J. M. (2004). Focus on hepatocellular carcinoma. Cancer cell 5(3), 215-9.

Calvisi, D. F., Wang, C., Ho, C., Ladu, S., Lee, S. A., Mattu, S., Destefanis, G., Delogu, S., Zimmermann, A., Ericsson, J., Brozzetti, S., Staniscia, T., Chen, X., Dombrowski, F., and Evert, M. (2011). Increased lipogenesis, induced by AKT-mTORC1-RPS6 signaling, promotes development of human hepatocellular carcinoma. Gastroenterology 140(3), 1071-83.

Grahame Hardie, D. (2014). AMP-activated protein kinase: a key regulator of energy balance with many roles in human disease. Journal of internal medicine 276(6), 543-59.

Gutierrez Ruiz, M. C., Dominguez Perez, M., Rodriguez Gonzalez, S., Nuno Lambarri, N., Licona Retama, C., and Gomez-Quiroz, 
L. E. (2012). [High cholesterol diet modifies the repaining effect of the hepatocyte growth factor]. Gaceta medica de Mexico 148(3), 23642.

Gutiérrez-Ruiz, M., Palestino-Dominguez, M., Dominguez-Pérez, M., Nuño Lámbarri, N., Souza, V., Bucio, L., and Gomez-Quiroz, L. (2013). La hepatotoxicidad de los lípidos no esterificados en el proceso de daño reparación. In Hepatología de la Ciencia Básica a la Aplicación Clínica (G. H. MS, Ed.) Eds.), Vol. 1. ZarPra.

Hanai, J., Doro, N., Sasaki, A. T., Kobayashi, S., Cantley, L. C., Seth, P., and Sukhatme, V. P. (2012). Inhibition of lung cancer growth: ATP citrate lyase knockdown and statin treatment leads to dual blockade of mitogen-activated protein kinase (MAPK) and phosphatidylinositol-3-kinase (PI3K) AKT pathways. Journal of cellular physiology 227(4), 1709-20.

Hatzivassiliou, G., Zhao, F., Bauer, D. E., Andreadis, C., Shaw, A. N., Dhanak, D., Hingorani, S. R., Tuveson, D. A., and Thompson, C. B. (2005). ATP citrate lyase inhibition can suppress tumor cell growth. Cancer cell 8(4), 311-21.

Ikonen, E. (2008). Cellular cholesterol trafficking and compartmentalization. Nature reviews. Molecular cell biology 9(2), 125-38.

Liu, X., Chhipa, R. R., Pooya, S., Wortman, M., Yachyshin, S., Chow, L. M., Kumar, A., Zhou, X., Sun, Y., Quinn, B., McPherson, C., Wamick, R. E., Kendler, A., Giri, S., Poels, J., Norga, K., Viollet, B., Grabowski, G. A., and Dasgupta, B. (2014). Discrete mechanisms of mTOR and cell cycle regulation by AMPK agonists independent of AMPK. Proceedings of the National Academy of Sciences of the United States of America 111(4), E435-44.
Ma, Z., Cao, M., Liu, Y., He, Y., Wang, Y., Yang, C., Wang, W., Du, Y., Zhou, M., and Gao, F. (2010). Mitochondrial F1FoATP synthase translocates to cell surface in hepatocytes and has high activity in tumor-like acidic and hypoxic environment. Acta Biochim Biophys Sin (Shanghai) 42(8), 530-7. Mari, M., Caballero, F., Colell, A., Morales, A., Caballeria, J., Fernandez, A., Enrich, C., Fernandez-Checa, J. C., and Garcia-Ruiz, C. (2006). Mitochondrial free cholesterol loading sensitizes to TNF- and Fas-mediated steatohepatitis. Cell metabolism 4(3), 185-98.

Menendez, J. A., and Lupu, R. (2007). Fatty acid synthase and the lipogenic phenotype in cancer pathogenesis. Nature reviews. Cancer 7(10), 763-77.

Morales, A., Mari, M., Garcia-Ruiz, C., Colell, A., and Fernandez-Checa, J. C. (2012). Hepatocarcinogenesis and ceramide/ cholesterol metabolism. Anti-cancer agents in medicinal chemistry 12(4), 364-75.

Perez-Aguilar, B., Vidal, C. J., Palomec, G., Garcia-Dolores, F., Gutierrez-Ruiz, M. C., Bucio, L., Gomez-Olivares, J. L., and GomezQuiroz, L. E. (2015). Acetylcholinesterase is associated with a decrease in cell proliferation of hepatocellular carcinoma cells. Biochimica et biophysica acta 1852(7), 1380-7.

Shi, L., and Tu, B. P. (2015). Acetyl-CoA and the regulation of metabolism: mechanisms and consequences. Current opinion in cell biology 33C, 125-131.

Xu, X., So, J. S., Park, J. G., and Lee, A. H. (2013). Transcriptional control of hepatic lipid metabolism by SREBP and ChREBP. Seminars in liver disease 33(4), 301-11. 


\title{
Typhus, yellow fever and Medicine in Mexico during the French intervention
}

Monserrat Gerardo-Ramírez¹, Jesús Zavaleta-Castro² and Luis Enrique Gómez-Quiroz ${ }^{1}$

${ }^{1}$ Department of Health Sciences, Universidad Autónoma Metropolitana Iztapalapa, Ciudad de México; 'Instituto Estatal de Documentación de Morelos, Cuernavaca, Mor., Mexico

\begin{abstract}
French intervention in Mexico (1861-1867) is particularly full of episodes of patriotic heroism in terms of military, politic and, even, religious affairs, however this history is also rich in episodes related to diseases and the evolution of Mexican scientific medicine practice, epidemics such as typhus (nowadays knows as rickettsiosis), yellow fever, or cholera. Principally, this context outlined the Mexican history and influenced the course of the nation. The epidemics served as fertile land for the development of medicine science leading by prominent physicians, particularly by doctor Miguel Francisco Jiménez.
\end{abstract}

KEY WORDS: Typhus. Yellow fever. French intervention. General Zaragoza. Maximilian of Habsburg.

\section{Introduction}

"Immense, extremely painful, perhaps irreparable, is the loss just suffered by the Republic", expressed Francisco Zarco that Saturday at the San Fernando Cemetery, before Ignacio Zaragoza's grave. Five days before, the morning of September 8, 1862, the hero of the $5^{\text {th }}$ of May battle had died as a consequence of typhus. After his victory over the French troops in Puebla, he contracted the disease when he passed by the Acultzingo Peaks, where he had paid visit to wounded and sick soldiers. General Zaragoza was assisted by Doctor Juan N. Navarro, who had been expressly sent by President Benito Juárez, and expired in the presence of his mother and one of his sisters ${ }^{1}$,

Four months prior, on May 5, Zaragoza had informed about the victory of the Mexican army over the invading forces in Puebla. On the military briefing, he highlighted "the behavior of my brave comrades", since "the glorious event that just has taken place shows their spirit and, by itself, recommends them" as patriots. When referring to the French army, he recognized that it "has fought with great bravery", in spite that "its general in chief has behaved awkwardly in the attack" to the city of Puebla. "National arms [...] have covered themselves with glory", concluded Zaragoza².

The period encompassed by the French intervention, since the landing of the European troops (1861) until Maximilian of Habsburg execution (1867), is with no doubt one of the most fascinating in the country's history. Beyond the warlike and political part, the presence of several diseases, such as typhus and yellow fever, shaped our nation; ironically, it is also a period where Mexican medicine arises with scientific bases thanks to French medicine.

\section{Typhus}

The year before the French intervention, Benito Juárez García, as president of the Republic, had issued the Foreign Debt Suspension Decree (July 17,

\author{
Correspondence: \\ Luis E. Gómez-Quiroz \\ Departamento de Ciencias de la Salud \\ Universidad Autónoma Metropolitana Iztapalapa \\ Av. San Rafael Atlixco, 186 \\ Col. Vicentina, Del. Iztapalapa \\ C.P. 09340, Ciudad de México, México \\ E-mail: legq@xanum.uam.mx
}

Date of reception: 02-11-2016

Date of acceptance: 02-11-2016

DOI://dx.doi.org/10.24875/GMM.M18000119
Gac Med Mex. 2018;154:88-93

Contents available at PubMed www.gacetamedicademexico.com 
1861), by means of which he cancelled "for a term of two years all payments, including those assigned to the debt contracted in London and to foreign conventions" ${ }^{\prime \prime}$. The rejection to this provision by the English and French governments was immediate, with the Spanish government joining in. As a consequence, on October 31, the Tripartite Convention was signed in London, which implied the shipment of "combined sea and land forces" to the Mexican territory in order to force it to pay its debts ${ }^{3}$.

Typhus is a disease that caused many problems in Mexico throughout its history. It is caused by a very particular type of bacteria of the rickettsia family, which was precisely discovered in Mexico by Doctor Howard Taylor Ricketts during the 1909 epidemic (Fig. 1), and that was to cause his death by the disease he was studying in May $1910^{4}$. The bacterium is transmitted by infected lice that excrete the microorganism in the feces, which is introduced in the wound left by the insect when the person scratches him/ herself as a consequence of the bite.

The word "typhus" derives from Greek typhus, which means "stupor". It is an infectious disease caused by bacteria such as Rickettsia typhi or Rickettsia prowazekii that often is mistaken with typhoid fever, which is caused by other bacterium, Salmonella typhi. In those times, there was much confusion and patients were often misdiagnosed, until Dr. Jiménez made it clear, as will be later explained.

It's not hard to imagine the scenario in the country for these epidemics to occur: overcrowding, poverty and lack of hydric and hygienic resources made for the disease to considerably spread. As previously mentioned, these were, to a large extent, the conditions prevailing in the country even before the Frenchmen arrival, and which worsened during the interventionist period.

The advance of epidemics may have worsened perhaps by the natural chaos caused, administratively, by the Reform Laws; for example, in February 1861, President Juárez decreed the secularization of hospitals and welfare establishments, which had been managed by the Catholic Church until then, and at the same time, to put order in these services, already in hands of the State, the Directorate General of Public Welfare Funds was created as a branch of the Ministry of the Interior. The institutions that were left under the control of this directorate included the Divino Salvador Hospital and La Cuna foundling house, and many other hospital institutions that one way or another were administered by the Church with experience ${ }^{5}$.

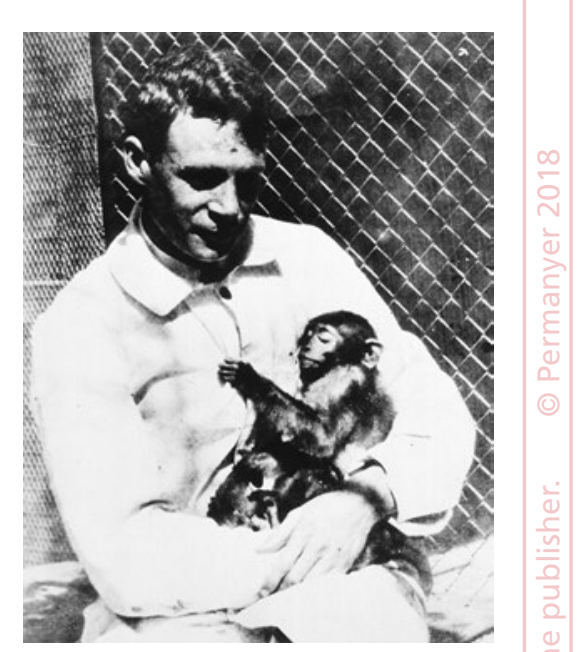

Figure 1. Picture of Doctor Howard Taylor Ricketts with one of his experimental animals (The National Library of Medicine, $\mathrm{NIH}$ ).

The relationship between lack of economic resources and the development of the disease can have, perhaps, as the greatest example, General Ignacio Zaragoza's own contagion and death.

Both in Mexico City and in Puebla, cases of typhus occurred in 1848 and continued in 1849. The disease spread from 1857, the year the Liberal Constitution was published, with Ignacio Comonfort being president of the Republic, to 1859. The same happened in 1861, 1862 (year of the $5^{\text {th }}$ of May Battle) and 1867 (year of the $2^{\text {nd }}$ of April Battle), as a consequence of "movements of military and civilian groups in conditions of insufficient hygienic means", which affected the Mexican troops that had been victorious in Puebla. Not only General Zaragoza, but also "many of his soldiers" and officers died as typhus victims.

After the victory of the Eastern Army over the French troops, communication between General Zaragoza and President Juárez was constant; there was no telegram in which General Zaragoza didn't ask for economic resources for the support of the army, not only in terms of food supplies, but also for the care of endemic diseases that, together with the invading army, attacked the national troops.

The inhabitants of the city of Puebla, far from cooperating, represented a certain obstacle. Such was the case that General Zaragoza himself reported on May 9: "this execrable city that I have not set on fire because there are innocent creatures in it... As for money, there is nothing to be done here, because these people are mean in general, and especially very indolent and selfish... Burning Puebla would be a good thing. It is in mourning due to the event of the $5^{\text {th }}$. It's sad to say this, but it is a shameful truth"'. Terrible the 
report given by the General about heroic Puebla inhabitants' attitude.

On September 1, 1862, General Zaragoza started experiencing symptoms of the infection, particularly high fever, and he was therefore sent to his station in Puebla. A few months before, he had received his daughter's visit, and his wife had died early that same year, to whom he could only provide with 100 pesos for her support, enough for 3 days, which can show the economic situation of the general, and therefore, of the entire Eastern Army. Ignacio Zaragoza died on September 8, 1862, at the age of 33 years, as a consequence of rickettsiosis or typhus ${ }^{7}$, which interrupted the General's brilliant career, which with no doubt could have given even much more to the nation.

"The [federal] government considers General Zaragoza's unexpected death to be a public misfortune", wrote Enrique de Wagner, minister of Prussia in Mexico. "After some days of illness, Zaragoza died of typhus in Puebla, where this epidemic wreaks great havoc, as well as in the entire zone comprised between this city and Orizaba." The Prussian diplomat warned that the French army would be exposed "to great dangers in case of taking the route of all these infested villages and cities", and recommended for "the majority of the forces to be mobilized through Jalapa and Perote, Huamantla, Otumba or San Martín", with the city of Puebla remaining under the protection of "a few thousand men"8.

Interestingly, rickettsioses are constant in warlike processes. In the 1480-1490 Spanish civil war, Christian and Moor troops are known to have been decimated by disease, while similar effects were caused in Napoleon troops in 1812, whereas in World War I, around 100,000 cases occurred in 1914 and 15,000 in 1916. ${ }^{\circ}$. Disease was also key in the plans for Jews elimination in the countries controlled by Nazi Germany, an aspect that is masterfully addressed in Dr. Naomi Baumslag's work ${ }^{4}$.

\section{Yellow fever}

Yellow fever is a disease caused by a virus of the arbovirus family, of the Flavivirus genus, and is transmitted by infected mosquitoes, such as Aedes aegypti (Fig. 2). The disease is characterized by high fever and severe liver damage, which generates jaundice in patients, and hence the term "yellow fever". Once again, a lack of sanitation in contaminated water containers is essential for the reproduction of the mosquito. The disease is currently relatively controlled thanks to

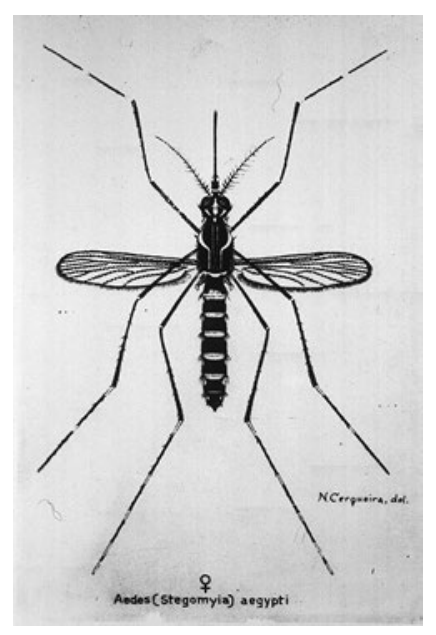

Figure 2. Classic representation of an Aedes (Stegomya) aegypti mosquito (The National Library of Medicine, $\mathrm{NIH}$ ).

vaccines and effective treatments, but in times of the French invasion this wasn't even imagined of.

Yellow fever, or yellow plague, was something that considerably worried invading armies. One of the first reports of this disease, also known as yellow jack, is referred by Jena-Jaques Ampère ${ }^{10}$, when stating that in Mexico there are two completely unbearable things: "la fièvre jaune et les brigands". Ampère's report is overwhelming: "one of the worst inconveniences (is yellow fever)"11.

Spaniards who had first arrived to the Gulf of Mexico coasts were the first victims of this disease, endemic of that region. General Juan Prim, the Spanish commander, a few weeks after having landed, sent around 800 soldiers to hospitals in Cuba for their care. Perhaps President Juárez took advantage of that "natural defense" and played with negotiation time, hoping for the disease to be a natural ally.

The negotiation resulted in the invaders being allowed to advance towards Orizaba, located at 2800 meters above sea level, where the mosquito hardly subsisted. When Spaniards and Englishmen noticed French intentions, they retired and sailed back to their countries, but as previously mentioned, French troops did not.

In 1963, Gloria Grajales published, in the Historia Mexicana journal, quotes from documents of the archive referring the intervention in Mexico by England, France and Spain, which are preserved in the Public Record Office in London. She particularly quotes those related to the French intervention (classification F.O. 97/278, Vol. I, and 97/279, Vol. II, with the title French Expedition) ${ }^{12}$. In said report, at least three entries can be read making reference to the yellow fever 
and to the difficulties the French had to deal with this problem. The first reference, with no date, but reported around August 1862 says: "No date - Arrival of 300 sailors in the Iphigenia frigate; yellow fever contagion in Veracruz" (F.O. 97/278, I, p. 97). Later it refers: "December 4, 1862 - Johnson to Count Russell (No. 1347): About mortality among French troops caused by yellow fever; recruiting of thousand Egyptian blacks to serve in expeditionary forces in Mexico (F.O. 97/278, I, p. 187). And then: Paris, January 6, 1863 - Johnson to Count Russel (No. 20, confidential): About possible reasons to send reinforcements to Mexico, to cover losses caused by disease and death (1500 soldiers and 62 officers dead). Confidential information obtained through captain Hore. Measures taken by the French government to defray the costs of the expedition, etc." (F.O. 97/278, I, pp. 213214). "Memorandum annexed to the previous document: Data obtained through Mister Xavier Raymond about the state of the French army in Mexico. Strong losses caused by yellow fever and other diseases. Roads in bad shape, need for transportation for the Tampico expedition. Monthly expenses for land transportation in Mexico are insufficient. Raymond thinks that the feeling against the expedition is unanimous, etc." (F.O. 97/278, I, pp. 216-218).

The French army was clearly decimated by losses and deaths caused by yellow fever, but information was kept confidential, perhaps in an attempt not to increase the victorious feelings in Mexican troops. Although yellow fever affected the invaders, it did not cause for them to ultimately miss their objective, at least temporarily.

\section{Veracruz, Maximillian and yellow fever}

"Veracruz is a filthy and narrow city, famous for its terrible weather and extreme heat", stated Count Carl Khevenhüller-Metsch, a member of the Austrian volunteer corps that arrived to Mexico to accompany Maximillian of Habsburg. After 3 weeks of journey on the Floride ship, more than 800 men arrived to the Veracruz port on December 7, 1864, where they had to endure $44{ }^{\circ} \mathrm{C}$ at night. Khevenhüller met "German and Austrian doctors who have to be paid the highest homage for their abnegation in times of the yellow fever, this terrible disease that snatches life in a few hours"13. On next day, they continued their journey to the capital of the country, afraid of contagion, given the insalubrious conditions of the port.
On Saturday May 8, 1863, the Novara ship, where Maximillian of Habsburg and his Wife Charlotte of Belgium and their court arrived, dropped anchor in the port of Veracruz. At $4 \mathrm{~h}$ in the morning of Sunday 29, everything was ready "to immediately continue the journey towards the capital, since a prolonged stay in Veracruz was not recommendable, owing to the yellow fever prevailing on that city, which is said to be especially dangerous for those recently arrived"14, stated Wilhelm Knechtel, official botanist of the emperor. However, 2 years later the emperor was to fall ill, with the care of a Mexican specialist being required to treat him.

Maximillian was "affected from the liver and in addition he had been suffering intermittent fevers contracted in one of the trips to warm lands"15. Friedrich Semmeleder, personal doctor of the Austrian, not knowing "too well the special treatment for [these] intermittent fevers", proposed the emperor to "consult with any of the local Mexican physicians who perfectly knew the treatment" against them. He was attended to by the physician Rafael Lucio, "who in those days was already an eminence". Initially, Lucio had resisted to that because "he was a staunch liberal and completely opposed to the imperial regime". Prior to leaving to Cuernavaca, Maximillian wanted to "settle his account with his Mexican doctor, [...] but the wise doctor completely refused receiving a single peso, claiming that having earned the Sovereign's gratitude sufficed him"14.

During the $19^{\text {th }}$ century, yellow fever, typhus, cholera, measles, plague and smallpox epidemic outbreaks added up to more than 70 in the State of Veracruz. Diseases attacked both cities and small villages, with not few of them being decimated. Although yellow fever epidemics were among the most common, "deaths were quantitatively fewer than with smallpox" After 1826 and 1855, 3 yellow fever epidemics occurred in a 5-year period: 1842, 1843 and 1847, the latter in the year of the North American intervention. Between 1850 and 1852 there was another outbreak of the disease, as well as during the French intervention in 1863 and 1867. "Public health in the Veracruz territory [as in other regions in the country] walked hand in hand with the weather and with internal and international fights in defense of sovereignty"16.

\section{State of medicine during the French intervention}

Ironically, the existence of multiple epidemics (in 1864, life expectancy of Mexicans was estimated 
to be 30 years) ${ }^{5}$ was accompanied by fundamental events in the history of medicine during the period the country was occupied by France (1862 to 1867).

On April 18, 1864, the Scientific, Literary and Artistic Commission was founded, and on the $30^{\text {th }}$ of that month, the first meeting of the Medical Sciences Section (later National Academy of Medicine) was carried out. The section was divided in 5 sub-sections: pathology, hygiene, legal medicine and medical statistics, veterinary medicine, medical matters and pharmacology, and physiology and anthropology. The chair was in hands of Doctor Carlos Alberto Ehrmann, and vice-chair was in charge of Doctor Miguel Francisco Jiménez, who was professor at the National School of Medicine. Among other illustrious physicians of those days who were members of the section, Dr. Rafael Lucio and Dr. José María Vértiz can be mentioned ${ }^{17}$. As already mentioned, this time period is with no doubt one of the greatest as regards exemplary physicians and scientists; in addition to the above list, Doctors Lauro Jiménez and Leopoldo Río de la Loza, who made important contributions to pharmacology, should be mentioned, among others.

One of the main accomplishments of the medical section was the publication of Gaceta Médica de México, journal of the scientific commission medical section, which later would be simply Gaceta Médica de México, as until currently is known. The first issue appeared on Thursday September 15, 1864, with its first chairman being Dr. Miguel Francisco Jiménez.

In the first issue, differences between typhus and typhoid fever are precisely discussed in an article written by Dr. Jiménez himself, mentioning that it is an endemic disease in the country and clearly establishing its importance.

\section{Dr. Miguel Francisco Jiménez, amebic hepatic abscess and Mexican scientific medicine}

Dr. Miguel Francisco Jiménez (Fig. 3) is a clear example of growing medical science in the Mexico of the Empire. He was an intelligent and educated man who strongly supported rational and scientific medicine, taking observation, rather than guessing as a basis; he was a strong follower of Auenbrugger and Laennec contributions; he was with no doubt a physician ahead of his time, who applied a scientific view to clinical training and to the entire practice of medicine.

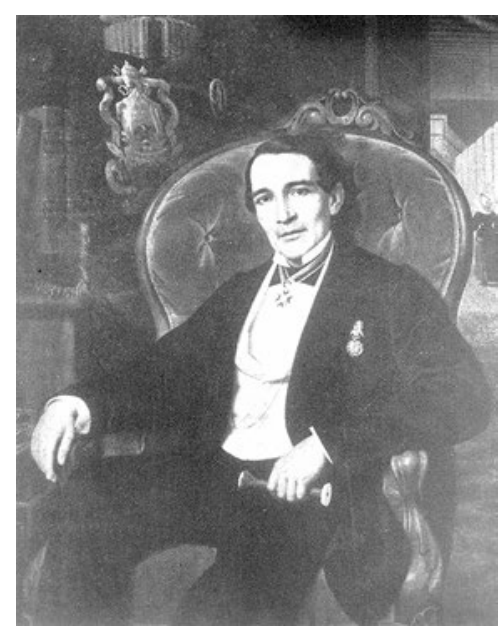

Figure 3. Doctor Miguel Francisco Jiménez.

He was born in Amozoc, Puebla in 1813. He graduated as a physician in 1838 at the Establishment of Medical Sciences, and almost immediately he occupied a post as a professor of pathology, and subsequently anatomy, teachings he offered until his death ${ }^{18}$.

In addition to the studies he carried out to distinguish between typhus and typhoid fever, he did research on other diseases that considerably afflicted the country's population, amebic hepatic abscess, which was very common in Mexico, even since the $16^{\text {th }}$ century.

Amebic hepatic abscess is an accumulation of pus in the liver as a response to the presence of Entamoeba histolytica. The disease is acquired by ingesting water or food contaminated with fecal matter. Once again, the high incidence of this disease speaks of overcrowding, poverty and of the unhealthy conditions of those days. Patients with the disease died regularly, even due to unfortunate medical interventions where a sickle-shaped blade knife was used without anesthesia or asepsis for the treatment not only of hepatic abscess, but for any type of abscess. If the patient didn't die from the disease, he/she died due to infection. This was common until the advance proposed by Dr. Jiménez, consisting in directly surgically intervening by means of a puncture to drain the abscess, which prevented its rupture and dissemination to other organs. It is not hard to imagine that this procedure saved lives and made for patients with the disease to have a better prognosis ${ }^{19}$.

Dr. Jiménez high professional and scientific level deserved the recognition of Maximillian of Habsburg, who invited him to join as one of his personal doctors, together with doctors Federico Semeleder, Samuel Basch and Rafael Lucio Nájera. 
Dr. Jiménez really thought that the arrival of the Empire was something good for the country, not in the plane of conservative exacerbation or apology of the monarchy, but he thought that a new national order could be established that would make the country move towards a better quality of life. In a letter he sent to José María Iglesias he mentions: "I am faithful that a new order could be founded which, being really accepted by everyone, would end once and forever the eternal anarchy that consumes us". Dr. Jiménez died in Mexico City in 1876.

\section{Conclusion}

The period of the French intervention has been one of the most convulsive epochs for the nation, since beyond the armed conflict and occupation, an economic, political and social disaster was experienced, which made for many of the public health problems to be exacerbated, thus affecting all and sundry, as we have seen. However, this is also period of time that marks the beginning of a revolution in medical science in our country by notorious physicians, and although not all of them have been mentioned, we have taken Dr. Francisco Jiménez example as a faithful representative of that generation of medical physicians who, interestingly, were trained in the French school of medicine. Finally, it was also on that period (Thursday September 15, 1864) that Gaceta Médica de Medicina started being published.

\section{Acknowledgements}

This work has been written for diffusion and divulgation purposes and had the support of CONACYT
Ciencia Básica No. 252942, Fronteras de la Ciencia 2015 No. 1320, Instituto Estatal de Documentación del Estado de Morelos and Universidad Autónoma Metropolitana Iztapalapa.

\section{References}

1. Gonzales Lezama R. Del triunfo republicano a la crisis política de 1861. El peor año de la república. Relatos e Historias en México. 2012;45:48-54.

2. Zaragoza I. Parte de Guerra del General Zaragoza. Relatos e Historias en México. 2012;4:68.

3. Porte Petit JM. Antecedentes de la intervención. Primer Congreso Nacional de Historia para el Estudio de la Guerra de Intervención, 1963. Sociedad Mexicana de Geografía y Estadística; 1963.

4. Baumslag N. Medicina asesina. Médicos nazis, experimentación con humanos y tifus. Barcelona: Plataforma Editorial; 2014.

5. Concheiro AA. Cronología médica mexicana. Cinco siglos. México: Siglo XXI; 2010.

6. Florescano E, Malvido E. Ensayos sobre la historia de las epidemias en México. Vol. 1. Instituto Mexicano del Seguro Social; 1982.

7. Rosas A. El patriotismo de Ignacio Zaragoza. Paisaje de la batalla. Relatos e Historias en México. 2012;45:71-6.

8. Díaz L. Versión francesa de México. Informes diplomáticos. 1862-1864. Vol. 3. El Colegio de México; 1965.

9. Peterson RKD. Insects, disease, and military history. The Napoleonic campaigns and historical perception. American Entomologist. 1995;41:147-61.

10. Ampère JJ. Promenade en Amérique. Etats-Unis-Cuba-Mexique. 2 ed. Vol. II. Paris: Michel Levy Freres; 1860.

11. Helguera MM. Posibles antecedentes de la intervención francesa. Historia Mexicana. 1965;15:1-24.

12. Grajales G. Intervención francesa y segundo imperio. Historia Mexicana. 1963;13:284-316

13. Hamann B. Con Maximiliano en México: del diario del príncipe Carl Khevenhüller, 1864-1867. México: FCE; 1992.

14. Knechtel W. Las memorias del jardinero de Maximiliano. Apuntes manuscritos de mis impresiones y experiencias personales en México entre 1864 y 1867. México: Instituto Nacional de Antropología e Historia; 2012.

15. Blasio JL. Maximiliano íntimo. El emperador Maximiliano y su corte. Memorias de un secretario particular. México: Librería de la Vda. de C. Bouret; 1905.

16. Aguilar Sánchez M, Ortiz Escamilla J. Historia general de Veracruz. México: Gobierno del Estado de Veracruz; 2011.

17. Rodríguez Pérez ME. De la Sección Médica a la Academia de Medicina de México: 1864-1880. En: La Academia Nacional de Medicina de México. 150 años de actividad ininterrumpida. México: Intersistemas editores, CONACYT; 2014

18. Martínez Guzmán M. Cuatro médicos personales del emperador Maximiliano de Habsburgo. 1864-1867. Boletín Mexicano de Historia y Filosofía de la Medicina. 2003;6:17-22

19. Fernández del Castillo F. El tratamiento de los abscesos hepáticos antes del doctor Miguel Francisco Jiménez. Gac Med Mex. 1957;87:395-410. 


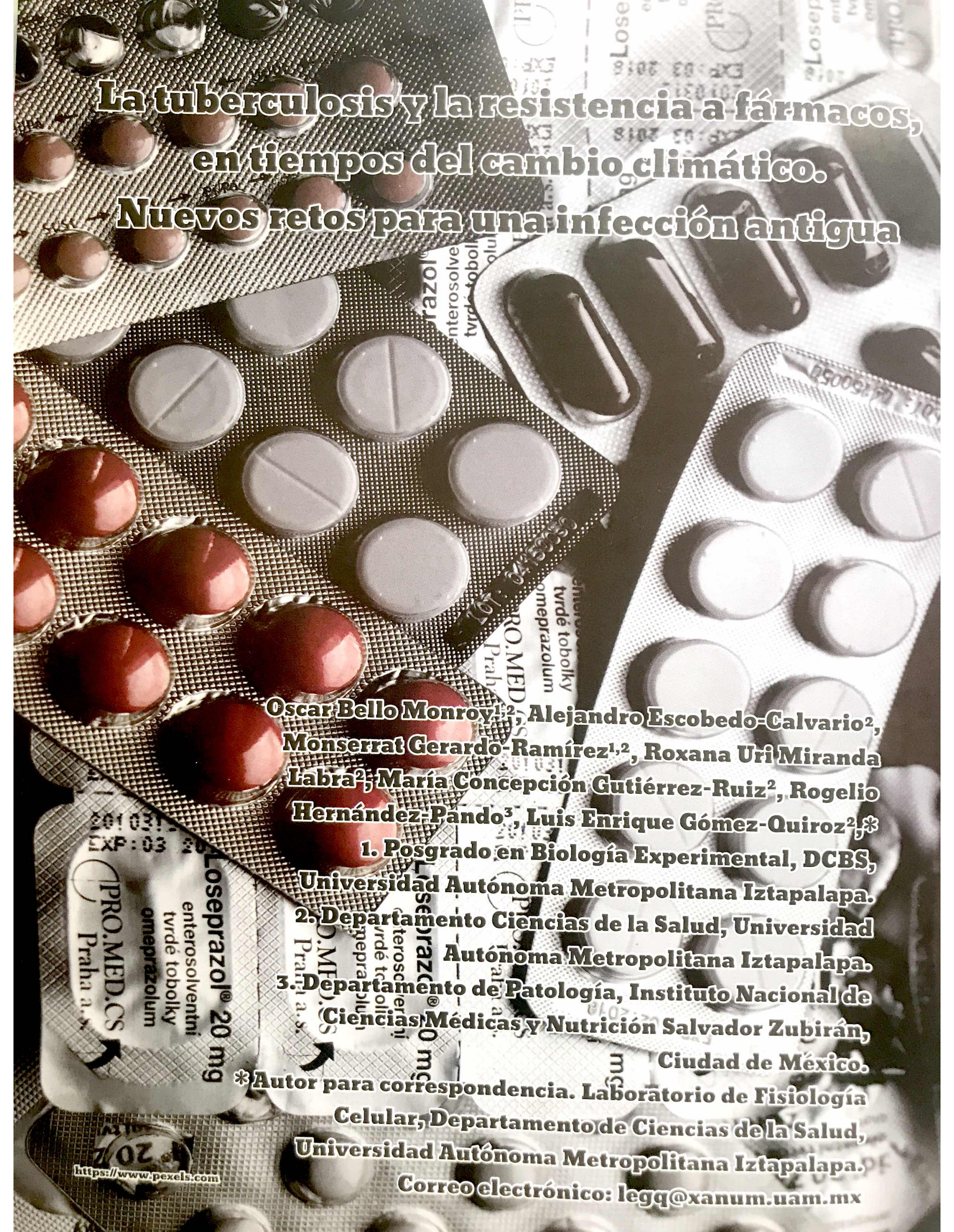




\section{Resumen}

La tuberculosis es un buen ejemplo de enfermedades tristemente célebres, la lista de personajes históricos que padecieron la enfermedad es muy extensa, baste citar solo unos pocos ejemplos para ilustrar: Federico Chopin, Antón Chejov, René Laënnec, Paganini, entre muchos otros, sin mencionar epidemias históricas registradas en los libros que marcaron definitivamente el rumbo de la historia en muchos sentidos.

El cambio climático está transformado la vida en el planeta. Cambios en los patrones de migración de varias especies animales que ponen en peligro su existencia. Los microorganismos están siendo también afectados, no solo aquellos que son transmitidos por insectos, sino también por mamíferos, incluyendo al ser humano.

La tuberculosis, está mostrando cambios que son presumiblemente inducidos por el cambio climático, es difícil tener la evidencia contundente de ello por el momento, pero estudios al respecto ya se conducen en varios países donde la infección es un problema grave de salud pública.

La aparición de cepas que son resistentes a los fármacos de primera línea, están generando la búsqueda de nuevas opciones de tratamiento eficaces, algunas opciones deben tomar en cuenta que la biotransformación de fármacos se realiza en el hígado y que dicho proceso puede comprometer tanto la función del órgano, como la vida del paciente.

Palabras clave: hígado, tuberculosis, resistencia a fármacos, cambio climático

\section{Abstract}

Tuberculosis is a good example of remarkable diseases in history, because many celebrities has suffered this infection with fatal consequences, such as Frédéric Chopin, Anton Chejov, René Laënnec, Niccoló Paganini, among others, even more this disease has been determinant in many social conflicts or wars that has changes the pathways of history.

Climate change is inducing profound changes in the planet. Changes in migration routes of many animal species, jeopardizing their existence. Microorganism have been affected, not only those associated to zoonosis, but mammals and humans as well. Tuberculosis has been exhibiting changes regarding bacillus strains, areas of morbidity and drug resistance, possibly associated to climate change, nowadays, it is quite difficult to address this statement but some research approaches are now in course, particularly in those counties with high incidence.

The rising of multidrug resistance strains of Mycobacterium tuberculosis is generating many concerns regarding the treatment, new therapeutic approaches must be investigated and implemented taking in consideration the liver function because most of the drugs are biotransformed in this organ inducing liver failure and, eventually, decease.

Keywords: liver, tuberculosis, drug resistance, climate change.

\section{Introducción}

El Grupo Intergubernamental de Expertos sobre el Cambio Climático (IPCC, por sus siglas en inglés) ha señalado que las actividades humanas están contribuyendo, de manera significativa, al Calentamiento Global (CG)(Pachauri RK et al., 2015).

La sociedad contemporánea se rehúsa a abandonar, en el mediano plazo, el uso de combustibles fósiles que producen gases con efecto invernadero, en particular el $\mathrm{CO} 2$, que contribuyen fuertemente al CG (Oyhantçabal et al., 2010).

Por otro lado, en países del tercer mundo, el uso de dendrocombustibles continúa siendo la 
forma principal de obtención de energía, particularmente en regiones rurales, donde además contribuye a la deforestación, permitiendo también la generación de gases con efecto invernadero (Schmidt, 2008).

El cambio de uso de suelo, es otro aspecto que incide fuertemente en el cambio climático (CC), generando pérdida de hábitats para plantas y animales, que aunado al $\mathrm{CC}$, está generando problemas de salud pública que están agravándose debido a la poca o casi nula intervención, no solo de las autoridades y gobiernos, sino también de la misma población quien, sin duda, es el principal factor generador del problema (Patzet al., 2004).

En el momento que se finaliza este artículo, (3 de Julio del 2017) se puede fácilmente encontrar en diversos medios de comunicación una serie de notas periodísticas sobre la aparición de brotes infecciosos del virus coxsackie en varios estados del país (García, 2017; Miranda J et al., 2017), se requiere de tiempo y análisis serios para confirmar si estos brotes tienen relación con el CC, (Hii et al., 2011; McIntyre et al., 2017; Paull et al., 2017). Existen reportes que apuntan que la incidencia de la enfermedad llamada "exantema vírico de manos, pies y boca", asociada predominantemente al virus coxsackie A16, tiene incrementos notables en temporadas de calor y lluvias, particularmente en los países asiáticos (Hii, et al., 2011), ¿será que los brotes actuales de ésta enfermedad vírica, están asociados al CC?

\section{Viejos problemas, nuevos paradigmas en el contexto del cambio climático}

Se ha reportado que el cambio climático está generando el incremento en la propagación de enfermedades transmitidas por insectos, entre las que se puede destacar el dengue, la malaria, la enfermedad de Lyme, el virus del oeste del Nilo, la fiebre del Valle Rift, el chikungunya y la fiebre amarilla, entre muchos otros (Oyhantçabal, et al., 2010; Paull, et al., 2017) todavía a finales del 2016 el temor de una pandemia de chikungunya era un tema común entre expertos en epidemiología y líderes de organizaciones de salud, preocupación que traían desde el 2015 (Diaz-Quinonez et al., 2016).

El cambio en el clima está prolongando las estaciones "naturales" de transmisión de enfermedades, alterando la distribución geográfica, entre otros factores; por ejemplo, se prevé una ampliación considerable de las zonas afectadas por la esquistosomiasis en China, una enfermedad transmitida por caracoles (Zhou et al., 2008), los cuales cada vez es más común encontrarlos en regiones en las que anteriormente no se observaban, otra explicación puede ser la falta de sus depredadores que han desaparecido también por elCC.

En el año 2008 se hizo público un documento conocido como 'the Deadly Dozen' donde se alerta sobre una docena de patógenos que, de seguir así las tendencias actuales con el CC, afectará significativamente a animales y personas, impactando en la salud y en la economía mundial (Pandve et al., 2009).

Entre las infecciones emergentes mencionadas en esta lista, se encuentra una que es, tal vez menos obvia, silenciosa, con poca propaganda en televisión u otros medios masivos de comunicación, pero que es, sin lugar a dudas, la más preocupante de todas: la tuberculosis.

\section{Tuberculosis}

Fuera de la región del África subsahariana, la incidencia en la tuberculosis (TB) está disminuyendo, pero está creciendo la preocupación con la aparición de cepas mutifármaco resistentes (MDR) y extensivamente fármaco resistente (XDR). La TB es una enfermedad infecto-contagiosa pulmonar de progresión lenta cuyo agente causal es el bacilo Mycobacterium tuberculosis. El bacilo es un aerobio estricto y prefiere sitios con alta concentración de oxígeno, capaz de 
sobrevivir durante meses en esputo mantenido en un lugar fresco y oscuro, y durante semanas en materiales como alfombras, cadáveres, abonos, papel o ropa, o bien formando parte del polvo. Es resistente al frío, a la congelación y a la desecación por largos periodos de tiempo, su pared celular está compuesta de ácidos micólicos que forman una pared cerosa y gruesa alrededor de la micobacteria, característica que le confiere adaptación ante los cambios climáticos, así como a la entrada de fármacos, debido a la disminución de la permeabilidad celular, lo que obliga un tratamiento costoso y de larga duración. (Barry et al., 1998).

La Organización Mundial de la Salud (WHO, por sus siglas en inglés), establece que la investigación y el desarrollo en TB necesitan mayores inversiones. Cada año mueren más personas de tuberculosis (1.4 millones en 2015) que por la infección del virus de la inmunodeficiencia humana (1.1 millones de muertes); 400,000 mueren por la combinación de ambas infecciones). A pesar de que en la actualidad el número de personas con tuberculosis MDR a nivel mundial asciende a 580,000, los niveles de inversión actuales $(\$ 620$ millones US) en investigación y desarrollo han alcanzado su mínimo desde 2008 (Bridgen et al., 2017). De acuerdo con la WHO, en su informe global sobre tuberculosis (WHO, 2016) en 2015 se estimó que el número de nuevos casos de TB era de 10.4 millones de los cuales el $56 \%$ eran hombres, el $34 \%$ eran mujeres y el $10 \%$ niños, mientras que las coinfecciones de TB y VIH representaron 1.2 millones de casos (11\%), de todos los casos nuevos reportados. En el 2015 murieron 1.8 millones de personas por la infección, de los cuales 400,000 fueron coinfección con el VIH (WHO, 2016).

Según el reporte de 2016, México se encuentra entre los países con una baja incidencia de TB, reportándose 21 casos por cada 100,000 habitantes y una mortalidad casi 20 veces menor que el promedio mundial. Sin embargo, las bajas incidencias de TB en nuestro país se asocian a un alto subregistro, un déficit en el pronóstico y, además muchas personas conviven con enfermos, de los cuales no todos están diagnosticados o bajo tratamiento. Sin embargo, llama la atención que el reporte de la WHO del 2016 se ha agregado a México en la lista de países con alta incidencia de casos de coinfecciones TB/VIH (WHO, 2016), por lo que ello debe generar la atención por parte de las autoridades de salud.

La TB es una enfermedad emergente pues la CENAPRECE ha reportado que el número de casos nuevos en México ha aumentado casi al doble en los últimos 25 años. Además, se estima que un tercio de la población mundial está infectada sin manifestar enfermedad (TB latente), de la cual el 10\% sufrirá TB activa por reactivación de bacterias latentes como consecuencia de la inmunodeficiencia producida por enfermedades como HIV/SIDA o diabetes mellitus tipo 2 (DM-2).

La relación DM-2 con $\mathrm{TB}$ es de gran importancia, pues en comparación con la población sana los diabéticos tienen un riesgo 3 veces mayor de sufrir TB activa y este riesgo es aún mayor en la población joven. La DM-2 es una enfermedad considerada como epidémica en nuestro país y la constante y creciente pobreza de buena parte de nuestra población son elementos cruciales que permiten predecir un mayor número de casos de TB activa en el futuro próximo. De hecho, se calcula que en México de todos los casos de TB activa el 67\% tienen DM-2 lo que corresponde al $11 \%$ de la población total. Es por estos motivos que se considera a la TB y su relación con la DM-2 como un importante problema nacional de salud (Ponce-De-Leon A etal., 2004).

Las estrategias de control de TB, desplegadas por los gobiernos, están enfocadas particularmente a la solución clínica, es decir, por medio de antibióticos, vacunas y acceso a programas e instituciones de salud. Estas acciones no han mostrado efectividad para 
detener a la TB, se requiere de intervenciones sociales y ambientales, las cuales pocas veces se ven contempladas en el sector salud, o en general en programas oficiales.

En términos generales las tasas de muertes se han reducido notablemente, siendo un 90\% menos de muertes asociadas a TB con respecto al 2015, y 80\% de reducción de nuevos casos.

El pronóstico para el paciente con la infección es bueno con antibióticos de primera línea (rifampicina, isoniazida, pirazinamida, etambutol), esto cuando se trata de infecciones con cepas clásicas, pero cada vez se presentan más casos de infecciones con cepas MDR, y XDR las cuales generan cuadros clínicos difíciles de tratar siendo, la mayoría de las veces, letales (Dheda et al., 2017).

\section{La resistencia a fármacos}

Las cepas MDR o XDR, representan una preocupación latente, como se ha mencionado. Se estima que mundialmente el $5 \%$ de los pacientes con tuberculosis están infectados con cepas MDR o XDR, pero entre ellos la tasa de muerte está por arriba del 40\%, 1legando al 60\% cuando la infección es con cepas XDR (WHO, 2016).

Solo 1 de cada 5 pacientes con infección con cepas MDR recibieron tratamiento, y de ellos solo la mitad se curó (WHO, 2016). Lo anterior preocupa aún más debido a que aquellos que recibieron el tratamiento, pero no fueron curados son potencialmente portadores de cepas aún más resistentes.

La tuberculosis MDR es la causada por una cepa que no responde al tratamiento con isoniazida y rifampicina, los dos medicamentos antituberculosos de primera línea más eficaces de que se dispone. La forma MDR se puede tratar y curar con medicamentos de segunda línea. Sin embargo, las opciones de tratamiento de segunda línea son limitadas y requieren quimioterapia de larga duración (hasta de dos años de tratamiento) con fármacos que además de caros son tóxicos, mientras que la TB XDR es una forma más grave de TB, causada por bacterias resistente no solo a la isoniazida y a la rifampicina, sino a cualquiera de los medicamentos antituberculosos de segunda línea más eficaces (fluoroquinolonas y cualquiera de los fármacos inyectables usados en el tratamiento de segunda línea como amikamicina, capreomicina, kanamicina), lo que deja a muchos pacientes sin otras opciones de tratamiento.

¿Cómo puede influenciar el cambio climático la progresión de la tuberculosis, particularmente, las cepas MDR?

Científicos mencionan que enfermedades como la gripe aviar, el ébola, el cólera y la tuberculosis, se propagarán aún más en el mundo como resultado de los cambios en las temperaturas y los niveles de precipitación fluvial. Y tendrán un enorme impacto en la salud humana, como en la naturaleza y las economías del mundo, dice el 'the Deadly Dozen". Asimismo, diferentes factores se suman para el éxito de estas enfermedades, tales como:

Desnutrición. Un buen estado nutricional es fundamental para un sistema inmunológico eficiente que combata la infección, particularmente la deficiencia de vitamina $D$ está asociado fuertemente a la progresión de la enfermedad, particularmente de cepas MDR(Wingfield et al., 2014), se ha documentado que el cambio climático está impactando en nutrición y migración en países asiáticos, con relevancia particularmente en niños (UNICEF, 2011).

Migraciones y hacinamiento. No es secreto que los cambios que conducen a la globalización, los intereses económicos, territoriales y religiosos está conduciendo a la pérdida de arraigo a la tierra, generando migraciones, que pueden ser pequeñas o masivas, como aquellas causadas por conflictos bélico-religiosos como en el caso de Siria 
llevando a serios retos en términos de salud, particularmente en tuberculosis (Cookson et al., 2015).

El hacinamiento es una constante en migraciones masivas de cualquier tipo, condición fundamental para la transmisión del bacilo. En México, esto se observa en regiones como Tijuana que tiene la mayor incidencia de $\mathrm{TB}$, particularmente por el estado en el que viven los migrantes en espera de cruzar la frontera.

Es interesante que los desplazamientos se dan de zonas ecuatoriales a zonas hemisféricas, particularmente hacia el norte (Europa y USA), puede ser que si bien los habitantes de estas zonas ecuatoriales, con radiación solar prácticamente todo el año, sean más resistentes a la TB porque la activación de vitamina D sea adecuada, dicha vitamina depende de fotoactivación para ejercer su efecto(Wingfield, et al., 2014). Al moverse hacia zonas hemisféricas la biodisponibilidad de vitamina $\mathrm{D}$ activa es menor, por menos radiación, y por lo tanto la infección (tal vez latente) se active y manifieste. La tuberculosis induce malnutrición, y la malnutrición condiciona a la tuberculosis (Kant et al., 2015).

Contaminación del aire de interiores, principalmente por la quema de dendrocombustibles, como el carbón o la leña, los cuales siguen siendo la primera opción para la cocción de alimentos y para el calefacción, en muchas regiones pobres del mundo, especialmente en los países con mayor incidencia de la enfermedad, como India y China (Santos et al., 2012). El humo, genera cuadros neumónicos que impiden un buen control para la eliminación de la bacteria en los pulmones de las personas con la infección.

Contaminación de agua. La pérdida de hábitats está generando que especies de animales, silvestres o domesticadas, se acerquen a ciudades en busca de agua y alimento, muchas especies de rumiantes son portadores del bacilo y la posibilidad de que contaminen yacimientos de agua para consumo humano es grande, empiezan a documentarse casos de infección con cepas de Mycobacterium bovis en humanos, representando del 5 al $10 \%$ de los casos totales de TB humana, cabe resaltar que la forma humana puede afectar a animales también, formando así, un circuito de infección constante (Davidson et al., 2017).

Cambio en el uso de suelo se presenta el avance de la urbanización, la construcción de carreteras, agricultura a gran escala, desecación de humedales, entre otros, lo que conduce a la pérdida de biodiversidad, generando que vectores se acerquen más a zonas habitadas. Por otro lado, se pierden también espacios para el cultivo, particularmente para el autoconsumo, en pequeñas comunidades, generando estados de malnutrición, de la cual se aprovechan la infección(Patz, et al., 2004).

El cambio en el uso de suelo está tomando el sitio como el principal factor del resurgimiento de enfermedades infecciosas. Se requieren de estudios sistemáticos para determinar las causas, pero se especula, con cierta razón, que está afectando regímenes alimenticios en poblaciones vulnerables, es importante recordar que la TB es una enfermedad de pobres. El factor nutrición es fundamental para la progresión de la enfermedad, como se ha mencionado. El cambio en el uso de suelo también lleva a la migración, como se ha mencionado, que favorece la transmisión en zonas de baja o nula incidencia.

\section{¿Cuál es el reto? En busca de nuevas opciones terapéuticas}

Desde hace varios años se han reportado nuevas cepas MDR y XDR, incluso se ha reportado que estas cepas están ya mostrando resistencia a nuevos antibióticos como la bedaquilina y delamanid. (Bloemberg et al., 2015). El tratamiento con dosis elevadas de rifampicina y de isoniazida puede ser una buena opción de tratamiento (Chang et al., 2010) pero es sabido 
también que dicho esquema induce daño hepático, particularmente en niños (Donald, 2011), lo cual está asociado a un incremento en casos de muerte, sobre todo en países asiáticos (Kumar et al., 2010). El hígado es el órgano donde los fármacos se biotransforman, y en dicho proceso generan intermediarios altamente tóxicos que pueden inducir, como se ha mencionado, la muerte de un paciente.

Estudios conducidos en nuestro laboratorio en animales de experimentación, han mostrado que el daño hepático inducido por dosis elevadas de fármacos antifímicos puede ser significativamente disminuido, por el cotratamiento con el factor de crecimiento de hepatocitos (HGF, por sus siglas en inglés) lo que lo posiciona como una excelente opción de cotratamiento en pacientes con cepas MDR o XDR (Enriquez-Cortina et al., 2013). Datos obtenidos recientemente muestran que además el HGF es capaz de desplegar efectos diferenciales tanto en hígado como en pulmón en ratones infectados con una cepa MDR, induciendo estrés oxidante en pulmón, fundamental para la eliminación de la bacteria; y reprimiendo la misma respuesta en el hígado, donde las especies reactivas de oxígeno (ROS) representan las principales entidades de daño, incluso el HGF por si solo mostró disminuir notablemente la neumonía observada por la enfermedad, sugiriendo efectos inmunomoduladores (Bello-Monroy et al., 2015).

El tratamiento convencional con los fármacos de primera línea en dosis elevadas en combinación con terapias celulares, al menos experimentalmente, muestra un efecto viable que podría ser llevado a la práctica clínica con resultados prometedores.

\section{Conclusión}

¿Que acciones se debe tomar para contrarrestar, lo más posible, el avance de la TB por el CC? Es importante que se implementen leyes y reglamentos que permitan la conservación y protección de la biodiversidad, aspectos que ha venido empujando fuertemente instituciones como la CONABIO, se deben aplicar nuevos mecanismos de evaluación ambiental, que permita llegar a un consenso a nivel mundial sobre medidas concretas que impacten en CC, con énfasis en enfermedades emergentes, por otro lado se requiere de la participación y capacitación de comunidades rurales para la gestión eficiente de recursos biológicos, que impacten en la conservación de hábitats que beneficien a la comunidad y a las especies animales y vegetales, sin que ello implique pérdida de identidades. Otro aspecto fundamental es que se contemple el cambio del uso de suelo en las políticas de salud, ya que esta presentando un impacto, no solo en tuberculosis, si no en otras infecciones.

La búsqueda de nuevas opciones de tratamiento, más allá de una quimioterapia convencional, puede ser una opción viable que frene el problema, o al menos lo retrase, nuevos enfoques soportados en terapia celular y molecular dirigida en combinación con fármacos, nuevos o convencionales, pudiera rendir buenos frutos.

Es muy claro ya como se ha incrementado los casos de infecciones MDR y XDR; el CC pareciera pues, estar empujando a favor de la enfermedad, como mencionamos, no queda aún del todo claro, pero definitivamente incidir desde ya en el problema con políticas públicas desde los gobiernos, y con conciencia y determinación en la población general, ayudará sin lugar a dudas en detener el problema o al menos, evitar daños que puedan ser históricamente lamentables, por la aparición de cepas incurables.

\section{Agradecimiento}

El presente artículo fue escrito gracias al financiamiento de CONACYT Ciencia Básica \# 252942. 


\section{Referencias}

Bello-Monroy, O., Enriquez-Cortina, C., Souza, V., Miranda Labra R, Gutierrez-Ruiz, M. C., Bucio, L., and Gomez-Quiroz, L. E. (2015). The protective effect of the HGF against the toxicity induced by isoniazid and rifampicin in a moise model of progresivve tuburculosis. . Annals of hepatology 14(4), 580-581.

Bloemberg, G. V., Keller, P. M., Stucki, D., Trauner, A., Borrell, S., Latshang, T., Coscolla, M., Rothe, T., Homke, R., Ritter, C., Feldmann, J., Schulthess, B., Gagneux, S., and Bottger, E. C. (2015). Acquired Resistance to Bedaquiline and Delamanid in Therapy for Tuberculosis. $\mathrm{N}$ Engl.J Med 373(20), 1986-8.

Chang, K. C., and Leung, C. C. (2010). The best approach to reintroducing tuberculosis treatment after hepatotoxicity is still open to debate. Clin Infect Dis 51(3), 366-7; author reply $367-8$.

Cookson, S. T., Abaza, H., Clarke, K. R., Burton, A., Sabrah, N.A., Rumman, K.A., Odeh, N., and Naoum, M. (2015). "Impact of and response to increased tuberculosis prevalence among Syrian refugees compared with Jordanian tuberculosis prevalence: case study of a tuberculosis public health strategy". Confl Health 9, 18.

Davidson, J. A., Loutet, M. G., O'Connor, C., Kearns, C., Smith, R. M., Lalor, M. K., Thomas, H. L., Abubakar, I., and Zenner, D. (2017). Epidemiology of Mycobacterium bovis Disease in Humans in England, Wales, and Northern Ireland, 2002-2014. Emerg Infect Dis 23(3), 377-386.

Dheda, K., Chang, K. C., Guglielmetti, L., Furin, J., Schaaf, H. S., Chesov, D., Esmail, A., and Lange, C. (2017). Clinical management of adults and children with multidrug-resistant and extensively drug-resistant tuberculosis. Clin Microbiol Infect 23(3), 131-140.

Diaz-Quinonez, J. A., Lopez-Martinez, I.,
Torres-Longoria, B., Vazquez-Pichardo, M., Cruz-Ramirez, E., Ramirez-Gonzalez, J. E., Ruiz-Matus, C., and Kuri-Morales, P. (2016). Evidence of the presence of the Zika virus in Mexico since early 2015. Virus Genes 52(6), 855-857.

Donald, P. R. (2011). Antituberculosis druginduced hepatotoxicity in children. Pediatr Rep $3(2), \mathrm{e} 16$.

Enriquez-Cortina, C., Almonte-Becerril, M., Clavijo-Cornejo, D., Palestino-Dominguez, M., Bello-Monroy, O., Nuno, N., Lopez, A., Bucio, L., Souza, V., Hernandez-Pando, R., Munoz, L., Gutierrez-Ruiz, M. C., and Gomez-Quiroz, L. E. (2013). Hepatocyte growth factor protects against isoniazid/rifampicin-induced oxidative liver damage. Toxicol Sci 135(1), 26-36.

García, I. (2017). Se elevan a 143 los casos del virus coxsackie en Oaxaca. In El Universal (doi: Digital ed., Ciudad de México.

Hii, Y. L., Rocklov, J., and Ng, N. (2011). Short term effects of weather on hand, foot and mouth disease. PLoS One 6(2), e16796.

Kant, S., Gupta, H., and Ahluwalia, S. (2015). Significance of nutrition in pulmonary tuberculosis. Crit Rev Food Sci Nutr 55(7), 95563.

Kumar, R., Shalimar, Bhatia, V., Khanal, S., Sreenivas, V., Gupta, S. D., Panda, S. K., and Acharya, S. K. (2010). Antituberculosis therapy-induced acute liver failure: magnitude, profile, prognosis, and predictors of outcome. Hepatology 51(5), 1665-74.

McIntyre, S., Rangel, E. F., Ready, P. D., and Carvalho, B. M. (2017). Species-specific ecological niche modelling predicts different range contractions for Lutzomyia intermedia and a related vector of Leishmania braziliensis following climate change in South America. Parasit Vectors 10(1), 157. 
Miranda J, and Miranda P (2017). El virus coxsackies ataca también a adultos. In El Universal (doi, México.

Oyhantçabal, W., Vitale, E., and Lagarmilla, P. (2010). El cambio climático y su relación con las enfermedades animales y la producción animal. Conf. OIE doi, 169-177.

Pachauri RK, and Meyer L (2015). IPCC, 2014: Cambio climático 2014: Informe de síntesis. Contribución de los Grupos de trabajo I, II y III al Quinto Informe de Evaluación del Grupo Intergubernamental de Expertos sobre el Cambio Climático. 1 ed.

Pandve, H. T., Fernandez, K., Singru, S. A., and Chawla, P. S. (2009). Climate change and the threat of deadly dozen. Indian J Occup Environ Med 13(3), 154.

Patz, J. A., Daszak, P., Tabor, G. M., Aguirre, A. A., Pearl, M., Epstein, J., Wolfe, N. D., Kilpatrick, A. M., Foufopoulos, J., Molyneux, D., Bradley, D. J., Working Group on Land Use, C., and Disease, E. (2004). Unhealthy landscapes: Policy recommendations on land use change and infectious disease emergence. Environ Health Perspect 112(10), 1092-8.

Paull, S. H., Horton, D. E., Ashfaq, M., Rastogi, D., Kramer, L. D., Diffenbaugh, N. S., and Kilpatrick, A. M. (2017). Drought and immunity determine the intensity of West Nile virus epidemics and climate change impacts. Proc Biol Sci 284(1848).

Ponce-De-Leon A, Garcia-Garcia Md M de L, Garcia-Sancho MC, Gomez- Perez FJ, and JL, V.-G. (2004). Tuberculosis and diabetes in southern Mexico. Diabetes care 27, 1584-1590.

Santos, L. G., Pires, G. N., Azeredo Bittencourt, L. R., Tufik, S., and Andersen, M. L. (2012). Chronobiology: relevance for tuberculosis. Tuberculosis (Edinb) 92(4), 293-300.
Schmidt, C. W. (2008). Linking TB and the environment: an overlooked mitigation strategy. Environ Health Perspect 116(11), A478-85.

UNICEF (2011). Children and Climate Change: The impacts of climate change on nutrition and migration

affecting children in Indonesia. 1 ed. UNICEF.

WHO (2016). Global tuberculosis report 2016. 1 ed.

Wingfield, T., Schumacher, S. G., Sandhu, G., Tovar, M. A., Zevallos, K., Baldwin, M. R., Montoya, R., Ramos, E. S., Jongkaewwattana, C., Lewis, J. J., Gilman, R. H., Friedland, J. S., and Evans, C. A. (2014). The seasonality of tuberculosis, sunlight, vitamin D, and household crowding. J Infect Dis 210(5), 774-83.

Zhou, X. N., Yang, G. J., Yang, K., Wang, X. H., Hong, Q. B., Sun, L. P., Malone, J. B., Kristensen, T. K., Bergquist, N. R., and Utzinger, J. (2008). Potential impact of climate change on schistosomiasis transmission in China. Am J Trop Med Hyg 78(2), 188-94. 


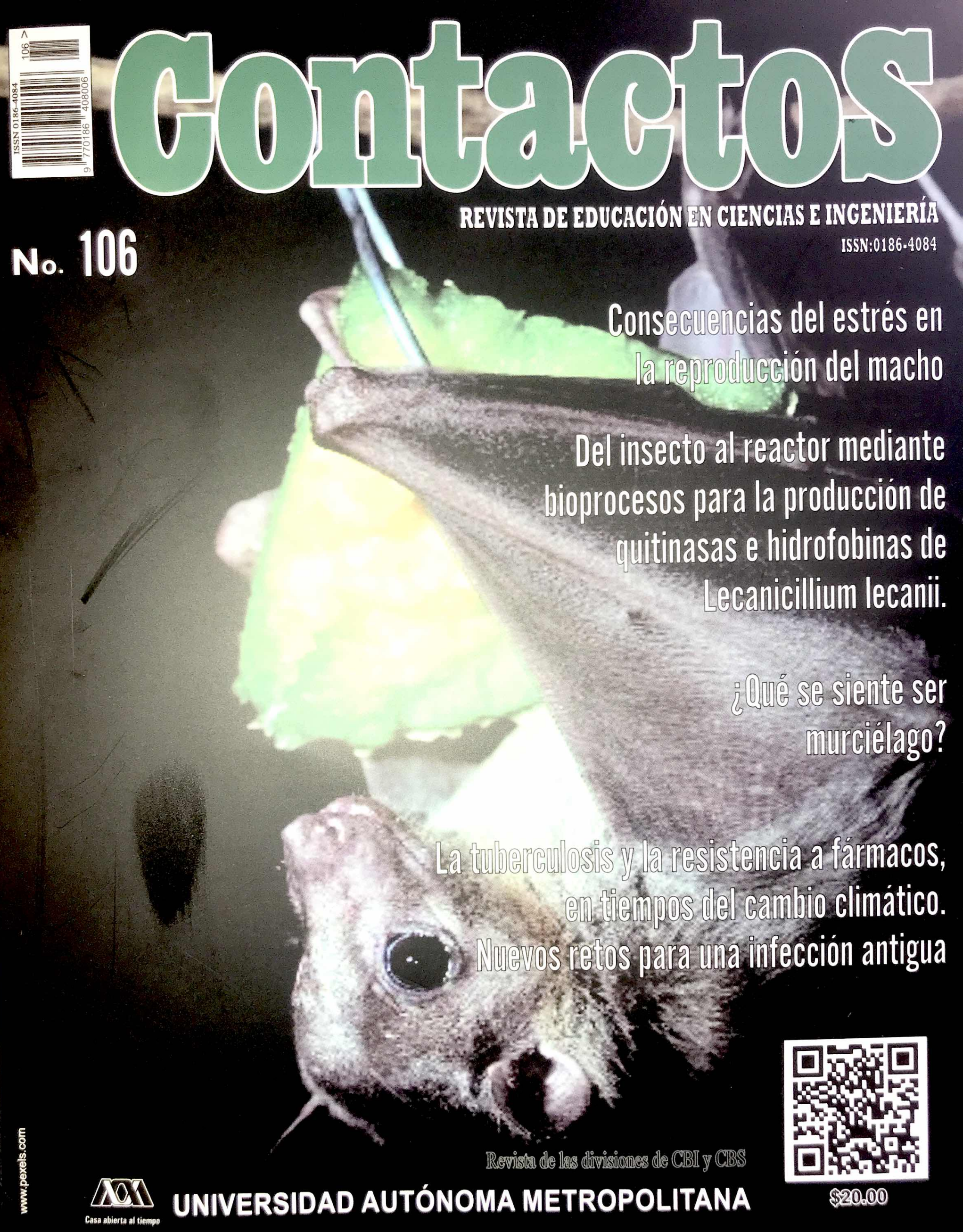




\section{Contenido}

\section{ContactoS No. 106, Octubre Diciembre 2017}

Influencia de la temperatura en la

determinación sexual de peces blancos

y charales (Chirostoma, Atherinopsidae).

Consecuencias del estrés en

la reproducción del macho.

María Cecilia Hernández Rubio,

María del Socorro I. Retana Márquez

Gerardo Figueroa Lucero,

Hortensia Montellano Rosales

Del insecto al reactor mediante

De América para el mundo: el jitomate.

bioprocesos para la producción de

(Solanum lycopersicum L.)

quitinasas e hidrofobinas de

Lecanicillium lecanii.

Zaizy Rocha-Pino y Keiko Shirai

Dra. Laura J. Pérez Flores

El papel de los diversos receptores

¿Qué se siente ser de estrógenos en el cáncer de mama.

murciélago?

Javier Esteban Jiménez-Salazar,

Pablo Damián-Matsumura

Dr. Ricardo López Wilchis

La tuberculosis y la resistencia a fármacos, $\quad 28$

Clasificación de estrés por en tiempos del cambio climático.

Nuevos retos para una infección antigua.

Oscar Bello Monroy, Alejandro Escobedo medio de una red neuronal. F. Daniel Gálvez Sánchez y Alma E. Martínez Licona

-Calvario, Monserrat Gerardo-Ramírez,

Roxana Uri Miranda Labra, María

Concepción Gutiérrez-Ruíz, Rogelio

Hernández-Pando, Luis Enrique Gómez-

Quiroz

ContactoS en la WEB

Lea los artículos publicados en ContactoS en http://www.izt.uam.mx/contactos 
Caracterización de la ruta de señalización activada por el factor de crecimiento y diferenciación 11 (GDF 11) y su impacto en la

tumorigénes is en

hepatocarcinoma humano.

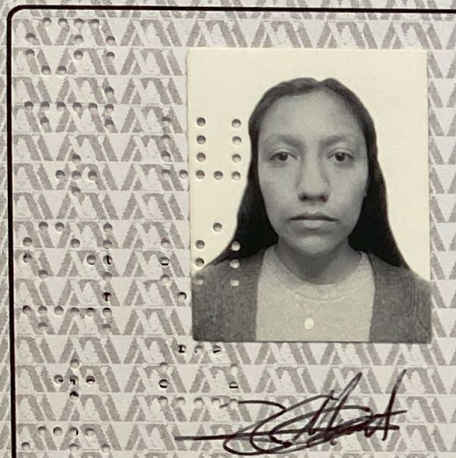

MONSERRAT GERARDO RAMIREZ ALUMNA

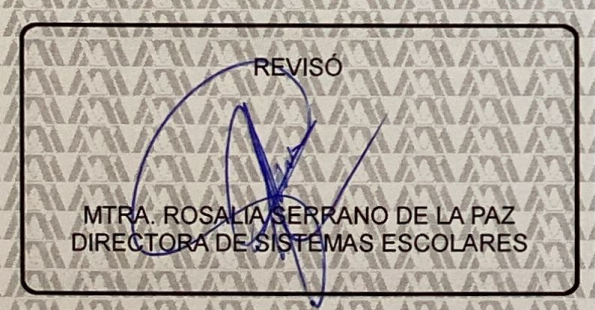

A DELA DIVISIÓN DE CBS

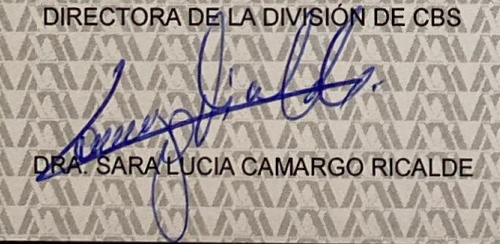

$y$ de acuerdo con el articulo 78 fracción II del

Reglamento del Estudios Superiores de la Universidad Autónoma Metropolitana, los los miembros del jurado resolvieron:

\section{APROBAR}

Acto continuo, Ia presidenta del jurado comunicó a la interesada el resultado de la evaluación y, en caso aprobatorio, le fue tomada la protesta.
Bajo la Presidencia de la primera y con carácter de cretaria la última, se reunieron para proceder al Examen obtención del grado de

MAESTRA EN BIOLOGIA EXPERIMENTAL

DE: MONSERRAT GERARDO RAMIREZ

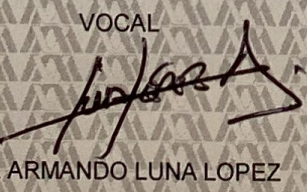

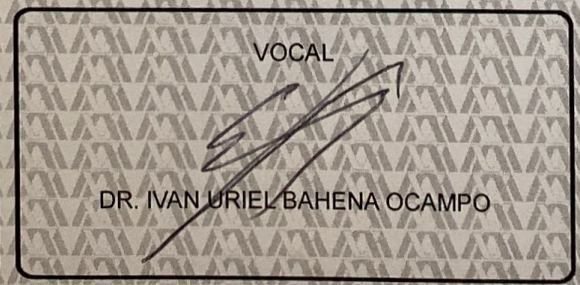

SECRETARIA

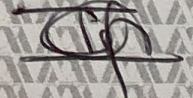

DRA. MARIA GUADALUPE ISABEL DOMINGUEZ GOMEZ 